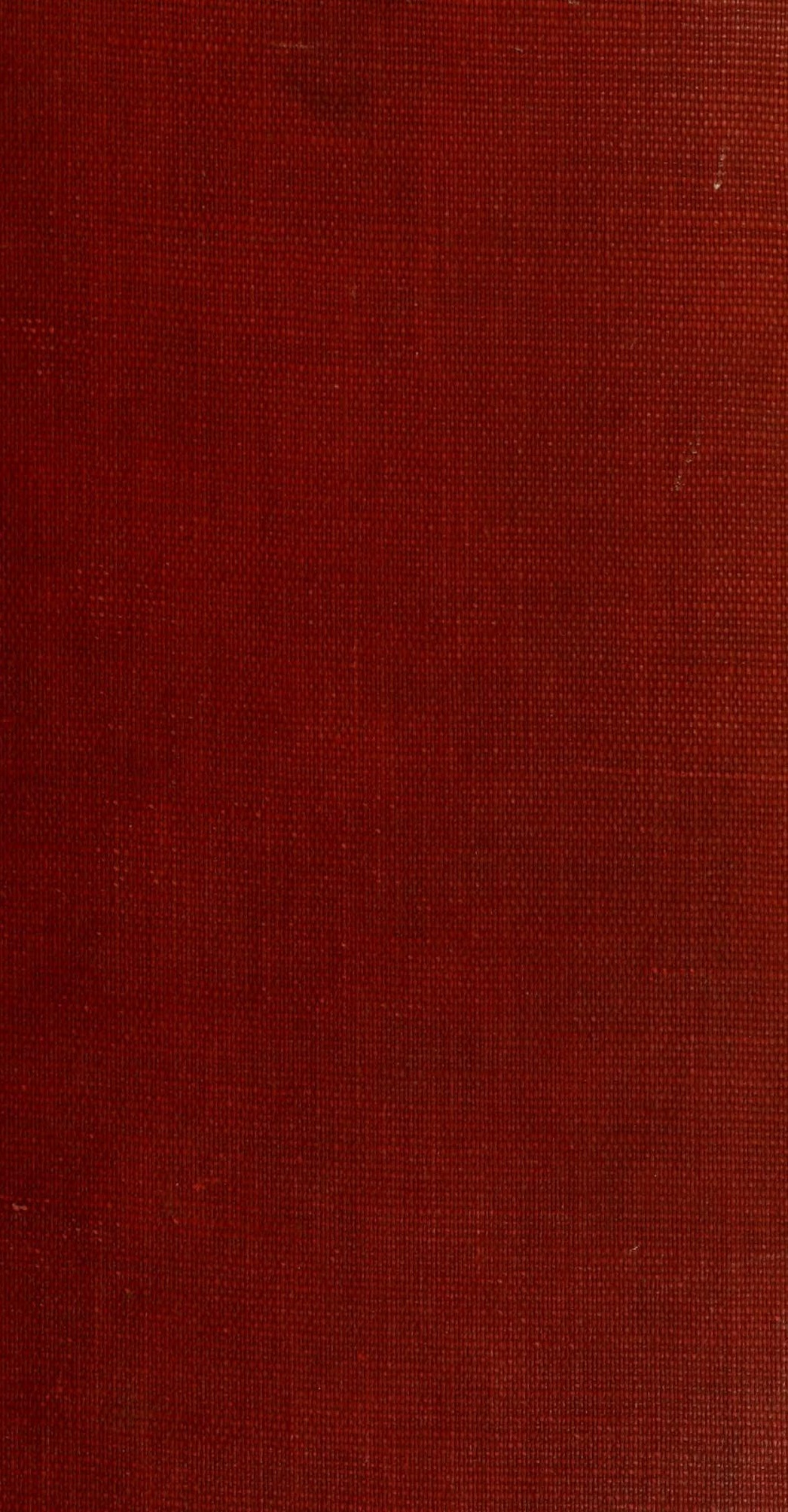




$$
\text { ช }
$$








\section{THE BOOK OF HARDY FLOWERS}


THE COMPLETE GARDENER ROCK GARDENING FOR AMATEURS

THE GARDEN AT HOME THE IDEAL GARDEN

GARDEN FLOWERS AS THEY GROW

GARDEN WORK FOR EVERY DAY

GARDENING DIFFICULTIES SOLVED

GARDEN PLANNING AND PLANTING

LITTLE GARDENS, HOW TO MAKE THE MOST OF THEM

POCKET GARDENER

INDOOR GARDENING

SWEET PEAS AND HOW TO GROW THEM

H. H. THOMAS \& WALTER EASLEA THE ROSE BOOK 
1

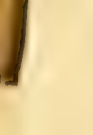

. 


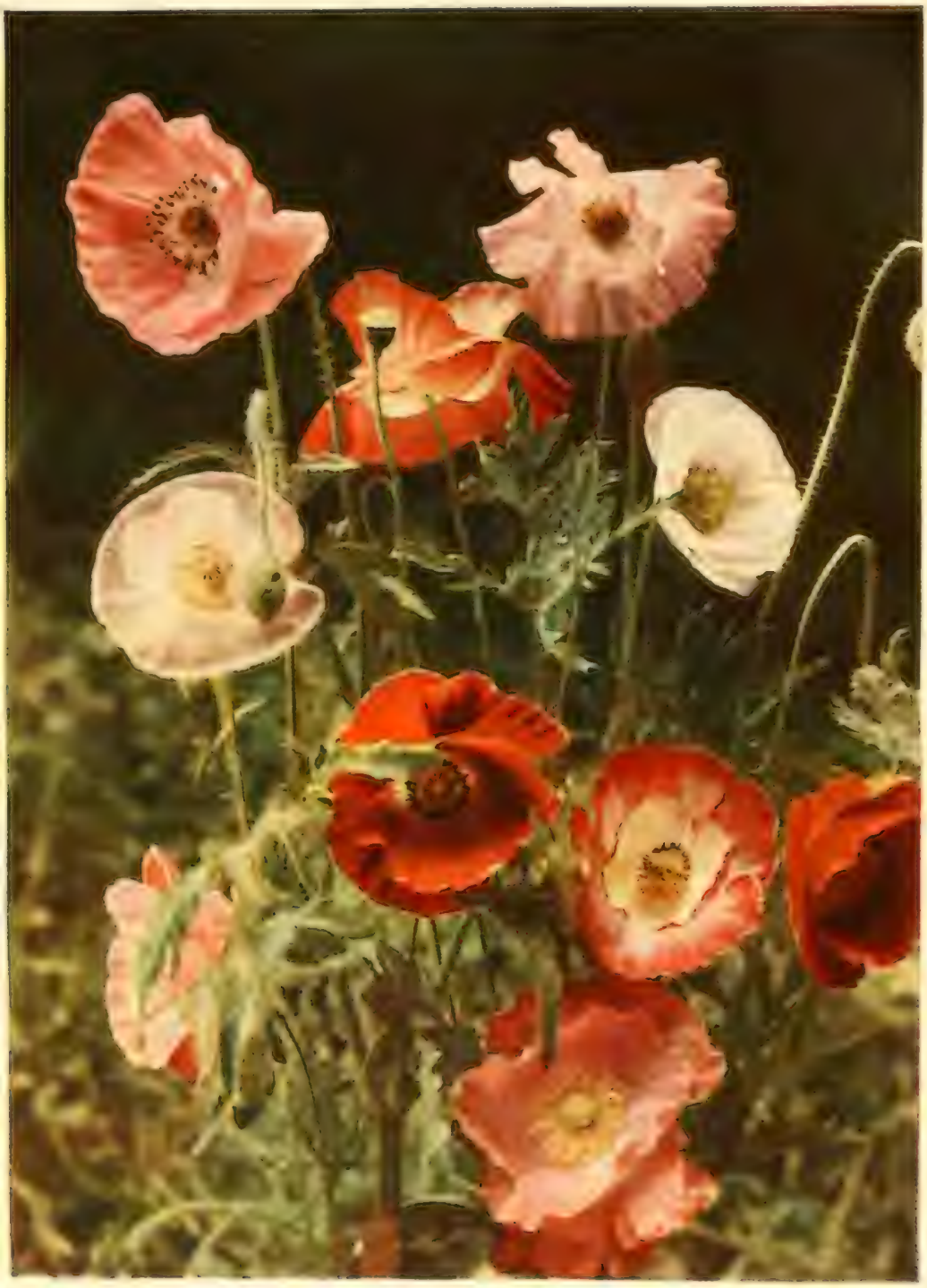

SHIRLEY POPPIES 


\section{THE BOOK OF HARDY FLOWERS}

A simple and complete descriptive guide to the cultivation in gardens of the trees and shrubs, perennial and annual flowers, that are hardy, or are suitable for planting out-of-doors in summer in temperate countries.

\section{EDITED BY \\ H. H. THOMAS}

Author of "The Ideal Garden," "The Complete Gardener," etc.

Beautifully Illustrated -with Thirty-two

Direct Color Photographs by

H. Essenhigh Corke

and Sixty-four half-

tone Plates

FUNK \& WAGNALLS COMPANY

New York

CASSELL \& COMPANY, Limited London 
Gifi

Puiliahor

तहT 33 ISा है

$\therefore \quad \vdots$

.. 


\section{PREFACE}

Trie "Book of Hardy Flowers" is an attempt to provide the garden lover, in as simple and non-technical a manner as possible. with a work of reference to which he may turn for essential information concerning the flowers, trees, and shrubs that are suitable for growing in these islands and in other countries or districts where similar climatic conditions prevail. Herbaceous perennials (those that lose their leaves and stems each autumn but start into fresh growth in spring) and annuals (those that perish after having blossomed) are grown more extensively than other kinds, and are given special attention in the following pages. Full reference, however, is made to plants that are indispensable in summer gardening though needing protection from frost in winter.

Although, for the sake of convenience and ready reference, the book is arranged in alphabetical order of botanical names, the popular names, if existing and of sufficient interest, are given also, and further to simplify reference an index of these is published at the end of the work.

It is often of value in gardening to know of the country in which a plant grows wild, for an acquaintance with the conditions in its native habitat may help towards its successful cultivation, more especially in the matters of providing an aspect and position suited to its needs. For this reason the country or place of origin of the various plants is stated.

The descriptions have been written with the view of giving not only the colour of the flowers, but the height of the plants 
and the season at which they are seen in full beauty If no time of blossoming is mentioned, it may be taken for granted that the flowers open in summer.

In the notes dealing with the propagation of trees and shrubs it will be noticed that the chief methods practised are sowing sceds, taking cuttings, grafting, budding, and layering. As in all cases the seasons for carrying out these "operations" are not mentioned, it may be well to give the following information. Theoretically, it is best to sow seeds as soon as they are ripe, though in practice this work is often deferred until spring, when, owing to increasing warmth, germination takes place more quickly. Some seeds are notoriously slow in germinating, as, for exampie, those of certain trees, shrubs, and alpines, and it is necessary to sow these immediately they have matured. The seeds of Oaks, Chestnuts, and a few other trees lose their vitality very quickly if allowed to become dry; therefore, if not sown as soon as ripe, they ought to be stored in moist sand. Cuttings of hardy shrubs are inserted in sandy soil in a closed frame in July or out-of-doors in carly autumn. Grafting is carried out in March, budding in July, and layering in March or late in summer, the layered branches being left undisturbed for at least eighteen months.

The illustrations are a feature of the book, and altogether show some two hundred different shrubs and flowers; thus it may be hoped that they will assist the reader in the identification of those with which he is not familiar.

I have to arknowledge the valued assistance of several contributors in the preparation of the "Book of Hardy Flowers," and particularly of Mr. Wr. l)allimore, Mr. Thomas Smith and Mr. W. Truelove 


\section{LIST OF ILLUSTRATIONS}

\section{COLOURED PLATES}

Shtrley Poppies

Frontispiece

FACING PAGE

Anchusa .

Alpine Auricula 22

Border of Thrift and Tufted Pansies . . . . . 38

Low Wall Planted with Spring Flowers . . . . 54

Bocconia cordata (Plume Poppy) • . . . . . . . 66

Border of Clarkia and other Annulas . . . . 78

Campanula Portenschlagtana (Bellflower) . . . . . 84

Sweet William, Torch Lily and Juniper . . . . 992

White Pinks as an Edging . . . . . . . 98

Border Chrysanthemums . . . . . . . . ito

ROCKERY MOUND . . . . . . . . . II8

Tulip Inglescombe Pink . . . . . . . . . 132

Dianthus Spencer Bickham (Alpine Pink) . . . . 150

Delphinium (Perennial Larkspur) . . . . . . . i64

Pinks in a Flagged Path . . . . . . . ${ }^{7} 72$

Lilium pardalinum (PANTher Lily) . . . . . I80

Hollyhock Palling Belle : . . . . . . $2 \mathrm{I}_{4}$

LYCHNIS CHALCEDONICA . . . . . . . . 222

Primula Unigue . . . . . . . . . . 230

Flag Irises and Tulits . . . . . . . . . . 234

Oenothera spectosa (Evening Primrose) . . . . 242

LyChNis Viscaria SPLENDENS PLENA . . . . . . 262 
Pirlox VIVID .

Pentstemon heterophyllus . . . . . . . . . 306

Philox G. A. Ströhlein . . . . . . . . . 322

Primula saxatilis . . . . . . . . . . 340

Rock GARDEN IN JUNE . . . . . . . . 356

RHODODENDRON PURPUREUM ELEGANS . . . . . . 370

Salvia splendens (Scarlet Sage) . . . . . . 390

Saxifraga Clibrani . . . . . . . . . . 402

SilenE PENDUla . . . . . . . . . . . 4 48

\section{BLACK-AND-WHITE PLATES}

Abies zasiocarpa (Silver Fir)

ACANthus mollis (Bear's BreEch) . . . . . . IO

Achillea filipendulina (Yellow Milfoil) . . . . io

Achillea Perry's White (White Milfoil) . . . . io

ACROCliniUm ROSEUM (FAIRY IMMORTELLE). . . . . IO

ACANtholmion venustum (Prickly Thrift) . . . . I4

ANdrosace lanuginosa (Rock Jasmine) . . . . . . I4

Amaryllis Belladonna (Belladonna Lily) . . . . is

ANEMONE SYLVESTRIS (SNOWDROP WINDFLOWER) . . . I8

ANthemis tinctoria (Chamomile) . . . . . . . i 8

AQuilegia glandulosa (Columbine) . . . . . . . . . . is

Anemone apennina (Apennine Anemone) . . . . . 26

AxmMone nemorosa flore rifico (Double Wood Avemone) - 26

ANTHEMS MONTana (Chamomile) . . . . . . . 26

Arenaria balearica (Balearic Sandwort) . . . . 26

AN IDEAL ROCK GARDEN . . . . . . . . . 30

AUBRIETIA IN THE ROCKERY . . . . . . . . . 34

Amemone Pulsatilla (Pasque Flower) . . . . . . 42

Anomatimeca cruenta . . . . . . . . . 42

BEGONIA . . . . . . . . . . . . 42

Braciycome iberidifolia (SwaN River DaISY). • . . 42

BANE PLANTED With ThriFt . . . . . . . 46 
ARENARIA LARICIFOLIA (SANDWORT) 50

HELICHRYSUM BELLIDIOIDES (EVERLASIING) 50

HARDY BORDER Flowers . 58

IVATER Lily PoOL . . . . . . . . . . . 62

Centaurea montana (Perennial Cornflower) . . . 70

Colchicum autumale (Meadow Saffron) . . . . 7o

Convolvulus CNeORum (BindWed) . . . . . . . 70

CRINUM CAPENSE . . . . . . . . . . . . 70

ROCK GARDEN IN A Hollow . . . . . . . 74

Campanula Medium (Canterbury Bbli) . . . . . 82

CHRYSANTHEMUMS FROM SEED . . . . . . . . 82

Chrysanthemum Parthenium . . . . . . . . 82

Crucianella stylosa (Crosswort) . $\quad . \quad$. $\quad . \quad . \quad 82$

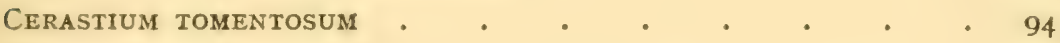

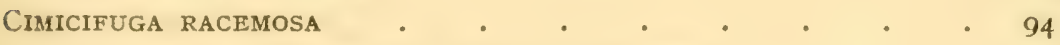

Choisya ternata (Mexican Orange Blossom) . . . . 102

Cistus ladaniferus (Rock Rose) . . . . . . 106

Clematis montana (Mountain Clematis) . . . . . . ir4

Clematis Nellie Moser . . . . . . . . . II4

CORTADERIA ARGENTEA . . . . . . . . . . II4

CYClaMEN REPANDUM . . . . . . . . . . II4

Cupressus lawsoniana lutea (Golden Cypress) - . . I22

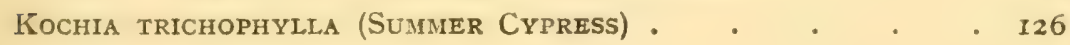

EdRatanthus pUMILIO . . . . . . . . . I40

ERODIUM TRICHOMANAEFOLIUM . . . . . . . . I . IO

Delphinium (PERENNIAL LARKSPUR) • • : . . . . I 46

DelPhinium (ANNUAl LARKSPUR) • . . . . . . 154

Dianthus caesius (Cheddar Pink) • . . . . . 154

Dianthus deltoides (MaIden Pink) . . . . . . I54

Dianthus (PINkS) IN DRY Wall . . . . . . . I54

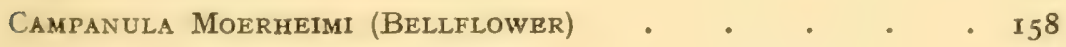

Daboecia polifolia (IRISH HeAth) . . . . . . I 58

DAPHNE CNEORUM . . . . . . . . . . 158

Dodecatheon MEdia (AMERICAN CoWslip) • • . • . 158

EChinops Ritro (Globe Thistle) • . • . . . . I66

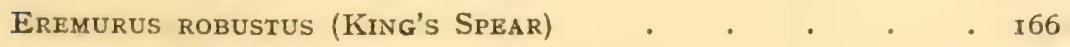

Fabiana imbricata . . . . . . . . . . . . . 66 
Funkia (Plantain lily).

Rose BLush RAMBLER I 66

RHODODENDRON BROUGHTONI AUREUM 170

Gentiana acaulis (Gentianella) I 88

Gentrana septemfida (Gentian) 194

Geraxium (CRANe's BILL) 194

HYDRANGEA HORTENSIS I94

Gentiana lutea (Yellow Gentian) I94

Galega Hartlandi (Goat's Rue) I98

Grass Steps in the Pleasure Grounds 202

GYPSOPHILA REPENS ROSEA 202

IKNIPHofia CAULEscens (TORCH LILY) 202

Habenaria (HaRdy ORChid) 202

Hemerocallis Fulva (DAY LiLy) 206

Heracleum giganteum 206

Hieracium (Haivkweed) . 206

HESPERIS MATRONALIS FLORE PLENO (Rocket) GILIA TRICOLOR

IMPATIENS HYBRIDA (BALSAM)

Iris stylosa (Algerian Iris)

Jasione Jankae (Sheep's Bit Scabious) .

Hardy Perennial Edging Plants.

LEONTOPODIUM MACRANTHUM (EDELIVEISS)

Linum perenne (Blue Flax)

LUPiNus arboreus (Tree LupiN)

Ly'simachia Clethroides .

Oxalis enNeaphylla (WOOD SORkel)

Leucothoe Catesbaei

Linum flatum (Yellow Flax)

Lithospermum intermedium (Gromwell) .

POLYGONUM LANIGERUM

LILIUM CROCEUM (ORANGE LILY) 206 210 - 218 218 - 218 - 218 $2: 26$ - 238 - 246 - 246 - 246 - 246 - 250 - 250 - 250 - 250

Lilium Martagon (Martagon Lily)

LILIUM LONGIFLORUM (WhITE TRUMPET LiLY) 254

LILIUM TESTACEUM (NANKEEN LILY) $25+$

PRIMULA LITTONIANA 254

SAPONARIA OCYMOIDES (SOAPWORT) 266 266 


\section{LIST OF ILLUSTRATIONS}

Magnolia soulangeana (Lily TREe)

274

Meconopsis aculeata (Hrmalayan Poppy) . . . 274

Mimulus cardinalis (Monkey Musk) . . . . . 274

Narcissus Johnstoni, QUEen of SPain . . . . . . . $\quad 274$

Mesembryanthemum (Ice Plant) . . . . . . 278

MESEmbryanthemum CRassulaceum . . . . . . 278

Nephrodium Filix-Mas (Male Fern) . . . . 278

Nymphaea (Water Lily) . . . . . . . . . 278

Magnolia conspicua (Yulan) . . . . . . . . 282

WISTARIA SinENSIS . . . . . . . . . . . . 282

NARCISSUS LADY OF THE SNOWS . . . . . . 286

Nemesia strumosa . . . . . . . . . . . . . 286

Nepeta Mussini . . . . . . . . . . . . 286

NoccaEa ALPINA . . . . . . . . . . . 286

Olearia stellulata (New Zealand Daisy Bush) . . . 300

ONONIS FRUTICOSA (REST HARROW) . . . . 3IO

ONopordon acanthium (COTton Thistle). . . . . 3io

Opuntia (Prickly Pear) . . . . . . . . . 3io

ORCHIS Foliosa (MAdEIRA ORCHIS) . . . . . . 3IO

Hardy Herbaceous Flowers in a Formal Garden. . . 3I4

Flower Borders in AN IRISH GARDEN . . . . . 3I8

Pentstemon Scouleri, the Beautiful Lilac-coloured • 326

Papater nudicaule (Iceland Poppy) . . . . . . 330

Pennisetum Longtstylum . . . . . . . . . 330

Philadelphus coronarius (Mock Orange) . . . . 330

Pyrethrum Pink Pearl . . . . . . . . 330

Picea pungens glauca (Spruce Fir) . . . . . 334

Pratia angulata . . . . . . . . . . 348

Primula bulleyana . . . . . . . . . . . 348

Primula frondosa . . . . . . . . . . 348

Primula Sikkimensis . . . . . . . . . . . 348

Olearia macrodonta . . . . . . . . 364

Ranunculus Flowers . . . . . . . . . . . 374

Rehmannia angulata . . . . . . . . . . 374

RODGERSIA PODOPHYLLA . . . . . . . . . . . 374

RUBUS BIFLORUS . . . . . . . . . . . . . . 374

RHOdOdENDRON Mrs. T. AgNEW . . . . . . 378 
Rose Gloire DE DIJON

Roses and Michaelmas Daisies 382

RUBUS DELICIOSUS 382

RUDBECKIA PURPUREA 382

Rose Dưcuess of Wellington 382

Rose FrançoIs CoppeE 386

Rose May Miller . 386

Rose Mrs. Alfred Tate. 386

SAXIFRAGA BURSERIANA 386

Scolopendrium (Hart's Tongue Fern) 394

SEdUM SPECTABILE (JAPANESE STONECROP) 394

SPIRAEA DECUMbENS 394

Salvia globosa 394

Salvia patens 398

SAXIFRAGA LONGIFOLIA 398

SAXIFraga Wallacei

SAXIFRAga lingulata

Shortia galaCifolia

SisyrinCHIUM STRIATUM

SPIRAEA JAPONICA 398

SCILla Hispanica 398 406 406 406 406

Silene pendula 410 410

Spiraea Aruncus 410

Spiraea Ceres 410

SCHIZOCODON SOLDANHLLOIDES

Sedum CaERuleum

SILENE ALPESTRIS $+14$ $+14$

TUlips IN THE Flower Gardin 414

VIBURNUM MARIESI 430

VIOLA CUCUlLata 460

VERBASCUM DRNSIFLORUM 400

YUCCA FILAMENTOSA. 460

YUCCA GLORIOSA 400 


\section{THE \\ BOOK OF HARDY FLOWERS}

Abelia.-The Abelias are highly decorative shrubs belonging to the Honeysuckle family (Caprifoliaceae). They are not thoroughly hardy, but may be grown in the open ground in the mildest parts of the country and against walls in the Midlands; in northern gardens the protection of a cool greenhouse is necessary. Propagation is easily effected by means of cuttings of young shoots taken during summer and inserted in pots of sandy soil in a closed, warm frame. Light, but rich loamy soil forms a suitable rooting medium, and no regular pruning, other than the removal of the old flower-heads, is required. Abelia grandiflora is a hybrid plant with evergreen leaves and white rose-flushed flowers produced in clusters from the ends of the branches in summer; floribunda, a handsome evergreen shrub, with long tubular red flowers, in April, native of Mexico; serrata, a vigorous shrub from Japan bearing red flowers in April ; and triflora, a tall-growing sort from the temperate Himalaya, with white flowers in summer, are all desirable. Abelia floribunda is the most delicate shrub, and must be given a sunny position against a wall if it is tried out-of-doors.

Abies (Silver Fir).--This group belongs to the cone-bearing trees (Natural Order Coniferae), and the numerous kinds are widely distributed through Europe, the Himalaya, Siberia, Japan, and North America. They are known collectively as Firs, or Silver Firs, and may be distinguished from the Spruces or Spruce Firs by several well-marked characters. In most cases the evergreen leaves are flattened, with blunt or notched ends, and are arranged in distinct rows on either side of the branches; in only one or two kinds do they surround the branches. It is usual to find two silvery lines on the lower surface. The cones, however, offer the chief distinguishing points from their close allies the Spruces (Picea), for they are borne in an upright position upon the branches and break up as soon as the seeds are mature. The cones of the Spruces, on the 
other hand, are pendulous, and do not break up when the seeds are ripe.

Although they are usually grown in this country as ornamental trees, many of the Abies produce valuable timber in their native habitats, and one kind, Abies pectinata, the common Silver Fir of Europe, is used for forest planting in the British Isles; its timber is white, easily worked, and often called White Deal, while the tree is particularly useful for shady places. They are excellent trees for country gardens, where the atmosphere is free from sulphurous and other noxious fumes, but are unsuitable for town planting. The cultural requirements embrace the suitable working of the ground before planting, shallow planting, i.e. placing the upper roots about half an inch below the surface, and the removal of dead inside shoots as well as any of the lower branches that may die or become unsightly. Propagation should be by seeds sown under glass in January or out-of-doors in March, and plants raised by other means must be looked upon with suspicion. Light or heavy loam and sandy peat, providing they are naturally moist but well drained, are alike suitable soils.

The most ornamental kinds are: amabilis, a grey-leaved tree from British Columbia, Oregon, etc.; brachyphylla, a tall, darkleaved tree of symmetrical outline, native of Japan; ccphalonica, the Grecian Fir, grows into a very large tree; concolor, lasiocarpa, and lowiana are Western North American trees of highly decorative character, known collectively as White Firs; firma is a darkleaved tree from Japan, with long deeply notched foliage; magnifica, native of California, forms a handsome specimen; while nobilis, a beautiful glaucous-leaved tree, often suffers from a disfiguring disease in the warmer parts of the British Isles. Other good kinds are : Numidica, Pinsapo, and Veitchii.

Abronia (Sand Verbena). - $\Lambda$ small family of half-hardy annuals and perennials, natives of California, belonging to the Natural Order Nyctaginaceae. They bear pretty Verbena-like flowers during summer and autumn. The plants are of trailing habit, thrive best in light sandy soil and a sunny position, and are suitable for the rockery or front of a flower border. Sow the sceds in a cold frame in antumn, or in a warm greenhouse in February and early March. Isually they are slow to germinate, and should be soaked in warm water for twclve hours previous to sowing. Plant out the young scedlings towards the end of May where they are to flower. Unless the perennials are in a sheltered position some protection must be afforded in winter. The most useful sorts are: arenaria, lemon-yellow, I2 


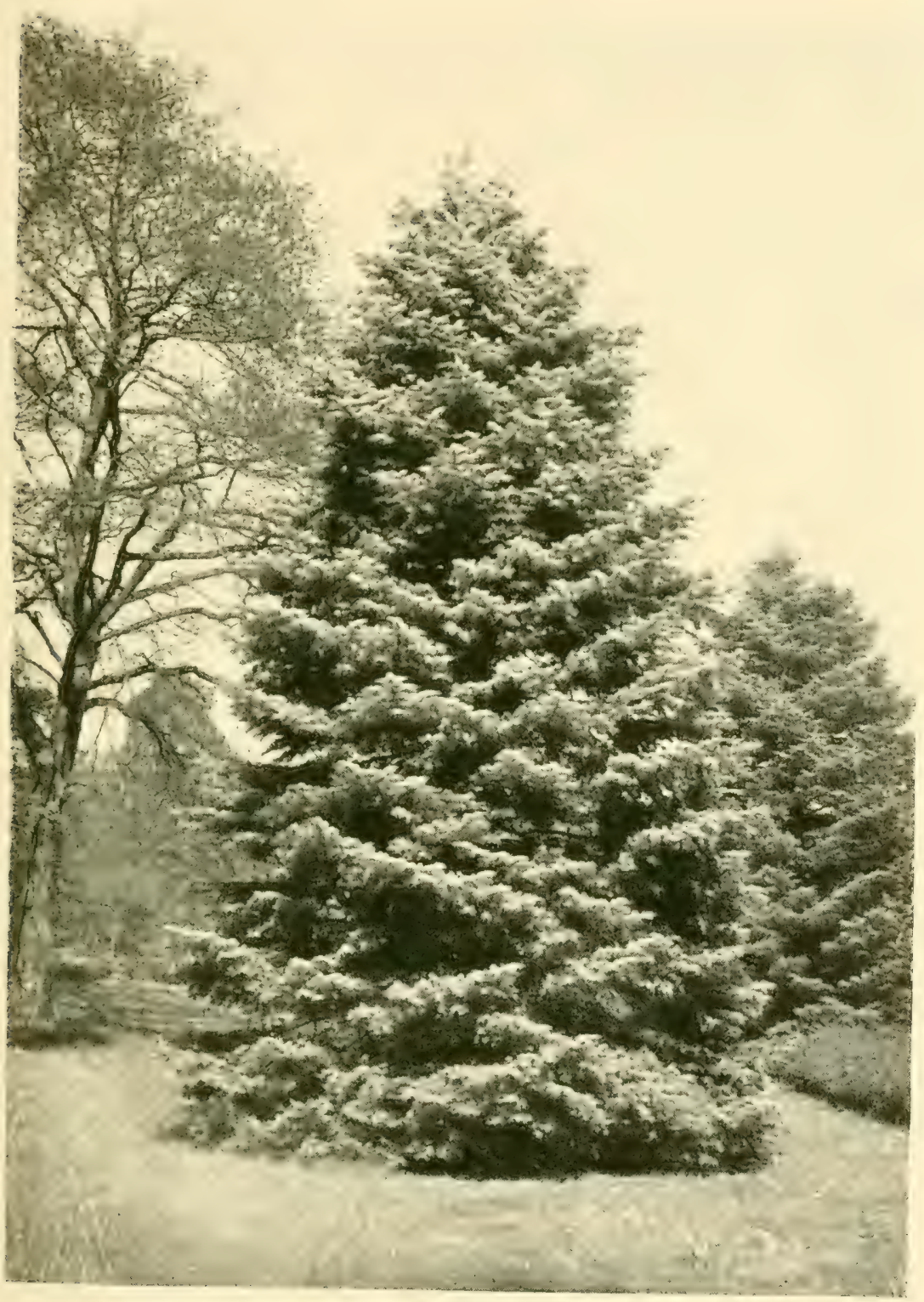

ONE OF THE SILVER FIRS (ABIES LASIOCARPA) 

inches, half-hardy perennial ; fragrans, white, I8 inches, half-hardy perennial; umbellata, rose-coloured, I2 inches, half-hardy annual.

Abutilon (Indian Mallow).-A group of decorative plants belonging to the Mallow family (Malvaceae), composed of numerous species or wild types, and many varieties raised by florists. They are found in tropical Asia, Africa, Brazil, Mexico, Colombia, Chili, and other countries. One kind, Abutilon vitifolium, is hardy in the milder parts of the British Isles; but the majority require the shelter of a greenhouse. They may be grown in pots or borders, and thrive in a compost of 4 parts fibrous loam, I part peat or leaf-mould, and I part coarse sand. When well rooted, manure water must be given once or twice a week. An annual pruning is necessary, February being a good time for the work. Cut all secondary branches back to within a few buds of the base of the previous year's growth. Any necessary repotting may be conducted when the new shoots are about half an inch long. In summer they are very useful for grouping in beds and borders out-of-doors, and thrive in light, rich soil. They are put in the open

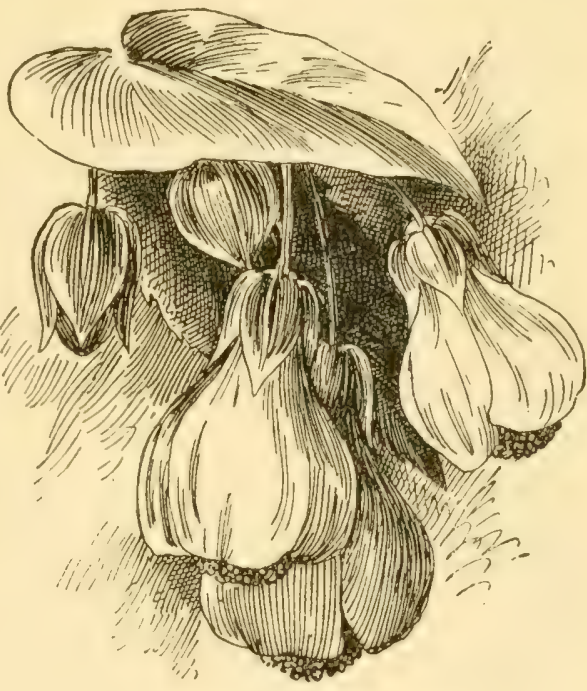

FLOWERS OF ABUTILON early in June and lifted about the end of September; if only small plants are required, insert a few pots of cuttings in the greenhouse during August. Store the old plants in a greenhouse during winter, and in spring, when growth is about to commence, prune the young shoots fairly hard, and repot when new shoots form. Some of them may be taken off and inserted as cuttings if further plants are wanted. Abutilons vary from 2 to 6 feet or even more in height, according to their age and the amount of pruning annually given in spring. Those having attractive foliage are: Savitzii, green and white; Thompsoni, mottled freely with yellow; Megapotamicum variegatum, long slender shoots, rather small leaves, mottled with yellow and green; Souvenir de Bonn, large green leaves, edged with white. Free-flowering Abutilons 
are Golden Fleece, yellow; Boule de Neige, white; Firefly, red; and Clochette, rosy-pink. Abutilon vitifolium, native of Chili, forms a bush from \& to 12 feet high, and bears violet-blue flowers in summer. Abutilons may be readily raised from seeds sown in a heated greenhouse during February and March:

Acacia (False).-(See Robinia.)

Acacia (IVattle).-The Acacias belong to the Pea family (Natural Order Leguminosae), and consist largely of timber trees, native of Australia, though comprising also numerous scrubby trees or bushes which are found in the arid regions of Arabia, East and South Africa, and other countries. The timber of several of the Australian kinds is valuable for furniture and other purposes, and the bark is rich in tannin. Gum, including Gum Arabic and Gum Senegal, is obtained from several of the African and Asiatic species. The flowers of many Australian sorts are very showy, and as several are adapted for growing in pots and blossom when small, they are highly desirable for the greenhouse. Some kinds thrive quite well and form goodsized trees in the open in the milder parts of Cornwall and Ireland, and in other places it is only necessary to protect them from frost. Large quantities of branches of one or two kinds are forced in the south of France and sent to this country during spring under the name Mimosa:

Propagation is effected by means of cuttings of young shoots dibbled into pots of sandy soil composed of 2 parts loam, 2 parts peat, and I part silver sand. The cuttings may be inserted during spring or early summer. Those required for pots must be grown in a warm, moist greenhouse and be stopped several times to induce a bushy habit. A compost made up of equal parts of loam and peat with a fair proportion of sand is necessary. It is often wise to feed the plants with manure water rather than repot frequently after they have reached the flowering size. They ought not to be allowed to bloom before the end of the second year. After flowering, cut the branches back, place the plants in a warm and moist greenlouse until new shoots appear, then repot if necessary. As soon as the roots are working into the new soil well, admit plenty of air, and about mid-June stand the plants out-of-doors in full sun, where they may remain until September. Do not allow them to become dry at the roots at any time. Throughout winter the plants may be grown in an ordinary dwelling-room, if desired. Plants grown in burders uncler glass should be pruned fairly hard after flowering. The following species are suitable for pots or a border under glass: armatia and its varicty angustifolia, Baileyana, cultriformis, Drum- 
mondii, leprosa, myrtifolia, platyptera, Riceana, pulchella, and verticillata. Acacia dealbata is only suitable for planting in a border.

Acaena (New Zealand Bur or Burwood). -Dwarf creeping or trailing plants, with evergreen foliage belonging to the Rose family (Rosaceae). They are easily grown in light soil, and are chiefly used in the rockery, in the crevices of stone paving and rough steps, or as an edging to a border of choice alpine plants. Acaenas are readily propagated by seeds sown in spring or summer, by division of the clumps from October to March, and by cuttings inserted in a cold frame from May to July. The dainty foliage, and the spine-like heads of fruits rather than the tiny flowers, are the chief attractions of Acaena. The following are the best: inermis, foliage bronzegreen, 6 inches; microphylla, close-growing bronze-green foliage, freely interspersed in autumn with spiny crimson heads of fruits, 2 to 3 inches; Novae-Zealandiae, dwarf-spreading growth, metallicbronze foliage, crimson fruits, 3 inches; argentea, metallic-green foliage, quaint spikelets or heads of fruits, 4 to 6 inches. All are natives of New Zealand except argentea, which comes from Chili.

Acalypha.-As they are natives of warm countries, the Acalyphas must be grown in a heated greenhouse in winter, but during summer, from early June until September, they may be planted in beds and borders out of doors, being especially valuable for sub-tropical bedding, in which plants with striking foliage are chiefly used. They belong to the Spurge family (Euphorbiaceae). The undermentioned kinds have inconspicuous flowers, borne on spikes which develop in the axils of the leaves during summer; their value lies in the handsome highly coloured leaves, which are large and beautifully variegated. Increase is by cuttings inserted during August or in spring. The plants may be "grown on" for several years: when in large pots or tubs they are invaluable for sunny but sheltered positions in the garden. If it is found necessary to limit the size of the plants slight pruning is practised in autumn and fairly hard pruning in early March. As a potting soil use equal parts loam, leaf-mould, and peat, with coarse sand. The best Acalyphas for sub-tropicalgardening are: Macafeeana, red, blotched bronze-crimson, Fiji ; macrophylla, russet-brown, pale blotches ; marginata, rich brown, margined rosy-carmine, India; musaica, bronzegreen, mottled with red and orange, Polynesia ; tricolor (or wilkesiana), copper-green, mottled with red and crimson, New Hebrides. The colour description refers to the leaves. The plants vary from $\mathrm{I}_{\frac{1}{2}}$ to 6 feet or more, according to the method of pruning. When only small plants are wanted root sufficient cuttings annually in August and discard the old plants in autumn: 
Acantholimon (Prickly Thrifl).-A small family of dwarf-tufted evergreen plants belonging to the Natural Order Plantagineae, which includes the Common Thrift. They are natives of Asia Minor, and, growing only 3 to $6 \mathrm{in}$. in height, are suitable for the rockery or the front row of the flower border. Propagation is by seeds sown in a cold frame in spring, by cuttings inserted during August or September, also in a coll frame, and by division in March or early April, this being the best time to replant, though if the plants are happy it is better not to disturb them. Sandy loam is a suitable soil, and a sunny position should be chosen. The best kind and that usually grown is Acantholimon glumaceum (sometimes called Statice Ararati), which forms a close-growing cushion of deep green spiny foliage. The wiry flower stalks push up to a height of some 6 inches in summer, each bearing six or more rose-coloured flowers $\frac{1}{2}$ inch across. A second lind is Acantholimon venustum, with rose-coloured flowers; it is rather larger in every way than the preceding, but is a rarer plant.

Acanthopanax.--This group belongs to the Aralia family (Araliaceae), and consists of trees and shrubs found in China and Japan. Three hardy kinds have been introduced, viz. ricinifolium, a timber tree with ornamental leaves, native of both countries; sessiliflorum, a rather uninteresting bush from China; and spinosum, a Chinese and Japanese bush. The last-named may be distinguished by its five-lubed leaves; its variety variegatum has pretty golden variegated leaves. They thrive in ordinary garden soil, and require no regular pruning. Propagation is by means of seed sown out-ofdours in early autumn. The variegated variety is increased by cuttings taken in July or September.

Acanthus (Bear's Breech).--Interesting hardy perennials belonging to the Natural Order Acanthaceae, and native of Southern Europe. The foliage is ornamental, being prettily divided, while from early July to Octuber bold spikes of purple and white flowers ase produced. l'ropagation is by division of the clumps in March, and by seeds sown in a greenhouse or frame from April to June. The plants will thrive in ordinary garden soil, except that which is heavy and ill-drained; the jusition may be in full sun or half-shady. Acanthus are not among the plants one would recommend for a small border of choice herbaceous perennials, but they deserve inclusion in a large border, are very pretty in groups along the front of the shrubbery border, make an attractive bed for a lawn, and may be freely used in the wilil garden. The most useful kinds are : longifolius, leaves 2 to 3 feet lon: flower spikes 3 to 4 feet high; mollis, prettily divided foliage, 


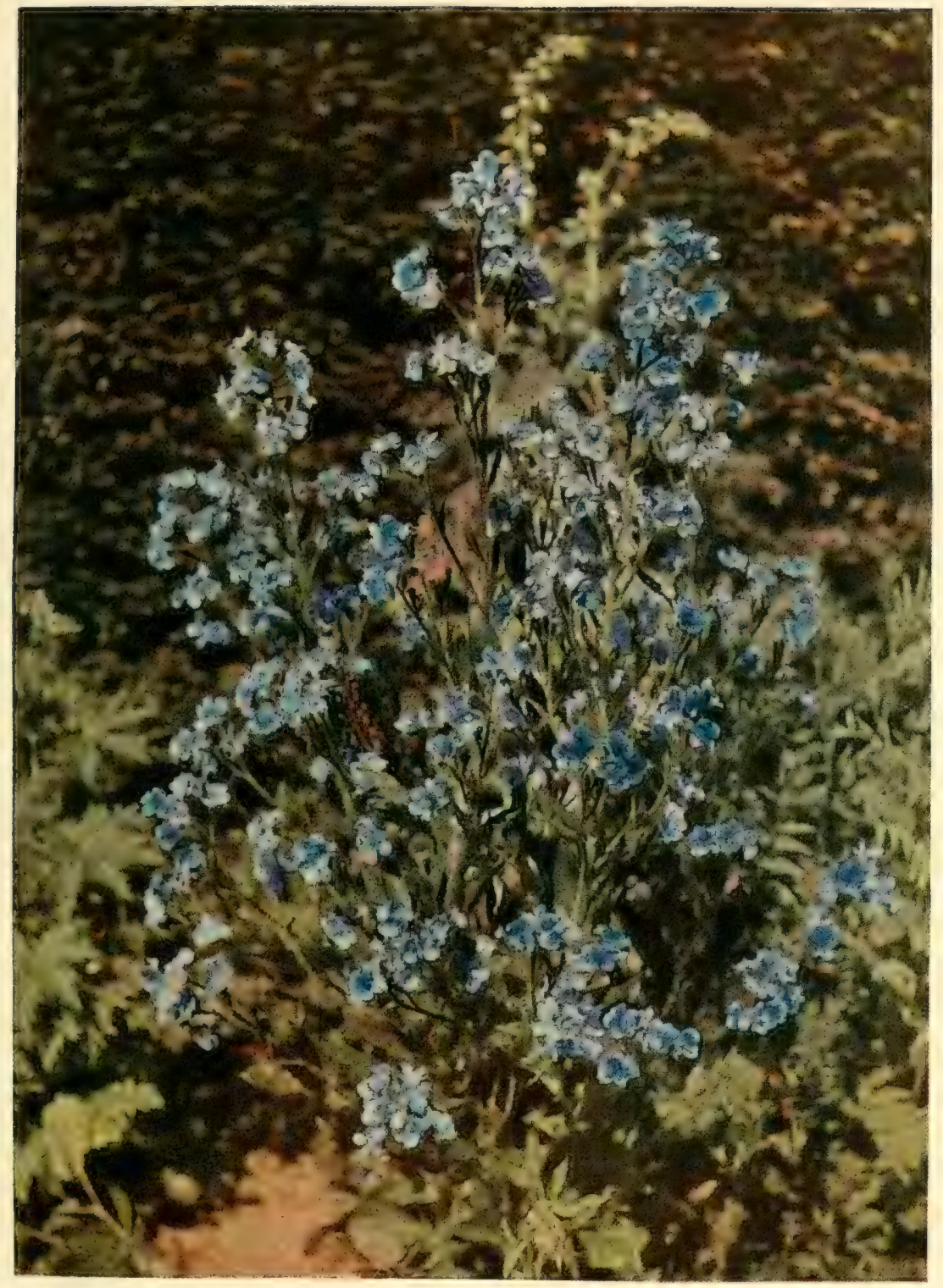

THE ITALIAN ALIEANET IANCIUUSA IT'LICA "OPAL " 

3 feet; var. latifolius, very useful for bedding, 5 feet, and spinosus, attractive spiny foliage, 2 to 3 feet.

Acer (Maple).-Large-growing trees and bushes, members of the Natural Order Sapindaceae. They are commonly called Maples, and are distributed through Europe, the Himalaya, China, Japan, and North America, several being important timber trees, whilst the sap of the North American Acer saccharinum provides Maple sugar: Two kinds, Pseudo-platanus (the Sycamore) and platanoides (the Norway Maple), are grown in this country for the sake of their timber, which is used largely for the rollers of mangles and washing-machines; whilst the wood of the Common Maple (campestre) is also of value. All the large-growing sorts are valuable for decorative planting, and may be used as isolated specimens, groups, or avenue trees. A group of dwarf kinds, known collectively as Japanese Maples, is composed of numerous varieties of Acer palmatum and japonicum. These varieties are attractive both by reason of their finely lobed leaves and the brilliant colouring of their foliage in spring and again in autumn. They are excellent for the outdoor garden, except in the coldest part; of the country, and are also useful for growing in pots for the greenhouse or conservatory in spring.

The Acers thrive in almost any kind of well-drained soil, but prefer that of a loamy character. Most of them have broad, conspicuously lobed leaves, but a few have pinnate leaves. There are numerous kinds with variegated foliage which are popular for ornamental planting. Seeds are usually used for the increase of species, whilst varieties are propagated by layering, budding, or grafting. Pruning should be limited to keeping the leaders clear of rivals and the removal of lower branches when necessary.

The following are among the best: campestre, Europe, 20 to 40 feet, and its vars. compactum and variegatum; carpinifolium, Japan, 20 to 30 feet, distinct foliage; circinatum, California, 8 to I5 feet, leaves colour brilliantly in autumn; dasycarpum (Silver Maple), Eastern North America, large tree, lower surface of leaves silvery ; japonicum, Japan, bush, showy leaves; also vars. aureum, microphyllum, etc.; macrophyllum, California, large tree, fine inflorescences; negundo (Box Elder), United States, 40 feet, pinnate leaves; the variety variegatum, with green and silver leaves, is a popular small tree.

Acer palmatum, from Japan, is a bush with decorative leaves; the following are beautiful varieties: crispum, roseo-marginatum, sanguineum, septemlobum, atropurpureum, elegans, dissectum, etc.

Other kinds are : platanoides (Norway Maple), Europe, large tree; 


\section{THE BOOK OF HARDY FLOWERS}

Pseudo-platanus (Sycamore), Central Europe and Western Asia, large tree; and its varieties, flavo-marginatum (Corstorphine Plane), golden variegated leaves, Prinz Handjery, golden leaves; purpureum, purple leaves. Acer rubrum (Red Maple), North America, is a large tree, red flowers, silvery bark; Volxemi, from the Caucasus, is a vigorous tree with large leaves.

Aceras anthropophora (Green: Man Orchis).-This is one of the British terrestrial Orchids (Natural Order Orchideae) fuund growing will in chalky meadow land in the south-eastern counties. This kind of soil must be introduced for its successful cultivation in the rockery or in the border devoted to the growing of rare and interesting treasures. Increase is by careful division of the tubers in autumn. The flowering season is June, when a spike of greenish flowers, lined or margined with red, Io to I2 inches high, appears.

Achillea (Milfoil or Yarrow). - This is rather an important class of hardy perennials belonging to the Daisy family (Compositae), and chiefly native of Europe. They are easily grown, and thrive in most soils and in a sunny or half-shaded position. Several of the taller growing sorts are important border plants, while those of dwarf habit are valuable in the rock garden. Propagation is by division during mild weather from the end of October to March, when replanting may also be done. Seeds may be sown during April or May in a cold frame or out-of-doors; another method of increase is to insert some of the young growths as cuttings in late spring when about 2 inches long. They root readily in a closed frame. The foliage of the Milfoils is distinctly ornamental, being more or less finely cut. The flowering season is from June until September. Several are very useful for supplying cut flowers for indoor decoration, notably Achillea Ptarmica The Pearl.

The best border kinds are: filipendulina (syn. Eupatorium), flat corymbs of golden-yellow flowers, 3 to 4 feet; Millefolium roseum or Corise Queen, rosy-crimson, $2 \frac{1}{2}$ to 3 feet; Ptarmica The Pearl, a double Sneezewort. pure white double flowers, 2 feet (Perry's variety has larger, double white flowers, and grows some 6 inches taller); sihirica (syn. mongulica), white, I to 2 feet; decolorans (syn. serrata) flore pleno, white llowers, pretty serrated foliage, 2 feet. Useful linds for the ruck garden and front of flower borders are: Clavennae, white, silvery foliage, 6 inches ; rupestris, pure white, pleasing rieh gren cuthion of evergreen leaves, 4 inches; compacta (Estn. sericea), white flowers. silvery rosettes of leaves, 6 inches, from the Orieat; tomentosa, a splendid plant with fern-like foliage and rich 
golden-yellow flower heads, 9 to I2 inches; umbellata, white flowers and silvery-white foliage, 6 inches.

Aconite, Winter.-(See ERANTHIS.)

Aconitum (Monkshood, Wolf s-bane).-C'seful herbaceous plants belonging to the Buttercup family (Ranunculaceae). The roots are poisonous. One kind (Aconitum Napel. lus) grows wild in the western counties and Wales. The Monkshoods thrive in ordinary garden soil in sunny or shaded positions; they are among the best perennials for a north border, while in the wild garden and shrubbery borders the blue flowers are indispensable. Propagation is by seeds sown on a border out-of-doors from April to June, and by division of the roots during M a r ch. When

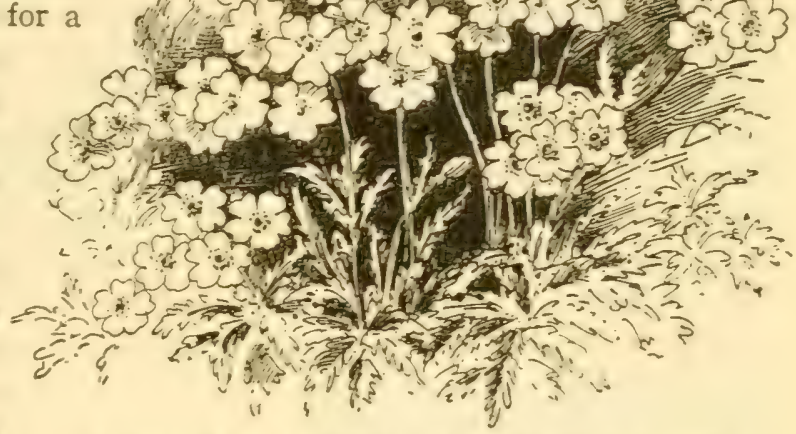

ACHILLEA CLAVENNAE, A YARROW FOR THE ROCK GARDEN

thriving and flowering freely leave the plants undisturbed for some years. The flowering season extends from June to October. The best kinds are: Fischeri, clear blue, September to October, 3 feet; japonicum, deep violet-blue, September and October, 3 to 4 feet; Napellus (the Common Monkshood), indigo-blue, June to September, 5 to 6 feet, in good soil ; var. album is white; var. bicolor, blue and white; and var. pyramidale, bluish-purple, July to September; Hemsleyanum, a twining Chinese plant some 6 feet high, purple, July to September; Wilsoni, violet, September to October, 5 to 6 feet, China.

Acorus (Sweet Flag or Myrtle Sedge).-For the sides of streams, ponds, and lakes this is an indispensable water plant (Natural Order Aroideae), but it is apt to increase rapidly, and unless checked will soon spoil other less vigorous ones. Propagate by division of the clumps from October to March, this also being the time for planting. There are two species: Calamus, wild in the Northern Hemisphere, with sword-shaped leaves about 3 feet high, and inconspicuous yellow 
flowers borne, in summer, on a cylindrical spadix, 4 or 5 inches long (var. variegatus is a very desirable waterside plant, with gold-striped leaves); gramineus, a smaller plant than the preceding, with grasslike leaves, is native of Japan (var. variegatus forms pleasing tufts of green and white striped leaves).

Acroclinium (A $A$ stralian Immortelle).-A dainty half-hardy annual with "everlasting" flowers, native of Australia; it belongs to the Daisy family (Compositae). The only kind is Acroclinium roseum, native of South-West Australia. A warm, sunny border and rather light sandy soil suit it best. Sow the seeds in a cool greenhouse or frame towards the end of March; or out-of-doors, the second half of April, where the plants are to flower. The best effect is obtained when the plants are only some 2 inches apart, so the seeds must be sown fairly thickly. The flowers are a pleasing rosy shade, and are borne singly on erect slender growths, about 12 inches high. The variety album has white flowers; flore albo pleno and flore roseo pleno are sorts with double white and double rose-coloured flowers respectively. If required for winter decoration, gather the blooms when quite dry and fully expanded, tie them in small bunches, and hang up, flower-heads downwards, in an airy shed to dry. The flower-heads are some $\$$ inch across with conspicuous golden-yellow centre:

Actaea (Bane-berry or Herb Christopher).--The Actaeas are herbaceous plants, belonging to the Buttercup family (Ranunculaceae). They have elegant fern-like foliage and graceful racemes of feathery white flowers during June and July, followed in autumn by red, white, or black berries. Propagation is chiefly by division of the clumps in late autumn or March, which is also the best time for planting; also by seeds sown from April to June in a cold frame. For preference, when planting choose a position which is not too hot and dry; an ideal spot is a moist, half-shaded border containing plenty of decayed leaf-mould in which the roots can ramble. There are only two species: alba, white berries, 2 feet, North America ; spicata, black berries, 12 to $\mathrm{I} S$ inches, Northern Hemisphere. Spicata rubra has scarlet berries.

Actinldia Chinensis is a most interesting plant, member of the family or Natural Order Ternstroemiaceac. It is a native of China, and was introduced to England about fourteen years ago. A vigorous climber, it may be planted against a wall, trellis, pergola, or small tree, in deep luamy soil. Weak ends of branches should be removed in spring. Its principal attraction lies in the reddish-purple hairs which form a dense covering to the young leaves and branches. The 


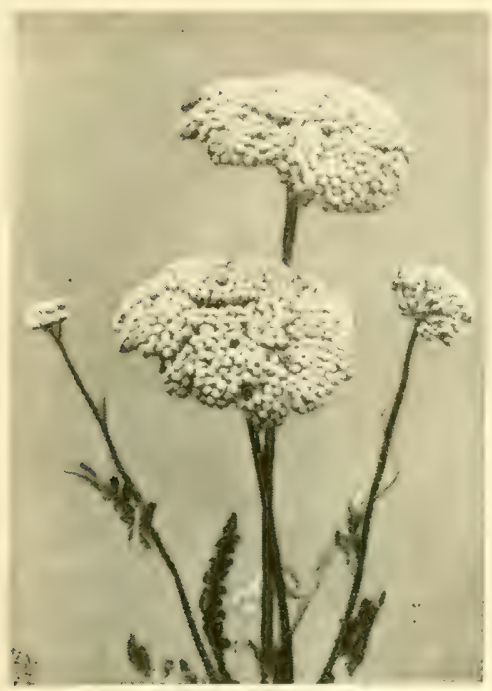

YELLOW MILFOIL (ACHILLEA FILIPENDULINA)

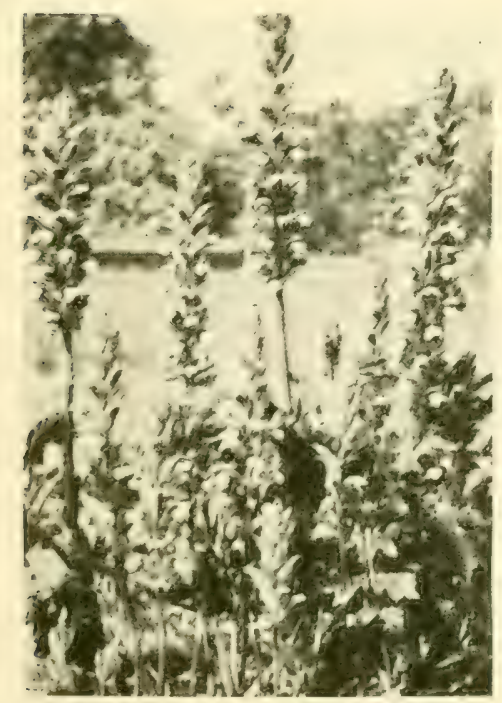

BEAR'S BREECH (ACANTHUS MOLLIS)

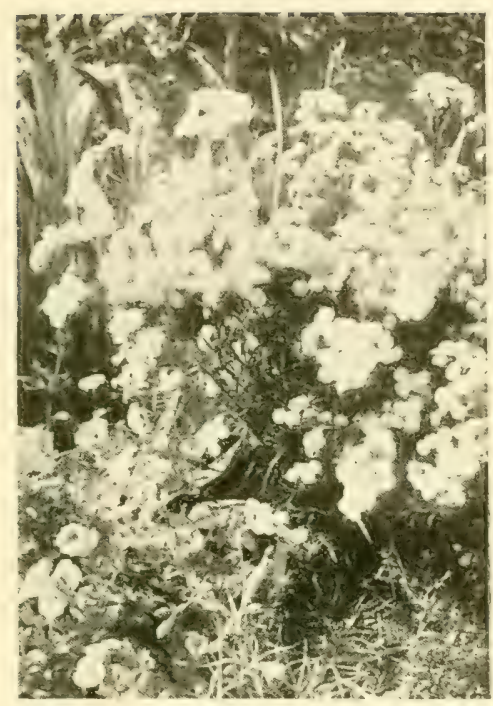

DOUBLE WHITE MILFOIL (ACHILLEA PTARMICA), PERRY'S WHITE

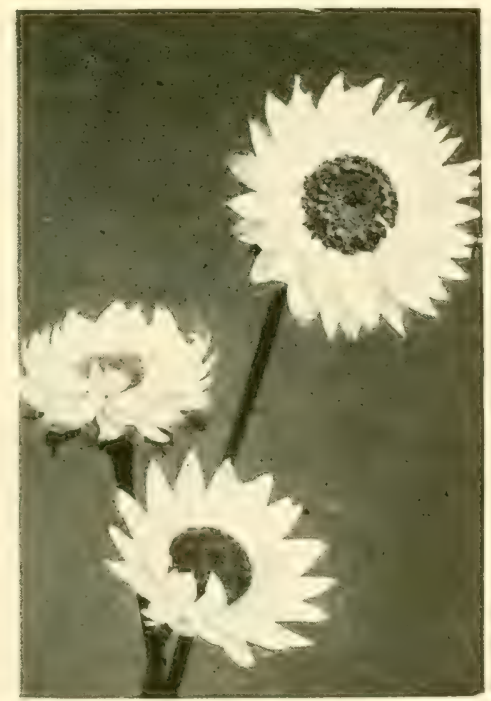

FAIRY IMMORTELLE (ACROCLINIUM ROSEUM) 

yellow flowers are upwards of I inch across, and the fruits are edible. Cuttings will root if placed in light soil in a close frame during summer. Actinidia arguta, Kolomikta, and polygama are coarsegrowing Japanese kinds. They do not require regular pruning. All are deciduous.

\section{Adam's Needle.-(See YuccA.) \\ Adder's Tongue.-(See Ophroglossum.)}

Adenocarpus decorticans is a Spanish shrub belonging to the Pea family (Leguminosae). Its chief attraction centres in the golden Broom-like blossoms, which are borne in profusion in May. As it is rather tender, a sunny position-preferably in the rock garden or at the foot of a wall-should be provided, and better results may be expected by planting it in light loam than in very rich soil. It forms a dense bush 2 feet or so high, and is usually increased by seeds in spring. No regular pruning is required.

Adenophora (Gland Bellflower).-A group of border perennials allied to the Campanulas, from which they are distinguished by a gland or nectary surrounding the base of the style. They belong to the Bellflower family (Campanulaceae). The plants thrive in a light, rich, rather moist soil and a sunny position. Increase is by seeds sown as soon as ripe or during spring in a cold frame. March is the time to plant ; but so long as the plants continue to thrive and blossom, leave them alone; few perennials suffer more from disturbance at the roots. Six of the best are: latifolia (syn. pereskiaefolia), blue, one to three drooping flowers on a stalk, July and August, $I_{\frac{1}{2}}$ feet, Siberia ; liliifolia, fragrant blue flowers, freely borne on a loose pyramidal inflorescence, July and August, I foot, Europe; polymorpha, large blue flowers, July and August, 2 feet, China; Potanini, pale blue, bell-shaped blooms on slender spikes, July and August, I $I_{2}^{\frac{1}{2}}$ to 2 feet, Turkestan-there is a white variety of this kind; stricta, with large blue flowers in July, grows 2 feet high, and is a native of Japan.

Adiantum (Maidenhair Fern).-Only two of the large number of Adiantum, members of the Fern family (Filices), can be cultivated out-of-doors successfully in this country, and one of these, our native British Maidenhair (Adiantum Capillus-Veneris) is hardy only in the south and west unless the position is unusually warm and sheltered. The most suitable soil for Maidenhair Ferns is a mixture of loam, peat, and leaf-mould with some coarse sand. Increase is by division of the clumps in spring. Plant in shady nooks of the rockery or in a moist, shady border. Adiantum Capillus-Veneris is an evergreen Fern, growing some 6 to 9 inches in height; it is widely distributed 
in the warmer temperate regions, including Britain; pedatum, a North American kind, is hardier, and thrives freely outside with the Hart's Tongues and Polypods. The elegantly branched and divided fronds attain from $I_{2}$ to $2 \frac{1}{2}$ feet in height. When the fronds die down in autumn, cover the roots for the winter with 2 or 3 inches of decayed leaves.

Adlumia cirrhosa (Climbing Flimitory).--This is a climbing biennial from North America, suitable for trailing over a trellis, veranda, or arbour in a sunny position; it belongs to the Poppy family (Papaveraceae). The plants thrive in ordinary light, welldrained garden soil. Sow the seeds from May to July where the plants are to blossom the following year. Under favourable conditions, self-sown seedlings germinate annually in autumn. The twining growths attain a height of from I $2_{2}$ to $I_{5}$ feet, having delicate green tripinnate foliage suggestive of a Maidenhair Fern. There are two forms, one with white, the other with rose-tinted flowers; these are tubular, about $\frac{1}{2}$ inch long, usually in clusters of four together, and are at their best in June.

Adonis (Pheasant's Eye; Ox-eye; Flower of Adonis).-A group) of annual and perennial plants, members of the Buttercup family (Ranunculaceae), flowering in spring and summer. The finest perennial species is Adonis amurensis, with rich yellow flowers, resembling a giant Buttercup, from February to April, Fern-like foliage, I foot, native of Manchuria; this is a charming plant for a sheltered corner in the rock garden, or at the foot of a south-west wall or fence; its double variety, flore pleno, is handsome. Other kinds are : pyrenaica, bright yellow, April to June, I foot, Pyrenees; vernalis, clear yellow, March to May, 6 to 9 inches, Europe. They thrive in a mixture of loam and leaf-mould, and are increased by division in September and October. The plants bloom best when left undisturbed for some years. The annual kinds are: autumnalis (Red Chamomile), scarlet, July, I foot, Europe, etc.; and aestivalis, crimson, June, I foot, Europe, Orient. Sow the seeds late in March or during April where the plants are to flower; select a sunny or half-shaded border, where the soil is rather light and well drained.

Aogle.-The best-known species of this group of plants, which belongs to the Rue family' (Rutaceac), is Aegle sepiaria, a green-branched bush armel with strong formidable spines, and bearing three-parted deciluous leaves, large white flowers, and orange-like fruits; it is a native of China and Japan, and may be grown as an isolated bush or in the shrubbery, in loamy soil, or in the south it might be employed for heiges. Cuttings root readily in summer in sandy soil in a close 
frame. A second species, Aegle marmelos, native of India, is sometimes grown in hothouses. Its fruits, known as Bael fruits, are astringent, and used in cases of dysentery. Unless grown as a hedge plant, Aegle does not require pruning, except such as is necessary to keep the plants shapely when young. Hedges may be clipped any time during summer.

Aesculus (Chestmut). - This group (Natural Order Sapindaceae) is composed of large- or small-growing deciduous trees and a few shrubs, all of which are of decorative value. It now includes all the trees which were at one time known as Pavia, there being no distinct dividing line between the various kinds. The most familiar representative is the Horse Chestnut, a native of the mountains of Greece, and one of the most popular ornamental trees in European gardens. Other kinds occur in the Himalaya, China, and the United States. The timber is soft, light, and white in colour, its clean appearance making it popular for turnery, the backs of brushes, kitchen and dairy requisites, etc. All the Aesculus (or Chestnuts, as they are called in Europe, and Buckeyes in America) are easily grown in any fairly good soil, while the common kind thrives in the lightest ground. They may be planted almost anywhere from mid-Scotland southwards, except in smoky towns, for which they are not adapted. Propagation of the true species or wild types is by seeds, sown as soon as ripe, and of the varieties and hybrids by grafting in March, or budding in July. Pruning is necessary during the early years to encourage proper development and a shapely habit. Later it is confined to the removal of dead or injured branches.

The following are the chief kinds : californica, a small wide-headed tree from California, which bears large inflorescences of white flowers in July; carnea, well known as the Red-flowered Horse Chestnut ; it is of hybrid origin, and a very popular kind for lawn planting, the inflorescences of red flowers are very handsome; the variety Briotii, however, is even better than the type. Flava is the Sweet Buckeye of North America, its chief charm lies in its yellow flowers; glabra, the Ohio Buckeye, forms a medium-sized tree, and bears yellowish flowers. Hippocastanum, the Common Horse Chestnut, is one of the most beautiful and useful of all flowering trees, whether for planting in groups, as isolated specimens, or to form an avenue, its appearance is too well known to need description; the variety flore pleno bears double flowers, and pyramidalis is of fastigiate habit. Indica, the Indian Horse Chestnut, is a native of the Western Himalaya; it has handsome leaves, and the flowers, which appear in July, are similar to those of the Common Horse Chestnut. Parviflora well deserves 


\section{THE BOOK OF HARDY FLOWERS}

consideration by reason of its shrubby habit and late flowering; it forms a dense bush $S$ to 12 feet high, and produces fine panicles of white flowers in August ; chinensis and turbinata are two new Chinese species with handsome foliage; they have not yet flowered in this country.

Aethionema (Burnt Candytuft).-A small family of hardy perennials and annuals allied to the Wallflower, and belonging to the Wallflower family (Cruciferae). They thrive in light, rather dry soils, and succeed best, as a rule, on a sunny rockery or along the front of the flower border. Sow seeds of the annual species in April where the plants are to flower, and of the perennials in a cold frame or out-ofdoors from April to June. The latter are also propagated by cuttings inserted in a cold frame or under a handlight during late summer. The best perennials are: coridifolium (Lebanon Candytuft), with close terminal heads of rosy-pink flowers, June to August, I foot, Orient; grandiflorum (Persian Candytuft), pink, summer, I foot, Persia ; persicum, pink, June to August, 9 inches, Persia ; pulchellum, purplishpink, June to July, 6 inches, Armenia. The best annual kind is cappadocicum, rose, June to July, 3 inches, Orient.

African Lily.-(See Agapanthus.)

African Marigold.-(See TAGETES.)

Agapanthus (African Lily).-Though usually cultivated in pots and kept in a frame or cool greenhouse during winter, the Agapanthus, which belongs to the Lily family (Liliaceae), may be grown outdoors in the south and west, also in many suburban gardens in the London district at the foot of a south wall, providing the roots are protected by a heap of ashes. Whichever method is practised, the African Lily and its numerous varieties are very desirable plants. In large pots or tubs they are especially attractive when in flower during August and September, and are then commonly used for placing on terraces, steps, etc. The best method of increase is by division of the clumps in March or early April. Loamy (turfy) soil, with the addition of leaf-mould and old decayed manure, forms a suitable compost for plants in pots; but those out-of-cloors must be in well-drained light loam. During summer the Agapanthus delights in an abundance of water and liquid manure; in fact, in hot, dry weather it revels in water, and plants are often plunged in the ground by the side of a pond. Repotting is seldom desirable; when necessary, it should be done in spring. The Agapanthus is a native of the Cape of Good Hope, and was first introduced to Britain in 1692 . The varieties vary considerably in size of leaf and height of the flower spikes. The typical kind, umbellatus, has bright blue funnel-shaped flowers, borne in an umbel or cluster on a stalk 2 to 


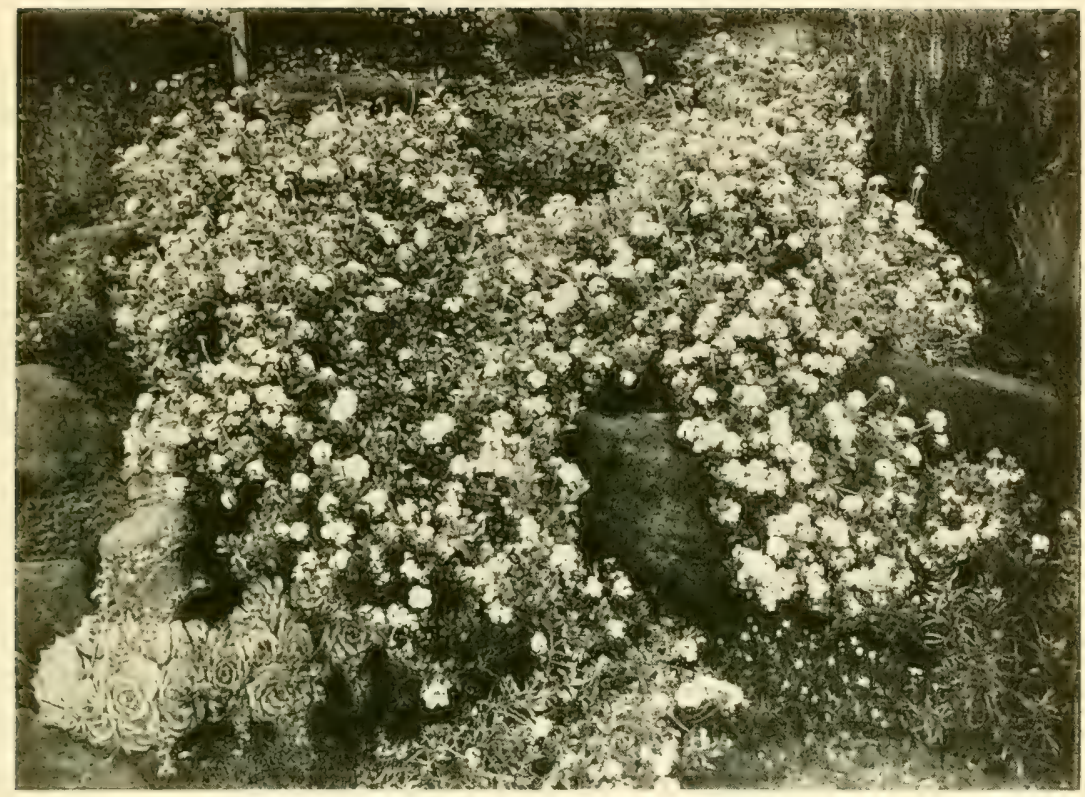

A ROCK JASMINE (ANDROSACE LANUGINOSA)

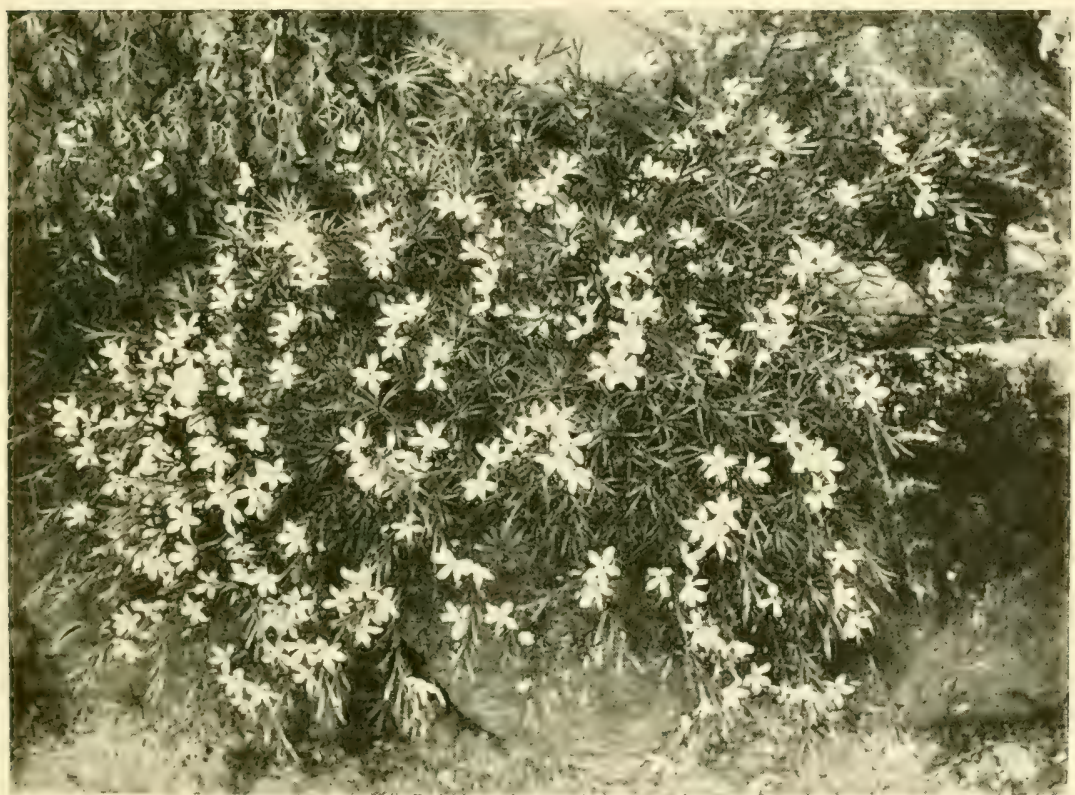

PRICKLY THRIFT (ACANTHOLIMON VENUSTUM) 

3 feet high; var. alba is similar, but with beautiful white blooms; var. flore pleno is double blue; var. maximus is more vigorous, larger in all its parts, and a handsome plant; var. minor is a dainty little kind, less than $I$ foot in height. Mooreanus is dark blue, I f feet, and var. variegatus has green and white-striped leaves.

Agathaea caelestis (Blue Daisy).-This is a pretty South African plant, with blue, Daisy-like flowers, and a member of the great Daisy family (Compositae). Though really a greenhouse plant, it blooms freely for several months in summer, June to September, when planted in beds and warm borders out-of-doors. In one or two of the London parks the Blue Daisy is largely grown for summer bedding. The plants are bushy in habit, growing from I foot to $I \frac{1}{2}$ feet in height. Increase is by cuttings inserted during August in a frame or greenhouse. During winter, keep the plants on a shelf in a greenhouse, pot singly in $3 \frac{1}{2}$ - or 4 -inch pots in March, harden off by placing the plants in a cold frame the first week in May, and at the end of that month or early in June plant them outside in beds or borders. The Blue Daisy thrives in a rather light soil made up of sandy loam and leaf-mould. There is a variety in which the leaves are spotted or blotched with yellow.

Agave (American or Mexican Aloe). - The Agaves are chiefly natives of Mexico, and belong to the Amaryllis family (Amaryllidaceae). They are striking plants for growing in large pots or tubs for the embellishment of steps, terrace walks and formal gardens in summer. Small plants are valued as "dot " plants in carpet bedding and beds of succulent plants. Agaves are propagated from suckers which push up around the parent plant, and by seeds sown in a greenhouse from March to July. A mixture of 3 parts loam and I part old mortar rubble and bricks constitutes a suitable soil. When repotting becomes necessary, which is not often, it should be done in spring. Agaves are of slow growth, and it is probably this fact which has led to their being designated " Century Plants," the theory being that the plants flower once in a hundred years. The facts are that they attain a considerable age before they flower-it may be twenty to fifty years or more-and after having flowered they die. During winter Agaves must be preserved from frost either in a cool greenhouse or a frost-proof shed where they can get a little light. The most popular and largely grown species is Agave americana, while its variety variegata, with green yellow-margined leaves, is even more striking. These plants in time grow to a large size, with thick, fleshy, spiny leaves 3 to 6 feet long and 6 to 9 inches wide. The crowning point of their life is reached when a tall strong stem gradually pushes 
up, and by the time the immense panicle of small yellowish-green flowers opens it has reached a height of 10 to 20 feet. Soon after the inflorescence dies a watch must be kept for suckers (growths from the base), or seeds may possibly be had.

Ageratum (Floss Flower). - In Ageratum mexicanum, member of the Daisy family (Compositae), we possess a most useful bedding plant, readily propagated either from seeds sown in warmth during February and March, or by cuttings. A few of the latter are inserted during August, kept in a heated greenhouse luring winter, then in spring, February and March, when the plants are growing freely, lots of cuttings can be taken off and made to form roots in a propagating frame. They make quick progress, and by June will be good plants, 3 or 4 inches high, ready to plant out in the beds and borders. Ageratums delight in a light, rich soil in which leafmould has been mixed. The plants flower freely from June until October, and are only then spoilt by frosts. The typical kind, Ageratum mexicanum, grows about 2 feet in height. Under cultivation the wild Mexican plant has been wonderfully improved, and we have now a number of named sorts varying from 4 inches to 2 feet in height. Seedlings from a reliable source come true with few exceptions, though many gardeners prefer, when using Ageratums for bedding, to raise plants from cuttings. Swanley Blue, lilac-blue; Tapis Blanc, white; The Zoo, blue; Princess Pauline, dwarf lilac-mauve; Dwarf Blue Perfection, and Compactum nanum album, are all good sorts. Then from seeds one can grow Imperial Dwarf Blue, 9 inches; Dwarf White, 9 inches; Little Blue Star, 4 inches, very dwarf and free, valuable as an edging to beds and borders. There are also the ordinary selected strains, Tall Blue and Tall White, $I_{2}^{\frac{1}{2}}$ to 2 feet in height.

Agrimonia (Agrimony).-This is a small group of hardy herbaceous perennials allied to the Potentilla and Geum, and belonging to the Rose family (Rosaceae). They are easily grown, thriving in ordinary garden soil. Increase is by division of the clumps from October to March, or by seeds sown on a border outside from April to June. About six species are in cultivation; the best known are: Agrimonia Eupatoria, small yellow flowers on long slender spikes in June and July, a common plant in the Northern Hemsiphere, including Britain, useful for the wild garden and for planting by the side of a woodland walk, thrives in sun or partial shade, 2 feet; odorata, yellow flowers on long slender spikes, native of Europe, 3 to 4 feet, usually referred to as the Sweet-scented Agrimony.

Agrostemma (Rose Campion).-A small class of hardy perennials and annuals allied to the Lychnis; in fact, some botanists include 
them in that family, but among growers of old-fashioned hardy plants the name Agrostemma is still used. They belong to the Pink family (Caryophyllaceae). They are easily grown, and showy border plants, thriving in common garden soil. The perennials may be increased by division during mild weather from October to March, and by seeds sown outside from April to June. Sow seeds of the annuals during March and April, where the plants are to blossom. Agrostemma Coeli-rosa (Rose of Heaven), rose, white, or purple flowers, is an annual growing about $\mathrm{I}$ foot high, flowering in summer, native of Levant; coronaria, rosy-red, white, and crimson, June and August, is a favourite perennial border plant in cottage and country gardens, thriving in sun or partial shade, and often grown among hardy ferns, where self-sown seedlings establish themselves; the plant has silvery-white foliage and stems, and when in flower is about 2 feet high and almost as much through ; native of Southern Europe. There are several named varieties of this kind (though these can all be obtained from a packet of seeds): for instance, alba, white; bicolor, white, red centre; atrosanguinea, crimson-purple. Agrostemma Flos-Jovis (Flower of Jove) has rose-pink flowers, June to September, and downy grey foliage, $I \frac{1}{2}$ to 2 feet; it is perennial, and native of Switzerland.

Agrostis (Cloud Grass, Spear Grass).--Interesting and elegant flowering grasses (Natural Order Gramineae), prized for cutting, and useful either green or in a dried state in vases with flowers. Agrostis laxiflora and nebulosa, I5 inches, are both European annuals and those most generally cultivated. Sow seeds outside in April where the grasses are to flower, or in patches and rows, so that when several inches high they can be lifted in small tufts and planted where required to flower in summer. The Cloud Grasses prefer a moderately light loamy soil.

Ailanthus glandulosa (Tree of Heaven). - This Chinese tree grows to a height of from 80 to roo feet, and is well adapted for the climate of the British Isles. It thrives in a great variety of soils and positions, and is attractive by reason of its long pinnate leaves and red fruits, which resemble those of the Ash. Of rapid growth, trees forty years old may be 60 feet high if growing in good loamy soil. Young trees planted in rich loam often produce leaves 4 feet in length, and it is customary to plant groups of them, and cut them to the ground each year, solely for the sake of the large leaves produced by the fresh annual shoots. Suckers, or shoots from the base, are produced, and may be used for propagation, though layers and seeds in March are often preferred. A new Chinese species, Ailanthus vilmoriniana, differs from the other kind in having spiny bark, while 
its leaves are quite as decorative. Naturally-grown trees should be lightly pruned every second year whilst young, in order to keep the leading shoots free from rivals, and to check undue development of branch growth. Lower branches must be removed occa. sionally until the trunk is clear of branclies to the desired height. Ailanthus which is deciduous belongs to the Natural Order Simarubaceae.

Aira (Hair Grass).- Two species of Hair Grasses (Natural Order Gramineae), Aira flexuosa, I foot, and pulchella, 6 to 9 inches, are worth growing for the garden border and for cutting. Aira pulchella is very pretty as an edging for beds and borders. Both are perennials, and may be increased by division in autumn or spring, or by seeds sown outside in April. Ordinary well-drained garden soil suits these Grasses. When cut and dried for winter decoration the inflorescences are very useful. The first-named is a native of north temperate regions and the other of Southern Europe.

A) Juga (Bugle Flower). - A group of dwarf perennials (belonging to the Natural Order Labiatae, of which the Dead Nettle and Salvia are examples), suitable for the rock garden and as an edging to beds or borders. They are easy to cultivate, thriving in ordinary soil, and readily increased by division from October to March. They are natives of Europe. Ajuga Brockbanki has deep blue flowers in spikes from May to August, 6 inches, makes a pretty carpet ; metallica crispa, crinkled foliage, blue flowers, effective in the rock garden, 6 inches. Reptans is the wild British plant, of which a white variety, alba, is worth a place in the rock garden; the varieties variegata, forming a dense carpet of silvery variegated leaves, and purpurea, dark violet flowers and purple-bronze foliage, 3 to 6 inches, are used extensively for carpet bedding:

Akobla.-A small family of vigorous-growing, woody climbers, belonging to the Barberry family (Berberidaceae), suitable for the npen garden in the Midlands and south and for a wall farther north. They thrive in ordinary garden soil, but prefer that of a light loamy character which is well drained. Cuttings root readily in summer if inserted in sandy soil in a closed frame. It is well to cut a little of the superfluous nuter growth away after the flowers fade. Two species are grown: lobata, from Japan, with three-lobed leaves; and quinata, native of China and Japan, distinguished by its five-lobed leaves. In each case the flowers are purple, and appear in short axillary racemes in April with the young leaves. The fruits are sausage-shaped, 2 to 3 inches long, and violet in colour. Akebias may be planted against a bush, a fence, or pergola: 


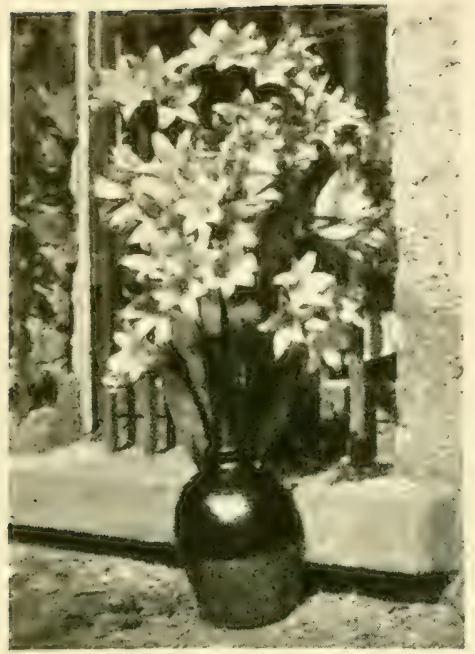

THE BELLADONNA LILY (AMARYLLIS BELLADONNA)

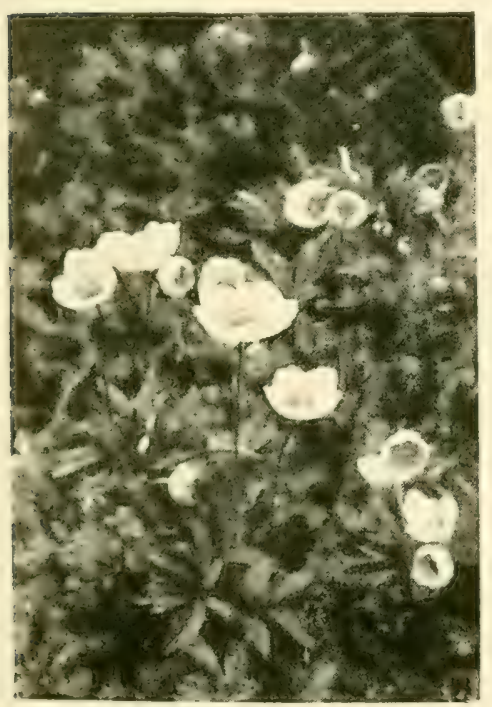

THE SNOWDROP WINDFLOWER (ANEMONE SYLVESTRIS)

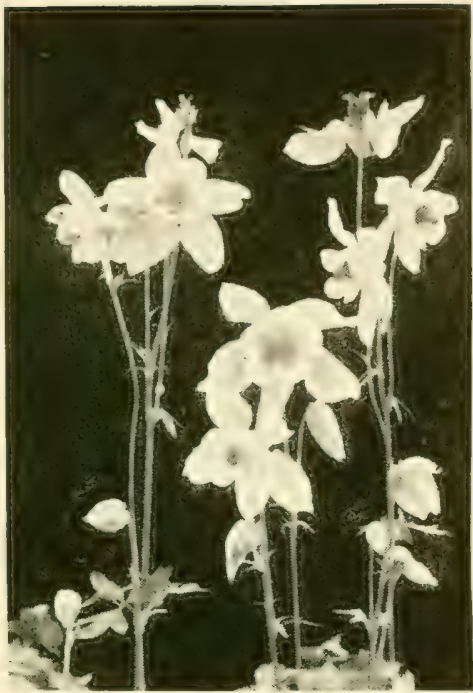

BLUE AND WHITE COLUMBINE (AQUILEGIA GLANDULOSA)

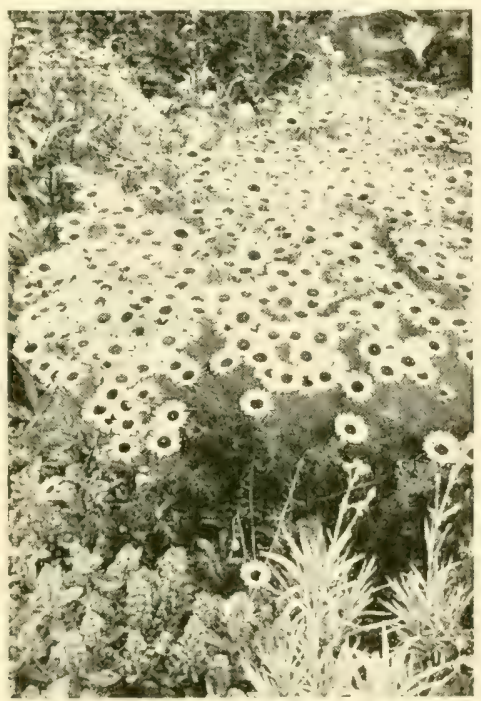

A SHOWY CHAMOMILE (ANTHEMIS TINCTORIA) 

Albizzia (syn. Acacia).-Only one species, Albizzia lophantha, is useful in the outdoor garden in summer. It belongs to the Pea family (Leguminosae), and is a native of Australia. It is readily raised from seeds sown in a warm greenhouse in spring. Having pretty finely cut foliage, and being of tall slender growth, 2 to 6 feet high, the plants are very effective as "dot " plants in the summer flower beds. Greenhouse protection must be given in winter. As a rule, the plants are not kept more than two years, fresh ones being raised from seeds. The flowers are yellow, but the plants do not often bloom. Another kind not often seen is Albizzia Julibrissin, the Pink Siris of Asia and tropical Africa; it is sometimes planted against high walls for the sake of its large, elegant deciduous leaves and pink flowers. No regular pruning is required.

Albuca.-South African bulbous plants, allied to the Ornithogalums, and members of the Lily family (Liliaceae). Albuca Nelsoni is the only species cultivated to any extent in this country. As the bulbs come from the Cape, they require a little extra care and attention; in fact, they are often grown in pots in a cool greenhouse. On a warm, sunny border outside, however, they flower freely during July and August. The soil should be light and well-drained, leafmould and coarse sand being mixed in previous to planting the bulbs in March. Some growers lift the bulbs in autumn and replant in spring; others protect them with leaves in winter. Plant the bulbs 4 inches deep and 6 inches apart. Increase is by offsets from the bulbs. The white flowers are borne on stalks 3 feet or so high:

Alchemilla (Lady's Mantle).-A genus of evergreen hardy herbaceous perennials and annuals, suitable for the rock garden and the front of borders, and belonging to the Rose family (Rosaceae). They are easily grown in ordinary soil in sunny or half-shaded positions. Increase is by division during open weather from October to March, and by seeds sown outside from April to June. The Alchemillas are valued as much for their foliage, which is evergreen and ornamental, as for the flowers, which are greenish in colour. Alchemilla alpina has very attractive silvery-grey leaves and not very conspicuous flowers in June, 6 inches, it is a British plant ; vulgaris, also a British plant, is 9 inches high, with grey-green evergreen foliage, particularly attractive in winter, greenish-yellow flowers, more interesting than pretty, in June, July.

\section{Alder.-(See Alnus.)}

Alisma. (Water Plantain).--These interesting and pretty water plants, members of the Natural Order Alismaceae, thrive in shallow water on the margins of ponds and pools, also in marshy ground. 
Increase is by division and sceds; lift, divide, and replant the roots in spring; sow the seeds when ripe in autumn, in pots of loamy soil, and submerge them in water. The common species is Alisma Plantago, a British plant growing about 3 feet in height, and producing during July and August a freely branched inflorescence of pale rosywhite flowers; a variety, lanceolata, has narrower leaves and pure white flowers. Alisma natans (or Elisma natans) is a smaller floating lind, with large solitary white flowers in July and August, native of Europe, including Britain; ranunculoides, 6 to 9 inches, bearing purplish-rose flowers in August, resembles Alisma Plantago, but is a smaller plant; it, too, is a native of Europe, including Britain.

Allium.-This is a large group of bulbous plants (which include the Onion and Shallot) belonging to the Lily family (Liliaceae). All are of easy cultivation, thriving in ordinary garden soil. With one or two exceptions, the Alliums should be planted in sunny positions along a border or in the rock garden. Several are attractive for naturalising in woods and the wild garden. Increase is by offsets when replanting from September to November, and by seeds sown on a border outside when ripe or in spring. Plant the bulbs 3 to 4 inches deep, according to their size, the larger ones the decper. A few of the best kinds are: acuminatum, rose, July and August, 9 to I2 inches, North America; caeruleum (syn. azureum), blue, July, I to 2 feet, Siberia; descendans, red-purple, July, 2 feet; karataviense, reddish-lilac, June, 6 inches, has large, broad grey-green leaves, Turkestan; Moly (Golden Garlic), I foot, bears yellow flowers in May, useful for borders and naturalising, Europe. Neapolitanum, native of Southern Europe, bearing white flowers in May, I to I feet, is the most useful of all the Alliums, being valuable for the borders, for naturalising, planting in the rock garden, hardy fernery, etc.; the flowers, when cut, are of value for indoor decoration and bouquets. Other good kinds are: Ostrowskianum, rose, May to June, 6 to 9 inches, is useful in the rockery and along the front of the flower border, Asia Minor; pedemontanum (syn. narcissiflorum), rosy-purple, June, 6 to 9 inches, South-West. Europe; pulchellum, rosy-purple, July, 9 inches, Europe ; Rosenbachianum, purple-rose, July, $2 \frac{1}{2}$ feet, Bokhara, a vigorous and very striking plant for a sunny border; roseum, bright rose, June to July, I foot, Mcditurranean region; triquetrum, white, striped green elegant-drooping flowers, June, I foot, Europe, one of the best for the wild garden, or hardy fernery.

Allosorus crispus (Parsley Firn).-A small, choice Fern (Natural Oreler Filices), found wild in Britain and worthy of association with 
the finest kinds. It is 5 or 6 inches high, and its popular name is owing to the much-divided fronds resembling the leaves of Parsley, not the dense moss-like Parsley of the present day, but the older type which used to be so much grown. Allosorus is seen at its best in the hilly districts of the northern counties; it is deciduous, losing its fronds towards the end of October and producing new ones early in May: It grows wild in the crevices of rocks or among loose stones where there is a fair amount of moisture, and is suitable for the rock garden, where it will flourish in a cool, moist, shady spot that is effectually drained. A suitable compost may be formed of loam, peat, sand, and broken stone or brick, but it must be free from lime. The American Allosorus acrostichoides is more vigorous than the British kind; some regard it as a distinct species, others as a variety of the latter.

Alnus (Alder).-Deciduous trees or sometimes large shrubs (Natural Order Cupuliferae) which are well adapted for planting in cold and wet land. In fact, no British tree succeeds more satisfactorily under such unfavourable conditions than the Common Alder. There are many species, which are widely distributed in Europe, North Africa, Asia, and North America. All are from temperate climes, and the majority are adapted to the climate of the British Isles. The stronger kinds thrive in almost any variety of soil, providing it is not very dry. Some, more particularly viridis, glutinosa, and incana, may be planted in cold, heavy clay as a preparatory crop for more valuable timber trees. As a rule, they are increased by seeds in spring, though suckers are often used, and Alnus viridis, which is often used on the Continent for fixing the soil on steep mountain sides in cold, wet, and exposed positions, is always propagated by suckers in winter. Alders may be used for rough hedges, and they stand pruning well. Trees may be pruned during summer, the efforts of the pruner being directed towards keeping the leaders clear, removing dead wood, and the production of well-balanced trees.

The wood of the Alder is used for a variety of purposes, notably the manufacture of clog soles, stakes, and the preparation of charcoal to be used in the manufacture of various explosives. For the latter purposes it is usually grown as a coppice tree. The following kinds all grow into moderate-sized trees: cordifolia, a tree with handsome, glossy, cordate leaves and large cone-like fruits, native of Southern Europe ; firma, of Japanese origin, an interesting tree, with rather narrow, prominently-veined leaves; glutinosa, the Common Alder of our river-sides, its varieties aurea, with golden leaves, and 
imperialis and laciniata, with finely-lobed leaves, are well worth planting; incana, the Speckled Alder of the north temperate regions, an invaluable tree for covering wet places about the lower elevations on mountain sides; viridis, the Mountain Alder of northern regions, particularly valuable for cold places.

Alonsoa (NIask Flower). - This is a small class of half-hardy perennials; they are members of the Snapdragon family (Scrophulariaceae), and can only be grown outside in summer. Propagation is by cuttings inserted in August and kept in the greenhouse during winter, and by seeds sown in a heated greenhouse in February or March. About the end of May or early in June nice plants should be available for beds and borders; they are also suitable for vases, and hanging baskets for a porch or veranda. If planted in a sunny position in light, rich soil, the Alonsoa flowers freely throughout summer and autumn. The most useful kinds are: incisifolia, scarlet, 2 feet or more, Peru and Chili; MIutisii, delicate pink, I foot; Warscewiczii, rosy-scarlet, $I \frac{1}{2}$ feet, Peru and Chili; var. compacta is a desirable bushy plant, I foot high, while Compact Scarlet and Compact Pink are two dwarf sorts, 9 inches high, useful for small beds or groups along the front of warm, sunny borders.

Alopecurus (Fox-tail Grass).-Six species of this grass (Natural Order Gramineae) are found wild in Britain, and with one exception they are perennial. The Common Meadow Fox-tail (Alopecurus pratensis) grows about 2 feet in height, and is one of the earliest grasses to flower, being at its best in May and early June. For beds and borders the variety foliis variegatis (syn. aurea), with prettily variegated yellow leaves, is effective. The perennials are readily increased by division in autumn. The other species are: alpinus (Alpine Fox-tail Grass), I foot, June to July; agrostis (Slender or Black Fox-tail Grass), annual, I foot to 2 feet, June to July, sow seeds in autumn or spring; geniculatus (Floating Fox-tail Grass), I foot or taller in wet and shaded positions, July and August ; bulbosus (Tuberous Fox-tail Grass), I foot, July, useful in wet positions; fulvus (Orange-spiked Fox-tail Grass), I foot to 2 feet, July, has very prominent orange-yellow anthers, a waterside grass.

Aloysia citriodora (Lemon-scented Verbena). - This is a plant one finds in most old-fashioned gardens either in the cool greenhouse or outside at the base of a sunny wall or fence; it belongs to the Verbena family (Verbenaceac). A light, well-drained loamy soil is most suitable, and increase is by cuttings inserted in a propagating frame or under a handlight in spring when the young growths are I inch to 2 inches long. The Lemon-scented Verbena is a deciduous shrub 


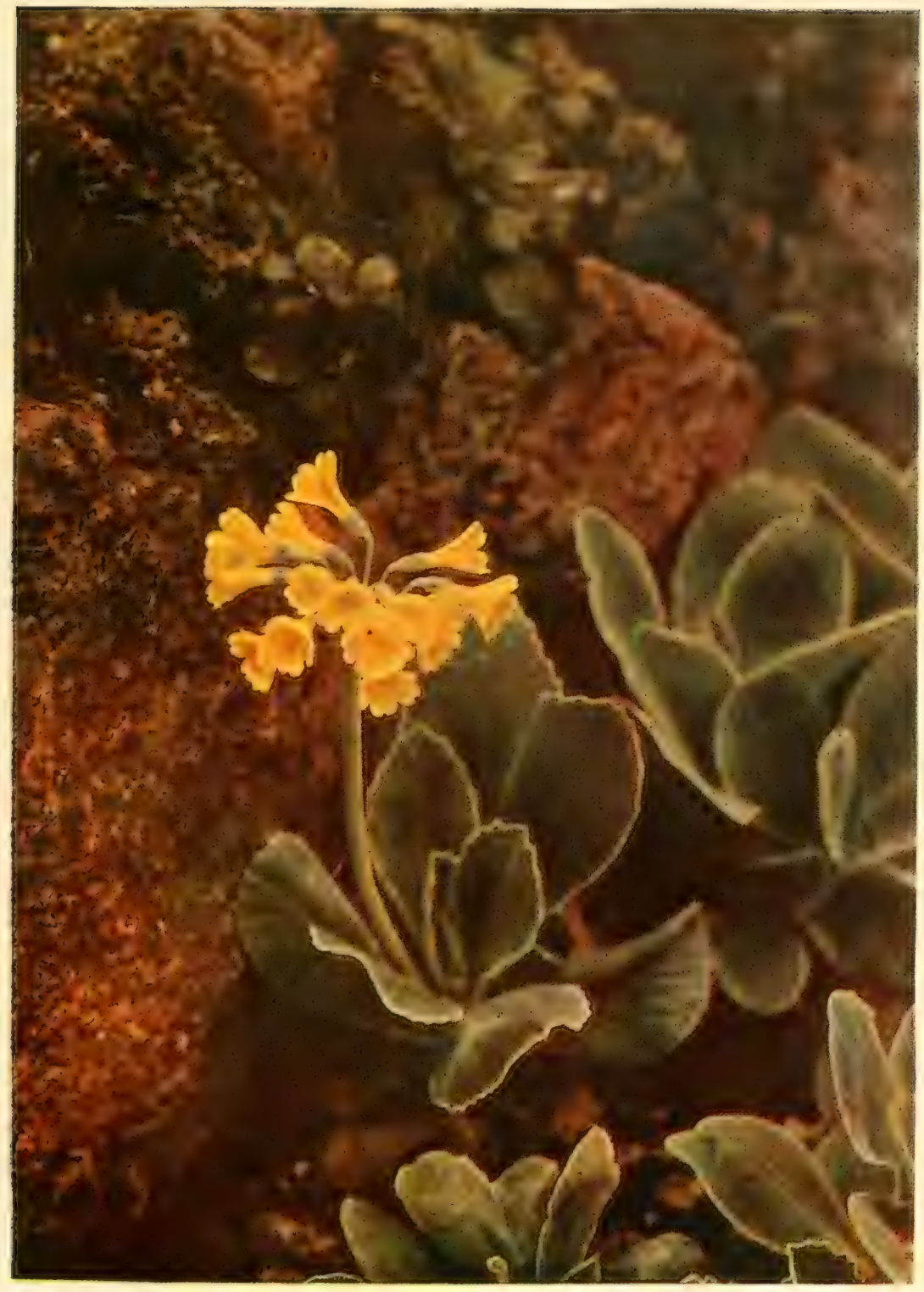

THE ALPINE AURICULA (PRIMULA AURICULA) 

first introduced from Chili in $178 \mathrm{r}$. During August panicles of small lilac-tinted white flowers are freely produced. The plant is somewhat tender. Thus in winter it is wise to protect the stems with bracken, straw, or mats. To keep the plants shapely the shoots of the previous season should be pruned each year in January or February before new growth commences.

Alstroemeria (Peruvian Lily).- This is a group of tuberousrooted plants, the hardy members of which are natives of Peru and Chili ; they belong to the Amaryllis family (Amaryllidaceae). They need a light, deep, and well-drained soil, and a warm, sunny position, as, for example, a border at the base of a south or south-west wall. If the soil in one's garden is heavy the Alstroemerias are well worth special preparation; take out the soil to a depth of $2 \frac{1}{2}$ to 3 feet, in the bottom put 6 inches of brick rubble, over this a layer of halfdecayed leaves and manure, then finally a bed of 2 parts sandy loam, I part leaf-mould or peat, and plenty of coarse sand. Plant the roots in spring 6 inches deep. Increase is by seeds and division of the roots. Sow the seeds in a heated greenhouse during February or March, prick off the seedlings into boxes when large enough, and later, about June, after hardening off in a cold frame, plant on a warm border outside. From an early sowing a few plants may flower late in the season, but it takes two years to get a good bed of Alstroemeria from seeds. Lifting and dividing the roots may be done in spring, but the less the roots are disturbed the better; it is preferable to plant seedlings than to divide old plants. Top-dress the border each autumn with a mixture of old cow manure and half-decayed leaves. The flowering season of Alstroemeria is July and August. The best kinds are: aurantiaca, orange, suffused red, spotted carmine, 3 feet ; chilensis hybrida, many lovely shades of crimson, orange, red, rose, buff, yellow, and blush with crimson or orange-yellow markings, 2 feet; lutea, yellow, spotted carmine, 3 feet; pelegrina, there are purple, white, and rose-coloured forms, I foot to I 1 feet ; psittacina, crimson, streaked with green and mahogany, 2 feet.

Alternanthera. - This plant, perhaps more than any other, is extensively used in carpet bedding. The different varieties grow only a few inches in height, and have brightly coloured foliagecrimson, red, pink, or yellow. The plants are usually clipped every week during summer with a small pair of shears to keep them dwarf, and to maintain the design of which they form a part. Alternantheras are natives of Brazil ; they thrive in any light, rich soil. Increase is by cuttings; the first of these are put in early in August, in pots or boxes, for stock, to be kept during the winter in a greenhouse. In 
increased warmth in spring the plants commence to grow freely, with the result that hundreds of cuttings can be obtained; these are inserted $I$ inch apart in boxes or pots, and placed in a closed propagating frame. They grow very quickly, and the tops will be ready to take off and insert as cuttings in from four to five wceks. Propagation should be carried out in a closed frame in a warm greenhouse from February to April. In May, place the boxes or pots in a cold frame to harden off preparatory to planting outside early in June. There are numerous sorts, including amoena, amabilis, magnifica, paronychioides (and its varieties, aurea, versicolor), and spectabilis. Alternanthera belongs to the Natural Order Amarantaceae.

Althaea (Hollyhock).-The Althaea or Hollyhock, which belongs to the Mallow family (Malvaceae), is, strictly speaking, a hardy perennial, but more satisfactory results are obtained, as a rule, by treating the plants as biennials. Formerly, when popular as a florists' flower, the Hollyhock was propagated by cuttings, divisions and eyes or buds. Named varieties were in great demand, and to keep them true one of these methods of increase was necessary. Though there are still a few named sorts, seedlings are generally grown. Sow the seeds on a border outside from April to June, and in September or October move the young plants to the positions where they are to flower the following summer. Favourite positions for Hollyhocks are in a bed on the lawn, in groups of three to six or more in the mixed flower border, while in the shrubbery border the tall imposing flower spikes are effective. Hollyhocks delight in a deeply cultivated soil enriched with decayed manure. The plants vary considerably in height ranging from 6 to ro or even I2 feet. July and August is the flowering season, though more often than not there are blooms on the plants until the end of September. There are several varieties or types of Hollyhocks. Taking the forms of Althaea rosea (native of the Orient) first, we find the ordinary single-flowered strain, another with large outer or guard petals, and a rosette of petals in the middle, and a third with perfectly double, rounded flowers. Seeds of these can be purchased in mixture or in a dozen separate colours, which include white, cream, yellow, blush, pink, rose, orange-yellow, red, and crimson. A second attractive group consists of the Fig-leaved Hollyhock, Althaea ficifolia, from Siberia. The typical plant has distinct deeply cut leaves and primrose-yellow flowers, while there are varieties in rose and pink shades, obtainable from a packet of mixed seeds. During recent years gardeners have given some attention to the treatment of Hollyhocks as annuals, the seeds being sown in a leated greenhouse during February or early March. These plants 
flower from August to October, thus considerably extending the season. The ordinary varieties will respond to this treatment, but those known as Annual Hollyhocks are better for the purpose. One of the best-named varieties is Palling Belle, delicate rosy-pink, with outer guard petals and a rosette in the centre. This comes quite true from seeds, and is a charming variety.

So far nothing has been said about the Hollyhock as a hardy perennial. When digging over the borders in late October or November, some of the plants will probably be found to be well supplied with young shoots at the base. When this is the case, the best of them should, of course, be left to flower the following year.

Alyssum (Madwort or Gold Dust).-Popular hardy perennials for large and small gardens, suitable for the rockery beds and borders. They are natives of Europe and Asia Minor, and are numerous in Alpine and mountainous districts. The Madworts, which belong to the Wallflower family (Cruciferae) succeed in ordinary garden soil which has been well dug and is not too heavy. Increase is by seeds, cuttings, or division of the clumps. Those which flower in spring and summer may be divided and replanted in September and October, or cuttings are inserted in a cold frame during July and August. Sow seeds in a cold frame or on a border out of doors from April to June. The best-known species is Alyssum saxatile, a plant with yellow flowers which should be grown in every rockery and mixed flower border, also for spring bedding in association with Wallflowers, Polyanthus, etc. It grows I foot in height, flowering freely from, April to June, native of Europe; the variety citrinum has lemoncoloured blossoms, flore pleno has double, golden yellow flowers, compactum is a dwarf, compact-growing, yellow-blossomed variety, 6 to 9 inches high, and variety variegatum has prettily variegated foliage. Other kinds are : Alyssum alpestre, yellow, April to June, 3 to 6 inches, suitable for the rockery and chinks of old walls; argenteum, yellow, May to July, trailing stems, light silvery foliage, I foot; montanum, yellow, May to July, fragrant, 3 to 6 inches, rockery; rostratum, yellow, May to July, silvery leaves, I foot; serpyllifolium, pale yellow, June to August, dwarf-spreading habit, 6 inches, grey foliage ; spinosum, white, June to August, spiny branches and small hoary green leaves, I foot.

The last to be mentioned, though not by any means the least important, is the Sweet Alyssum (maritimum), known also as Koeniga maritima. Though strictly a perennial, this delightfully fragrant whiteflowered plant is more often treated as an annual. Sow the seeds in a cool greenhouse or frame early in April, or outside where the plants 
are to flower. Growing only I foot in height, the Sweet Alyssum is much used as a carpet plant and as an edging to beds and borders; it flowers from June to October. There are several dwarf sorts of Sweet Alyssum grown under various names, as minimum, compactum, Little Gem, Little Dorrit, Dwarf Bouquet, and procumbens; all have a more or less compact dwarf habit, and carpet the ground with their snow-white flowers throughout summer. For edgings to beds or borders, and carpet bedding, these dainty little plants are unsurpassed. These and the variety variegata, which has green and white leaves, were formerly propagated almost exclusively by cuttings, a few for stock being inserted in August, and the young plants kept in a greenhouse during winter, and further increased by cuttings from February to April. To-day a large percentage of plants from seeds come true-in a reliable strain not more than two or three in a hundred plants deviate from the desired dwarf compact habit.

Amarantus (Love-lies-Bleeding).-Hardy and half-hardy annuals, interesting and useful for beds and borders in summer. Though one or two kinds can be successfully grown from seed sown out of doors, towards the end of March or early in April, it is better to sow seeds of all sorts in a warm greenhouse during April. They are easily cultivated, and grow quickly in a warm, moist atmosphere in spring. When space permits, it is worth while keeping the plants singly in small pots; failing this, prick off the seedlings in shallow boxes. Use a rich soil of 2 parts loam, I part leaf-mould, I part decayed manure, and I part coarse sand. Plant outside at the end of May or early in June in a sunny position. The chief kinds are : bicolor ruber, carmine-scarlet leaves mingled with green, 2 feet, India; caudatus (Love-lies-Bleeding), pendulous racemes of dark red flowers, 2 to 3 feet, Tropics; Henderi, ornamental foliage, rosy-carmine, orange, yellow, and green, a garden variety, 3 feet ; hypochondriacus (Prince's Feather), crimson flowers on terminal, erect, densely-packed spikes, 3 to 5 feet, North America; melancholicus ruber, very effective for beds, bright-red foliage, I foot, Japan; salicifolius, long, narrow, undulated leaves, variously coloured, orange, carmine, bronze, 3 feet, Philippine Isles; tricolor (Joscph's Coat), scarlet and yellow foliage, shaded with light green and cream, 2 feet, East Indies; and its variety splendens, having broader leaves, scarlet-crimson, marked with yellow and green, $I_{2} \frac{1}{2}$ feet. Amarantus belongs to the Natural Order Amarantaceae.

Amaryllis Belladonna (Belladonna Lily').-This Lily, which is a native of the Cape of Good Hope, belongs to the Natural Order Amaryllidaceae, and is one of the treasures of our garden in autumn: The 


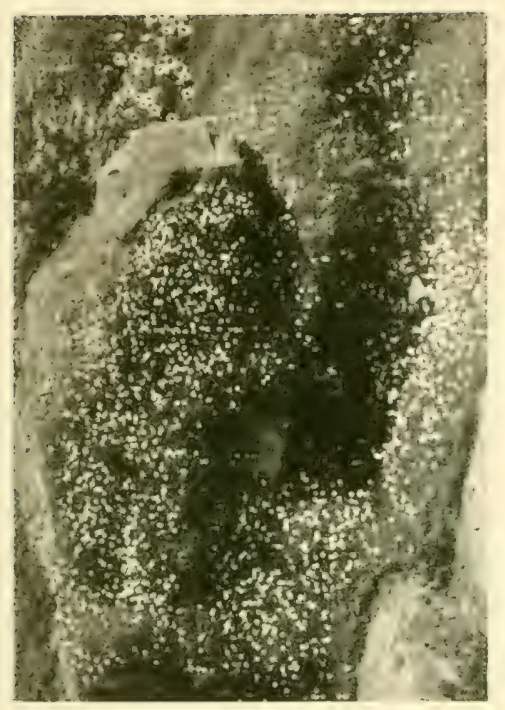

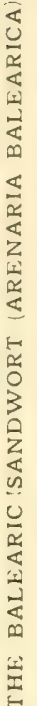

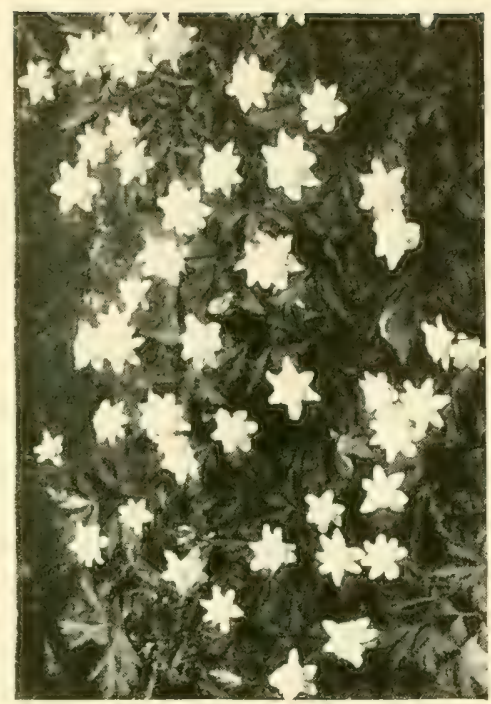

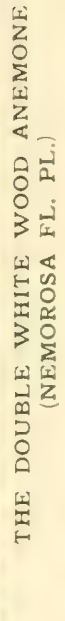
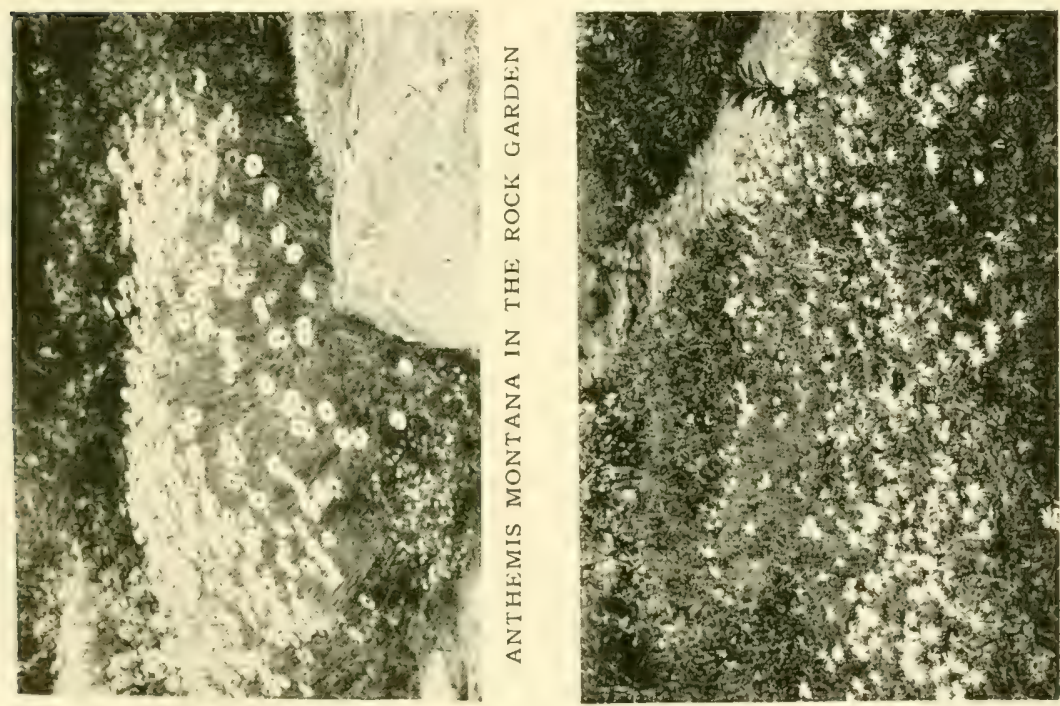

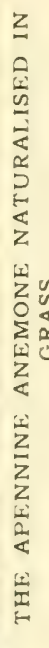



bulbs need a warm and sheltered position, e.g. the foot of a south or south-west wall. If the position chosen is not well drained, take out the soil to a depth of 3 feet and put in I foot of old broken bricks and mortar rubble; on this place a mixture of turfy loam, leaf-mould, well-decayed cow manure, and plenty of coarse sand to make the soil porous. June and July is the best time to plant the bulbs. Increase is by transplanting the offsets that form on the bulbs, and by seeds, preferably the former. Plant the bulbs 6 inches deep, I foot apart, and in winter mulch with several inches of half-decayed leaves. The flowers appear in September and October, while the leaves push up early in the new year. When once planted the bulbs ought to remain undisturbed for some years. The flowers are large, rosypink, funnel-shaped, and fragrant, half a dozen or more flowers in an umbel or cluster on a stalk about $I \frac{1}{2}$ feet high; the leaves are long and strap-shaped. There are several varieties, the colours varying considerably in intensity. The most distinct are : purpurea maxima, earlier to flower and deeper in colour than the type; blanda, pallida, and major.

Amelanohier (Snowy Mespilus).-Several showy flowering trees and bushes are included in this group, which belongs to the Rose family (Rosaceae). The majority are natives of North America, but one is found in Europe and another in Japan. The larger-growing kinds form short trunks with wide-spreading heads of branches, whilst the others occur as bushes a few feet high. In most instances the flowers are white, though in one or two cases they incline to cream colour. April and May is the usual flowering time, the period varying somewhat according to the season and the district in which the plants are growing. The leaves often colour brilliantly in autumn, especially when the trees are in moderately good soil. They thrive in any fair garden soil, and do fairly well in sandy ground. Propagation of most kinds is by seeds, though one or two may be increased by division of the clumps. No regular pruning is necessary, though the larger-growing kinds are benefited by an occasional thinning. The following are the best kinds: alnifolia, an upright-growing bush from North-West America, bearing white flowers; canadensis, the Juneberry or Service-berry of North America, and the commonest kind in cultivation; it grows from 15 to 30 feet high, with a wide-spreading head, and never fails to bear a profusion of white flowers. The variety oblongifolia is of bushy habit, 4 to 6 feet high, spreads by suckers, and blossoms with the greatest freedom; it is excellent for a bed, and the effect is enhanced by carpeting with Muscari conicum (Grape Hyacinth). Amelanchier oligocarpa, a rare, bushy kind from the 


\section{THE BOOK OF HARDY FLOWERS}

Northern United States, bears larger flowers than most others; vulgaris is a bush or small tree, native of Europe.

Ammoblum (W'ingad Everlasting).--Only one species, Ammobium alatum, from Australia, is grown in gardens. It belongs to the Daisy family (Compositac), is really a perennial, but is best treated as an annual or biennial. Sow the seeds during August and September in a cold frame, or in a greenhouse in March. Plant outside towards the end of May, choosing a sunny position and light, sandy soil. The plants grow about $2 \frac{1}{2}$ feet high, have curiously winged stems (hence the name "alatum", , and silvery white flowers I inch to $I_{2} \frac{1}{2}$ inches across, with golden-yellow centre. In addition to their decorative value in the garden the flowers of the Winged Everlasting are valuable to cut and dry for winter. About the middle of August, on a dry, sunny afternoon, when the flowers are fully open, cut them with long stems, tie up in small bunches, and hang heads-downward in an airy shed to dry.

Amorpha.-A group of shrubs, members of the Pea family (Leguminosae), of which two kinds only call for remark. These are Amorpha fruticosa, the False Indigo of the Southern United States; and canescens the Lead Plant of the United States. The former grows from 6 to Io feet high, and is recognised by its green pinnate leaves and terminal heads of purple flowers, borne in July. The dead points of the shoots should be removed in February, or, if grown for the sake of the foliage alone, the previous year's shoots may be cut hard back in early spring. Amorpha canescens bears silvery or greyish pinnate leaves and terminal panicles of purple flowers. It grows 2 to 3 feet high, and the previous year's branches should be cut back to within a bud or two of the base in February. Propagation by seeds or cuttings in autumn.

Ampelopsis.-(See VrTis.)

Amsonia. - Hardy herbaceous perennials, natives of North America, and members of the Periwinkle family (Apocynaceae). Only one species appears to be in cultivation, and that is Amsonia Tabernaemontana. This grows $2 \frac{1}{2}$ to 3 feet in height, and bears pretty one-sided bunches (cymes) of pale blue flowers in summer. Increase is by division of the clumps in autumn or spring, and by cuttings inserted in a slightly heated frame towards the end of April or early in May, when the young growths usually push up freely. Amsonia thrives in ordinary garden soil in a sunny or partially shaded border, and is quite a good plant for the shrubbery border.

Anagallis (Pimpermel). - Annual and perennial plants for the rockery and front of flower borders; they belong to the Primula family (Primulaceae). Rich, rather light soil suits them best. It is usual to 
treat them as half-hardy annuals, sowing the secds under glass or in a warm, sheltered spot outside during April. The flowering season extends from July to August, varying according to when the seeds are sown. The best kinds are: indica, small deep blue flowers, July, trailing growth, an annual from Nepaul; linifolia, an annual, the Italian Pimpernel, a European species, 6 inches, of which there are numerous varieties, with red, crimson, lilac, or blue flowers (two of the best are Parksii, large-flowered red, and Phillipsii, large deep blue). For the bog garden and moist positions along the foot of the rock garden the British Bog Pimpernel (Anagallis tenella) is worth a position. It is a trailing plant, with dainty pink flowers in summer. Being perennial, the roots may be lifted and divided in March, or seeds sown during March and April where the plants are to flower.

Anaphalis (Pearly Everlasting).-Only one species is much grown : Anaphalis (syn. Antennaria margaritacea), native of North America: It is a hardy herbaceous perennial, member of the Daisy family (Compositae), growing about 2 feet high, and having, in August, clusters of white flowers. These are extensively grown for market, and in a dried state are dyed in various colours and sold in florists' shops during the winter for decorative purposes under the name of Immortelle. Propagation is by division of the roots in spring, and by seeds sown in a greenhouse or frame during March. Plant in light soil on a sunny border, or in the rock garden.

Anastatica (Rose of Jericho, Resurrection Plant).-Anastatica hierochuntica is a curious little annual, belonging to the Wallflower family (Cruciferae), having the remarkable property of being able to revive when placed in water after being kept dry for several years. Sow the seeds in light sandy soil in a heated greenhouse during February or March. Grow the young plants singly in small pots, and plant outside on a rather dry, sunny border early in June. The tiny white flowers are disposed along the branches in small spikes usually during July and August; fruits follow these, and the leaves fall off. The Rose of Jericho grows wild in the Orient, and attains a height of about 6 inches.

Anchusa (Alkanet).-Annuals and perennials, belonging to the Borage family (Boragineae), easily grown in ordinary soil. All may be increased by seeds. Sow the annuals in March in a slightly heated greenhouse or frame, or out-of-doors in April, and the perennial kinds in a frame from April to June. A preferable method, however, is to propagate the perennials from pieces of the thick, fleshy roots. Cut them into pieces 2 inches or so in length, and plant in light sandy 
soil outside, or in a box in a cold frame; each piece will speedily grow into a young plant. This work may be done in autumn, whenever the old plants can be lifted to obtain the roots. In many gardens the old plants of the Dropmore Anchusa die after flowering; it is, however, an easy matter to maintain a stock of plants by root cuttings. September is a good time to plant the perennial kinds. Taking them in alphabetical order, the first is Anchusa Barrelieri, a hardy perennial, with small, deep blue flowers, June to July, 3 feet, South

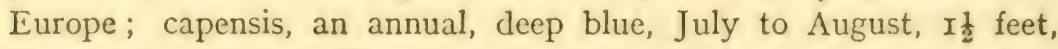
Cape of Good Hope. These two plants may also be treated as biennials, sowing the seeds in a cold frame during July or August, keeping them in the frame during winter, and planting outside early in May. A variety of Anchusa italica (blue, summer, 3 to 4 feet, Mediterranean region), known as the Dropmore Anchusa, has lovely rich gentian blue flowers, freely borne from May to August on tall branching plants, 5 or 6 feet in height; a second variety, Opal, is similar in habit, but has paler blue flowers; both may be raised from seeds, but all the seedlings do not come true to colour. These two plants well repay liberal cultivation; trench the ground $\mathrm{I}_{2}^{\frac{1}{2}}$ fect deep, working in some decayed manure and wood ashes, mulch with manure during May, and water freely during dry weather. In small gardens probably space can only be found for two or three groups in the flower border, but in larger gardens a bed filled with the Dropmore Anchusa is most effective. Other kinds are: officinalis (Common Alkanet or Borage), an annual, blue, June to September, I foot to $I \frac{1}{2}$ feet, Europe, selfsown scedlings come up frecly; sempervirens (Evergreen Alkanet), perennial, rich blue flowers from May onwards, 2 feet, Europe, and myosotidiflora, perennial, having large blooms and Forget-me-notlike flowers in May, it is about 2 feet high. The Anchusas are favourite flowers of the honey-bee.

Andromeda.--Polifolia is the only species of this group (which belongs to the Heather family, Ericaceac) that calls for remark. A native of the northern and arctic regions, it is sometimes found wild in the British Isles. It grows naturally in clamp, peaty soil, and is at home in the drier parts of peat bogs. Rarely exceeling I f or 2 feet in height, it is recognised by its narrow evergreen greyish leaves, which bear some resemblance to those of the Rosemary, and by its pink urn-shaped blossoms, which appear in spring. The varieties angustifolia and major have narrower and wider leaves respectively than the type. Plant in peaty soil, propagate by seeds or division in spring, and do not prune.

Androsace (Rock Jasmine).-The Androsaces, which belong to 


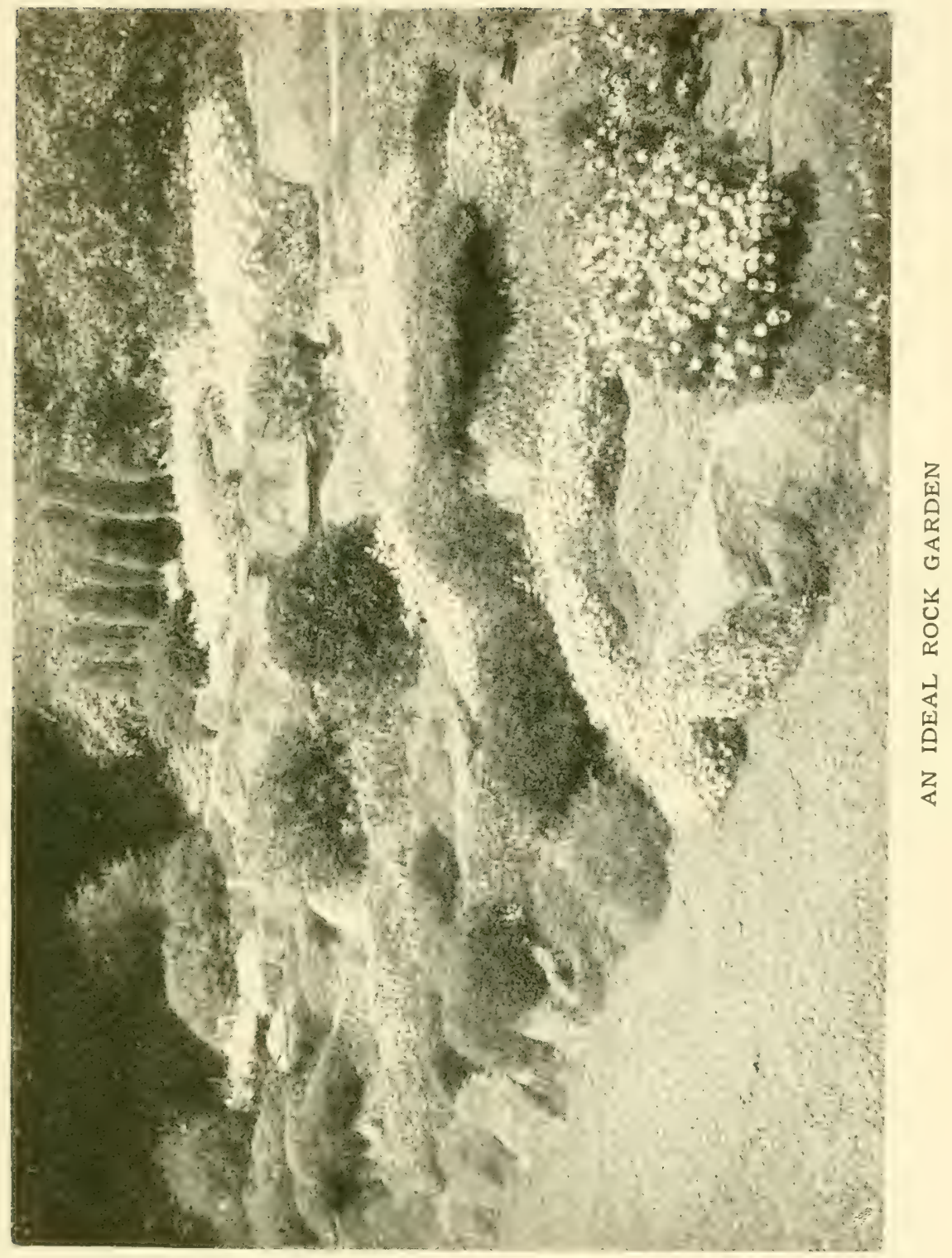



the Primrose family (Primulaceae), are natives of the high alpine regions of Europe and the Himalaya; they are among the most charming of rock garden plants, of low growth, and flowering freely when happily placed. Some kinds, those having silky leaves, must be protected from rain during winter by means of a pane of glass raised a few inches above them. While several Androsaces are difficult to grow, others give little trouble providing the conditions essential to their welfare are not wanting ; these are well-drained, loamy, stony soil, and generally a sunny position. The easiest of all to grow is lanuginosa, from the Himalaya, with silky leaves and rosy-lilac flowers in summer ; it looks well on a sunny, stony slope, the var. Leichtlini is of a paler shade with crimson centre. Androsace sarmentosa, another Himalayan kind, is very showy in May, when its bunches of rosecoloured blooms are at their best; in well-drained gritty soil this kind spreads quickly by means of runners, which may be induced to form roots by pegging down, thus offering a ready means of propagation. Androsace Chumbyi is a nearly allied sort with flowers of carmine colour in May, needing a similar soil and position.

Androsace villosa, from the Alps of Europe and Asia, has fragrant rosy flowers in May and June, and forms a tuft of silvery leaves; it needs exceptionally well-drained, stony soil and a sunny spot. Androsace carnea, from the European Alps, is a dainty little tufted plant, with green leaves and rosy blooms in May; Laggeri, from the Pyrenees, has grey foliage and rose flowers. Both thrive in stony soil.

Androsace foliosa, from the Himalaya, is altogether a more vigorous plant, bearing rose-lilac blooms on stems 8 or Io inches high during summer. This kind prefers slight shade and a sandy loam, with which a little leaf-soil is mixed. Two others which may rank among the easily grown sorts are villosa and Chamaejasme; both are natives of the European Alps and other districts; the flowers of villosa are rose-coloured, those of Chamaejasme almost white. Stony soil and full sunshine provide conditions that meet their requirements.

Among Androsaces that are more fastidious in their needs are the following: Androsace glacialis is a delightful little plant from the European Alps that, when happy, bears a profusion of bright rosecoloured blooms in April and May; it is most likely to succeed in a moraine composed of granite chips with which a little light soil is mixed. Androsace alpina, from the Alps of Europe, bearing white blooms in April, and ciliata, native of the Pyrenees, with rose flowers in spring, thrive in a shady crevice in moraine mixture.

Anemone (Windflower). - This is a most useful class of hardy plants for both large and small gardens; they are members of the 
Buttercup family (Ranunculaceac). Included are a large number of tuberous-rooted plants and numerous hardy herbaceous perennials, together providing a continuous display of blossom from early spring until late autumn. They differ so widely that we take them in alphabetical order, and tourh brichly on the most important points of each. The first is Anemone alpina (Alpine Windfluwer), with pinnate leaves, white flowers tinged with blue, June to August, thrives in ordinary soil, in sun or partial shade, I foot to $I \frac{1}{2}$ feet; increased by division in autumn or spring;

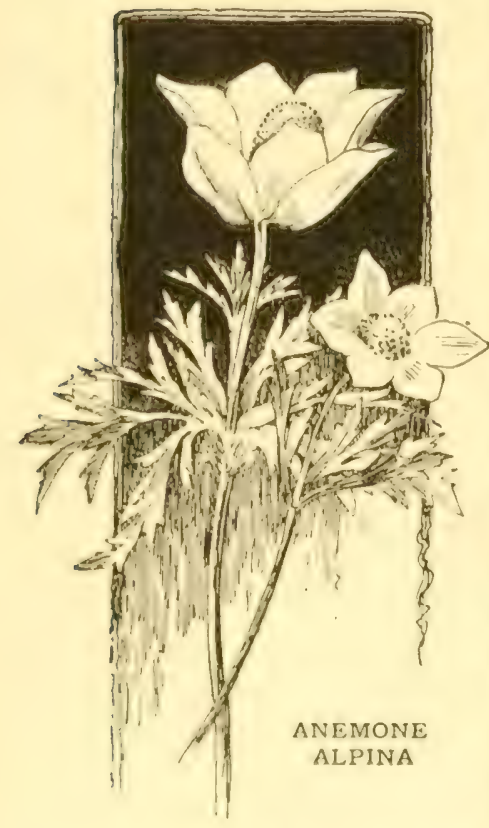
native of Europe. Apennina (Apennine Anemone) has sky-blue flowers in March and April, thrives in light soil, in half shade, 6 inches, and is particularly effective under deciduous trees and shrubs. It is planted in autumn, the roots being covered with 2 inches of soil, and placed 3 inches apart; increased by division of tubers in autumn; native of Europe. Blanda (Greek Windflower) bears deep blue blooms in February and March, needs the same treatment as the preceding, 6 inches; native of Asia Minor.

Anemone coronaria (Poppy Anemone) has flowers of many rich shades of colour, single and double, from early spring to midsummer, 9 to 12 inches; plant in October, November, January, and February, in light rich soil, sun or partial shade, 2 to 3 inches deep, 3 to 4 inches apart; increase is by seeds sown outside on a sheltered border as soon as ripe and by division of tubers; native of Mediterranean region. The St. Brigid, Single and Double Poppy, Caen, Nice, and Chrysanthemum-flowered are popular strains of this Anemone, and for forming brilliant beds and borders from April to June they are unequalled. Good named varietics are: The Bride, white; Scarlet King; Rose de Nice, delicate rose; King of Violets; Fire King. double scarlet; Bluebeard, dark purplish blue, and Rose Mignon, deep rose.

Anemone Hepatica (Common Hepatica) bears red, white, blue, single and double flowers, from March to May, 5 or 6 inches; increased by division in August or September. Do not disturb the roots as long as they flower freely, and plant in shade or partial sharle among hardy ferns, or the rock garden, in light leafy soil; 
native of the Northern Hemisphere. Hortensis (Starry Windflower or Peacock Anemone) produces numerous flowers of beautiful colours in spring, 9 to 12 inches; native of Southern Europe; its distinct variety, fulgens (the Scarlet Windflower of Greece and the Pyrenees), with dazzling scarlet blooms, is well known. Plant in similar positions and treat as advised for Anemone coronaria.

Anemone japonica (Japanese Windflower) is one of our best late summer and autumn flowering herbaceous plants, a favourite for the north border and shady front garden. The Japanese Anemone delights in deeply-dug, well-manured soil, resents disturbance at the root, and will flower freely for years in the same position; propagated by division in March, native of Japan. There are many beautiful varieties, varying from 2 to $3 \frac{1}{2}$ feet in height. A few of the best are: alba, white; Coupe d'Argent, semi-double white; elegans, soft rose; Lady Ardilaun, tall, semi-double white; Mont Rose, rose-pink; Prince Heinrich, crimson, semi-double; Queen Charlotte, semi-double, rose; and Whirlwind, pure white, semidouble:

Anemone nemorosa (Wood Anemone) has white, or rosy-white, flowers in March and April, 4 to 6 inches; beautiful varieties are: Robinsoniana, pale lavender; alba fl. pl., double white; rosea fl. pl., double rose; they are natives of the Northern Hemisphere, including Britain, and need the same treatment as Anemone apennina.

Anemone Pulsatilla (Pasque Flower) bears shaggy, violet-mauve blossoms in April and May, 9 to 12 inches; native of Europe. Plant in a half-shady position in light soil containing leaf-mould and old mortar rubble. Increase is by seeds sown as soon as ripe, and by division in late summer or early autumn; leave the roots undisturbed as long as possible.

Other Anemones are: ranunculoides (Yellow Wood Anemone), with Buttercup-yellow flowers, from March to May, 4 to 6 inches, Europetreat as advised for Anemone apennina; sylvestris (Snowdrop Windflower), having satiny-white, drooping flowers in early summer, I2 to I8 inches, Europe-a useful herbaceous plant for shady borders and the rock garden.

Anemonopsis.-There is only one species in cultivation, namely macrophylla (Natural Order Ranunculaceae, Buttercup family). In habit and general appearance the plant suggests a small Anemone japonica. It grows about 2 feet in height, bears lilac-coloured flowers during June and July, and thrives in ordinary garden soil. Increase is by division of the roots in spring, and by seeds sown preferably as soon as ripe. The Anemonopsis is a native of Japan. 
Antennaria (Cut's Eay).--This is a little group of dwarf alpine peremials, belonging to the Diticy family (Compositac), suitable for the rock garden. The chief kints are : alpina, a tufted plant with rose-coloured flowers in June and July, 4 to 6 inches, North Europe ; dioica, pink flower-lieads in June and July, and hoary foliage, 3 inches, Europe, including Britain ; the variety minor is a miniature rock plant with pink flower-heads in May and June; and variety tomentosa, with silvery foliage and white flowers, is a useful and popular plant for carpet-bedding and for use as an edging for beds and borders. Increase is by division in autumn or spring; the last-named can also be propagated from seeds sown in a frame, or outside, from April to July. The plants thrive in light sandy soil.

Anthemis (Chamomile).--Of the numerous kinds of Anthemis (Natural Order Compositae, Daisy family), only two or three find a place in the flower borders. They are herbaccous perennials, easily cultivated in ordinary garden soil, and increased by division of the roots in autumm or spring, and by seeds sown on a border outside from April to June. Anthemis Biebersteini has silvery foliage and bears yellow flowers in June and July, I 2 inches, Orient ; macedonica, silvery leaves, large white flowers, from July to September, useful in the rockery, 6 inches. Several varieties of tinctoria (Ox-eye Chamomile) are good border plants, namely E. C. Buxton, lemon-ycllow; grandiflora, golden-yellow; Kelwayi, bright yellow; Mrs. H. T. Brooks, pale creamy-yellow; and pallicla, sulphur yellow. In height the plants vary from $\mathrm{I} \frac{1}{2}$ to 2 feet, and continue to flower freely from June until September.

Anthericum (St. Bernard's Lily).-Dainty border perennials, members of the Lily family (Liliaceae), forming clumps or tufts of grass-like leaves, and bearing freely branched spikes of white flowers. Anthericums thrive in sun or partial shade, in light, rather rich soil. Plant in March. Propagate by division of the clumps in spring, and by seerls sown in a cold frame as sonn as ripe. The chief sorts are: Anthericum Liliago, 2 feet, Europe and North Africa ; varjety Algeriense (major), 3 feet ; ramosum, 2 feet, Europe ; a third species, Liliastrum, is now grown as Paradisia Liliastrum.

Antholyza. - A small class of South African bulbous plants with Iris-like leaves (Natural Orler Irideac) and attractive flower spikes. A warm, sheltered position at the fort of a sumny south wall and a bed of light sandy soil consisting of equal parts peat, from, loal-mould, and coarse sand are necessuy. Increase is by division of the offiets during Fohruary or carly March. During winter cover the ground with several inches of half-decayed leaves 


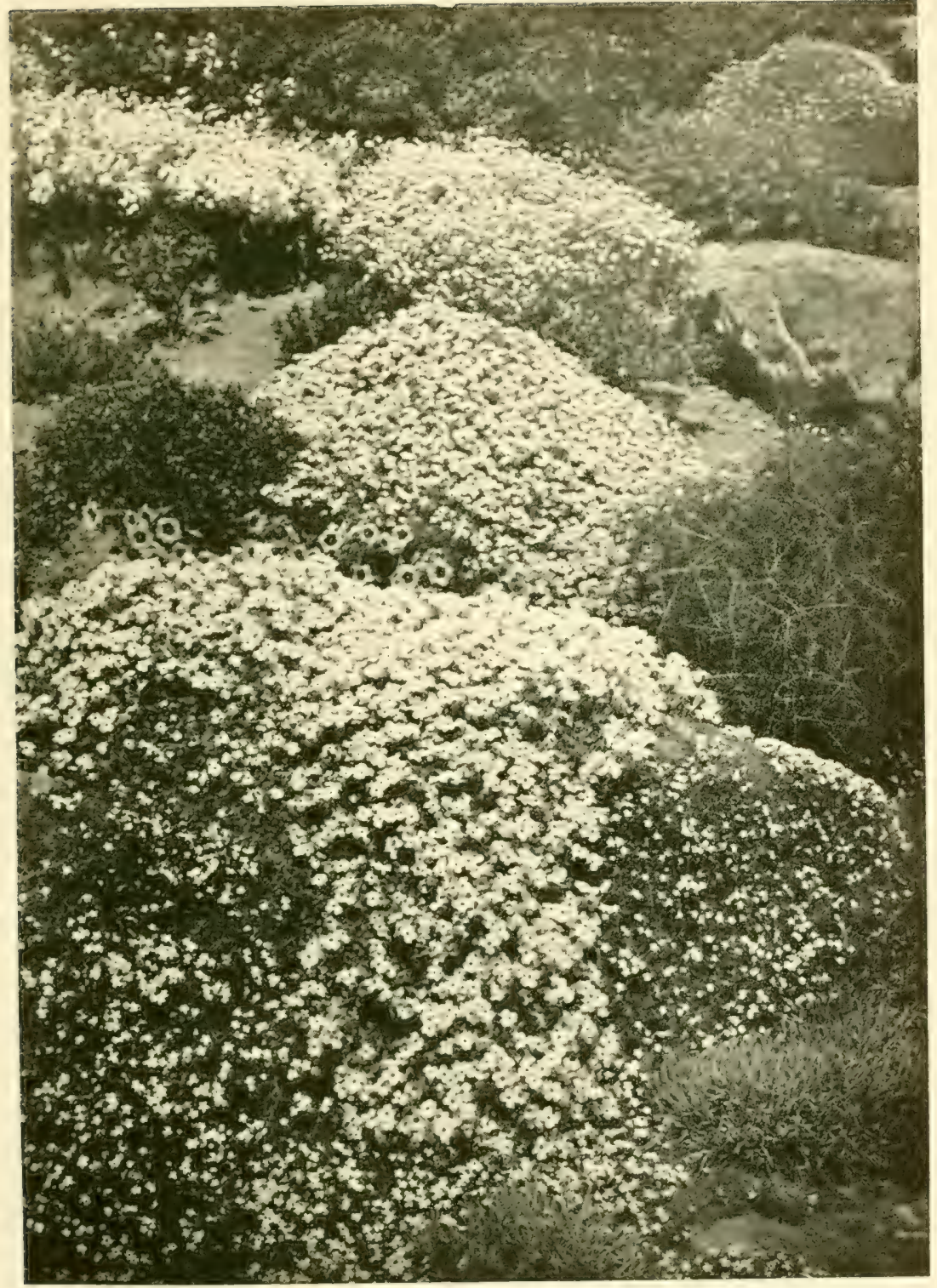

A FLOWER CASCADE-MAUVE AND PINK AUBRIETIA 

as a protection against frosts. Plant the bulbs 6 to 8 inches deep in spring. Some growers prefer to lift the bulbs in autumn, store them in sand or light soil in a frost-proof shed, and replant in spring. The best species are: aethiopica, scarlet and yellowishgreen flowers, June, 2 to 3 feet; caffra, rich scarlet, July, 2 feet; cunonia, scarlet and black, July, 2 feet; paniculata, deep crimson, July, 4 feet; crocosmioides (a hybrid between paniculata and crocosma), reddish-orange, September, 3 feet.

Anthoxanthum (Vernal Grass). - The best-known species of these ornamental grasses (Natural Order Gramineae) is Anthoxanthum odoratum, a pretty native perennial kind, growing $I$ foot in height and thriving in ordinary border soil. Increase is by division of the roots in autumn or spring and by seeds sown in September or March. It is an early flowering grass, being in full bloom by the middle of April. The Vernal Grass is not one that can be recommended for the flower border, but is worth growing in the wild garden and by the waterside. A second species, Anthoxanthum Puelii, from Central Europe, is an annual. This has more slender stems and a thinner panicle of bloom.

Anthyllis (Kidney Vetch). - Shrubs, perennials, and annuals, belonging to the Pea family (Leguminosae). The best known is Anthyllis montana, a pretty rock plant of trailing habit and silvery silky foliage that bears rose-pink flowers in June, it is native of the European Alps; add lime rubble to the soil when planting, increased by division in autumn or spring, and by seeds sown preferably in a cold frame when ripe. Anthyllis erinacea (Prickly Kidney Vetch), with bluish-purple flowers in April and May, 9 to I2 inches, is a spiny plant from Spain ; plant in a warm position on a dry, sunny rockery, increase by seeds or cuttings inserted under a bell-glass during summer. Anthyllis Barba-Jovis is a shrub with silky leaves, bearing pale yellow flowers in March and April, native of Spain; plant against a warm, sunny fence or wall, in well-drained soil.

Antirrhinum (Snapdragon).- The most important of the Snapdragons (Natural Order Scrophulariaceae) is majus. Strictly speaking, this is a shrubby perennial, for in sheltered gardens the plants continue to grow and flower for some years. They are, however, so readily raised from seeds as to be usually treated as annuals or biennials. Sow the seeds in a cold frame during July, or in a heated greenhouse during February. The plants delight in loamy soil enriched with leaf-mould and decayed manure. Plant outside during May: For beds and borders the Antirrhinum is unsurpassed when a brilliant display of flowers is desired from the end of June until 
Octohur. During recent years their use in summer bedding has become popular.

There are three sections: tall, intermediate, and dwarf. The tall varieties grow about 3 feet in height, and are favourites for borkers, being sold in mixed colours, or seeds of some twelve shades of colour may be purchased separately. The intermediate section or varieties of medium height, I $\frac{1}{2}$ to 2 feet, are the most popular for summer bedding, and may be obtained in numerous distinct colours. The Tom Thumb or dwarf varieties, 6 to 9 inches, are very uevful for edgings to beds and borders; the three best sorts are Yellow Prince, White Quecn, and Crimion King. In company with the Wallflower, the Snapdragon is very pretty on old walls and in dry, stony borlers. Formerly florists propagated named varieties of Snaplragons extensively from cuttings in much the same way as bedling Calceolarias, inserting the cuttungs during September, and leeping them in a cold frame during the winter. Named sorts may still be procured from some hardy plant nurseries.

Two or three species are useful in the rock garden : asarina (Italian Snapdragon) has light, sulphur-coloured flowers, 6 inches, from May to September, trailing habit, native of Italy; plant in warm, sunny. position; rlutinosa, white suffused lilac, May to July, 6 inches, trailing, Spain: s'mpervirens, trailing evergreen, with white flowers, produced throughnut the summer. These are perennials and may be propagated from seeds or cuttings inserted in a cold frame during late summer.

Apera. - Two species in this family of grasses (Natural Order Gramineace) are worth cultivating in gardens. The first, Apera arunlinarea, native of Jew Zealand, grows 2 feet high, and in summer bears elegant drooping plumes, some + feet in length. of purplishbrown colour, which, when dried, are very useful for decoration in winter. The plants are perennial, thrive in ordinary garden soil, and nay be increased by division in autumn or spring and by seeds sown in September in a cold frame. Cloose a sheltered rather than a winl-swept position for this beautiful New Zealand grass. Apera (-111. Agrestis) spica-renti is a European annual grass, with light and graceful flower panicle. Sow in September or March.

Aphyllanthes (Lily I'ink).- There is only one species of this quaint and interesting plant, namely monspeliensis (Natural Order Liliarine. Lily family). It comes from the Merliterranean region, and slould be planted in sandy soil in a warm, sunny part of the ruk sirden. The plants grow from 9 to r 2 inches in height, and the Whe wh hidi-lida theners are borne from June to August on leaf- 
like stems. Protect with bracken or a few evergreen twigs during severe frosts. Increase by division in March, or sow the seed in a cool greenhouse as soon as ripe.

Apios (Wild Bean).-The chief kind, Apios tuberosa, native of North America, is a tuberous-rooted perennial climber (Natural Order Leguminosae, the Pea family), of which the stems reach a height of from 5 to 8 feet; the brownish-purple flowers are produced from June to August and are fragrant. Plant the roots in warm, sandy soil at the foot of a sunny wall or fence, placing a few twiggy Peasticks over which the growths may ramble. Increase is by division of the tubers in spring.

Aponogeton (Water Hawthorn or Cape Pond Weed). - Aponogeton distachyon (Natural Order Alismaceae) is a desirable hardy water-plant for pools and ponds. The leaves float on the water. The white flowers with black anthers are borne on a twospiked stem, each 3 to 4 inches long. They are deliciously fragrant, with Hawthorn-like perfume. The flowering season extends throughout the summer. The Cape Pond Weed is readily propagated by division of the offsets in spring. To establish it in a pond or lake, place half a dozen plants in a basket of loamy soil, and sink it in about 2 feet of water in April. The position may be sunny or partially shaded, but it should not be where the plants are exposed to cold winds. This Aponogeton is native of the Cape of Good Hope.

Aquilegia (Columbine).-A charming group of hardy perennials, members of the Buttercup family (Ranunculaceae), which thrive equally well in half-shady and shady borders, or, in fact, better than in sunny positions. In addition to their value for beds, the rockery, and borders, they are charming when naturalised in the wall garden, by the side of woodland walks, and on grassy slopes. When cut, the flowers lend themselves to light and graceful arrangement. Aquilegias thrive in a moderately rich, rather light soil. If the ground is heary, work in plenty of old mortar rubble, leaf-mould, and woodashes previous to planting. Increase is by division and seeds. Lift and divide the plants preferably during September, which is also the best time for replanting. Sow the seed in a cold frame in spring and early summer, or on a border outside between April and July. It is even worth while sowing seeds of the long-spurred hybrids every year, treating them as biennials. The flowering season extends from April to July. For general garden decoration the long-spurred hybrids are the most popular; they comprise a wide range of bright and pleasing colours. The plants vary from 2 to 3 feet in height. 


\section{THE BOOK OF HARDY FLOWERS}

If desired, seeds of these can be obtained in separate colours: white, pink shades, blue shades, and yellow.

The clief species or wild types are: alpina, violet and white, a rockery plant, I 2 inches, Europe; cacrulea (Rocky MIountain Columbine), blue and white, 2 feet, North-West America; Canadensis, reddish-orange and yellow, I 2 to 2 feet, North America; chrysantha, primrose-ycllow and golden-ycllow, 2 to 3 feet, New MIexico, a beautiful border plant, flowering from May to July; glandulosa, a lovely rock garden kind, with dainty blue and white flowers, I2 inches, Siberia ; vulgaris (Common Columbine), deep purple, 2 to $2 ?$ feet, Europe; this is the short-spurred Columbine which one meets with so frequently in old-fashioned borders and cottage gardens; when undisturbed for years the plants increase in size, forming lovely clumps of colour during May and June. Munstead Giant White is a fine white variety. There are other varieties in numerous colours. Some of the lovely rock garlen kinds are short-lived, and need to be raised from seed frequently.

Arabis (Rock Cress).--The most useful among the Arabis (Natural Order Cruciferae, Wallflower family) are the White Wall Cress, Arabis albida and the double white variety, flore pleno. There are, however, several other dainty and useful species suitable for the rock garden. The plants thrive in well-rarained sunny positions in the rock garden, anel are increased by cuttings inserted in a cold frame or handlight towards the end of the summer and by division, preferably in early autumn. Arabis androsace has white flowers in June, silvery foliage, tufted habit, 3 to $f$ inches, Asia Minor; lucicla variegata has pretty yellow and green foliage; Billardierii bears pink blooms in May and June, 6 inches, Orient. Arabis albila (White Wall Cress), native of the Mediterranean region, and its varieties, are among our hest springflowering plants for beds, borders, and the rougher parts of the rock sirclen. As an elging to borders of spring flowers and in beds with Daffodils, Tulips, Wallflowers, etc, they are invaluable. The double variety, flore pleno (syns. Corbeille d'Argent and Snowdrift) is the best, and lasts in flower all spring and summer, though in fullest bloom during April and May. The variety variegata, with yellow and sreen foliage, is particularly eftective as an edging. To obtain these plants in quantity for bedding. make up a becl of light sancly soil in a cold frame, and insert the cuttings cluring June and July.

Aralia.-Trees, shrubs, and herbaceous plants, members of the Aralia family (Araliaceae) from temperate and tropical countries. The herbaceous kinds are not of general importance, although Aralia carhenirica, cordifolia, and racemosia are sometimes grown in the 


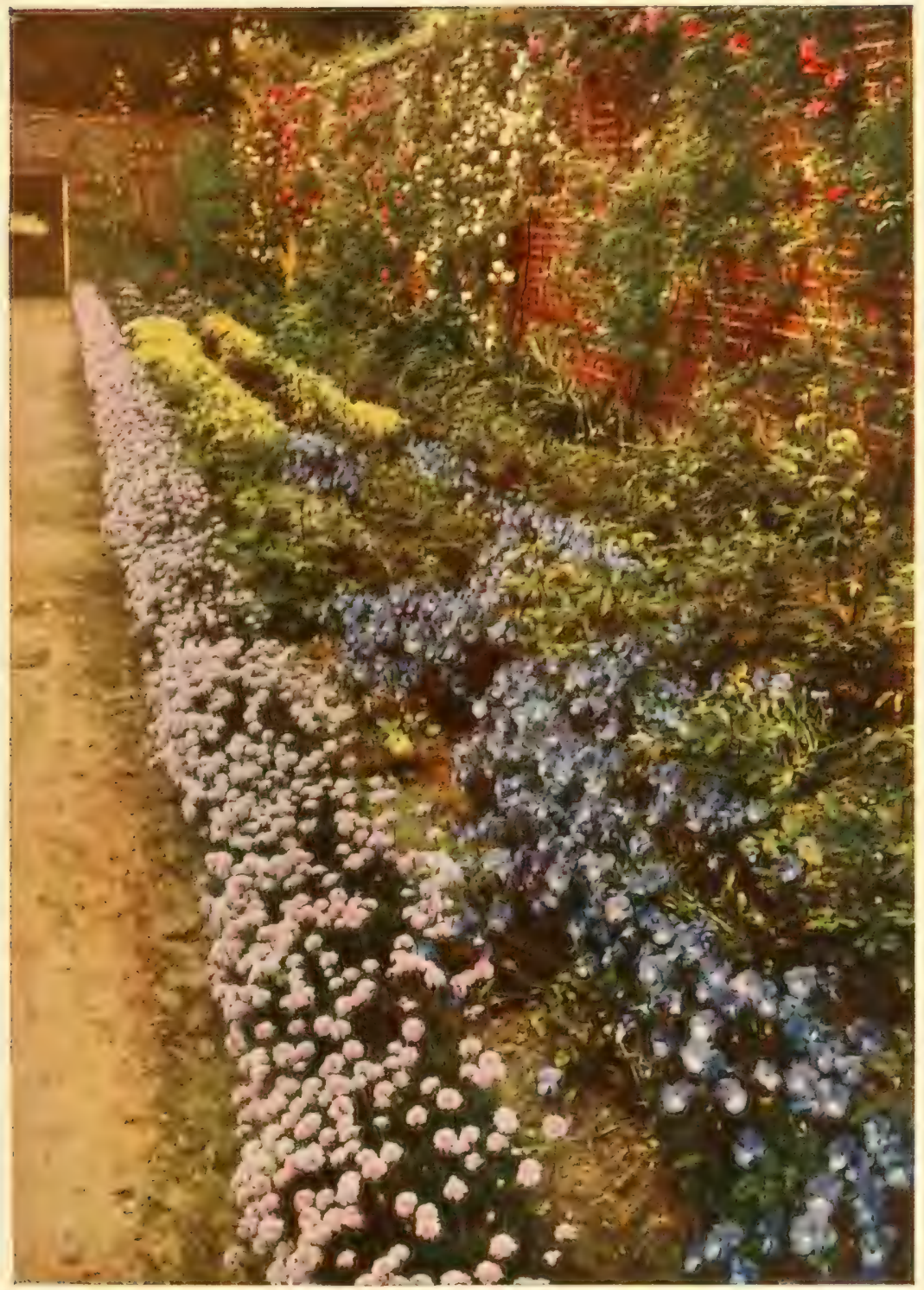

BORDER OF TUFTED PANSIES EDGED WITH THRIFT AND BACKED BY A ROSE-COVERED WALL 



\section{ARAUCARIA}

wild garden for the sake of their ornamental leaves. Aralia chinensis, a Chinese shrub or small tree, is grown in shrubberies for its large handsome, many-lobed leaves, which terminate stout, gaunt branches. The variety albo-marginata bears ornamental silver-variegated leaves, and there is also a form with golden-variegated leaves. Propagation is by seed except for the varieties, which are increased by grafting. Aralia spinosa, the Hercules Club or Angelica Tree of the Eastern United States, also bears very large decorative leaves, and in autumn immense panicles of cream-coloured flowers. Neither kind requires pruning, and both thrive in ordinary garden soil in sunny positions: The tender sorts are grown in greenhouses, and some are highly esteemed for decorative work, their foliage being peculiarly light and graceful. Perhaps the best for this purpose is Aralia Veitchii, a native of $\mathrm{New}$ Caledonia; its bronzy leaves are divided into numerous fine segments so long as the plant is confined in small pots, but if planted in a border of rich soil they undergo a great change, for the leaves become 2 feet or more across, with segments 12 or I5 inches long by 2 to 3 inches wide. Another tender kind is found in Aralia elegantissima. Both these are grafted upon commoner kinds, thrive in 3 parts fibrous loam and I part leaf-mould or peat, with a little sand, and require a warm temperature and moist atmosphere.

Araucaria.-This group belongs to the cone-bearing trees (Coniferae), and is composed of evergreen trees found in two distinct parts of the world. One species, Araucaria imbricata, occurs in Chili and Tierra del Fuego ; another, brasiliana, in the mountains of Southern Brazil ; whilst the remainder are found in Queensland, Norfolk Island, and New Caledonia. The first-named only is hardy in the British Isles, but it may be grown almost anywhere, where moist but welldrained soil, moist climatic conditions, and a moderately pure atmosphere prevail. In such places it forms a handsome though somewhat formal tree, but on dry, gravelly soil it soon loses its lower branches and becomes an eyesore. It is essentially a tree for the garden, its peculiar habit and leaf arrangement preventing it from grouping well with native trees. The common name of Chili Pine has been given to it in its native country, whilst it is here familiarly known as Monkey Puzzle. Although often planted in small front gardens, it is totally unsuited to such a purpose. Male and female flowers are usually borne by different trees, the latter being followed by cones as large as ordinary coconuts. They contain many large edible seeds, which may be used for propagation if necessary. The only pruning required is the removal of dead branches. Araucaria excelsa, the Norfolk Island Pine, is frequently grown in green- 
houses as an ornamental plant, and many thousands are suld amnually for house decoration. Although a large tree naturally; it succeeds quite well in small pots, and is generally admired by reason of its symmetrical habit and bright green leaves. Cuttings root quite readily in sincly soil in a closed case in spring, but they must be made from upright shoots taken from plants which have been cut back. Three parts loam to I part of leaf-mould or peat suits it. (Other useful sorts are: Bidwillii, Cunninghamii, and Rulci. The timber of most kinds is of value for building purposes.

Araujia. - Climbing plants (Natural Order Asclepiadaceae) usually grown in a warm, sumy greenhouse, though one species may be cultivated against south or west walls in the South of England, Ireland, and some parts of Western Scotland. This is Araujia sericifera, which grows quite freely in a cool greenhouse or out-of-doors in such situations as referred to. It is native of Peru and Brazil, and bears white Howers in July. It is propagated by cuttings of young shoots in spring and shoukl be planted in a compost of 3 parts loam to I of leaf-mould or peat. Prune fairly severely in February.

Arbor-Vitae.-(See ThUYA.)

Arbutus.--This is an important group (belonging to the Heather family, Ericaceae), insomuch that it is composed of ormamental, free-flowering evergreen trees or shrubs, which are for the most part hardy in the South of England and Ireland. A few kinds, however, are from warm temperate regions, and require greenhouse shelter. All of them object to soil containing lime. Sandy peat or loam, which is naturally moist but well drained, and moist climatic conditions are gencrally desirable. Propagation may be effected by means of seeds or liyers, whilst varieties are sometimes increased by grafting. The common Arbutus Lnedo stands pruning well, though regular pruning is not necessary after the bushes have once formed a good foundation. April is a good time for pruning. It is a wise plan to place the plants in permanent positions while they are quite small, as they sometimes transplant rather badly when 6 or $\&$ feet high. They are found in Southern Europe, the Levant, the Canary Islands, North America, and Chili.

The best kinds are: Andracline, a small tree, native of the region of the Levant, peculiar by reason of its bark being shed each year in strips; the thick oval leaves are prominent, and the panicles of ream-coloured flowers are showy in carly spring. Furiens is a (hilian speries suitable for outdoor cultivation in the South of England; of bushy habit, it bears small leaves and axillary inflorescences of white flowers. Menziesii, the Matrono of the Californian 
forests, grows into an extremely handsome tree of considerable size in its native country; here it forms a tree of moderate size with large oblong leaves, and bears large panicles of cream-coloured flowers in July; the bark pecls off the trunk and branches annually. Unedo, the common "Strawberry Tree," is a native of Southern Europe, but is also found wild in Ireland; sometimes met with in tree form, it is more familiar as a large bush with dark-green oval leaves; the panicles of cream or reddish flowers are borne in autumn, to be followed a year later by handsome, round, scarlet and orange fruits. There are numerous varieties, of which the most distinct is rubra or Croomii, which bears red flowers. Arbutus hybrida is a hybrid between Andrachne and Unedo.

Arctostaphylos. - A group of shrubs belonging to the Heather family (Ericaceae), which vary considerably in habit, sometimes forming very large bushes, and at other times occurring as prostrate plants scarcely 2 inches above the ground. They thrive in loam or peat, and whilst one or two kinds are widely distributed throughout the cooler parts of the Northern Hemisphere, the majority are natives of the Pacific Coast of North America. The trailing kinds can be increased by cuttings, others by seeds. No pruning is necessary. The commonest kind is Arctostaphylos Uva-ursi, the Bearberry of the Northern Hemisphere and a native of Scotland; it is a trailing evergreen, which bears pink flowers in spring; both this and alpina are suitable for the rockery. Manzanita is perhaps the best of the Californian species; it is a vigorous, upright bush, with thick, attractive leaves, and bears pink flowers in terminal inflorescences in spring. Other useful kinds are: pungens, tomentosa, and viscida.

Arctotis.-Two species of this interesting Cape family of plants are suitable for outdoor cultivation in summer. They belong to the Daisy family (Compositae). Arctotis speciosa (syn. breviscapa) is really a half-hardy perennial, but being readily raised from seeds it is more often treated as an annual, the seeds being sown in a warm greenhouse during February or Narch, and the young plants put out on a sunny border early in June. The flower-heads are rich orange, showy, and freely produced during July and August. It is a stemless plant with spreading pinnatifid leaves, and together with the flowers is only 6 inches high. The second species, Arctotis grandis, is sometimes referred to as the Blue Marguerite; it is a half-hardy annual with grey, pubescent foliage and stems; the large Daisy-like flowers are white with a tinge of blue, the centre of the flowers mauve, and the outside of the petals greyish-blue. The plants are very free-flowering from July to September or October, 
and about 2 feet in height. Sow the seeds outside towards the cme of April, where the plants are to flower, or durng March or April uncler glass. Plant on a warm, sunny border or on a sunny rockery ; the soil should be light and well drained. Both species are natives of South Africa.

Ardisia. - The Ardisias (Natural Order Myrsineae) consist chictly of shrubby plants from tropical and sub-tropical countries; one species, however, Ardisia japonica, from Clina and Japan, may be grown out-of-loors in the warmer parts of the country. Of the other kinds, crenata from China and Oliveri from Costa Rica are best worth growing. They require a warm greenhouse temperature. Arlisia crenata is much admired during autumn and winter by reason of the wonderful crop of rich red berries which are well set off by the dark evergreen leaves.

Arenaria (Sandwort). - The Arenarias or Sandworts are dwarftufted or creeping alpine plants for the rock garden and the front of flower borders. They belong to the Pink family (Caryophyllaceae), and flower during spring and summer. Increase is by seeds sown in a cold frame during spring and early summer, by division of the plants in autumn, preferably September, and by cuttings inserted in pots of sandy soil and placed in a cold frame during July or August. Choose an open position, and plant outside during September and March. The Sandworts thrive in rather light loamy soil in which are mixed leaf-mould and broken stone. They are suitable for placing near large boulders, so that the growths may trail over the face of the latter. The following Arenarias are hardy peremials: balearica (Creeping Sandwort) forms close tuft-like carpet of vivid green studderl with white flowers in May, Balearic Isles; granditlora, a trailing rock plant, \& to 6 inches high, with comparatively large white flowers in spring, Europe; laricifolia forms a green carpet, and bears white flowers in June, Europe; montana (.Iountain Sandwort) bears fairly large snow-white flowers from June to August, 6 inches, invaluable in the rock garden, where it yields a profusion of blossom, Spain, etc.; purpurascens, purplish-white or lilac, May to June, 3 inches, close-tufted growth, Pyrenees; tetraqquetra, white, June to July, 3 inches, l'yrenees; verna, tufts of green foliage starred with white flowers, in May, Europe and North America. Arenaria halearica will cover a shady rock face delightfully. The showiest of all is montana.

Argemone (Priclily Poppy).- These interesting and showy plants (Aatur.l Orier I'apaveracene), with delicate Poppy-like flowers, are natives of California and liexico. They are best treated as half- 


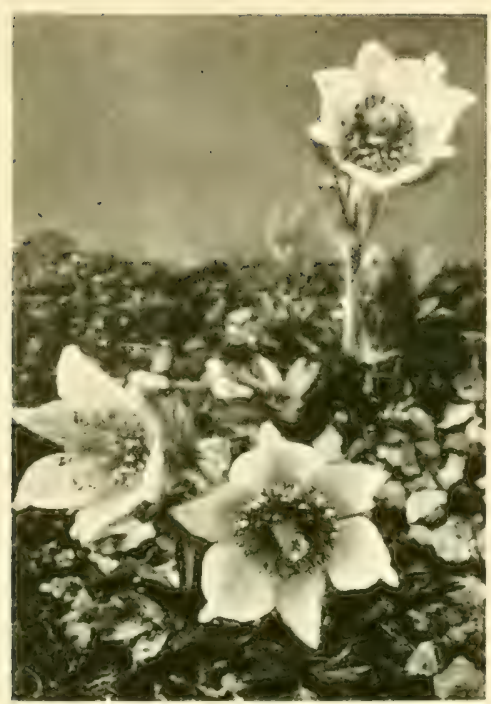

THE PASOUE FLOWER (ANEMONE PULSATILLA)

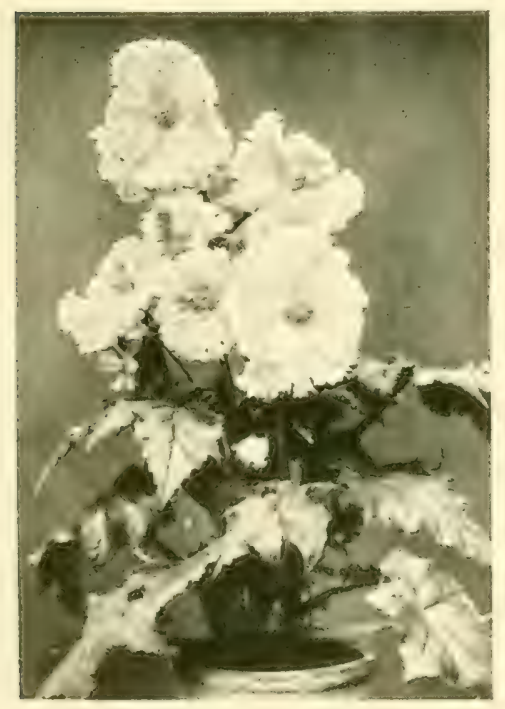

A FRILLED VARIETY OF TUBEROUS BEGONIA

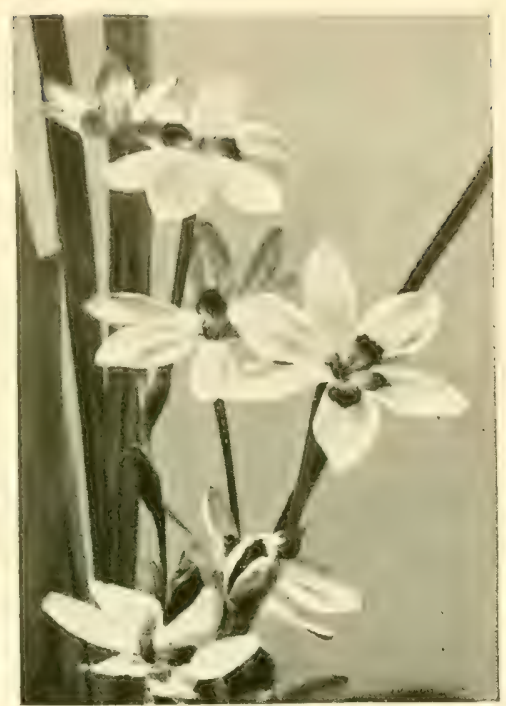

ANOMATHECA CRUENTA, WITH ROSE-RED BLOOMS

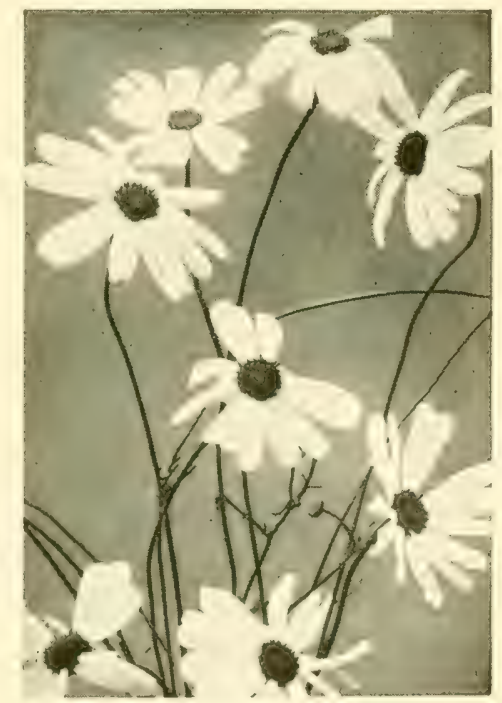

SWAN RIVER DAISY (BRACHYCOME IBERIDIFOLIA) 

hardy annuals, sowing the seeds under glass during March and April, or on a warm, sumny border out-of-doors in April. The soil should be fairly rich but well drained, and the position must be sunny. Two chicf kinds are : grandiflora, large white flowers, July to September, spiny, whitish foliage, $2 \frac{1}{2}$ to 3 feet, California; and mexicana, pale yellow, July to September, Poppy-like foliage, 2 feet, Mexico.

Aristolochia.-This family (Natural Order Aristolochiaceae) is composed of climbing plants which have usually woody branches, although a few produce new branches yearly from the rootstock, the old ones dying down in autumn. The majority are found in tropical countries, such as Brazil, Mexico, Guatemala, West Africa, Philippine Islands, etc., although a few have appeared from temperate climes, notably the United States, Southern Europe, California, and China. All are remarkable for their curious-shaped and usually evil-smelling flowers. In some instances the blossoms are small; in other cases very large with wonderful tail-like appendages and extraordinary colouring. The hardy kinds thrive in well-drained-loamy soil, and soon cover a considerable area with luxuriant foliage; the flowers are not conspicuous however. Propagation is by cuttings in summer, and the branches may be pruned moderately in February if outgrowing their space. The tender kinds may be grown in pots or borders and trained to the rafters of greenhouses or stoves. They are usually propagated by cuttings, and are kept within bounds by pruning the secondary branches back to within a bud or two of the older wood in January or February each year.

The following are hardy kinds: Aristolochia californica, a vigorous-growing Californian plant with hairy leaves and small yellowish flowers; moupinensis is a new species from China, which promises to be of an ornamental character; Sipho, a very hardy kind from the Southern United States, and the commonest of all ; it is sometimes called the Dutchman's Pipe by reason of the curious shape of its small brownish flowers, which, like the others, open in early summer.

Armeria (Thrift or Sea Pink).-These are attractive dwarf perennials (Natural Order Plumbaginaceae), suitable for the rock garden or as an edging to a border, while one or two of the taller kinds are good border plants. They are easily grown, thriving in most soils and positions, being especially good in well-drained ground and in seaside gardens. Increase is usually by division in September or March, which is also the best time for planting. Most kinds produce seeds, which should be sown in April or May in a cold frame. The most useful species and varieties are : bracteata rubra, a variety 
with bright red flower-heads, July to August, I 2 inches: caespitosit. a miniature plant with pink flowers, May to August, f inches, Spain and l'ortugal, one of the best Thrifts for rock crevices and fissures; juncea, a miniature kind, pink flowers, May to July, bright green foliage, + inches, Southern France; latifolia, rosy-likac, May to Auguet, I 2 inches, Portugal; certain varieties of this are very uscful as an edging to a burder, nutably alba, white; rosea, deep pink; rubra (syn. cephalotes rubra), rosy-crimson, the latter being a great favourite for cutting.

Armeria maritima (syn. vulgaris), the Cliff Rose or Cushion rink, is a wild British plant, very useful as an edging, it bears pale rose flower's from June to August, 9 inches; Laucheana, rich rose or rusycrimson; purpurea, lilac-rose; and alba, white, are sood varietic.s. Armeria plantaginea has rose-coloured blooms from May to July, I2 inches, Europe; its variety, splendens, bears vivid rose or rosycrimson flowers.

Arnebia (Prophet Flower).-.The kind most generally cultivated is Arnebia echioides, another name for which is Macrotumia echioides. It is native of Armenia, and a member of the Borage family (Boraginaceae). This is a valuable rockery plant, and must also find a place in a border of choice hardy peremials. The flowers are tuluular, in teminal spikes, rich yellow, with five dark-brown spots, which disappear as the blooms become older, while the general colour changes to primrose-yellow. The plants are from I foot to I g feet hish, the flowering season lasting from April to August. Plant in light, welldrained loamy soil in March or early April. Increase is hy cuttings inserted in pots of sandy soil during August, and placed in a cool greenhouse or frame; also by cuttings made of the thicker pieres of root taken off at almost any time and put in pots of sandy soil in a warm greenhouse. Those who have no plants can sometimes purchase seeds, which ought to be sown in a slightly heated greenhouse in March or April. A second species, Arnebia cornuta, is an annual from Turlestan; the flowers are yellow with five black spots on each: it blooms from July to September, and is ahout Iz inches hish; sow seeds under glass in March, and put out the seedlings in May.

Arrhenatherum (Oat Grass).-Arrhenatherum avenarem is a tall, British grass (Natural Order Gramineae), common in the hedgerow and woodland; a variety of this with swollen bases to the stem, named variety lubosum, is known as the Onion Couch: Veither is worthy of a place in gardens, hut they are mentioned becinse an allied varicty, bulbosun var. variegatum, is a beatuful variegated grass, 
useful for the front of borders, as an edging to summer beds, and for association with coloured foliage plants. Ordinary soil is suitable, and the plants can be rapidly increased by division in early spring.

\section{Arrowhead.-(See SagitTaria.)}

Artemisia (Wommeood).-Hardy herbaceous and shrubby plants, with fragrant ornamental foliage, several, including Artemisia Abrotanum, are valued as medicinal plants. They belong to the Daisy family (Compositae). The Wormwoods thrive in ordinary soil, preferring that which is rather light. The shrubby kinds are increased by cuttings, inserted in a cold frame during August and September. The herbaceous perennials are propagated by division of the roots, preferably in February and March. The chief kinds are: Abrotanum (Southernwood), yellow flowers, August to September, fragrant hoary foliage, 3 feet or more in height, Europe, Temperate Asia ; Absinthium (Common Wormwood), yellow, August, $\mathrm{I}_{2} \frac{1}{2}$ feet, Europe-the variety argentea (variegata) is an attractive plant, with silvery-white foliage, useful on a sunny rockery ; dracunculoides (Tarragon Plant), whitishgreen, July, 2 feet, North America; lactiflora, creamy-white, late summer, 4 to 6 feet, a splendid border plant; Stelleriana, yellow, summer, conspicuous white foliage, a useful trailing plant for the ledges of a rockery border or sloping bank, 6 inches, North America ; and tridentata, yellow, summer, a shrubby plant with attractive hoary white leaves, 2 to 4 feet or more, North America.

Arum (Cuckoo Pint).-On a shady or half-shady border, and among hardy ferns where there is a fair amount of moisture, several of the Arums (Natural Order Aroideae) deserve attention. They are bulbous or tuberous rooted, thrive in light leafy soil, and are increased by offsets taken off in early autumn, this being also the best time for replanting, though it may also be done in spring. The three species easiest to obtain are: Dracunculus (Dragon or Snake Plant, also grown in some gardens as Dracunculus vulgaris), purple-red and black flowers, July, marbled stems, elegant pedate leaves, 2 to 3 feet, Southern Europe; italicum (Italian Arum), greenish-white or creamywhite, Narch to April, hastate, green leaves, $I \frac{1}{2}$ to 2 feet, usually bears attractive scarlet fruits in autumn, Europe; sanctum (syn: palaestinum), the Black Arum, purple-black, May to June, $I_{\frac{1}{2}}$ feet, a remarkable plant from the Orient, requires a warm, sheltered position, preferably at the foot of a south-west wall or fence.

Arundinaria.-This is an important group (Natural Order Gramineae), as it includes a considerable number of the hardy Bamboos. The hardy kinds are principally natives of China and Japan; one, however, has been introduced from the United States, and several 
others, which are hardy in the miklest parts of the British Isles, are from the llimalara. Bambons are a welcome addition to most sardens, but they are not suitable for indiscriminate planting in every direction; rather confine them to one position, and, if possible, let that pert be shut away to some extent from the rest of the garden. The reason for this is that although from July until lebruary Bamboos posecs a grace and beauty unequalled by any other evergreen, from Febriary until the end of June they are often unsightly, for the cold winls of spring, together with the natural decay of the leaves, turn the rich green colour to dingy brown.

They require rich loamy soil which is constantly moist, and, if possible, should be planted in the vicinity of a pool or stream. In dry weather provision must be made for watering them regularly, otherwise they will soon suffer. Transplanting should be carried out during May or September, the former montl being preferable. When planting, a little leaf-mould may be placed about the roots with advantage, and in the case of established plants a surface dressing of cow manure, applicel in May, will do good. Propagation is by division of the clumps. If the divisions or pieces are large they may be planted in the open at once, but if small they had better be established in pots in a close and moist greenhouse before being placed out-of-doors. As a rule, plants which flower die within a short period, therefore stepss should be taken to save seed. This is sown under glass when ripe, and the seedlings are grown in nursery beds until they are large enowgh to transfer to permanent positions. Pruning is an important item, and takes the form of removing the older shoots right to the base in April. A guide as to those which ought to be removed may be found in the condition of the tops; those that are beconing thin and dry ought to be cut away. Be careful to remove them to the ground line, and do not leave them 6 or 8 inches in length, as is often done. There are a few kinds, such as pygmaea and Teitchii, which are improved by being cut down to the ground each year. Simply cut them over with a pair of shears. The chief kinds are: Arundinaria anceps, an upright plant of elegant habit, growing \& to Io feet high-it spreads rapilly; auricoma, a Japanese species, with Folden-variegated leaves-its height is about 4 feet; falcata and Faloneri, two Himalayan semi-tender kinds, grow 20 to 25 feet high ; Fortunei, 3 feet, has silver varicgated leaves: Hindsii graminca, iz to I5 feet, is of upright habit; japonica, I2 to I5 feet, has large leaves, and is very harly; nitila, $S$ to I 2 feet, is of peculiarly graceful outline, and one of the daintiest of all Bamboos; pygmaca. I2 to 15 inches, furms a dense carpet; Simoni, 15 to $x 8$ fort, is of upright and statcly 


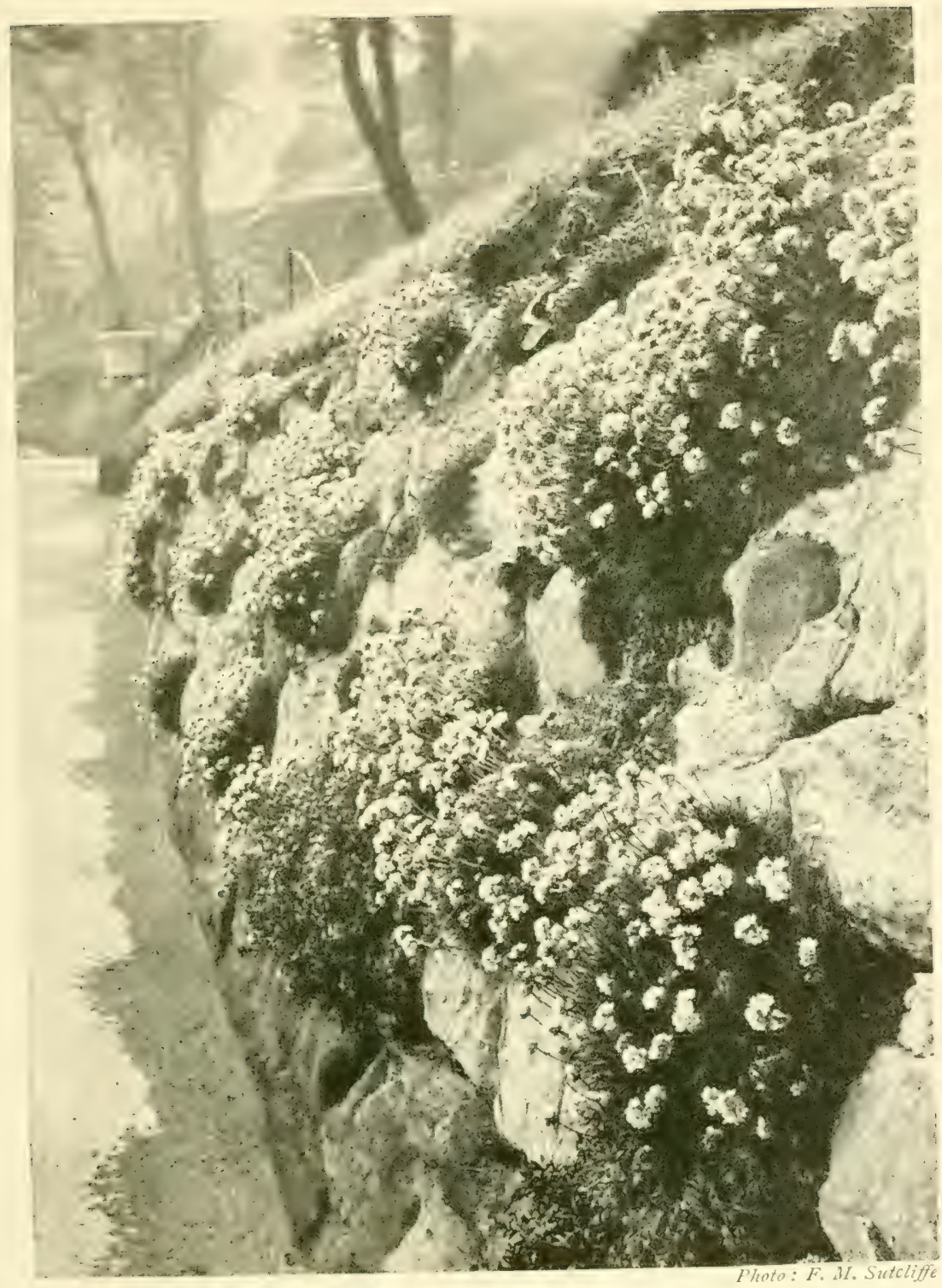

A ROCKY BANK PLANTED WITH SEA PINK OR THRIFT (ARMERIA VULGARIS) 

outline: Veitchii is a curious plant, I2 to $I 5$ inches high, of dense habit; the margins of the leaves always die early, and from a distance a plant has the appearance of being variegated.

Arundo (Giant Reed).- Vigorous grasses (Natural Order Gramineac), effective in the shrubbery border, the centre of a flower-bed, by the waterside, and in a large bog garden. They are increased by division in spring, which is also the best time for replanting. The Reeds delight in a loamy soil, not of a clayey nature. Arundo (Cortaderia) conspicua (New Zealand Reed) has silky plumes, July to October, 6 to 8 feet or more in height; it is rather tender, and should be planted in sheltered spots and protected with bracken in winter, except in the south and west, where it is splendid in full exposure. Arundo Donax (Provence Reed) bears brownish panicles in autumn, 8 to I2 feet, Southern Europe, requires protection in exposed gardens ; the variety versicolor is a smaller plant, of which the leaves are banded with white, needs the protection of a frame in many gardens in winter. Arundo Phragmites aurea variegata (variegated Spire Reed) is a golden variegated variety of our Common Waterside Reed, growing 3 to 4 feet high.

Asarum (Asarabacca).-Hardy herbaceous perennials (Natural Order Aristolochiaceae), more curious than attractive, suitable for the front of a shady border, among hardy ferns, or a shady corner of the rock garden. Asarum europaeum, I2 inches, is the best-known kind; it grows wild in some parts of Britain, but most probably has been introduced; it has kidney-shaped, violet-like leaves, borne on a creeping rootstock, from which also spring in May curious, solitary, drooping, purple-green flowers. Increase is by division in autumn; ordinary garden soil is suitable.

Asclepias (Swallow Wort, Milk Weed).-North American border plants (Natural Order Asclepiadaceae), delighting in a peaty or leafy soil. They are propagated by division of the roots in spring, and in one or two instances from seeds sown in a cool greenhouse or frame in spring or when ripe. The chief kinds are: incarnata, purplish-red, 2 to 3 feet, July (variety pulchra is a taller plant with crimson flowers); tuberosa (the Butterfly Weed), orange, July to September, $I \frac{1}{2}$ to 2 feet; speciosa, purple, fragrant, autumn, 3 feet.

Ash Tree.-(See Fraxinus.)

Aspen.-(See Populus Tremula.)

Asperula (Woodruff).--Useful hardy perennials and annuals (Natural Order Rubiaceae) for the rock garden, or an edging to beds and borders. They are easily grown, thriving in most soils and situations. The annuals are increased by seeds sown in autumn 
or spring, and the perennials by division of the roots in September or March. Asperula azurea setosa is a popular hardy annual, $g$ to I 2 inches high, native of Syria, with fragrant pale blue flowers; if sown in autumn the plants commence to flower in May; those sown in spring bloom from June onwards. Asperula odorata (Swcet Woodruff) bears fragrant snowy-white flowers in May and June, 6 to 9 inches, Europe, including Britain; it is pretty in shrubbery borders, or as an edging to a shady border. Other kinds are: hexaphylla, a tall, slender-growing plant with white flowers, June to August, is to 30) inches, Italy and Hungary; longifolia, white, fragrant, June, I foot, Eastern Europe. Gussonii (syn. niticla), a low-growing plant with small white flowers, June to August, Sicily ; and sulerosa, silverywhite foliage, pink flowers, June to August, 3 or + inches, Greece. The two last-named are charming rock garden plants, needing gritty soil with which a little peat is mixed.

Asphodeline (Leafless Asphodel).-Aspliodeline, member of the Lily family (Liliareae), is allied to the Aspholel, but is casily distinguished by its leafless flower stems. The several kinds are hardy herbaceous peremnials thriving in ordinary soil in partial shade or sun. Plant in autumn or spring. Propagation is by secels and division of the roots, preferably in spring. The best kind is Asphodeline lutea, bearing fragrant yellow star-shaped flowers on stately spikes, $2 !$ to 4 feet high, from June to August, Mediterranean region; flore pleno is a useful double variety. Asphodeline liburnica has rellow flowers, striped with green in summer, IS to $2 f$ inches, South-East Europe.

Asphodelus ( 4 sphodel).-These are harly perennials with narrow, grass-like leaves and tuberous roots (Natural Order Liliaceac), valuable for the flower and shrubbery border, also for naturalising in the wild garden. Plant in ordinary garden soil in autumn or spring. Increase is by division of the roots in March or by seds when they can be obtained. The Asphodels are favourites in some cottage borders and old-fashioned gardens. The best sorts are: albus, white, May to June, 2 feet, Southern Europe; fistulosus (Onion Asphodel). white, July to September, I $\frac{1}{2}$ feet, Mediterranean region ; and ramosus (King's Spear), pure white. June to August, 4 feet, Southern Europe.

Aspidium (Buckler or Shicld Firn).-One of the most useful classes of hardy ferns (Natural Orler Filices); they thrive under ordinary garden conditions in sun or shade and in most soils. The Shield fierns are evergreen, thus being particularly useful for odel corners in the garlen, and provide attractive greenery in what might otherwise be unsighty and bare places. Increase is by division in spring, 
which is also the best time for planting. A second method is to place some of the older fronds, bearing little plants, on soil in shallow boxes or pots. Many fern enthusiasts raise large numbers of the Hard Shield Fern (Aspidium aculeatum) and the Soft Shield Fern (Aspidium angulare) from spores in the hope of obtaining new varieties, of which we already have many of great beauty. A few varieties of Aspidium angulare are cruciato-polydactylum, divisilobum foliosum, grande, laxum, plumosum, proliferum, and Wollaston's variety. Varieties of Aspidium aculeatum are cruciatum, polydactylum and pilosum. Other useiul hardy Aspidiums are lonchitis (Holly Fern), British; munitum, from North America, and setosum, from Japan. The various kinds of Aspidium are also known as Polystichum.

Asplenium (Lady Fern). - These ferns (Natural Order Filices) require similar treatment to, and are propagated by division and spores in the same way as, the Shield Ferns. The most important species is Asplenium Filix-foemina (the Lady Fern), also known as Athyrium Filix-foemina. The numerous varieties of this are among the most highly prized of British ferns ; ten of the best are coronatum, cristatum, cruciato-cristatum, cruciatum, Fieldiae, Frizelliae, percristatum, plumosum, polydactylum, and Victoriae; they have fronds from I foot to 3 feet long. For planting in the rock garden and in old walls the following Spleenworts are deserving of attention: adiantum-nigrum (the Black Spleenwort); Ruta-muraria (Wall Rue Spleenwort); and Trichomanes (Common Spleenwort). All are British ferns.

Aster (Michaelmas Daisy, Starwort).-It is only during comparatively recent years that the value of the Michaelmas Daisy (Natural Order Compositae, Daisy family) for the decoration of the garden and home has been fully appreciated. From August to November this flower is invaluable, providing masses of colour in the garden, while providing an endless supply of cut bloom. There are varieties for all kinds of positions, varying in height from I foot to 6 or 7 feet, and flowers varying from the large blooms of Climax, 2 inches across, to the dainty cloud-like masses of the varieties Freedom and Delight. The Starworts thrive in most soils and situations, in sun or partial shade. Previous to planting, trench the ground $I_{2}^{1}$ feet deep, working in plenty of decayed manure. Increase is by division of the roots from November to March, by seeds sown in a cool greenhouse or frame during February or March, and by cuttings in spring when the young shoots are $I_{2}^{\frac{1}{2}}$ to 2 inches in height. Lifting and replanting is desirable in alternate years, or in the case of vigorous sorts it may even be done with good results every year. A few of the 
best sorts are: Acris (I), laven(er-1)lue, 2 feet; Amellus (2), violetblue, I $\frac{1}{2}$ feet ; var. bessarabicus (2), clear violet-blue, 2 feet ; Beauty of Colwall (2), lavender-blue, double, $4 \frac{1}{2}$ feet ; Climax (3). light blue, yollow centre, very large flowers; Delight (2), tiny white flowers, Invely sprays, 3 feet ; Esme (I), white. 2 fect ; Ideal (2), pale lavender, profusion of small flowers, $3 \frac{1}{2}$ feet; Hilda Morris (2), large, pale blue, \& feet; Keston Blue (3), 5 feet; Lil Fardell (2), rose-pink, large flowers, 5 feet; Mrs. J. F. Rayner (3), rosy-crimson, 5 feet ; Perry's Favourite (2), soft lilac-pink, $2 !$ feet; Maiclenhood (2), small white flowers in long sprays, 5 feet; subcacruleus, violet-blue, a summer flowering Starwort for the rock garden and borker, I foot; White Spray (2), large white flowers, 5 feet; and William Marshall (2), large, soft blue, 4 feet. The figures relate to the periorl of flowering; those marked (I) open first, then come those marked (2), and finally the remaining ones (3).

Astilbe (Goat's Bearl).--These are hardy herbaceous perennials (Natural Order Saxifragaceac) grown in some gardens under the name of Spiraea. The plants thrive in rich, moist garden soil, and are suitable for half-shady positions and bog gardens and pond sides, but they will thrive quite well in sunny positions if given an abundance of water in summer. The feathery plumes of white or pink flowers, together with the graceful pinnate leaves, rencler the plants very handsome. Spring is the best time to lift, divide, and plant, though it may be done at any time between October and March when the weather is favourable. The best kinds are: Davidii, rosycrimson, August to September, 4 feet, China; grandis, white, August to September, \& to 6 feet, China; japonica, white, June, a feet, Japan, a beautiful plant, largely grown in pots for greenhouse decoration, though equally valuable outside in beds and borders; there are numerous varietics, compactum, multiflorum, W. E. Gladstone, etc. Queen Alexandra and Peach Blossom are two beautiful pink-flowered kinds raised in gardens between japonica and Davidii ; they grow abont 2 feet in height and flower in June and July ; rivularis (Common Goat's Bearil), has white branching plumes, June to July, \& feet, Himalava; var. major is an improved variety; Thunbergii, var. Mocrheimi, is pure white. July to August, \& to $5 \mathrm{fect}$. Japan.

Astragalus. Shrubs and herbaceous plants, members of the Pea family (Lezuminosac), many of no horticultural value, and others suitable for the rock sarten or herbaceous borter. They are found in Europe, Asia, North Ameriat, etr.. and screral are of economic importance. From the hrandes of Astragalus summifer and others a riscirl grm exudes; this is collected in Asia Ninor, Greece, and 


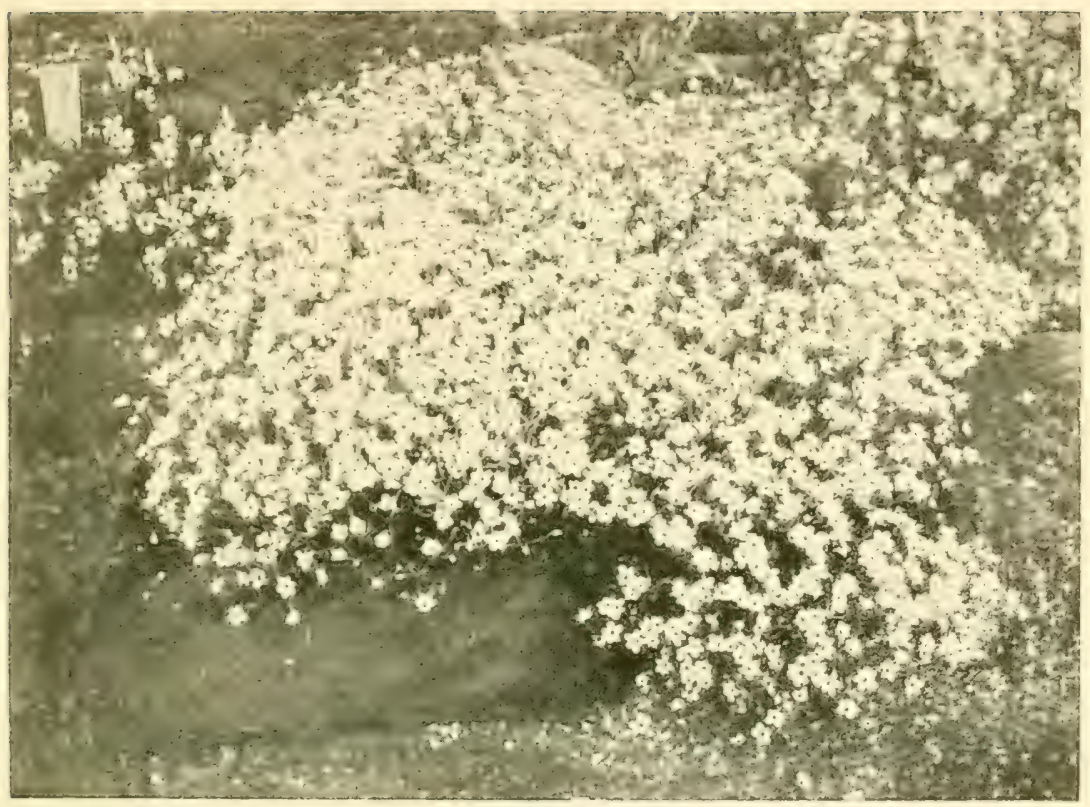

ONE OF THE SANDWORTS (ARENARIA LARICIFOLIA)

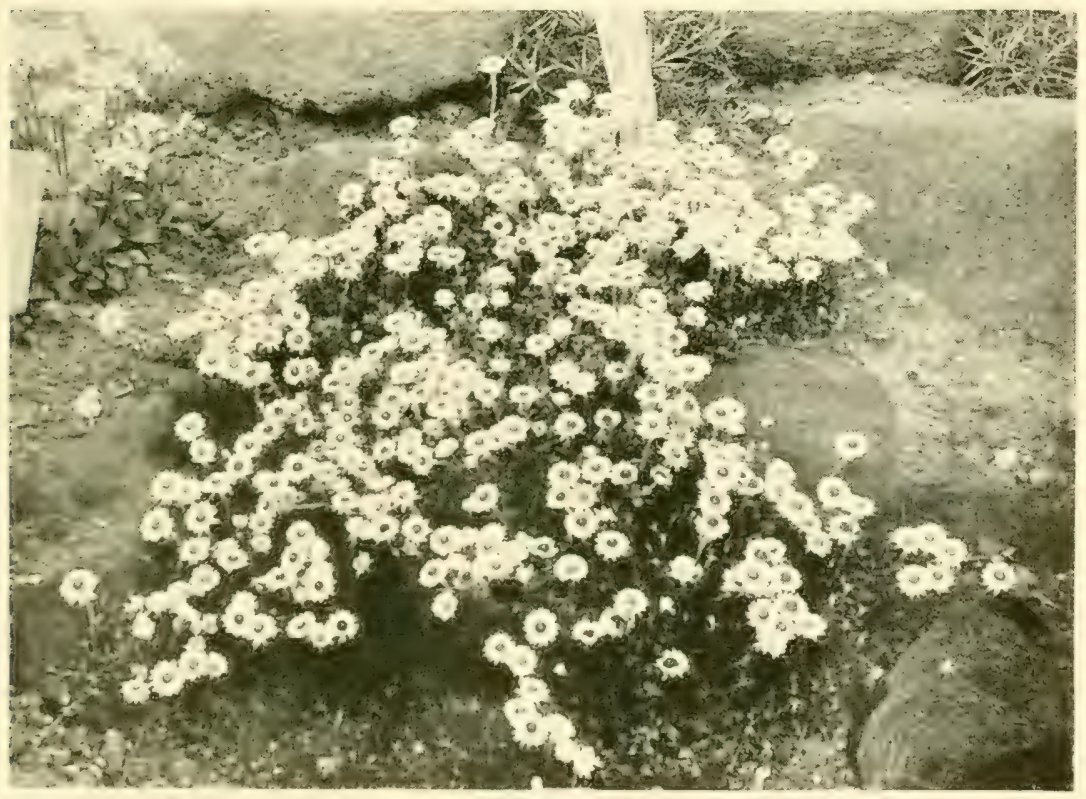

AN EVERLASTING (HELICHRYSUM BELLIDIOIDES) 

other countries, and forms the Gum Tragacanth of commerce. The various kinds of Astragalus grow in rather poor soil, but are not averse to that of good quality. The shrubby sorts are quite dwarftufted plants, and require no pruning. Propagation is usually by sceds sown as soon as ripe in a cold frame. The best are: Echinus, a dwarf-tufted, spiny shrub from Syria; and Tragacantha, which grows I2 to I5 inches high, forming a dense mass of stunted, spiny branches. The Pea-shaped flowers are pale lilac in colour and borne in May.

Astrantia (Master-wort). - Three species of Astrantia (Natural Order Umbelliferae) may worthily find a place in gardens, for they thrive in shade and poor soil, conditions that are unfavourable to many plants. They are herbaceous perennials, with leafy bracts that add beauty to the flower stems. Propagation is by division in autumn or spring and by seeds sown as soon as ripe or in spring under glass or outside. The chief kinds are: carniolica, greenish-white, June to July, very free-flowering, I foot to 2 feet, Eastern Europe; helleborifolia, pink, June to August, 2 feet, Caucasus; major (Black Masterwort), pink and white, surrounded by bracts similar in colour, which continue showy until late autumn, June to August, I $I_{2}^{\frac{1}{2}}$ to 2 feet, Europe.

Athrotaxis. - This is a small but interesting group of cone-bearing trees (Natural Order Coniferae), the three kinds in cultivation being natives of Tasmania. They are Athrotaxis cupressoides, laxifolia, and selaginoides. All are graceful and ornamental plants, but rather rare. They are not suitable for general cultivation in the British Isles, but grow quite well in places where the soil is moist but naturally well drained, and where the climatic conditions are rather moist. There are many suitable places for them in the West of England, Ireland, and Scotland. It is little use, however, planting them in dry or limy soil. Propagation may be carried on by cuttings, but the best plants are raised from seeds. No regular pruning is required. Although they grow into large trees in their native country, they are only bushes here.

Atriplex (Mountain Spinach).---Some eight or ten species (Natural Order Chenopodiaceae) may be found represented in a botanic garden. Only two of these are worthy of cultivation in gardens generally. Atriplex hortensis (Mountain Spinach) from Northern Asia is cultivated in the kitchen garden, the leaves being prepared in the same way as Spinach. For flower beds and borders a variety of this (Atriplex hortensis var. rubra or atrosanguinea) is grown ; it is a hardy annual, and is known as the Red Mountain Spinach in reference to 
the highly coloured red foliage which with age assumes a purple tint. The plants grow some \& feet in height, and may be effectively planted in groups in the mixed flower border, or in summer bedding. A light, rich soil is the most suitable. Sow the seeds under glass, or outside in March and April. A few of the shrubby kinds are worth growing for the sake of their greyish or silvery leaves, heing serviceable on this account for planting with other coloured foliage shrubs for summer effect. They are also of value for planting on sand dunes near the sea, as they do not object to a saline atmosphere, nor to salt in the soil. The branches may be cut over each spring. Good bincls are Breweri, canescens, confertifolia, and Halimus.

Atropa (Diadly Nightshadc).--The only species of note is Atropa Belladoma, a native of Europe, including Britain and some parts of Asia. It belongs to the Potato family (Solanaceae). It is at herlaceous perennial, the stems of which grow to a height of 3 to if feet and die down in late autumn. The drooping bell-shaped flowers bone $i_{i 1}$ summer are purplish-brown, $\frac{3}{4}$ to $x$ inch in length, surrounded hy a persistent leafy calyx. Within this, following the flower, is a Shining black berry the size of a small cherry. All parts of the plant are poisonous. The Deadly Nightshade grows in waste, stony places in this country, showing partiality for a chalky soil ; it is of no decorative value.

Aubrietia (Purple Rock Cress). - It must be a very small garden inclerel which can afford to do without a few plants of the Purple Rock Cress, which belongs to the Wallflower family (Cruciferae). They are dwarf evergreen plants indispensable in the rock garden, valubthe as an edging to beds and borders, and effective for sprins bediding. The greatest wealth of colour is produced from April to June. but, as a rule, the flowering season of most of the sorts extends from March to August; the plant grow about 3 or 4 inches high. As will be seen hy the appended list of sorts, the colours include numerous rich and delicate tints from white to deep purple and crimcon, inclurling rose, mauve, and lilac. There are three ways of propagating Aubrictias, hy seeds, cuttings, and livision. Sow the seeds during April or May in a cold frame, insert cuttings in boxes of sandy. soil in a cold frame in July and Angust, lift, divide, and replant the root from July to September. These who are able to afford the lime and space required grow seedling Aubrietias and others propasaterl from rutting- on a spare piece of ground for twelve to fifteen mont ths before planting them permanently - a work that is best done in Sepumber or Oetnber. Old plants may be divided in March and srown in a receve border for six months. Ordinary, rather light. 
garden soil is suitable for Aubrietias: The sorts grown in gardens are varieties of Aubrietia deltoidea, a native of Southern Europe ; they must be planted in sunny positions. Twelve of the best sorts are: Bridesmaid, blush ; Campbelli, violet-purple; Dr. Mules, rich purple; Fire King, crimson; graeca, pale lavender; H. Marshall, mauve; Lavender, lavender-blue ; Leichtlini, rosy-red; Moerheimi, soft rose ; Mrs. Lloyd Edwards, crimson; Pritchard's AI, purple; and tauricola alba, white.

Aucuba.--The principal kind in this group of shrubs (members of the Dogwood family, Cornaceae) is japonica, a Japanese bush which is widely grown in the British Isles. When first introduced it was considered to be tender and was grown under glass, but it has since proved itself to be as hardy as the Common Laurel. There are green-leaved and golden-variegated-leaved kinds; the latter have been most widely planted, and have been over-done in some gardens, their spotted leaves becoming wearisome. Those with green leaves, however, ought to be planted more frequently. Nale and female flowers are borne on different plants, and it is necessary to grow them together if a crop of red berries, which are a feature of the shrubs in winter, is desired. Some people, however, convey pollen to the female flowers from male bushes growing elsewhere. A dwarf variety, often grown as vera, is used as a pot plant. Large cuttings are rooted in warmth in spring, and grown on for the sake of their berries in winter. Aucubas are very useful for planting in dark, shady corners, particularly beneath the shade of trees. They also do well in full sun in any kind of garden soil. A little pruning is necessary now and then to shape the bushes, and such may be done at any period between March and September. Propagation may be effected in summer by large cuttings in warmth, by small cuttings in a cold frame, and by layering the branches. Of the many varieties the following are distinct: Bruantii, grandis, latimaculata, longifolia, macrophylla, macrophylla maculata, rotundifolia, splendida, vera, viridis. Macrophylla, vera, and viridis have green leaves.

Auricula (Bear's Ears).-. The garden Auricula is the progeny of Primula Auricula, a Swiss alpine plant, some 4 or 5 inches high, that bears rich yellow flowers in April and May. It belongs to the Primula family (Primulaceae). There are two distinct types of Auricula in cultivation, the Alpine or Border section, and the Show or Florists' varieties. For the outdoor garden the first-named are the most useful, the show varieties being more suitable for cultivation in a frame or cool greenhouse. The Alpine Auriculas are of freer growth and generally easier to manage out-of-doors; there is no "meal" or "paste" on the 
flowers or foliage to be disfigured by rain, dirt, ete, as in the case of the show sorts. Auriculas are propagater by seeds, offsets, and division of the clumps. Sow the seeds in boxes of sandy soil in a cold frame, or cool greenhouse in late summer as soon as ripe; the seeds are irregular in germinating, and if not sown until spring germination is even more erratic. September is a good time to lift. divide, and replant Auriculas; it is worth while doing this about every third year, giving in the spring of the intervening years a liberal top-dressing of loamy soil, to which are added leaf-mould and old cow manure. Offsets may be taken off at any time between March and September, potting them up or planting in a box in a cold frame. Auriculas delight in a fibrous loamy soil, to which should be added leaf-mould, decayed manure, wood ashes, and old mortar rubble. A light, but not a hot, sunny position is the best for them, though they will also give satisfaction in partial shade. Alpine Auriculas are delightful plants for the mixed border, for the rock garden, or even as an edging to a border. From a packet of mixed seeds beautiful flowers of varied colours can be raised.

A farourite with amateurs is the Sweet-scented Giant Yellow Auricula, which comes quite true from seeds. Another beautiful strain is that known as Blue and Heliotrope Shades, comprising dainty tints of lilac, mauve, purple, and pale blue. A dozen of the best-named Alpine Auriculas are Dean Hole, maroon-crimson, gold centre; Duke of York, crimson-maroon, yellow centre; Firefly, crimson shaded maroon, yellow centre; Ganymede, reddish-brown shading to buff, cream centre; Mrs. Douglas, deep purple, paler edge, white centre; Mrs. Harry Turner, purple-maroon, cream centre ; Mrs. Markham, reddish-maroon, yellow centre; Rosy Morn, bronzeyellow, gold centre; Teviotale, purple, white centre; The Bride, rosy-buff, gold centre; Uranie, blood-red, paler edge, yellow centre; and Ziska, crimson, yellow centre.

Avens.-(See GeUm.)

Azalea.-(See RHODODENDRON.)

Azara microphylla is a large bush or small tree (Natural Order Bixineac) with tiny evergreen leaves and bearing large numbers of small, cream, or yellowish flowers from the leaf axils during early summer. It is a native of Chili, and may be grown in many parts of the Midlands and South of England, but is too tender for general cultivation. Light loamy soil suits it, and no regrular pruning is required. Azara Gillesii, also from Chili, is suitable for planting asianst a wall in the southern counties; it has glossy rounded leaves, and bears a profusion of golden flowers. Grown as a bush, no pruning is necessary. 


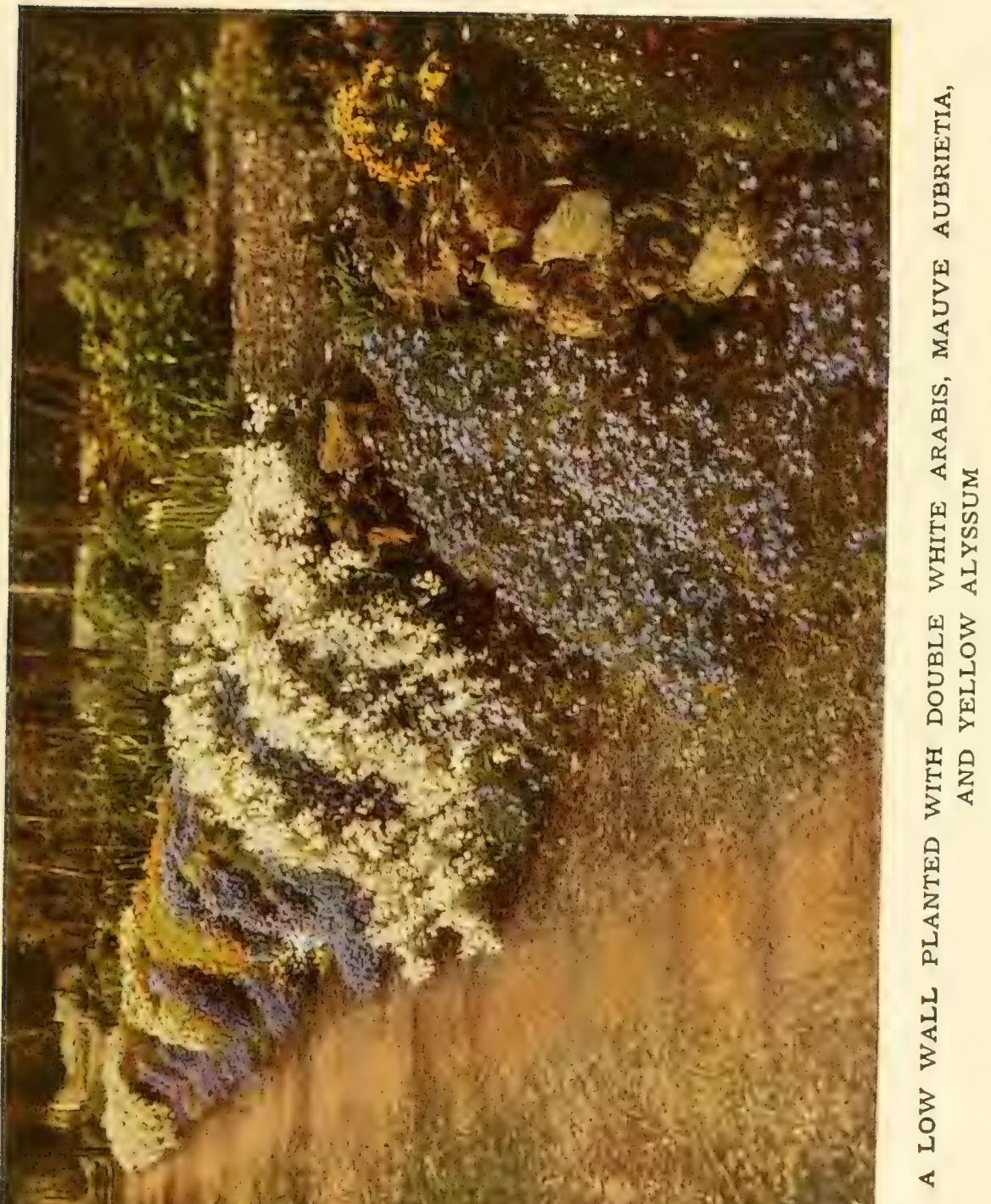



Azolla.--This is a little water-plant allied to the Ferns and Mosses, and belonging to the Natural Order Rhizocarpeae. It floats on the water, forms roots freely on the lower side of the thin stems, and spreads rapidly as a thin moss over the surface of the water. The "fronds" are $\frac{1}{2}$ inch to I inch long, pale green in spring, changing to a reddish-purple tint in autumn. Azolla caroliniana, the species usually grown, is a native of the Southern United States. Though sometimes in sheltered ponds and water gardens the Azolla survives the winter, it is usual to place the plants in a tub, pan, or tank in the greenhouse during that season. It is only necessary to save a small quantity as the plants increase very rapidly when placed outside in May or early June in the pond or tubs with Water Lilies.

Babiana.-B ul bous、 plants, all natives of South Africa and belonging to the Iris family (Iridaceae). The flower stem reaches a height of 6 to 9 inches, the lower part being clothed with tapering, plaited leaves, more or less hairy. The blossoms, 2 inches or so across, are borne in a many-flowered raceme. They are remarkable for their distinct colours, in
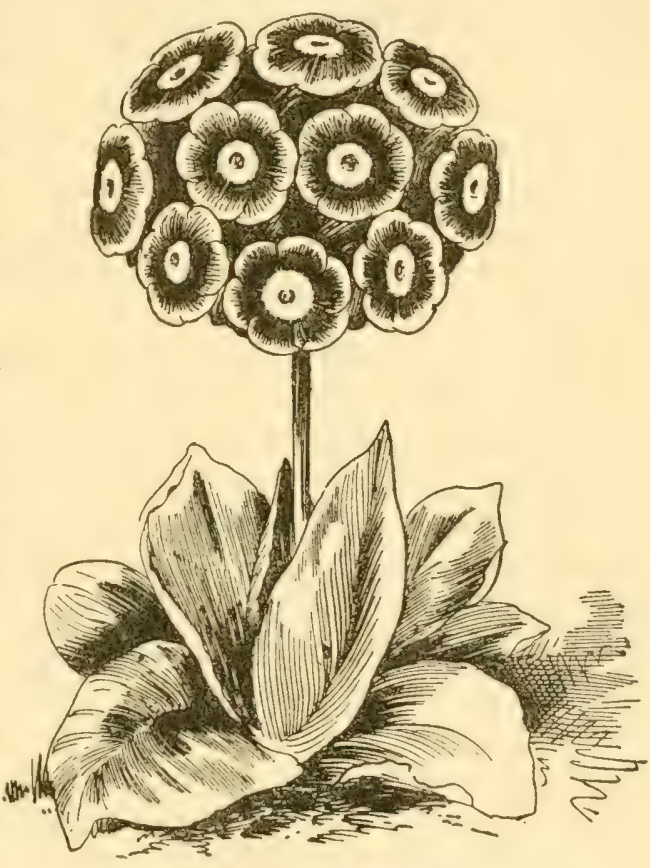

A TYPICAL FLORIST'S VARIETY OF AURICULA

which various shades of metallic blue and purple are represented; other tints that also occur amongst them are lavender and yellow. As a rule, the blossoms appear in May and June. Babianas can be successfully grown out-of-doors in the warmer districts, providing a suitable spot be prepared for them. The best place is a narrow border in front of a greenhouse facing south; it should be well drained, and if the soil is heavy it must be improved by mixing in leaf-mould and silver sand. The bulbs are placed in a layer of silver and at such a depth that there is 4 inches 
of soil above their tops. Dormant bulbs can be oltained in August, and ought to be planted as soon as possible after that time. In winter such protection as is afforded by a mound of cocoanut fibre or dried leaves is beneficial some of the finest forms are atro-cyanea, purple, blue, and white; Attraction, blue; General Scott, lavender ; Ifellas, yellow; Julia, white and blue; and rubro-cyanea, a startling combination of blue and crimson.

Baccharis.-A small group of shrubs belonging to the Daisy family (Compositae). Three or four species have been introduced, notably Baccharis halimifulia, from North America; patagonica, from the Magellanic region; and salicifolia, from the Southern United States. Baccharis patagonica, a bush 4 to 5 feet high, with small, glossy, evergreen leaves and Groundsel-like flowers, in July, is the most ornamental. Plant in loamy soil and prune once or twice a year when young to induce a bushy habit. Afterwards simply remose the old flower-heads. The other sorts may be cut back each fiebruary to within a bud or two of the base of the previous year's growths.

Balm.-(See MELissa.)

Balm of Gilead.-(Sie CedroNella trIPHYLla.)

Balsam.-(See ImpatiENs.)

Bambusa (Natural Order Gramineae).-Includes a number of the hardy. Bamboos; they are grown under similar conditions to those recommended for Arundinaria. All the following are hardy, and are native of China and Japan : angustifolia, a dwarf Japanese kind with small leaves; disticha, a curious, upright-growing species, about 2 feet high, with stiff branches; palmata, a vigorous plant, 8 feet high, with leares 8 or 9 inches long and 2 to 3 inches wide-it spreads rapidly; tessellata, grows 3 feet high and produces larger leaves than any other hardy Bamboo-they are sometimes $I_{3} 3$ inclies long and 4 inches wide. Tender (i.e. not hardy) kinds are: arundinacea, a vigorous plant from India; quadrangularis, notable by reason of its four-angled stems: it is a native of India, and may be grown out-of-doors in the milder parts of the British Isles; vulgaris, a common and strong-growing kind from India.

Baptisia.- North American herbaceous perennials, members of the Pea family (Leguminosac). One species, Baptisia tinctoria, is known as Wild Indigo. They grow readily, and flower in the most satisfactory manner in deep, well-drained soil in a sunny spot. Most of them bear a considerable resemblance to the lupins, and are at their best during the months of June and July. They vary in height from 2 to 4 feet. A selection of the most desirable includes alba, white; anstralis, blue; confusa, dark blue; and tincturia, yellow. 
All are realily increased by division in autumn, or by secds sown when ripe on a sheltered border out-of-doors.

Bartonia. - The chief lind, and the only one commonly grown, is Bartonia aurea, native of California; it belongs to the Natural Order Loasaceae, and is also known as Mentzelia Lindleyii. In common with all Californian plants, it enjoys full exposure to the sun. The deeply-cut leaves are freely clothed with downy hairs. The plants reach a height of about 18 inches, and flower very freely: the five-petalled blossoms, which are individually nearly 2 inches across, being of rich yellow colour. This annual may be sown in the open ground towards the end of April, but a much longer period of bloom is ensured if the seeds are sown early in the month under glass, the seedlings being planted out when sufficiently advanced.

Basil.-(See Calamintha.)

Bay Tree.-(See Laurus.)

Bear Bind.-(See Calystegia.)

Bear's Breech.-(See ACANTHus.)

Beech.-(See FAGus.)

Beet.-(See Beta vUlgaris.)

Begonias for Bedding.-Begonias (Natural Order Begoniaceae) occur more or less plentifully throughout the warmer regions of the globe. The tuberous-rooted species, from which the numerous garden varieties of this section have originated, are natives of the Andean district of South America. Large numbers of tuberous Begonias are used for bedding, as well as many fibrous-rooted kinds, notably the varieties of Begonia semperflorens and some of the garden forms obtained by the crossing of this kind with others.

Tuberous-rooted Begonias.-In dealing first with the tuberousrooted varieties most suitable for bedding, it may be pointed out that large heavy flowers, which make such a striking show in the greenhouse, are not well adapted for the purpose ; owing to their weight they are liable to be broken off by strong winds or heavy rains, whereas the sturdier kinds, with small or medium-sized flowers, are not damaged. When seedlings are grown for bedding out we are often told to sow the seed early in the year, and the young plants will be ready for bedding out late in Hay or early in June. This is all very well when hot-houses and convenient appliances are at hand, but it cannot be recommended to the amateur. One-year-old tubers are by far more satisfactory for bedding out. To raise these the seed is sown in February in a temperature of $60^{\circ}$ to $70^{\circ}$, using for the purpose clean, well-drained pans of light soil, such as equal parts of loam and leaf-mould, with a liberal sprinkling of sand, the top layer of 
soil having been passed through a fine sieve. I'lunge the pan to the rim in water, so that the soil may be moistened through ; then sprinkle the seed rery tininly on the soil surface. Cover with a square of glats and shade from the sum, and the young seeflings will soon make their appearance. Subseduent treatment consists in transferring the young plants to other pans as soon as they are large enough to liandle, and potting off singly when further advanced. Begonias like a considerable amount of leaf-mould in the soil, hence the proportion above referred to for sowing the seeds in may be adhered to later on. When large enough and the weather is favourable, the young plants may be put out in prepared beds, where most of them will flower before frost sets in. A selection may then be macle of those most suitable for bedling and for growing in pots another season. Tuberous Begonias should be lifted directly the frost injures the upper leaves, and laid in a shed or on the stage of a greenhouse to dry. In a few days the succulent shoots will fall away from the tubers, from which as much of the old soil is removed as can be taken off without injury to the roots. They are then laid in snallow boxes of dry soil and stored where they will be safe from frost and yet not parched. In spring they are potted singly in 4 -inch pots, and placed on a shelf in the greenhouse. They will not require much water at first, but as they grow more must, of course, be given.

While the above remarks refer to the raising of seedlings for bedding, attention may also be directed to the fact that Begonia specialists supply selected tubers true to colour at a very cheap rate for berlding purposes. There are, in addition, some well-recognised kinds that are largely employed for bedding. These are increased by cuttings of the young shoots in spring or by division of the tubers when more than one shoot pushes up from each root. Cuttings cannot be formed until the growths are about an inch in length. They are inserted in small pots of light sandy soil platced in a closed propagating case, where, if there is slight heat, they will soon root. Care must be taken to see that they do not " clamp off" ; they are liable to do this in ton moist an atmosphere. If signs of decay are noticed, the light may be tilted each day for a short time.

The best of the named tuberous rooted varieties generally used for beelding are: Double (all of freely branched, sturdy habit)-Argus, scarlet; Calliope, pink; Count Zeppelin, orange-scarlet ; Gladiateur, crimson; Jafayette, crimson-scarlet; Major Hope, light rose ; Marquis of Stafford, deep crimson; Miss .M. Griffith, white: Mrs. Langtry, white; President Savoye, pale yellow: Rev. E. Lascelles, deep yellow; anl Washington, brilliant scarlet. Single fof upright growth, with 


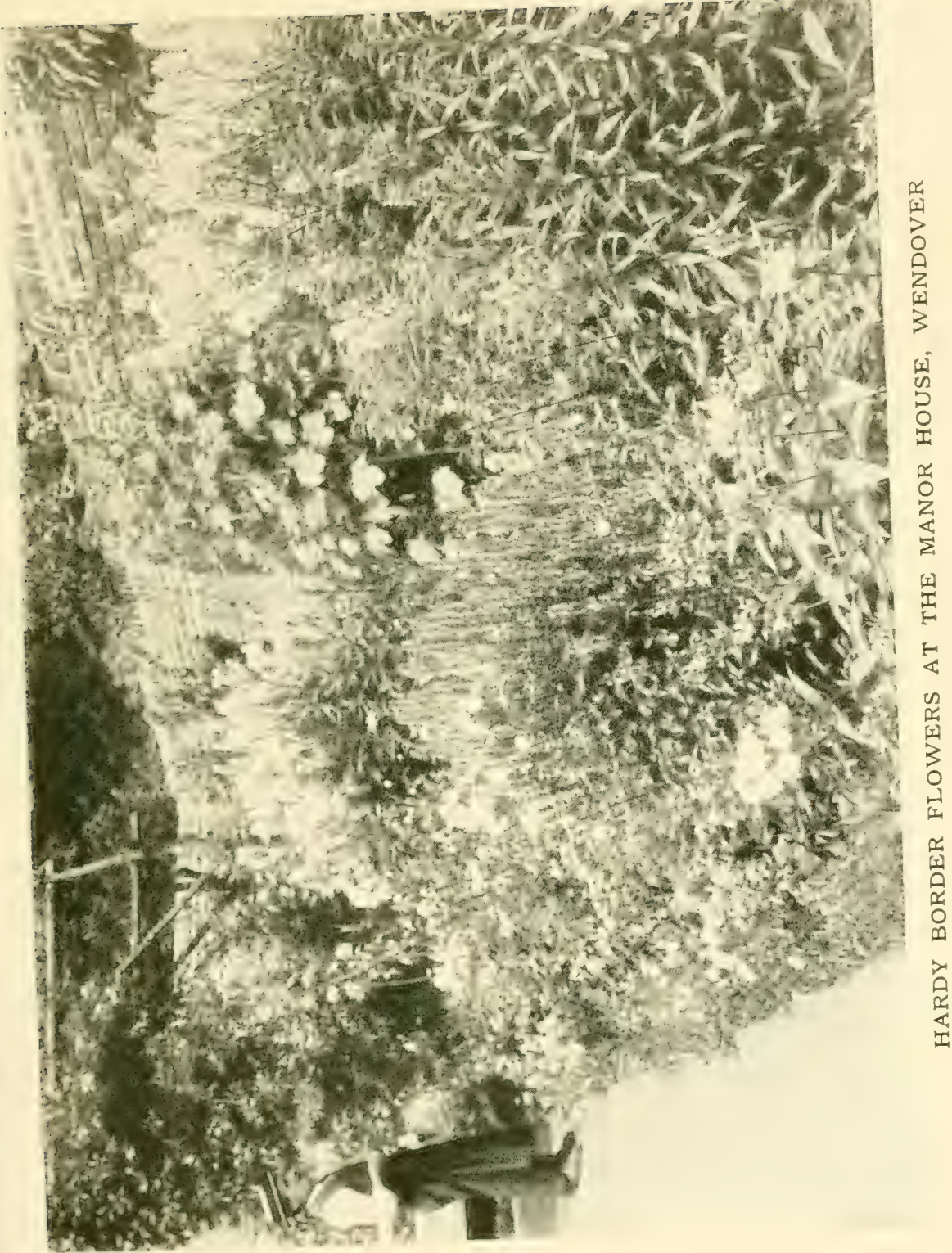



long, pointed petals)-Bertinii, orange-scarlet; and Worthiana, vermilion.

Fibrous-rooted Begonias.--The exceedingly variable Begonia semperflorens is, in one or other of its many varieties, largely used for bedding. The plants flower continuously throughout the season, and, what is more, the foliage of many varieties becomes of an intense crimson tint. The flowers vary in colour from white to the richest red. Some of the plants are very dwarf, and these may be depended upon to come true from seed if it is obtained from a reliable firm. Among the best varieties of this class are: Gloire de Châtelaine, pink; gracilis, deep pink; Limmosa, scarlet; Magnifica, dark foliage and scarlet flowers ; Snow Queen, white; Triomphe de Lorraine, crimson leaves and flowers; and Vernon, like the last, but very dwarf. When the Begonias of this section are raised from seed this should be sown early in the year in order to have plants available for bedding-out time. The directions for sowing the seed of the tuberous varieties apply to these. Another mode of increase for the very dwarf kinds is to lift them early in autumn before the frost has done any damage, divide them as one would a herbaceous plant, and put the pieces in small pots of soil. In a light position in a greenhouse, where a temperature of $45^{\circ}$ to $55^{\circ}$ is maintained, they will pass the winter safely, and form good plants by spring. The taller-growing varieties of the same section are increased by cuttings, which, if taken early in August, soon root in sandy soil in a closed and shaded frame. If potted singly as soon as they are well rooted they will pass the winter safely in the greenhouse, under the conditions just described. There are other varieties of fibrous-rooted Begonias of larger growth than those previously mentioned, and at the same time of great value for summer bedding. Chief among them are Ascotensis, pink; Corbeille de Feu, bright red; Knowsleyana, silvery blush, and Weltoniensis, deep pink.

Belladonna.-(See ATropa.)

Belladonna Lily.--(See Amaryilis Belladonna.)

Bellflower.-(See Campanula.)

Bellis (Daisy).-Native of Europe. The Daisy (Natural Order Compositae) is familiar to everyone, and all have a soft spot in their heart for the "wee modest crimson-tipped flower" of the poet Burns, even though it occur in well-kept lawns. Apart from the common kind there is quite a long list of garden varieties, which are largely grown for spring bedding. Some have very fine flowers, and all bloom continuously over a long period. So floriferous are they that it is often a difficult matter to steel one's heart to remove them when 
it is necessary to make way for the summer bedding plants. When there is a reserve border set asile for the reception of Daisies and similar plants during the summer, it should, if possible, be so situater that it does not get dry at any time, as not only the Daisy, but the Polyanthus, with which it is often associated in spring beds, resents such conditions A well-tilled soil, not necessirily very rich, is just the plare for Daisies. When they are lifted from the spring beds all the flowers should be cut off, and the plants divided to the extent that may be desired. Then they are planted in rows, taking care that the soil is male firm around each plant. Should the weather be dry the plants benefit by an immediate soaking of water. During summer no attention is necessary beyond an occasional hoeing between the rows in order to keep down weeds and loosen the surface soil. A good selection of varieties is as follow's: Alice, salmon-pink; Dreslen China, delicate pink; Monstrosum, white and red, mottled, very large; Rob Roy, quilled flowers, intense red; Snowdrift, white, quilled; and Venus, double white. Beside these there is a singular form known to botanists as Bellis perennis monstrosum, and popularly termed the Hen and Chickens Daisy. In this variety the central flower is surrounded by smaller ones; it is a curiosity, but for beauty does not compare with the others.

In adclition to the common Daisy and its varieties there is the Blue Daisy of Morocco (Bellis rotundifolia cacrulescens): this has round leaves with particularly long slender stalks, while the flowerheards much resemble those of the common Daisy, except that the florets are fewer and often broader, while the colour is a pleasing shate of pale blue. This Daisy is much less hardy than its English representative, and repuires a warm, well-drained part of the rockwork or some similar position.

Bellium (Fulse Daisy). - This, which is native of the Mediterranean region, is nearly related to the Daisy; indeed, it is only separated therefrom by slight botanical features, and belongs to the same family (Compositae). There are but three species. Bellium belliclioicles forms a tuft of spathulate leaves, and makes its way by means of (reeping stolons. The flower-heads, which are borne on slenter stems about $f$ inches in height, are white, and produced during the summer months. Bellium crassifolium has thick oborite leaves of a somewhat downy nature; the Daisy-like flower heads are of whitish yellow colour. Bellium minutum is quite, a miniature plant with whitish flowers; it needs a well-(lrained position on a sunny part of the rokkery; incleed, all the labe Daisies must be regarded as rockwork plants. 


\section{Bent Grass.--(See Agrostis.)}

Berberidopsis corallina is a Chilian plant belonging to the Barberry family (Berberidaceae). Of climbing habit, its long, slender woody branches are clothed with dark evergreen leaves, which have spiny margins and somewhat resemble those of the Mahonia. The coral-red flowers are borne during late spring in large axillary pendent clusters. Although somewhat tender, it gives excellent results if planted against a west wall in the South of England, and is suitable for greenhouse cultivation. Warm and well-drained loamy soil will do, but if a little peat can be added at planting time it will be appreciated. Propagation is by seeds, cuttings, or layers. Pruning is confined to shortening the branches after the flowers are over in order to keep the plant within bounds.

Berberis.-This is an important genus (Natural Order Berberi-

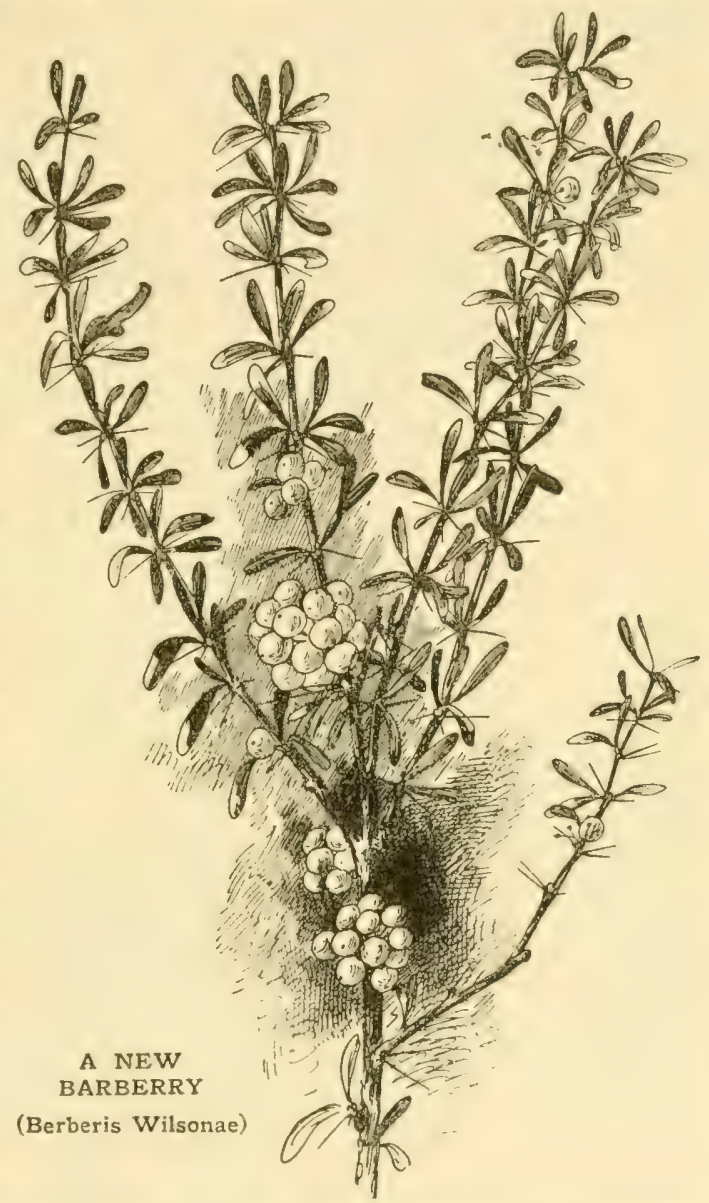
(laceae), composed largely of hardy shrubs, either evergreen or deciduous. They are widely distributed through Europe, the Himalaya, China, Japan, North America, the southern part of South America, etc. One species, Berberis vulgaris, is wild in the British Isles. Recent explorations in China have added many new kinds to the previously long list of those in cultivation, and Berberis may now be considered one of the most important groups of hardy shrubs. The majority are good flowering plants, whilst some are conspicuous again in autumn when covered with showy fruit. The fruit is wholesome, and can be 
make into jelly; in some countries it is in regular use. As a rule, cultivation offers no difficulties, for, given ordinary good garden soil, they grow well and give little trouble. Exrept when grown for some special purpose, they require no regular pruning, and may be left many years without thiming. Berberis Aquifolium, however, a plant often known as Mahonia, is excellent for clothing bare banks either in partial shate or full sun, and it is necessary to prume it severely to keep it to the desired height. This pruning may be done any time between April and July. The best plan is to remove the longer and wilder shoots each year. Propagation of many kinds is by seeds, but a few-notably Berberis stenophylla-are increased by means of cuttings. Semi-ripe shoots, 4 inches long, should be taken in August and inserted in sandy soil in a closed but cold frame. In this position they must remain until the following April, when roots will have formed. The young plants may then be planted in nursery borders.

The chief kinds are: Aquifolium (Mahonia), a Western North American shrub, 3 to 8 feet high, with large, evergreen, pinnate leaves and inforescences of yellow fluwers in spring, which are followed by deep purple fruits, covered by a clense bloom, in autumn; aristata is a very vigorous shrub from the Himalaya, it grows from $x 2$ to $x 8$ feet high, and bears yellow flowers in May and purple fruits later; buxifolia is a charming kind from Chili, of semi-evergreen habit, it bears small Box-like leaves, and solitary, fragrant, golden blossoms from the leaf axils in April ; candidula, a new evergreen from China, is of low, compact habit, and is excellent for the rock garden or border ; concimat, a IImalayan plant, conspicuous by reason of the silvery unlersurface of the leaves and large solitary yellow flowers, followed by lare, oval, scarlet fruits. Darwinii, an evergreen Chilian plant, me of the best of all, sometimes grows I $_{2}$ to $\mathrm{I}_{5}$ feet high and as far through, but is usually much smaller; the racemes of rich orange, or sometimes orange-scarlet flowers, are very attractive amongst the dark leates in April and May. Japonica belongs to the Mahonia set, and has very long leathery leaves made up of about eleven leaflets, the golden flowers are borne in large heads in March, a very difficult shrub to transplant; I-rium is a vigorous shrub from the Himalaya, it srows I2 to I.5 feet high and as far through: semicaulialata is a new Clinese species, with small deciduons leaves, it is of elegant latiat, ant bears rather small yellow flowers, followed by a profusion of mall coral-red fruits which remain through the greater part of winter.

lierberis stemonhylla is perhaps the most generally useful of all shrubs. () hybrid origin, it clains two Chilian species (I)arwinii and 


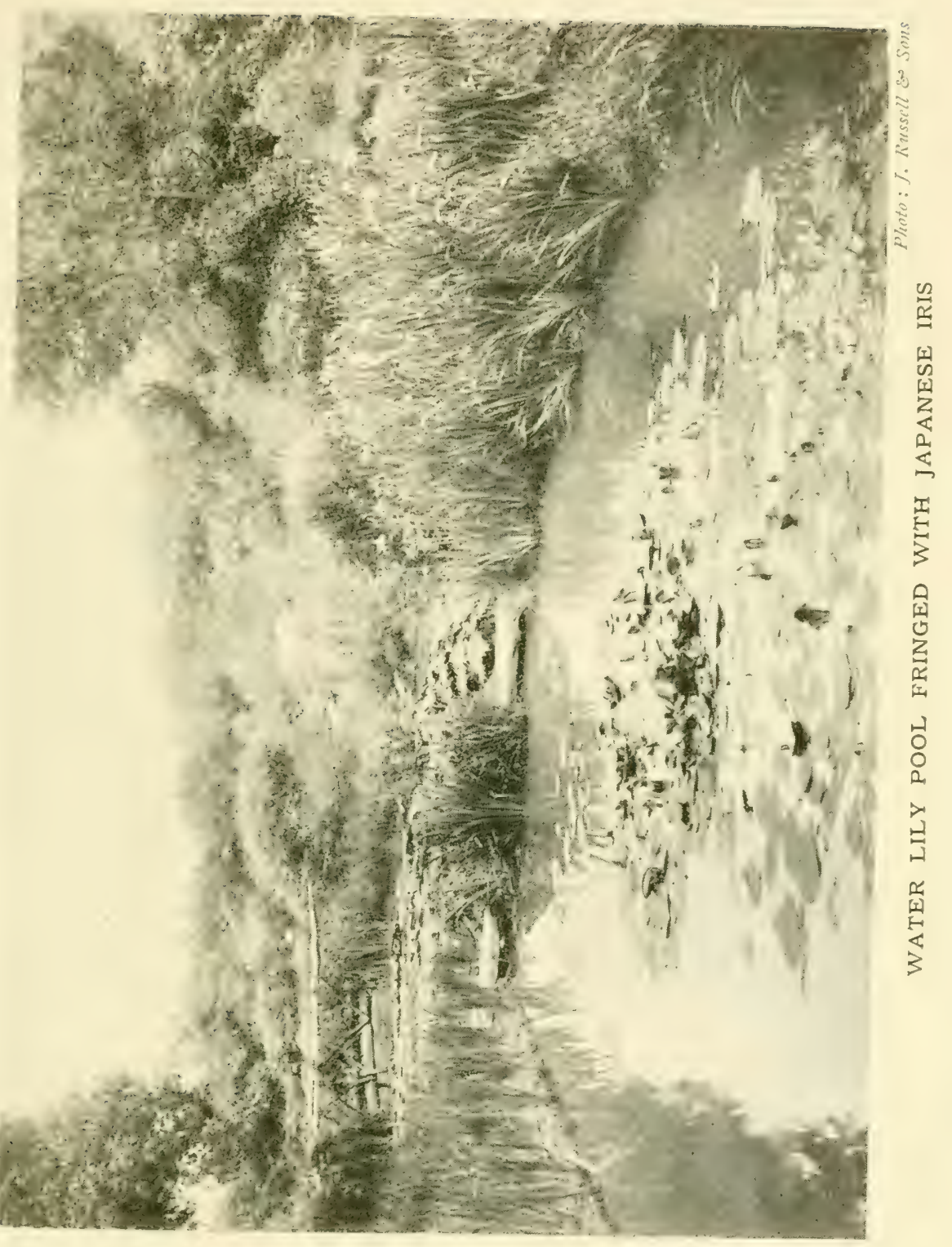



empetrifolia) as parents; it forms a shapely bush 8 to ro feet high and 12 feet in diameter without pruning. During April or early May the golden, fragrant flowers are borne in such profusion as quite to hide the narrow evergreen leaves. It may be used as a specimen bush, group, or hedge.

Berberis Thunbergii is a Japanese kind renowned for the brilliant colour assumed by the leaves previous to falling; vulgaris is the Common Barberry of our hedgerows, it is worth growing both for its yellow flowers and scarlet fruits; Wilsonae is a new Chinese species of graceful outline, it is grown both for its golden flowers and scarlet fruit.

Berchemia volubilis belongs to the order Rhamnaceae, and is a native of the Southern United States, where it is known under the name of Supple Jack. Of rambling growth, it requires to be planted near a trellis or low fence over which it may ramble at will, for no pruning is necessary. Loamy soil suits it, and propagation is by seeds. The flowers, greenish and opening in summer, are not conspicuous; they are followed by violet-coloured berries. This is not a very important plant.

Bessera. - This genus consists of but one species, namely Bessera elegans, a charming little bulbous plant with bell-shaped scarlet flowers borne during the summer months. It is native of Mexico, and belongs to the Lily family (Liliaceae). In shade of colour the blossoms vary somewhat, hence other names have been bestowed upon the most distinct. The leaves are long, narrow, and grass-like, while the slender flower scape reaches a height of 8 inches or even more. For the successful cultivation of this delightful little bulb a warm and sheltered spot and a well-drained soil are necessary; indeed, the cultural directions given for Babiana apply.

Beta vulgaris.-Most of the forms of Beet, which belong to the Natural Order Chenopodiaceae and are native of Europe, are grown as vegetables or for the extraction of sugar from the roots. Some of those with richly coloured leaves are, however, used for summer bedding; especially useful is that known as the Brazilian or Chilian Beet, a strong-growing kind, with small roots and with leaves of different tints of red and orange, with scarlet midrib. Dell's Crimson, one of the best for eating, is of dwarf growth, with rich crimson leaves; it is also used for bedding. In order to display the foliage at its best the ground should be well dug and manured. The seed may be sown where the plants are to remain, or in a reserve bed early in April, the young plants removed into their permanent quarters in early June. Transplanting needs to be carefully carried out.

Betony.-(See Stachys Betonica.) 
Betula (birk). This is an important group, composed chicfly of hardy trees with a few shrubs, natives of Europe, Asia from the Himalara northwards, and North America, and belonging to the Natural Order Cupuliferae. They thrive on poor land, and some of them are well adipted for planting on exposed hillsiles and on hare sand near the const. Two species, verruma and pubescens, are found will in the British Isles. the former in dry and the latter on moist land. Both seed freely, and seellings spring up spontancously whenever the seed is blown on to suitable stomml. Betula verrucosia is the commoner tree, and large quantities of its woud are nsed for cotton reels, shuttles, furniture, ches soles. ete. The wook srown in the British Isles is less useful than that from Vorth Europe, more especially that which is grown in Finlanel. Large quantities of American Birih are also imported into British markets. This is used largely for furniture. spinning shuttles and for cutting into voneer to slue together for use as ply-wood. The Birches may be grown in almost any garden without trouble, and some of the kinds, particularly those with pendent branches, make handsome lawn trees. In some instances the bark is white, in others hrown or yellow$i=h$, and few trees are so beautiful during winter. Propagation of the species is ly sects and of the varieties by grafting. Whilst the trees are young they should be pruned lightly each year in onler to keep the leaders clear of rival shoots and the trees shapely. In later life no pruning is required or desirable unless branches are broken by wind.

The most important are: verrucosa (Silver Birch), a hanclsome tree for light, ory land: the weeping varieties, pendula and pendula Joungi, are very graceful and desirable trees: pubecens may be distinguished by its hairy branches and leares (A.B.- these two sorts are forms of Betula alha, commonly known as the silver Birch). Davurica is a very hardy tree from North Asia and North America; lenta, the Cherry Birch of North America, important there for its timler, is grown here for decorative purposes: luten the lellow Birch of North America, forms a handsome tree: nigra is a landsome kind from North Ameria, its romgh, rebli-h-hown hark is attractive: Maximowic ii is a particularly vigorom. uprightegrowing tree from Japun: paprerifera. the Paper Birch or Canse Birch of North America, forms a shapely tree of attractive outline: the timber is useful and the tree very hardy.

Bidens (bur Marigold).- The members of this sroup, which Welong to the Daisy fomily (Compositae), ant ase mative of morth temparate countries, are of no special decorative value, unless it 
be Bidens atrosanguinea, which is classed by the latest botanical authorities with the Dahlias under the name of Dahlia Zimapanii. This, which forms a tuberous root after the manner of a Dahlia, should be given the same treatment, the roots being protected from frost during winter. The flowers of Bidens atrosanguinea are remarkable for their deep blackish-crimson tint. As above stated, the other members of this group are of little value from a decorative standpoint. They reach a height of 2 to 6 feet, or even more, and the flower-heads are for the most part of a white or yellow tint.

Bigelovia graveolens is a loose-growing shrub from Western North America suitable for planting against a wall in the South of England. It belongs to the Daisy family (Compositae), and on a south wall attains a height of Io or I2 feet. The leaves are long, narrow, and grass-like, and the flowers individually small. They are yellowish in colour and produced in conspicuous heads during late summer. Plant in a sunny position in warm, loamy soil ; propagate by seeds, and shorten the branches back to the wall during winter. This shrub is known also as Chrysocoma graveolens and Linosyris graveolens.

Bignonia.-Though there are many sorts of Bignonia, the only species which can be looked upon as hardy is Bignonia capreolata (Natural Order Bignoniaceae), the Cross Vine of the Southern United States. Even this is not suited to all localities, and is seen at its best only in the milder parts of the country. It is a free-growing climber of a shrubby character, that attaches itself to any support by small but powerful tendrils. On the south front of a dwellinghouse its requirements are well met, as there it receives a certain amount of protection during severe weather, while the shoots are well ripened in autumn. The leaves are, as a rule, divided into a couple of leaflets, broadly ovate in shape and of a dark green colour. The flowers, which are, as in many other of the Bignonias, funnel-shaped, are borne during the summer months. When this Bignonia is trained to a wall the only pruning required is to cut off any old and exhausted shoots early in spring before growth recommences.

Bindweed.-(See Convolvulus.)

Birch.--(See Betula.)

Bird Cherry.-(See Prunus.)

Bitter Cress.-(See CARDAMINE.)

Bitter Sweet.-(See Solanum Dulcamara.)

Bitter Vetch.-(See Orobus.)

Bladder Fern.-(See Cystopteris.) 
Blechnum Spicant. (Hard Firn).- Known also as Blechnum borcale and Lomaria Spirant. This distinct fern (Natural Order Filices) is found wild in many parts of this country, ancl is also a native of nearly all portions of the globe. It is an evergreen, and its dwarf and sturdy habit, together with the deep) green colour of the barren fronls, renders it useful for the outloor rockery, where in a moist shady nook it is bright and green all the winter, when 50 many hardy ferns are dormant. It is not at all particular as to soil, proviling it be free from lime, for this fern resents lime in any form. The varieties of the Hard Fern are almost innumerable, but the majority of them are less ornamental than a good form of the typical plant. All the other species of Blechnum are tender, and are therefore unfitted for the outdoor garden.

\section{Blessed Thistle.-(See CARBENIA BENEDICTA.)}

Bletia.-The tender plants of this genus, which belongs to the Orchid family (Orchidaceae), are numerous, but the only hardy one is Bletia hyacinthina, a native of China. It forms a tuft of pleasing green lanceolate leaves, I foot or little more in height, and the flower spike, which well overtops the foliage, bears a racenc of bright purple. hlussums early in summer. This Bletia may be grown in pots, but it is seen to far greater advantage in a bed macle up of peat and sand, and so arranged that while it is effectually drained the soil can be kept moist whenever required. It must be included in any sclection of hardy Orchids, however choice, for it is of refined appearance, distinct from any other, and its successful cultivation does not present any special diffeulties. Protection afforded by a few leaves around the crowns during winter is beneficial.

Bloomeria.-Two pretty flowering bulbs, native of California and nembers of the I.ily family (Liliaceac), compose this group; ther are usually at their best about midsummer. The hest known and most reatily obtainel from dealers is Bloomeria aurea, which grows about I fuot high and bears a sprearling, many-flowered hunch of golelen-yellow" flowers about I inch across. The second kind, Bloomeria Clevelandii, murle reenbles the preceling, but the flowers are smaller and the stem more stenter. The Bloomerias need a light, well-elraned soil in a sunny spot : inded, the treatment recommended for Bahiana suits them.

Bluebell.-(Sec Campanula rotundifolia and Scilla.)

Bocconia (Ilame loppy). -Ornamental herlaceous plants, natises of China and Japan, ant belonging to the P'oppy lamily (P'apaveraceac). Owing to their striking foliage they are very hambome when occupyine an isulated position or in a beel to themaclves. In gool soil the rowts sprearl quickly, and the stems, which reach a height of 6 to 


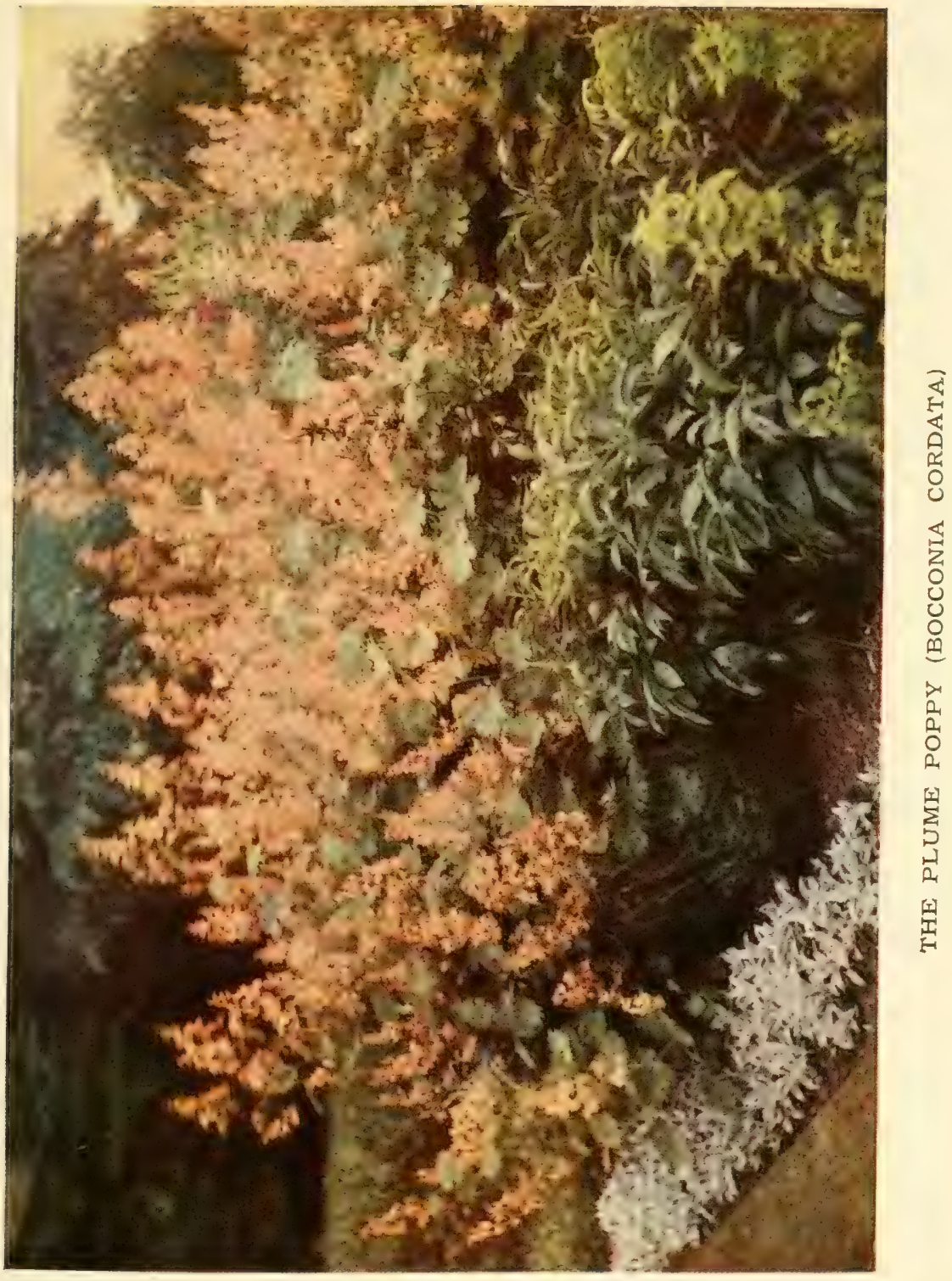



Io fect, are clothed with large, glaucous, Poppy-like leaves, and terminated by plumes of blossoms of a creamy tint. The Bocconias are readily increased by seed or by division. The kinds are cordata (also known as japonica), the oldest and most generally grown one; Geraldii purpurea, with very large, handsome foliage and panicles of white flowers, followed by distinct brown seed pods; and microphylla, taller than the others, with small white flowers, reddish in the bud state. Though quite hardy, the Bocconias are often used for subtropical bedding, for they harmonise well with the various tender plants employed for the same purpose, and bloom in July.

Boltonia (False Starwort).- The Boltonias, which are natives of North America, are a class of Aster-like plants, members of the Daisy family (Compositae); indeed, they are often confounded with the Michaelmas Daisies. They will grow freely in any good garden soil, and are readily increased by division in autumn or spring. Like the perennial Asters, they soon become exhausted if allowed to remain in one spot for some time; hence every second year the plants should be divided and replanted. In replanting, the shoots in the centre of the plant should not be chosen for the purpose, as they are naturally weak, by far the best being those from the outside of the clump. They reach a height of 4 to 5 feet. The principal kinds are : asteroides, with white or pale pinkish flowers (also known as glastifolia); decurrens, pink; and latisquama, white. Like the Michaelmas Daisies, sprays of these Boltonias are very useful in a cut state, as they last well in water; the plants bloom in July and August.

Bomarea.-A fairly extensive group of plants, nearly related to Alstroemeria, from which they are mainly distinguished by their climbing habit. They belong to the Amaryllis family (Amaryllidaceae), and are principally natives of South America, in some parts of which they are widely distributed. Generally speaking, they must be regarded as greenhouse plants, but two species are hardy under particularly favourable conditions, such as a sheltered position in the warmer parts of the country or in a well-drained border in front of the greenhouse. They are Bomarea acutifolia with flowers in early summer of an orange colour; and Bomarea Salsilla, which is even hardier. This is a slender climber, and produces in June small purple flowers about $\frac{1}{2}$ inch long, and disposed in loose clusters. The interior of the flower has a couple of darker spots at the base, and the segments are slightly tipped with green. Like its ally the Alstroemeria, Bomarea, when once established, should be allowed to remain undisturbed for some years.

Borage.-(See Borago.) 
Borago (Borage).-From the charming blue tint of their blossoms, the different kinds of Borage are remarkably attractive, and one, the Common Borage (Borago officinalis), is largely used as a flavouring in many prepared drinks. They are native of Southern Europe and Asia Minor, and belong to the Natural Order Boraginaceac. There are white and purple varieties of the common kind. The flowers of the Borage are borne in drooping panicles, and when in full bloom it is decidedly attractive, but it is seldom regarded from that standpoint, being chiefly grown for its economic value. It is readily increased either by division or seeds, and will grow freely in ordinary garden soil. A second species, Borago laxiflora, with drooping clusters of blue flowers, is ornamental, and blooms from June to the end of the summer; it reaches a height of $\mathrm{x} 2$ to $\mathrm{I} 8$ inches, and it is equally at home in the rock garden, herbaceous border, or wall garden. This is the only Borage commonly grown in the flower garden.

Botrychium (Moon Wort).--The only hardy member of this group of Ferns (Natural Order Filices) is our British Moon Wort (Botrychium Lunaria). It belongs to what are termed Flowering Ferns, of which the Royal Fern (Osmunda regalis) is a well-known example. In the Flowering Ferns the spores, instead of being arranged on the undersides of the fronds, are disposed in a separate branching spike, which usually overtops the sterile fronds. This Botrychium is deciduous (leaf losing), and forms altogrether a somewhat thin plant; the sterile fronds are pinnate, each consisting of about a dozen fan-shaperl pinne. The fertile spike reaches a height of about $\mathrm{I}_{2}$ inches, and is much branched. In a state of nature this Fern is found in the temperate and northem regions of both hemispheres; it is not at all amenable to enltivation, chief sucress being obtained when it is planted in a peaty bed and kept moist at all seasons.

Bougainvillea.-At some seasons of the year the Bongainvilleas, which are native of South America, and belong to the Nitural Order Nyctaginaceae, require the temperature of a warm greenhouse, but they do well outsicle during the summer months, and are much used for summer berding. They are generally used in mixed beds of flowering plants which are now very popular, and in a sunny spot they flower continuously from early summer until autumn. By far the bet for the purpose are Bougainvillea slabra and its variety Sanderiana, the last-named having richer coloured hracts. The real flowers of the Bouganvillea, borne in small clueters, are not at all showy; each cluster, however, is surrounded by leaf-like bracts, which are of rich colour, waslly of come shate of purple. In order to have them at their best for becling furposes, the plants need 
careful attention in spring. They pass the winter in a partially dormant state, during which time they are kept in a greenhouse, where a temperature of $50^{\circ}$ to $60^{\circ}$ is maintained; little water is given, the object being to ensure a period of partial rest. About the end of February or early in March all straggling shoots should be shortened in order to keep the plants shapely, and any old and exhausted shoots cut out. If the plants need repotting it must be done at once, using for the purpose a mixture of loam, peat and sand. Whether repotted or not, the plants will require more water, a higher temperature, and a moister atmosphere when growth begins. The plants must be well exposed to light and air, so that they do not suffer when taken out-of-doors. Generally speaking, the middle of June is a good time to put them outside. The white-flowered Solanum jasminoides and the deep orange-coloured Browallia (Streptosolen) Jamesonii are often associated with Bougainvillea. The Browallia should not be planted out in the beds; it is far more satisfactory when the pots are plunged in the soil.

Boussingaultia.-This group (which belongs to the Natural Order Chenopodiaceae) consists of a few plants, natives of South America, of which only one, Boussingaultia baselloides, is in cultivation in this country, where it is sometimes known as the Madeira Vine. It is a rapid-growing climber of a herbaceous character, with tuberous roots, the reddish stems being clothed with thick, dark green cordate leaves. The flowers are whitish, and appear in autumn from the upper parts of the shoots; they are not particularly showy, but have a somewhat Hawthorn-like fragrance. Where a rapid-growing climber, that depends for its beauty upon its foliage alone, is required, the Boussingaultia can be recommended. It succeeds best in light soil and a warm position. A curious feature is the presence of tubercules on the stems, from which young plants can be raised; the tubercules are exceedingly brittle. Another species recognised by botanists is cordata, which is a good deal similar to the preceding, but the leaves are more pronouncedly heart-shape.

\section{Box.-(See Buxus.)}

Box Edging (Dwarf Box).-This is a miniature form of the common Box, which is a good deal used as an edging to walks, flower beds, etc. It has long been employed in this way, the practice having been, in the first place, copied from the Dutch, in whose formal gardens it figured largely. Edgings of Box are not now used to the same extent as they once were, for a more natural style of gardening prevails, and, further, the Box often affords a resting-place for various garden pests. There is, however, a good deal to be said in favour of well- 
kept bos edging in the formal garden, but when neylerted it is far from pleasing. What is termed the dwauf Dutch Fox is the best for the purpose, and planting may be done from octolere to March, but unless unavoidable it should not be carried ont in the depth of winter. If a piece of old Box edging, that has beren liept regularly trimmed, is taken up, it will be found that it consists of a dense mass of shoots, all or nearly all of which have formed roots of their own. for planting purposes these are pulled apart, and earh hit trimmed into shape by shortening any straggling roots and tops. If the planting is done by the side of a gravel path, the gravel should be pulled back for a little distance in order to allow some good soil to be mixed in. The Box loves a chalky soil, so if the ground is stiff and rlayey, a little powdered chalk will be beneficial. If, on the other hand, the natural soil is poor and thin, a loamy compost enriched by manure should be added. In plinting Box edging a shallow trench must be taken out, the ground being made quite level and firm on the side against which the Box is to be placed. The plants being put into position so that the tops are from 2 to 3 inches above the ground, the soil is filled in and trodden down firmly. Care is necessary to jut the plants uniformly deep, otherwise the line will not be corn. It may be necessary to trim off a shoot here and there in order to impart a neat finish to the elging. However carefully it may be planted, even the best Box edging will in time get unsightly unless it is regularly trimmed. The month of April is the best time for carrying out this work, or it may be done again in August.

Brachycomo iberidifolia (Swan liver Daisy'). - A pretty halfhardy annual (Natural Order Compositate) that was introrluced from the Swan River district of Westem Australia about seventy years ago. It is a frecly-branched yet slender-growing plint, that reaches a height of 6 to 9 inches; the flowers, which are a good deal like those of a Star Cineraria, are a pleasing shacte of blue, there being also white and pink forms. It prefers a light, rather rich soil and a sunny spot, under which conditions it will flower throughout the greater part of the summer. The seed may be sown outside in April unless in very cold districts, when the young plants mat be raised under glass and planted out in May.

\section{Bracken.-(Sec PTERIS AQUILINA.)}

Bravoa.-The only Bravoa in general cultivation is geminiflora. It is native of Mexico and belongs to the Amaryllis family (Amaryllidaceac). It is a bullous plint, that produces long narrow leaves, while the flower stem, which reaches a heisht of a feet or so, bears on its upper portion drooping tubular orange-red flowers. It usually 


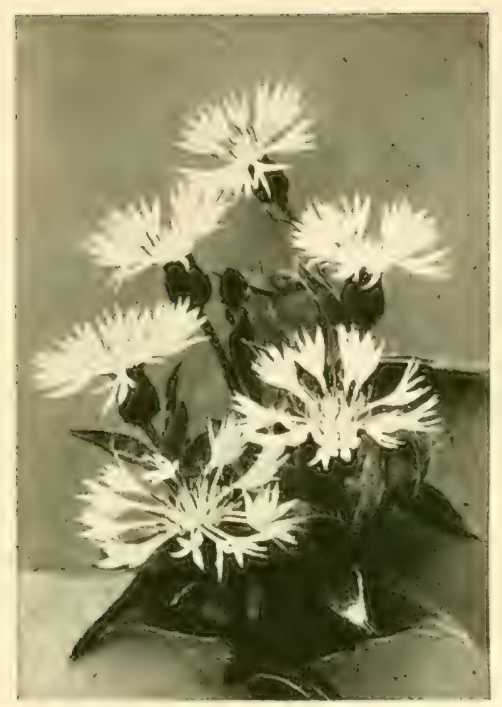

PERENNIAL CORNFLOWER (CENTAUREA MONTANA)

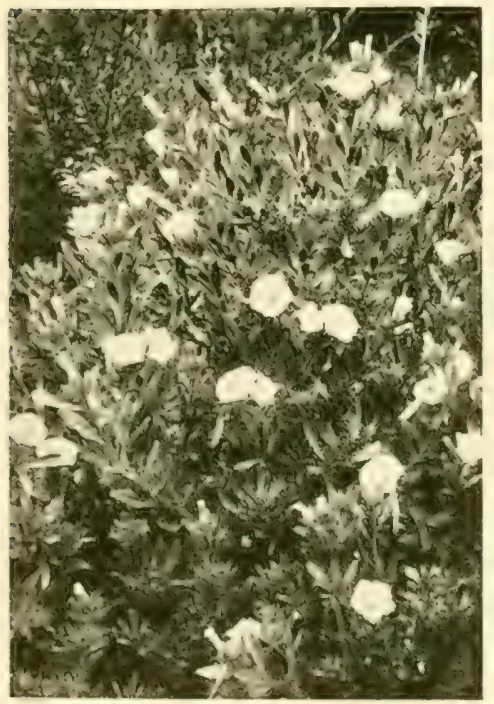

A SHOWY BINDWEED (CONVOLVULUS CNEORUM)

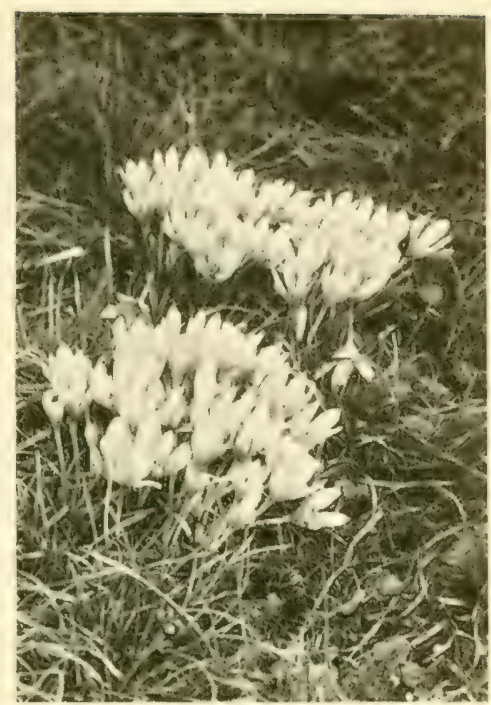

MEADOW SAFFRON (COLCHICUM AUTUMNALE)

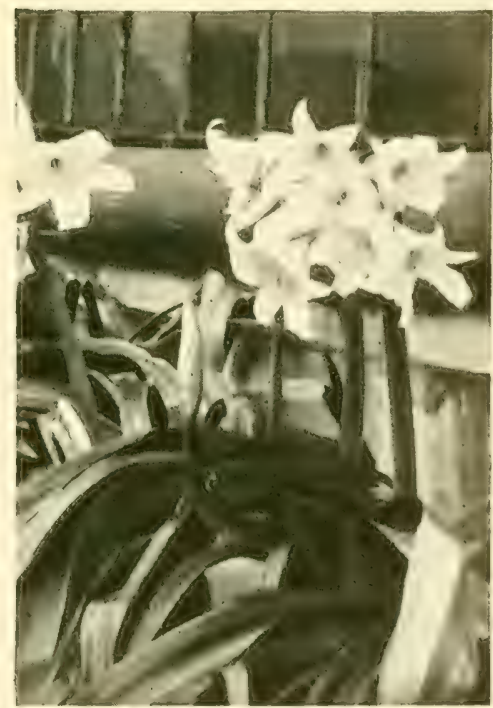

A HARDY CRINUM (CRINUM CAPENSE) 

hooms in July. This Bravoa is hardy uncler particularly favourable comlitions, and the treatment recommended for bibliana is suitable.

Briza (Qudking or Joller Grass).- Ormamental hardy Grasses (Natural Order Gramineate), some of which are natives of this country. They are of annual duration only and grow freely in any good garden soil. In clumps or masses, as many anmuals are grown, Brizas have a very pretly effect in the garden, while for associating with cut flowers they are invaluable. What is more, if the spilies are cut a little before the seeds are quite ripe and hung up to dry, they are useful for various decorative purposes during the winter months. The seed may be sown in the open ground in spring. The best are Briza maxima, media, and minor, the names referring to the size of the flower spikelets.

Brodiaea (NTissonri IIyacinth).--The Brodicats are slender bulbous plants, natives of California and North-West America, and belong to the Lily family (Liliaceace). All require a wam, well-drained sumny spot, and it is uscless to attempt to grow them in cold, heavy soil. While their repuirements are about the same, they differ widely from catch other in general, some sending up tall spikes whike others are quite dwarf. They bloom, as a rule, during Jume and July. A wellprepared and well-drained border, if possible under a sumy wall, should be prepared for Brodiaea, the bulbs being buried to at depth of 3 to $f$ inches, and surrounded with silver sand. Planting is done in autumn ats soon as well-ripened bulbs are obtainable. A selection of the best inclucles Bridgesii, purplish-blue; candicla, light porcelain blue; capitata, deep violet; cocrinea (Vergetable Fire Cracker of California), blood-red below, the apex of the tube and segments yellowish-green; congesta, blue, tall grower; IIendersonii, bright ycllow; Inowellii, lilac blue; ixioides, yellow, striperl purple; lactea, white; multiflora, deep blue; Orcuttii, lavender ; Purilyii, blue; and volubilis, rose. The last-named is remarkable, inasmuch as the flowerstem entwines itself around any support, and will often reach a height: of several feet.

Bromus (Broom Grass). - An extensive group of Grasses (Natural Order Gramineac), most of which are natives of the Northern Iemisphere. White many of them are of considerable economic value, their ornamental qualitie's do not, as a rule, rank high. Far and away the most effective from a decorative standpoint is Bromus brizacformis; it is a native of the Caucasus, and forms a tuft about 2 foet in height. In general appoarance it is suggestive of Briza maxima, but is of looser and more elegant growth. Like the Briza, 
it is useful for ascociating with cut flowers, and when dried lasts for a long time.

\section{Broom.-(See CyTisus.) \\ Broom, Spanish.-(See Spartium.)}

Broussonetia papyrifera is the principal species in this group or genus of the Nettle family (Urticaceac). It is closely allied to the? Mulberry, and is a native of China, Japan, and other Eastern countries. Its large, ornamental, hairy leaves vary in outline, and are nswally deeply lobed, sometimes being divided into numerous fine segments. In this country it forms a large-spreading bush 20 feet or more high, and sometimes a small tree. In China it attains the dimensions of a medium-sized tree, but is often grown as a coppice plant or the young branches, which are used in the manufacture of paper, and the fibre for coarse cloth. Plant in well-drained loamy soil, propagate from cuttings of ripened growths out-of-doors, and cut out dead shoots in summer, shortening any wild branches at the same time. By cutting plants to the ground each year in February, annual stems, bearing large leaves, are produced. The variety laciniata has finelycut leaves and macrophylla bears very large leaves.

Browallia.-The Browallias are all natives of South America, and belong to the Potato family (Solanaceac). They are not very numerous, but some of them are nuch used for bedding out during the summer months. The best are Browallia clata, popularly termed the Iorget-me-not of the Andes; this forms an upright, much branched plant, from I5 to 18 inches high, and bears during summer a profusion of pale blue flowers ; it is also known ats Browallia demissa. It is best raised from seeds sown in warmth in spring. A kind widely removed from the rest is Browallia Jamesoni, more frequently met with under the name of Streptusolen. It is altogether a larger grower than the others, and plants from of to 6 feet in height, crowded with bright orange-red blossoms, form a striking feature in mixed beds of flowers. The purple flowered Browallia speciosa major, a shrubby kind from IS inches to 2 feet in height, flowers continuously throughout the season; it is much appreciated for greenhouse decoration as well as for summer bedding. The last to mention is Browalliar visosat, of which the blosems, much smaller than those of speciosa major, are decp blue, with conspicuons white ege; it is dwarfer and more compact than the preceding, but cyually floriforous. The Browallias (except clata) need to be wintered in a greenhouse safe from frost, and at that season kept moderately dry. With the return of pring more water may be given, when they will start into growth. If young shoots are taken as cuttings they strike root as 
readily as a Fuchsia, and if grown in the greenhouse will be ready for beclding out in early summer. Older plants, however, make the best display when bedded out. Sceds of speciosa major and viscosa are sometimes obtainable, and from these young plants can be readily raised if treated as recommended for elata.

Bruckenthalia spiculifolia, a pretty little Heath-like shrub belonging to the Heather family (Ericaceae), and native of Eastern Europe and Asia Minor. Mature plants are from 3 to 6 inches high and form dense tufts of rich green leaves about the size of those of the Common Heather. The upright inflorescences are in the form of short, dense heads well above the foliage, the flowers being white or white tinged with pink. They are produced in May. Moist, peaty soil, or light loam free from lime, suits, whilst propagation is by cuttings placed in sandy soil under a handlight in August, or by layers. Pruning is confined to the removal of the old flower-heads. It may be planted in the rockery or in beds with Heaths.

Bryanthus.-This is a small but ornamental genus of Heath-like shrubs (Natural Order Ericaceae) which require somewhat similar treatment to Erica, but must not be planted in ground subject to drought. They may be placed in the rock garden or in beds, but it is well to select a position shaded from the midday sun. Peaty soil or light loam free from lime is suitable, and pruning is limited to the removal of the faded flower heads. Increase is by seeds, cuttings, or layers, the first and last being the easiest methods. Bryanthus Breweri and empetriformis are natives of the mountains of Western North America from British Columbia to Southern California; they grow a few inches high and bear reddish flowers in May. Bryanthus taxifolius is widely distributed through the alpine regions of the Northern Hemisphere; its flowers may be red or bluish in colour, and it grows from 3 to 9 inches high. Bryanthus erectus is really a hybrid between Bryanthus empetriformis and Rhodothamnus Chamaecistus; growing about 6 inches high, it bears showy reddish flowers, but is very rare.

Bryonia (Bryony).--The only hardy kind is our British Bryonia dioica, known also as the Devil's Turnip. It belongs to the Gourd family (Cucurbitaceae). It is a tuberous-rooted perennial, and sends up strong-growing shoots of annual duration, which are clothed with five-lobed leaves. When rambling over a fence or arbour it is decidedly ornamental, especially as the whitish flowers are succeeded by berries, which, when ripe, are bright red. This Bryonia will grow freely in almost any soil.

Bryony.-(See Bryonia.) 


\section{Buckbean.-(See Menyanthes.) \\ Buckthorn, Sea.-(Sec HipPopin̈.)}

Buddleia. -. Vigorous shrubs or small trees (Natural Order Loganiaceac) from the Ifimalaya, China, Chili and Peru. With one exception the flowers are produced in racemes. In the case of Buddleia globosa, however, they are in globular heads. All thrive in loamy soil, and several are available for general cultivation, others being hardy only in the warmer counties. Propagation is usually carried on by means of cuttings, although seeds, which are produced in abundance, may also be sown. Pruning is referred to in the following notes. Buddleia Colvilei, a native of Sikkim, attains tree-like proportions in its native country, and grows quite well against walls in the milder parts of this country, where its handsome tubular flowers, each I inch or more in diameter and red or rose in colour, are produced in long racemes in summer. Cut back the shoots after flowering. Buddleia globosa is an evergreen from Chili and Peru with globular heads of small golden flowers, which are very fragrant; it is quite hardy; no pruning is necessary except to keep the bushes shapely. Buddleia variabilis is a very variable plant from China, growing at least Io feet high and bearing racemes of rosy-lilac flowers from July onwards. It is, however, surpassed in beauty and value by its rarieties Veitchiana and magnifica, comparatively new kinds with racemes or branched panicles of flowers up to $\mathrm{I}_{\frac{1}{2}}$ or 2 feet in length. Both are excellent shrubs, suitable for general cultivation. They must be given rich, loamy soil and be pruned back to within I or 2 inches of the base of the previous season's growth each spring. The flowers are very popular with bees.

Buldleia salicifolia is a handsome kind, with long and graceful racemes of fragrant white flowers, suitable for outcloor planting in the milder counties and for the greenhouse elsewhere. I'rune hard after flowering.

Buddleia officinalis is a new Chinese plant, rather tender, and usually grown under glass; its rosy-lilac flowers are borne in winter. Prune hard after flowering.

Bugbano.-(See Cimicifuga.)

Bugle.-(See AjUgA.)

Bulbocodium vernum (Spring Miadow Saffron).-A pretty little bulbous plant, much resembling a Crocus, from which it differs in minor botanical features. It is known also as Bulbocodium ruthenicum, and belongs to the Lily family (Liliaceae). It grows to a height of 4 to 6 inches, and bears rosy-purple flowers quite early in spring. This Bubocodium is a native of Spain, and succeeds under much the 


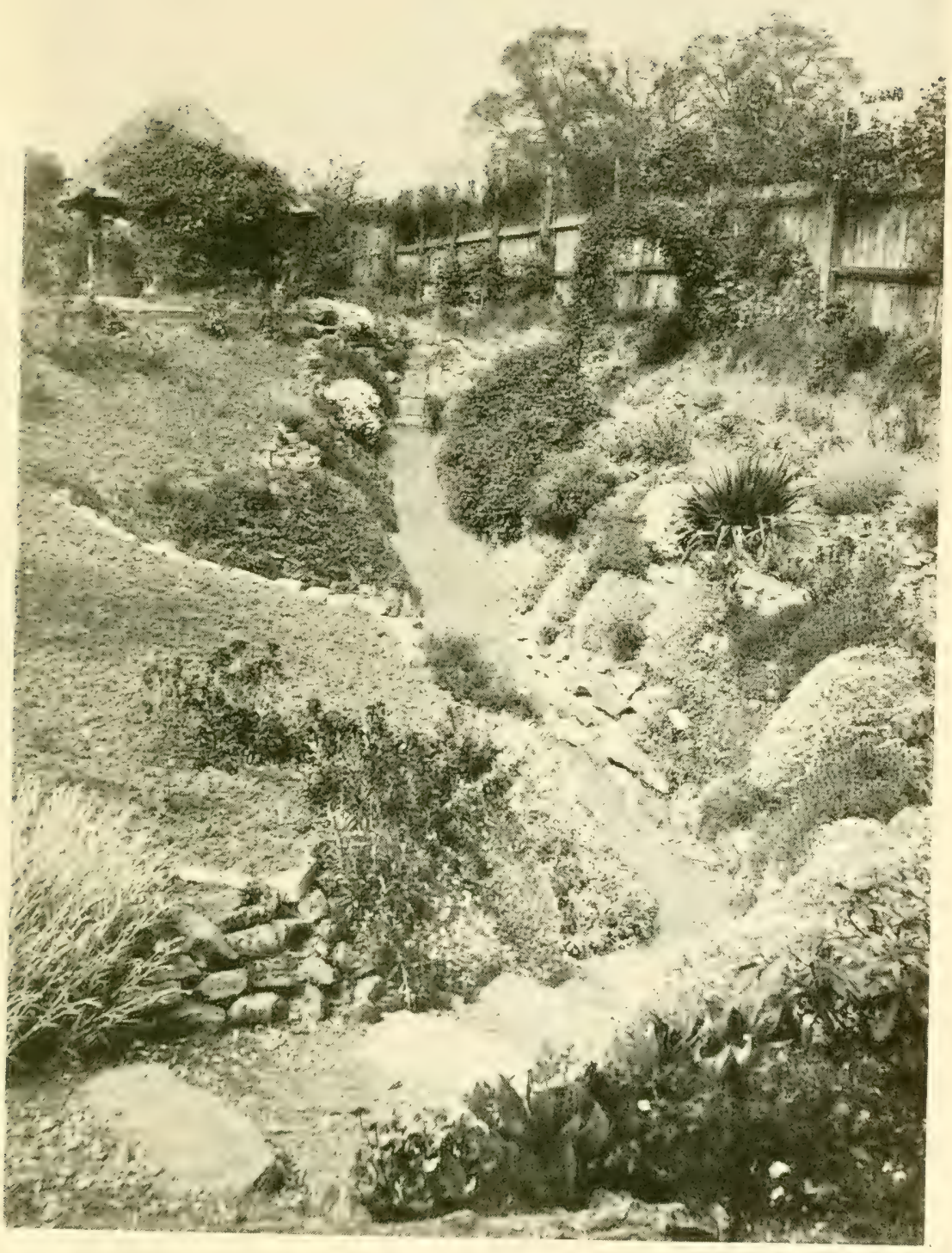

ROCK GARDEN IN A HOLLOW 

same conditions as a Crocus, the bulbs being planted about 2 inches deep. It is prolific in offsets; hence the bulbs should be occasionally lifted and replanted in July or August. Slugs are particularly fond of the young shoots, and these pests must be guarded against.

Bulrush.-(See TYPHA.)

Buphthalmum $(O x$ Eye).-Showy perennials, members of the Daisy family (Compositae), that will thrive in ordinary garden soil. and may be readily increased by division, carried out in autumn. They are natives of Central and Southern Europe. The chief kinds are: salicifolium, bearing large, solitary, and bright yellow flowers in summer, 2 feet; speciosum (also known as cordifolium, and Telekia speciosissima) is a much stronger plant, for it grows from 5 to 6 feet high. The large leaves are thickly clothed with hairs, and the yellow flower-heads have a striking appearance during the latter part of summer. The Buphthalmums are particularly adapted for the wild or semi-wild portions of the garden; they are rather too coarse for the border proper.

Bupleurum (Hare's Ear).-Plants belonging to the Natural Order Umbelliferae, and for the most part of little interest or beauty. Some are annuals, others are perennials, while one at least is a shrub. This is Bupleurum fruticosum, native of Spain. It forms a much-branched bush from 3 to 6 feet in height, clothed with oblong, glaucous leaves that persist during winter; the yellow flowers, in small umbels, appear late in summer, but do not add much to the beauty of the plant, of which the most notable feature is the grey-blue foliage. This shrub is rather apt to get bare at the base, and may be cut back hard in April. Cuttings taken in August, and placed in a frame kept closed and shaded, soon root, or they may be taken in October and inserted in a sheltered border out-of-doors. There are many other species, but this is practically the only one worth growing.

Bupleurum fruticosum is singular amongst hardy shrubs as being the only one belonging to the Natural Order Umbelliferae that can be grown out-of-doors. It is native of the Mediterranean region, and may be grown as a bush in the south-west and against a wall elsewhere; its glaucous-green, oblong leaves are evergreen, and the yellowish flowers in fair-sized umbels or flattish bunches appear in August. Increase may be by seeds; plant in loamy soil and

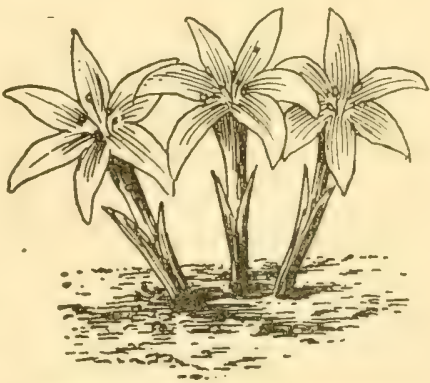

SPRING MEADOW SAFFRON 
prune in spring to keep the plints shapely and within bounds. The flower-heads must be removed when the blooms are over.

Bur IMarigold.-(See BIDENS.)

Burning Bush.-(See Dictamnus.)

Butcher's Broom.-(See Ruscus.)

Butomus umbellatus (Flowering Rush).-The only species is a British plant, common in swampy places throughout the country. It belongs to the Natural Order Alismaceac. It forms a tuft of upright, sharp-edged leaves some 2 to 3 feet high. The erect flower stem, which well overtops the foliage, is terminated by an umbel of rose-coloured blossoms during the summer months. The Flowering Tush thrives in boggy ground, and is readily increased by division, best carried out in early spring before growth recommences. It is a first-rate plant for the margins of lakes and similar spots, or for the water garden.

\section{Butterfiy Tulip.-(See Calochortus.)}

Buxus (Box).-This group, which belongs to the Spurge family (Euphorbiaceae), is composed of a few evergreen trees or shrubs, natives of Europe, North Africa, South Africa, the Himalaya, China, and Japan. One, sempervirens, is found wild in England, notably on Box Hill, in Surrey; the hardy sorts are extremely useful by reason of their decorative effect and their ability to withstand severe clipping. The last qualification, added to a dense branch system, has led to Buxus sempervirens, the Common Box, being used extensively for topiary work, and plants clipped into all kinds of grotesque forms may be procured. Such plants live for a very long period, and are kept in shape by clipping the young shoots back once or twice during summer. There are many varieties of the Common Box; pendula, with graceful drooping branches, forms the best specimen plant; IIandsworthii, latifolia, and pyramidalis are excellent kinds for hedges ; elegantissima and argentea lave silver-varicgated leaves; aurea maculata, aurea pendula, and aurca marginata have golden-marked foliage; prostrata is of creeping habit ; rosmarinifolia is renowned for its close growth and tiny narrow leaves; whilst suffruticosa is a compact, low-growing kind in great demand as an edging to borders and paths. The last-named and those grown as hedges must be clipped once a year, but those grown as specimen plants require no other pruning than that necessary to make them shapely. They thrive in ordinary garden soil, and are increased by cuttings, or, in the case of Edging Box, by division. The wood of most of the Buxus or Boxes is very hard, close-grained, and valuable for engraving blocks, the mamufacture of mathematical instruments, etc. In addition to the 
Common Box (Buxus sempervirens) the following are worth mention : balearica, a small tree with leaves upwards of an inch long, found in the Balearic Islands and about the Black Sea; Harlandi, a Chinese shrub, with pale green rounded leaves; Chinensis, distinct by reason of its low, stiff habit and long, narrow leaves; Wallichiana, a native of the Himalaya, a very distinct kind, its leaves are dark green, I $I_{4}^{\frac{3}{4}}$ to $2 \frac{1}{2}$ inches long and barely $\frac{1}{2}$ inch wide.

Cacalia.-(See Emilia.)

Cactus.- The term Cactus is applied to a great variety of succulent plants, natives of the dry and arid regions of the warmer portions of the globe, and belonging to the Natural Order Cactaceae. Some are occasionally used for associating with other succulent plants for summer bedding, but most of them require glass protection even in summer. The only hardy Cacti are a few of the Opuntias, namely, monacantha, Rafinesqui, and vulgaris, all natives of North America. They have flowers of some shade of yellow, produced during the summer months. They resent an excess of moisture, hence should be planted in a sunny, well-drained spot, and if protected from heavy rains in winter, so much the better. Light sandy soil at the foot of a greenhouse or wall and a south aspect fulfil their needs.

Caesalpinia.-This is a large genus, composed principally of tropical plants, very few of which can be considered to be of much importance in the garden. They belong to the Pea family. Two sorts, however, japonica from Japan and Gilliesii from South America, both very beautiful flowering shrubs, are sometimes grown out-ofdoors in this country. Caesalpinia japonica forms a wide-spreading bush with long, rambling, spiny branches, clothed with large bright green leaves divided into numerous small lobes, and produces in summer large panicles of golden flowers. Gilliesii must be grown against a south or west wall, when it will attain a height of 20 feet; its manyparted leaves are very beautiful, but its chief charm centres in the immense terminal inflorescences of large golden flowers with long red stamens. Light, loamy soil is suitable. The last-named kind requires little pruning; the branches of the other should be shortened in spring. Caesalpinia japonica is increased by root cuttings, and Gilliesii by seeds.

Calamintha.-Pretty herbaceous plants, native of northern temperate regions, nearly related to the Sage and members of the same family (Labiatae). They are easily grown in ordinary garden soil. The principal species are Acinos, which grows about 6 inches high ; alpina, a small, creeping plant well suited for rockwork ; chenopodium (Wild Basil) and grandiflora, about I foot high, all of which bear purple flowers in summer. 
Calandrinia (Rock Purdent), - The principal hardy kinds (Natural Order Portulaceac) are natives of Chili, and they all thrive in a light, suny, well-drained spot. With the exception of umbellata, they are annuals. socts of which may be sewn out-uf-dours in early spring. Sotue gardeners raise them under glass. but this is by no meatns necessary; all flower during the summer montl.s. The best are: grandiflora. which grows about is inches high and bears large rosc-coloured b.ossons with yellow anthers; and Menziesii or speciosa, which only reaches about halt the height of the uthers, and bears purplish-crimson Rowors. Calandrinia umbellata, as above statel, is a pronuial suitabie for the rockory; it reaches a heitht of about $g$ inches, and the rich magenta-crimsun flowers appear throughout the sumumer.

Calceolaria (Stipper Wont).-A remarkably showy class of plants, mest nif which are natives of South Anurica; they bulong to the Smapdragon family (Scrophulariactae). Some of them are very ornamental, and have hoot ornsind and intererossed to suel an event that the earden varieties are now almost endless. Those termed Iicrbaccous Calcolarias are solely usod for the doomation of the Gruathouse, but many of the gardien warictics are largely enployed for summer bedding. Of the true specte, especial mention may be made of Caloodaria amplevicaulis, a tall-growing kind with lemoncoloned flowers; it is much usud for summer bots and will continue to flower until frosts soe in. Calcoularid integrifolit is quite a shmb, and in the West of Enyland it is romarkably fues, the goldenyellow blossoms being chiotly borne during the autumn months. In most parts of the country it cannot, however, be dequended upon cut-uf-dorors unles in an epesilly sheltered spot. Calooblaria plantagima is a hardy horbacoous rilant about I toot ligh, of which the rich ycllow tuwers ar: borue in the summer. A fairly ood, moist soil suits it bet. Another hardy kind is polyrhiza a crocpinf plant absut 6 incles high, the yellow flowers of which are slightly ibted with red; it is a charming rockery plant.

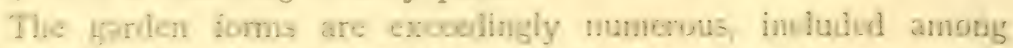

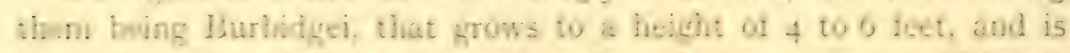
eunonlly mot with in parks and gerdens during sunumer; Clbrani, at. excoodingly florifemus kimbl, with pale yellow lowers, which doe not. Lowerer, blocen through cut tar sagon; Golden Gem, rich

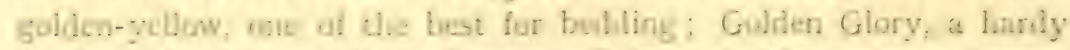
kind, with harye yellow dowers; Sultan, bright crimon-brown. and numerous others.

The lethacens kints can be increasel by divition, and the others are ceadily propogated by moany of cutcings, which, fut iu saudy 


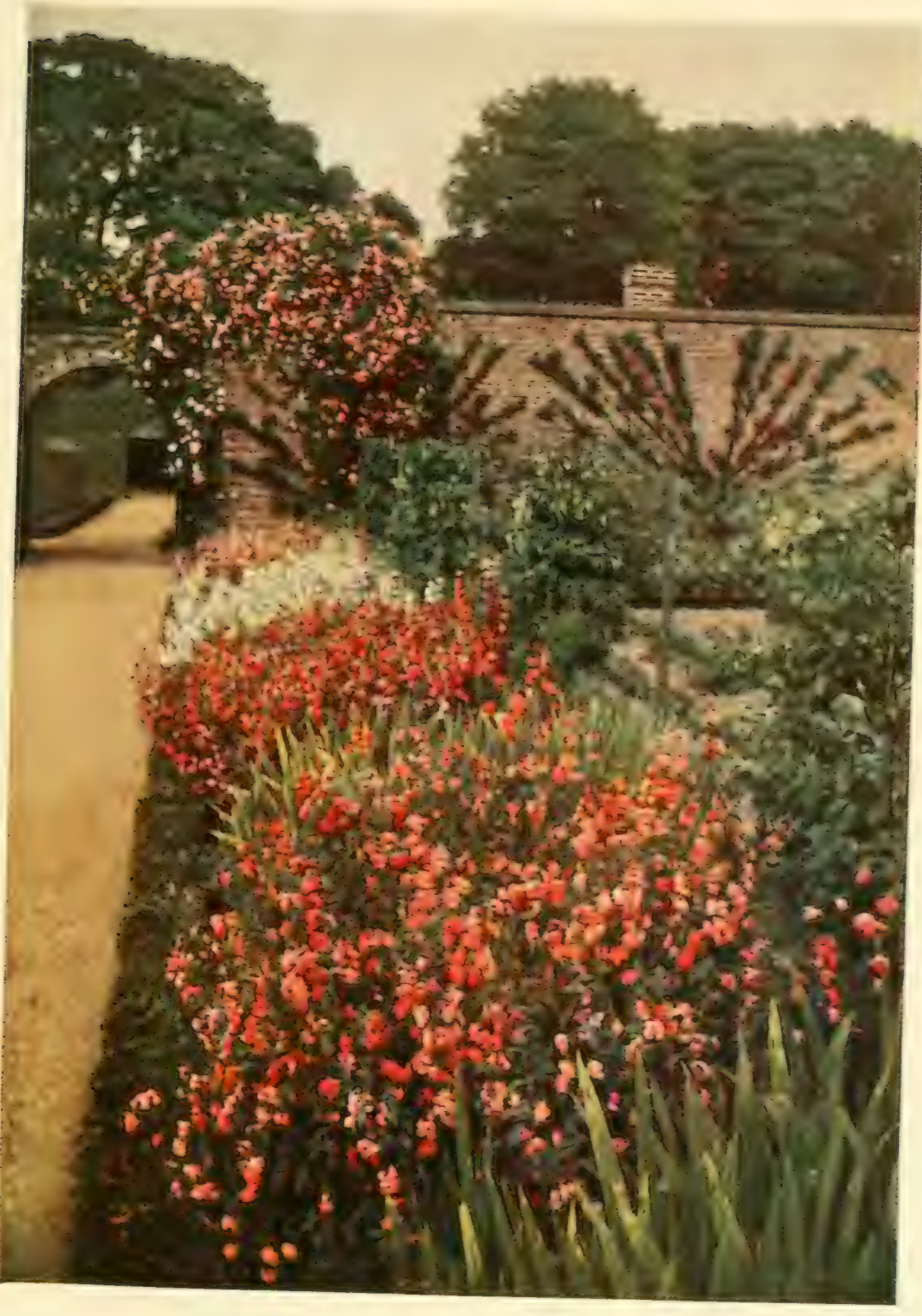

A BORDER OF CLARKIA AND OTHER ANNUALS 

soil in a closed propagating case, will strike at almost any season of the year. The usual time, however, for putting in cuttings of the bedding varieties is in September; they are dibbled in pots or boxes of sandy soil, and kept shaded from bright sunshine until rooted. They only require protection from frost during the winter, for Calceolarias particularly resent being "coddled" at that season. In carly spring they may be potted singly in readiness for bedding out late in May or early June.

Calendula (Marigold).-Far and away the best of the Calendulas, which belong to the Daisy family (Compositae), is the common Marigold or at all eventssome of the varieties which have been obtained from it. The Marigold is a persistent bloomer, and even under the most adverse conditions in town gardens its golden-ycllow blossoms enliven up an otherwise dull spot. This remark refers to the common kind, which springs up from seed everywhere, but by a process of sclection many greatly improved varieties have been obtained. Prominent among the best are Lemon Queen, soft lemon-yellow; Meteor, orange-yellow, striped lemon-yellow; Orange King, brilliant orange, very double; Prince of Orange, orange, striped pale yellow; and Yellow Queen, golden-yellow. Other kinds are: arvensis, yellow, 2 feet high, and Maderensis, orange. They are raised from seed sown under glass in March or out-of-doors in April.

Californian Poppy.-(See Eschscholtzia.)

Calla palustris (Marsh Calla).-A pretty little bog plant, with rich green oval leaves, and during the summer a profusion of small white flowers suggestive of a miniature form of the Arum Lily. It is native of the Northern Hemisphere, and belongs to the Natural Order Aroideae. The entire plant when in bloom is not more than 9 inches in height.

Callicarpa purpurea is a shrubby member of the Verbena family (Terbenaceae), and a native of China and Japan. It is hardy in the milder parts of the British Isles, but gives more satisfactory results when grown in a greenhouse. It forms long slender branches, which bear large quantities of small flowers during summer, and these are followed by a profusion of purple fruits. The plant is grown for its fruit alone, as neither leaves nor flowers have any pretensions to beauty. It must be grown from cuttings rooted in spring, and be given a compost of 3 parts loam, I part leaf-mould and well-rotted manure, and I part sand. Old plants may be pruned hard back in spring, and be kept for another year if necessary. There are several other kinds, but purpurea is the best for pots. Callicarpa japonica, a native of Japan, is most often tried out-of-doors. 
one, a good selection therefrom being: albus, pearly-white, lined with silky hairs; amocnus, rosy-purple; Benthamii, rich ycllow; clavatus, bright yellow, large flower; elegans, white, purple base; Howellii, creamy-white, brown hairs in centre; Kennedyii, bright scarlet; lilacinus, lilac; luteus, yellow; macrocarpus, violet-blue; Maweanus, white, lined with blue hairs; Plummerae, satiny-lilac; pulchellus (Cyclobothra pulchella) and renustus, represented by numerous varieties, but all have the eye-like spots characteristic of the butterfly, in the interior of the flower.

Calophaca wolgarica belongs to the Pea family (Leguminosae), and is native of South Russia. It forms a rather loose bush, 3 or 4 fect high, and is recognised by its small pinnate leaves and yellow Pea-shaped flowers, which appear in racemes in June. Although often grafted upon stocks of Colutea arborescens, it gives better results on its own roots, and should be grown from sced. Loamy soil suits its requirements, and pruning is unnecessary. A sunny position is desirable, and it may be given a place about the summit of the rockery.

Caltha (Marsh Marigold).--The Calthas are a race of moistureloving herbaceous perennials, belonging to the Buttercup family (Ranunculaceae), and natives, for the most part, of the Northern Hemisphere. They are seen at their best when treated as waterside plants, and luxuriate under such conditions; they are readily increased by division during the dormant season. Except in Caltha leptosepala (which is white), the flowers of the species are of some shade of yellow, and are produced in spring and early summer. One species, namely Caltha palustris, is a native of Great Britain; this reaches a height of about 12 inches, and has large golden-ycllow blossoms. The varieties of this kind are numerous, there being alba, white; flore pleno, clouble; minor, smaller than the type; monstrosa plena, very large; semi-plena, semi-double. Polypetala, which reaches a height of $x \&$ inches, and has very large leaves and blossoms of rich golden-yellow colour, is native of Asia MInor.

Calvary Clover.-(Sec Medicago Echinus.)

Calycanthus.- The several members of this group (Natural Order Calycanthaceae) are known as Allspice, by reason of the peculiar fragrance of their reddish-brown, many-petalled flowers. Three harly kinds have been introduced: florilus and glaucus from the Southern Lnited States, and occilentalis from Californiat. The last-namal is the most vigorous slirub, for it sometimes grows \& or Io feet and Io feet across. As a rule, however, it is from of to 5 feet high. Calycanthus glaucus is a very similar plant, except that the under-sides 


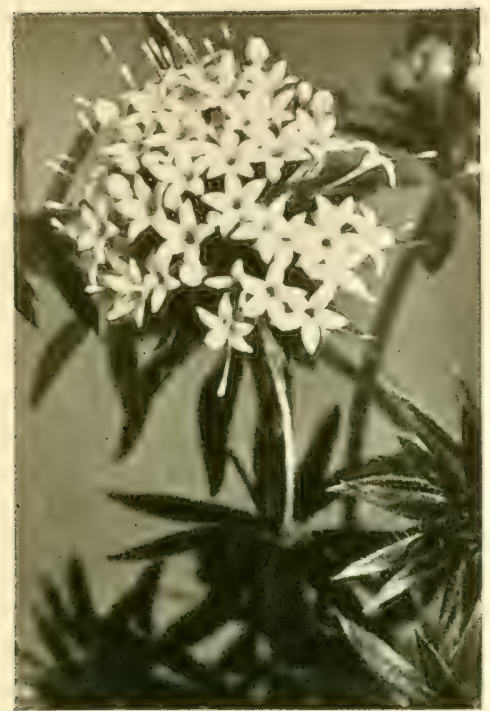

THE CROSSWORT (CRUCIANELLA STYLOSA)

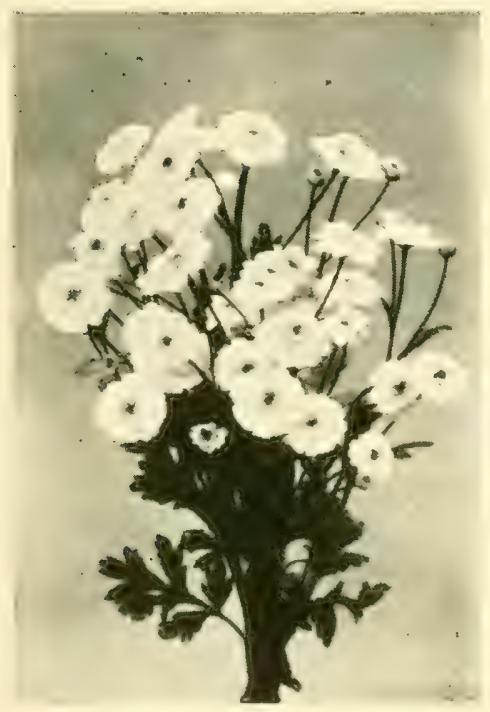

DOUBLE WHITE FEVERFEW (CHRYSANTHEMUM PARTHENIUM)

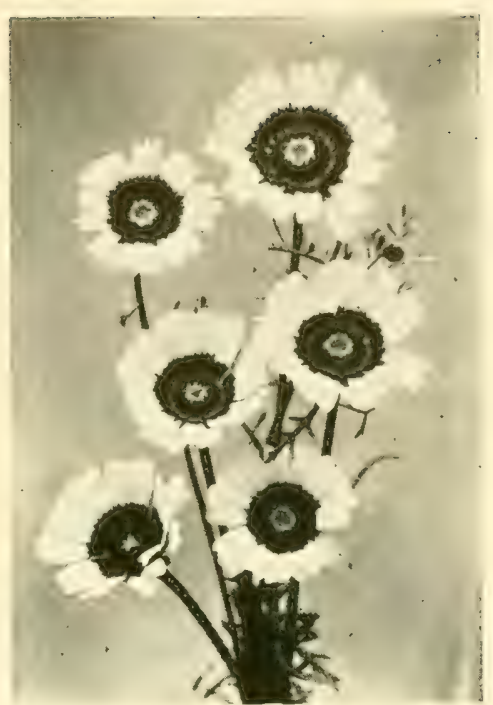

FLOWERS OF ONE OF THE ANNUAL CHRYSANTHEMUMS

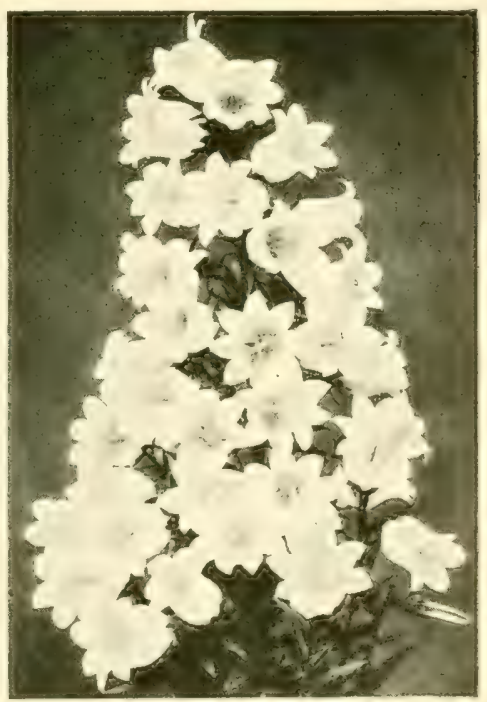

CANTERBURY BELL (CAMPANULA MEDIUM) 

of the leaves are glaucous. They enjoy a sunny position in light loamy soil, and may be increased by seeds, cuttings, or division of the plants. No regular pruning is required; simply thin the plants now and then, and cut them back in spring if they are outgrowing their positions. The flowers are borne during summer.

Calypso borealis.--This, which is the only member of the genus, is a terrestrial Orchid (Natural Order Orchidaceae), native of cold districts in the Northern Hemisphere. It produces a solitary leaf and a slender stem, about $\mathrm{I} 2$ inches high, bearing a single flower. The blossoms, which in shape are a good deal similai to those of a Cypripedium, are pink marked with brown, with a yellow crest on the lip. The Calypso needs a moist position and a soil largely consisting of peat and leaf-mould. It is not an easy plant to maintain in a flourishing state. Summer flowering.

Calystegia (Bear Bind).--Some of our most troublesome weeds belong to this group, among them being the Hedge Bindweed, Calystegia sepium (Natural Order Convolvulaceae), of which the large white flowers are very showy, but owing to its long creeping shoots it is difficult to eradicate once it gets into garden ground: The only one grown for its ornamental qualities is pubescens, also known as hederacea. This is vigorous, and bears a profusion of double rosecoloured blossoms for a long time during the summer. For furnishing screens and trellises at that season it is very attractive, but it is as troublesome to get rid of as the common Bindweed.

Camassia.-Pretty flowering bulbous plants, natives of NorthWest America and belonging to the Lily family (Liliaceae). They produce an erect flower stem varying from I foot to 2 feet in height; the flowers, which open in May and June, are borne on the upper part, and vary from white to blue. The bulbs prefer a rather moist, loamy soil, and should be planted in autumn at a depth of 4 to 5 inches. The chicf species are: Cusickii, pale blue; esculenta, deep blue; Fraserii, light blue; and Leichtlinii, creamy-white.

Camellia.-This is a very important group, both from decorative and economic points of view, for on the one hand it includes a considerable number of valuable evergreens and ornamental flowering shrubs, and on the other hand one of its members is the common Tea plant. It belongs to the Natural Order Ternstroemiaceae. The seeds of various kinds are also rich in oil, which is extracted and forms an article of commerce. They are natives of China and Japan, and the best known in this country is japonica, which is represented by a large number of varieties bearing single, semi-double, or double flowers, of all shades from white to pink and deep red. Although 
generally grown in a cool greenhouse, they are hardier than many people imagine, and there are numerous gardens in the South of England where large bushes grow luxuriantly in the open ground, and they blosiom almost every year. When grown out-of-doors they give less trouble than when planted in borders under glass, providing they have well-drained, warm soil. Pruning is not often necessary except for the purpose of shaping the bushes, but if plants are becoming thin about the base they may be cut hard back in spring.

Plants under glass may be grown in pots or borders, but in whichever way they are grown they must be given thorough drainage, for anything approaching sourness of the soil or improper drainage is against the perfection of the flowers. Complaints are frequently made about bud-dropping of Camellias, and the cause may often be traced to unsatisfactory soil or drainage. Broken bricks, covered by clinkers, form excellent drainage for beds, and over that a layer of turves should be placed, grass side downward:. From $1 \frac{1}{2}$ to 2 feet of soil will be ample, and the compost should consist of 3 parts loam, I part peat, and I part coarse sand. Propagation is effected by grafting the varieties upon stocks of the type under glass in spring.

Good varieties are: Chandleri elegans, rose; alba plena, double white; Contessa Lavinia Maggii, white, red stripes; C. H. Hovey, crimson; imbricata, a fine double red; Marchioness of Exeter, rose; Mathotiana, large double red; M. alba, white; Thomas Noore, carmine. Donckelaarii, a deep red scmi-double, is one of the best kinds for outdoor planting.

Among the species or wild types are: reticulata, a handsome Clinese plant, requiring greenhouse shelter, the red flowers are semidouble and very large; rosacflora, a native of China, has pretty little double rose-coloured flowers, scarcely İ inches arross; Sasancua is a Chinese and Japanese bush, with small ovate leaves, it bears single or double flowers, 2 to 3 inches across; there are many varieties. Camellia theifera, the common Tea plant, which bears white flowers about $\mathrm{I}_{2}^{\frac{1}{2}}$ inches across, is worth growing as a plant of more than general interest. The dried young leaves form the tea of commerce.

Campanula (Bell Flower).-A very large group (Natural Order Campanulacene), consisting chiefly of hardy herbaceous perennials; the flowers of nearly all are white or of some sharle of blue. While some of the alpine species need care and attention, most of them flourish under ordinarily favourable conditions. Mrost of the Campanulas are natives of Europe, but a few of them are found in Northern Asia. All have more or less bell-shaped flowers, hence the popular name of Bell Flower: 


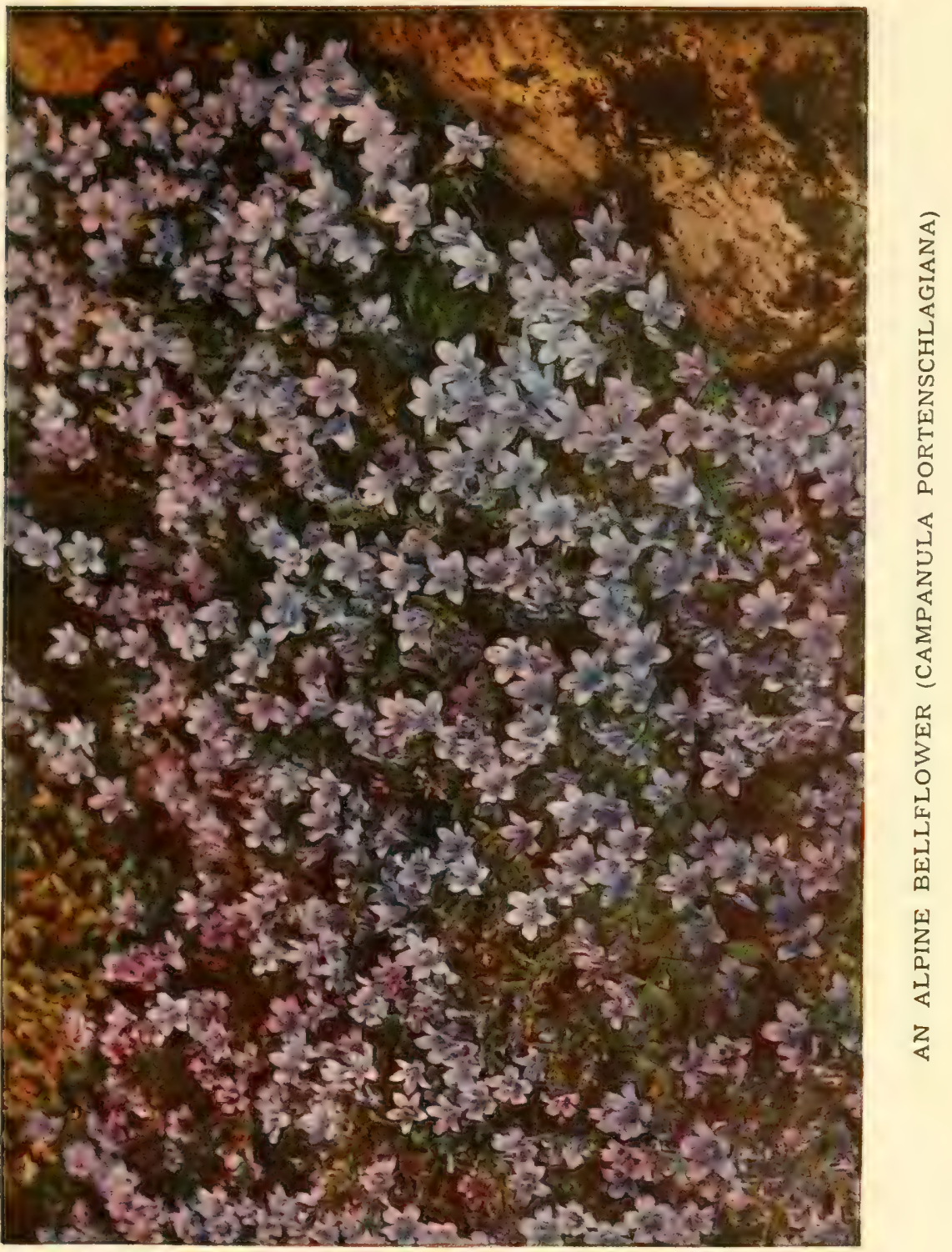



There are a few annual kinds, namely, drabaefolia, a dense-growing little plant, with purple-blue flowers; ramosissima (Loreyii) grows about I8 inches high, its violet-blue flowers are borne during the summer months; and macrostyla, from the Taurus Mountains, a strange-looking plant, with stiff, hairy stems and erect, solitary blue flowers. The two first-named may be sown in the open ground, but the last needs to be sown on a warm, sheltered border.

Of biennial Campanulas, only one species need be mentioned, namely, the Canterbury Bell (Campanula Medium). This, represented by several forms, is probably grown to a far greater extent than any other. Canterbury Bells are largely employed for greenhouse decoration, but more particularly for the embellishment of the outdoor garden. For the latter purpose the seed is sown in May or June, and when the young plants are sufficiently advanced they are planted out in prepared beds until the border is ready for them in which they are to flower the next year. The extent to which the varieties differ from the type in the case of the Canterbury Bell is truly remarkable, for not only does the normal form bear flowers of different shades of rose, white, and blue, but there are varieties with double blossoms, in which the range in colour is just as great. Added to these there is a singular form known as Campanula Medium calycanthema, in which the calyx is large and spreading and of the same colour as the corolla; this is popularly termed the Cup and Saucer Canterbury Bell ; the same colours are also represented in this as in the ordinary form. When Canterbury Bells are flowering in the outdoor garden, especial care should be taken to see that they do not seed; if the old flowers are cut off as soon as they are past their best, a secondary and fairly effective display will be the result:

The different perennials may be divided into two classes: firstly, those of vigorous growth, which may be planted in the herbaceous border and similar positions; and secondly, the low-growing kinds, suitable for the rock garden:

A selection of the best of the taller growers includes alliariaefolia, 2 feet, creamy-white; glomerata, $\mathrm{I}_{2}^{\frac{1}{2}}$ feet, blue; grandiflora, $\mathrm{I} \frac{1}{2}$ feet, blue; Hendersonii, I2 inches, mauve; lactiflora, 2 feet, white, tinged blue; latifolia, 4 feet, blue; and persicifolia, 3 feet. The last-named is the finest of all the border Campanulas, and there are many varieties with double and single flowers in blue and white: Campanula pyramidalis and its variety alba, which reach a height of 4 to 6 feet, are very effective in the outdoor garden during summer. Other kinds are: Trachelium, 3 feet, blue; Trachelium flore pleno, 3 feet, blue, double; and Van Houttei, 2 feet, blue. 
Dwarf kinds suitable for rockwork and similar positions are: carpatica, of which there are several varieties; (i. Ii. Wilson, purplishblue; garganica, blue, with white eye; isophylla, blue; isophylla alba, white; muralis, pale blue; pulla, deep purple; pusilla, blue and white; Rainerii, blue; turbinata, different shades of blue and white; and Waldsteiniana, light blue. All of these Campanulas flower during the summer months. Campanula rotundifolia, a native spieces, is in different parts of the United Kingdom known by the names of Blucbell and Harebell. It grow's about I foot high.

The following are the most difficult of the rock garden Campanulas: Allioni, very dwarf, pale blue, is best in the moraine; alpina, 6 inches, with blue-fringed fluwers, likes loam containing lime; cenisia, dwarf, blue, star-shaped blooms, must be grown in the moraine; excisa, with miniature, drooping, purple flowers, needs similar treatment; Rainerii, having somewhat larger flowers, is best in the moraine; so, too, is Zoysii, a tiny plant with blue tube-shaped flowers. The other dwarf-growing kinds named like gritty soil and either a half-shady or sunny spot.

\section{Campion, Rose.-(See LyChNis.) \\ Canary Grass.-(See Phalaris.) \\ Candytuft.-(See IBERIS.)}

Canna (Indian Shot).-There are comparatively fow species of Canna (Natural Order Scitamineae), but there are innumerable garden varieties of great value for various decorative purposes. They are largely used for bedding during the summer months, and, from their bold, handsome foliage, varying from light glaucous green to bronzyred, and blossoms of many colours, they form an imposing feature. The cultivation is not at all difficult; the chief point to remember is that they need rich soil. Manure should be incorporated with the soil, while they must not be allowed to suffer from want of water. Cannas form creeping underground roots or rhizomes, as they are termed; if these are divided in spring, each piece with a growing point will form a separate plant if it is potted singly and placed in a warm greenhouse. Plants obtained in this way are of useful size for bedding out in June. At the first approach of frost, the clumps should be lifted and placed where they are safe, but are at the same time not subjected to much heat. During the winter they may be kept dry, for they remain totally dormant. Camnas may be used in pots or tubs, and are then useful for standing on terraces, balconies, and in similar positions during summer. Seeds can be bought cheaply, and young plants are readily raised in warmth. Owing to their excessive hardness, whence the name of Indian Shot is derived, 
the seeds take some time to germinate unless they are assisted in some way; this is done by filing the hard outer surface of the seeds, or by soaking them in warm water for twenty-four hours previous to sowing. Raising from seed is, however, scarcely to be recommended, as rhizomes or roots of the best kinds, when dormant, can be purchased cheaply.

The following varieties can be recommended: Adolf Grimmonger, clear carmine; A. Ortmann, velvety-purple; Duc Ernst, reddishscarlet; Duke of York, crimson, golden border; Elizabeth Hoss, canary-yellow, spotted red; Evolution, rich golden-yellow, pink centre; Frau E. Kracht, rosy-salmon; Furst Weid, crimson; J. B. Van der Schoot, yellow, purple spots; King Humbert, orange-scarlet; Niagara, scarlet, gold margin; Ottawa, rosy-cerise; R. Wallace, canary-yellow; Stuttgartia, orange-scarlet, edged light yellow; The Gaikwar of Baroda, rich yellow, large crimson spots; and William Saunders, bright scarlet.

Cannabis sativa (Hemp).-An easily grown hardy annual, belonging to the Nettle family (Urticaceae), and native of India, that will succeed in ordinary garden soil. The seeds are usually sown in Narch, in the greenhouse, though they may be sown out-of-doors in April. Apart from its economic value, the Hemp, owing to its elegantly cut leaves, is decidedly ornamental. It is frequently used for sub-tropical bedding. There is an extra vigorous variety known as the Giant Hemp, which is employed for this purpose even more than the typical kind.

\section{Canterbury Bell.-(See CAmpanula Medium.)}

Caragana.-This group of deciduous shrubs, belonging to the Pea family (Leguminosae), consists of a number of ornamental species which are generaliy hardy throughout the British Isles. They are natives of Siberia, Central Asia, Japan, etc., and most of them thrive in ordinary garden soil, preferring that of a loamy character. They are usually grown from seeds, but certain varieties are grafted upon stocks of their respective types, the work being conducted under glass in spring. Very little pruning is necessary, save when plants are outgrowing their positions; then they are cut back somewhat after flowering; a little pruning to keep them shapely is all that is required at other times. They may be planted in shrubberies or grown singly as specimen plants. The chief kinds are: arborescens, a Siberian shrub, which grows I2 to I5 feet high, it bears yellow Peashaped flowers in May-there are several distinct varieties, nana being dwarf and compact, pendula is a variety with weeping branches, whilst Redowskii is very striking by reason of its long vigorous 
branches, which often assume a penclent character; aurantiaca is a slender-growing bush, 2 to 3 foet high, which bears its bronze and orange flowers freely; frutescens is widdy distributed from Southern Russia acruss Central Asia to Japan, it grows from ro to I 2 feet high, and produces yellow flowers freely in May ; grandiflora, angustifolia, and pendula are well-marked varieties.

Carbenia benedicta (Blessed Thistle).-A hardy annual (also known as Cnicus benedictus), member of the I) aisy family (Compositae), and native of Southern Europe; it bears heads of pale yelluw blussoms. It is not, lowever, the flowers that form the most attractive feature of this plant, but the handsome leaves. These are much cut, with somewhat spiny margins, and are blotched and marbled with silvery-white. From seed sown in spring out-of-doors. this Thistle will grow in any ordinary garden soil ; it forms a pleasing feature in the herbaceous border or front of the shrubbery.

Cardamine (Bitter Cress).-An extensive group of low-growing plants, natives of the temperate regions of both hemispleres, and belonging to the Wallflower family (Cruciferae). Many of them are but weeds. The perennials most useful for garden purposes are: macrophylla, which reaches a height of about 12 inches, and bears spikes of purple blossoms cluring summer; pratensis flore pleno, a double-flowered variety of our own Cuckoo flower or Ladies' Smock, with lilac blossoms; and trifolia, a pretty little spreading evergreen plant, of which the pure white flowers are borne in spring. All are easily increased by division, which is best carricl out immeriately after flowering or during the dormant season.

Cardinal Flower.-(Sëe LOBELIA CARDINALIS.)

Carduus (Thistle).-A family of Thistles of no ornamental value, which will thrive in any ordinary garden soil. They belong to the I) aisy family (Compositae): Many plants that used to be included in this genus are now classed under another name, e.g. Cnicus.

Carex (Sedge). - The different Sedges (Natural Order Cyperaceae) occur generally in camp or marshy places throughout the grcater part of the globe. The majority are of no horticultural value, being, in fact, under certain conditions troublesome weds. For waterside planting the following are suitable: acuta variesata forms tufts of pretty grass-like foliage, striped with white; gallica variegata has golden variegated foliage, about $\delta$ inches in height; Morrowii varienatia is a pretty variegated sedge, stronger in growth than the preceding; pendula is a pretty waterside plant that will reach a height of 5 feet or so, and bears graceful spikes of blossoms; and riparia variegata, growing 3 feet high, has clealy variggated leaves. 
Carlina.--The two members of the genus Carlina (Natural Order Compositae) are very distinct and decidedly ornamental. Both of them are natives of the South of Europe. The first, Carlina acanthifolia, has large-spreading pinnate, spiny leaves, from the centre of which arises a pretty white Thistle-like head some 2 feet high. The second, Carlina acaulis, is a remarkable plant, forming a flat rosette of dark green leaves, with a large head of white flowers resting in the centre; the effect produced by the wide-spreading leaves and large flower cluster, of a height of only a few inches above the ground, is decidedly singular. Both are perennial, and will thrive in ordinary garden soil in a sunny spot.

Carmichaelia is a curious and interesting group of shrubs, members of the Pea family (Leguminosae). The various species are natives of New Zealand, and are peculiar by reason of their slender, rush-like branches, which are sparingly clothed with small leaves. The Peashaped flowers are usually lilac in colour, and are produced freely during June and July. They are not generally hardy in the British Isles, but thrive in the South of England and in other places where a moderately mild winter temperature prevails. Propagation is by seeds or cuttings; no pruning is necessary, and a mixture of peat and sandy loam forms a suitable soil. A sunny position is desirable in order that the branches may become thoroughly ripened. The chief species are: australis, Enysii, and flagelliformis.

\section{Carnation.-(See Dianthius.)}

Carpenteria californica is a very beautiful shrub belonging to the Natural Order Saxifragaceae. A native of California, it forms a bush 4 to 8 feet high, bearing narrow, oblong, evergreen leaves 3 to 5 inches long. The white flowers are upwards of 2 inches across, with conspicuous tufts of golden stamens; they are produced several together in short racemes during early summer. Although it is not generally hardy, it may be grown out-of-doors in sheltered corners in a good many gardens, whilst it is also adapted to planting against a wall or in a cool greenhouse. Propagation is by seeds and layers. Light and well-drained loamy soil, with a little leaf-mould or peat, suits it, whilst there is no necessity to prune more severely than the shaping of the bush demands. It is allied to the Mock Oranges, and the flowers, though larger, are similar:

Carpinus (Hornbeam).-Moderate-sized trees, suitable for ornamental purposes or for planting under forest conditions (Natural Order Cupuliferae). They withstand a fair amount of shade, and may be planted as undergrowth to thicken up thin woods. The wood is hard, heavy, and durable, but is difficult to procure in large quan- 
titics. Increase is by secls. Hornbeams thrive most satisfactorily on moderately heavy loam, although they may also be grown on light land. Whilst the trees are young, a certain amount of pruning is necessary each year in order to keep the leading shoots free from rivals, and the side branches from developing too rapidly in width. The numerous varictics are increased by grafting upon stocks of the Common Hornbeam. In all cases the flowers of the Hornbeam are inconspicuous, but the fruits are distinct and interesting. The greyish, smooth bark is also distinct, and produces a similar winter effect to that of the Beech. The chief kinds are: Betulus (Common Hornbeam), native of Europe and Western Asia, growing up to 50 feet high ; there are many varieties, of which asplenifolia, with cut leaves, columnaris and pyramidalis, of stiff, pyramidal outline, and pendula, with weeping branches, are very distinct. Caroliniana is the American Hornbeam, a tall tree with softly pubescent leaves; japonica and laxiflora are two graceful trees from Japan; orientalis, the Oriental Hornbeam, is also a useful kind.

Carya (Hickory).-Handsome trees (Natural Order Juglandaceae) closely related to the Walnuts and, like them, having handsome pinnate foliage. The leaves in most instances possess the attraction of turning a brilliant golden-yellow in autumn for two or three weeks previous to their fall. Nine or ten species have been introduced from the United States, where they form handsome trees, valuable alike for their timber and oily edible nuts. The timber is renowned for strength and clasticity. Several, notably tomentosa and olivaeformis, are grown on purpose for their nuts, which are used for dessert ; the nuts of the latter are received regularly in our markets under the name of Pecan or Peccan Nuts. In this country the trees are grown solely for decorative purposes, their best proportions being attained in deep loamy soil. Propagation is by sceds sown, when possible, where the trees are to grow; but when transplanting is necessary, care should be taken to procure trees which are well furnished with fibrous roots. They are naturally deep rooting, and have a tendency to form long roots with a small amount of fibre. It is wise to plant them in permanent positions as early in life as possible: Pruning is necessary while the trees are young in order to keep them shapely and the leaders free. This may be done any time during summer. The principal kinds are: alba, shell bark Hickory, an upright-growing tree with large handsome leaves, which are very showy in autumn; amara, this differs from the other kinds by bearing bitter instead of sweet nuts, it is less ornamental than the foregoing tree; olivaeformis is one of the most important nut-bearers, it is, however, rather 
too tender for general cultivation in the British Isles; porcina, commonly called the Pig-nut, is the hardiest of all, it bears large quantities of small hard-shelled nuts, which ripen well in this country when the summer is fairly warm; sulcata is a handsome tree, and one of the best for timber; tomentosa has perhaps the finest leaves of all, and they are, with those of alba, the most brilliantly coloured in autumn; it is a strong-growing tree.

Caryopteris Mastacanthus is a Chinese and Japanese shrub belonging to the Natural Order Verbenaceae. It grows from 2 to 3 feet high with a similar spread, bears small, deeply-lobed, greyishgreen leaves, and produces pretty heads of bright blue flowers in September; the variety candicans bears white flowers. It is not very hardy, and usually gives the best results when planted in light loamy soil near the foot of a warm wall. The only pruning required is the removal of the flower-heads when the flowers fade. Propagation is by cuttings under glass.

Cassandra calyculata (Leather Leaf).- This shrub, which is native of the Northern Hemisphere, and a member of the Heather family (Ericaceae), is perfectly hardy, and forms an upright bush 2 to 3 feet high with evergreen oblong leaves, and bears white flowers from the leaf axils in April or May. The variety latifolia grows somewhat

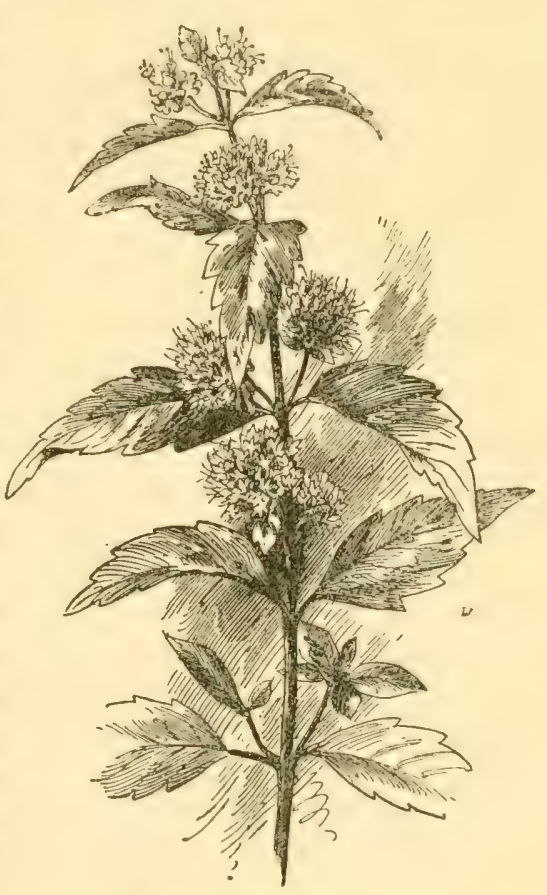

A BLUE-FLOWERED SHRUB

(Caryopteris Mastacanthus) taller than the typical kind, whilst nana is dwarfer and more compact and the best plant of the three: Moist, peaty soil or light loam free from lime is required; propagation is by seeds, and pruning is unnecessary.

Cassia.-The Cassias consist of an extensive group of trees and shrubs belonging to the Pea family (Leguminosae), and natives, for the most part, of the warmer regions of the globe. One of them, namely marylandica, is a sub-shrub, and is the only hardy kind. This, which dies almost to the ground during winter, produces annual 
shoots to a height of 3 feet or so; these are clothed with neat pinnate leaves, and bear on their upper part axillary racemes of bright yellow blossoms. This Cassia thrives best in a warm, well-drained soil and a sunny spot. The second species in general cultivation is corymbosa, which during winter requires the protection of a greenhouse, but is often used for bedding purposes in summer. It is an evergreen shrub with pinnate leaves of dark glossy green tint, and bears a profusion of golden yellow blossoms throughout the summer. It may be readily raised from cuttings, inserted in warmth in spring, and established plants can be wintered in an ordinary greenhouse. It is generally met with in the summer as a bush from 4 to 6 feet in height, and associated with Heliotrope, Solanum jasminoides, Browallia Jamesonii, etc. Cassia marylandica can be readily increased by division in autumn.

Cassinia.-Evergreen shrubs, belonging to the Daisy family (Compositae), which are of decorative appearance by reason of their tiny bright-coloured leaves. Thus the undersides of the leaves and the young bark of Cassinia fulvida are golden in colour. In the case of Cassinia leptophylla the colouring is silver, whilst that of Vauvilliersii is between the two. All are natives of New Zealand, and they are naturally of rather loose growth; they, however, respond well to pruning, and become quite dense in time. Cuttings root well in summer and the plants thrive in light soil. Pruning may be practised any time during summer. Cassinia Vauvilliersii is not very hardy.

Cassiope.-Heath-like shrubs (Natural Order Ericaceae) which require similar soil conditions to the Heaths. Three species are in cultivation, fastigiata from the Alpine Himalaya, and hypnoides and tetragona from the alpine regions of the Northern Hemisphere. They are rather curious little plants by reason of the angled arrangement of the small dark green, scale-like leaves, from among which the white bell-shaped flowers appear during summer. Propagation is by seeds or cuttings; no pruning is required.

Castanea (Spanish Chestmut).-This is a small but important genus of timber trees (Natural Order Cupuliferae), including as its best-known representative the Spanish or Eating Chestnut (Castanea sativa): There are three kinds in cultivation, sativa from South Europe, North Africa, etc. ; pumila from the Southern United States, and dentata of North America, commonly called the American Chestnut. The nuts of the common sort are an important product in Spain, France, and Corsica, whilst in the latter country a large business has leveloped within the last few years by the extraction of tannin from the wood. The timber bears a strong resemblance to Oak, and is 


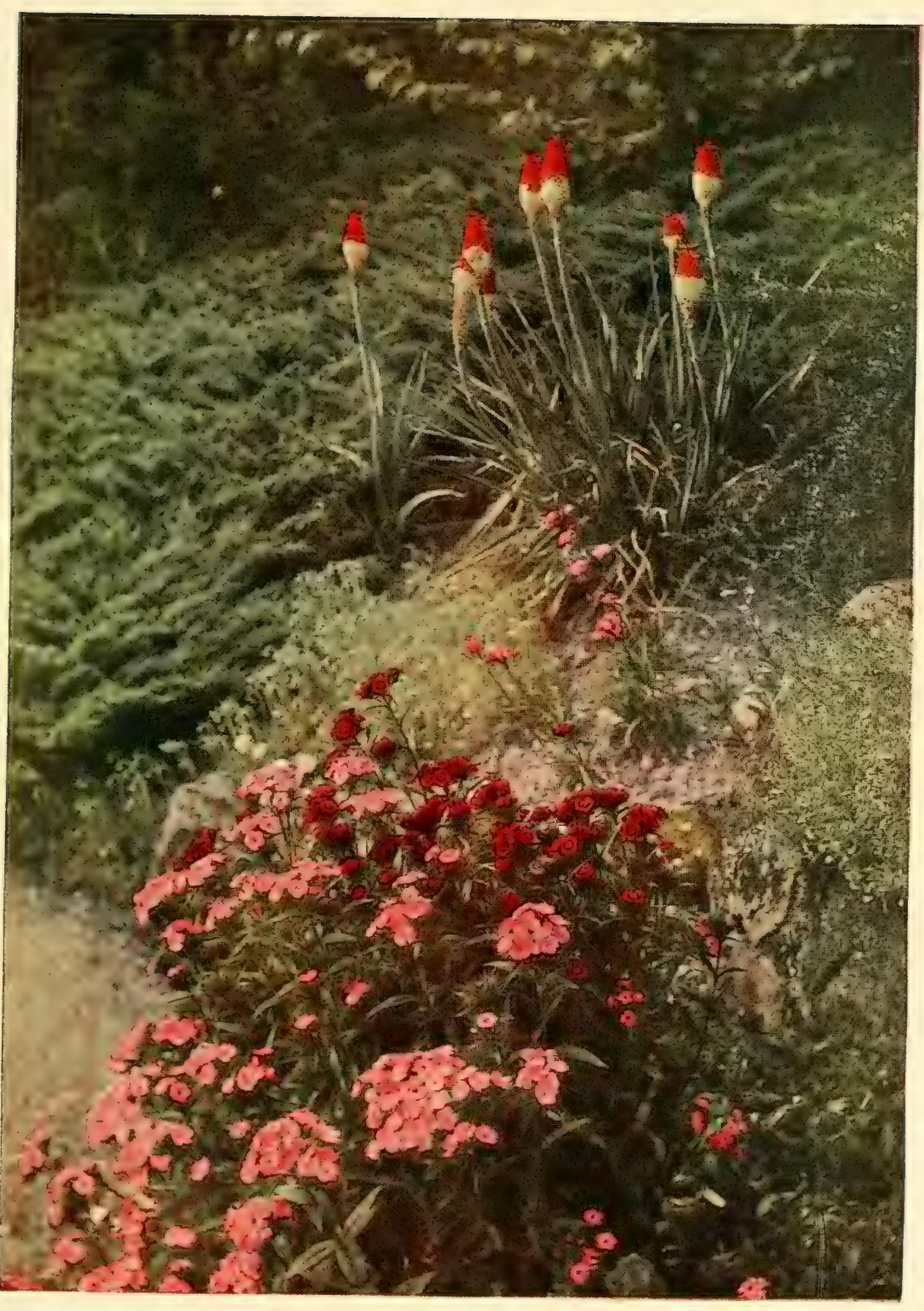

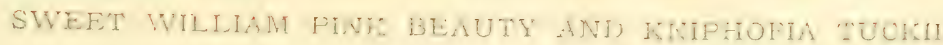



used for similar purposes. A great deal of Chestnut wood from small clean-grown trees is split and used for fencing, whilst it is also serviceable for posts and stakes. The tree coppices well, and is often used for that purpose. Both the common Chestnut and its varieties are planted widely as decorative trees, but they are less beautiful than the Oaks for landscape effects. They prefer loamy soil, but are not very particular providing it is moderately deep. Propagation of the species is by sowing the nuts out-of-doors and of the varieties by grafting or budding upon the typical kind. Pruning is necessary each year, whilst the trees are young, in order to keep them shapely and well-balanced. Later it is confined to the removal of dead and broken branches during summer. Good varieties of Castanea sativa are asplenifolia, Downtoniana, and pyramidalis. Some varieties are little more than monstrosities. The typical kind often attains a height of 90 or Ioo feet, with a trunk diameter of from 3 to 5 feet; the bark has often a tendency to a spiral arrangement.

Castanopsis chrysophylla (Golden-leaved Chestnut).-This tree (Natural Order Cupuliferae) is known as the Golden-leaved Chestnut by reason of the golden reverse of its evergreen leaves. It is native of California. There are other kinds, but this is the only one of any importance in the British Isles. It is closely related to the Sweet Chestnut, differing by its evergreen leaves, which resemble those of the Evergreen or Holm Oak in outline, and by its fruits taking about fifteen months to ripen from the time when the flowers appear. Those of the Sweet Chestnut ripen the same year. In its native country it forms a large tree; here, a small tree or bush. It thrives in light loamy soil in the southern counties, and should only be pruned sufficiently to keep it shapely. Propagation is by seeds. A fairly sheltered position on a lawn should be provided, or, if it is planted amongst other bushes or trees, it should be allowed proper space for development:

\section{Castor Oil Plant.-(See Ricinus.)}

Catalpa.-This is a very important group of decorative trees belonging to the Natural Order Bignoniaceae, natives of the United States, Japan, and China, the better-known kinds being from the first-named country with one exception, which comes from Japan. The Chinese kinds are of recent introduction, and are not in general cultivation yet; some of them, however, promise to be as ornamental as the better-known sorts. All have large ornamental leaves, usually more or less heart-shaped, but sometimes rounded, with deep lobes. The flowers are usually large and conspicuous, and are borne in large terminal panicles during July or August. In some instances they 



\section{Catch Fly.--(See Lychnis.)}

Cathcartia villosa.-A Poppy-like perennial (Natural Order Papaveraceae), native of the Himalayas, that forms a tuft about I2 inches in height; the leaves are Vine-like, 3 inches across, and densely hairy, while the rich yellow flowers, 2 inches in diameter, are at their best in June. It thrives in a sheltered, sunny spot in light, well-drained soil, and may be increased by division in autumn. This Cathcartia is comparatively rare in gardens.

Ceanothus (Mountiin Swect).-The Ceanothuses (Natural Order Rhamnaceae) occupy a prominent position amongst flowering shrubs, both by reason of their free blossoming character and because a number of them produce blue flowers, a colour which is uncommon amongst shrubs. They are natives of North America, the majority being found in California or other Western States, but a few occurring in other parts. The different kinds may be divided into two distinct groups by reason of the manner in which they produce their flowers. One group, composed of two or three species and a number of hybrids, bear flowers from the points of the current year's shoots during summer and early autumn, and the younger branches should be pruned back to within a few buds of the base each February. Weak shoots may be removed altogether, and if an old branch appears to be dying, it may be removed and a vigorous young shoot left to take its place. The other kinds, chiefly natives of California, blossom in spring from shoots formed the previous year; these must not be pruned until after the flowers are over, and it then depends how they are grown as to the amount of pruning required. It is customary to plant them against walls, as they are rather tender. When that is done all the side shoots must be cut back to within a bud or two of the main branches. But a few are grown in the open ground, and when that is the case pruning is unnecessary except for shaping the bushes. All may be increased by cuttings taken during July and inserted in sandy soil in a closed frame. Light but moderately good and welldrained loamy soil is suitable for all of them. It is unwise to plant any of the Ceanothus in very cold places, though the garden hybrids may be grown in many parts of the country, especially if a little dry Bracken is sprinkled amongst the branches during frosty weather.

The following are the chief species and hybrids: americanus is a bush, 2 to 4 feet high, from the Eastern United States, it bears terminal heads of white or light-coloured flowers during summer and early autumn; azureus is a Mexican shrub, 3 feet high, which blooms in summer and autumn; between these two kinds hybrids have been raised and a system of intercrossing has resulted in a group of hand- 
some sorts which are very free-flowering, and offer a wide range of colour from white to pink and from mauve to deep blue. All bloom from July to October. Though usually grown in beds, they are sometimes planted against walls. Good kinds are : Carmine Gem, carmine; Ceres, rose; Charles Detriche, dark blue; Gloire de Versailles, rich blue; grandiflora, blue, grandiflora alba, white; Indigro, dark blue; Lustre, rose-carmine; and Rose Perle, rose.

Ceanothus divaricatus is a spring-flowering evergreen with blue flowers; integerrimus bears large heads of lilac flowers during late spring; papillosus is a curious kind by reason of its leaves being covered by viscid glands, its blue flowers open during May; rigidus is a handsome April-flowering kind, bearing rich deep blue blossoms; thyrsiflorus, the Californian Lilac, is one of the hardiest of the springflowering set, its flowers are blue, whilst those of the var. griseus are pale lilac; Veitchianus is a charming blue-flowered species with small evergreen leaves, it blooms in May.

Cedrela Sinensis is the only member of this useful group of timber trees (belonging to the Natural Order Meliaceae) which is of any value for decorative planting in the British Isles. Of medium size, it resembles the Tree of Heaven (Ailanthus glandulosa) in its foliage, which is its most decorative asset. It may be planted in warm, well-drained loamy soil, is increased by seeds, and attention to pruning is necessary during its early development, summer being the best time for the removal of superfluous branches. It is a native of China and Japan. Cedrela Toona, the Toon Tree of India, and odorata, the West Indian Cedar, are two important allied linds; the wool of the former is in request for many purposes, and amongst other things the timber of the latter is very largely used for cigar boxes.

Cedronella. - Of the members of this group, which belong to the Sage family (Labiatae), Cedronella cana is a pretty Salvia-like plant, with spikes of bright red flowers borne during the summer months. It is a good plant for a warm border, where it reaches a height of IS inches or so. The second to mention is Cedronclla triphylla, which used to be known as Dracocephalum Canariensis, and popularly as the Balm of Gilead ; in cold districts it is usually regarded as a greenhouse plant, but in the milder parts of the country it is quite hardy on a warm border in well-drained soil, and grows 3 feet or more high. The flowers, produced in long spiles during summer, are of bright purple colour; the chicf attraction of Ceclronella triphylla is, however, not in the blossoms, but in the fragrant foliage. In former days, when it was more often grown than now, this Ceclronella was to be found in almost every greenhouse to supply cut sprays for the nose- 
gays of that period: Cedronella cana is a native of Mexico, while triphylla comes from the Canary Isles, the date of its introduction being as long ago as I697. Both may be increased from cuttings put in a closed case in sandy soil in spring.

Cedrus (Cedar).-This group of Conifers (Natural Order Coniferae) includes three handsome and popular evergreen trees: Libani is the Cedar of Lebanon, atlantica, the Atlas Mountain Cedar, and Deodara, the Deodar of the Himalaya. The last-named is the most important commercial tree, for its timber is in great request for building purposes, etc., in certain parts of India. It is the most tender of the three, but can be grown in most parts of the British Isles, except where climatic conditions are very dry or the atmosphere impure. Old trees of the Lebanon Cedar, with their massive trunks and widespreading tabular heads of branches, are very picturesque, but fullygrown trees of the other kinds are not yet to be found in this country. As young trees, they are superior in their decorative qualities to the Lebanon Cedar, the glaucous-leaved forms being particularly handsome. They must be increased by seeds, and should be planted in moist, but well-drained soil of fairly good quality. Very little pruning is necessary except to remove dead branches. The Cedars must be allowed ample space, for no tree looks worse when crowded by others or grown amongst cramped surroundings. They are, however, useful alike as isolated specimens, for groups or avenues. At one time grafted trees were sold by some nurserymen, and it may be that the practice still survives. Such plants must, however, always be left alone, for they are never satisfactory.

Colastrus.-Climbing shrubs (Natural Order Celastraceae), of which the chief attraction lies in the showy fruits, which ripen during autumn and remain on the plants until the New Year. The outer parts of the fruits are golden, but when ripe the coat splits open and reveals the orange-coloured seeds within. They thrive in loamy soil, require plenty of space, are increased by sceds, and do not require regular pruning. Celastrus articulatus and scandens are the two most satisfactory kinds to plant; the former is from China and Japan, and the latter from North America.

Celmisia.-The Celmisias are dwarf, Aster-like plants (Natural Order Compositae), natives chiefly of the mountainous districts of New Zealand; the majority of them have a rosette-like cluster of lanceolate leaves, densely covered with long silky hairs. The flowerheads have usually white ray florets and a yellow disc, and are borne on firm, erect stems which overtop the foliage. The Celmisias are very difficult to cultivate successfully in this country; owing to the 
silky nature of the foliage, the dampness in winter often proves fatal to them, while at the same time they cannot well stand very sharp frosts. The conditions most favourable to their well-doing are a welldrained, sunny spot on rockwork, and a certain amount of protection from heavy rains in winter. There are about twenty-five species known to botanists, but comparatively few have been introduced. The best-known are: coriacea, with flower heads from $I_{2} \frac{1}{2}$ to 3 inches in diameter, the white ray florets being especially numerous; Lindsayi, altogether a smaller-growing plant; holosericea, the hardiest; and spectabilis, of which the florets are sometimes tinged with lilac. The Celmisias are increased by means of seeds, and need a soil consisting of loam and sand.

Celosia.-The plumose varieties of Celosia (Natural Order Amarantaceae) are very largely employed for summer bedding in the flower garden. Some of the colours are almost startling in their brightness, but judiciously used many striking effects may be produced. The various shades of purple, scarlet, and orange are freely represented in the flowers of Celosia plumosa. In order to obtain plants for summer bedding, seed is sown towards the end of March or early in April, in a temperature of $50^{\circ}$ to $60^{\circ}$. The seedlings will then make rapid progress, and care must be taken that they are not checked. As soon as they are large enough to handle the young plants are pricked off into pans or boxes of light soil. It will not be long before they are ready to pot singly in flower-pots 3 to 4 inches wide. Throughout the whole of this period the plants must have a light position in the greenhouse in order to prevent their becoming in any way "drawn." They are tender, and must not be planted out-of-doors before June. While Celosia plumosa is chiefly used for bedding, the Cockscomb (Celosia cristata) is sometimes employed for the purpose. It should be given the same treatment as the other, and from its uncommon appearance is sure to attract attention.

Celsia.-Annual, biennial, and peremnial herbs, natives principally of the Mediterranean region, most of them being hardy only in light soils and in a warm situation. They belong to the Snapdragon family (Scrophulariaceae). All are readily raised from seeds sown in spring or early summer. A selection of the best includes Arcturus, that reaches a height of about 4 feet, with branching spikes studded with yellow blossoms; betonicaefolia, 3 feet high, flowers yellowish, marked inside with purplish-brown; cretica (Cretan Mullein), which reaches a height of quite 6 feet, and bears erect spikes of rich golden-yellow blossoms with two brownish spots inside. All flower during the 


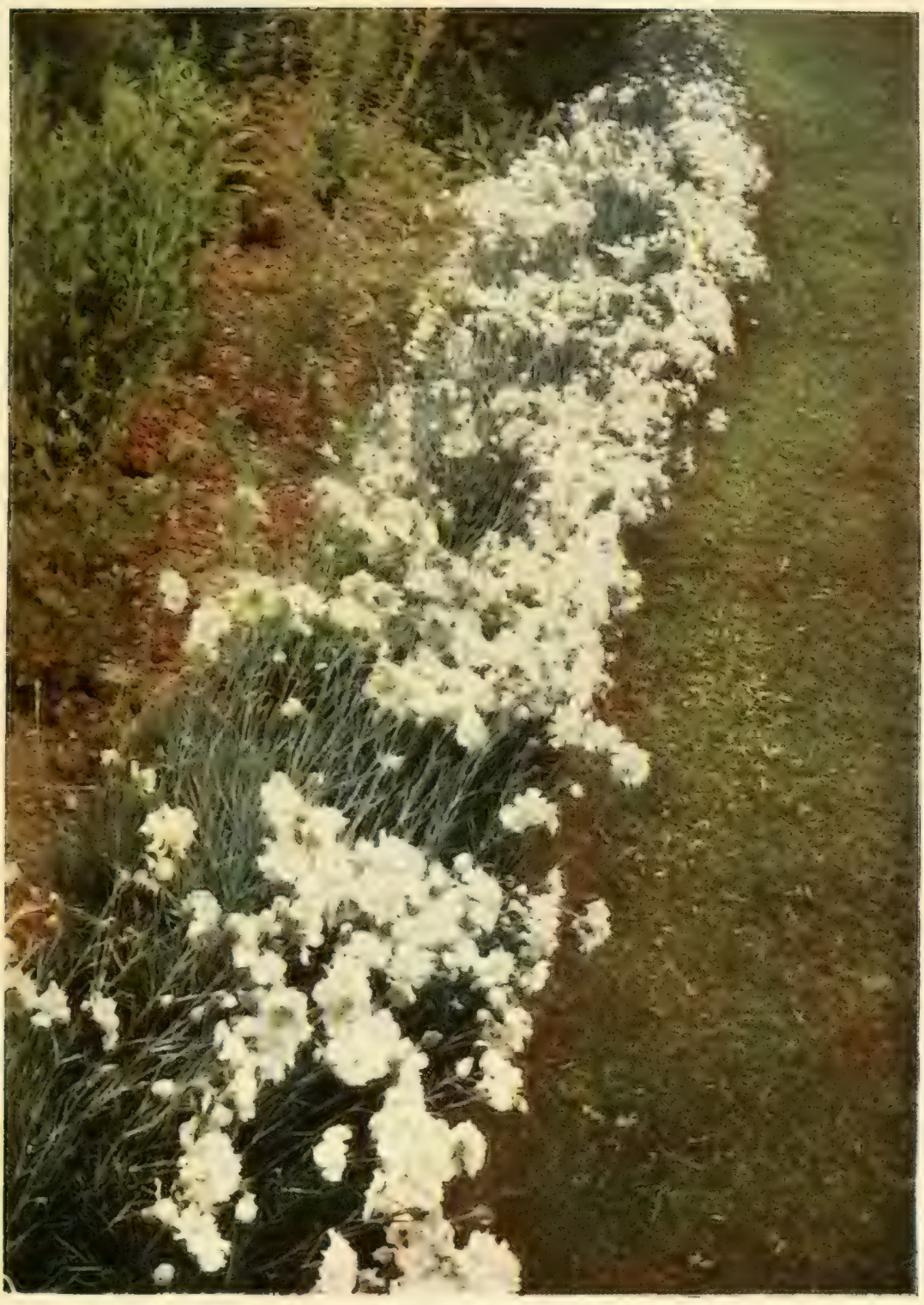

AN EDGING OF WHITE PINKS (MRS. SINKINS) 

summer months, are best treated as biennials, and are usually grown in the greenhouse.

Celtis.-Small trees, belonging to the Nettle family (Urticaceae), possessing very hard timber; they are found in Southern Europe, the Caucasus, China, Japan, and North America. About eight species have been introduced, but none is widely grown as the decorative qualities are limited to the golden colour of the leaves in autumn. They thrive in any ordinary garden soil, are increased by seeds, and require sufficient pruning when young to form shapely trees. Some of the chief kinds are: australis, caucasica, and occidentalis.

Centaurea (Knapweed).-Most of the members of this group, which belong to the Daisy family (Compositae), are natives of Europe, though some occur in Asia, North Africa, and North America. They consist for the most part of herbaceous perennials, though some are annuals. Among the best of the annuals is Centaurea Cyanus (Cornflower). In a wild state its brilliant blue flowers are very conspicuous, especially in cornfields, hence its popular name. Under cultivation various forms have been produced, so that now we can obtain seeds of deep blue, light blue, rose, and white-flowered sorts, while there is also a race with double flowers, and another in which the plants are dwarf. The Cornflower is a hardy annual, and may be sown either in autumn or spring in the open ground. Well-dug soil is necessary, and room for the plants to develop, as overcrowding is particularly harmful. Another delightful annual is Centaurea moschata (Sweet Sultan), which, like the preceding, is of great value as a cut flower. This reaches a height of $I 8$ inches to 3 feet, and if seed does not form will continue in beauty for a long time: The blossoms are from 2 to 3 inches in diameter, the finely-cut florets giving a particularly elegant appearance. While the typical kind has purple flowers, there are varieties in rose, yellow or white. Beside these, there is an improved race consisting of the varieties The Bride, white; Bridesmaid, pale lemon-yellow; Bridegroom, rose-pink; and Honeymoon, bright golden-yellow. Other annuals include Centaurea americana, which reaches a height of about 3 feet and bears heads of reddish flowers, and depressa, somewhat like a low-growing Cornflower.

The perennial kinds especially noteworthy for the beauty of their blossoms include Centaurea aurea, which reaches a height of 4 feet and bears Thistle-like heads of golden-yellow flowers; babylonica, 8 feet or so high, with silvery foliage and yellow flowers; dealbata, rosypurple flowers, 2 feet; glastifolia, yellow flowers in dense pyramids, while the foliage is also very graceful, height 4 feet; macrocephala, a stately plant, with large golden-yellow flower-heads, height 4 feet; 
montana (Perennial Cornflower), 2 feet high, and of which there are varieties bearing blue, red, sulphur, and white flowers; ruthenica, a graceful plant, with straw-coloured blossoms, height 4 feet. All these perennial species will grow in ordinary garden soil, and can be readily increased by division during autumn or by seeds sown in spring.

Some Centaureas are grown solely for summer bedding, their distinctive character being the silvery whiteness of the leaves; these consist for the most part of ragusina and ruthenica, of which there are some selected forms, namely, candidissima, a compact, shapely plant about I 2 inches high with silvery white leaves; Clementei, leaves of the same tint but deeply cut, while the plant reaches twice the height of the preceding; and gymnocarpa, about the same height as Clementei, but with the leaves less divided. Of these candidissima is often used as an edging to flower beds, while all of them are generally employed as " dot " plants among low-growing plants. These silvery. leaved kinds can be raised from seed sown under glass early in spring, but at times they vary somewhat in shade. This being the case, the very best forms are often increased by means of cuttings taken about the end of August, inserted in pots of sandy soil, and placed in a frame kept close and shaded until they are rooted, which will be in about a month. If the cuttings show signs of "damping off " a little air must be given for a time. These Centaureas need to be kept safe from frost during the winter.

Centaury.-(See Centaurea.)

Centranthus (Valerian).- These are pretty, free-flowering, herbaceous annuals or perennials (Natural Order Valerianaceae) that produce a succession of bloom throughout the summer. By far the showiest is the Common Valerian (Centranthus ruber), which reaches a height of about 3 feet, and bears terminal heads of rose-red flowers; there is also a white variety. Other species are: Calcitrapa, a smaller grower than the preceding, and macrosiphon, with rosy-carmine flowers. The two last-named are annuals.

Cephalanthera pallens. - There is but one specics of this genus, namely Cephalanthera pallens, a pretty little terrestrial Orchid (Natural Order Orchidaceae), which reaches a height of about 9 inches, and bears in May and June distinct sulphur-coloured flowers. This Orchid thrives best in a soil mainly consisting of chalky loam:

Cephalaria.--Strong-growing herbaceous perennials (Natural ()rder Dipsaceae) that reach a height of 5 to 7 feet. They grow frecly in any garden soil, and may be readily increased by division. The Cephalarias are nearly related to the Teasels, and are more fitted for the wild garden than for association with border plants. The flower- 
heads are very useful for cutting. The chief species are alpina, rich yellow, leucantha, creamy-white, and tatarica, sulphur-yellow. All of them flower in June and July.

Cephalotaxus is a group of conifers (Natural Order Coniferae) closely allied to the Yews. There are four species : drupacea and pedunculata, natives of Japan, and Fortunei and Oliveri from China. All form ornamental, wide-spreading bushes with long dark green leaves which have silvery lines on the under-side. There is, however, a variety of pedunculata, named fastigiata, which is of pyramidal outline. They thrive in any garden soil where lime is not present in quantity, require no other pruning save that which is necessary to keep the bushes shapely, and are usually increased by seeds. They form good, isolated specimens, and are useful for undergrowth in thin plantations of conifers.

Corastium (Mouse Ear Chickweed).-Low-growing perennials, belonging to the Pink family (Caryophyllaceae), which are well suited for planting in the rock garden or for carpeting beds in the flower garden. Some of them are little better than weeds. The best are alpinum, a creeping plant, the leaves clothed with silky hairs, flowers white in June and July; arvense and its var. grandiflorum, of which the white flowers are borne all the summer; Biebersteinii, a vigorous kind, similar to tomentosum, but with larger leaves and flowers; glacialis, bearing comparatively large white flowers during summer, a good rockery plant, and tomentosum, known popularly as Snow in Summer. The last-named is a small creeping plant, with oblongshaped silvery leaves; the plants should be grown in a spot fully exposed to the sun. It is the best white-leaved plant in cultivation for summer bedding, will thrive in almost any soil, and can be readily increased by division in autumn.

Ceratostigma plumbaginoides.-Also known as Plumbago Larpentae. A charming autumn flowering plant (Natural Order Plumbaginaceae) for the rock garden, where on a spot well exposed to the sun the slender, wiry stems bear a profusion of brilliant cobalt blue flowers, disposed in terminal heads. Not only is it one of the most delightful of autumn flowers, but at that season the leaves take on a distinct reddish tinge. It needs a well-drained sandy loam, and can be readily increased by division in early spring.

Corcis siliquastrum (Judas Tree).-An interesting small tree or large shrub belonging to the Pea family (Leguminosae). It is a native of the Mediterranean region, and its common name originated from the legend that it was a tree of the same species upon which Judas Iscariot hanged himself after the betrayal of the Saviour. It 
has considerable value as a decorative tree, for its rosy-red leashapel flowers are burne in profusion from young and old wood alike during May. There is also a variety with white flowers, and several other species may be procured. Of the latter, canadensis is the Redbud of North America; occidentalis is from California; semiformis is a native of Texas; and Chinensis of China. All are, however, inferior in general beauty to the Judas Tree. They thrive in well-drained loamy soil. are usually increased by seeds, and require no other pruning save the removal of dead wood occasionally. Anyone growing these trees must be prepared for the loss of branches now and then owing to the Coral-spot Fungus (Nectria cinnabarina), a disease to which the wood is particularly susceptible. All wounds must be dressed at once with coal-tar in order in minimise the chances of the spread of the fungus.

Cestrum.--Loose-growing showy shrubs, belonging to the Potato family (Solanaceae). One or two may be grown out-of-cloors against walls or trellises in Cornwall, but, as a rule, they are better adapted for the greenhouse. They are natives of Mexico, Guatemala, Peru, Brazil, and other countries. Though naturally bushes, their long slender branches are well adapted for clothing greenhouse pillars and walls, hence their frequent use for these purposes. Few greenhouse plants have a longer flowering period or so well repay the care expended upon them. They are easily increased by cuttings in spring, and thrive in a compost of 4 parts loam, I part leaf-mould, I part well-decayed manure, and I part sand. All secondary branches should be pruned to within a bud or two of the base in spring, the exact time for pruning being determined by the condition of the flowers. Specimens planted in borders are rarely without flowers from July to Christmas or after. Good kinds are : aurantiacum, from Guatemala, with orange-coloured flowers; elegans, a native of Mexico, with bright red flowers, sometimes grown out-of-doors against sunny walls; fascicularis, a red-flowered, vigorous kind from Mexico; Newellii, a very free-flowering kind with scarlet flowers, often blossoms during spring, and pruning is deferred until after the flowers fade.

Chamaepeuce (Fish Bone Thistle). - This genus consists of two distinct species, both of which are extensively used as "dot" plants in formal beds during the summer months. They belong to the Daisy family (Compositae). Chamaepeuce Cassabonae has long spreading dark green leaves, covered with white spines; in Diacantha the leaves are white, margined with green. Both are biennials, and should be sown in a frame in April in order to yield plants for effective bedding the following year. They are natives of the Mediterranean region. 


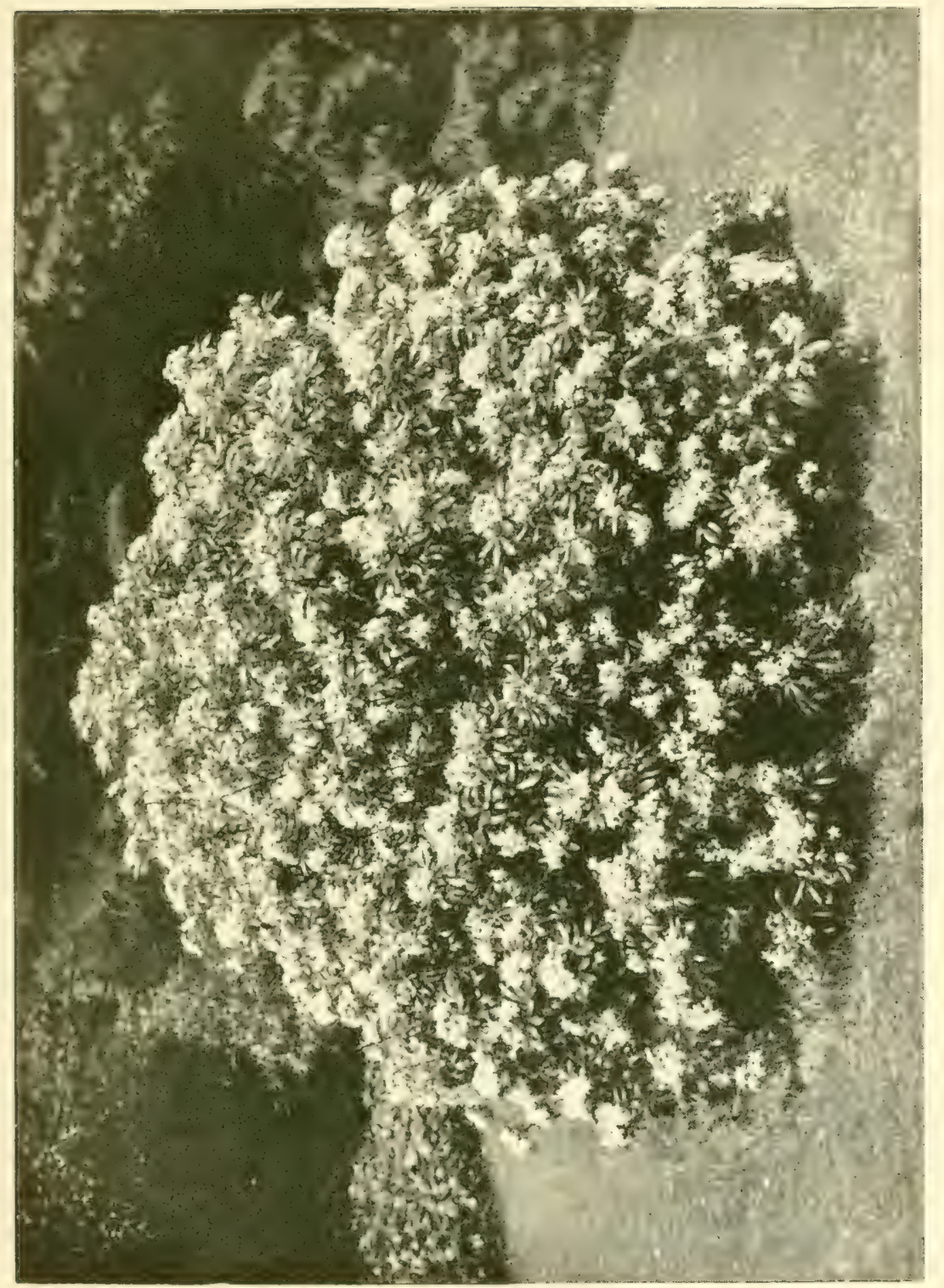



Cheiranthus (IVallfower). - A small group or genus (Natural Order Cruciferae), yet it contains one of the most popular of all garden flowers, Cheiranthus Cheiri, the Wallfower. Of late years some improved varieties have been introduced by florists, many seedsmen having their own special strains, which, as a rule, can be depended upon to come true from seed. Wallflowers can be readily raised from cuttings. They may remain in one spot undisturbed year after year and will flower freely. The general practice, however, is to treat them as biennials; that is to say, to raise them from seed one year to flower the following spring. The seed may be sown in the open border in April or May, the young plants being pricked off into prepared beds as soon as they are large enough to handle. Space should be allowed for full development, so that the seedlings may form well-rooted bushy plants ready to be put in their permanent quarters in October. Before planting out the seedlings for the summer it is wise to shorten the principal root. One purpose for which Wallflowers are seldom used, yet well adapted, is for window-boxes; when in bloom the delicious perfume pervades the room when the windows are opened. The flowers of the different sorts vary from pale yellow, almost ivory-white, to an intense dark crimson and deep purple. The intermediate shades include yellow, orange, salmon, and various tints of red and scarlet. Other kinds are Allionii, orange; alpinus, pale yellow; and Marshallii, deep orange, all being suitable for a sunny spot and light soil in the rock garden. The Common Wallflower is splendid for sowing in a dry wall.

Chelidonium majus (Celandine).-A pretty British plant, belonging to the Poppy family (Papaveraceae), more fitted for the wild garden than for associating with choice kinds. It grows about 2 feet high, and bears a loose umbel of small Poppy-like flowers in spring and early summer; the soft green divided leaves are also attractive. The Celandine grows far more freely in fairly damp, partially shaded spots than where fully exposed to sun and air.

Chelone.-A small group of plants native of North America, and nearly related to the Pentstemon (Natural Order Scrophulariaceae). Many of those formerly regarded as Chelone are now included in Pentstemon. They grow about 2 feet in height and flower throughout the summer. Chelone glabra has purplish flowers; Lyoni, rosy-pink ; nemorosa, rosy-purple; obliqua, violet-purple; and obliqua alba, white. They are quite hardy, will thrive in ordinary garden soil, and can be readily increased by division in autumn.

Chicory.-(See CichorIum.)

Chimney Bell Flower.-(See Campanula pyramidalis.) 
Chimonanthus fragrans (Winter Sweet).--This is the only species, and belongs to the Natural Order Calycanthaceae. It is a hardy shrub, native of China and Japan, and succeeds quite well in a sunny position in the shrubbery in the vicinity of London, though in many gardens it is used as a wall shrub. It blossoms in mid-winter, the flowers being very fragrant, and having cream-coloured petals and reddishbrown calyx lobes. There is a less hardy varicty, grandiflora, which bears larger golden flowers; this must be given a position against a south or west wall. When grown in the open the typical kind attains a height of 4 or 5 feet if planted in warm, loamy soil containing a little leaf-mould or peat. The type is increased by seeds and the variety by grafting. Bushes need no pruning when growing in the open, but the secondary branches of those against walls must be cut back after the flowers fade. The flowers are borne from the leaf axils of the previous year's shoots.

\section{China Aster.-(See Callistephus.)}

Chionanthus (Fringe Flower).-This is a showy class of hardy shrubs or small trees (Natural Order Oleaceae). Two species are in cultivation, retusus from China and Japan, and virginica from the Southern United States. Both are of vigorous growth, thriving in good but moist, loamy soil, rich in humus. They form bushes up to 8 or ro feet high here, but grow much taller in their native countries. The lance-shaped or ovate leaves are often 4 or 5 inches long, and from the axils the showy white fringe-like flowers appear during early summer. Propagation is by seeds, and regular pruning is unnecessary. Chionanthus virginica, the Snowflower or Fringe Tree, is the more beautiful of the two, its inflorescences being finer than those of the other.

Chionodoxa (Glory of the Snow).-Charming little early flowering bulbs from Asia Minor, that serve to render our gardens gay before the dark days of winter have fully passed. They belong to the Lily family (Liliaceae), may be grouped freely in the garden or woodland, as they readily reproduce themselves from seed, and soon cover a considerable space of ground. On the exposed portions of the rockwork, colonies of Chionodoxas are very effective. In little borders near the house they are also much appreciated. The bulbs should be planted in August or September; if kept out of the soil for long they deteriorate. The soil most suitable for them is well-drained sandy loam; the bulbs are planted from 2 to 3 inches deep. The oldest and best-known species is Luciliae, with beautiful blue whitecentred flowers. Other distinct forms which are regarded by botanists only as varieties of Luciliae are Alleni or gigantea, with much larger 
blossoms but fewer on a stem; Sardensis, with smaller deepercoloured flowers; and Tmoli, the last to bloom, similar to Luciliae but of deeper colour. The Chionodoxas can be recommended for the out-of-door garden, as good flowering bulbs can be purchased at a cheap rate. There is a very pretty hybrid between Chionodoxa Luciliae and Scilla bifolia, known as Chionoscilla Allenii. Though somewhat variable, it is in general appearance about midway between its parents and needs the same treatment.

Choisya ternata (Mexican Orange Flower).--This shrub belongs to the Natural Order Rutaceae, which includes the Orange as one of its members. It is a native of Mexico, and hardy in the Midlands, South of England, and other places where similar climatic conditions prevail. Elsewhere it may be planted against a wall or grown in a cold greenhouse. Plants in the open may be from 3 to Io feet high ; they grow into shapely bushes well clothed with branches, and need no other attention from the pruner than the checking of vigorous branches during the first two or three years, and, in later life, cutting back when outgrowing their positions. Cuttings inserted in sandy soil under glass root readily during summer, and loamy soil for general planting is suitable. The three-parted evergreen leaves are of a bright glossy green, and form a good setting for the fragrant white flowers in May.

\section{Christmas Rose.-(See Helleborus Niger.)}

Chrysanthemum.-By some botanical authorities the Matricaria and Pyrethrum are now included in the genus Chrysanthemum, but it will be more convenient to refer to them under their respective names. They belong to the Daisy family (Compositae). Of Chrysanthemums proper the list of true species is not a long one, but the garden varieties are practically endless. The most valuable kinds can be divided into four groups, namely, the annuals, which are such a delightful ornament of the garden during the summer months; next, the Ox-eye section, of which Chrysanthemum maximum and its several varieties are among the best. The third group consists of the shrubby kinds, which originated from Chrysanthemum frutescens, and now, under the collective title of Marguerites, are much used for summer bedding, window-boxes, and similar purposes. The fourth, to mention, but by far the largest section, consists of florists' varieties. Included under this heading are those grown in pots and brought into the greenhouse in autumn; they include the Japanese, Chinese, Incurved, Anemone flowered, Pompon, and others. Many of them are unsuitable for out-of-door cultivation, but of late years a good deal of attention has been directed towards the raising of early flower- 
ing varieties, and the result has been so far successful that whereas the early flowered kinds of former days consisted of only a few pompons there are now numerous varieties of the Japanese section suitable for the outdoor garden, combining as they do early flowering with sturdy habit and decided colours:

Early Outdoor Chrysanthemums.-Most of these early kinds are very prolific in suckers (shoots from the base), hence in most cases all that is necessary is to divide them just as they start into growth in spring. They are, moreover, as readily raised from cuttings as the ordinary florists' Chrysanthemums, therefore they can be increased to practically any extent, as rooted cuttings planted out in April will flower well. The ground should be well dug and moderately manured, taking care afterwards that the plants do not suffer from want of water, while the taller kinds must also be supported by sticks before they fall about. After flowering the plants may, if desired, be left in the beds or border throughout the winter and protected with a few leaves or some other suitable material in the colder parts of the country. To increase a variety to as great an extent as possible, lift the roots from the open ground as soon as the flowering season is over and plant them in a frame. With this amount of protection young shoots will push up freely, and when about 2 to 3 inches high may be taken off and inserted as cuttings. They can be put into pots or boxes of sandy soil, and if kept in a closed frame for a little while will soon form roots.

These early flowering Chrysanthemums may also be treated solely as hardy herbaceous plants in the open border; that is, allowed to pass the winter without any protection. During sharp frost a few kinds may perish ; but most of them will form good clumps the second year. They should not remain undisturbed more than two seasons, or the plants get weak; in fact, many gardeners grow them fresh from cuttings each year.

A good selection of outdoor Chrysanthemums includes, of large flowered kinds: Ada, salmon-pink, gold tips; Anita, pink; Border Beauty, fiery orange ; Carrie, golden-yellow ; Cranford White, white ; Crimson Marie Masse, crimson; Diana, bronze-orange; Elstob Yellow, rich yellow ; Emily, pure white ; liée Parisienne, rosy-mauve ; Glory of Merstham, soft pink; Goacher's Crimson, rich crimson ; Goacher's Pink, bright pink; Harrie, bronzy-orange; Harvest Home, red, gold tips; Holmes' White, white; Horace Martin, golden-yellow ; J. Bannister, red and yellow; Le Neva, purest white; Leslie, buttercup yellow; Madame Desgranges, white; Madame Marie Masse, lilac-mauve; Minnie Carpenter, rich terra-cotta; Mrs. A. Thomson, 


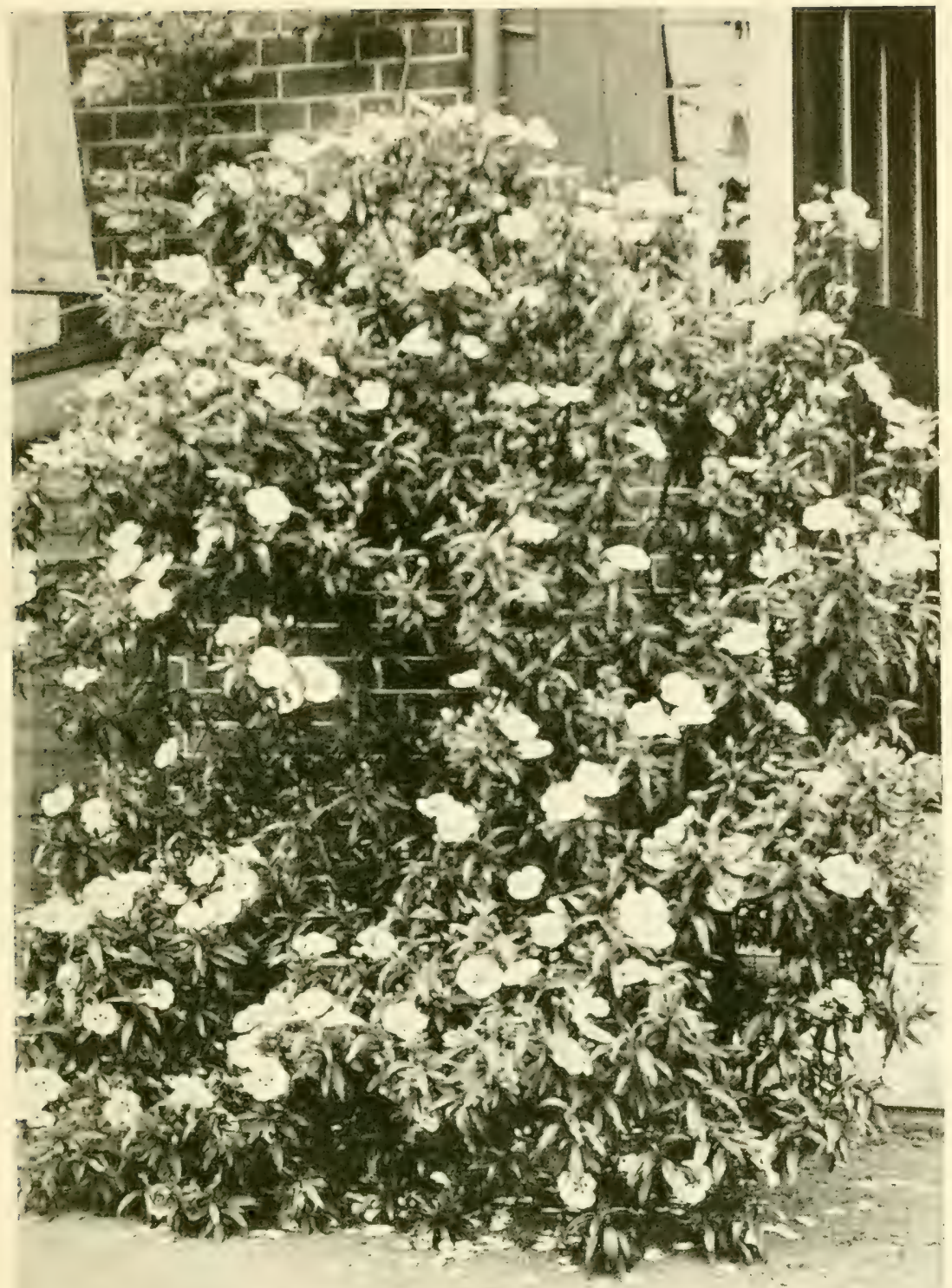

THE HARDIEST ROCK ROSE (CIS'TUS LADANIFERUS) 

richest yellow; Nellie Brown, reddish-orange; Nina Blick, brilliant red and orange; Norbet Purvis, golden-salmon; Queen of Earlies, pure white; Rabbie Burns, salmon-pink; Rio des Jaunes, yellow ; Roi des Precoces, crimson and gold; Ryecroft Beauty, pink; Ryecroft Glory, bronzy-yellow; Tapis de Neige, pure white; Well's Crimson, crimson with golden reverse; and Well's Primrose, pale yellow.

Of early flowering Pompons good sorts are: Crimson Précocité, reddish-crimson; Flora, golden-yellow; Madame E. Lefort, bronzyyellow; Orange Pet, orange, shaded terra-cotta; Précocité, bright yellow; St. Croutts, pink, and White Lady, white.

Early flowering Singles comprise: Ada Nice, yellow; Blush Star, blush ; Brazier's Beauty, blush; Canada, salmon; Dr. Ingram, terracotta ; Dazzler, crimson; Dorothy, purplish-rose ; Early Rose, pink ; Eric, bronze; Holmthorpe, terra-cotta ; John Woolman, pink ; Joan Carter, yellow; Joe, crimson amaranth; Marion Bannister, white; Merstham Beauty, rosy-pink, white zone; Merstham Glory, crimson; White City, white; Ruby, ruby-red; and W. A. Cull, brilliant red.

Early flowering Chrysanthemums are of great value for cutting, for the blooms remain fresh a long time in water.

Anmual Chrysanthemums. - These are the product of the crossing and intercrossing of three distinct species, namely, coronarium, carinatum, and segetum. The influence of coronarium is largely shown in the beautifully marked flowers of some of them, while the shorter kinds owe their dwarf stature largely to the influence of the other two species. The Chrysanthemums of this section must certainly be regarded as among the most beautiful annuals for garden decoration; they continue to bloom for weeks if the old flowers are cut off as they fade. The long firm stems of the taller-growing sorts render them admirable for cutting, as they can be arranged with graceful effect. Like most annuals, these Chrysanthemums need deeply dug soil, as they flower during the summer months when periods of drought may be expected, and consequently on shallow soils they are likely to suffer. Seed may be sown in autumn or under glass in the spring for early flowering, while if sown in the open ground in April the plants will flower freely in summer. Overcrowding must be guarded against when the seed is sown, as the stronger kinds are seen at their best when the plants are about I 8 inches apart. The dwarfer sorts need less space. The varieties of Annual Chrysanthemums are numerous, and seed from reliable sources may be depended upon to come true. The following are all good: Burridgeanum, pure white with crimson ring; atrococcineum, deep scarlet; carinatum, white and 
crimson; Evening Star, golden-yellow; Lord Beaconsfield, crimson and gold; Morning Star, sulphur, dark centre; The Sultan, crimsonmaroon; venustum, crimson and white; and W. E. Gladstone, crimson. Beside these there are some double flowered varieties, of which the best are the Double White and the Double Golden; these are shorter than the preceding. Seedlings of annual Chrysanthemums, the product of seed sown in spring, may, if desired, be grown in pots, under which conditions they thrive well.

Marguerites. - The different Marguerites, or shrubby Chrysanthemums, have originated from Chrysanthemum frutescens, native of the Canary Islands. They need protection from frost during winter, but are largely used for the embellishment of the outdoor garden in summer; in fact, they must now be looked upon as one of the most popular of bedding plants. In conjunction with the scarlet Pelargonium and the blue Lobelia, they supply the popular colour arrangement of red, white and blue. When allowed enough space the Marguerites form quite large bushes which flower profusely. If grown in large pots or tubs they form handsome plants for terraces, balconies, or similar places; in window boxes, too, they will grow and flower well. When using them for bedding out in the summer, allowance must be made for their rapid increase in size. Propagation is effected by means of cuttings, taken either late in summer or in spring. Cuttings from plants that have been bedded out are inserted towards the end of August in well-drained pots or boxes of sandy soil. Placed in an ordinary garden frame kept closed and shaded, they will be well rooted in about a month. As soon as this happens plenty of air must be given in order to keep the plants as hardy as possible. Throughout winter they need to be kept safe from frost, while the soil should not be too damp. When the cuttings are rooted the question whether they shall be then potted off singly will depend to a great extent upon the space available. If there is ample room they will, of course, make more headway in single pots than if they are kept until spring in the original boxes or pots. In the latter case they must be potted singly as early in spring as possible. In taking the cuttings, shoots of medium vigour, about 3 inches long, rather than very strong or weak ones, should be chosen. All flowers and buds must be cut off.

In the spring the growing point of the shoot should be pinched out in order to induce the formation of side shoots, for it is as bushy little specimens that Marguerites are most effective. If stock is limited the best of the old plants may be carefully lifted in autumn and potted, the more vigorous stems and roots being shortened. For this purpose 
the pots should not be too large, as if small ones are used it admits of the plants being repotted in spring before bedding out. In growing Marguerites a sharp look-out must be kept for a very troublesome pest, namely, the leaf-mining maggot. This burrows through the leaf substance and leaves disfiguring white marks; it may be killed by a squeeze between finger and thumb directly it is noticed. Syringing the leaves with tar water tends to prevent its appearance, while if the plants are under glass fumigating with Auto Shreds is advised. Big bushes in rather small pots should have frequent doses of liquid manure, or one of the many plant stimulants now much used.

There are several varieties of Marguerite, some with single and others with double or semi-double flowers. There have been several semi-double kinds, but they are all now superseded by the variety Mrs. F. Sander, which has a raised Anemone-like centre.

Ox-eye Daisies. - Of the Ox-eye section of Chrysanthemums by far the finest is maximum, a native of Spain and Portugal. The typical kind may be compared with our native Ox-eye (Chrysanthemum Leucanthemum), but is altogether a more vigorous plant, while the flowers are much larger. There are several varieties of Chrysanthemum maximum in cultivation; the blossoms of some are exceedingly large, sometimes 6 inches in diameter on vigorous plants. In height they vary from 2 to 3 feet. The best are: Duchess of Abercorn, dwarf, with the tips of the florets serrated; King Edward VII., the largest of all, and one of the most vigorous, reaching fully 3 feet in height; Mrs. Charles Lowthian Bell, a fine large bloom; Progress, the dwarfest of all with semi-double flowers; Rev. H. Saunders, of strong growth, with extra broad florets to the large flowers; robinsoniana, remarkable for its laciniated florets; Triumph, a very fine border kind of vigorous growth; Tunstall, the florets of which reflex in a particularly graceful manner; and Wynyard, of compact habit, with large, bold, regularly shaped blossoms. These are among the finest of border flowers; if the old flowers are cut off as they fade the season of blooming extends from early summer until autumn. When treated liberally few plants yield so liberal a return in blossom. They form large clumps, and the shoots in the centre are apt to get starved unless the plants are divided at least once in three years, while some prefer to treat them in this way annually. On lifting them it will be found that the newer shoots which have formed on the outside of the clump, where they get fresh soil and more light and air, are the strongest, and in replanting these should be selected.

The soil ought to be well dug and manured before replanting: 
The leaves of Chrysanthemum maximum are somewhat liable to be attacked by the leaf-mining grub referred to in the notes on the Marguerites.

Other Chrysanthemums that may be especially referred to are: alpinum, a neat little plant about 3 inches high, with rather large white flowers; argenteum, an alpine species $\mathrm{I} 2$ inches or so high, with silvery leaves and pale yellow blossoms; Leucanthemum, the Ox-eye or Horse Daisy of our fields, well known everywhere; Leucanthemum semi-duplex, a variety with semi-double flowers; nipponicum, a shrubby species from Japan, with Marguerite-like flowers in late summer and autumn, somewhat tender. The last to mention is a particularly valuable one, namely, Chrysanthemum uliginosum (Pyrethrum uliginosum), a native of Eastern Europe, and of bold, free growth, reaching a height of 5 or 6 feet. The large Oxcye-like flowers are borne in great profusion in early autumn. This Chrysanthemum is well suited for planting in the back row of the herbaceous border. Those suited to the rock garden need gritty, well-drained soil and a sunny spot.

Chrysogonum virginicum (Golden Knee).-The bright yellow flowers of this low-growing perennial, which belongs to the Daisy family (Compositae), are produced for a considerable period throughout the summer months. It is a desirable plant for the rock garden or front of the herbaceous border, and can be readily increased by division, carried out at any time during the dormant season. It thrives in ordinary soil, and is native of North America.

Cichorium Intybus (Chicory or Succory).--This well-known plant, native of Europe, grown chicfly for its cconomic value, is really worthy of a place in the herbaceous border, though the flowers are open only in the morning: It reaches a height of 4 to 5 feet, and from the much-branched stems a succession of blossoms is kept up for some time in summer; they are more than I inch across, and of clear blue colour. The Chicory, which belongs to the Daisy family (Compositae), can be readily increased by root cuttings, dug up in winter, cut into lengths of about 3 inches, and buried some 3 inches deep in well-drained sandy soil.

Cimicifuga (Bugbane).-The Cimicifugas are an ornamental race of hardy herbaceous perennials, natives of North America, China, and Japan, and members of the Buttercup family (Ranunculaceae). They vary in height from 3 to 4 feet or thereabouts, and have long, terminal, feathery racemes of white or whitish flowers. All these plants can be increased by division when dormant, and thrive in ordinary garden soil, especially if it is somewhat moist. The best 


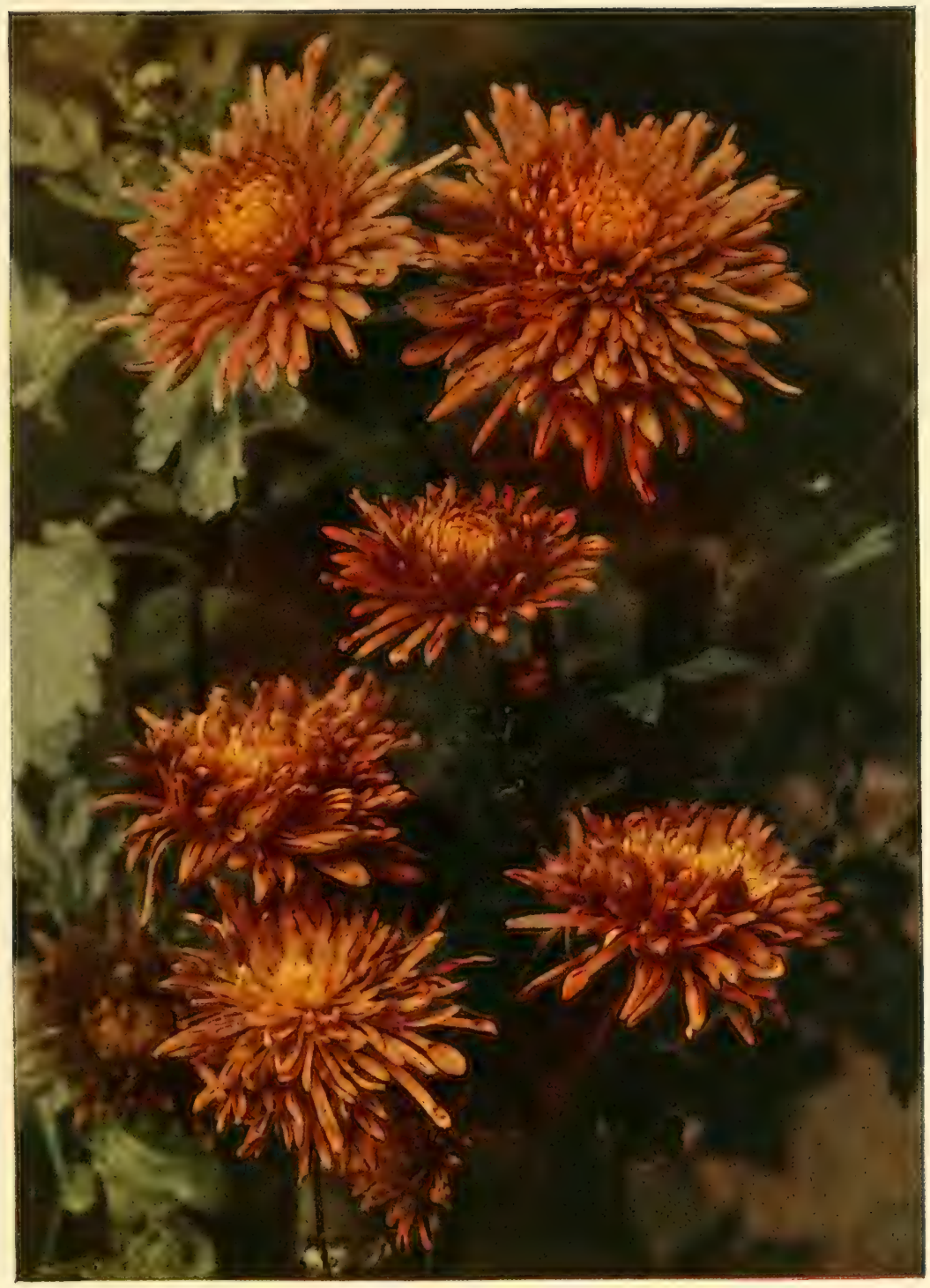

BORDER CHRYSANTHEMUM DIANA 

known are: americana, which flowers in August and September; cordifolia, with heart-shaped leaves; davurica, a distinct species from China, the racemes being of a particularly "feathery" character ; fœtida (simplex), the only European kind; japonica, remarkable for its handsome lobed leaves, black shining stems, and white flowers; racemosa, with much-divided leaves and twisted flower racemes in August. Those of which the flowering season is not named bloom in July.

Cineraria.-By botanists Cineraria, which belongs to the Daisy family (Compositae), is now merged into that of Senecio, but as Cinerarias these plants are universally grown. With one exception they are used only for greenhouse decoration: maritima is largely employed for bedding out during the summer months. For this purpose seed is sown in early spring, in pans or boxes of light sandy soil, the seedlings being pricked off when large enough to handle. If potted singly when sufficiently advanced, they will attain an effective size by bedding-out time. The attractive feature of maritima is the silvery tint of the prettily divided leaves, owing to which it is much used as a foil to brilliantly coloured flowers.

Cinquefoil.-(See Potentilla.)

Cistus (Rock Rose).-Very free-flowering shrubs, belonging to the Natural Order Cistaceae, suitable for planting in dry soil in sunny positions. The majority are natives of the various parts of the Mediterranean region, some coming from rather warm countries. All are not hardy, and those unfitted for out-of-doors are of little use for the greenhouse. As a rule, they are of rapid growth, but it is a mistake to plant them in rich soil in order to induce them to grow quickly. It is preferable to try and keep them short-jointed and sturdy, for such plants not only withstand cold weather better, but flower more profusely. They are increased by seeds sown in spring or by cuttings inserted in pots of sandy soil in a closed frame during summer. In either case it is necessary to keep the young plants in pots until they can be placed in permanent positions, for they transplant very badly from borders. Cistuses are essentially sun-loving plants, therefore choose an open place either on a bank or about the rockery for preference. Excellent results are sometimes obtained by planting them in large masses on rocky hillsides. Pruning is confined to stopping the shoots of young plants and removing the old flower-heads from older specimens. The chief kinds are: albidus, 2 to 3 feet, flowers, rosy-lilac, leaves whitish; corbariensis, I to 2 feet, white; crispus. 3 to 4 feet, grey leaves, rose ; cyprius, 2 to 4 feet, white with red blotch, one of the best; florentinus, 2 feet, white; ladaniferus, 3 to 4 feet, 
white with red blotch; laurifolius, 4 to 6 feet, white, the hardiest of all ; Loretii, 4 feet, white with dark blotches; Monspeliensis, 2 feet, white; purpureus, 3 feet, purple; salvifolius, 3 feet, red ; villosus, 3 feet, rose. All bloom in summer.

Cladrastis (Yellow Wood). - Two hardy species of this group, which belongs to the Pea family (Leguminosae), are in cultivation, Amurensis from Amurland, and tinctoria from the United States; there is also a variety of the former species called Buergeri. The Asiatic kind forms a bush or low tree of little decorative worth, but the other is a much larger tree, sometimes attaining a height of 30 or 40 feet with a considerable spread, and more ornamental by reason of its handsome pinnate leaves and long, Laburnum-like inflorescences of white flowers in July. It requires plenty of sun and loamy soil. Propagation is by seeds, and pruning is unnecessary except for training purposes, when the trees are young. The timber is peculiar by reason of its deep yellow colour from which the common name of Yellow Wood is derived. It is used as a dye. Cladrastis Amurensis is now usually called Maackia Amurensis.

Clarkia.-Of late years the different Clarkias, which belong to the Evening Primrose family (Onagraceae) and are natives of Western North America, have become one of the most popular annual flowers, a fact that need occasion no surprise, as the improved forms are showy and distinct from other plants of annual duration. There are three species in cultivation, namely, elegans, pulchella, and rhomboidea. It is from the two first-named that the garden varieties of the present day have sprung, as rhomboidea with small purple blossoms is less ornamental. When in good soil and with space allowed for their development, Clarkias will reach a height of $2 \frac{1}{2}$ to 3 feet, and flower profusely over a long period. They are hardy annuals; that is to say, seed may be sown out-of-doors in autumn to flower early the following season, and in spring to produce summer bloom. In this way a succession may be maintained, if care is taken to cut off the old flowers as they fade. Clarkias produce seed very freely, and seeding puts a stop to flowering. Apart from their beauty in the open ground, the Clarkias are also of great value for cutting, the colours of some of them look particularly well under artificial light. Some of the improved varieties have single and others double blossoms. Of the latter the leading sorts are: Brilliant Princess, glowing rose; Firefly, scarlet-crimson; Purple King, purple ; Salmon Queen, bright salmon; Scarlet King, scarlet, and White Prince, pure white. The single varieties, though very showy, are not so numerous as the double ones. When sowing Clarkias, do not allow them to be crowded. 
Claytonia (Spring Beauty).- The Claytonias are pretty springflowering plants chiefly with tuberous roots, and belong to the Natural Order Portulaceae. They are natives of the northern regions of both hemispheres, thrive best in a moist soil, and can be readily increased by means of seeds. The chief species are caroliniana, some 9 inches high, that bears a profusion of bright rose-coloured blossoms from April to June; a good deal similar is sibirica, while virginica, rather shorter, has pure white flowers. Claytonias are suitable for the moist part of the rockery. Particular interest is attached to an annual species, Claytonia perfoliata, not from any beauty it possesses, but from the fact that, though a native of North America, it some years ago overran the market gardens in the neighbourhood of London as a weed.

Clematis. - This group consists of shrubby and herbaceous climbers and sub-shrubby and ordinary herbaceous plants, belonging to the Buttercup family (Ranunculaceae). The majority are of a showy character and invaluable for garden adornment, whilst others are useful additions to the wild garden. One species, Vitalba, the Traveller's Joy or Old Man's Beard, is a native of the British Isles, and is found in copses and hedgerows in many directions. The other kinds have a wide distribution, some being found in Europe, others in Asia, America, New Zealand, Australia, and Africa. With a few exceptions, the hardier kinds are the more ornamental, and those requiring a warm greenhouse are given little attention. The soil most suitable for Clematises is deep, rich loam, which contains lime. Propagation is effected in various ways. Thus the species may be raised from seeds or cuttings, and the garden varieties from cuttings, layers, or grafts. The grafts are usually placed upon sections of root of Clematis Vitalba, but grafting should only be practised when other methods fail.

Pruning requires a considerable amount of care, for some kinds bloom on shoots of the previous year, and others on the current year's growths. Thus the garden varieties are included in five distinct groups under the following headings: Florida, Patens, Lanuginosa, Jackmani, and Viticella. In the cases of the two first-named, the flowers are borne from the previous year's shoots, and any necessary pruning-which is usually very little-must be reserved until after the flowers are over in June. The others, however, blossom on the current year's stems, and require cutting back severely in February. If not cut back, these kinds become very bare about the base, and the upper parts appear as a mass of tangled shoots. The true species, or wild types, require similar treatment; those like montana and alpina, 
which bloom from old stems, must not be pruned until after the flowers have fallen, whereas autumn or late summer flowering kinds, such as Flammula and orientalis, may be pruned in spring. The herbaceous Clematises must be cut over in the ordinary way and the clumps divided in autumn when necessary. An evergreen species, from New Zealand, indivisa, is too tender for outdoor cultivation except in the warmer counties, where its plentiful white star-like flowers make a wonderful display, but it may be grown in a cool and airy greenhouse with considerable success, either on rafters or pillars or in pots, on trellises or trained round stakes.

The following is a selection of garden varieties. All these should have their roots and the lower parts of their stems shielded from bright sun :

Florida Group.-Belle of Woking, double, silver-grey; Countess of Lovelace, double, bluish-lilac; Duchess of Edinburgh, double, white; John Gould Veitch, lavender; Venus Victrix, lavender.

Patens Group.-Albert Victor, lavender; Fair Rosamond, white ; Lady Londesborough, silver-grey; Marcel Moser, white; Nellie Moser, blush white with red bars; The Queen, mauve.

Lanuginosa Group.-Anderson Henryi, creamy-white; Beauty of Worcester, violet; Duchess of Teck, white; Fairy Queen, flesh; Empress Eugénie, white; Gloire de St. Julien, white; La France, violet-purple; Sensation, mauve.

Jackmani Group.-Alexandra, violet; Earl of Beaconsfield, purple; Jackmani alba, white; rubra, red ; Snow White, white; superba, purple; Madame Baron-Veillard, rose; Madame Edouard André, red; Star of India, purple with reddish bars.

Viticella Group.--Ascotensis, blue; Lady Bovill, blue; Madame Grange, crimson-violet; Madame Thibaut, lilac; Thomas Moore, violet; Viticel'x alba, white; grandiflora, red.

The following are the chief species: alpina, 8 to I2 feet, mauve, bluc, white, or red, April ; campaniflora, at least 15 feet, whitc and mauve, summer ; calycina, evergreen, cream or white, winter; Flammula, 15 to 18 feet, white, fragrant, August, var. rubro-marginata, has red margins to the flowers; heracleaefolia, a sub-shrubby kind from China, bearing large quantities of tubular blue flowers in July and August-improved varieties are Davidiana and Lavallei; indivisa, an evergreen, tender kind from New Zealand, bearing white flowers in spring; montana, one of the best of the Chinese kinds, grows quite 20 feet high, and bears white flowers freely in May-the var. rubens has red fowers. Orientalis is an Oriental kind, bearing small yellow flowers during late summer - the var. tangutica is better 


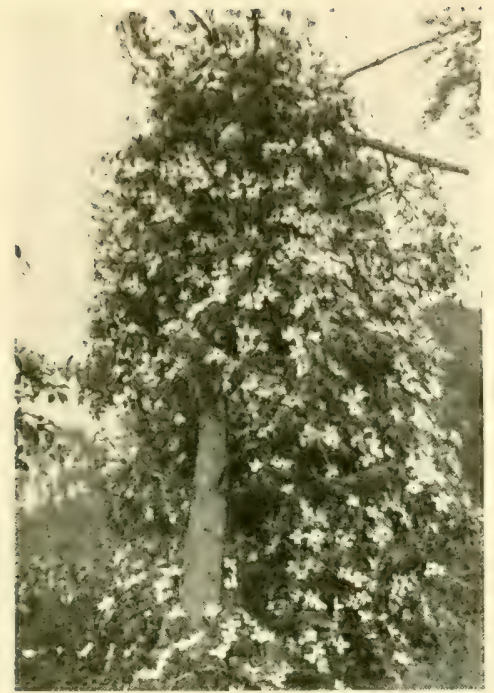

THE MOUNTAIN CLEMATIS (CLEMATIS MONTANA)

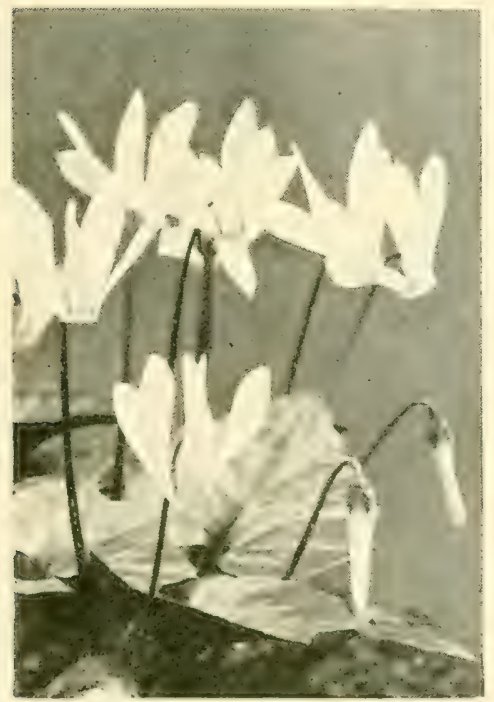

A HARDY CYCLAMEN (CYCLAMEN REPANDUM)

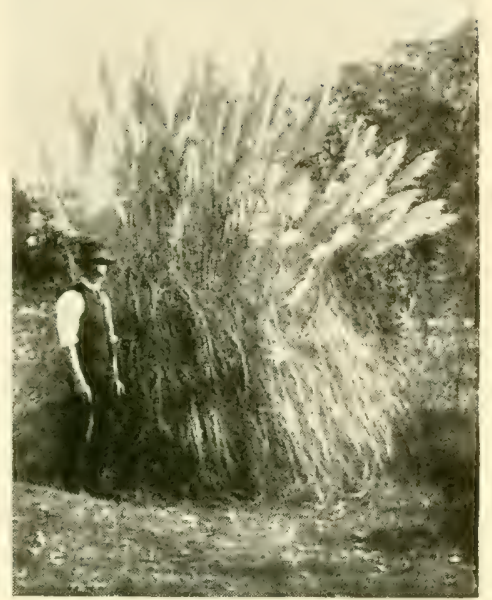

PAMPAS GRASS (CORTADERIA ARGENTEA)

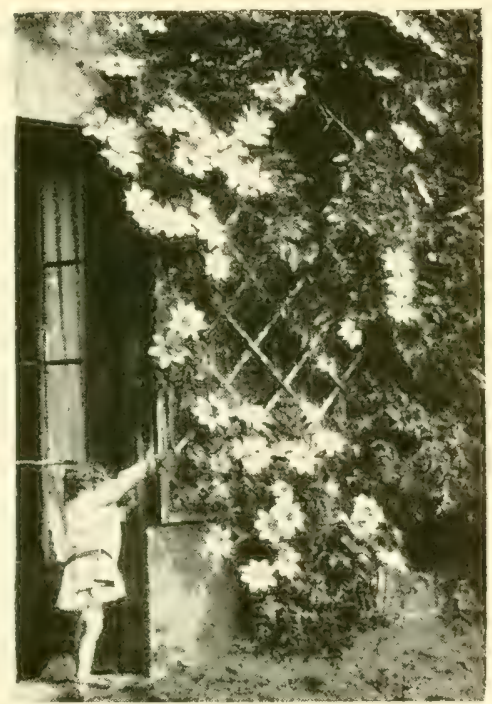

CLEMATIS NELLIE MOSER ON WALL TRELLIS 

than the type; Pitcheri is an ornamental summer-flowering species from Colorado. Amongst the herbaceous kinds, recta, with white flowers ; coccinea, with scarlet blooms; and integrifolia, with purple blossoms, should be grown.

\section{Clerodendron.-} This group (Natural Order Verbenaceae)contains numerous tropical, and a few temperate, shrubs. The hardier kinds are natives of China and Japan, whilst the others are found in the West Indies,

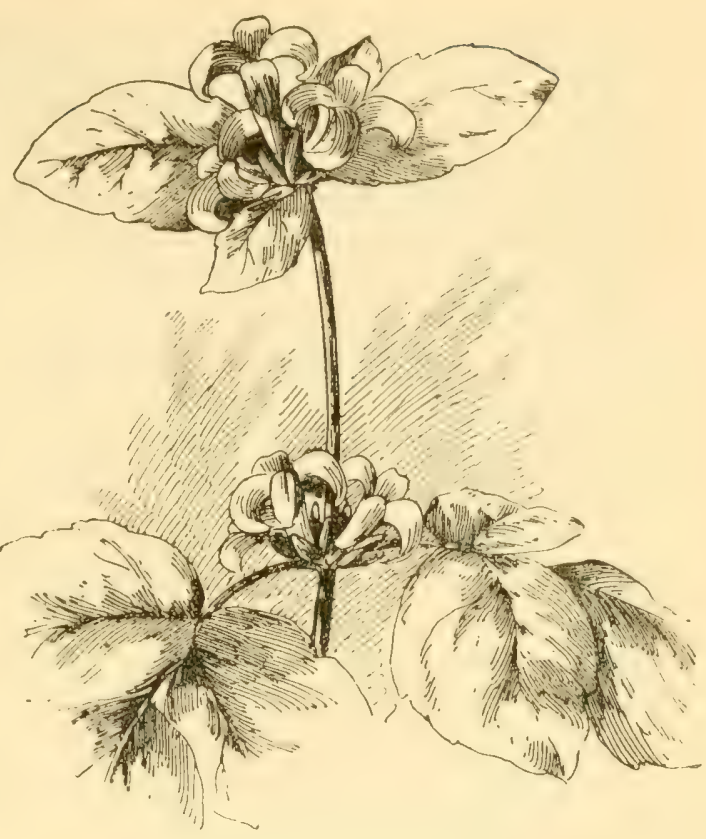
India, Africa, the Ma-

CLEMATIS HERACLEAEFOLIA

laya, Australia, and other countries. The hardy Clerodendrons require sunny positions, and are better adapted to the southern than to the northern counties. They thrive in light, well-drained loam, and are increased by root cuttings placed in sandy soil under glass in spring. Sections of root as thick as a lead-pencil may be cut in lengths of 4 inches for the purpose. Clerodendron foetidum may be cut down to the ground each year; in other cases pruning is confined to the removal of dead wood. The best hardy kinds are : foetidum, 3 to 4 feet, China, flowers red, August; Fargesii, 6 to ro feet, China, flowers white, fragrant, August; trichotomum, Io to I5 feet, China and Japan, flowers white, fragrant, August and September.

There are numerous tender kinds which require a warm greenhouse temperature. Some are climbers, others bushes.

Clethra.--The Clethras, which belong to the Heather family (Ericaceae), comprise several deciduous shrubs from North America, one from China and Japan, and an evergreen kind from Madeira. The American kinds, acuminata and alnifolia, are the hardiest. They succeed in moist, peaty soil, form bushes 2 to 4 feet high, and bear a profusion of clusters of fragrant white flowers during August. There are several varieties of alnifolia, those called Michauxii and paniculata 
being especially worthy of note. The Asiatic kind, canescens, is an upright bush, 4 feet high, which bears fragrant white flowers in autumn. It is not very hardy when young. All the pruning required is the removal of the flower-heads. Clethra arborea from Madeira is a very different plant. Of vigorous habit, it forms a shapely bush, 12 to 15 feet high with handsome dark evergreen leaves, and bears large clusters of white bell-shaped flowers, from which the common name of Lily of the Valley Tree has arisen. Except in the warmer countics, it must be grown in a cool greenhouse. Equal parts of loam and peat form a suitable compost; prune after flowering when any shaping is required, otherwise simply remove the flower-heads.

\section{Climbing Fumitory.--(See AdLumia.)}

Clintonia.-A small genus of plants belonging to the Lily family (Liliaceae), and natives chiefly of North America. They are but rarely met with in gardens, though they are fully entitled to more attention than is usually bestowed upon them. For their successful treatment they need a moist, peaty soil in a partially-shaded spot, and can be increased by division in spring. The species are andrewsiana, which reaches a height of 2 feet and bears drooping, bell-shaped, rose-coloured blossoms in umbels; this flowers in May and June, so, too, does borealis, but this only reaches a height of about 6 inches, and the flowers are yellow. In Clintonia umbellata, which is also only some 6 inches high, the blossoms are whitish. A distinct feature of uniflora is that the stem is, as a rule, one-flowered, though occasionally two (white) blooms are produced.

Cnicus (Horse Thistle).-An extensive group (Natural Order Compositae), many of the kinds being classed by different authorities under various names. The majority of them are but weeds. Perhaps the best of all-and that is only fit for the wild garden-is heterophyllus, that reaches a height of 4 to 6 feet, and bears large heads of purple flowers. It will grow in almost any soil.

Cobaea scandens.-A rapid-growing climbing plant, native of Mexico, and belonging to the same Natural Order as Jacob's Ladder (Polcmoniaceae). For its full development, a large greenhouse or conservatory is necessary. It is, however, often used for beds in the outdoor garden in summer, for if the seed is sown in warmth early in the spring the young plants will grow freely, and in late May can he safely planted out. If put into some fairly light, moderately rich soil, they will make rapid headway and cover a considerable space of trellis or other support by the latter part of the summer. At that time the large purple bell-shaped flowers open, and a succession is lept up until frost puts in an appearance. The Cobaca has woody 
stems, and should it survive the winter, which is not likely except in especially favoured spots, it will grow freely the next year.

Cockscomb.-(See Celosia CRISTATA.)

Codonopsis.-Herbaceous perennials, that bear bell-shaped blossoms on a climbing stem during summer. They belong to the Bellflower family (Campanulaceae), and are natives of the Himalaya, China, and Japan. The chief species are: clematidea, which reaches a height of 2 feet, and bears whitish flowers marked with purple; lanceolata, with tuberous root, flowers pale lilac without and violet within; ovata, soft grey-blue; and rotundifolia, with purple flowers veined with yellow. They thrive best in a fairly cool, moist, though well-drained spot in ordinary soil, and are an interesting and ornamental class of plants.

Coix lachryma (Job's Tears).-An ornamental Grass (Natural Order Gramineae), native of tropical Asia, and suitable only for planting out-of-doors for the summer months. The seeds, which are very hard, and about the size of a Cherry-stone, are sown in warmth in February, and the young plants put out in good soil in a sunny spot, late in May or early June. This Grass will then form a dense tuft, 3 feet or more in height, and bear half-drooping clusters of its pretty seeds, to which the popular name of Job's Tears is applied. The seeds are of bluish-white tint, and have a polished surface like that of porcelain, and are much used for beads, especially in the making of rosaries, etc. As they are so hard, it is a good plan to soak them in warm water for twenty-four hours before sowing.

Colchicum (Meadow Safron). - The different species of Colchicum are of wide geographical distribution in Asia and Europe. They belong to the Lily family (Liliaceae). A second popular name, Autumn Crocus, has been given them, firstly owing to their general resemblance to a Crocus, and secondly from the fact that most of them flower in autumn. Colchicums need a sandy, loamy soil, and the bulbs are planted in July and August. Though the autumn Colchicums produce their flowers at that season, the leaves do not appear until spring ; for this reason the bulbs are often planted in grass, which serves to protect them from rough winds and heavy rains during their flowering period and provide a setting for the flowers. They may also be planted in the front of a border, disposed in irregular-shaped clumps, preferably among some tufted evergreens. In planting Colchicum the top of the bulb or corm, as it is more correctly termed, should be about 3 inches below the surface of the soil. There are many species and varieties, some of which closely resemble each other. A selection of the best includes: autumnale, purple; autumnale album, white; 
autumnale album plenum, double white; autumnale roseum plenum, double rose; Bornmülleri, lilac, white centre; byzantinum, soft mauve, feathered with white; giganteum, dark lilac; Parkinsonii, rose-purple and white, chequered in a strange manner; speciosum, the largest of all, rose-purple; speciosum album, pure white; and variegatum, chequered after the manner of Parkinsonii. Quite a

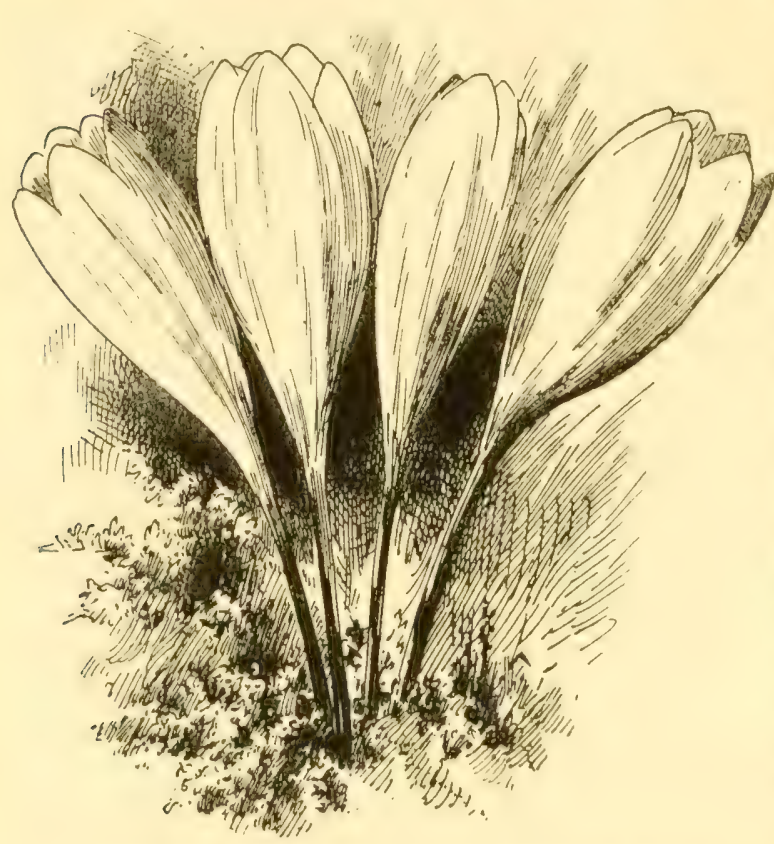

MEADOW SAFFRON (Colchicum autumnale album) miniature kind is crociflorum, which does not bloom until spring; the flowers are white, lined with violet.

Colletia cruciata is an extraordinary shrub belonging to the Natural Order Rhamnaceae: It is a native of Uruguay, and is peculiar by reason of its branches being armed with ferocious spines among which the small leaves are not very evident. The spines differ widely on different plants, sometimes being long and moderately slender, and at others being considerably thickened near the base, forming almost a part of the branch system. The small red and brown flowers are borne freely in April, after the bushes have attained full size. Plant in loamy soil in the southern counties. No pruning is required.

Collinsia.-Pretty free-flowering hardy annuals, native principally of California, and belonging to the Snapdragon family (Scrophulariaceae). They thrive in any good garden soil. The seed may be sown out-of-doors either in autumn for spring bloom, or in spring for summer flowers. Most of them grow about 12 inches high, and the flowers are borne in whorls along the greater part of the shoots. The principal species are bartisacfolia, purple and white; bicolor, white, rosy-purple lip ; bicolor candiclissima, white; corymbosa, white 


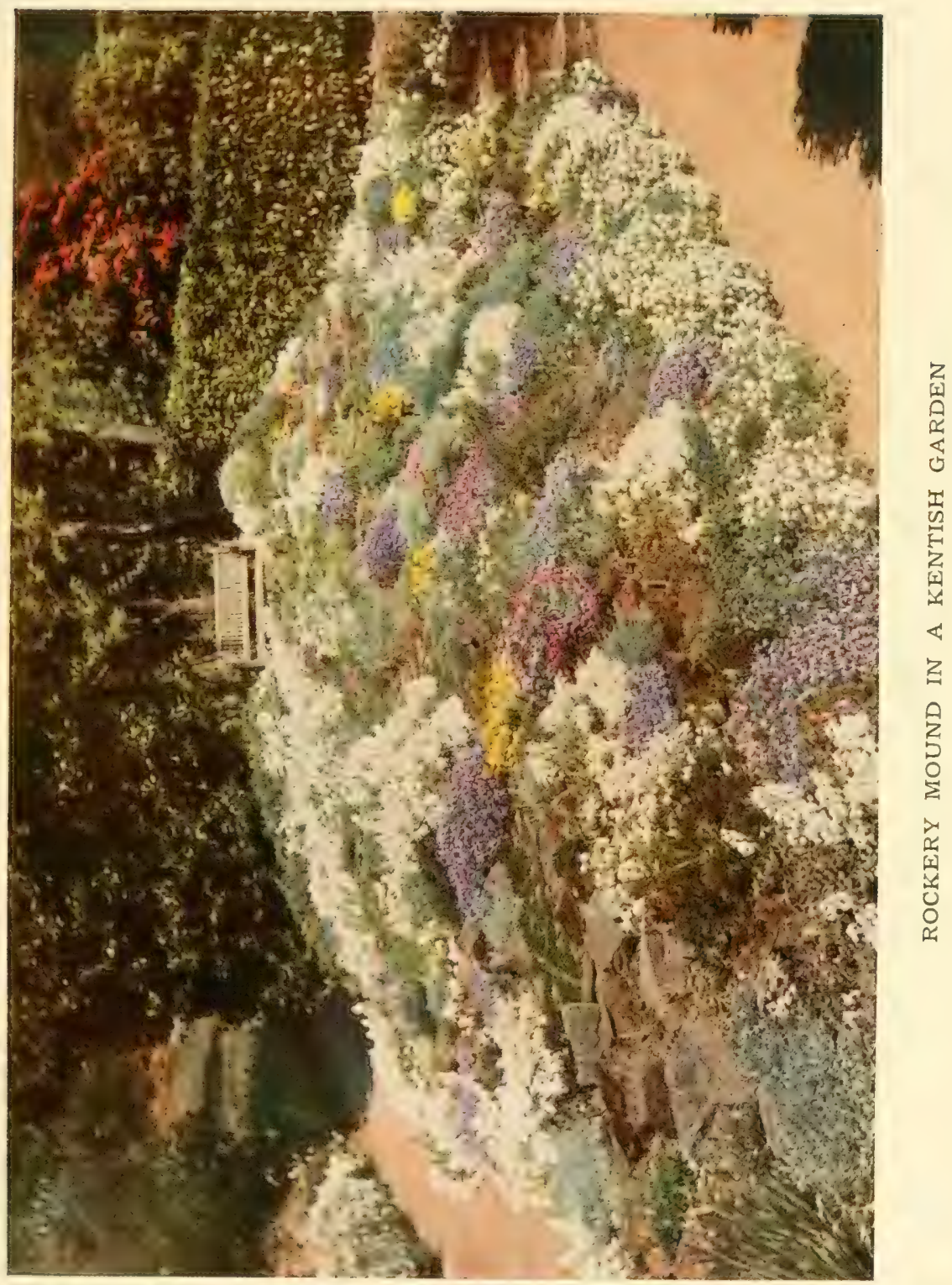



and blue ; grandiflora, purplish-blue; parviflora, blue and purple ; and verna, white, blue lip. The last-named should be sown in autumn, as it is at its best in spring.

Collomia.-Hardy annuals belonging to the Natural Order Polemoniaceae, and native chiefly of North-West America. All are quite hardy; that is to say, they may be sown in autumn to stand the winter, and flower in spring and early summer, or in April to bloom later on. They grow about 18 inches high, and the flowers are disposed in dense heads. All of them do well in ordinary garden soil, in a sunny spot. The principal species are coccinea, deep red ; grandiflora, reddish-yellow; heterophylla, purple; and linearis, reddishbrown.

\section{Columblne.-(See AQUILEgIA.)}

Colutea (Bladder Senna).- -Hardy shrubs belonging to the Pea family (Leguminosae), natives of the Mediterranean region and Asia Minor. They form bushes 3 to 8 feet high, with pinnate leaves and golden or brownish flowers which are followed by curious, inflated, parchment-like pods, from which the common name of Bladder Senna has arisen. They are grown in ordinary garden soil, are usually increased by seeds, and are often allowed to grow 2 or 3 feet in height with several branches from the base, and are then cut back each year to within an inch or so of the base of the previous year's wood. The best flowers are produced by this method, though regular pruning is not absolutely necessary. The chief sorts are : arborescens, Common Bladder Senna, flowers golden, June; cilicia, Asia Minor, yellow; cruenta, Orient, brown or reddish-brown; longialata, Asia Minor, yellow.

Commelina.-An extensive group (Natural Order Commelinaceae) containing nearly a hundred kinds, most of which are tropical weeds, and are therefore unsuitable for outdoor cultivation in this country. In light, warm soils and a sunny spot, one sort, caelestis, forms a very pleasing feature in the outdoor garden during summer, for it blooms over a lengthened period. It forms a tuberous root, from which arise green stems to a height of 18 inches. The stems are clothed with bright green, oblong, lanceolate leaves, and the flowers, several of which are enclosed within a large shell-like bract on the points of the shoots, are of a delightful shade of light blue. They only last for a single day, but a succession is kept up for a long time. Commelinas are hardy only in light, warm soil, but, where there is any risk of their surviving the winter, the tuberous roots may be readily lifted and stored in the same manner as Dahlias. They are readily increased by seeds, which should be sown out-of-doors in a warm spot in April. So freely are 
the seels produced, that where the conditions are favourable scedlings come up like weeds. The old plants that survive the winter out-ofdoors, or are stored safe from frost and planted out in spring, are more effective than seedlings of the first year.

Conandron.--This hardy plant, which belongs to the same family as the Gloxinia (Gesneraceae), and is native of Japan, forms a tuft of dark green leaves, very suggestive of those of Ramondia, and bears in summer, on stems about 6 inches high, pale lilac flowers with purple centre. It is a plant for which a suitable spot in the rock garden must be chosen. The best conditions are a fairly moist, yet welldrained, shady clink between two stones, and a soil of loam, peat, and sand.

\section{Cone Flower.--(See RUDBECKIA.)}

Convallaria majalis (Lily of the Valley).-By some authorities the Solomon's Seal is included in the genus Convallaria, but it is now generally known as Polygonatum. The Lily of the Valley, which belongs to the Lily family (Liliaceac), and is found wild in north temperate regions, is a universal favourite; it will flourish in practically every garden if some care is taken in planting. If an old-established bed of Lily of the Valley is examined it will be found to consist of a dense mat-like mass of underground stems and roots with a considerable number of buds, or crowns, as they are usually termed. In time, when these get overcrowded, the flowers become poor, and then the bed should be replanted, selecting for the purpose a fresh spot if possible. The ground must be well dug, and a liberal amount of leaf-mould and decayed manure mixed in. The old clumps are divided up into portions each containing two or three crowns, which are replanted about 3 inches apart over the surface of the bed, which may be in a partially-shaded spot. The work of dividing and replanting is done in winter, when the plants are dormant, and care must must be taken that they do not suffer from want of water afterwards. Top-dressing the bed in autumn with a mixture of loam, leaf-mould, and manure, the whole being passed through a $\frac{1}{2}$-inch sieve, often improves the plants considerably, and gives them a new lease of life. In picking flowers the spike should be pulled out, as in this way a greater length of stem is obtained. There are several varieties of Lily of the Valley that differ in a more or less marked manner from the common kind. Included among them are flore pleno, with double flowers; prolificans, in which the segments are more spreading than usual; rosea, with blossoms of pinkish tinge, and variegata, with variegated leaves. Besides these we have what are termed Berlin crowns, so much used for forcing, the individual 
flowers being very widely expanded; and Fontin's variety, of vigorous growth and bearing large blooms. This last-named is particularly effective in a bed or clump.

Convolvulus (Bindweed).-Many of the perennial Bindweeds (Natural Order Convolvulaceae) are decidedly ornamental, but a clisadvantage of some of them lies in the creeping roots, which encroach on neighbouring plants. Chief among them are althaeoides, a lovely little creeping plant with rosy-pink flowers, produced throughout the summer; it is often recommended for the rock garden, but it spreads rapidly, and should not be put near choice plants. Convolvulus arvensis (Small Bindweed) is, though pretty, one of the worst weeds of the garden; Cneorum, quite a little bush, clothed with silvery leaves and in early summer sprinkled with pretty pink blossoms, is hardy only in warm districts; it is a native of the South of Europe. mauritanicus is another somewhat tender kind, of creeping habit, and when grown in a suspended basket it is very attractive; the flowers are blue, and borne from June till the autumn. In warm gardens, it is a desirable plant for the rockery. Rather light, sandy soil is suitable for the choicer kinds.

Anmual Convolvulus.-The best of these are selected forms of two species, namely, tricolor, more generally known as minor, and major, which is also known as Ipomoea purpurea. Of the last-named, seed may be sown out-of-doors late in April, and the plants so obtained will bloom during summer. If a frame or greenhouse is available seeds may be sown in pots in March, and the seedlings planted out in May. These flower earlier than when the seed is sown out-of-doors. This Convolvulus, which is a rapid climber, is admirably adapted for growing in boxes, for placing near the window or balcony, or an arch, round which the stems may grow. A sunny spot suits the plants, as they are seen at their best during bright sunshine. The flowers are of shades of blue and purple, while there are also rose, crimson, and striped kinds. The dwarf Convolvulus tricolor, more generally known as minor, also has flowers of

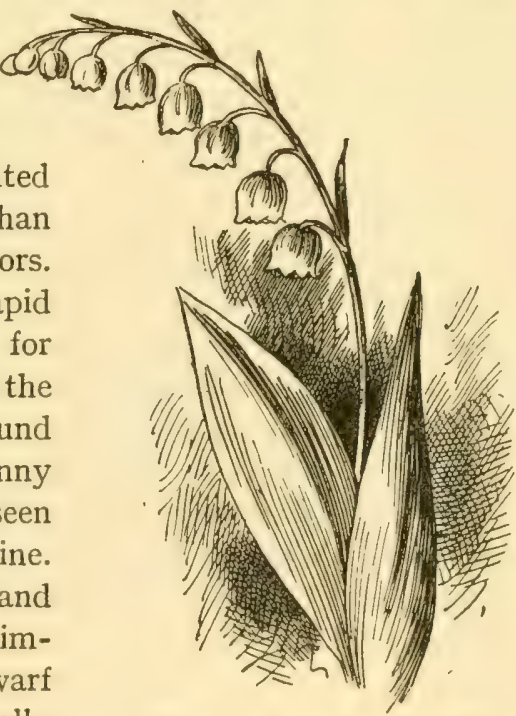

LILY OF THE VALLEY

(Convallaria majalis) 
similar shade of colour, though many of them have a yellow centre. The blossoms of Convolvulus do not last long, but a succession is liept up throughout the summer. A well-dug, but not rich, soil and a sunny spot meet their needs. Seed may be sown in autumn or spring, as the plants are hardy.

Coptis.-Hardy perennials, growing from 6 to I2 inches in height, belonging to the Buttercup family (Ranunculaceae), and natives of the Northern Hemisphere. They succeed best in a moist, peaty soil, and are well suited for small bog gardens. The best known are occidentalis, with trifoliate leaves and white Ranunculus-like flowers, in May and June; orientalis, leaves pinnate, with deeply cut lobes and white flowers, usually borne three together on a stem; and trifolia, with trifoliate leaves and small white flowers, borne singly from April to July.

Cordyline.-Most of the Cordylines, which belong to the Lily family (Liliaceae), are hothouse plants, the only one that is useful for outdoor planting being australis, a native of New Zealand. It forms an upright stem, which, in old plants, is crowned with long, strap-shaped, arching leaves. In the warmer parts of England and in Ireland this Cordyline attains quite tree-like dimensions, while as a smaller plant it is commonly used in summer bedding, chiefly as a "dot " plant in formal flower beds; larger specimens, in tubs or pots, are plunged in the turf of the lawn, especially where a sub-tropical effect is aimed at. When the plants need repotting, it should be done in spring, a suitable compost being made up of a mixture of loam, peat and sand. Increase is by seed, which sometimes ripens in this country, in addition to which considerable numbers are sent here from New Zealand; it is sown as soon as possible after receipt, in the greenhouse. When large enough the young plants are put singly in small pots and repotted as becomes necessary. Cordyline australis is sometimes known as Dracaena australis and Dracaena indivisa, but the last name is rightly applied to a totally different kind.

Coreopsis (Tickseed).--Showy annuals and perennials, chiefly natives of North America, members of the Daisy family (Compositac). They are known also as Calliopsis. The annual kinds, which grow from I foot to 3 feet in height, are exceedingly beautiful. The flowers are on long wiry stems, and are admirable for cutting. They vary in colour from yellow to deep crimson or brown, and in many of them these colours are blended in varied and striking fashion. The annual kinds may be sown either in autumn or spring; for autumn sowing outof-doors light, well-drained soil must be chosen. From seed sown in the open ground in April the young plants make rapid headway, and 


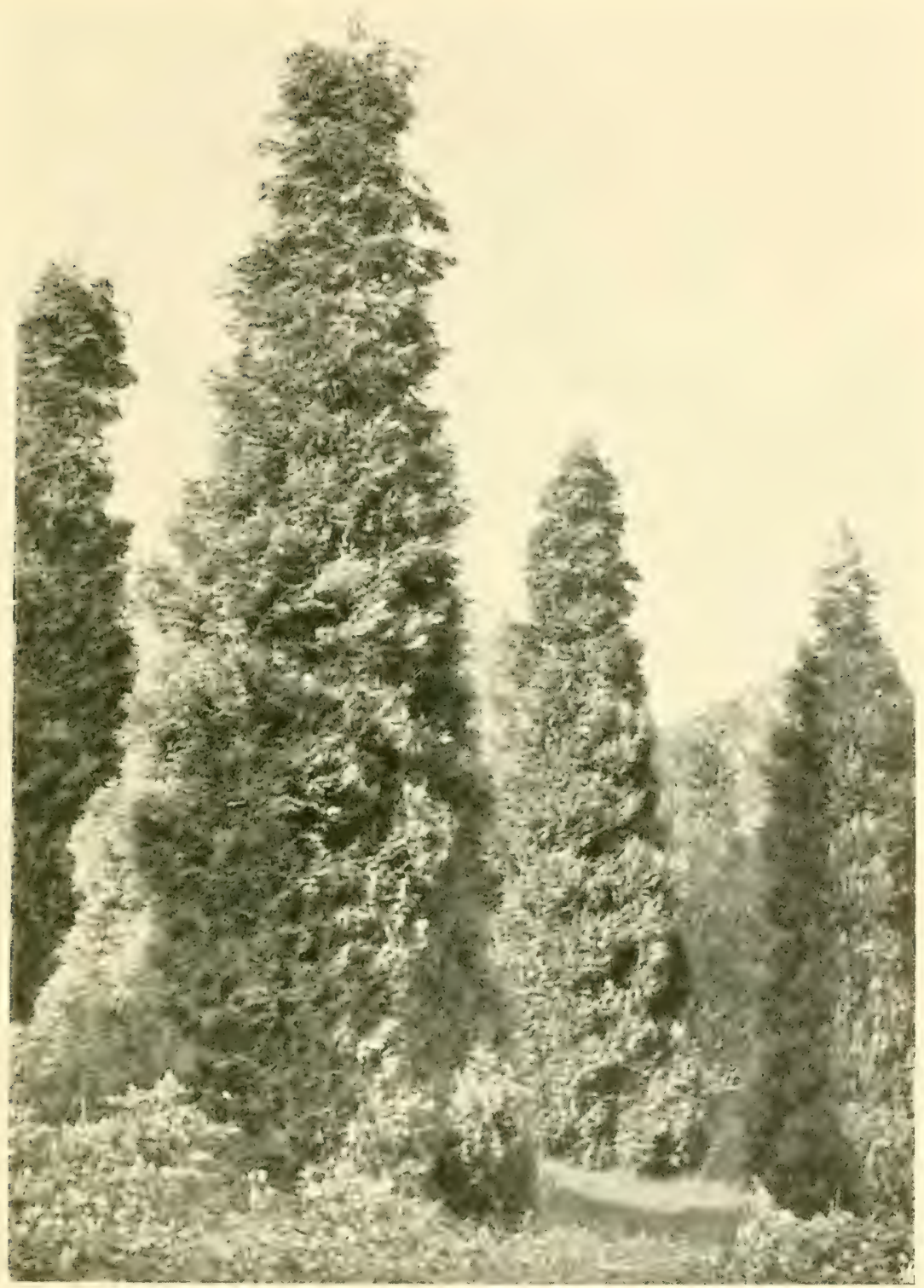

A GOLDEN-LEAVED CYPRESS (CUPRESSUS LAWSONIANA

LUTEA) 

soon reach flowering size. Well-grown plants branch out freely, hence care must be taken that they are not overcrowded.

Of the perennial kinds may be especially mentioned: auriculata, yellow with dark zone; grandiflora, flowers $2 \frac{1}{2}$ inches across, of bright golden-yellow; Eldorado, an improved form of grandiflora; lanceolata, rich yellow; palmata, yellow ; rosea, about $\mathrm{r} 2$ inches high, pink flowers; and verticillata, yellow, an upright-growing plant, of which the leaves, disposed in whorls, are much divided. All, except rosea, have rich yellow flowers, and reach a height of 18 inches to 2 feet; they bloom throughout the greater part of the summer, and are of great service for cutting. They may be increased by division, carried out in the new year, before they start into growth, and will thrive in any good garden soil. In the herbaceous border they form a very attractive feature. Coreopsis grandiflora is only a biennial in many gardens and dies after flowering, hence it must be raised from seed each May to bloom the following year.

\section{Cork Oak.-(See Quercus.) \\ Corn Flag.-(See Gladiolus.) \\ Cornflower.-(See Centaurea.)}

Cornus (Dogwood).-This group (Natural Order Cornaceae) is made up of a considerable number of hardy shrubs, commonly called Dogwoods, which vary as much in appearance as in their garden value. They are widely distributed in Europe, North Asia, and North America. In some instances the decorative qualities are limited to showy bark, in other cases variegated foliage is the attraction, whilst some are grown for their beautiful flowers. Except that a few are tender and their planting is restricted to sunny positions in the warmer parts of the country, the Cornus give little trouble, for they thrive in any good garden soil. Propagation is by seeds, layers or cuttings of the ripened wood inserted out-of-doors during autumn or winter. Those kinds which have decorative bark are often cut down to the ground annually or biennially in March. By this means the richest colour is secured. Otherwise an occasional thinning is all that is necessary.

The following form a selection of the best kinds: alba, an Asiatic species with bright red bark, the var. Spaethii is probably the best of all the golden variegated shrubs, and variegata is a very useful plant, with silver variegated leaves; Baileyi is a red-barked shrub from North America ; florida, the flowering Dogwood of Eastern North America, is very showy by reason of the white, or sometimes red, bracts which surround the flower-heads-it must have a sunny spot; macrophylla is a handsome tree-like kind from North India, China, 
and Japan, its large blue-green leaves and heads of cream flowers are attractive; Mas is the Common Dogwood, Cornelian Cherry, or Cornel of our hedgerows, it forms a large bush up to 20 feet high, and bears bright yellow flowers during February and March-there are several useful varieties with variegated leaves; Nuttallii, one of the more tender kinds, is from California, its attractions are the large, white bracts surrounding the flower-heads, and the rich autumnal colouring of the leaves; stolonifera, from North America, has bright red bark, and the var. flaviramea, golden bark.

Corokia Cotoneaster is the most useful kind in this group, which belongs to the Dogwood family (Cornaceae). It is a curious and showy shrub from New Zealand, suitable for a position against a south or west wall in the South of England, or in some parts it may be grown in the open. Grown naturally, it forms a dense bush of thin, wiry, tortuous shoots, clothed with small, spoon-shaped, dark green leaves, and in May or June bears a profusion of star-shaped golden blossoms. As a bush it requires no regular pruning. Against a wall sufficient pruning must be given after flowering to keep it in place. Scarlet fruits sometimes ripen on plants against a wall. Ordinary garden soil is suitable, and increase is by means of cuttings.

Coronilla.-A group of plants belonging to the Pea family (Leguminosae), principally natives of Southern Europe, and composed of herbaceous perennials and shrubs. Nost of them need a light, well-drained soil in a sunny spot. The herbaceous kinds are increased by seeds, and the shrubby kinds by cuttings put in sandy soil in a close and shaded frame in August. The chief species are: cappadocica, a pretty little trailing plant, suitable for the rock garden, the yellow Pea-shaped blossoms appear during July and August; coronata, of half-shrubby character, 2 feet high, bears yellow flowers in umbels in July and August ; elegans is a trailing kind with pinkishwhite blossoms from July to October, it thrives well on old walls; Emerus is a hardy deciduous shrub, reaching a height of 4 to 5 feet, and bearing yellow Pea-shaped flowers in spring; glauca is an evergreen species, hardy in the milder parts of the country, but in others requiring greenhouse protection, it bears a profusion of light yellow flowers; varia bears pink Pea-shaped blossoms, borne from June to autumn, it reaches the height of 2 feet, and will thrive in dry, sandy soil.

Cortaderia (Pampas Grass).-The genus Cortaderia (Natural Order Gramineae) is but a small one, but contains some of the most ornamental of all hardy grasses. The best known is the Pampas Grass, Cortaderia argentea, which used to be known, and is still usually 


\section{CORYDALIS}

met with in gardens, as Gynerium argenteum. It forms a handsome mass of gracefully recurving leaves, and late in summer, or more often in autumn, the large plume-like heads of silvery white flowers appear. As an isolated specimen on the lawn the Pampas Grass is most striking. The popular name is derived from the fact that the plant is a native of the open Pampas of South America. If the large plumes are cut while they are still in good condition and hung up in an airy room to dry, they are of great service for decorative purposes during winter. Under cultivation different forms of the Pampas Grass have been obtained; the var. nanum is characterised by dwarfer growth, while the flower-heads develop sooner than those of the typical kind. In some districts this is an advantage, as the inflorescences of the ordinary one are sometimes injured by frosts. There is a variety of which the flower plumes are of pink shade, known as carneum, Rendatlerii, and Roi des Roses; there appears to be little if any difference between them. Cortaderia conspicua, from New Zealand, resembles the Pampas Grass, but is smaller and more slender in growth, while its plumes develop a little earlier; this used to be known as Arundo conspicua. The third to mention is a very scarce and little-known species, namely jubata, with flower panicles of pale straw tint suffused with purple; the inflorescences are branching, and well overtop the long, narrow drooping leaves. Before planting Cortaderia, the ground must be deeply dug, well-decayed manure being freely mixed in. A sheltered spot should be chosen, so that the plumes may not be damaged by strong wind.

Corydalis (Fumitory).-An extensive group (Natural Order Fumariaceae), chiefly hardy herbaceous perennials, most of which are easily grown; many are well suited to the rock garden, preferring light soil. They are often grown in an old wall, and will cover a rough bank attractively. They are natives of the temperate regions of the globe, several new kinds having recently been imported from China. The flowers, which are in terminal spikes or heads, are usually of a somewhat tubular shape with a prominent lip, and often attended by large leaf-like bracts. Many of the Fumitories are attractive by reason of their prettily divided leaves, often of glaucous tint. The average height is about I 2 inches. A selection of the best comprises: bracteata, yellow, May and June; bulbosa, pale pink, April and May; cheilanthifolia, fern-like leaves and yellow flowers from spring until autumn; lutea, yellow flowers nearly throughout the year, fern-like foliage, very useful for old walls; nobilis, yellow flowers with dark centre and prettily cut leaves; this needs a fairly moist soil in a shady spot. In Corydalis thalictrifolia the pale green leaves are very 
finely divided, and the yellow flowers profusely borne throughout the summer months; this is one of the most ornamental, but being somewhat tender it requires a sheltered, well-drained position on the rock garden; a little-known Chinese species is Wilsonii, with glaucous, fern-like leaves and bright yellow flowers. There are several tuberous-rooted kinds, of which Scouleri, rose-purple, May; and tuberosa, purplish, March, are the best. These are increased by offsets from the tubers in autumn, or by seed; and the fibrousrooted kinds by division in autumn or by seed.

Corylopsis.-A group of shrubs from China, Japan and the Himalaya, allied to the Witch Hazels, and belonging to the same family (Hamamelidaceac), but less generally hardy. So far as winter is concerned they never suffer, but growth and flowers appear early in April, and late frosts sometimes cut both rather badly. The flowers are usually fragrant, golden in colour with red anthers, and borne in catkins from buds on the previous year's shoots. They require fairly light loam in which a little peat or leaf-mould has been dug, and are increased by means of seeds. Pruning is confined to an occasional thinning of the old worn-out growths. The best are: Griffithii, a Himalayan bush, 4 to 5 feet high; pauciflora, an elegant free-flowering kind from Japan, with pale yellow flowers and dainty leaves, which are green and bronze during early spring-it is worth growing in the greenhouse; spicata, a Japanese bush and fairly hardy; Veitchii, a new species from China.

Corylus $(\mathrm{N} u t)$.- This group consists of nut-bearing trees and shrubs (Natural Order Cupuliferae), its best-known representatives being the Common Hazel of our woods and hedgerows, and the Filberts and Cobnuts of gardens. The different kinds are found in Europe, Asia and North America. As a rule, they are large bushes up to 20 feet high, but certain Eastern European, Himalayan and Chinese sorts form moderate-sized trees with trunks 12 to 15 inches in diameter. The timber of such trees is useful for cabinet work, etc., whilst coppice grown plants of Common Hazel produce good stakes which are used for crate and basket making, hurdles, etc. All thrive in loamy soil which may be either light or heavy, and the species are increased by seeds, the varieties by grafting, cuttings and layering. Bushes must be kept moderately thin for fruiting purposes, and Cobnuts and Filberts are often pruned on the spur system, the side shoots being cut back in winter. The Hazels are included in the catkin-bearing section of trees and shrubs, the tassel-like catkins of golden male flowers being conspicuous during late winter. The small red female flowers appear on the same bushes. A few kinds are grown for their ornamental 


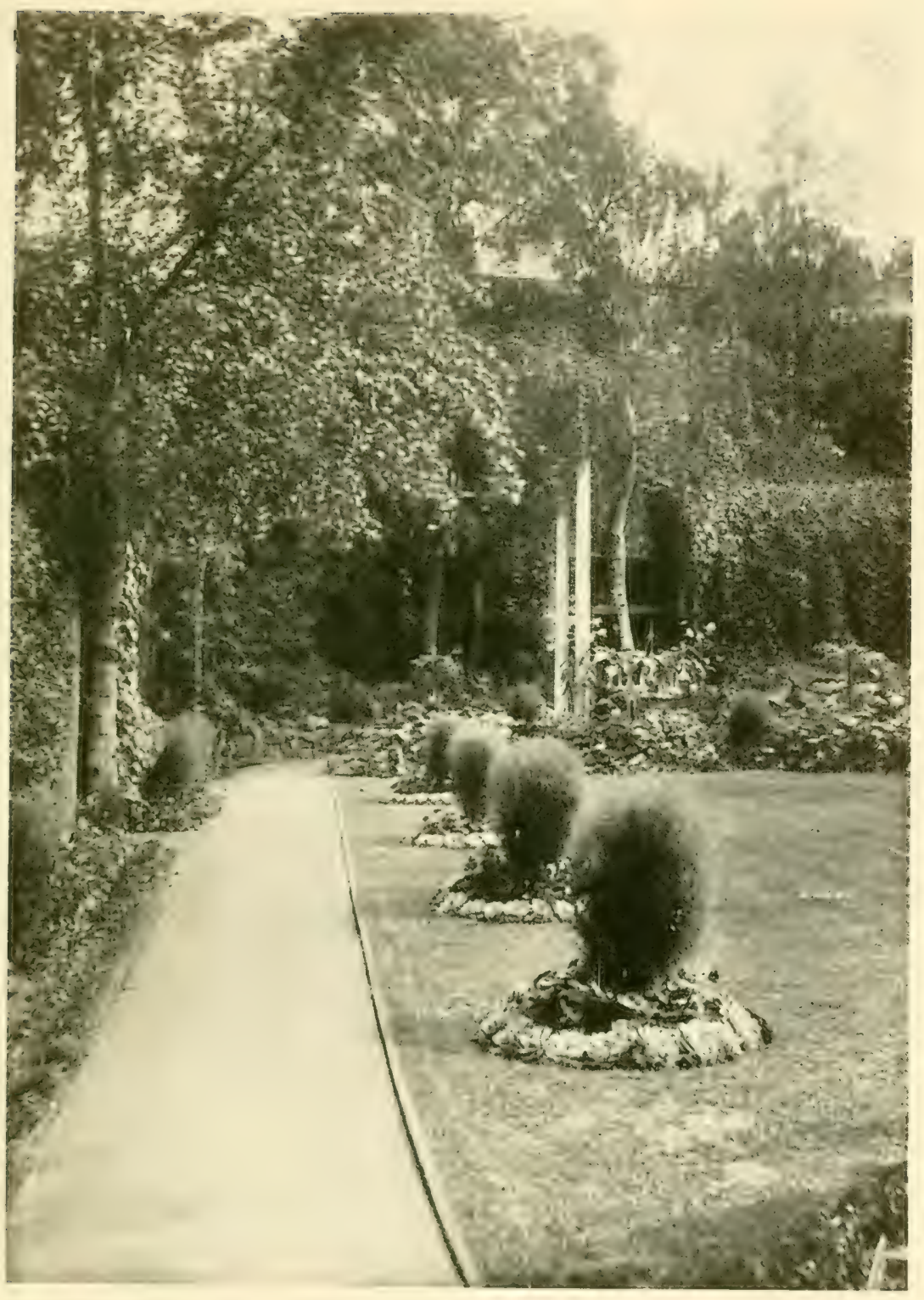

BEDS OF THE SUMMER CYPRESS (KOCHIA TRICHOPHYLLA) 

foliage. The best sorts are: Avellana, Common Hazel-the variety aurea has golden leaves, heterophylla finely cut leaves, and pendula has weeping branches; Colurna, the Constantinople Hazel, forms a tree 30 to 40 feet high, it is useful as a lawn specimen; Jacquemonti is a Himalayan tree, somewhat like the last-named; maxima, from South Europe, is best known by its purple-leaved var. atropurpureathe Barcelona nuts are considered to be derived from a form of this species; americana is a North American species, the leaves of which colour well in autumn. Good garden nuts are: Bergeri, a free-bearing cob; Kentish Cob, a good market variety; Webb's Prize Cob, very fine nuts; Prolific Filbert, a good-flavoured kind; Red Filbert, a handsome variety.

Cosmos.-Annuals with prettily divided leaves and single Dahlialike flowers, belonging to the Daisy family (Compositae). They reach a height of from 3 to 6 feet. The Cosmos have long been known in this country, and though popular in America have never been much grown here, owing to the fact that their blossoms open late and are liable to be spoilt by frost. Of late, however, by continual selection, an earlier flowering race has been obtained, and this has led to their being more generally cultivated. The flowers in the different varieties are of various shades of white, pink, rose, and crimson; they are extremely useful for cutting. Seed must be sown in warmth in February, and the young plants put in the open ground late in May. Moderately rich soil suits them best.

Cotoneaster (Rockspray).--An important group of evergreen or deciduous shrubs or small trees, natives of Europe, the Himalaya, China, and a few from other countries. They belong to the Rose family (Rosaceae). The majority are found in the Himalaya and China, those from the former region having been introduced about the middle of last century, whilst the greater number of the Chinese kinds have been brought to our gardens within the last fifteen years. Most kinds are perfectly hardy and are grown largely on account of their decorative fruits; a few are, however, showy when in flower, others are good evergreens, whilst the leaves of some of the deciduous kinds colour well in autumn. The large-growing sorts are excellent plants for shrubberies, specimen groups, or isolated plants, whilst those of dwarf or more or less scandent growth are useful for the rock garden, dry banks, or for planting against walls. Loamy soil, light rather than heavy, is most suitable, though they are not very particular in this respect. Propagation is by cuttings or seeds. Various kinds are sometimes grafted upon the Common Thorn, but the practice ought not to be encouraged. Pruning is confined to cutting 
back young plants in order to obtain a sturdy foundation, and others which may be outgrowing their positions. Regular pruning, however, is unnecessary.

The best of the older kinds are: acutifolia, an upright-growing kind from Mongolia, etc., with showy fruits ; bacillaris, one of the most vigorous Himalayan kinds, grows from I 8 to 25 feet high, spreads widely, and bears a profusion of small dark purple fruits; buxifolia is a vigorous evergreen bush, with small Box-like leaves, the white flowers are followed by showy red fruits ; Franchetii, native of Yunnan, grows 8 feet high and bears scarlet fruits; frigida sometimes grows from 30 to 35 feet high, with a very wide spread, it is native of the Himalaya, and bears large dense heads of cream-coloured flowers, which are followed by bright red fruits. Horizontalis is a very distinct Himalayan kind: as a bush it grows about 18 inches high, but against a wall it will attain a height of 12 feet, the scarlet fruits and autumnal leaf-colouring are alike attractive; microphylla is a dwarf kind, suitable for the rock garden, but it also thrive against a wall, sometimes attaining a height of 15 or I 8 feet, its tiny evergreen leaves, white flowers and red fruits are all ornamental-the var. glacialis is dwarfer than the type. Rotundifolia is a sub-evergreen Himalayan species, for the leaves are retained until early spring : it is, perhaps, the most useful of all, for its bright red fruits remain in good condition from October until March; Simonsii is an upright-growing Himalayan shrub with scarlet and yellow fruits.

The chief new kinds are: bullata, native of China, a deciduous bush with wrinkled ovate leaves, which bears large bunches of rich red fruits; divaricata, a handsome deciduous bush, 3 or 4 feet high, with something of the general appearance of horizontalis, though more vigorous; harroviana is a small red-fruited evergreen; henryana, 8 to ro feet high, forms a loose bush, bearing evergreen leaves and red fruits; salicifolia has long, narrow leaves and red fruits; there are several varicties of this, of which floccosa and rugosa are distinct.

Cotton Thistle.-(See ONOPORDON.)

Cotyledon.-The few hardy Cotyledons (Natural Order Crassulaceac) are of little value from an ornamental point of view, but there are now included different succulent plants so much used for summer bedding, and commonly known as Echeveria. This name is too firmly fixed to be easily eliminated, but all botanists concur in regarding them as Cotyledon. The different kinds are used in various ways, the dwarf ones, and especially secunda glauca, being generally employed as an edging to beds. In carpet bedding this plant often furnishes the required dividing lines, one great advantage being that 
it does not outgrow the height required. The larger growing kinds, of which metallica may be taken as an example, are often used as "dot" plants among low plants in formal bedding, while in beds of succulents arranged out-of-doors during summer the metallic tone of foliage imparts pleasing variety. The Cotyledons or Echeverias are readily increased by seeds, when they can be obtained; they are sown in spring in warmth, the seedlings being pricked off when large enough to handle. The popular variety secunda glauca is, however, so prolific in suckers or side growths that it can be propagated to almost any extent in that way. The plants are lifted in autumn before frost has injured them, and the side shoots are pulled off and dibbled in boxes of light sandy soil. If wintered on a greenhouse shelf they will form good plants by the time the bedding-out season comes round. The older plants may be wintered in the same way or potted singly: Failing seed of the larger kinds, such as metallica, they may be propagated by pulling off in autumn any leaves that can be spared from the lower portion of the stem, inserting them as cuttings in light sandy soil, and keeping them on a greenhouse shelf, giving little water. Cotyledons must be wintered in a structure from which frost is excluded, and very little water is required. Any attempts to winter them in a cold frame and protect from frost by heavy coverings generally end in failure, owing to an excess of moisture, which proves harmful.

Crambe (Sea Kalc).- One member of this group, which belongs to the Wallflower family (Cruciferae), namely Crambe maritima (Sea Kale), is of considerable value from an economic standpoint, being a choice and much-appreciated vegetable. As far as ornamental qualities are concerned it is, however, greatly surpassed by cordifolia, a native of the Caucasian district. This is a stately and noble plant, with large heart-shaped leaves that require ample room for their development. The loose flower-heads, which are often 6 feet in height, and nearly as much through, are composed of myriads of small white flowers, which at a little distance may be likened to a giant specimen of Gypsophila; it blooms during June and July. Like the Sea Kale itself, this Crambe may be readily increased by root cuttings taken in winter, pieces of root 4 to 5 inches long being planted in open, sandy soil ; they should be placed in an upright position, and covered with about 3 inches of soil.

\section{Crane's Bill.-(See Geranium.)}

Crataego-Mespilus is a group composed of two kinds of tree belonging to the Rose family (Rosaceae). These trees are of more than ordinary interest, for they originated as graft hybrids after a 
Mespilus or Medlar had been grafted upon a stock of Common Crataegus or White Thorn. Shoots were produced which eventually bore leaves, flowers, and fruits of three distinct kinds, some exactly like those of the Medlar, some similar to those of the White Thorn, and others intermediate between the two. These kinds lave been perpetuated by grafting, and are good decorative trees; they are named Dardari and Asnieresii. Both bear white flowers and require treatment similar to the Thorns.

Crataegus (Thom).--This is a showy and important group of trees and shrubs belonging to the Rose family (Rosaceae), natives of Europe, Asia, and North America, chiefly of the last-named country. The best known is the Common Whitethorn of our commons and hedgerows, while there are others with double scarlet and white flowers which are conspicuous throughout the country in spring and by their showy fruits in autumn. Many hundreds of species have been described, but some are much better than others for ornamental planting. There are few parts of the country where the Thorns may not be planted, for they are generally hardy, and thrive in a great variety of soils, loam being the best. When young, it is desirable to keep the side branches shortened and thimned out, in order that strength may be transmitted to the leading shoots and so encourage height growth. Pruning in later life is confined to thinning the branches, and this may be done after the flowers have fallen. Propagation of the species is by seeds, and of the varieties by grafting or budding upon stocks of the type. Seeds often take from two to three years to vegetate after being sown, and to economise space they are often stored for one year in a heap of sand. The Whitethorn or Quick is one of the best of all hedge plants, especially for loamy or heavy land, and there is no better fence than a well-kept hedge of Quick for farm land. Of dense habit, with spiny branches, it stands clipping well, and if kept free from coarse weeds and clipped regularly, such a hedge remains in good condition for a very long period.

The chief species and varieties are: Azarolus, a native of the Orient, bears white flowers in May, which are followed by large, fleshy, sweet fruits which ripen in September; Carrièrei, a hybrid which blooms in late Nay, the orange-scarlet fruits ripen in September and remain until Christmas; coccinea, the Scarlet Haw of the United States, is one of the most beautiful Thorns, the white flowers of May are followed by large bunches of rich red fruits in September, the leaves turning to golden shades before they fall; cordata, the Washington Thorn, forms a good-sized tree, which bears large quantities of small scarlet Ilaws. Crus-galli is the Cockspur or Newcastle Thorn (the former 
name was originally adopted by reason of the long, straight spines which arm the branches), flowers and fruits are showy-the varieties ovalifolia and splendens are specially worthy of note; macracantha, of the United States, bears very beautiful red fruits; mollis is much like coccinea, except that it has hairy leaves.

Crataegus Oxyacantha, the Common Hawthorn or Whitethorn, is made up of two subspecies, monogyna and oxyacanthoides: there are many varieties of both, but those with double flowers are most approved : flore pleno albo, with white flowers; flore pleno coccineo, scarlet; flore pleno puniceo, red; and flore pleno rosea, rose, are the best of the doubles. Other useful varieties are : aurea, pendula, macrocarpa, praecox (the Glastonbury Thorn), and stricta.

Crataegus prunifolia is showy alike for fruits and autumn foliage, while orientalis and punctata are worth growing. Crataegus Pyracantha is referred to under the latter name.

Crinum. - Nearly all the Crinums (Natural Order Amaryllidaceae) require a warm greenhouse. The hardiest is longifolium, a native of the Cape of Good Hope; this has a clubshaped bulb, which passes the winter in a dormant state-the leaves produced in spring are strap-shaped and over 3 feet long. In summer the flower spike

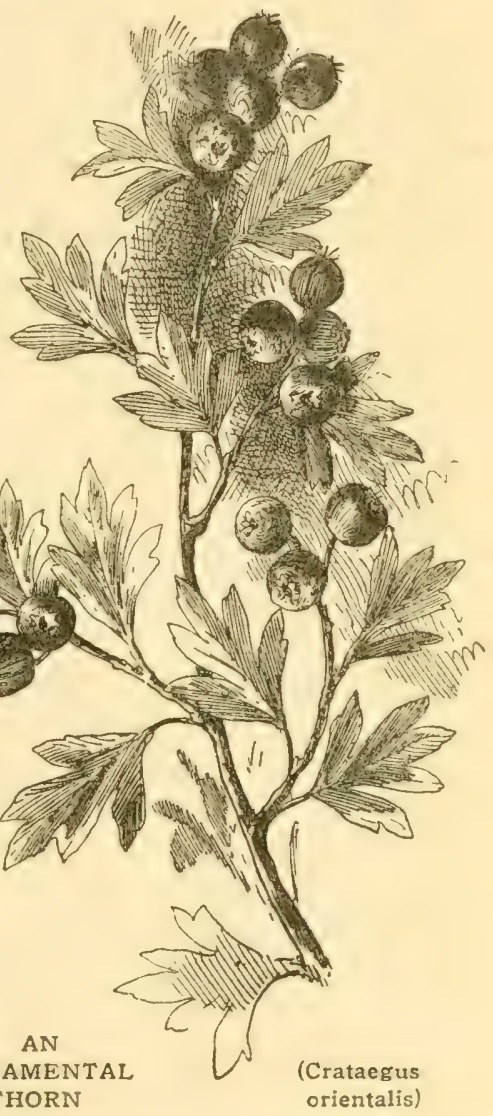
reaches a height of 3 to 4 feet, bearing a terminal umbel of six to eight funnel-shaped flowers about 6 inches in length, white, flushed on the exterior with pink. Another species, Crinum Moorei, is fairly hardy in a sheltered spot, but not so reliable as longifolium. The bulb of Crinum Nioorei is more globose than that of the other, while the flowers are larger and more widely expanded. They are white at first, afterwards becoming slightly suffused with blush. Between 
these two species a hybrid has been raised, which is without doubt the finest hardy Crinum we have. This is Crinum Powellii, altogether a more vigorous plant than either of its parents. Full-grown bulbs are nearly as long and stout as a man's leg, and fully-developed leaves are about 6 feet in length; the sturdy flower spike, which develops from the side of the bulb, bears an umbel of broadly funnel-shaped flowers. In the typical kind they are of some shade of deep pink or rose, but there is a variety with pure white blossoms which is really charming. The flowers are, as a rule, at their best in July and August. In planting Crinums a certain amount of care is needed. It is not sufficient just to stick the bulb in the ground, but sound preparation is necessary. In the case of large bulbs of Powellii the ground must be taken out to a depth of at least 4 feet, for the bulb must be nearly buried. Good drainage is essential, and the compost should consist of turfy soil, well-decayed manure, and sand, some of the latter being placed under and around the bulb. Crinums need a warm, sumny spot, such as in the angle formed by two walls, as the leaves, which are somewhat brittle, are thus protected from rough winds.

Crocosmia aurea.-A pretty little bulbous plant of the Iris family (Iridaceae), native of South Africa, that produces several swordshaped leaves which are overtopped by a 2 -feet high stem, bearing a spike of orange-red flowers in July. It is not quite hardy, and needs to be planted about 6 inches deep in a warm, well-drained border in early spring. Apart from its own intrinsic merit, the Crocosmia is of especial interest from the fact that, crossed with Montbretia Pottsii, it gave rise to the present-day race of Mont. bretias, which form such a striking feature of our gardens during the late summer.

Crocus. - The genus Crocus (Natural Order Iridaceae) is an extensive one, most of the species being natives of the Mediterranean region extending into Asia Minor. Although the Crocus is prominent among spring flowers, very few of the species or wild kinds are grown to any great extent. The garden varieties, corms (roots) of which are annually sent to this country from Holland in large quantities, are varieties of Crocus vernus, native of Southern Europe. While the Dutch varieties flower at much the same time, by growing some of the species one may have a succession of bloom over a long period. Crocuses, especially the early flowering ones, should be planted in July and August; the flowers are not nearly so fine if the roots are kept out of the ground too long. Crocuses thrive best in sandy loam, but the popular varieties are not fastidious; they are frequently grown in grass, and in this 


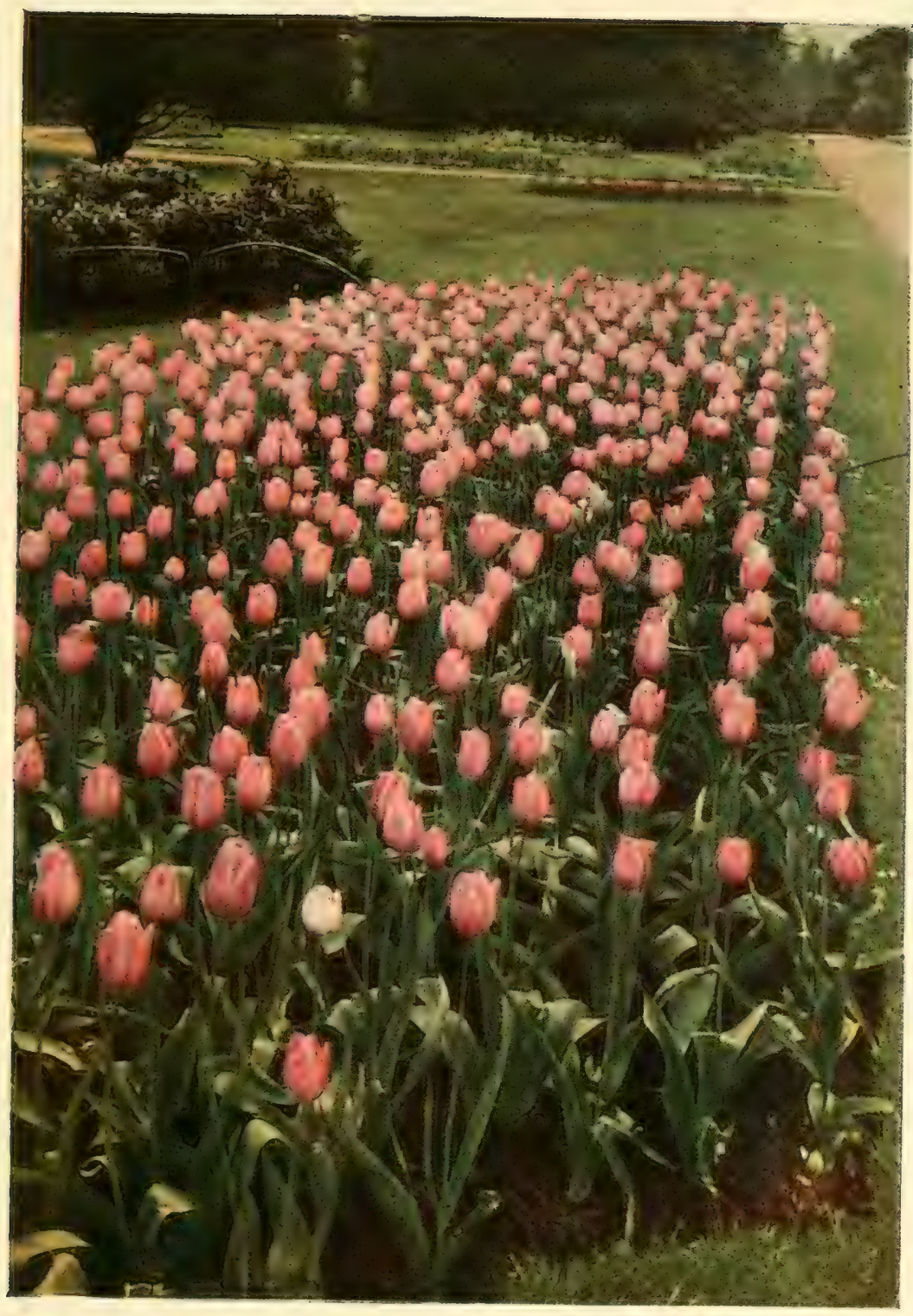

A BED OF TULIP INGLESCOMBE PINK 

way make a charming show. The yellow-flowered varieties are the showiest of all for this purpose. A suitable tool for planting bulbs in turf may be obtained, and by its use a large number can be planted in a short time. For purposes such as this those classed according to colour may be used, but if choicer kinds are desired the following can be recommended: Albion, blue and white striped; Caesar, purple; Celestial, blue; Golden Yellow; Kathleen Parlow, white; Kring of the Blues, rich purple-blue; Maximilian, blue, shaded pink; MIont Blanc, white; Pallas, finely striped blue and white; Prince Albert, dark blue; Purpurea grandiflora, deep purple; and Sir Walter Scott, white, striped lilac.

Of the species the following are autumn flowering: asturicus, ranging in colour from pale mauve to purple-lilac, with darker stripes at the base; Fleischerii, white, purple base; hadriaticus, white, purple base ; iridiflorus, deep lilac; longiflorus, lilac ; medius, white, veined inside; pulchellus, lavender-blue; Salzmannii, blue; sativus, violet, feathered purple; speciosus, blue, the finest of all the autumn kinds; and Tournefortii, rose lilac.

A few kinds bloom in winter, but are, as a rule, not seen at their best out-of-doors at that season unless the flowers are protected. Chief among them are: chrysanthus, flowers more or less golden; Imperati, bluish-white, purple stripes, yellow throat; Korolkowii, yellow, dark outside; Sieberii, pale violet; suaveolens, lilac inside, dark striped outside ; and tommasinianus, lavender and white. They are charming for pots in a cold greenhouse.

The spring-flowering species are numerous, a good selection teing : alatavicus, white, veined black outside; ancyrensis, orange-yellow; aureus, deep orange; biflorus, white, striped purple; lunatus, white, striped violet ; luteus, golden-yellow ; stellaris, orange, feathered purplish-brown; and versicolor, white, richly striped purple, ycllow throat.

Crosswort.-(See Crucianella.)

Crowfoot.-(See Ranunculus.)

Crown Imperial.-(See Fritillaria.)

Crucianella (Crosswort).-Chiefly low-growing herbaceous perennials belonging to the same family as Bouvardia (Rubiaceae). Crucianella stylosa is chiefly grown; this is a good trailing plant, suitable for sunny parts of the rock garden, and produces its pretty, bright pink flower-heads from spring until autumn. Others are: angustifolia, white; glauca, with yellow flowers; maritima, cream-coloured; and suaveolens, yellow. They are all easily grown in ordinary welldrained soil, and may be increased by division in autumn or by seeds in spring. 
most parts of the country, exeept in or near smoky towns. Where are many varicties, of which aurea, lutea, and gracilis aurea, with golden leaves; glauca and Silver Queen, with silvery foliage; and gracilis pendula, intertexta, and filiformis, of pendent habit, should be grown.

Cupressus nootkatensis is another useful tree from Oregon and British Columbia; it can be distinguished from the Lawson Cypress by its spiny cones and strong resinous smell; obtusa (Retinospora obtusa) is a distinct Japanese kind - the vars. aurea, compacta, gracilis aurea, and lycopodioides are worthy of note; pisifera (Retinospora pisifera), also a Japanese tree, is another showy kind the varieties plumosa aurea, aresentea, flavescens, and squarrosa sulphurea are amongst the most ornamental of the small bushy Conifers.

Cuscuta (Dodder).--The Cuscutas (Natural Order Convolvulaceae) are singular climbing plants, remarkable from the fact that they are quite leafless, and consist only of thread-like stems. They are also of a parasitic nature, and the slender stems attach themselves to the host plant by a number of little vesicles, by means of which the parasite derives its nourishment from the plant which supports it. Two kinds are native of this country, namely, the greater and the lesser Dodder, the last being the more common; it may often be found growing on the Heath, Thyme, and Furze, while to some field crops -notably Vetches - it is very injurious. Pelargoniums bedded out during summer are sometimes attacked by it ; indeed, the Pelargonium seems to be a good host plant for all the Dodders. An Indian sort, reflexa, may sometimes be seen growing on a Pelargonium in a greenhouse. The flowers of the Dodders are small and bell-shaped, and in some cases fragrant. Seeds may be sown in proximity to the host plant, to which the young twining stems will soon attach themselves. One point, however, to remember is that the Dodders, owing to their parasitic nature, are dangerous plants to introduce into the garden.

Cyananthus.-A group consisting of two species of pretty, freeflowering, procumbent plants, bearing a consiclerable resemblance to a Campanula. They belong to the Bellflower family (Campanulaceae). Both are natives of the Himalaya, and repuire a cool, moist situation in the rock garden, among the stones of which the roots can find ample supplies of moisture. A partially sladed spot and sandy peat soil are essential. They are increased by division, carried out in spring before they start into growth, but they should be chisturbed as little as possible. The best known is Cyananthus lobatus, having purple-blue funnel-shaped flowers, with fine spreading segments. 
Cyananthus incanus is a much rarer plant, similar, but with soft azure-blue flowers; they bloom in August.

Cyclamen (Sowbread).-Everyone knows the Persian Cyclamen (persicum), a popular greenhouse flower, but the hardy kinds are not so generally appreciated. The Cyclamen belongs to the Primrose family (Primulaceae), and the hardy kinds are natives of the Mediterranean region. Though consisting of less than a dozen recognised species, there is enough variety among them to satisfy the most fastidious. Their flowering period is chiefly in spring and autumn; they grow well in the shade of trees, and are admirably adapted for the rock garden. A fairly light, leafy soil, containing pieces of sandstone, suits them provided the situation is well drained. Above all, care must be taken that they are not fully exposed to the sun. The chief kinds are: africanum, a native of the calcareous mountains of Algeria, and a near relative of neapolitanum--the large, prettily marbled leaves are a distinguishing feature, in vigorous plants they measure from 6 to 7 inches in diameter; the flowers, which open in September and October, are reddish, with a bright purple spot at the base of the segments. In planting the corm must be entirely covered, as this species roots over its entire surface, unlike some of the others, that root only from their base. Cyclamen cilicicum is a pretty little kind, more delicate than some of the others, and is particularly suitable for a sheltered spot on the rock garden; the flowers are whitish with red centre, and appear in early spring.

Cyclamen Coum is a delightful little plant, and one of the most popular as well as most distinct. The corms (roots) are small and regular in shape, while the small, roundish, dark-green leaves are evergreen, or nearly so; at all events, they are in good condition when the rose-red flowers are open, from January to April. There are varieties with blossoms in shades of pink, and an especially charming one has pure white blooms:

Cyclamen europaeum is more particular in its cultural requirements than some; it seems to prefer leafy, sandy soil in a shaded position. The corms, which emit roots from the undersides only, should not be quite covered, otherwise they are apt to decay; the bright rosecoloured flowers are sweetly scented, and are borne in September and October. The leaves are often prettily marbled.

Cyclamen ibericum, sometimes known as vernum, flowers usually in February and March. It is somewhat similar to Coum, but the corms are larger, while the leaves are somewhat marbled. The pretty little kind grown in gardens as Atkinsii is regarded by botanists as a variety of ibericum: 


\section{I3S THE BOOK OF HARDY FLOWERS}

Cyclamen neapolitanum bears a considerable resemblance to africanum, but it is hardier; the leaves, too, are especially variable in shape, the flowers being chiefly reddish, though individuals vary, for some are almost white.

Cyclamen repandum: Though this is the correct name, the species in question is more generally met with under the specific name of hederaefolium. It is a charming plant, the leaves, which are marbled on the upper surface and tinged with purple underneath, opening with the flowers, which are of deep reddish coluur, and at their best during spring.

Cynara (Atichoke).--As the two kinds in this group are both classed as vegetables, their ornamental qualities are rarely taken into consideration. They belong to the Daisy family (Compositae), and are natives of Southern Europe. Cynara Cardunculus is the Cardoon, and Scolymus the Globe Artichole. Both are tall, Thistle-like plants with handsome leaves, and large bold heads of purple flowers. They can be propagated either from seeds sown in spring or by suckers from the old roots. When grown solely for their ornamental qualities, which are very evident when the plants are seen towards the back of the herbaceous border, they must be planted in rich, well-drained soil; stagnant moisture cluring the winter months is injurious to them.

Cynoglossum (Hound's Tongue).-The members of this genus are for the most part coarse-growing, Borage-like plants of a biennial or perennial nature. They belong to the Borage family (Boraginaceac). Ordinary garden soil is suitable. They can be readily increased, the biennial kinds by seeds and the perennial ones by division before growth takes place in spring. A selection of the best includes: amabile, blue, June and July, height I2 inches; apenninum, rich blue, 2 feet, July and August ; flircatum, blue, I2 inches, summer; and officinale, reddish, 2 feet, June.

Cypella.--Iris-like plants (Natural Order Iridaceae), natives of South America. They are not quite hardy in the open ground, but will thrive in a narrow border at the foot of a sunny wall. Some grow them successfully by lifting the roots in the autumn, wintering them safe from frost, and replanting out-of-doors in spring. The species are Herbertii, flowers varying from light yellow to a deep chrome tint; peruviana, bright yellow, spotted with reddish-brown; and plumbea, with lead-coloured flowers tinged with yellow in the centre. The last-named, which is also known as Pohlia platensis, flowers in autumn, the two others in summer.

Cyperus. - An extensive group of (rrass- or Sedge-like plants (Natural Order Cyperaceac), most of which are natives of tropical 
regions and are therefore unsuited for outdoor cultivation in this country. One, however, Cyperus longus, native of Europe and North Africa (occasionally occurring in Great Britain), is attractive when planted on the margin of water. It reaches a height of about 3 feet, and the long, narrow leaves are very graceful. It is readily increased by division, carried out in winter or early spring, and is not particular as to soil provided the situation is a swampy one.

Cypripedium (Lady's Slipper). - Most of the Cypripediums (Natural Order Orchidaceae) are evergreen, and need the shelter of a warm greenhouse. However, some are perfectly hardy, all of them being deciduous. In their cultural requirements they differ considerably, so that no general instructions will apply. Nost of them will thrive in a mixture of peat, leaf-mould, and sand. Others (our own native Cypripedium Calceolus, for instance) prefer loam soil containing lime. Generally speaking, all the hardy Cypripediums do best in a partially shaded spot where the soil is fairly moist and at the same time not waterlogged.

Cypripedium acaule, also known as humile, produces from each crown two broad hairy leaves, and on an upright spike bears an abnormally large flower, as much as 3 inches across the segments. The pouch, fully 2 inches deep, is of rosy-purple colour, and split right down the front so as to present the appearance of two lobes. This kind grows readily in loam and sand, with the addition of a little peat or leaf-mould. Cypripedium Calceolus is a free-growing kind that reaches a height of about 2 feet. Generally two flowers are borne on a spike, their colour being yellow and brown; the lip is yellow. Cypripedium californicum has leaves similar to those of Calceolus, but the erect flower spike bears sometimes as many as ten flowers. They are small and distinct, the pouch being white tinged with pink, while the rest of the flower is yellowish. This needs a peaty soil with a mixture of loam. Cypripedium macranthum is an exceedingly handsome species, bearing large rosy-purple flowers on stems about I2 inches high. It is often grown in association with Calceolus, and needs the same soil and treatment. Cypripedium montanum produces flower stems about I2 inches high, bearing several flowers with twisted sepals of a purplish tint; the pouch is whitish. Like the preceding, this may be treated as recommended for Calceolus.

Cypripedium pubescens is one of the larger kinds, of which the flower stems reach 2 feet high and overtop the large hairy leaves. The petals and sepals, which are drooping and much twisted, are brown, tinged with yellow; the pouch is yellow. This will thrive in moist, peaty soil. Cypripedium spectabile (also known as regale), 
popularly termed the Moccasin Flower, is undoubtedly the finest of all the harly Cypripediums. It will reach a height of 2 to 3 feet, and bears two or three flowers on each stem; they are white, with the exception of the lip, which is tinged more or less with rose. The Moccasin Flower likes well-chained yet moist, peaty soil. A wellestablished clump forms a very striking feiture in a moist, sheltered spot in the rock garden. The various Cypripediums mentioned flower as a rule in May or June; most of them are natives of North America, though macranthum comes from Siberia.

Cyrilla racemiflora (Leatherwood).--This shrub (Natural Order Cyrillaceae) is a native of the Southern United States, where it is known as Leatherwood. Forming a small bush 2 or 3 feet high, it bears racemes of small white flowers during August. Plant in the southern counties, in light loamy soil containing a little leaf-mould or peat, and propagate from cuttings or seeds. I,imit pruning to the removal of the points of the shoots in spring.

Cystopteris (Bladder Ferm).-A small group of Ferns (Natural Order Filices) with delicately cut fronds and of refined appearance. Of the four kinds in cultivation three are natives of this country, but not of this country alone, while one, Cystopteris bulbifera, comes from North America. The Bladder Ferns are well suited for planting in moist, shady portions of the rock garden close to the eye, so that their fronds can be closely inspected. A soil of loam, peat, leaf-mould, broken mortar, and pieces of limestone suits them. They are deciduous; the leaves dic off early in autumn, and are late starting into growth in the spring. The species are: alpina, fronds from + to 8 inches long and 2 incheswide - it is rare in Britain but common on many of the mountains of Europe; the second, bulbifera, more vigorous, is native of a considerable portion of North America-the bulbils towards the ends of the fronds are a distinguishing feature. Of quite a cosmopolitan character is fragilis, for it occurs in nearly all the temperate regions of the globe; there are many garden forms of this. Cystopteris montana, the most beautiful of all, netels particular care; it requires a moist, shady spot and a compost male up of stones, fibrous peat, and sand.

Cytisus (Broom).- This is an important genus of the I'ea family (Leguminosae), comprising a considerable number of hardy shrubs and a few which are too tender for general outdoor cultivation in the British Isles. The majority are natives of Europe, and one species, scoparius, is wild in the British Isles. The last-named is known als the Common Broom, and the term Broom is generally applied to them all. They thrive in ordinary garden soil, but prefer that of a light loamy nature. 


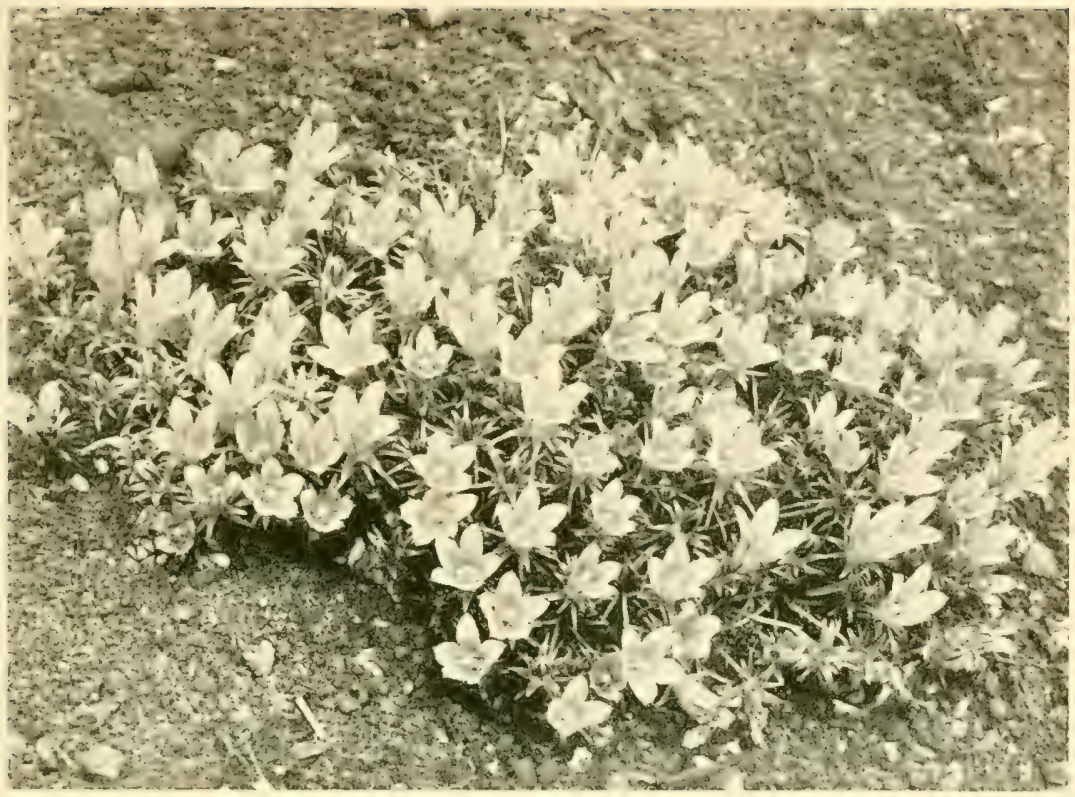

ON THE MORAINE (EDRAIANTHUS PUMILIO)

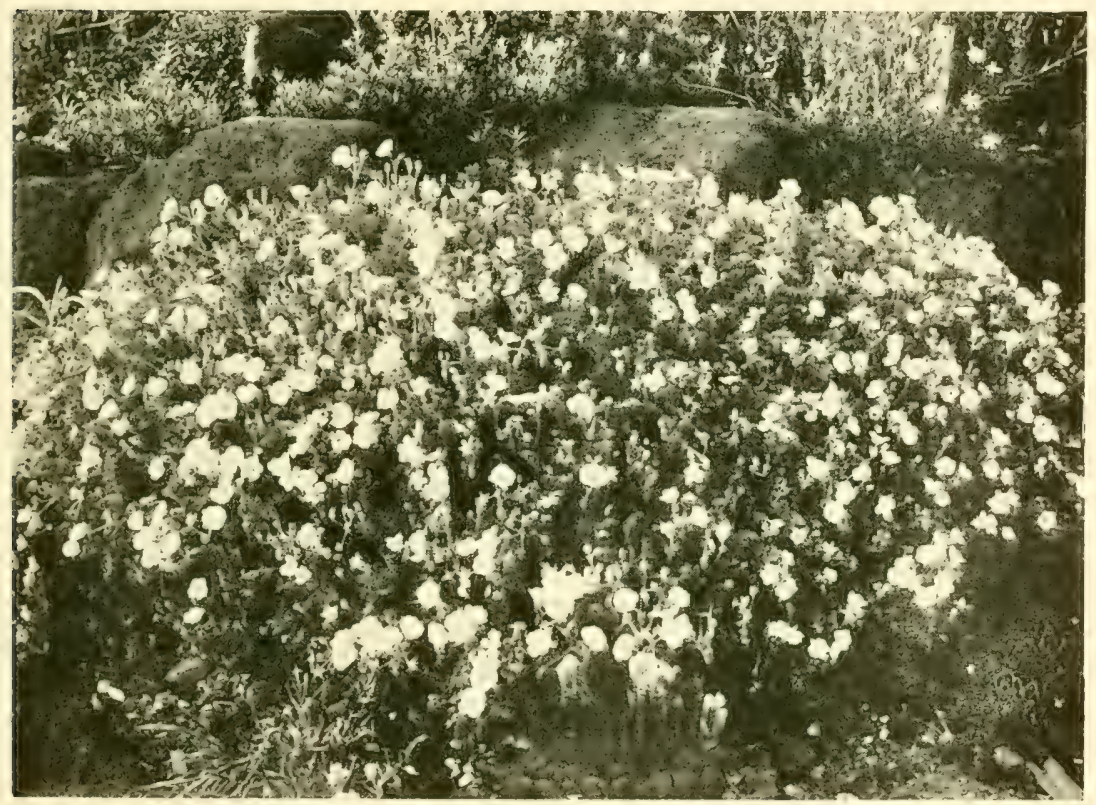

HERON'S BILL (ERODIUM TRICHOMANAEFOLIUM) 

Some kinds, howerer, are wonderfully successful in poor, gravelly soil on sunny banks. Propagation is effected by several means; the species are usually raised from seeds, whilst the hybrids and varieties are increased by cuttings or by grafting upon stocks of Laburnum. The latter is perhaps the better means, providing fairly hard shoots are used as scions. Plants must be placed in permanent quarters whilst (quite small, as large ones transplant badly. In fact, it is a good plan to place them straight out from pots. The tops of young plants should be cut back occasionally to induce a bushy habit. Pruning in after life consists of shortening the previous year's shoots after flowering. On no account cut plants back into older wood, for young shoots will not appear from old branches. One kind, purpureus, needs different pruning; the branches may be cut away each year after flowering; new ones will then be formed from the base. The Brooms do not remain at their best for more than six or eight years.

The following form a selection of species and varicties: albus, White Spanish Broom, native of Spain and Portugal, white, May; Ardoini, a prostrate, golden-flowered plant from the Maritime Alps, suitable for the rockery; Beanii is a beautiful golden-flowered hybrid of low growth, it is a good rockery plant; biflorus, from Eastern Europe, blooms in April ; Dallimorei is a new, tall-growing hybrid with showy, rosy purple flowers; Kewensis, a dwarf kind with cream flowers, is suitable for the rock garden; nigricans flowers in July from the young wood, it may be pruned in spring; praecox is a free-growing and freeflowering hybrid with cream-coloured flowers, it grows 4 to 5 feet high, and is a good shrubbery plant; purpureus is an Eastern European plant, I2 to 8 inches high, it bears purplish flowers in May ; scoparius, the Common Broom, is handsome either in a state of nature or in the garden, its var. Andreanus has bronze and golden flowers, whilst sulphurcus, sometimes called the Moonlight Broom, has sulphurcoloured blossoms.

Daboëcia polifolia (Irish Hcath).-This plant is closely allied to the Heaths (Natural Order Ericaceae), and is sometimes called St. Dabeoc's Heath. It is native of South-West Europe, and also occurs wild in Ireland. It grows from 6 to 15 inches high, and requires similar treatment to the true Heaths. Light soil is the most suitable, but it must be free from lime. Pruning takes the form of removing the flower heads and an inch or so of each branch after the blossoms are over. The red, white, or purplish flowers are urn-shaped and borne in crect racemes. Flowering commences in June and is continued throughout summer until a glorious burst of blossom, lasting from the middle of August until towards the end of September, brings 
the sea:on to an end. The var. alba has white flowers, and bicolor bears red and white flowers on the same stalk.

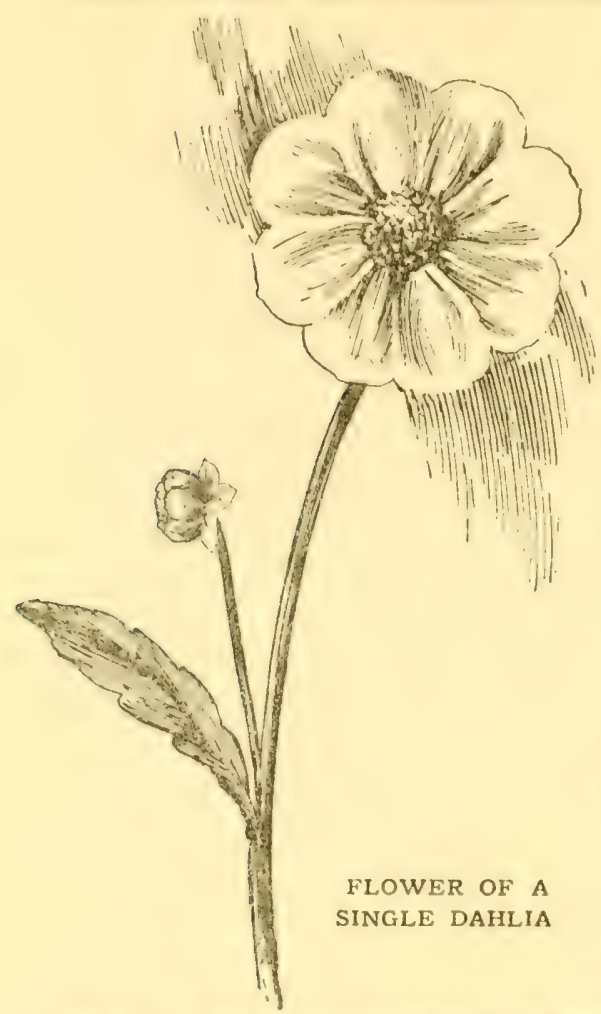

Dacrydium.-This is a small group of Conifers (Natural Order Coniferae), the four introduced kinds being natives of New Caledonia, New Zealand, Malaya, and Tasmania respectively. All are tender, and the hardier ones can only be grown out-of-doors in a few gardens in the British Isles. They are therefore of little general interest. Dacrydium cupressinum and Franklini are the hardiest kinds. Plant in well-drained soil composed of loam and peat or loam and leaf-mould.

Dactylis (Cock's-foot Grass).Hardy Grasses (Natural Order Gramineae), a few of which are grown in gardens. Dactylis glomerata is a common grass in Europe, including Britain; it grows about 2 feet high, and is of no garden value, but there is an attractive variety with green and silvery striped leaves which is grown for use in summer bedding, generally as an edging to large beds or borders, though sometimes planted as a groundwork for tall Fuchsias, Heliotropes, etc., or as "dot" plants in low bels. The variegated Cock's-foot Grass (glomerata var variegata) is a hardy perennial, readily propagated by division of the roots in October; it may be planted in autumn or spring, and thrives freely in ordinary soil.

\section{Daffodil.-(See Narcissus.)}

Dahlia.-... Nost if not all the beautiful Dahlias (Natural Order Compositae) now in cultivation are thought to have been obtained from Dahlia coccinea and Dahlia variabilis, two tuberous-rooted, halfhardy perennials, natives of Mexico. They are propagated from seeds, cuttings, and division of the tuberous roots. Sow the séeds in a heated greenhnuse during lebruary and March, pot of the seedlings singly when large enough, and grow in a greenhouse or frame until the end of May, when it is safe to plant out-of-doors. Single Dahlias come fairly 
true from seeds, but in the case of the Show and Cactus section only a few with good full-double flowers can be hoped for. Florists who specialise in Dahlias raise hundreds of seedlings every year, but very few are retained as worthy to be named and distributed. The favourite method of increasing Dahlias is by cuttings. Early in February bring out the roots from their winter quarters, place them in a warm greenhouse in boxes containing leaf-mould, but do not cover the tubers. Syringe morning and evening on bright days, then young shoots will soon commence to push out. When these are about 2 inches long, remove them with a small portion of the old tuber attached, and insert in pots of sandy soil in a closed frame. When rooted, pot off singly and grow as advised for the seedlings. Increase by division of the tubers is best done when growth has started, so that when pulling the roots apart shoots are left on each portion For this purpose the tubers should be started in a greenhouse or frame in March and early April. When increase of stock is not required the roots may be taken straight from the store and planted outside at the end of April. By this method one obtains large bushy plants and lots of flowers, but the latter are not so fine as those on plants grown from cuttings:

Dahlias delight in -rich, deeply dug soil. In beds and borders the plants flower freely from July until October or even later when the weather is mild. Owners of small gardens complain that Dahlias make too much growth, but there are now numbers of varieties 3 to 4 feet in height, compact and free-flowering. One essential in Dahlia cultivation is to grow the plants in open sunny positions. Thinning the shoots is necessary at intervals throughout the season, beginning when the young shoots are a few inches high; these must be restricted to three or four. Secure each plant to a good stake and water liberally during dry weather, giving also liquid manure occasionally. It is necessary to remove the old flowers as they fade, otherwise (especially in the case of the single sorts) the production of seed pods restricts the supply of

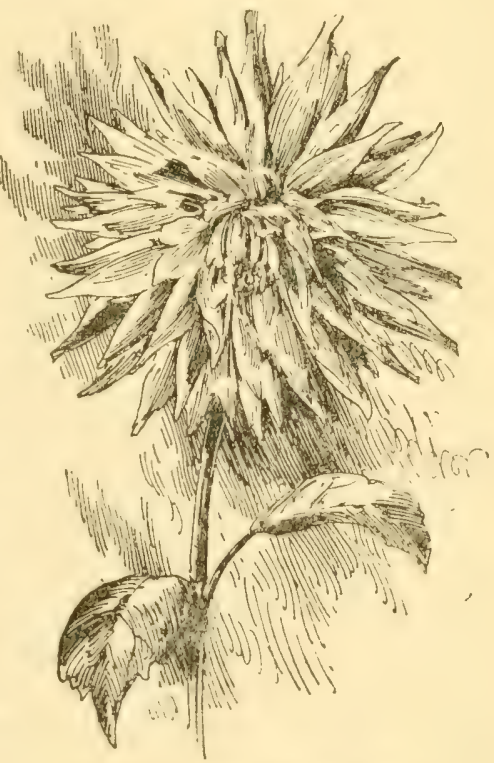

CACTUS DAHLIA BLOOM 
bloom. In late autumn or early winter, when frost kills the flowers and leaves, cut down the stems to within about IS inches of the sround, lift the roots carefully, and store in a frost-proof shed or cellar, covering, if thought necessary, with dry litter.

Dahlias grow from about 2 to 7 feet high; the Paeony-flowered variety King Leopold sometimes reaches 9 feet in height. They are divided into groups or sections, according, generally, to the shape and size of the flowers. The Cactus type is one of the most popular, and is largely grown. The correct flowers are star-shaped, with numerous rolled or twisted petals radiating symmetrically from the centre. For garden decoration there are varieties known as Decorative Cactus Dahlias, in which the petals are more or less flat, or perhaps only twisted at the tips. The Show Dahlia has large, double, symmetrically formed blooms closely packed with petals of one colour. These are the oldest of the exhibition Dahlias, and still find chief favour in cottage gardens. The Fancy Dahlia is similar in build, but the flowers may comprise two or more colours. The Single Dahlias are very freeblooming, and are invaluable for indoor decoration. The quaint little flowers of the Pompon Dahlia, borne frecly on stiff, erect stems, find many admirers.

More recently the Pacony-flowered Dahlias, the first varieties of which came from Holland, have increased rapidly in popular favour. The big loose blooms on long stalks are freely produced, and make a brave show in the border, but the plants are too tall and branching for small gardens. The Collarette Dahlias are the latest to claim special attention; they resemble the single varieties, but have a circular frill surrounding the yellow centre. The plants are of moderate rigour and free-flowering. Still another section has recently been added, namely, the Star or Cosmea-flowered Dahlias; these bloom freely and have single flowers. Two of the best are Crawley Star, rose; and White Star.

New and improved varieties of Dahlias are constantly appearing; a list of sorts given here would soon be out of date, consequently it will be more helpful to the grower if the list of a Dahlia cultivator is consulted.

\section{Daisy.-(See BELLIS PERENNIS.)}

Danaea Laurus (Alexandrian Laurel) is a (Wwarf shrubby plant belonging to the Lily family (Liliaceae). It is allied to the Butcher's Broom, but is a more elegant plant with foliage of a lighter and more cheerful shade of green. The flowers are small and of little account, but they are succeded by bright red berries. Cut branches are appreciated for house decoration in winter, either associated with 
other evergreens or used with flowers. It is a native of Asia Minor, grows about I 8 inches high, and thrives in loamy soil in semi-shade or in sunny places. Propagate by seeds or division of the clumps, and restrict pruning to the removal of the older shoots.

Daphne.-Fragrant flowered shrubs (Natural Order Thymelaceac) suitable for the front of the shrubbery or for the rock garden. A few, however, are not generally hardy, and must be given the protection of a cool greenhouse. Some require soil containing lime, but Blagayana and Cneorum thrive in sandy peat. They dislike hot, dry situations, and the best results are secured when the roots are in constantly moist, but not saturated, soil. Some kinds are increased by seeds, some by cuttings, and others by grafting; propagation other than by seed is, however, rather difficult. The following species and varieties are chiefly worth attention: Blagayana, a dwarf kind with cream-coloured flowers, from Carniola; it should be grown on the rockery and the branches must be constantly weighted down by stones. Cneorum is the Garland Flower of the Alps, the beautiful, fragrant, rose-coloured blossoms are very attractive: plant on the rockery; Laureola is an evergreen, British species, suitable for a shady spot; Mezereum, the Common Mezereon, is well known as a handsome February-flowering bush, the reddish-purple flowers are very fragrant: the vars. alba and grandiffora, too, should be grown. Odora is a tender evergreen plant from China and Japan ; its fragrant flowers are attractive during winter. In Cornwall it may be grown out-of-doors.

Daphniphyllum macropodum is a handsome evergreen bush from China and Japan, belonging to the Spurge family (Euphorbiaceae). It grows from 5 to 8 feet high and forms a wide-spreading shrub with glaucous green leaves with red stalks. The flowers are not conspicuous. Propagation is by seeds, and the plant thrives in loamy soil or in loam and peat. No pruning is necessary after the bushes have once formed a number of branches from near the ground. Jezoensis is a dwarf variety, and variegata has pretty, silver variegated leaves. Unfortunately the last-named is not hardy.

Darlingtonia (Californian Pitcher Plant). - This is one of the few Pitcher Plants (Natural Order Sarraceniaceae) that can be grown out-of-doors in this country. There is only one species, californica; it grows from I foot to 2 feet in height, and has greenish-yellow flowers marked with dark red-brown veins during April and May. The leaves or pitchers are more ornamental than the flowers; they are narrow at the base, and gradually increasing in width form at the top a kind of inflated hood; they are green, mottled with white, with prominent 


\section{I46 THE BOOK OF HARDY FLOWERS}

reddish-pink veins. Propagation is by division in March and by seeds sown in a cool greenhouse when ripe. Prepare a compost of sphagnum moss, peat, charcoal, and coarse sand, sow the seeds on this, stand the pot in a saucer of water, and cover with a bell-glass. Plant in a moist, shady position in the rockery, bog garden, or with hardy ferns in a mixture of peat, sphagnum moss, broken limestone, and coarse sand. It is sometimes found desirable to cover the plants in winter with a handlight.

Datura (Thorn Apple).-An interesting group of half-hardy annuals and greenhouse shrubs, belonging to the Potato family (Solanaceae), and natives of tropical America chicfly; the former are the more important for outdoor gardening, though in warm, sheltered gardens the greenhouse Daturas (Brugmansia) are often placed outside from June to September. The annual Thorn Apples are readily raised from seeds sown in a warm greenhouse during February and March. Pot the seedlings singly in small pots, subsequently transfer them to 5- or 6-inch pots, and plant in beds and borders out-of-doors in late May or early June. They like light, rich soil, made up of 2 parts sandy loam, I part leaf-mould, I part decayed manure, and I part coarse sand. The following are annuals, unless it is otherwise stated: ceratocaula, bears white, fragrant, trumpetshaped flowers, tinged with purple, in July and August, 3 feet high; cornucopia has double white flowers, shaded purple, in July to September, 2 to 3 feet; chlorantha flore pleno, with yellow, trumpet-shaped flowers in July and August, is a greenhouse perennial, but if sown early may be treated as an annual, 2 feet high upwards; Metel bears white, fragrant, trumpet-shaped blooms from June onwards, 2 feet. Stramonium (Common Thorn Apple) has white flowers in July and August, followed by thorny or spiny fruits: it is about 2 feet high, and is found wild in many parts of the world, including Britain.

Datura meteloides (Wrightii) produces large, fragrant, trumpetshaped flowers, white, tinged with purple; it is a Californian shrub and a splendid greenhouse plant, but if sown early it will grow about 3 feet in height the first year, and flower outside during August and September.

Davidia involucrata is a new tree belonging to the Dogwood family (Cornaceae). It is a native of China, and reports of its decorative character in a state of nature were such that Messrs. Veitch, of Chelsea, decided to send a collector to China, with the collection of seeds of this tree as one of the principal objects of his mission. One or two plants had been previously introduced to France, but it was through the initiative of Messrs. Veitch that the tree became available 


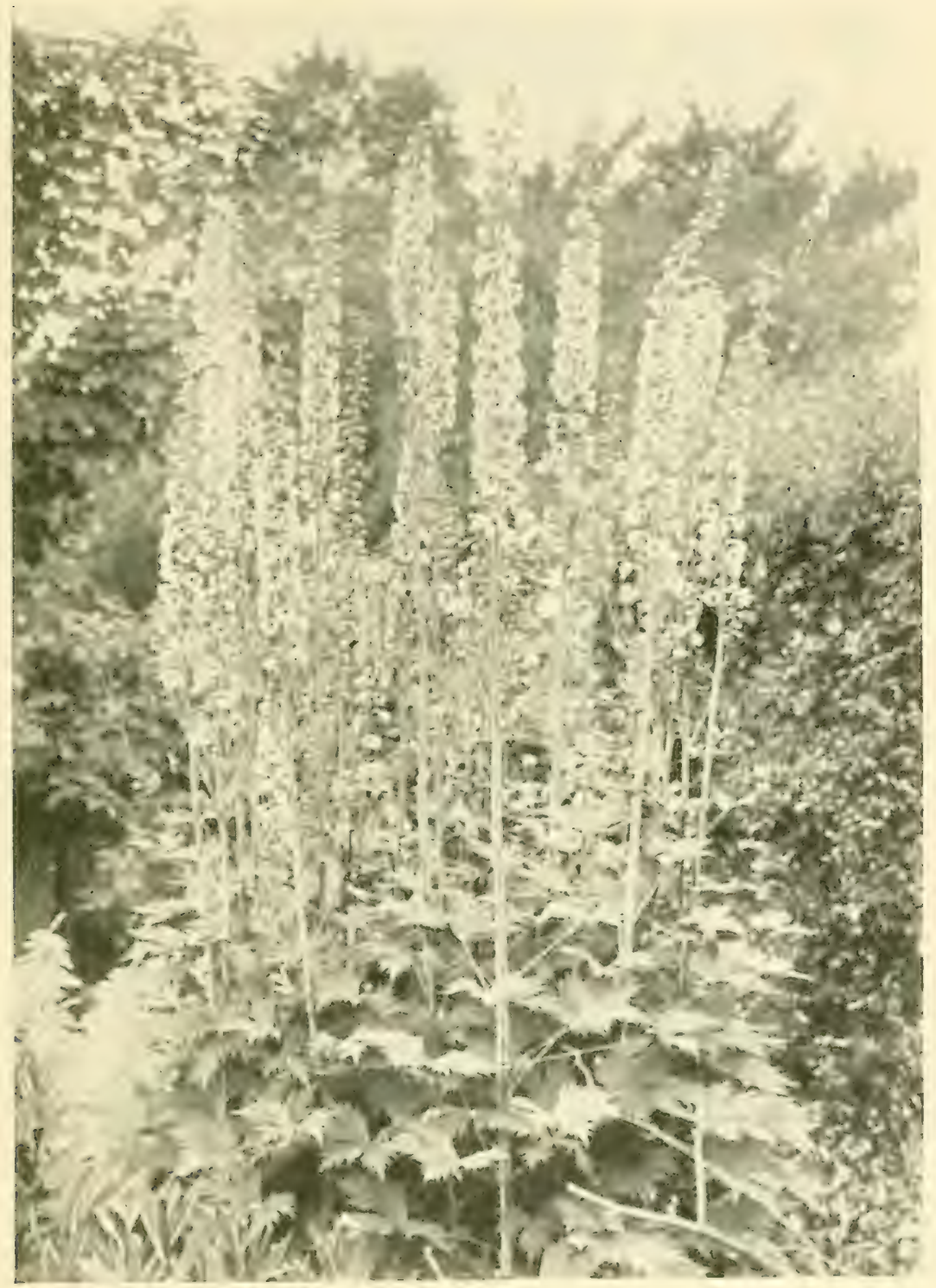

A CLUMP OF PERENNIAL LARKSPUR (DELPHINIUM) 



\section{DECUMARIA}

in quantity. It is said to attain similar proportions in China to those of the Horse Chestnut here. The leaves are more or less ovate and up to 6 inches long. The flowers are small and borne in dense heads from buds on mature wood; they are not showy, but this deficiency is made good by the large and handsome, white, leaf-like bracts which attend each inflorescence. In this country it grows vigorously in loamy soil, and has already flowered in several gardens. Propagation can be carried on by seeds or by cuttings. Prune to keep a clear leader and to remove superfluous branches. It is thought that more than one species is in cultivation, and different names have already been suggested for one or two kinds which vary in character of foliage. Of these Vilmorinii is perhaps the most distinct.

\section{Day Lily.-(See HEMEROCALLIS.)}

Decumaria.-The best known of the Decumarias, which belong to the Natural Order Saxifragaceae, is barbara, a deciduous (leaf-losing) twiner from the Southern United States. It has white fragrant flowers in May and June, borne in terminal corymbs suggestive of Hydrangea, to which it is closely related. Propagation is by cuttings inserted in sandy soil in a cold frame during August and September. It comes from the Southern United States and is rather tender, so should be planted against a sheltered fence or wall in well-drained soil of sandy loam, leaf-mould, and peat.

Delphinium (Larkspur).--The numerous annual and perennial Larkspurs, which belong to the Buttercup family (Ranunculaceae), furnish our gardens with brilliant colouring throughout summer. The perennials are the best blue-flowered border plants; they vary from 3 to 6 feet or more in height, and flower from June to September. The florists' named varieties are exceedingly numerous, practically every shade of blue is represented in single, double, and semi-double flowers, while recently several varieties with white flowers have been introduced. The following are excellent varieties, comprising a wide range of colours: Double or Semi-double-Antigone, Carmen, King of Delphiniums, Mrs. Creighton, Perfection, Primrose, Rev. E. Lascelles. Single-Belladonna, Duke of Connaught, Julia, Lamartin, Lizzie van Veen, Moerheimi (pure white), Persimmon, Queen Wilhelmina. While the named sorts make the bravest show in the garden, there are several very beautiful perennial species. The best are: Brunonianum, light blue, June to August, I $\frac{1}{2}$ feet, Himalaya; cardinale, scarlet, July to August, 3 feet, California ; cashmirianum, slaty blue, June to August, $I_{2}^{1}$ feet, Himalaya; formosum, rich indigo blue, June to July, 3 to 4 feet, Armenia; grandiflorum, beautiful gentian blue, June to September, I foot to 2 feet, Siberia: var. album is pure white, and 


\section{I4 THE BOOK OF HARDY FLOWERS}

var. caelestinum grey-blue; nudicaule, orange-red, May to July, $\mathrm{I} ! 2$ feet, California; sulphureum (Zalil), pale sulphur-yellow, June to August, 2 to 3 feet, Syria.

The perennial Larkspurs are readily raised from seeds sown on a border out-of-cloors or in a cold frame from April to June. To produce flowering plants the same year seeds are sown in a warm greenhouse during February. The named varieties of florists' Delphiniums are the best, though many beautiful sorts can be raised from a packet of mixed seeds. These plants delight in deep, well-tilled, loamy soil enriched with decayed manure, leaf-mould, and wood ashes. They are increased by division of the roots in September or March. They dislike being disturbed, and may be left for four or five years without lifting. If the first flower spikes are cut off when the blooms fade a second display may be looked for in August if the plants are watered during dry weather and given liquid manure. For an autumn display of flowers seedlings raised in warmth early in the year are valuable. Most of the clumps produce numerous shoots and some should be removed; if libbled singly in small pots filled with sandy soil and placed in a closed frame they will root readily and make nice plants for autumn flowering.

The annual Larkspurs are very effective in beds and borders. Plants of the different sections vary from I foot to 4 feet in height. The dwarf sorts are varieties of Delphinium Ajacis, a wild British kind, and the taller branching sorts are derived from Consolida, a European species. Seeds are best sown in the borders or beds where the plants are to flower, as they do not transplant readily. Sow in autumn or spring. The following are excellent strains of annual Larkepur: Dwarf Rocket, I2 inches; Double Stock-flowered, 3 feet; Emperor, 2 feet; and Ranunculus-flowered, I 8 inches. These strains can be purchaserl in mixed colours, or the following are obtainable separately: white, apple blossom, rose, lilac, dark blue, light blue, rosy-scarlet, purple, mauve, and violet.

Dendromecon (Tree Poppy).- This is a rare Californian shrub, belonging to the Poppy family (Papaveraceac). The only specics is rigidum, which has yellow Poppy-like flowers luring summer. It reguires a sheltered spot in most gardens; against a south or west wall or fence it will grow to a height of 5 feet or more. The border must be well drained; if the soil is at all heavy dig it out to a depth of 2 feet, put in 6 to 9 inches of brick rubble, and fill up with 2 parts sandy loam, I part peat, and I part leaf-mould. Increase is by cuttings inserted in pots of sancly soil during August. Plunge the pots to the rim in a propagating frame with slight bottom heat. 
Another method of propagation is to layer the lower branches in autumn.

Desfontainea spinosa is a decorative evergreen shrub (Natural Order Loganiaceae) from Chili and Peru. Of rather stiff and upright habit, it attains a height of 4 or 5 feet and is a popular slirub in the milder parts of the country. The somewhat thick, spiny-margined leaves suggest those of the Holly, though they are lighter coloured. The tubular scarlet and yellow flowers are, however, the chief attraction. Each one is about I $I_{2}$ inches long and $\frac{1}{2}$ inch in diameter; they are borne freely during summer. It may be planted in loamy soil or soil containing peat, requires a sunny position, and is increased by seeds or layers: Regular pruning is unnecessary. In those gardens where it will not grow successfully in the open border on account of an unfavourable climate, it may be planted against a wall.

Deutzia.-The value of several kinds of Deutzia (Natural Order

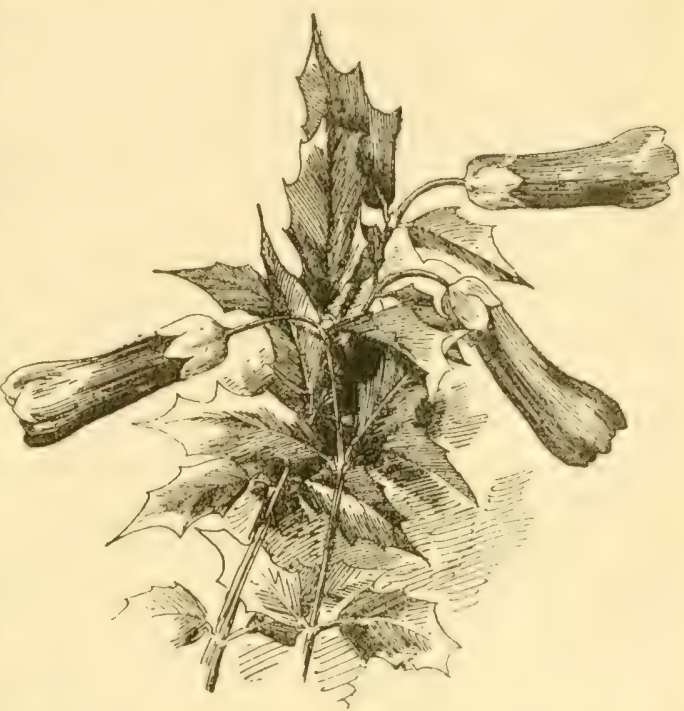

A Chilian Shrub (Desfontainea spinosa), having red and yellow flowers and Holly-like leaves

Saxifragaceae) as showy flowering shrubs has been appreciated for many years, but recently a number of others have been introduced from China and are equal in decorative qualities to the best of the older kinds. In addition, both new and old sorts have been crossed with very good results, and we have now a set of free-flowering and showy hybrids. The Deutzias, however, have one defect: they commence to grow very early, and the flower-buds of many kinds appear simultaneously with the young shoots, although the actual flowering time is not until May, and their precocious nature frequently leads to the crippling of the flowers by late frosts. However, there are many gardens which escape late frosts, and whether or not, the earlier sorts are exceptionally valuable shrubs for forcing for greenhouse decoration during early spring. The Deutzias must be given rich loamy soil and a top-dressing of manure once a year, for they are "rank 
feeders." Propagation is by cuttings of the young shoots in summer. In pruning the dwarfer linds and the hybrids it is a good plan to remove most of the flowering wood as soon as the flowers are over, thus leaving plenty of room for the numerous young shoots which appear from the base. The tall-growing sorts simply need an occasional thinning.

The chief kinds are: corymbosa, a handsome Himalayan plant, bearing very large heads of white flowers; crenata, a plant of many names, native of Japan, is often called scabra, and is one of the most vigorous kinds, growing to feet high, it bears long racemes of white flowers with great regularity (flore pleno extus purpurea has double flowers shaded with purple, and Pride of Rochester has double white blossoms); discolor, a Chinese species, 3 to 4 feet high, bears purple-shaded flowers - the var. purpurascens is an improvement on the type; gracilis is a well-known species from Japan, growing $I \frac{1}{2}$ to 2 feet high, and bearing white flowers freely: it is often used for forcing; parviflora, a native of China, grows 4 feet high, and bears white flowers freely. The three last-named kinds have been intercrossed, and there are many handsome hybrids, including campanulata, kalmiaeflora, Lemoinei, Apple Blossom, and compacta.

Deutzia Wilsoni is a new Chinese species, with large heads of white flowers; Veitchii, another new species from China, bears rich purple blossoms; Vilmorineae, from the mountains of Setchuen, is a vigorous bush 8 feet high with large inflorescences of fine white flowers.

Dianthus (Carnation, Picotec, Pink, Szeect William).-The Dianthus (Natural Order Caryophyllaceae) is a very large and important group of plants including as it does several well-known and highly valued garden flowers.

Alpine or Rock Pinks.-We find some of these in every rock garden. They require a sunny position, gritty soil, and are never happier than when growing in the chinks between stones and boulders, or in old walls. Patches or groups of the free-growing kinds are effective along the front of a sunny border. Propagation is by division in September, by cuttings inserted in a cold frame during July and August, and by seeds sown in well-drained pans of sandy soil in a cold frame from April to July. The chicf kinds are : alpinus, deep rose, spotted crimson, June to July, 4 inches, Alps of Austria, etc. ; arenarius, white, pale purple base, fringed, 6 inches, Europe; atrorubens, dark crimson, I2 to I8 inches, June to August, Southern Europe; caesius (Cheddar Pink), rosy-purple, May to July, 2 or 3 inches, a good plant for old walls, Europe, including Britain; deltoides (Maiden 


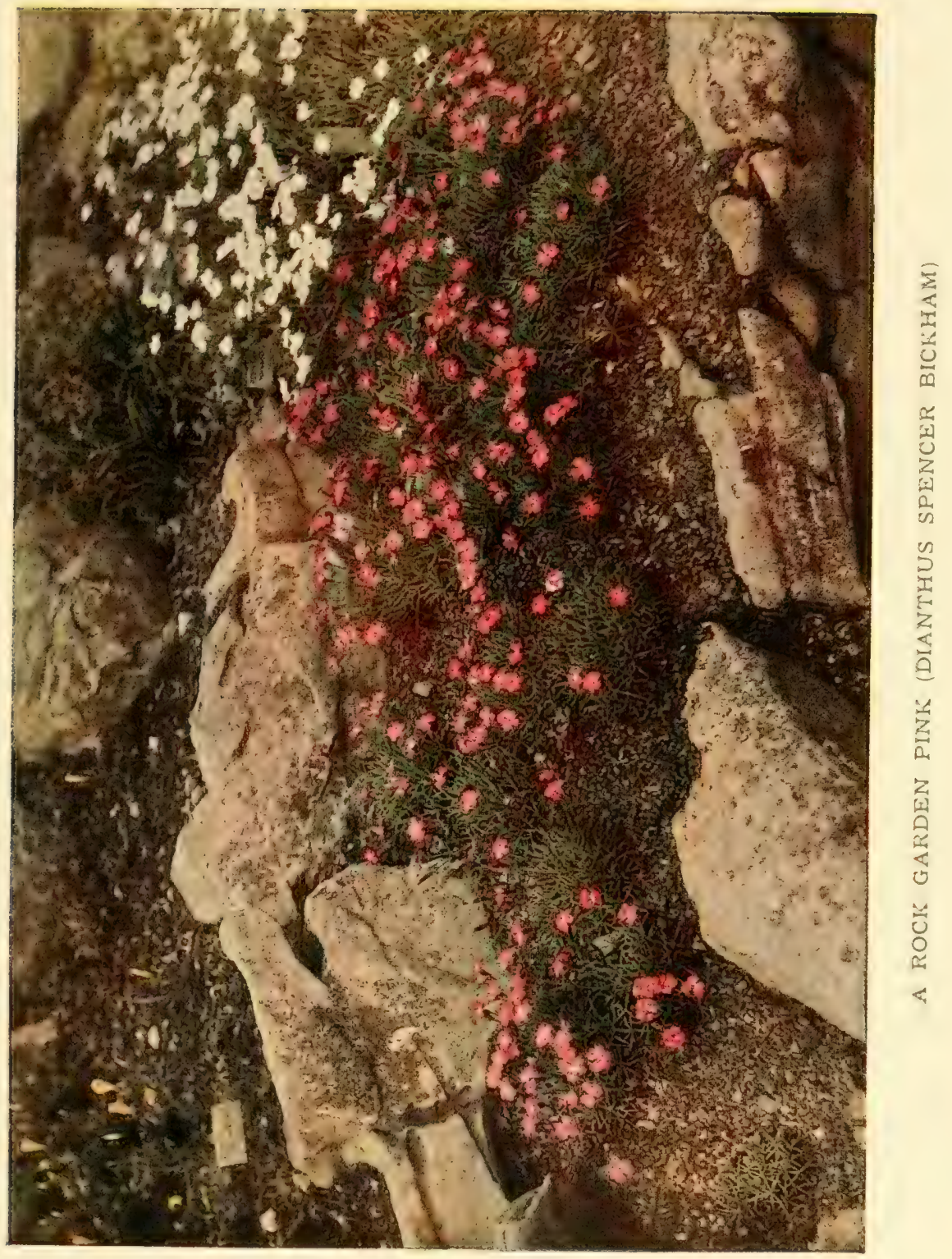



Pink), rosy-purple, tufted habit, May to July, 6 inches, Europe : the var. graniticus has deep-coloured flowers; fragans, white single flowers, very fragrant, useful in rockery and border, July to August, I2 inches, Caucasus; glacialis, large rosy-crimson flowers, June to July, 3 inches, Alps of Europe ; Knappii, interesting because the flowers are pale yellow, May to July, I2 inches, Hungary, etc.; neglectus (Glacier Pink), cherry red, June to July, quite a miniature species, 2 to 4 inches, Europe; superbus, rose, very fragrant, I2 inches, a favourite plant for the rockery and border.

Some of the Alpine Pinks are quite easily grown in well-drained gritty soil with which broken brick or stone is freely mixed, but others need special care. Those that give no trouble are: arenarius, atrorubens, caesius, deltoides, graniticus, fragrans, Knappii, and superbus. The Alpine Pink (alpinus) needs well-drained loam containing lime; neglectus thrives in gritty loam with which lime rubble is mixed; glacialis is very difficult, and is most likely to succeed in a compost of loam and peat containing granite or sandstone chips, and if placed in a slightly shaded rock crevice. Others worthy of mention are: callizonus, bearing unusually large crimson flowers with carmine marking, and needing a cool spot in well-drained sandy soil ; cal-alpinus, a hybrid between callizonus and alpinus, needs similar treatment to alpinus; microlepis is a tiny Pink that likes a well-drained soil of peat and loam. These choice Alpine Pinks are often grown in a moraine; in other words, on a slightly sloping bank from which the soil has been removed about 18 inches deep and replaced by stone chips with which a small proportion of soil is mixed.

Border Pinks may be described as the sweetest of early summer flowers. The parent of the garden Pinks is Dianthus plumarius a wild plant of Eastern Europe. Pinks are never more effective than when forming an edging to the flower border, as shown in one of the colour photographs. The two chief requirements of the Pink are a sunny position and well-drained soil. Propagation is by layering the shoots immediately after flowering, by cuttings or pipings taken off early in July and inserted in boxes of sandy soil in a cold frame, or under a handlight on a cool, half-shaded border. A third method is to lift, divide, and replant in September. Pinks are also easily raised from seeds sown in April and May in boxes of light soil out-ofdoors or in a frame.

The Pinks are divided into two sections, the Border and Laced kinds. The following are some of the best. Border varieties-Albino, pure white; Anne Boleyn, rosy-purple, dark purple centre; Ascot, pink, darker centre; Excelsior, rose, crimson centre; Gloriosa, deep 
pink; Her Majesty, pure white; Mrs. Lakin, white, pink centre; Mrs. Sinkins, pure white; Progress, deep rose, crimson centre; and Snowflake, pure white. Laced varieties-Amy, maroon; Chantilly, white, maroon centre; Excellent, crimson; Godfrey, reddish; John Bull, dark plum; Mrs. Waite, crimson; Morna, maroon, crimson, and white; Old Chelsea, rosy-red; Reliance, red; and Sarah, dark red.

Several hybrid or Mule Pinks, crosses between two distinct types, have been raised in gardens: Napoleon III., crimson; Lady Dixon, reddish crimson, and Marie Paré, pure white, are three of the best.

Sroeet William.-Dianthus barbatus, native of Southern and Eastern Europe, is the parent of the Sweet William. Seeds are sown outside during April or May, the seedlings, when large enough, being transplanted, and in October or Narch-the former for preference-placed where they are to flower in June and July. The several strains of Sweet Williams have been considerably improved during recent years. This is particularly noticeable in the pink, salmon, and scarlet shades, of which, from seeds sold in separate packets, a very large percentage come true to colour. The following are distinct: Scarlet Beauty; Pink Beauty; Giant White; Nigricans (dark crimson), dark red foliage and flowers; auriculaeflora (Auricula-eyed), white edge, coloured centre; Harlequin, flowers individually of several colours, very striking; the grandiflorus strain comprises many attractive shades of colour, and flore pleno is a distinct strain with double flowers.

Chinese Pink.-Dianthus Chinensis, a Chinese kind, is really a biennial but more often treated as an annual, seeds being sown under glass in a heated greenhouse or frame in spring to produce flowering plants in July and August. From seed sown in a cold frame in August or September the plants will bloom in June. Plant outside towards the end of May in sunny positions, and rich, rather light garden soil. The numerous sorts grown in gardens are variously known as Chinese, Indian, and Japanese Pinks; growing from 9 to 15 inches in height, they are very showy for beds and borders. There are varieties with single and double flowers. Seeds are sold in mixture or as follows: Heddewigii, a mixed strain; Salmon Queen; Scarlet Queen; Single Pure White; The Bride, white, rosy-purple eye; Snowdrift, double white; Fireball, double scarlet; Laciniatus, fringed flowers in numerous colours.

Carnation.-The parent of the Carnation is Dianthus Caryophyllus, a European species which is sometimes found wild in this country. Carnations thrive in well-dug garden soil; if it is heavy, old mortar rubble should be mixed in when digging; if light, add some turfy 
soil. October and March are the best times to plant Carnations. In damp, low-lying districts and in town gardens it is sometimes found necessary to pot the layers in autumn, keep them in a cold frame during winter, and plant in spring. Wherever possible, however, autumn planting is desirable, as the Carnation is a perfectly hardy plant. Layering is the best method of propagation, this being done as soon as the flowers are over. Cuttings are sometimes inserted in August in a cold frame or under a handlight on a sheltered border outside. Carnations are readily raised from seeds sown in shallow pans or boxes from March to May and placed in a cool greenhouse or cold frame; they must be planted permanently in September or October, and will bloom the following year. The Marguerite Carnations are a quick-flowering race of perpetual blooming Carnations. From seed sown in a warm greenhouse during February, the plants will bloom from August to October. A strain called Vanguard has similar characteristics, and flowers in six months from seed sowing.

Carnations are divided into several sections: Selfs have flowers of one colour ; Fancies, the groundwork of one colour is marked with another; Bizarres, the ground colour is striped with two or three others; Flakes, white, striped with purple, scarlet, or rose. For the border the Selfs, Fancies, and Yellow Ground Picotees are the best.

Twenty of the best Border Carnations are: Basuto, crimson; Bookham White; Border Yellow; Brigadier, scarlet; Daffodil, yellow; Duchess of Wellington, lavender; Elizabeth Shiffner, straw colour ; Ellen Douglas, silvery-grey ; Fujiyama, red ; Furthest North, white; Greyhound, heliotrope; Innocence, blush pink; Miss Willmott, coral pink; Mrs. George Marshall, crimson; Mrs. Griffith Jones, apricot; Mrs. Robert Gordon, pink; Purple Emperor; Rosy Morn, rose; Mrs. Andrew Brotherstone, purple and white; Mrs. J. J. Keen, yellow, edged rose; and Montrose, white with scarlet markings.

The Picotee is similar to the Carnation, but the ground colour of white or yellow is edged with red, purple, scarlet, or rose.

Diascia.-The only Diascia is a half-hardy annual, from South Africa, belonging to the Snapdragon family (Scrophulariaceae); it is of slender growth, 9 to I2 inches high, and bears coral pink flowers freely in summer. Seeds may be sown outside in April where the plants are to flower, or in a cold frame during March, the seedlings being subsequently transplanted. Rather light soil is suitable, and a sunny spot should be chosen.

Dicentra (Lyre Flower or Bleeding Heart).--Some nine or ten species of this group of the Fumitory family (Fumariaceae) find a place in botanic gardens, but only two are in general cultivation. Chief of 
these is spectabilis, perhaps more familiar as Dielytra spectabilis, a native of China and Japan, and known under the popular name of Bleeding lfeart. It grows about a feet high, has elegant pinnate foliage, and during May and June bears graceful racemes of pink and white flowers. The plant starts into growth early in spring, and should be put in a shelered, partially-shaded border or on the west side of a fence; it atsociates well with hardy ferns. Dicentra formosat, from North-West Americat, has red or crimson flowers in Maty and early fune. It grows only 6 to 9 inches high, and is usclul for the rock garden or for the front of the herbaceous border; it needs shate during the hottest part of the day. The Dicentras prefer rather rich, light, well-dratined soil. Previous to planting in September, work in plenty of leaf-mouhl and decayed manme. Increase is by division of the clumps in September. The thick, fleshy roots should be pulled apart carefully with a hand-fork.

Dicksonia. - Only one Dicksonia (member of the fern family, Filices) is hardy, and that is the North American kind, punctilobulat. This is a deciduous fern with creeping rhizomes and fragrant bipinnate fronds, abont is incles high. $\Lambda$ shaty position and a soil of leaf-mould and peat are suitable. Increase is by division of roots or rhizomes in March. 1)icksonia antarctica, an Australian Tree Fern, grows out-of-doors in very wam nowks in the south-west counties. In other parts of the country plants in tubs or large pots are placed outside in summer and returned to the cool greenhonse in antumn.

Dictamnus (Burning bush, firuxinella). There are several varieties of this hardy perennial, which belongs to the Rue family (Rutaceac), but they are all forms of Dictammus albus (or liaxinella, which is a commoner name in gardens). The plants grow 2103 fect in leeight, flowering frecly from June to August. The name Burning Bush refers to a remarkable peculiarity of the plint. 1)uring hot summer evenings the plints exude a volatile inflammable oil, and if a lighterl match is applied it cause's a bluish flame to envelop the plants. The chicf varieties are: albus, pure white, Europe; purpureus (syn. Fraxinellat), reddish-purple; cancasicus, a strong-growing variety of the last-named with red-purple flowers, of feet high. The Fraxincllas thrive in light, rich, well-drained soil, and may be planted in sun or partial shade in September, October, and March. Increase is by seeds sown outsick or in a cold frame when ripe, and by cuttings made of the thick, fleshy roots, preferably in March:

Diervilla (Woigela) (Bush Honcysucki). - A very useful group of hardy shrubs, belonging to the Ifoneysuckle fanily (Caprifoliaceae), for most of them blowm freely and the flowers are showy. They com- 


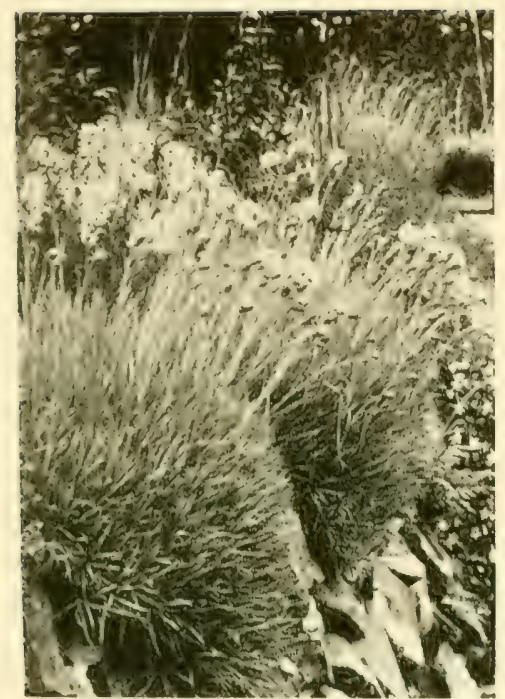

PINKS (DIANTHUS) IN A DRY STONE WALL

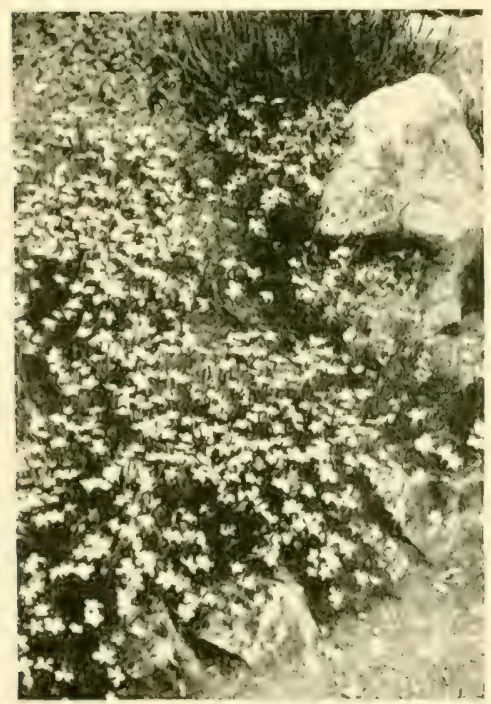

THE MAIDEN PINK (DIANTHUS DELTOIDES)

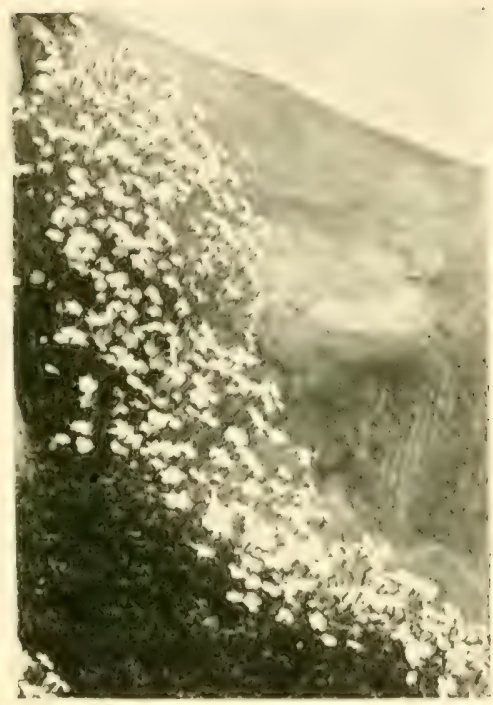

THE CHEDDAR PINK (DIANTHUS CAESIUS)

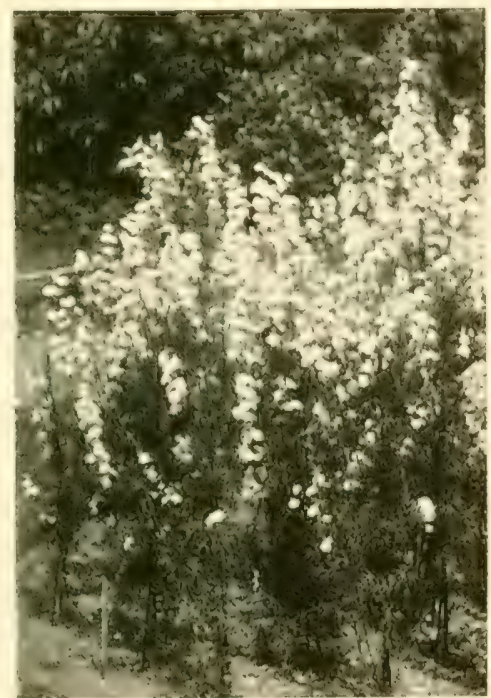

BLUE ANNUAL LARKSPUR (DELPHINIUM) 

prise a useful set of garden hybrids which for decorative planting are even better than the species or wild types: The latter are found in China, Japan, Siberia, and North America; all thrive in any good garden soil, moderately rich loam being preferable when available. Cuttings of soft shoots inserted in sandy soil in warmth during May and June form a sure and rapid means of increase. The species and more vigorous garden varieties may be thinned out after flowering every second or third year, taking care not to cut the younger shoots; but the weaker sorts and those that bloom most freely are benefited by the removal of a certain amount of the older wood each year as soon as flowering is over. The Diervillas or Weigelas are useful for planting in a bed, for isolated specimens, groups in shrubberies, or for forcing.

A selection of the best includes: floribunda, native of Japan, 3 feet or so high : it provides a number of varieties in Lavallei, Lowei, and versicolor; florida is a Chinese shrub, bearing reddish or rosecoloured flowers freely, the var. candida has white flowers; grandiflora is a showy, free-flowering kind from Japan, growing 6 or 8 feet in height.

Numerous hybrids have been raised between these species, and are known collectively as Diervilla hybrida. The following are all showy and useful : Abel Carrière, rich rose; Eva Rathké, deep crimson, blooms over a long season; Conquête, deep rose; Esperance, white, shaded rose; Heroine, white, tinged rose ; Le Printemps, rose ; Mont Blanc, white.

Diervilla japonica is a Japanese species of which the var. Hortensis has beautiful white flowers; middendorfiana is a Siberian species with large sulphur-coloured blossoms, rather tender; praecox is an early Japanese kind with deep rose flowers.

Digitalis (Foxglove).-These are favourite old-fashioned garden plants for the flower and shrubbery borders, the wild garden, and for naturalising in half-shady nooks. They belong to the Snapdragon family (Scrophulariaceae). The plants thrive in ordinary soil, and though some of them flower a second time, the usual method is to treat them as biennials, sowing the seeds in April or May to produce flowering plants in June and July of the year following. However, self-sown seedlings come up in all sorts of places, and in the case of the Common Foxglove it is usually unnecessary to sow seeds. When sowing, scatter the seeds thinly where the plants are to flower, or sow in a border and transplant the seedlings in autumn. Digitalis purpurea (Common Foxglove), with purple, spotted flowers, grows 4 to 5 feet high, is native of Europe, and found wild in parts of Britain; the 
var. alba has white, more or less spotted flowers; var. gloxinioides (monstrosa) has one very large flower at the top of the spike of normal blooms. For garden borders an improved strain, called Giant Spotted or Spotted Hybrids, is recommended. Giant Primrose is a most beautiful Foxglove, with rich cream or buff flowers. Those who desire further kinds may sow seeds of ambigua, yellow, 3 feet, Europe; ferruginea, pale yellow, veined with purple, 4 feet, Europe; laevigata, bronzy-yellow, 3 feet, Eastern Europe; lanata, purplish flowers, 2 feet, Eastern Europe, and lutea, pale yellow, 3 feet, Europe.

Dimorphotheca (Cape Marigold).-The kinds in cultivation are annuals: they belong to the Daisy family (Compositae). The Cape Marigolds must have warm, sunny positions in the garden, either on the rockery or a south border, and thrive best in light, well-drained loamy soil. Sow the seeds in April out-of-doors, where the plants are to flower. Dimorphotheca aurantiaca, the Orange Daisy, is a comparatively recent introduction, and is now the most popular kind; it is a South African annual, about 18 inches high, with orange-coloured flowers borne in profusion throughout the summer. The plants grow about I foot high, and commence flowering in seven or eight weeks from seed. For a small bed on the lawn this is one of the most useful and showy annuals. A strain with variously coloured flowers, obtained by crossing aurantiaca and pluvialis, is known as aurantiaca hybrida, and includes salmon, buff, apricot, yellow, primrose and white. Dimorphotheca Ecklonis has white flowers, shaded purple, it is from $\mathrm{I}_{2} \frac{1}{2}$ to 2 feet high; pluvialis has white yellow-centred flowers, shaded blue outside, and grows from I foot to $I \frac{1}{2}$ feet high.

Dioscorea (Yam).-Climbing plants (Natural Order Dioscoreaceae) with annual stems and tubers which, in the countries where they grow, are cooked and used as here we use potatoes. The flowers are inconspicuous, but in large gardens the elegant twining growths may be used to clothe arbours, verandas, and bare fences. The two bestknown kinds are Batatus, from the Philippines, and Decaisneana, from China. The annual stems grow to a height of some 6 to $8 \mathrm{ft}$. Increase is by division of the tubers in spring before growth starts.

Diospyros (Persimmon).-Two hardy trees, Diospyros Lotus from temperate $A$ sia and virginiana from the United States, are included in this group (Natural Order Ebenaceae). Neither is very decorative, though both are interesting and rather rare trees. Diospyros virginiana is the Persimmon of North America, and is curious by reason of the thick bark of mature trees being divided into cubes. Both grow in ordinary garden soil, are increased from seeds, and require sufficient pruning when young to ensure shapely trees. The wood of the American 
tree is valuable for the manufacture of shuttles, etc., whilst that of several tropical kinds is extremely valuable on account of its colouring and hardness. Diospyros Ebenum, from South India and Ceylon, is the Ebony of commerce, and Kurzii is the celebrated Andaman Marble or Zebra Wood. Another, Diospyros Kaki, of Japan, produces a valuable fruit which is known as the Kaki of Japan, or the Chinese Date Plum; there are many cultivated varieties, which are used in a fresh and dried state. Fruits have been ripened on walls in the South of England, and the tree is suitable for cultivation in a greenhouse, where a crop of fruit is far more certain than out-of-doors..

Dipelta.-This is a new class of shrubs from China, allied to the Diervilla and belonging to the Honeysuckle family (Caprifoliaceae). The flowers are similar in shape to those of Diervilla (Bush Honeysuckle), but have several minor

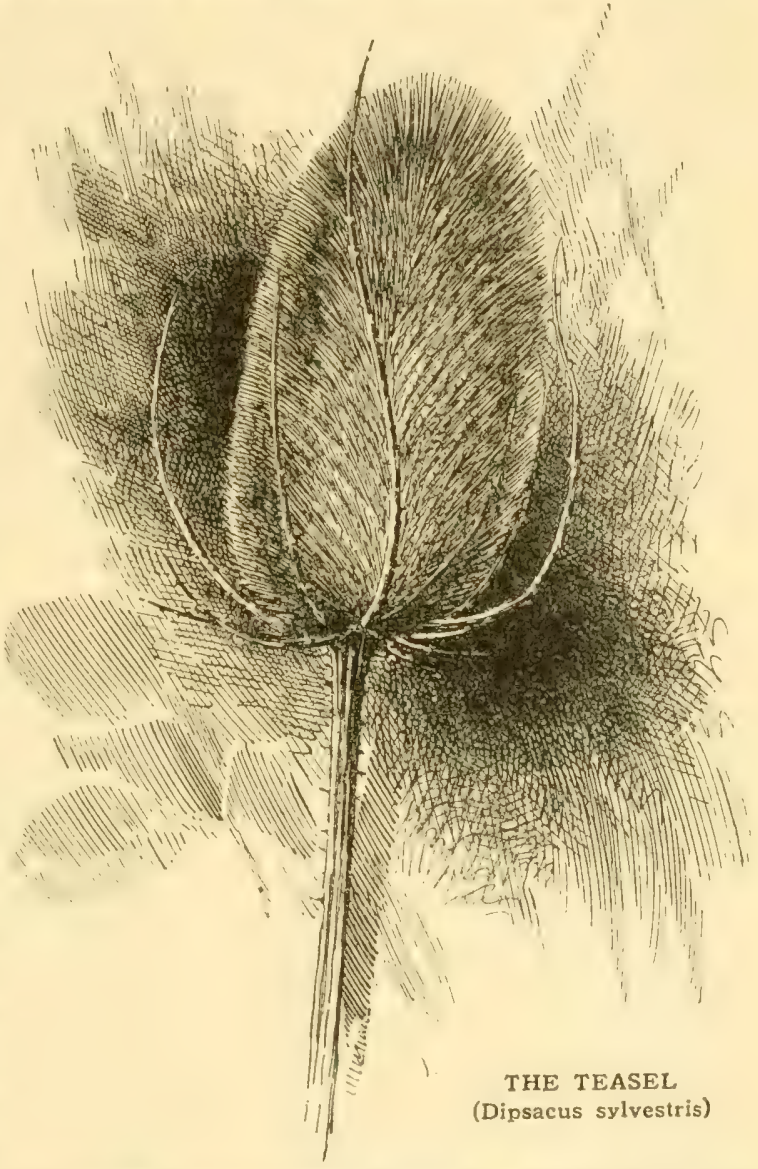
structural differences, the most conspicuous being the presence of two bracts at the base of each flower which continue to grow after the flower fades and remain until the seeds are ripe. The cultural requirements are similar to those recommended for Diervilla. The chief species are: elegans, a bush 3 to 4 feet high; floribunda, found in Hupch, growing from to to 15 , but sometimes fo feet high: the flowers are borne in clusters during May and June, and are rose-pink without and white and orange within; ventricosa, a bush 6 to $I_{5}$ feet high, 
bears clusters of flowers which are reddish-purple without and pale within; Zunnenensis grows from 4 to I2 feet high and bears pale lilac flowers.

Dipsacus (Teasel). - The Teasels (Natural Order Dipsaceae) are novel and interesting rather than showy flowering plants. They thrive in almost any soil, and though a plant or two may be included in the flower border, the best place for them is in the wild garden, shrubbery border, and odd corners unsuitable for choice plants. The best known are Fullonum (Fuller's Teasel), with whitish flower-heads and pale purple anthers, July, 4 to 6 feet, Europe; laciniatus, whitish flower-heads, red anthers, July, 3 to 5 feet, Siberia ; sylvestris (Common Teasel), pale lilac flower-heads, July, 6 feet, Europe, including Britain. The Teasels are best treated as biennials; scatter the seeds in May where the plants are to flower the following summer.

Disanthus cercidifolia is a rare shrub belonging to the Witch Hazel family (Hamamelidaceae). It is native of Japan, and forms a bush several feet high, with rounded or broadly heart-shaped leaves which turn to rich, vinous purple in autumn, a colour retained for scieral weeks. The flowers are small, but have not appeared freely in this country yet. It must be planted in a sheltered position in light, well-drained loam containing a little peat. Propagation is by imported seeds and layers, and no regular pruning is required. This shrub is well worth planting for the sake of its distinct autumn colouring; few are more conspicuous.

Discaria.-Three species of these curious shrubs (Natural Orcler Rhamnaceac) are sometimes grown in our gardens. They are : longispina, from Uruguay, serratifolia, from Chili, and Toumatou (Witr Irishman), from New Zealand. All are intenscly spiny bushes of somewhat rambling growth. The leaves are small and rather inconspicuous, but the white flowers are borne freely. The Discarias are only suitable for the southern counties, where they may be grown in light loam in open borders or against a wall. Cuttings may be rooted, though propagation is usually by sceds. A little pruning is necessary now and then to keep the bushes within bounds.

Dodder.-(See Cuscuta.)

Dodecatheon (American Cowslip, Shooting Stars).-.-Dainty dwarf perennials, members of the Primrose family (Primulaceac), natives of North America. The plants thrive best in a cool position, shaded from the mid-day sun, and like a compost of sandy loam, leaf-mould, and peat, together with an annual top-dressing of leaf-mould in March. The nodling flowers, which resemble those of Cyclamen, appear on a slender stem in early summer. If after three or four years the 

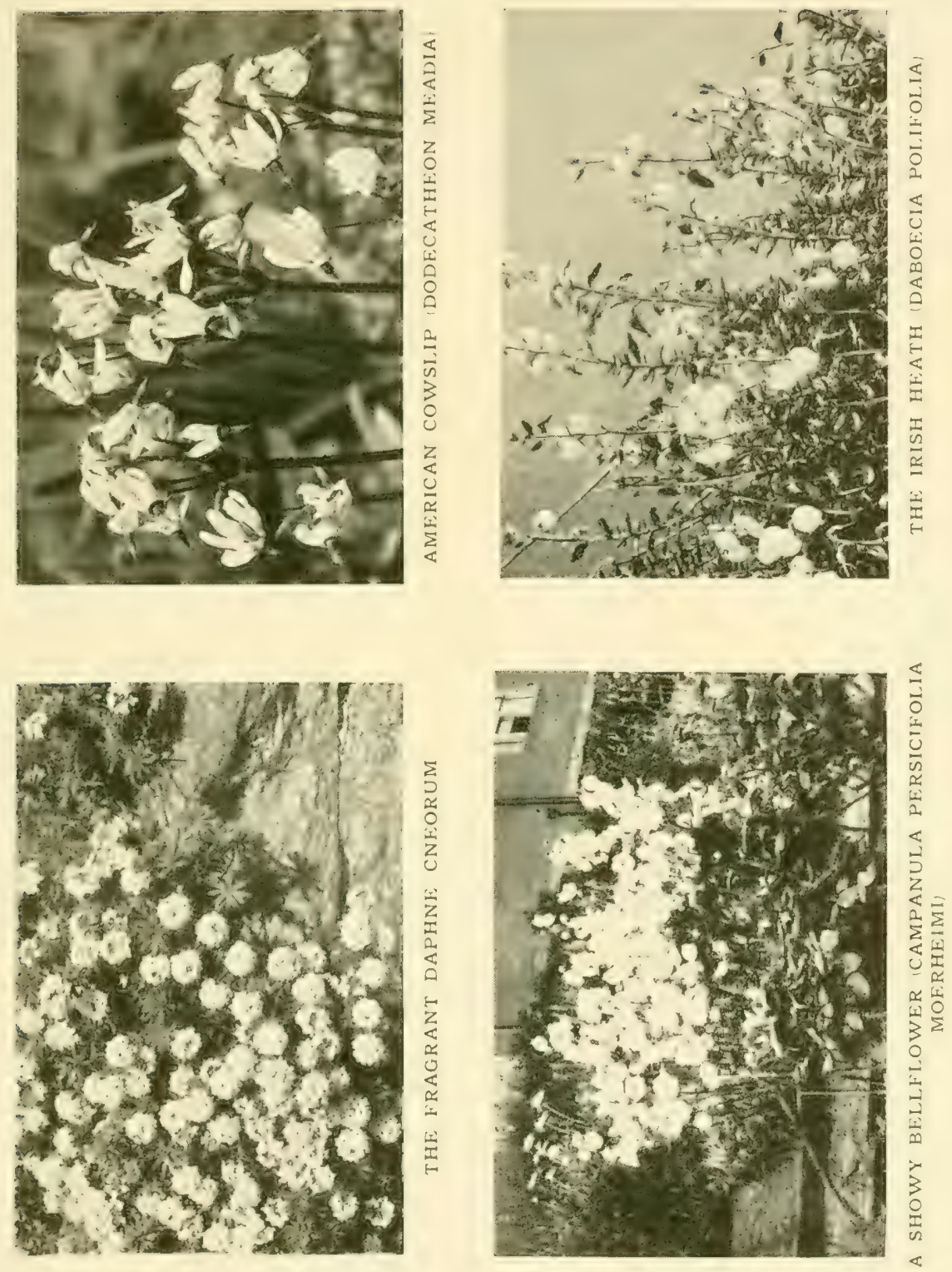

plants show signs of deteriorating, they should be lifted in February, and some fresh soil added before replanting. They are propagated by division of the roots in February, and by seeds sown on moist soil in a cold frame as soon as ripe. The species and varieties generally grown are: Clevelandii, violet-purple, 18 inches; Hendersoni, crimson-violet, I2 inches; Jeffreyi, rosy-purple, large handsome leaves, I 8 inches; Meadia (Common American Cowslip), rosy-purple, I 2 inches. Good varieties of the last-named are album, white; elegans, rich rosy-purple; splendens, crimson with yellow ring; and lilacinum, delicate lilac shade.

\section{Dog's Tooth Violet.-(See ERyThronium.)}

Doronicum (Leopard's Bane).-Easily grown hardy herbaceous perennials (Natural Order Compositae), natives of Europe, flowering in spring and early summer ; the flowers are useful for cutting. There are few soils in which the Leopard's Bane will not thrive, and in full sun or shade the plants flower freely. Increase is by division, preferably in September or October, also by seeds sown in a cold frame or outside in April or May. The chief kinds are : austriacum, goldenyellow, March to April, I2 to I8 inches; caucasicum, bright yellow, March to May, I2 to I8 inches; glaciale (syn. Clusii), rich yellow, very free, March to June, I foot to 2 feet; Pardalianches (Great Lcopard's Bane), yellow, several flowers on a stem, April to June, I $\frac{1}{2}$ to 3 feet; plantagineum, yellow, 2 to 3 feet, spring: the variety excelsum (syn. Harpur Crewe) has large golden-yellow blooms from April to July, and is very free flowering. This variety is the best of all and a splendid plant.

Douglasia.-Alpine plants allied to the Androsace and belonging to the Primrose family (Primulaceae). The best-known species is vitaliana from the Pyrenees; it is about 3 inches high and bears rich, ycllow flowers from April to June. In some catalogues it appears as Androsace vitaliana. Douglasia lacvigata is a dainty alpine of recent introduction, of dwarf, tufted habit, and with carmine flowers. The best position for these plants is a sunny place in the rock garden, and they need a well-drained calcareous soil, such as is provided by a limestone moraine. Seeds sown in a cold frame as soon as ripe, and division in early spring, are the methods of propagation practised.

Draba (Whitlow Grass).-Dwarf Alpines belonging to the Wallflower family (Cruciferae), which thrive best in crevices between the stones in the rockery and on old walls; they must have well-drained gritty soil, and a sunny position. They are hardy evergreen perennials, propagated by division in September or October and in spring by seeds, which should be scattered where the plants are to grow. 
The best species are: aizoides, ycllow, March to April, 3 inches, Europe; Aizoon, yellow, April to May, 3 inches, Europe; bruniaefolia, yellow, March, 3 inches, Caucasus; pyrenaica, rosy-lilac, April to May, 3 inches, Pyrenees; stellata, white, June to July, 6 inches, northern and arctic regions. Draba pyrenaica (syn. Petrocallis pyrenaica) needs special care, and the moraine, which consists of stone chips and rery little soil, seems the best place for it; it must be protected from wet in winter by glass, though this must not be so arranged as to exclude fresh air.

Dracocephalum (Dragon's Head).-Mostly hardy perennials, belonging to the Sage family (Labiatae), but at least one annual is in cultivation. They produce showy spikes, the flowers being arranged in whorls. A sumny position and ordinary, well-drained garden soil are suitable. Increase of the perennial species is by seeds sown in a cool greenhouse or frame in spring or early summer, division of the roots in February and March, and by cuttings made of the young shoots during April and May; these root readily under a bell-glass in a cool greenhouse or frame. Seeds of the annual kind, Dracocephalum Moldavica, should be sown in April where the plants are to flower. The best kinds are: austriacum, blue, July to September, I f feet, Europe, etc ; Moldavica, violet, July to September, I font, Siberia ; nutans (alpinum), blue, July to September, I foot, Eastern Russia; Ruprechtii, rosy-purple, July to August, 9 to I2 inches, Turlestan; Ruyschianum, blue, July to September, I 8 inches, Europe, etc. ; the var. Japonicum is blue and white, $I \frac{1}{2}$ to 2 feet. Dracocephalum virginicum is synonymous with Physostegia virginiana (zehich sce).

Drimys.-This is a group of shrubs belonging to the Magnolia family (Magnoliaceae), of which two species, aromatica from Tasmania and Victoria, and Winteri from South America, form handsome evergreen bushes in the milder southern counties. The former grows into a clense shrub 8 or to feet high, bearing rather small leaves and white flowers, and the latter is from I2 to I5 feet high, with conspicuous oblong leaves up to 6 inches long, and bearing large loose heads of pale yellowish blossoms. Drimys Winteri is also of value (more especially in the Magellanic region), by reason of its bark, which has medicinal properties. It is used as a tonic. Plant in ordinary garden soil in the warmer counties, increase by seeds, and prune in summer merely to keep the bushes shapely. Except in mild districts they must be grown as greenhouse plants.

Dryas (MIountain Aicns).-Dwarf erergreen alpine plants for the rockery. They belong to the Rose family (Rosaceac). They should be planted in well-drained soil containing a little peat with plenty 
of broken stone mixed in and placed on the surface; slight shade is beneficial. Propagation is by division in autumn or spring, the former for preference, which is also the best time for replanting. Seeds are sown in a cold frame from April to June, while cuttings may be inserted in pots of sandy soil in a frame during summer or early autumn. Dryas Drummondii, an evergreen trailer, bears golden-yellow blooms in summer, 4 to 6 inches, North America; octopetala has white flowers with golden-yellow stamens, May to July, 4 to 6 inches, Europe, including Britain.

Eccremocarpus scaber.-This is a handsome climbing plant of sub-shrubby habit, belonging to the Bignonia family (Bignoniaceae). It should be grown in a sheltered corner against a wall or trellis, and its branches be cut back quite half-way, or even to the ground line, each winter or spring, but it may also be treated as an annual or biennial with good results, and this is the most satisfactory method for the colder parts of the country. Seeds are sown under glass in sandy soil during autumn or spring, and the young plants grown in a compost of 3 parts loam to I part leaf-mould with a little sand, ready for planting out in May. The larger the plants are at that time the better will be the results. If they are left out-of-doors through the winter it is a good plan to place a small heap of cinders over their base to give a little protection. This climber is a native of Chili, and the scarlet and orange flowers are very showy and freely produced in late summer.

\section{Echeveria.-(See Cotyledon.)}

Echinacea (Purple Cone Flower).--This is a showy, hardy peren. nial, closely allied to the Rudbeckia, with which it is sometimes included; it belongs to the Daisy family (Compositae). The branching flower stems, which are stout and erect, reach a height of 3 to 4 feet, and bear star-like flowers, 4 inches across, of reddish-purple colour, with a black, cone-like disc. It is first-rate for cutting, as the flowers last a long time in water. The Echinacea, which is a native of North America, is readily increased by division, and will grow in any ordinary garden soil.

Echinops (Globe Thistle).-The Globe Thistles are an ornamental and distinct class of hardy herbaceous perennials, natives chiefly of Mediterranean districts, and belonging to the Daisy family (Compositae). The branching stems, which are from 3 to 6 feet high, are terminated by a globose head of Thistle-like blossoms of some shade of blue. The best are : bannaticus, deep blue; humilis, a dwarf species with bright blue flowers; Ritro, rich blue; and sphaerocephalus, with silvery foliage and pale, steely blue flowers. They thrive 
in ordinary soil, and can be increased by division, seeds, or root cuttings; the latter should be taken in winter, cut up into lengths of about 4 inches, and dibbled in a bed of sandy soil in the open ground. Owing to their bold appearance and indifference as to soil, the Globe Thistles are fit subjects for the wild garden.

Echium (Bugloss).-A near relative of the Borage (Natural Order Boraginaceae), and, like that plant, having flowers chiefly of some shade of blue. The different kinds will grow in ordinary garden soil, and bear their attractive flowers from June to August. They are readily increased by division in autumn, or in some cases by seeds, which may be sown in the open border in spring. The chief sorts are : plantagineum, a biennial with flowers of rich purplish-blue, this must be raised from seed each summer; Thomsonii, bright carmine; and vulgare, with pretty blue and white flowers. All reach a height of 2 to 3 feet.

\section{Edelweiss.-(See Leontopodium.)}

Edgeworthia chrysantha is a Chinese and Japanese shrub belonging to the Natural Order Thymelaceae. It may be grown out-of-doors in the milder parts of the country, where its small, yellowish, Daphne-like flowers are produced in April or May. Elsewhere the protection of a cool greenhouse is necessary. Seeds are usually used for propagation, and it thrives in loamy soil or in loam containing leaf-mould or peat. No regular pruning is necessary; simply shorten long branches to induce the basal buds to break into growth freely. From the bark of an allied species, Edgeworthia Gardneri, a fine kind of paper is manufactured in Nepal.

\section{Edraianthus.-(See WAHLENBERGIA.)}

Elaeagnus.-Ornamental evergreen and deciduous species of trees and shrubs (Natural Order Elaeagnaceae), most of which are suitable for outdoor cultivation in the British Isles. They are natives of the Mediterranean region, the Orient, China, Japan, and North America. The flowers of most kinds are white or cream and fragrant. In some cases they are followed by showy fruits, but their foliage is the chief attraction. They may be used for shrubberies, specimen bushes or groups, whilst they are available for all except the most exposed parts of the country. In some instances the foliage is green; in others, silver; whilst some have prettily variegated leaves. Good loamy soil meets their requirements; it must, however, be well drained. It is usual to increase the species by seeds and the varieties by cuttings inserted in sandy soil in a frame in July. Pruning is restricted to keeping the bushes shapely, and the removal of greenleaved shoots from variegated kinds. This may be done in summer. 
The chief sorts are: pungens, a Chinese and Japanese shrub, growing $\mathrm{I} 2$ or $\mathrm{I} 5$ feet high, with evergreen leaves; the varieties aurea, aureo-picta, and Simoni have handsome golden variegated leaves; angustifolia, of the Mediterranean region and the Orient, forms a small tree with narrow, silvery, deciduous leaves; argentea is a silver-leaved kind from North America - it bears silver-coloured berries; macrophylla, a handsome evergreen, with greyish green leaves, native of Japan and Formosa, flowers during late autumn; multiflora is a deciduous kind from China and Japan, which bears a large number of fragrant flowers in May, followed by showy fruits later ; it is sometimes called longipes.

Elliottia racemosa is one of the rarest shrubs in cultivation; it belongs to the Heather family (Ericaceae). It has seldom been found in a state of nature, and few examples have been introduced to Europe. There is also a difficulty in procuring seeds, whilst it apparently defies propagation by other methods. It is a deciduous, upright-growing bush from Georgia, growing at least 6 feet high, with handsome terminal panicles of showy, waxy white flowers, which open in July. A fine example is to be seen in the Royal Botanic Gardens, Kew, where it occupies a position amongst a bed of Heaths, the light loam containing a little peat in which the Heaths are at home, being apparently equally suitable for the Elliottia:

\section{Elm.-(See Ulmus.)}

Elsholtzla Stauntoni is a sub-shrub from China, belonging to the Natural Order Labiatae. Of recent introduction, it is still a rare plant, but its free-flowering qualities and late blossoming season are bound to make it popular in the near future. Growing from 4 to 6 feet high, it looks more like a herbaceous plant than a shrub, although the lower parts of the branches are persistent. The ovate leaves are up to 6 inches long and fragrant, and the reddish or deep pink flowers are borne in very large terminal inflorescences in September. It may be used in the shrubbery or herbaceous border, and must be planted in good, deep loamy soil. Cut the branches well back after flowering.

Elymus (Lyme Grass).-A fairly extensive group of Grasses (Natural Order Gramineae), none of which, however, is of any particular garden value except Elymus glaucifolius, with leaves of greyblue tint. This is desirable for waterside planting, and in such conditions flourishes. A second species, Elymus arenarius, though but a weed, is of value from the fact that, growing on the seaside as it does, it tends to bind the shifting sands together; it progresses rapidly by means of long spreading underground rhizomes, so that it forms a living mat which prevents the sand being washed away. 
Embothrium coccineum.-A remarkably handsome large shrub or small tree, belonging to the Natural Order Proteaceae, and native of South America; it is hardy only in particularly favoured parts of Great Britain. In parts of Devon and Cornwall it forms quite a striking feature during its flowering period, which is early summer. Proximity to the sea seems to be particularly conducive to its welfare. This Embothrium forms a much-branched specimen clothed with Willow-like leaves, while the flowers, which are borne towards the ends of the shoots, are of somewhat similar shape to those of a Honeysuckle and of an orange-scarlet colour. A soil of sandy loam, with a little peat intermixed, is suitable. It is increased by seeds, which should be sown as soon as ripe in a mixture of loam, peat, and sand, and placed in the greenhouse. Providing it is in an open space, this shrub needs no pruning.

Emilia coccinea (Tassel Flower).-This showy annual is generally met with in nurserymen's lists as Cacalia coccinea. It belongs to the Daisy family (Compositae), and is native of India. If sown out-ofdoors during spring it flowers throughout the summer. The plant reaches a height of about 18 inches, and the flowers, which are in clusters like a bunch of tassels, are of orange-scarlet colour. It is a very distinct annual.

Empetrum nigrum.-This is a prostrate-growing shrub (Natural Order Empetraceae), with small, dark evergreen leaves, and is widely distributed through the colder regions of the Northern Hemisphere. It is common in many parts of the Highlands of Scotland, where it is often found on rocky, mountainous land in exposed places. As it forms a dense, carpet-like mass it is useful for planting on dry banks or in rock gardens. The light-coloured flowers in May are followed by showy, though small, bright black fruits at a later date. Propagation is by seeds; plant in light soil. Pruning is unnecessary.

Enkianthus is a showy group of hardy or half-hardy deciduous shrubs, belonging to the Heather family (Ericaceae), and native of the Himalaya, China, and Japan. Like most other plants in the same order, they need moist soil which is fairly free from lime, and preferably containing peat. The flowers appear in May or June, usually with the young leaves, and they are whitc or sometimes reddish in colour. They should be given a sheltered position, where they are not affected by cold winds, for though perfectly hardy so far as winter cold is concerned, the young shoots are easily injured in spring. Propagation is by seeds and cuttings, and no pruning is necessary other than that given by "stopping" the shoots of young plants to induce a bushy shape. The chief kinds are: campanulatus, a Japanese 


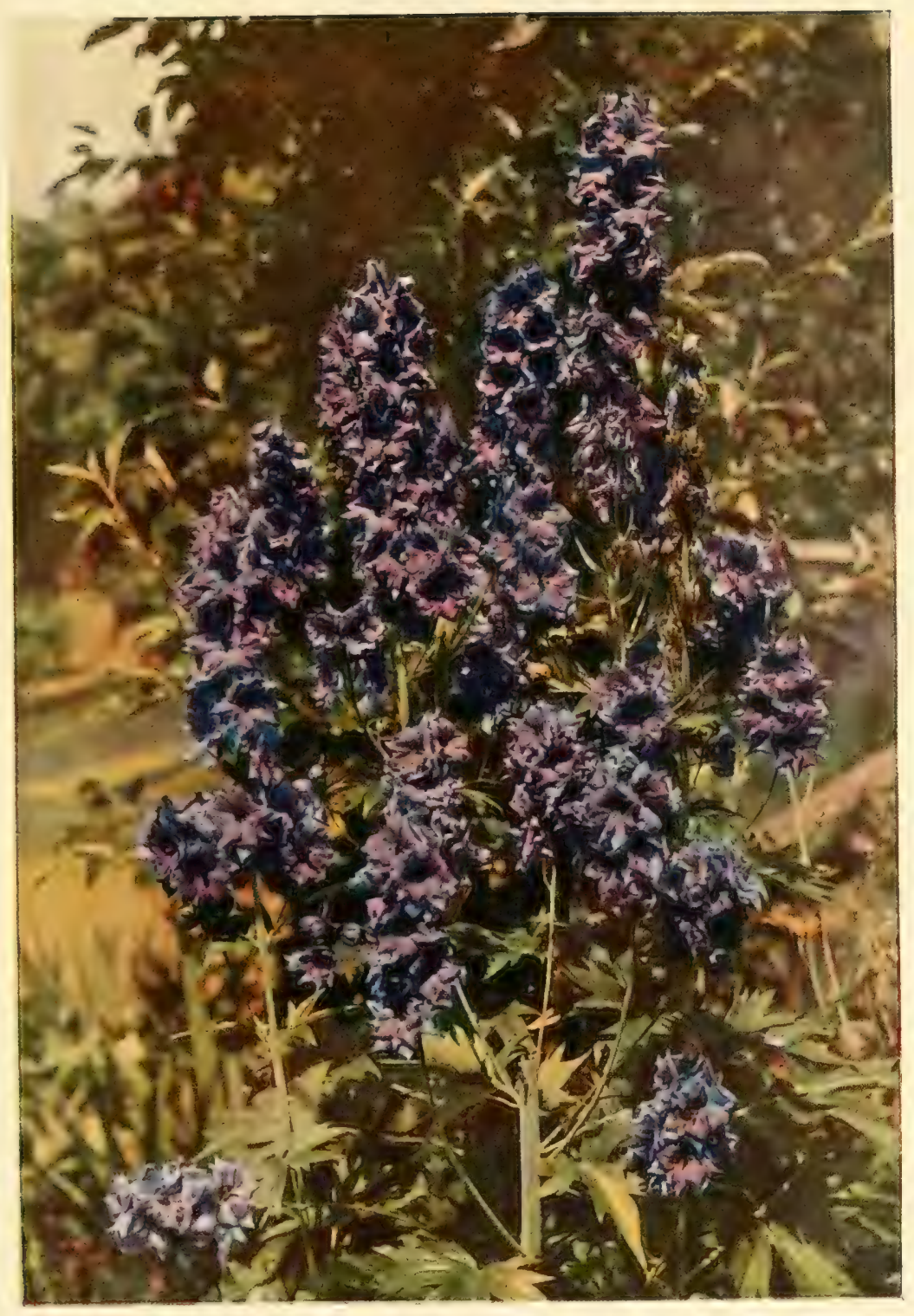

ONE OF THE MANY VARIETIES OF PERENNIAL LARKSPUR (DELPHINIUM) 


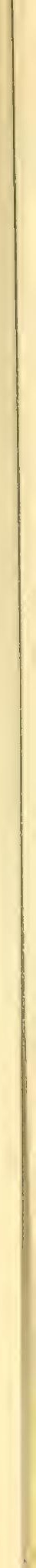


shrub, bearing red flowers in Nay; cernuus, from Japan, having reddish blossoms; himalaicus, native of the Himalaya and China, conspicuous by reason of its showy flowers, which, though usually yellowish, are sometimes red; japonicus and quinqueflorus have, usually, white flowers, though those of some forms of the last-named are rose.

Eomecon chionantha (Chinese Poppy Wort).-A pretty little member of the Poppy family (Papaveraceae), native of China, and seen at its best in a moist and partially shaded spot. It reaches a height of 12 inches or rather more, and has comparatively large heart-shaped leaves. The flowers, which open early in summer, are 2 inches or so in diameter, pure white, and very suggestive of those of a Poppy. It is an uncommon plant, and one that it is useless to attempt to grow in a hot, dry soil. Increase is mainly by division, which should be carried out just before growth recommences in spring ; this must be done very carefully, otherwise failure will result.

Ephedra.-This group of shrubs, though possessing considerable scientific interest as being the connecting link between Conifers and other kinds of plants, is not of any great horticultural value. The Natural Order is Cynetaceae. The species are natives of North and South America, Europe, and Asia, and form dense masses of green Rush-like shoots sometimes 2 or 3 feet, at others less than I foot, high. They thrive in light soil on rocky ground, may be increased by seeds or division, and do not require regular pruning:

Epigaea repens (May Flower).-This charming little shrub belongs to North America, and is a member of the Heather family (Ericaceae). It creeps along the ground, and spreads by means of shoots from the root-stock. The dark green oval leaves are thick and persist throughout the winter, and the fragrant, white, rosetinted flowers appear in clusters about the points of the shoots in April and May. It requires light peaty soil which is always moist, and must be in partial shade, bright sun soon proving fatal. Usually grown in the rock garden. Propagation is by division of the clumps or by seeds. Pruning is not required.

Epilobium (Willow Herb).-An extensive group of plants, belonging to the Evening Primrose family (Onagraceae), and found wild in various parts of the world. Many of them are troublesome weeds in this and other countries, while on the other hand the Rose Bay (angustifolium) is exceedingly ornamental, and of great value for the waterside or wild garden; it grows about 4 feet high, and in June and July bears long terminal spikes of bright rosy-purple blossoms; there is a white variety. Another desirable sort is Dodonoei, which 
grows about I2 inches high and bears pretty, bright rose-coloured flowers from June to August; it is a good rock garden plant for a sunny spot, and will stand drought well; hirsutum, a British plant, known in some districts as Codlins and Cream, grows over 3 feet high, and has pale pink flowers in July; it is essentially a plant for the wild garden, especially in moist spots. Hectorii is a tiny creeping plant from New Zealand with white flowers in summer; it is used in the rock garden, as also is the Californian kind, obcordatum, which is of creeping growth, and has showy rose-coloured flowers throughout summer. The last to mention is sericeum, which grows 3 or 4 feet high. The flowers are rose-coloured and are produced for a long time; it is fit only for the wild garden and waterside. All these Epilobiums are readily increased by division, which is best carried out in autumn.

Epimedium (Barren Wort).-A very pretty race of spring and early summer flowering plants of herbaceous character, belonging to the Barberry family (Berberidaceae); they are natives of Europe and temperate Asia. They grow about $\mathrm{I} 2$ inches high, and the leaves, which are on twiggy stems, are of firm, leathery texture. In autumn the leaves of most kinds assume beautiful tints, and often persist until well on in winter. These plants need a fairly moist, partially shaded spot, and a soil chiefly of sandy peat. The flowers, which are in loose panicles, are of various shades of white, yellow, and red. All are increased by division, which may be carried out in August and September or in early spring. The best are: alpinum, crimson and yellow; macranthum, white; macranthum violaceum, purplish ; Musschianum, white; Musschianum rubrum, red; Perralderianum, sulphur-yellow; pinnatum, deep yellow; rubrum, red; and versicolor, red and yellow. The sprays of beautifully tinted leaves are extremely useful in a cut state during autumn and early winter. In water they remain fresh and bright for a long time.

Epipactis (Helleborine). - A small group of terrestrial Orchids (Natural Order Orchidaceae), natives of the temperate regions of both hemispheres, and quite hardy in this country. They thrive in a compost of loam, peat, and sand in a moist, shady spot. The best are alba, with long racemes of white flowers; gigantea, flowers dark brown and purple; latifolia, greenish-purple; and palustris, whitish, tinged with red. These Orchids reach a height of from I to 2 feet and flower in summer. They are all increased by division in late summer.

Equisetum (Horsetail).-A strange class of leafless herbs (Natural Order Equisetaceae) with creeping perennial rootstock, and erect, 


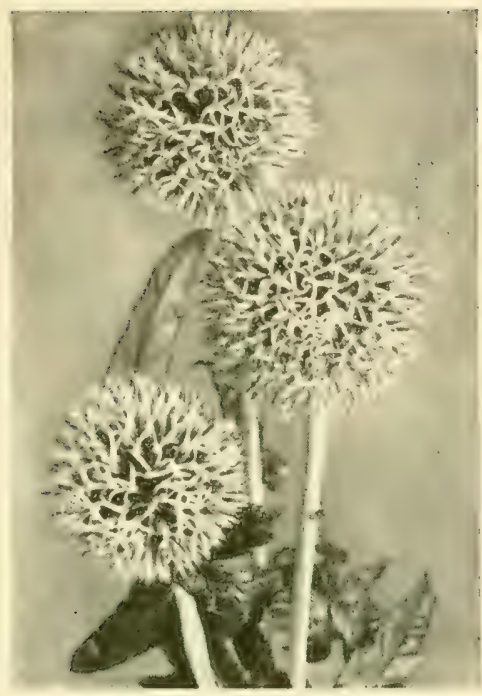

GLOBE THISTLE (ECHINOPS RITRO)

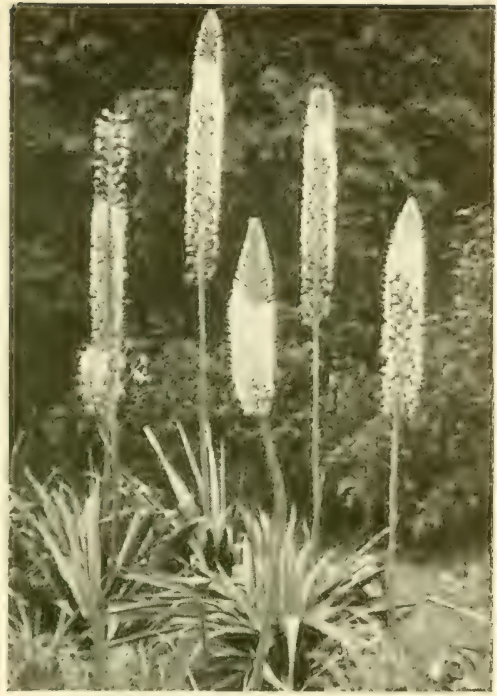

KING'S SPEAR (EREMURUS ROBUSTUS)

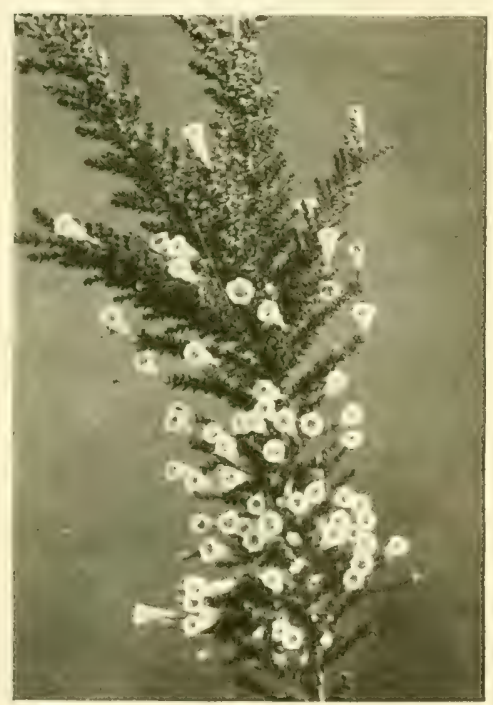

A PERUVIAN FLOWERING SHRUB (FABIANA IMBRICATA 

Rush-like, hollow, and jointed stems; the secondary branches are disposed in regular whorls. Most of them are troublesome weeds, but some are useful for planting in moist spots, such as in boggy plices or at the elge of the water. The best are: maximum, which in muddy places will reach a height of 6 feet, and sylvaticum, the most graceful of all; this will thrive in the wild garden under drier conditions than the preceding, but still it needs a good deal of moisture. On no account should it be introduced into cultivated ground, as it is a most pernicious weed.

Eragrostis (Love Grass).--Some very pretty grasses, both annual and perennial, are included among the various Eragrostis (Natural Order Gramineae). Those most generally grown for garden purposes are the annual kinds, elegans and maxima. The inflorescences of both are light and graceful, and if cut before they are too ripe and hung up to dry, they are useful for winter decoration. Eragrostis clegans reaches a height of about 18 inches, while the other is taller. Seeds of both may be sown out-of-doors in spring, and the flower-heads will develop in the course of the summer. They grow readily in ordinary garden soil.

Eranthis hyomalis (Winter Aconite).-A delightful flower of early spring; though the period of blooming varies somewhat with the season it is often in flower by January, while sometimes not over until March. It belongs to the Buttercup family (Ranunculaceae), is native of various parts of Europe, and a very old inhabitant of our gardens. The large Buttercup-like yellow flowers are encircled by a frill of green leaves, and the whole plant is not more than about 4 inches high when in bloom. It succeeds in ordinary garden soil, and whether as an edging to the flower border or grouped in the rock garden or under deciduous shrubs, it is equally appreciated, as practically the first of the New Year's flowers. It may also be planted in short grass. The small and curious tubers (roots) of the Winter Aconite may be bought cheaply, and should be planted in July and August or early September at the latest. A second kind, cilicicus, is in cultivation, but it is not common. The flowers of this are deeper in colour and later than those of the common Winter Aconite.

Ercilla volubilis. - The chief interest attached to this plant (Natural Order Phytolaccaceae) lies in its being

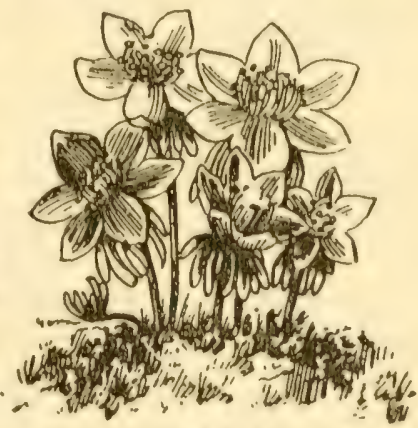

THE WINTER ACONITE (Eranthis hyemulis) 
an evergreen, self-clinging, climbing plant. It is a native of Chili and Peru, and can only be considered hardy in the milder parts of the country, although it may be grown against a wall in many places. It has bright green oblong leaves and small spikes of brownish flowers. The long trailing shoots produce aerial roots after the manner of the Ivy. Propagation may be carried out in summer by means of cuttings inserted in sandy soil in a frame. Any good garden soil suits its requirements, and pruning may be carried out in spring, all surplus growth then being cut back to within a bud or two of the main shoots. This climber is known also as Bridgesia spicata.

Eremurus (Giant Asphodel).-The Eremuri are among the most stately of herbaceous perennials; they belong to the Lily family (Liliaceae), and are natives chiefly of Central Asia. The leaves are long and strap-shaped, and from the centre of the tuft the flower spike arises. It is erect, as straight as a gun barrel, and in some kinds from 8 to ro feet in height. The upper half of the stem consists of a cylindrical spike of blossoms, which continue to unfold as the stem lengthens, the flowers are closely packed together, and a succession is kept up for some time during May, June, and July. The roots of the Eremuri are no less remarkable than the flowers, particularly those of Eremurus robustus and its varieties; the stout, fleshy roots radiate from the central crown like the spokes of a wheel, of which the crown itself forms the hub. As the roots are brittle and extend in a horizontal direction, it is evident that special care is needed in planting; the leaves appear early in spring, so a sheltered spot should be chosen for planting. Well-drained loam meets their requirements, they will not thrive in cold, heavy soil; some well decayed manure may with advantage be mixed with the original soil. Planting is best carried out in the autumn, and as the Eremuri are none too hardy, a slight covering of decayed leaves should be given, at all events during the first winter. The roots are put about 6 inches below the surface, and the hole prepared must be sufficiently wide to allow of the roots being spread out in a natural manner. Eremuri are increased by means of seeds, which ripen freely if the flowers are artificially fertilised. The seeds are sown as soon as ripe, and protected by a frame until they are large enough to plant out. The smaller kinds, such as Eremurus Bungei, produce offsets much more freely than the others. When planted in a bed or clump, Eremuri are seen to the best advantage against a background of shrubs, or a few plants look especially well in a large rock garden. If planted in a group the stronger growing kinds ought to be put from 5 to 6 feet apart. 
The best-known kinds are: Bungei, from 4 to 6 feet in height, with clear, yellow flowers; Himalaicus, white, 6 to 8 feet; Himrob, pale pink, 8 feet; Olgae, somewhat similar to Bungei, with white red-tinted flowers; robustus, the giant of the group, with rosy-pinkcoloured flowers, ro feet; robustus Elwesianus, flowers deeper colour ; and Warei, 6 to 8 feet, with reddish-bronze flowers:

Erianthus.-A small group of Grasses (Natural Order Gramineae), natives of different parts of the globe. The only species in general cultivation is Erianthus Ravennae, an ornamental perennial kind, with showy purplish plumes, seen to the best advantage during a hot summer. It will thrive in ordinary soil, but as warm a spot as possible should be chosen for it; the flower stem will reach a height of 6 feet.

Erica (Heath).-This is a very important group (Natural Order Ericaceae), inasmuch as it includes all the plants, hardy and tender, which are known under the popular name of Heath. Other plants are sometimes called Heaths, though this name is correctly applied to Erica only. The Ericas are found in two widely separate regions, Europe and South Africa. Those from South Africa are generally too tender for outdoor cultivation in the British Isles, though a few of the hardier kinds have been planted with success in Cornwall. About the middle of last century they were amongst the most popular of greenhouse plants, many varieties being grown, and the successful management of a collection was considered to be the supreme test of a gardener's skill. Now few sorts are grown, and their cultivation is usually in the hands of a few commercial firms, who grow the plants to flowering size and then place them on the market. As a rule, they are destroyed after flowering, although by care they may be kept for years.

With the European sorts it is quite different, for they have never been more popular than at present. Although all are not hardy throughout the British Isles, those from the more northerly regions are, whilst the southern sorts are appropriate for all the milder counties. Several species are natives of the British Isles.

Cultivation of the hardy kinds offers no serious difficulties, providing lime is not present in the soil to any serious extent. Even then one or two kinds may be grown. They thrive in both peat and loam, and give excellent results in sandy soil in which a little peat or leafmould has been dug. In preparing ground for Heaths, remove the turf or coarse weeds, then dig it over, afterwards forking leaf-mould or peat into the upper few inches. Plant in autumn or early spring, and be careful to water when necessary and keep the ground free from weeds until the plants can look after themselves. 
Propagation may be effected by means of seeds, layers, or cuttings. Perhaps the last-named method is the best. Cuttings must be taken during July or August and dibbled into pots of sandy peat made very firm, each pot then being placed under a bell-glass or handlight until the cuttings are rooted. They are then planted in a reserve border, and the points of the shoots must be removed frequently to induce a bushy habit. Pruning in after-life is restricted to cutting back the flower-bearing shoots as soon as the blossoms are over.

The tender kinds are also increased by cuttings, but they are grown in pots in a greenhouse throughout the greater part of the year. They are, however, usually plunged out-of-doors from the end of June to the end of August. The best results are obtained when they are placed in a light and airy house, on a stage covered with ashes. No artificial heat should be given until the temperature is likely to fall below $35^{\circ} \mathrm{F}$. Careful watering, thorough drainage, and firm potting in sandy peat are essential to success.

A good selection of hardy kinds includes: arborea, Tree Heath, native of the Mediterranean region, etc., grows 6 to 20 feet high and bears white fragrant flowers from March to May, hardy in the milder counties-the var. alpina has brighter green leaves, and is of more upright growth; australis, from Portugal, is another kind from the milder counties, it grows from 4 to 6 feet high, is of straggling habit, and bears large red flowers freely from March to May; carnea is a very hardy kind from the European Alps, growing 6 to 9 inches high, it bears reddish flowers from early February to May-the var. alba has white flowers; ciliaris is a creeping species which is found wild in the south-west counties of England, its red flowers are borne in summer: Maweana is a denser growing variety, 6 to 9 inches high, and one of the best of the late summer-flowering sorts.

Erica cinerea, the Common Heather of our commons and hill-sides, is a well-known decorative shrub of dwarf habit. Alba, white; atropurpurea, purple; atrosanguinea, rich red; coccinea, scarlet; and rosea, rose, are all excellent varieties. Lusitanica, often called codonodes, is largely grown in the South of England; its plumose branches, clothed with bright green leaves, are often 4 to 8 feet high, the white flowers commence to open in November, and flowers may still be found at the end of April. Mediterranea, a handsome kind from South-West Europe, forms a bush 4 to $\mathrm{I} 2$ feet high; it may be grown from the Midlands southwards and bears reddish flowers from February to May; alba, white; hibernica, a variety found in Ireland, and nana, of dwarf habit, are useful varieties; one called hybrida is a cross 


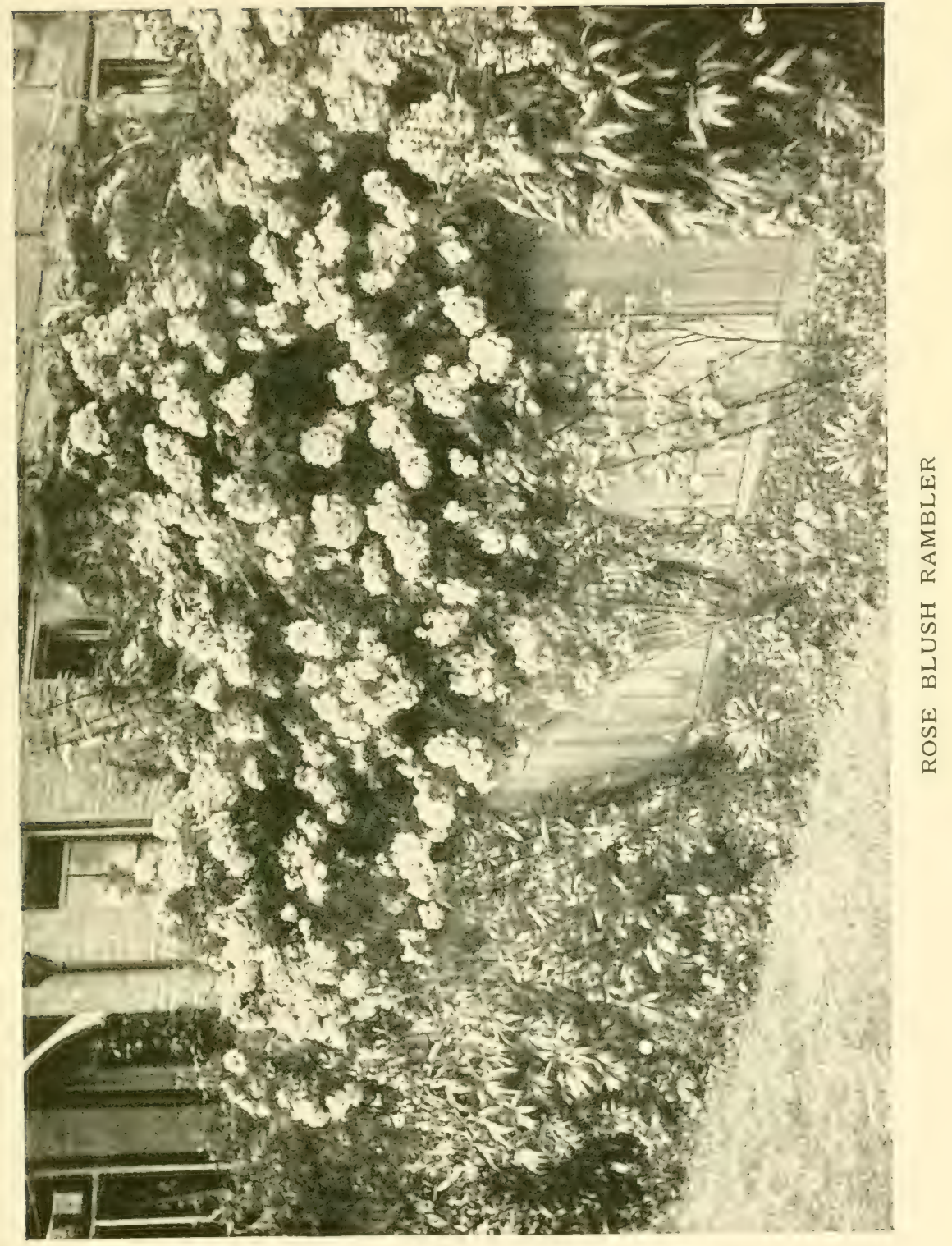



between mediterranea and carnea : it grows 12 to 15 inches high, and blooms continuously from November to May.

Erica stricta is a Heath of stiff growth from South Europe, the red flowers open in July ; vagans, the Cornish Heath, is a very useful autumn-flowering sort: there are forms with red, white, and pink blooms; Veitchii, a hybrid between arborea and lusitanica, bears its white flowers with great freedom in spring.

Among the chief greenhouse kinds are: caffra, an easily grown white-flowered kind from South Africa; Cavendishiana, a yellowflowered hybrid with long, handsome, wax-like flowers; gracilis, a handsome dwarf, autumn-flowering species with reddish flowers; hyemalis, a popular spring-flowering kind, with long, tubular, red and white blossoms; and melanthera, a vigorous white-flowered Heath from South Africa.

Erigeron (Flea Bane).-Aster-like plants (Natural Order Compositae), natives largely of North America, though some occur in the temperate regions of the Eastern Hemisphere. They will grow in ordinary garden soil, and may be readily increased by means of division in autumn, or by seeds sown in spring. The best are : alpinus, purplish blue, June and July, 9 inches; aurantiacus, bright orange, all summer, 6 inches; Coulterii, white, June to August, I2 inches; glabellus, violet, summer, 9 inches ; glaucus, purple, June to August, I2 inches; grandiflorus, lavender, summer, I8 inches; mucronatus, white, all the summer, 4 inches ; philadelphicus, rose, from spring until autumn, 2 feet, and speciosus, with its varieties. The typical Erigeron speciosus, which reaches a height of 2 feet, bears a profusion of deep mauve, Daisy-like flowers for several weeks in summer. There are some distinct forms of this species, namely : Asa Gray, apricot buff ; Edina, white; and Quakeress, lavender-blue. They are among the most useful of hardy border plants, and the flowers are valuable for cutting. After the earlier blooms are cut, secondary ones soon appear.

Erinacea pungens is a charming little plant for the rockery. It belongs to the Pea family (Leguminosae), and is a native of the Eastern Pyrenees and North-West Africa. Of tufted habit, it rises but a few inches above the ground and grows slowly, the branches having the peculiar rigid, stunted appearance common to many plants which occupy stony, arid regions. The Pea-shaped flowers are violet or bluish in colour and very attractive. In addition to being useful for the rock garden, it may be planted on dry, sunny banks. Propagation is by seeds, cuttings, or layers; loamy soil is suitable, and pruning is unnecessary.

Erinus alpinus.-An attractive rock garden plant, and equally 
desirable for wall gardening. It belongs to the Snapdragon family (Scrophulariaceae), and is native of the mountains of Western Europe. In narrow crevices and among the rocks it will grow and flower freely in light soil from April to June, soon forming a fair-sized plant. It may be increased by division, or, better still, by sowing seeds as soon as ripe where the plants are to grow. The plant itself is about 4 inches high, and the flowers are rosy-purple. There are two distinct varieties: albus, white, and carmineus, bright carmine.

Eriobotrya japonica (Loquat). - This shrub belongs to the Rose family (Rosaceae), is native of China and Japan, and is closely allied to the Medlar. It is, however, abundantly distinct both by its large, handsome, persistent leaves and by its clusters of golden fruits. In the mildest parts of the country it succeeds in sheltered places and against walls out-of-doors, and the white hawthorn-scented flowers are often borne late in the year. Fruits are, however, rarely developed here, though they are common and used for dessert in the South of France. However, the greyish oblong leaves, which are up to I2 inches long on vigorous plants, make it of sufficient importance for decorative gardening. Plant in loamy soil, increase by means of seeds, and prune in spring, but only when the plants are outgrowing their positions.

Eriogonum.-Although this is an extensive group of plants, few are in general cultivation. They belong to the Natural Order Polygonaceae, and are native of North America. The best and practically the only one that can be obtained from nurseries is Eriogonum umbellatum, a pretty little rock plant that forms tufts about 9 inches high, and bears small umbels of bright yellow flowers during summer. It prefers a well-drained, sunny spot and peaty soil, and can be readily increased by division.

Eriophorum (Cotton Grass).-Grass-like plants of the Sedge family (Cyperaceae), several of which are natives of Britain. The most desirable is angustifolum, about 2 feet high, bearing tufts of cottony white flower-heads. It is suitable for planting by the water's edge.

Eritrichium.-The chief plant of this genus, which belongs to the Borage family (Boraginaceae), is Eritrichium nanum, a lovely miniature alpine plant that is very difficult to grow, and sometimes referred to as the Glory of the Alps. It is a tiny Forget-me-not-like plant, about 3 inches high; the blossoms are of brilliant sky blue with yellow centre, and open in early summer. In the Swiss Alps where it grows wild, it lives in rocky crevices, and during winter is covered with deep snow. In our rock gardens it is most likely to succeed in the moraine, in stone chips mixed with a little sandy loam, 


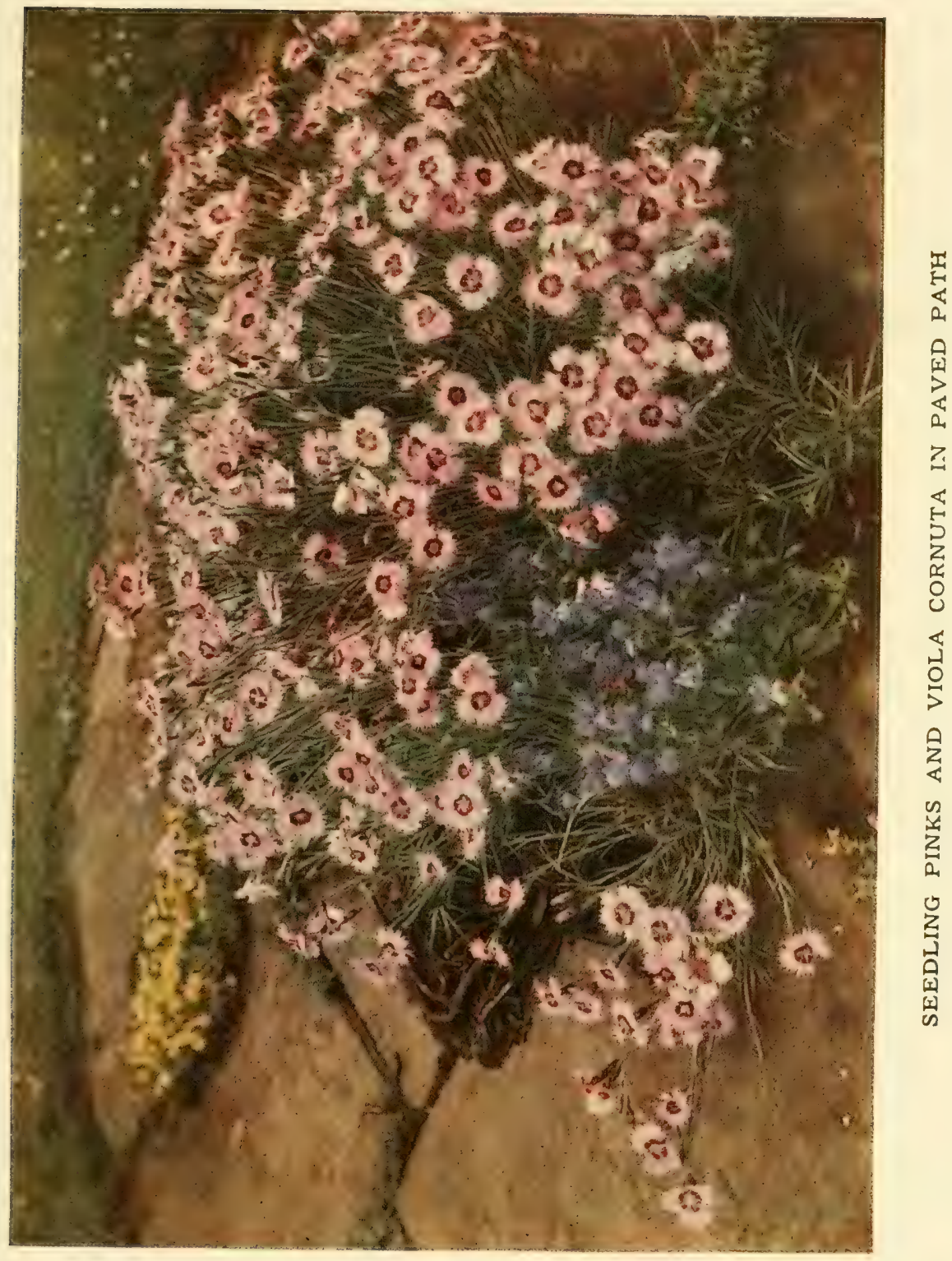


and when supplied with moisture from below. It needs to be sheltered by glass in winter to keep off heavy rains, though air must not be excluded. No one manages to keep it alive for very long.

Erodium (Heron's Bill). - These, which belong to the Geranium family (Geraniaceae), may be looked upon as dwarf forms of the hardy Geraniums, though most of them have markedly pinnate leaves. They are natives principally of the Mediterranean region, and thrive best on dry, sunny parts of rockwork, where they will bloom almost continuously throughout late spring and in summer. They are readily increased by seeds in spring or by division in September, and sandy loam suits them best. The most desirable are: alpinum, purple, I2 inches; chrysanthum, yellowish, 6 inches; guttatum, white, 6 inches; hymenoides, white, lower petals lined purple, I2 inches or more; macradenum, white, marked with violet, 6 inches; Manescavi, reddish-rose, 18 inches ; Reichardii, white, veined pink, 2 inches ; and Sibthorpii, pale lilac, 2 inches.

Eryngium (Sea Holly).-A striking group of summer-flowering, hardy, herbaceous perennials, belonging to the Natural Order Umbelliferae, natives principally of Mediterranean districts and South America. In general appearance they are somewhat Thistle-like, and are remarkable for the more or less blue tone of the foliage and flower heads. If cut when at their best and dried the flowers retain their colour for a long time. Eryngiums thrive in ordinary garden soil, and should be planted in full sunshine, as this tends to bring out the metallic blue lustre. They are readily increased by division in autumn. The most striking are: alpinum, flower-heads and leaves metallic blue, 3 feet; amethystinum, delightful amethyst blue; Bourgatii, I8 inches; giganteum, silvery white stems and flower-heads; Oliverianum, one of the finest coloured of all ; pandanaefolium, a tall grower, suitable for the wild garden; planum, the blue flower-heads of which are small and exceedingly numerous; and Zabelii, a finely coloured kind. Most of those of which the height is not given are from 3 to 4 feet.

Erysimum (Fairy Wallflower).- These plants are nearly related to the Wallflowers, to which some of the species bear a great resemblance. They belong to the same family (Cruciferae). There are both annual and perennial species, all easily grown, and usually raised from seed sown in autumn or spring. Of the annuals two are very showy: arkansanum, with bright yellow blossoms, like small Wallflowers; and Perofskianum, in which they are rich orange. Both these are among the most accommodating of hardy annuals, and if sown in autumn will survive the winter and flower in spring; those 
sown in April will make rapid progress and yield a wealth of blossoms in summer. Self-sown seedlings frequently spring up in considerable numbers. The best kinds, in addition to those named, are : asperum, yellow, 8 inches, biennial; asperum purpureum, purple; helveticum, orange, 12 inches, perennial; pulchellum, yellow, 6 inches, perennial ; pumilum, yellow, 2 inches, perennial ; and rupestre, about 3 inches, perennial. The three last-named are easily grown rock garden plants.

Erythraea (Centaury).--Pretty flowering plants, nearly related to the Gentian (Natural Order Gentianaceae). They are widely distributed in various countries. Some are only of annual duration, one of the best of this class being Centaurium, which grows about $\mathrm{I} 2$ inches high and bears bright rose-coloured blossoms during summer. Other annual kinds are spicata and venusta, both with pink flowers. Of the perennials practically the only one met with in gardens is Mussonii, more generally known as diffusa; this forms a neat-growing little plant about 4 inches high, studded with bright rose-coloured flowers throughout the summer. It is suitable for a sunny spot in the rock garden. The annuals seed freely, and the last-named kind may be increased by division, best carried out in late summer or early spring before growth recommences.

Erythrina (Coral Tree).--Several of the Erythrinas, which belong to the Pea family (Leguminosae), form good-sized trees in warmer countries, and with us need the accommodation of a large glass house. Practically the only one grown in gardens is the Brazilian Erythrina Crista galli, which is used for summer bedding. It forms a stout, woody rootstock, from which annual shoots grow 3 or 4 feet high; these are furnished with trifoliate leaves, and during August bear deep scarlet Pea-shaped blossoms. After flowering the stems gradually die away, leaving only the sturdy rootstock or trunk. This ought to be wintered where it is safe from frost, during which period it must be kept practically dry at the root. In spring, when young shoots make their appearance, a light position in the greenhouse is necessary. The plants, kept in their large pots or tubs, are placed out-of-doors in early June. If the plants need repotting it should be done in spring before growth recommences, using for the purpose a compost made up of loam, leaf-mould, and sand. However, when established in large pots, annual re-potting is not needed. If planted in a sunny corner formed by two greenhouses or walls, the Erythrina will pass the winter if the dormant root is protected by mats. It is propagated by cuttings of the weakest of the young shoots taken in spring, when they are 4 inches long, and put in pots of sandy 
soil in a closed case in the greenhouse. A second species, even hardier than the other, is herbacea, from the Southern United States. It is, however, not much grown, as it often fails to flower in a satisfactory manner.

Erythronium (Dog's Tooth Violet).-A charming group of early spring flowers, belonging to the Lily family (Liliaceae). They form small, curious-shaped bulbs, suggestive of a dog's tooth, hence the popular name. The leaves, which are broadly oval, are mottled and marbled with purplish-brown and white, and are attractive in early spring. The solitary drooping flowers are about 2 inches in diameter with reflexed segments, and on stems about 6 inches high. This description refers especially to the European Dog's Tooth Violet (Erythronium Denscanis), but a strong family likeness runs through all of them. The flowers of Denscanis vary from white to purple, through various intermediate shades of pink and rose. There are also some fine varieties raised in Holland, which are likely to supersede the common kind. Erythroniums may be planted towards the front of the flower border, and are also favourite rock garden plants. They prefer

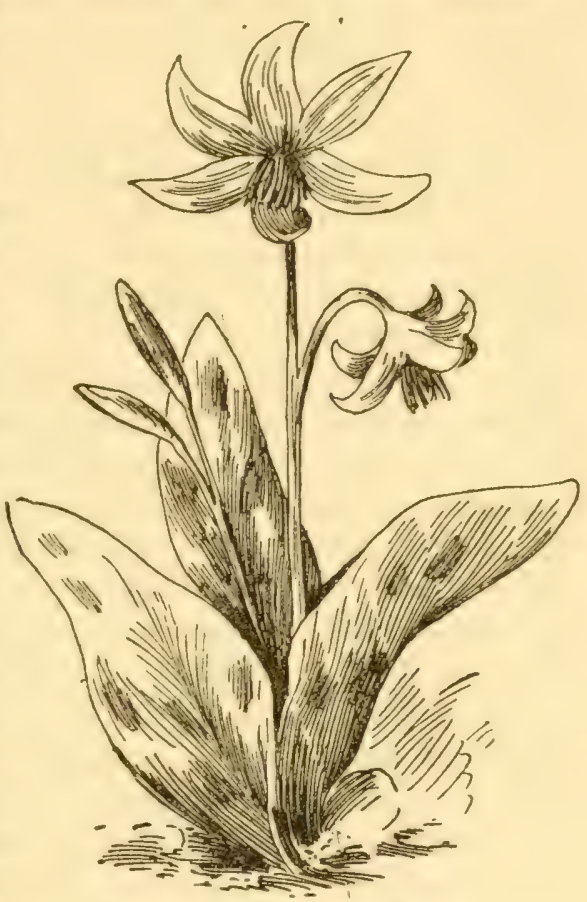

THE DOG'S TOOTH VIOLET

(Erythronium) partial shade and a moist, peaty or leafy soil. The American kinds need a sunnier spot than the others. Chief among them are: albidum, white, purple tinted ; americanum, yellow ; grandiflorum, bright yellow; Hartwegii, yellow; Hendersonii, pale purple; Howellii, pale yellow, orange base, suffused purple; Nuttallianum, yellow, red anthers; and revolutum, pinkish-purple, afterwards deepening in colour.

Escallonia.-Important shrubs belonging to the Natural Order Saxifragaceae; the majority are evergreens and bear showy flowers. They are largely natives of Chili, a few coming from adjoining countries, 


\section{I76 THE BOOK OF HARDY FLOWERS}

whilst several useful hybrids have been raised. Unfortunately, they are not very hardy, and with a few exceptions are only available for the mildest parts of the country. There, however, they are invaluable, for they thrive close to the sea, and one kind particularly, Escallonia macrantha, from Chiloe, can be used for hedges to protect other plants which are more susceptible to injury from the sea air. They thrive in any good garden soil, are easily increased from cuttings in summer, and require no regular pruning. Plants grown against walls or bushes which are outgrowing their positions, may be cut back in spring. As groups in the shrubbery or as specimen plants or hedges, Escallonias are useful. The hardiest kinds are the white-flowered philippiana from Valdivia, a deciduous shrub 3 to 4 feet high; Langleyensis, an attractive garden hybrid of loose growth, which bears showy pink flowers with the greatest freedom; and the white-flowered exoniensis, which forms a bush I $_{5}$ feet or more high. For the milder counties Escallonia macrantha is the most useful of all ; it is an evergreen with bold dark green leaves, and it bears a profusion of rich rose-coloured flowers. Other good sorts are: floribunda, pterocladon, pulverulenta, and rubra; montevidensis should be grown against a wall; it bears large heads of white flowers late in the summer.

Eschscholtzia (Californian Poppy).--One of the showiest of hardy annuals; it belongs to the Poppy family (Natural Order Papaveraceae). The typical Eschscholtzia californica, which has given rise to the various forms now in cultivation, forms a wide-spreading plant from I2 to I8 inches high, with pretty, much-divided, glaucous foliage, and bears for weeks in summer large Poppy-like flowers of brilliant yellow with orange centre. The range in colour of the garden varieties is now considerable, varying as they do from almost white to deep ruby red. Among the best are : Carmine King, rich carmine, suffused with orange; Diana, pale pink; Mandarin, orange, scarlet, and gold ; Mikado, orange-crimson; Rose Cardinal, deep rose ; and Ruby King, deep ruby. Eschscholtzias are not at all particular as to soil; they will grow on poor ground, but they must have a sunny spot, as it is only then that their brilliant flowers are seen at their best. The seed-pods must be cut off as soon as the flowers drop, or the period of blooming is shortened. The seed may be sown either in autumn or spring ; the seedlings should be thinned out to about 9 inches apart.

Eucalyptus (Blue Gum).-Among the Eucalyptus, which belong to the Natural Order Myrtaceae, are found the largest growing trees of the Southern Hemisphere, and probably of the world, for some are said to exceed the dimensions of the Sequoias of California ; the timber of numerous kinds is very hard and durable. Jarrah and Karri, which 
are probably the two most serviceable woods known, and are used for street paving, are species of Eucalyptus, the former being the wood of marginata and the latter of diversicolor. Although natives of Australia, the Eucalyptus adapt themselves quickly to the conditions of other countries, and large quantities are being grown in South Africa, British Central Africa, California, and elsewhere. Many of them can be grown out-of-doors in the milder parts of the British Isles. The hardiest is Gunnii, after which come Globulus, amygdalina, and robusta. Eucalyptus Globulus is often grown in pots, and is used for summer bedding on account of its showy glaucous blue leaves. There are trees 30 to 40 feet or more high in Cornwall. Plant in any good garden soil. Regular pruning is unnecessary. Most of the Eucalyptus are easily raised from seed sown in a greenhouse in spring, and grow quickly.

Eucharidium.-Two useful summer flowering annuals, natives of California, are found among Eucharidium, which belongs to the Evening Primrose family (Onagraceae). They are very uncommon, but well worth more extended cultivation. Eucharidium Breweri is about 6 inches high, with pale rose-coloured blossoms; while those of concinnum, a somewhat taller plant, vary from lilac to purple. The seed may be sown in early autumn for early summer bloom, while a sowing in April will give a display from July onwards. Well-drained sandy loam is a suitable soil, though these plants are not fastidious, but full exposure to sunshine is necessary.

Eucomis.-Pretty, free-flowering, bulbous plants, members of the Lily family (Liliaceae), and natives of South Africa. The hardiest and most ornamental kind is punctata, which forms a tuft of prettily undulated leaves, and produces a stout, erect flower stem, 2 feet high, and curiously mottled with brown, bearing in summer or early autumn numerous blossoms; these, which are crowded together on the upper part of the stem, are greenish-white, tinged with rose. Other kinds are: pallidiflora, taller and with greenish-white flowers, and regia, white. Eucomis is not thoroughly hardy, and is usually grown in a grecnhouse. The plants will, however, thrive in a narrow, sunny border at the foot of a south wall, providing the soil is good loam and well drained; the bulbs should be planted about 6 inches deep. Planting is best done in autumn as soon as the leaves die down, and the bulbs may be protected in winter by a few leaves or Cocoanut fibre refuse. They produce offsets which are available for purposes of propagation, while they can also be raised from seeds; in the open these rarely ripen, but they will do so if the flowers are artificially pollinated and the plants kept in the greenhouse. 
Eucommia ulmifolia is a new shrub from China, belonging to the Natural Order Trochodendraceae. It is of rapid growth, and forms an upright-growing tree or large bush. There is nothing, however, about either flowers or leaves to attract attention, but it is of interest because all parts of the plant contain caoutchoue, or an inferior kind of rubber, a product which is not known to occur in any other tree or shrub hardy in this country. In China the bark is said to be a valuable medicine. Male and female flowers are produced on different plants, but neither is showy. Plant in loamy soil, propagate from cuttings, and cut away the lower branches when necessary, clearing the leading shoot and shortening the sideshoots at the same time. Summer is a good time for the work.

Eucryphia.-This is a very showy group of shrubs, belonging to the Rose family (Rosaceae). Three species are in cultivation: Billardieri from Tasmania, and cordifolia and pinnatifolia from Chili. The lastnamed is the best known and hardiest ; it grows to a height of from 12 to 20 feet, with a wide spread. The dark green leaves are usually made up of about five narrow leaflets, which may be either deciduous or persistent, according to the climatic conditions. The white flowers are nearly 3 inches across; they are borne in July in sufficient numbers almost to hide the leaves. Eucryphia cordifolia is an equally showy bush with simple, oblong, evergreen leaves and white flowers. It is more tender, and only suitable for the warmer counties. The Tasmanian kind has smaller leaves and flowers, and is an inferior bush. Plant in well-drained warm loam containing a little peat, and propagate from seeds whenever it is possible. Plants are sometimes raised from layers, but they are never very satisfactory. No regular pruning is required, but a few of the weaker inside shoots may be removed occasionally. It is not wise to transplant the bushes oftener than is absolutely necessary.

Eugenia.-A large group of trees and shrubs allied to the Myrtles (Natural Order Myrtaceae). Several grown in the gardens of the south-west counties under the name of Eugenia are really species of Myrtus. Thus Eugenia apculata is really Myrtus Luma and Eugenia Ugni is Myrtus Ugni. These are referred to under Myrtus. The majority of the true Eugenias are tropical trees or shrubs which are widely distributed in Brazil, India, Malaya, Australia, and other countries. Many of them bear handsome edible fruits. Of these Jambos, the Rose Apple of tropical Asia, and malaccensis, the Malay Apple, are two of the best known. The wood of some kinds is also of value. A few are sometimes grown in tropical glasshouses in this country, but they are not common. 
Eulalia (Miscanthus).-An ornamental group of Grasses (Natural Order Gramineac), natives of China and Japan. The only kind in general cultivation is Eulalia japonica with its varieties. This forms a tuft of tall stems to a height of 5 to 6 feet or even more, the leaves recurve in a graceful manner, while the crown-like inflorescence, which well overtops the foliage, is striking. The varieties are : albo lineata, leaves striped with white; gracillima, of graceful habit, the long, narrow leaves having a white midrib ; and zebrina, remarkable from the fact that bars of yellow run across the leaves instead of longitudinally, as in most variegated-leaved Grasses. Eulalias thrive in ordinary garden soil, provided it is fairly moist, while they are effective by the side of water. Two varieties, namely, albo lineata and gracillima, when grown in pots are sometimes used as "dot" plants in summer bedding.

Euonymus. - Evergreen and deciduous shrubs (Natural Order Celastraceae), which are of considerable value in the garden. A few kinds are not generally hardy, however. The majority bear handsome fruits, and are cultivated for that purpose alone; others are grown for their evergreen leaves and their ability to withstand the effects of a salt-laden atmosphere

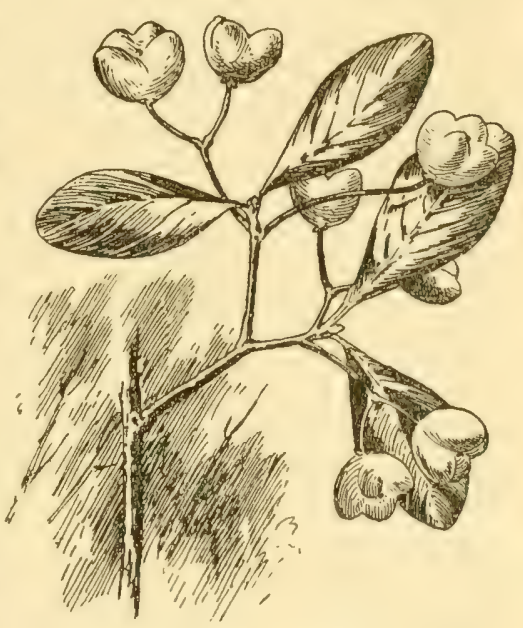

FRUITS OF THE SPINDLE TREE (Euonymus europaeus) within a few feet of high-water mark near the sea; whilst others, again, are showy in autumn by reason of their richly coloured leaves. They are found in Europe, Asia, and North America, whilst one species, europaeus, is included in the British flora. They thrive in ordinary garden soil, are propagated by seeds or cuttings, one kind, radicans, by division, and any necessary pruning should be done in summer. Euonymus alatus is most showy by reason of its autumn tints, whilst the fruits of europaeus, americanus, latifolius, and oxyphyllus are very attractive. Euonymus japonicus is very useful, as it forms a large bush quite close to the sea, and can be used for all kinds of purposes, including hedges. Its rich dark green leaves are always attractive, whilst its golden- and silver-leaved varieties are in constant use as garden shrubs in the south and for greenhouse decoration farther north. Its one defect-at least in 
inland gardens-is its liability to attacks from caterpillars of, chiefly, the Magpie Moth. Euonymus radicans is also useful, as it grows almost as well as the common Ivy beneath the shade of trees. The clumps may be divided and the sections planted I2 inches apart on bare ground, when they will soon grow into a dense mass. By clipping over in May or June a good carpet is formed; both green and silver varieties can be procured.

Eupatorium (Hemp Agrimony).- - Herbaceous perennials or subshrubs belonging to the Daisy family (Compositae), and natives chiefly of the Western Hemisphere. Those from North America are quite hardy, while some tender kinds, fit only for the greenhouse, occur farther south. Those suitable for the herbaceous border, or for the wild garden, for they will hold their own almost anywhere, even in boggy places, are: ageratoides, 3 or 4 feet high, with large heads of small white flowers in late summer and early autumn; cannabinum (native of Britain), taller, bears terminal umbels of pink flowers in late summer, while the North American kind, purpureum, has deep purple flowers. This, which blooms at the same season, grows 5 or 6 feet high. All are readily increased by division.

Euphorbia (Spurge).- There are hundreds of Euphorbias (Natural Order Euphorbiaceae), but few of them are of garden value, and some are tender and quite unfitted for the open garden. Among the best are: capitata, I6 inches high, with little grey Box-like foliage and yellow flowers; Characias, 2 feet, long glaucous leaves and greenish flowers with dark centre; Cyparissias, I2 inches, yellowish-green, on a dry, stony bank in full sun the pale green leaves of this kind change to a brilliant red, in which stage it is very effective. One of the best of all is Euphorbia epithymoides, of which the young leaves, floral bracts, and blossoms are of a golden tint; it reaches a height of about I foot, and is at its best in spring, becoming greener as the season advances. A pretty little trailing plant is Euphorbia Myrsinites, with small glaucous leaves and bright yellow flowers: The leaf-like bracts, which surround the flower-heads and are of the same golden tint as the blossoms, render Euphorbia pilosa major very attractive during May and June; it grows about 18 inches high. $\Lambda$ more continuous flowering kind than most others is Euphorbia polychroma, with yellow flower-heads and bracts. The last to mention is the largest of all, namely, Euphorbia Wulfenii, that forms a sturdy bush 4 to 5 feet in height, with glaucous foliage and greenish-yellow flowers.

Euphorbias are well suited for planting in dry, stony soils, as under such conditions the colouring of the leaves and floral bracts 


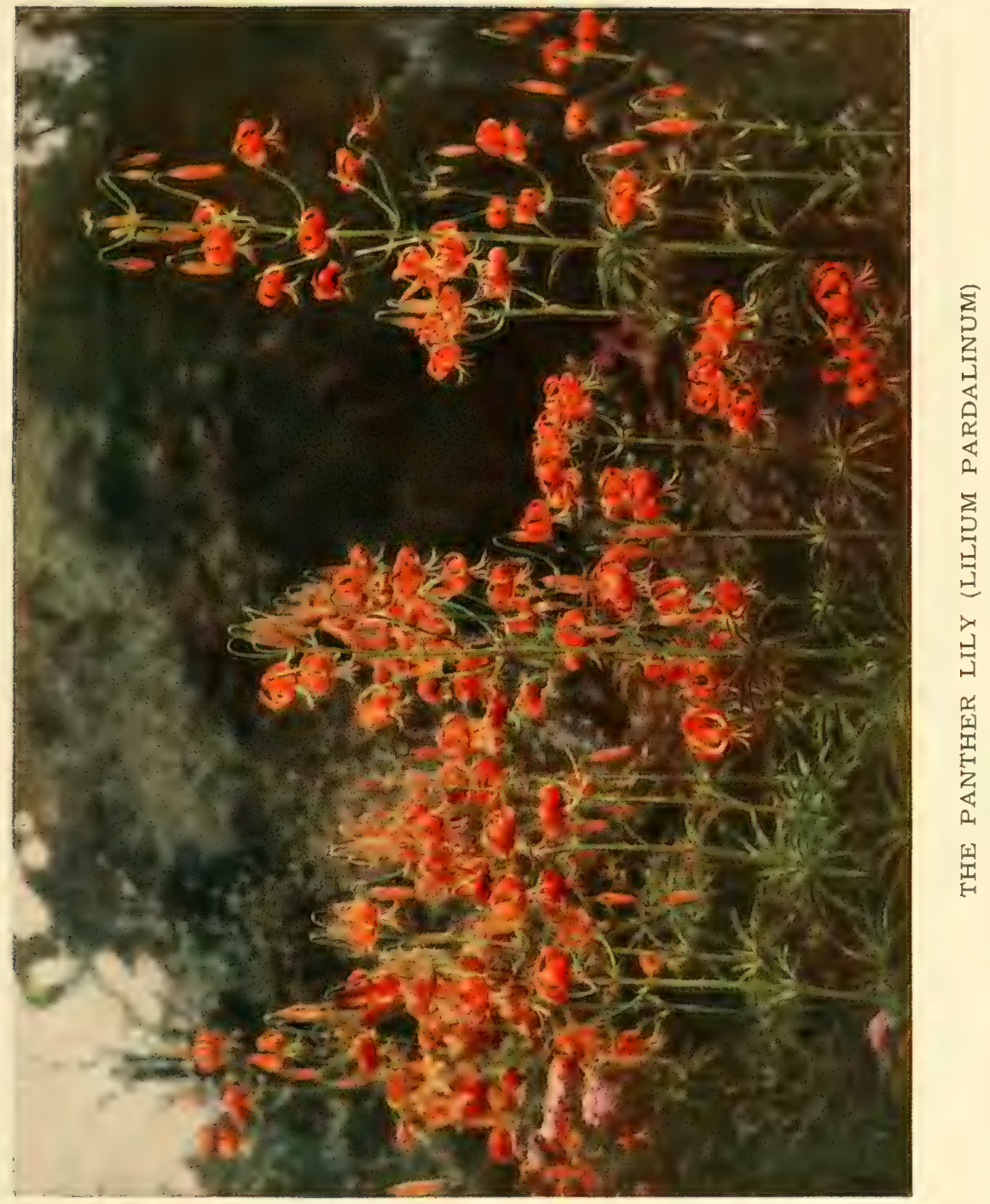



is much brighter than in richer soil. They are readily increased by division.

Eurya.-Evergreen shrubs, near relatives of the Camellia (Natural Order Ternstroemiaceae), which in general appearance they somewhat resemble. The hardiest is Eurya japonica, but even this is available only for planting in particularly favoured spots, such as the extreme south-west of England. The best known is japonica latifolia variegata, in which the young leaves are freely variegated with various shades of green and yellow, suffused with red. As the leaves mature the reddish tint disappears, but the different tones of yellow and green remain. This plant is occasionally used in summer bedding. it must be wintered in the greenhouse. Cuttings of the half-ripened shoots, put in a closed case in a slight warmth in July, can be tried, but they do not root at all readily. It is of neat growth, and requires no pruning beyond that necessary to keep the plants shapely.

\section{Evening Primrose.-(See OENOTHERA.)}

Everlasting Pea.-(See Lathyrus.)

Exochorda.-Two kinds of Exochorda (member of the Rose family, Rosaceae) are known, one a native of Turkestan and the other of China. They are large-growing bushes allied to Spiraeas, their flowers are, however, considerably larger. The cultural requirements are similar to those of the spring-flowering Spiraeas, for they thrive in loamy soil, may be increased by means of cuttings in summer, or by seeds, and require no regular pruning. What little pruning is done should take the form of thinning away weak inside shoots during summer. They must be given a sunny position, and are suitable for the shrubbery or for planting as isolated specimens. The flowering time is May. The species are: Alberti, from Turkestan, a bush 8 or Io feet high; and grandiflora, from China, which grows from I2 to 15 feet in height. The flowers in both instances are white.

Fabiana imbricata.-An interesting and decorative plant belonging to the Potato family (Solanaceae) and a native of Peru and adjoining countries, suitable for the open ground in the southern counties, for walls in the Midlands and west, and for the greenhouse elsewhere. Its growth is suggestive of that of the Heaths, for the tiny evergreen leaves are produced closely together on upright branches, which attain a height of 3 to 4 feet. The tubular white flowers, each $I$ inch long, which appear from the leaf axils during late spring or early summer, are, however, quite distinct. It grows in ordinarily good garden soil, is increased from cuttings during spring and summer, and its branches should be shortened by several inches after flowering. 
Fagus (Beech).--The most important species in this group (Natural Order Cupuliferae) is the Common Beech, Fagus sylvatica, a wellknown forest tree in the British Isles and throughout a considerable part of Europe. There is, however, another hardy Beech, also a tree, native of North America, namely, Fagus ferruginea, the American Beech. Several kinds from South America and from New Zealand are sometimes included with Fagus; they are, however, correctly named Nothofagus.

Beech, though available for general cultivation throughout the British Isles, is peculiarly adapted for chalky land, and attains great luxuriance in the neighbourhood of the Chiltern Hills, a well-known chalky district. There the wood has become very popular for the manufacture of chairs, toys, backs of brushes, and all kinds of small articles. It is a valuable tree for ornamental planting, and is also esteemed by the forester not only for the value of its timber, but because its heavy leafage enriches the ground upon which it grows. It can also endure a considerable amount of shade in its youth, and is useful for underplanting thin woods composed of large trees. There are many garden varieties, of which those with purple- or copper-coloured leaves are the most popular. Good ones are: atropurpurea norwegiensis, purpurea major, and "Sweet Margaret," with purple leaves; cuprea, with copper-coloured foliage; macrophylla, and Prince George of Crete, with very large leaves; and pendula, pendula borneyensis, and miltonensis, with weeping branches. Fagus ferruginea may be grown as a change.

The species are raised from seeds sown as soon as ripe, and the varieties by grafting upon stocks of the type. Pruning should take the form of keeping the trees to a single trunk, and to the thinning of surplus and the removal of lower branches from young trees. This may be done in summer. The Common Beech is often used for hedges.

Fairy Rings.-Disfiguring marks, circular in outline, are often found on lawns, golf greens, tennis courts, and bowling greens; they are known familiarly as "fairy rings," and are due to the presence of fungi. Several kinds of fungus act in a similar manner, one of the commonest being Marasmius oreades. A ring may originate from a single spore. The mycelium or underground stage of the fungus always grows in a circular manner and in an outward direction, thus continually adding to the circumference of the circle. During summer or early autumn the fructification stage appears in the form of small toadstools, from which spores are distributed to other places. There are two methods of destroying the fungus. One is to dig the mycelium out, which can be done by removing the soil to a depth of about 
Io inches, taking care to remove 3 or 4 inches of the grass beyond the outer edge of the ring, and filling with good soil ; and the other method is thoroughly to soak the affected area with water containing sulphate of iron at the rate of I pound of the chemical to I $\frac{1}{2}$ gallons of water. The mixture must be applied when the ground is wet, and sufficient should be given to soak the soil.

\section{False Daisy.-(See Bellium.)}

False Starwort.-(See BoltoniA.)

Fatsia (Aralia).-This genus is composed of shrubby plants (Natural Order Araliaceae), which are closely related to the Aralia. The two hardiest kinds are : horrida, a spiny shrub from North-West America and North-East Asia; and japonica, a native of Japan. The former is of little horticultural importance, but japonica is an excellent evergreen for the southern counties in almost any soil. It forms a large bush with comparatively few branches, each one terminated by a fine head of large, dark green, fan-shaped leaves. Very late in the year, often in October, immense inflorescences of cream-coloured flowers appear. Ivy-like fruits are sometimes matured, and the seeds form a good means of increase. Cuttings of the smaller shoots can also be rooted by inserting them in a warm and closed frame in spring or summer. There is a variety with pretty silver variegated leaves; it is somewhat less hardy than the type. Both plants are sometimes grown in pots for room decoration under the wrong name of Castor Oil Plant.

Fendlera rupicola.-This is a rare and pretty shrub (Natural Order Saxifragaceae) from the South-West United States. It is of slender twiggy growth, bearing small, greyish-green, ovate leaves, and white flowers in May, which are nearly I inch across. Except in the warmer counties, it is unsuitable for borders, and should be given a position against a south or west wall, using loamy soil in which a little peat or leaf-mould has been mixed. It is increased by cuttings in summer, and needs no other pruning save what is necessary in order to train it to a wall. A sunny position is essential to success.

Ferula (Fennel).-Decorative herbaceous plants belonging to the Natural Order Umbelliferae, known under the common name of Giant Fennel. The various kinds thrive in any rich garden soil, such as suits other herbaceous plants, and should only be planted in places where they can have abundance of room, for it is only when the large finely. cut leaves are not crowded by other plants that their beauty is appreciated. They are found in South Europe, Persia, the Canary Islands, North Africa, and other countries, and upwards of a dozen species can be procured. A few of the best are: communis, from the Medi- 
terranean region; Ferulago, South Europe; glauca, South Europe; and Narthex, from the Orient. All have yellow flowers in large inflorescences. Asafoetida of commerce is obtained from Ferula Asafoetida. All may be increased by seeds or by division:

Festuca. - This group of Grasses (Natural Order Gramineae) contains a number of useful perennial kinds usually included in mixtures of seed for permanent pastures and for lawns. The more important ones for this purpose are duriuscula, the Hard Fescue Grass ; elatior, Dover Grass; elatior var. pratensis, Meadow Fescue Grass; ovina, the Sheep's Fescue Grass; ovina, var. tenuifolia; and rubra, the Red Fescue Grass. They are common European Grasses (included in the British Flora) of neat growth, and constant mowing assists them to form a compact, velvety sward. They give good results on light soils, and when a particularly close surface is required a dressing of sea sand now and then is of great assistance. Festuca glauca is a pretty kind, with blue-green leaves.

Ficus (Fig).-The importance of this genus (which belongs to the Natural Order Urticaceae) is considerable, although its value is more fully appreciated in the Tropics than elsewhere. The various species are very widely distributed through tropical Asia, Africa, Australia, etc., and they vary considerably in growth, some being weak, climbing, or prostrate shrnbs, others small trees, and others, again, trees of considerable dimensions. In one instance the fruit is an important article of commerce in both fresh and dried conditions, whilst one kind, the Common Fig (Ficus carica), is grown in this country solely for its fruit in many gardens. Then, a valuable rubber is produced by some species, notably elastica, from India, and Vogelii, from Lagos. A rubber-like substance is, however, present throughout the genus, for if an incision is made in the stem of any kind, a white, milky exudation will occur. This, if touched, will be found to be of a viscid nature. Another interesting tree is Ficus Sycamorus, sometimes called the Sycamore Fig of Egypt. The fruits are eaten by the Arabs, and the timber is of interest as being the so-called Sycamore Wood of Egypt, from which the ancient Egyptians often made coffins, etc.

Ficus carica, the Common Fig, native of Afghanistan and Eastern Persia, is a familiar bush or small tree in this country. It is moderately hardy, and grows quite well as a bush in the open in many parts of the United Kingdom. Fruits are not ripened regularly, however, except against warm walls or under glass. The ornamental leaves warrant its being placed in a shrubbery, where it may be expected to grow quite well in ordinary garden soil, and to require no regular pruning. 
Ficus elastica is probably next in importance, for its large, leathery, evergreen leaves make it valuable for both greenhouse and room decoration. It is propagated by means of cuttings, buds, or by "ringing" the terminal shoots of plants which have become bare below.

\section{Fishbone Thistle.-(Sec Chamaepeuce.)}

Fitzroya patagonica is a handsome evergreen Conifer (Natural Order Coniferae). It is a native of the mountains of Western Patagonia, Chili, and Valdivia, and has only one known relative, that being Fitzroya Archeri, from Tasmania. Fitzroya patagonica forms a small tree of upright growth with elegant branchlets clothed with tiny darkgreen leaves. It is at home in the gardens of the south-west counties, Ireland, and other places, where similar climatic conditions prevail, and is seen to the best advantage when grown as an isolated specimen in a sheltered position. Moist but well-drained soil is necessary, propagation is by seeds or cuttings, and pruning is unnecessary except to keep the plant shapely.

Fleabane.-(See ERIGERON.)

Flowering Rush.-(See Butomus.)

Foam Flower.-(See TiARella.)

Forget-me-not.-(See Mrosotis.)

Forsythia (Golden Bell).-An important group of shrubs belonging to the Natural Order Oleaceae. All bear yellow flowers and blossom during April. There are three species, a hybrid, and several varieties. Two of the species are natives of China and the third of Albania. All thrive in ordinary garden soil, and are available for cultivation in most parts of the British Isles. Cuttings of soft shoots inserted in a little warmth root quickly during June. In addition to being of the greatest value for groups in the open or in the shrubbery, they may also be used for forcing, and good-sized plants are very pleasing when arranged with Ferns, Palms, or other foliage plants. Forsythia europaea is not so ornamental as the rest; it forms an upright bush 4 feet or so high, and should only be selected when a full collection is desired. Forsythia suspensa is one of the twelve best early-flowering shrubs; in its normal condition it forms upright main growths, with long, pendent, secondary branchlets, and it is from these that the flowers appear from almost every bud. When planted against a trellis, wall or other support it is very effective, whilst it looks well in a shrubbery. It may, however, be grown in quite a different manner. If planted in the open and cut back each year, strong, erect stems, 3 to 4 feet long, are formed instead of the slender pendent shoots of natural growth; they bloom with remarkable 
freedom. Plant in rich loamy soil, and cut back the secondary branches to within a bud or two of the main branches as soon as the flowers fade.

Forsythia viridissima is an upright bush, 3 to 4 feet high and the same in width; it is recognised by its deep green leaves and green bark; the flowers appear a fortnight later than those of suspensa. Forsythia intermedia is a hybrid between the two last-named; of very vigorous habit, it grows 8 or Io feet high, and blooms freely. Specially good forms of this are spectabilis and densiflora. The variegated-leaved Forsythias are of little value.

Fothergilla.-Two kinds of Fothergilla, which belong to the Witch Hazel family (Hamamelidaceae), are available for garden decoration; Gardeni and major, both natives of the United States. Although allied to the Witch Hazels, they are of very different appearance, and the flowers are produced in dense heads during May. In both instances the flowers are white and rather showy, while the leaves colour well in autumn. Fothergilla major is the better and more vigorous shrub of the two ; growing 3 or 4 feet high, it forms a bushy plant, and bears its flower-heads with freedom. The leaves are golden in autumn. Although introduced within recent years, it has already taken kindly to our gardens, and thrives in light loamy soil in which a little peat has been dug. Cuttings may be rooted during summer, and pruning is unnecessary. Fothergilla Gardeni is often less than 2 feet high; its branches are more slender than those of the other species.

Foxglove.-(See Digitalis.)

Fragaria (Strawberry). - This group, which belongs to the Rose family (Rosaceae), is interesting from the fact that it includes the Strawberry, Fragaria vesca. It is composed of low-growing herbaceous plants, which spread by means of runners, and are distributed through Europe, India, China, and North and South America; they thrive in ordinary garden soil, and a few kinds may be planted in the rock garden. In each case propagation is effected by division of the clumps or by the removal of runners. As in the case of the Strawberry, it is advisable to remove any runners during summer that are not required for increasing the stock. Moreover, it is wise to commence again with young plants every few years. A few useful kinds are: chiloënsis, a Chilian and Californian plant, growing 6 to 9 inches high and bearing white flowers in May; indica, a dwarf, white-flowered plant from India and China, suitable for the rockery; and vesca flore pleno, a double-flowered form of the common Wild Strawberry. Other species are elatior, californica, and virginiana. 
Francoa (Bridal Wreath). - The Francoas are very useful herbaceous plants, belonging to the Natural Order Saxifragaceae. They do not die down to the ground, and may only be considered to be really hardy in the south and south-west counties. Nevertheless, their beauty is such that in colder districts it is worth while storing them in cold frames during winter to plant out in May; whilst one kind, Francoa ramosa, commonly called the Bridal Wreath plant, is often grown in pots for greenhouse decoration. Those planted out-of-doors should have well-drained, rather light soil ; whilst those grown in pots require a compost of 3 parts fibrous loam to $\frac{1}{2}$ part each of leaf-mould, decayed manure, and sand. Propagation is by seeds or by cuttings. The three cultivated kinds are: appendiculata, growing, when in flower, 2 or $2 \frac{1}{2}$ feet high and bearing purplish flowers; ramosa, 2 to $2 \frac{1}{2}$ feet, with white, pink-flushed blooms; and sonchifolia, similar in height, with light purplish blossoms. All are natives of Chili, and all bloom in summer except when grown under glass.

Frankenia laevis (Sea Heath).-A low-growing shrub, native of Europe and other countries, belonging to the Natural Order Frankeniaceae. As a rule, its branches are prostrate and clothed with tiny leaves in whorls after the manner of some of the Heaths. The flowers are rosecoloured and small. Its interest centres in the fact that it thrives in soil near the sea which is saturated with salt, hence it may be used to help to bind shifting sand. It is sometimes spoken of as the Sea Heath. Propagation is by seeds; when once the plants are established, they ought not to be disturbed. Frankenias are sometimes planted in the rock garden, but are little better than curiosities.

Fraxinus $(A s h)$.- This is an important genus (Natural Order Oleaceae), for it includes several valuable timber trees. British Ash is considered to be one of the toughest of European woods, and is in great demand for the manufacture of agricultural implements, aeroplanes, etc. ; American Ash is used for similar purposes. Fraxinus thrives in any good soil, but gives the best results on deep, moist, moderately heavy loam, and the best timber is obtained from young trees. The vigorous kinds are more suitable for the woodland than for the garden. Planting may be carried out any time between early October and late March. All the species are increased by seeds sown as soon as ripe, in beds of light soil out-of-doors. Varieties are grafted upon stocks of their respective species in spring or are sometimes raised from layers. The only pruning required is that which is necessary to keep the leading shoots clear of rivals, and an occasional thinning of branches and removal of the lower ones:

The Ashes are divided into two distinct groups, one of which 
bears showy, and the other inconspicuous, blooms. The first set is represented in Europe by the Manna Ash (Fraxinus Ornus). This is a bushy-headed tree, 50 to 60 feet high, which produces large terminal panicles of white flowers in May or June. Manna of commerce is obtained in Southern Europe from a solidified exudation from the trunk and branches. Mariesii, from Central China, is another flowering kind of considerable merit; it has creamy-white flowers followed by reddish fruits. Another of the same group is longicuspis, a Japanese tree, 20 to 30 feet high, which is rather uncommon in this country. All the flowering Ashes form good garden trees.

Of the other Ashes, the best known is the Common Ash (Excelsior), a native of Europe. It is an important woodland and hedgerow tree, growing up to I 45 feet high, with a trunk 3 to 4 feet in diameter. There are many varieties, of which pendula and pendula Wentworthii, with weeping branches, are very popular as lawn trees. Another variety, which is variously called heterophylla, monophylla and integrifolia, is distinct by reason of its single-lobed leaves, the Ashes generally having pinnate leaves; var. aurea has golden stems and leaves; foliis argenteis has silver variegated leaves, but is not pretty, and globosa is of dwarf habit. There are many other varieties. Other useful species are americana (White Ash), native of North America, a tree r2o feet high, with a trunk 5 to 6 feet in diameter; angustifolia, 60 to 70 feet, long leaves with narrow leaflets, Southern Europe and North Africa ; dimorpha, 20 feet, leaves up to 3 inches long, North Africa (the var. dumosa is even dwarfer); oregona, 80 feet, Western North America; parvifolia, small tree, narrow leaves, Southern Europe and Asia Minor. There are many more species.

Fremontia californica.--This is a small tree or large shrub, native of California, belonging to the Natural Order Sterculiaceae, too tender for general out-door cultivation in the British Isles, but suitable for the milder counties, where it is often planted against walls, but sometimes in the open. Of rapid growth, it forms rather soft, pithy branches clothed with ornamental greyish leaves; and from the buds on the previous year's shoots quantities of rich goldenyellow flowers, each 2 to 3 inches across, are produced in May and June. It is often seen from Io to I2 feet high, but sometimes twice as much. Unfortunately, it is short-lived, and plants have an unaccountable habit of dying suddenly. Increase is by means of seeds. Plant in warm, loamy soil containing a little peat, and prune no more than is absolutely necessary to keep it within bounds. This should be done after the fall of the flowers.

Fritillaria (Fritillary).-A considerable number of attractive 


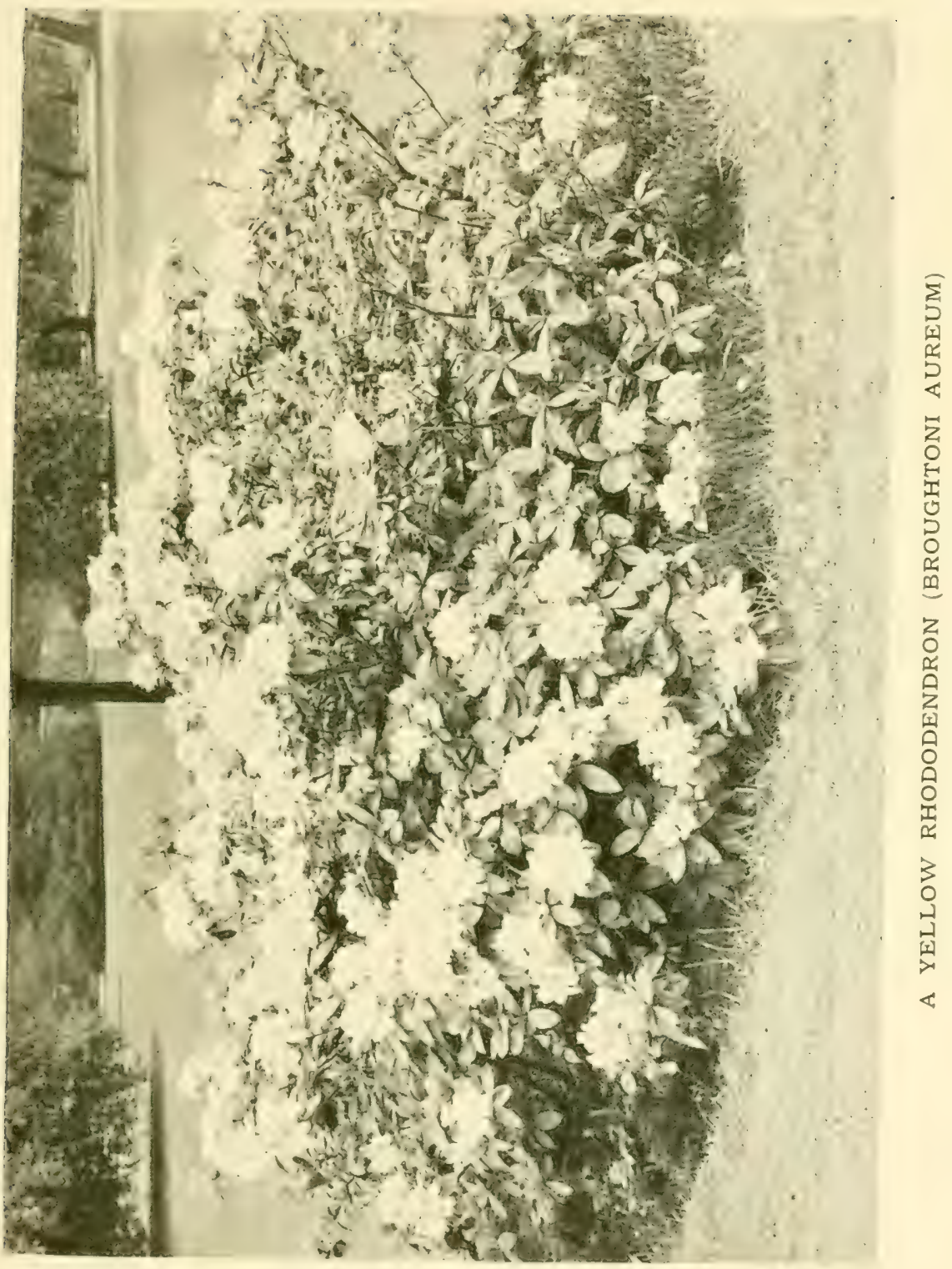



bulbous plants are included in Fritillaria, which belongs to the Lily family (Liliaceae). They are widely distributed through Europe, Asia Minor, Algeria, Siberia, North America, and other countries, one kind being found wild in the British Isles. Many of them are available for outdoor planting here, some thriving in beds in the open ground, and others giving the best results when planted in a border at the foot of a wall. Well-drained loamy soil, light rather than heavy, suits them, and the bulbs should be planted 2 or 3 inches deep in October or November for flowering the following spring. It is not necessary to lift the bulbs each year, for they bloom satisfactorily for two or three years in one place. Propagation is usually by offsets from the old bulbs, but seeds, sown as soon as ripe, may also be used. Two of the best-known kinds are Imperialis, native of the Orient, and Meleagris, a European kind, wild in the British Isles. The former, the Crown Imperial of gardens, is a vigorous plant, 2 or $2 \frac{1}{2}$ feet high, bearing large, showy bell-like flowers in spring; there are several forms with red, orange, and yellow blooms; the bulbs must be planted 6 inches deep. Fritillaria Meleagris is often called the Snake's-head Fritillary; it is a dainty little plant, 8 to I5 inches high, each stem bearing a solitary, fairly large, pendent blossom, which may be purple, yellowish, or white, with beautifully tesselated marks of darker colours. Both kinds thrive in the open, and may be used in the wild garden, where a moderate amount of shade exists. Other good kinds are : aurea, a hardy plant, 4 or 5 inches high, from Asia Minor, with yellowish flowers marked with brown; citrina, a yellow-flowered species from Asia Minor; gibbosa, a dwarf plant, 4 or 5 inches high, with purplish blooms. Latifolia, a very variable kind from the Caucasus, grows I2 inches high, its flowers may be purple, almost black, yellow, or lilac; there are many named varieties. Fritillaria pudica, from North America, grows 6 inches high, and bears yellow flowers.

Fuchsia.-Showy shrubs, belonging to the Natural Order Onagraceae, chiefly natives of Chili and Peru, though some are also found in Mexico, Brazil, and New Zealand. They are so widely grown as greenhouse plants that their value for outdoor planting is often overlooked. The hardiest kind is macrostemma, from Chili; this and a number of well-marked varieties are excellent plants for shrubberies, specimen plants, and hedges in the maritime counties, where examples 6 to ro fect high are common. Elsewhere they are treated as herbaceous plants and cut to the ground line each spring, a crop of vigorous young shoots being produced afterwards which blossom finely throughout summer. They thrive in ordinary garden soil, are easily increased by cuttings dibbled into a shady border in summer; when 
grown as bushes the previous year's shoots are cut well back in February, the majority of the very weak shoots being removed at the same time. Distinct varicties are: conica, corallina, discolor, globosa, gracilis, and gracilis variegata. All have red and purple flowers. Fuchsia Riccartoni is among the hardiest of all, as it is certainly one of the most beautiful; sometimes classed as a varicty of macrostemma, it is by other people considered to be a hybrid. Whatever its origin, it is a very attractive free-flowering bush, $\delta$ or ro feet high, and as far through, while it is also available for informal hedges, giving excellent results even when exposed to the full force of strong sea breezes. Its flowers are red and purple.

Tender Fuchsias, usually grown under glass, are excellent subjects for summer bedding, either as standards or as dwarf plants. If planted out in May they give first-rate results, flowering freely throughout summer. People who have a frost-proof shed or cellar can keep the plants quite well during winter. They are placed in pots in autumn and left out-of-doors until the leaves have fallen; then being taken inside and kept dry until spring. In Narch put them in a light place and water sparingly until new roots are active; then give manure water once or twice a week until planting-out time. Do not allow the young growths to overcrowd each other, but remove a number when 2 or 3 inches long ; these may be put in as cuttings if necessary. Any necessary cutting back of the old shoots is done in March. The singleflowered kinds are, as a rule, better than doubles for outdoor planting.

Fumaria (Fumitory').-Many of the plants which were at one time included in this group of the Poppy family (Papaveraceae) should now be classed with Corydalis. Most of the Fumarias proper are annuals of a rather weedy character, and are known by the common name of Fumitory. Several kinds, such as capreolata, officinalis, densiflora, and parviflora, are common weeds in cultivated and waste land. Several of those which are now referred to as Corydalis have, however, considerable horticultural merit, and are worth a good and well-drained position in the rock garden in rather light soil. A few of the best are: bulbosa, a purple-flowered European plant, 6 inches high, with finely cut leaves; lutea, the Fellow Fumitory of Europe; cheilanthifolia, a Chinese plant, 6 inches high, with finely cut leaves and inflorescences of yellow flowers; thalictrifolia, another Chinese plant, with pretty finely divided leaves and yellow flowers; tomentosa, also from China, a yellow-flowered plant, 5 to 7 inches high; and Wilsonii, a very attractive species from China, with yellow flowers and finely cut, glaucous leaves. Other useful kinds are: nobilis, racemosa, and tuberosa. 
Fumitory.-(See Fumaria and CORYDalis.)

Funkia (Plantain Lily).--Hardy decorative border plants, belonging to the Lily family (Liliaceae). The various species are natives of Japan, and are generally called Plantation or Plantain Lilies. The large oval leaves of several of the kinds are extremely ornamental, whilst those with variegated leaves are perhaps the most effective of variegated herbaceous plants. In addition, they produce showy inflorescences, whilst one, tardiflora, is one of our latest flowering border plants, its blossoms expanding during October and November. They are easily increased by division of the clumps in spring, and thrive in light but rich loamy soil. A moderate amount of moisture throughout the growing time is essential to success, and although they stand a fair amount of sun they give quite good results in semishade. Dwarf kinds, such as lancifolia and tardiflora, are useful for carpeting thin beds of shrubs or for use as edging plants. The leaves of the last-named grow 6 inches high, above which the inflorescences of mauve flowers rise another 6 inches. Funkia Fortunei is a vigorous plant with white or mauve flowers; glauca is renowned for its showy blue-green leaves; ovata has large, handsome leaves and tall flower stems I 8 inches high, terminated by deep lilac flowers; its varieties aurea and marginata have pretty variegated leaves, the former being especially attractive. Funkia Sieboldiana is another vigorous kind, with large leaves and creamy-lilac fragrant flowers; subcordata, sometimes called grandiflora, is known as the Corfu Lily; its large leaves and fragrant white flowers are equally attractive. The narrowleaved Funkia lancifolia previously mentioned has several varieties. The variegated-leaved kinds are sometimes grown in pots for greenhouse decoration.

Gaillardia (Blanket Flower).-Hardy annual and perennial plants are found in Gaillardia, which belongs to the Daisy family (Com. positae). The majority bloom very freely; the flowers are showy, and in addition to being of great decorative use in the garden are useful for cutting. They thrive in ordinary, well-drained garden soil, and it is usual to sow seeds of the annual sorts in a greenhouse or frame in March, afterwards pricking out the seedlings in boxes 2 inches apart each way, or placing them singly in 3 -inch pots to plant out in May. Seeds may also be sown out-of-doors in April. Seedlings should be left quite 9 inches apart, for the plants grow rapidly and require considerable space. The perennial kinds are increased by cuttings placed in a cold frame in August, and it is advisable to keep a few plants in a frame for the winter, for those out-of-doors are apt to suffer from damp and cold, and in heavy ground often 
dic after flowering. Seedsmen offer several varieties of the annual kinds which show variations of colour from red and yellow to red, yellow, or white. The flower-heads are often 3 inches across. The following species, all of North Amcrican origin, may be procured: amblyodon, annual, 2 to $2 \frac{1}{2}$ feet high, flowers red; aristata, perennial, I8 inches high, flowers yellow or red and yellow, many forms of this are obtainable, and it and its varieties or hybrids are better known than other kinds. The popular plant known as Gaillardia grandiflora, which has red and yellow blooms 4 inches across, belongs to this species. Gaillardia lanceolata is an annual with red and yellow flowers; and pulchella, also an annual, is another very attractive plant with blooms of similar colour. Gaillardia hybrida includes a large number of decorative garden kinds, e.g. alba, white; aurea, golden ; coccinea, bright red ; and Josephus, red and yellow, are all good sorts.

Galanthus (Snowdrop).--The plants in this genus (Natural Order Amaryllidaceae) are more familiar under the common name of Snowdrop, and their flowers are perhaps more eagerly sought after than those of any other bulbous plant, for they begin to open early in the new year, and are the harbingers of other spring flowers. They are not very fastidious regarding soil, and may be planted in sun and shade, though they thrive best perhaps in good but light loamy soil in semi-shady positions. Snowdrops are excellent for planting in borders, shrubberies, woods, the wild garden, beneath trees, or as clumps in the rockery; but they are less well adapted for planting amongst dense grass than Daffodils and Crocuses. In suitable positions they increase rapidly, and a few bulbs planted in August or September soon provide good-sized colonies. When grouping Snowdrops in the wilder parts of the garden care should be taken to spread them about so that no formal designs are noticeable. A good plan is to remove soil to a depth of from 4 to 6 inches, scatter the bulbs over the surface, rather close in some parts and thin in others, then replace the soil and insert a few small clusters outside the margins of the main group. Snowlrops are common in Asia Minor, and one or two kinds are found wild in Europe. Galanthus Elwesii, from Asia Minor, and nivalis, a native of Europe, are the two commonest kinds. Both have several varieties; of the former, ochrospeilus and unguiculatus may be obtained, whilst of the latter there are octobrensis, which blooms very early, Racheliae, and flore pleno, the last having double flowers. A few other species are: Alleni, byzantinus, caucasicus, Fosteri, latifolius, Olgae, and plicatus.

Galax aphylla (Carpenter's Leaf).-A charming little evergrecn 
plant from North America, suitable for planting in a moist position in peaty soil in the rock garden. It belongs to the Natural Order Diapensiaceae, and is a tufted plant 6 to 9 inches high, with many rounded leaves borne on very slender stalks appearing from a common rootstock. In winter the leaves become beautifully shaded with red and bronze. About June or July a further attraction is found in the delicately beautiful white flowers. Propagation is by division in autumn or spring. In the absence of peat a suitable soil may be provided by mixing leaf-mould and sandy loam in equal proportions. The common names of Wand Plant and Carpenter's Leaf are given to this plant.

Galega (Goat's Ruc).-Strong-growing and showy herbaceous plants belonging to the Pea family (Leguminosae). Two species are commonly met with-officinalis, a native of Europe, etc., and orientalis, from the Caucasus. Both are perennials, and are commonly called Goat's Rue from the fact that goats fed upon the leaves and shoots are supposed to give an increased yield of milk. They thrive in any good garden soil, and usually grow about 3 feet high. Galega officinalis has pinkish flowers and orientalis bluish blossoms. Each one has a white-flowered variety. Propagation is by seeds and by division of the clumps in spring.

Galium.-A group of plants belonging to the Bouvardia family (Rubiaceae), of little horticultural value. Several are found wild in the British Isles, and their white or yellow flowers sometimes make walls and dry banks attractive. Others

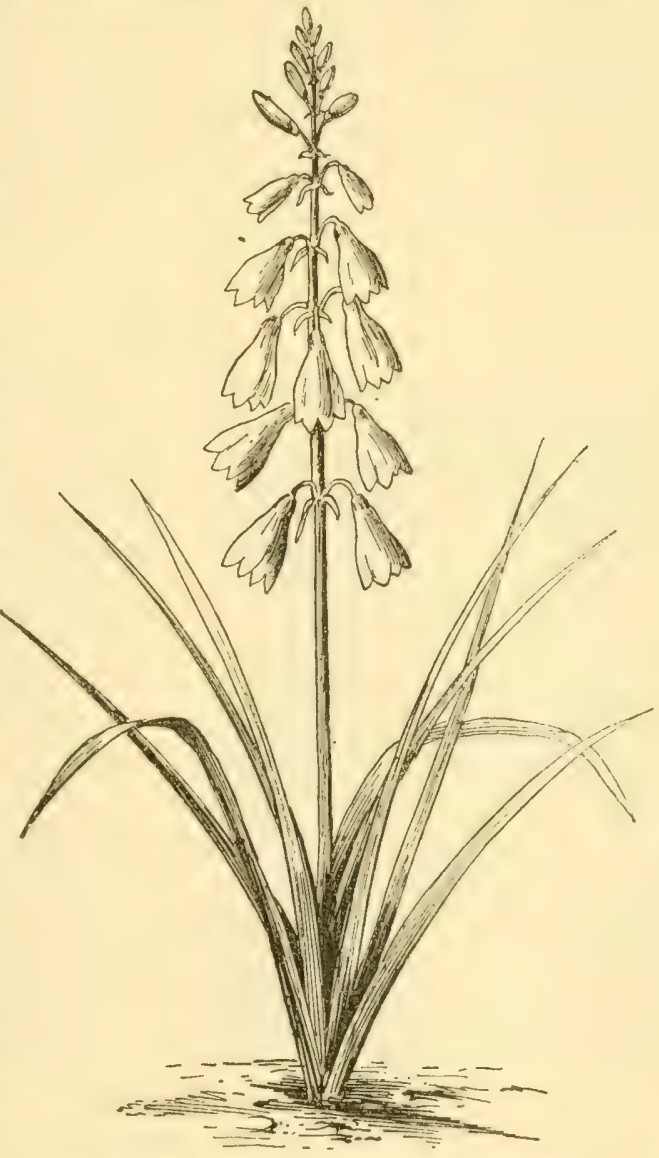

THE CAPE HYACINTH (Galtonia candicans) 
are, however, coarse weeds. The common name of Bedstraw is applied to several, whilst Galium Aparine is known as the Goose Grass, and its fruits as Cleavers, from their habit of fastening themsolves to anything with which they come in contact. Some are of annual, others of perennial cluration, but none is really worth attention in the garden.

Galtonia candicans (Cape Hyacinth).-This is the best-known species of this genus, which belongs to the Lily family (Liliaceae). It is a strong-growing bulbous plant, with leaves 2 to $2 \frac{1}{2}$ feet long and flower spikes rising to a height of 3 or $3 \frac{1}{2}$ feet, bearing numerous penclent white flowers resembling giant Snowdrops. The bulbs are usually planted in March, 6 or 7 inches below the surface, in rich and deep soil, and the flowers appear during July and August. They are sometimes grown for several years in the same position without lifting, but they are liable to injury from cold in winter, and are best taken up in autumn and stored in a cool room until spring. It is a native of South Africa, and is sometimes called Hyacinthus candicans. Groups planted in the wilder parts of the garden or in the herbaceous border are very effective. Increase is by offsets taken off in autumn, or by seeds sown as soon as ripe.

Garrya elliptica. - A handsome evergreen shrub belonging to the Dogwood family (Cornaceae). A native of California, it is not sufficiently hardy for general cultivation in the British Isles, though there are many places where it gives excellent results against east, south, or west walls, and in the southern counties it may be grown quite well in the open. It has two attractions, for it is a useful evergreen and a pretty and uncommon flowering shrub. Male and female flowers appear on different plants, those of the former being the more showy. They are borne from January to March in long, yellowishgreen catkins, and the branches are useful for room decoration. Propagation is by cuttings or layers. Plant in warm, loamy soil, and only give sufficient pruning to keep the plants shapely. Those planted against walls must not be hard pruned. There are other species, but they are inferior to the one described.

Gaultheria.-Evergreen shrubs, belonging to the Heather family (Ericaceae), several of which are suitable for the outdoor garden. Gaultheria Shallon-the Shallon or Salal of Western North Americasrows from 2 to 3 feet high and bears attractive foliage and racemes of pinkish-white flowers; the flowering time is late spring, and the fonvers are followed by dark purple or black fruits. It may be used as an undergrowth in thin woods in loamy or peaty soil, and when once established maly be left undisturbed for many years. It can 

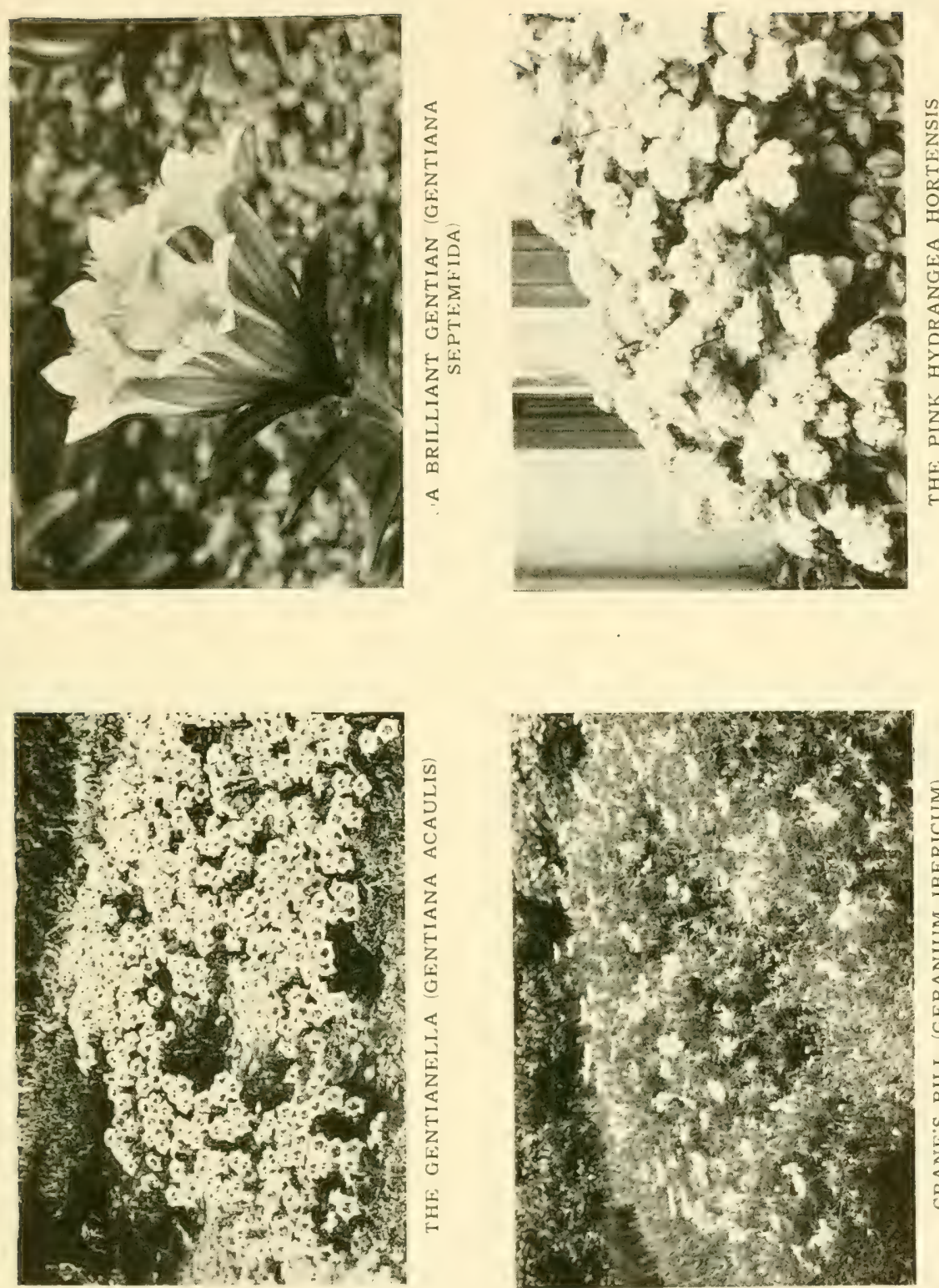

also be userl effectively in the garden. Increase is by seeds or division; it needs no pruning. Gaultheria procumbens is the Partridge Berry or Creeping Wintergreen of North America. Scarcely rising to a height of 6 inches above the ground, it makes a pretty carpet of foliage relieved by white flowers in spring and red berries later. It must have a rather shady place in cool, moist soil. Gaultheria nummularioides, from the Himalaya ; antipoda, from Tasmania and New Zealand ; and pyrolaefolia, from the Himalaya, are all dwarf, rather tender shrubby plants, suitable for the rock garden in the warmer counties. All are increased by seeds or cuttings, and require no pruning.

Gaura.-Annual or perennial herbaceous plants and sub-shrubs, members of the Evening Primrose family (Onagraceae). Gaura Lindheimeri, a native of Texas, is a pretty perennial growing 3 or 4 feet in height, which bears pink and white flowers freely during July and August. Gaura angustifolia is another pretty kind with pink flowers in August, whilst parviflora is a yellow-flowered annual, growing I2 to I8 inches high. Plant in good loamy soil which is rather light and well drained. Lindheimeri is the only one commonly grown; it is rather tender, and is usually raised each year from seeds sown in warmth in early spring.

Gaylussacia is a group of shrubs allied to the Vacciniums, and belonging to the Natural Order Vacciniaceae. They require similar conditions to the Vacciniums and thrive in moist, peaty soil ; in fact, they may very well be used for planting on land which is inclined to be boggy. In some instances the leaves colour finely in autumn. All are natives of North America, and they are not grown much in this country. Propagation is by seeds and cuttings, and pruning is unnecessary. The species are brachycera, dumosa, frondosa, resinosa, and ursina.

Gazania (Treasure Flower).--Showy plants belonging to the Daisy family (Compositae). The different kinds are only seen to advantage when planted in sunny positions, and they are well suited for grouping in the rock garden. Light soil suits better than heavy, and as they are not very hardy it is a good plan to root a few cuttings each year, and keep them in a cold frame during winter. One kind, Gazania splendens, is grown extensively for summer bedding; it is of dwarf habit, with long, narrow leaves, and produces gorgeous, orange-coloured flowers 2 to 3 inches across. This is increased by cuttings in August, and again in spring ; it and other kinds are natives of South Africa. Gazania bracteata bears white and yellow flowers; longiscapa, yellow; lutea, yellow; Pavonia, orange-scarlet; and pygmaea, those of orange colour: 


\section{Ig6 THE BOOK OF HARDY FLOWERS}

Genista (Broom).- This group of shrubs, which are members of the l'ea family (Leguminosac), is closely allied to Cytisus, and the various species require somewhat similar treatment. Pruning, however, differs, for although it is wise to prune the taller growing kinds frequently whilst they are young to induce bushy growth, the pruning of older plants may be dispensed with. One species, however, Genista tinctoria, may be pruned every spring, for the flowers appear in July from the ends of the shoots formed during the current year. Some kinds can be increased by cuttings, but, as a rule, the best results are obtained by sowing seeds. The greenhouse plants usually grown as Genista racemosa and elegans are really Cytisus. The former is Cytisus fragrans, and the latter fragrans var. elegans. Both belong to the Canary Islands, and are excellent spring-flowering greenhouse plants, or in the southern counties they sometimes form large bushes out-of-doors.

Genista acthnensis, the Mount Etna Broom, is a native of Sicily, etc., and is one of the greatest ornaments of the garden in July. Growing from I2 to I 8 feet high, it has graceful, drooping, secondary i)ranches which become streamers of golden blossoms; anglica is a dwarf, spiny, yellow-flowered shrub, often found wild in this country; cinerea, native of South-West Europe, forms a well-branched bush 8 or ro feet high, and bears golden blossoms in June; dalmatica is a dwarf kind from Southern Europe suitable for the rock garden, it grows but a few inches high, but is covered with golden blooms in May.

Genista hispanica, the Spanish Gorse, is one of the most ornamental of dwarf kinds; when isolated, the plants form globular specimens of crowded spiny shoots which in May are covered by golden blossoms; it may be grown in the rock garden or in the open.

Genista pilosa is a dwarf, spreading plant I2 to IS inches high, native of Europe, it is excellent for carpeting ground beneath taller growing plants, the freely-borne flowers are golden in colour; sagittalis grows from 6 to 9 inches high, forming a dense mat of green, winged shoots which in May are covered with golden flowers.

Genista tinctoria differs from other kinds by flowering in July from the points of the young wood, it is sometimes called Dyer's Greenwood; the var. clatior, $2 \frac{1}{2}$ feet high, is an improvement on the type, whilst the dwarf flore pleno should also be grown; virgata, a native of Madeira, is a very useful large-growing Broom, even in poor, sancly soil in full sun or semi-shade it forms bushy plants I2 feet or more high, which in June are covered with golden flowers.

Gontiana (Gentiun).-The Gentians, which belong to the Natural Order Gentianaceae, are remarkable chiefly for the wonderful blue 
colouring of their blossoms; they vary very considerably in growth, some kinds being quite dwarf and suitable only for the rock garden, while others are noble plants for the flower garden. They are found wild in the European Alps, North and South America, the Himalaya, Japan, and other countries, while one kind, Gentiana verna, grows - though not abundantly -in the Highlands of Scotland and in Cumberland. All the rock garden Gentians are somewhat tantalising plants: in some places they are grown successfully without the least difficulty, while in others they fail, not to grow, but to flower. The most popular of the dwarf kinds is Gentiana acaulis, native of the Swiss Alps, known popularly as the Gentianella; it forms a tuft of rich green leaves, and in April and May bears large trumpet-shaped flowers, intense blue, with a greenish-yellow mark inside. In some gardens this Gentian is so easily grown that it is used as an edging in the flower garden; in others, when the greatest pains are taken, it can scarcely be induced to bloom. It is most likely to succeed in deep, moist, loamy soil containing stones, and a sunny position; very firm planting is essential, while copious supplies of water in spring and early summer are needed. It is said that protecting the plants in winter with a pane of glass (so arranged as to admit air freely) assists them to bloom. Gentiana bavarica, native of the European Alps, is a small plant with exquisite blue flowers in July; it is difficult to grow, and should be planted in the moraine and supplied freely with moisture in spring and early summer.

Gentiana Freyniana, from Asia Minor, and septemfida, from the Caucasus, are much alike, having showy blue flowers, the former in July and the latter in June; they thrive best in a somewhat shady spot in the rock garden and in deep loamy and peaty soil. Gentiana decumbens, which blooms in July, and Kurroo, which flowers in September, are natives of the Himalaya, and should be given similar conditions to those advised for Gentiana septemfida. Gentiana Przewalskyii, from China, is another beautiful kind that is happy in partial shade in deep moist soil. The exquisite Vernal Gentian (Gentiana verna) is one of the chief favourites; its bright blue flowers open in April. The conditions most likely to ensure success are a sunny position in the rock garden, and deep sandy loam ; it must be freely watered in spring and summer, for it is found wild in moist mountain pastures.

The Willow-leaved Gentian (Gentiana asclepiadea), from SouthEast Europe, is a vigorous herbaceous plant, of which the flower stems reach a height of 18 inches, the showy blue flowers opening in July. Deep moist soil and a partially shaded position fulfil its 
needs, such, for example, as are often provided in the bog garden. Gentiana lutea, from the European Alps, is a striking plant, with large leaves and bearing tall spikes, 2 or 3 feet high, of yellow flowers in July ; it likes well-drained loamy soil. The most satisfactory method of raising Gentians is by means of seed, which ought to be sown as soon as it is ripe, in pots of light soil placed in a cold frame. Gentians camnot be grown successfully in shallow soil that dries up quickly; a moist root run is essential to all of them, and partial shade is beneficial to most kinds.

Geranium.-The various plants contained in this group (Natural Order Geraniaceae) are closely allied to Pelargonium, and some confusion has arisen between the two. The plants so commonly used for summer bedding, for instance, under the name of Zonal Geraniums, and the so-called scented-leaved Geraniums, are not Geraniums at all, but Pelargoniums. The true Geraniums are herbaceous plants, suitable for the flower border or rock garden. Several are wild in this country; one, Geranium pratense, being the Common Crowfoot of our meadows, a handsome plant with large blue or purplish flowers. Another one, phaeum, with dark purplish flowers $\frac{3}{4}$ inch across, is known in some parts as the Mourning Widow; whilst some forms of sanguineum are very beautiful, and suitable alike for border or rock garden. The flowers of this species are various shades of red or rose.

There are many exotic kinds which are well worth attention for herbaceous border or rock garden. Geranium argenteum, for instance, a native of the Alps of Europe, is a charming little plant 3 or 4 inches high, with silvery leaves and rose-coloured flowers. Endressi, a more vigorous plant, from the Pyrenees, with rose-coloured flowers, is also attractive, as also are the blue-flowered Caucasian ibericum; the purple-flowered macrorrhizum, an Eastern European plant of vigorous habit, suitable for naturalising in the wild garden; pyrenaicum, with purple flowers; and Wallichianum, with purple blossoms. Plant in well-drained, light loamy soil and increase by means of seeds or by division. The very dwarf kinds with hairy leaves, such as Geranium argenteum, should be placed in a dry, sunny position where damp cannot remain long on the leaves.

Gerbera (Transvaal Daisy). - The Gerberas, which belong to the I)aisy family (Compositae), are distributed in South Africa, Siberia, and the Himalaya, but by far the most important one is the South African Gerbera Jamesoni, commonly called the Barberton or Transvaal Daisy. It is a very beautiful herbaceous flowering plant; numerous leaves, 12 inches or so long, and not unlike those of the Dandelion in shape, are produced from a common rootstock, and well above them 


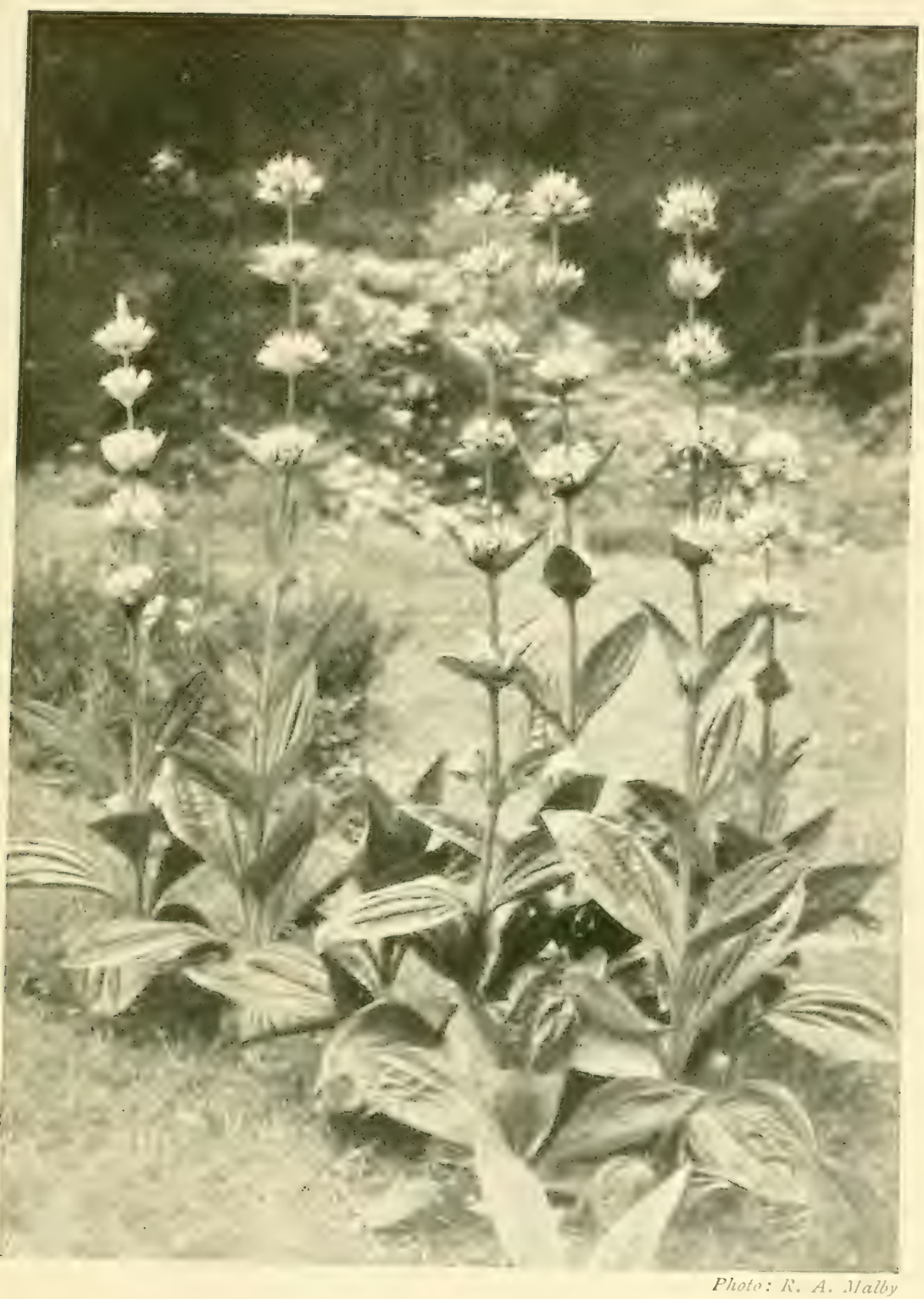

THE YELLOW GENTIAN (GENTIANA LUTEA) 

the lirge Daisy-like heads of flowers appear during the greater part of summer and early autumn. The flowers vary somewhat in colour, but are generally a rich shade of red or scarlet, and the fully expancied heads are about 3 inches across. Unfortunately, this extremely handsome plant is rather tender, yet it gives excellent results in sunny borders in the neighbourhood of London. A border facing south at the foot of a warm greenhouse wall is an excellent place, the heat from the glasshouse being sufficient to provide a little protection and to prevent the border from becoming cold and wet in winter. Gerbera Anandeia, from Siberia, and Kunzeana and nivea, whiteflowered kinds from the Himalaya, though less showy, are hardier. In addition to these, a set of very beautiful hybrids has been raised by using Jamesoni as one parent; they have flowers as large as those of the Barberton Daisy, with a wide range of colour from white to pink and red and from yellow to orange. They thrive under similar conditions to Gerbera Jamesoni, and in places where they will not thrive out-of-doors they are well worth growing in pots in a sunny greenhouse or frame. Good loamy soil, containing leaf-mould and sand, forms a suitable rooting medium, whilst increase is by seeds or division of the clumps in spring. The inflorescences are excellent for table decoration, both by reason of their graceful poise and exquisite colouring.

Geum (Avens).-A number of very attractive herbaceous plants and numerous weeds are included in Geum (Natural Order Rosaceae). The British plants known under the common name of Avens are Geums. Geum chiloënse, a native of Chili, is one of the most useful kinds; it forms a tufted plant with leaves 8 to ro inches long from the axils of which showy bright red flowers are borne during the greater part of summer; the var. grandiflorum plenum has double flowers, and the double red-flowered Mrs. Bradshaw, which may be raised true from seed, is another very fine variety. Geum coccineum, from Greece and Asia Minor, is a useful red-flowered kind, while montanum and its var. grandiflorum bear beautiful yellow flowers. Geum reptans is a dwarf plant 6 to 8 inches high, and both it and its double-flowered variety bear yellow blossoms. The Geums are easily grown in rich garden soil, and are increased by division and seeds. It is unwise to keep old plants, for young ones blossom more profusely. A sunny position is desirable.

Giant Asphodel.-(See EREMURUs.)

Gilia.-Several very beautiful annuals are found in this group (Natural Order Polemoniaceae). They are natives of the New World, the majority being from California, but one or two are found wild 
in other parts of North America, and one in Chili and Peru. They give the best results in rather light but rich loany seil, and the seeds may either be sown thinly in boxes in March or out-of-doors in April. Plants raised under glass must be pricked out in boxes $I_{2}^{1}$ to 2 inches apart each way, and when they are planted towards the end of May, they may be put + to 6 inches apart. Seedlings raised out-of-doors must also be well thinned out, for no good object is gained by allowing annuals of any kind to stand close togrether. A few useful kinds are: achilleacfolia, I2 inches high with blue flowers (the variety alba has white flowers); androsacea, a variable plant 6 to 12 inches high, with lilac, pink, or white blossoms; capitata, 9 inches high, flowers lavender; dianthoides, 6 inches high, with lilac blossoms; tricolor, a variable plant with varieties bearing blue, white, pink, or rose flowers, several colours or shades appear in the same flower.

Gillenia.-Two herbaceous peremnials are found in this genus (Natural ()rder Rosaceae)-Gillenia stipulacea, sometimes called American Ipecacuanha, and trifoliata, which is known as Indian Physic. Both are North American plants and are closely allied to Spiraca, the points of distinction being more apparent to the botanist than to the gardener. The roots have medicinal properties which are said to be very similar to those of Ipecacuanha, but the plants are grown here for ornamental gardening alone. They should be planted in the herbaceous border in well-manured soil, and may then be expected to grow about 3 feet high. They may have red or white flowers, according to the variety. l'ropagation is by division of the clumps in spring.

Ginkgo biloba (Maidenhair Tre).--This Conifer (Natural Order Coniferae) is sometimes called Salisburia adiantifolia, and is a native of China. It is of very ornamental appearance, and quite distinct from any other tree known. Belonging to one of the few groups of deciluous Conifers, it differs from many of the evergreen kinds by being suitable for town gardens. Of upright, though graceful habit, it forms a tree go or roo feet high, numerous specimens in this country being upwards of 60 feet in height. Although it is not uncommon, it might be planted more frequently; for it makes a handsome lawn specimen, and is quite hardy. Its peculiar interest centres in its foliage, for the bright green leaves are large and flat, bearing a striking resemblance to a gigantic pinnule of the frond of a Maidenhair Fern, hence the popular name of Maidenhair Tree. The fruits, which are rarely produced in this country, are golden and plum-like when ripe, the central seed being surrounded by pulp. Male and female flowers are on different tree's. It might be used with advantage for avenues, 
its habit of growth being peculiarly appropriate for the purpose. Plant in ordinary garden soil, and prune in summer to keep the trees shapely. Increase is by imported seeds.

Gladiolus is a very important group of flowering plants, for it includes not only a wide selection of decorative kinds, but also several distinct races of hybrids, each of which contains many showy sorts. Gladiolus belongs to the Iris family (Irideae), and most of the kinds are natives of South Africa, a few being found in Southern Europe, Asia Minor, etc. All are herbaceous in character, and the rootstock consists of a corm somewhat similar to that of the Crocus, though, of course, much larger, each corm being capable of producing a vigorous central shoot, and if that should be injured, several weaker shoots from dormant buds. This peculiarity has been taken advantage of by florists, and to produce extra plants of choice varieties the corms are divided up into sections, each one containing a dormant bud. These, if placed in sand, soon emit roots and shoots, and are then planted in soil in the ordinary way. Another convenient method of increasing new varieties is available in addition to that of dividing a vigorous root, for many tiny bulbils are formed about the base of each. By carefully collecting these and planting them in a bed of light, sandy soil containing leaf-mould, quantities of plants are soon produced. It is a good plan to make up a bed in a cold frame for this purpose. Species and new varieties are raised from seed. The seed should be sown in boxes or pans of sancly soil as soon as ripe, preferably in a light and warm frame or greenhouse. As soon as the young leaves are 2 or 3 inches ligh, the plants are pricked out from I to 2 inches apart each way in a bed of well-drained soil. Here they are allowed to remain for two or three years, according to their vigour, and are then taken up and sorted. A cold frame should be provided for the purpose.

As the majority of the Gladioli are rather tender in most districts, it is inadvisable to leave them in the ground throughout winter. Rather lift them before the tops have fully withered in autumn, dry the roots, remove the dead tops, clear away any dirt, and store them in a cool but frost-proof room or shed until the following spring. The best time to plant is late March or early April. Any rich garden soil is suitable, the stronger growing kinds thriving in moderately heavy soil, whilst the weaker ones prefer soil of a lighter nature which is well drained. A light, open position is essential, and they may often be used with satisfactory results as clumps in thin shrubberies or to furnish beds which contain early flowering herbaceous plants. They are also effective in the herbaceous border. The corms are 
usually placed from 9 to 12 inches apart, and are coveren with about 3 inches of soil. In heary ground it is wise to place a litte coarse sand under each root. In land that has been manured the plants grow vigorously, but in poor soil two or three applications of liquid manure during the growing season are beneficial. When inflorescences are to be exhibited this feeding process should begin as soon as the roots are really active. Where summer drought is experienced a mulch of well-decayed manure and leaves may be applied in May with advantage.

The hardier species are: atroviolaceus, a purplish-flowered plant from Syria, etc.; byzantinus, native of the Mediterranean region, 2 feet high, bears reddish-purple flowers, and may be naturalised in the warmer counties, it is sometimes called the Turkish Corn Flag; segetum, the common Corn Flag of the Mediterranean region, has purplish flowers. All these may be left in the ground throughout winter.

Other groups are as follows:

Gladiolus Colvillei.--This grows about 2 feet high and bears crimson-purple flowers on graceful inflorescences. It is typical of a smallflowered group which blossoms early (May and June), and is invaluable for cutting; large quantities of flowers are grown for market purposes, and many corms are planted in pots for greenhouse decoration. Roseus, with salmon-rose flowers with deeper-coloured stripes, and The Bride, with white flowers, are effective varieties of this group. These are fairly hardy and may be planted in autumn.

Gladiolus cardinalis is a South African kind with branched inflorescences of large bright scarlet flowers, with a few blotches of white on the lower segments. Its varieties bloom during July. A few good sorts are: Blushing Bride, ivory-white with crimson marks; Crimson Queen, scarlet-crimson with carmine and white marks; Iairy Queen, salmon-rose with white blotches and crimson margin; Favourite, salmon-rose with cream-coloured blotches and crimson margin; General Scott, white, shaded rose; I'each Blossom, rosyblush blotched rose and cream; Rose Queen, soft rose, blotched with blood-red, eye cream.

Gladiolus brenchleyensis.--This, like Gladiolus gandavensis, is a garden hybrid raised by crossing psittacinus and cardinalis. Both have large, rich, scarlet flowers in long, dense spikes. They are much alike, but brenchleyensis is said to bloom before the other. Of gandavensis there are numerous forms with red, scarlet, crimson, and rose colouring ; also others with white and yellow grounds with markings of other colours. They may be procured cheaply as un- 


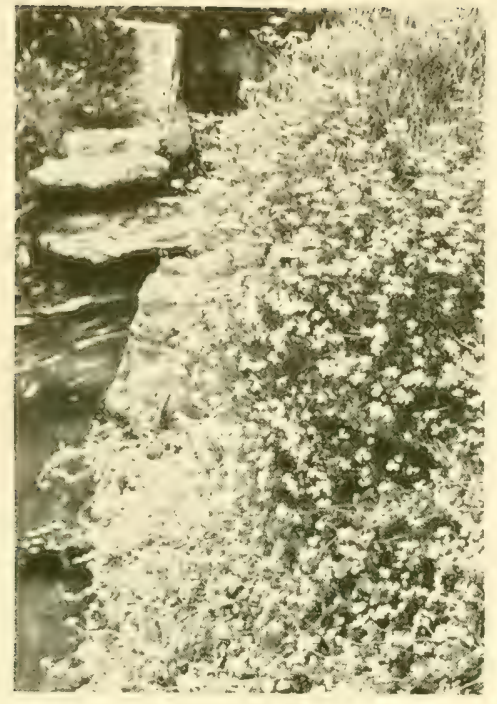

THE CREEPING GYPSOPHILA REPENS ROSEA

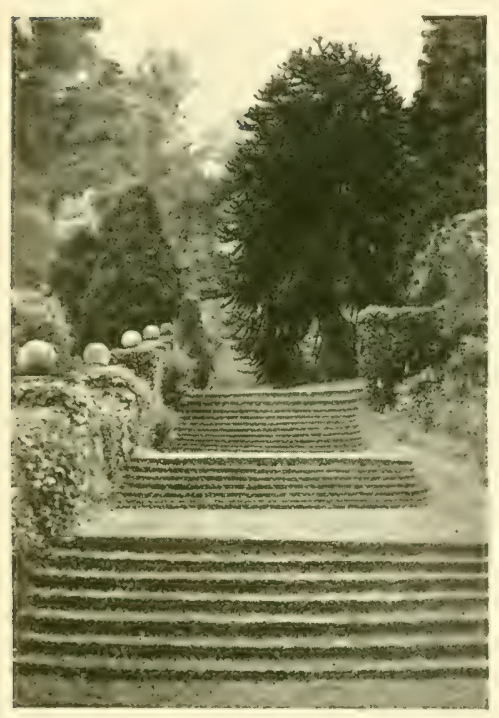

GRASS STEPS IN THE PLEASURE GROUNDS

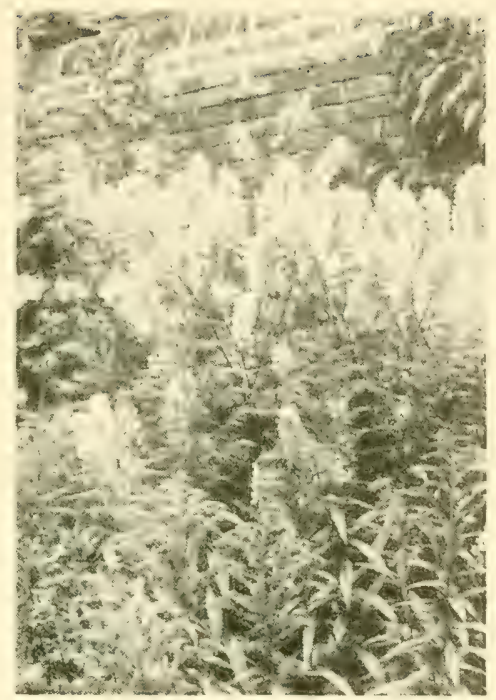

GOAT'S RUE (GALEGA HARTLANDI)

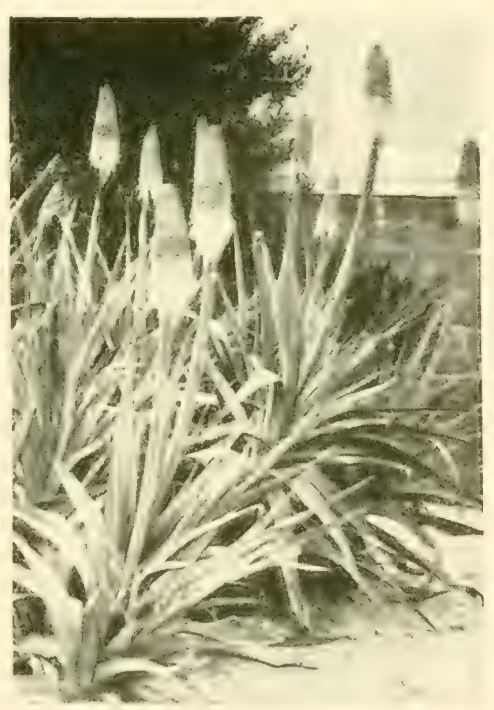

A HANDSOME TORCH LILY (KNIPHOFIA CAULESCENS) 

named varieties. One, called Mikado, brought to notice within the list few years, produces very fine spikes of flowers in which blushrose, cream, crimson, and primrose are blended.

Gludiolus Lemoinei is the type of a group of hybrids raised by crossing gandavensis with purpureo-auratus. The flowers are rather small, slightly hooded, and bear conspicuous blotches upon yellow, purple, or white ground. A few good ones are: Docteur Regel, Fustell de Coulanger, Hippolyta, Lafayette, J. J. Weiss, Vesuve. It is advisable, however, to purchase unnamed varieties; they are quite as beautiful and much cheaper.

Gladiolus nanceiamus, like the last-named, is a hybrid raised by the late M. Lemoine, of Nancy. Its parents were Lemoinei and Saundersii. The flowers are large and richly coloured. Very good selections of unnamed kinds can be procured.

Gladiolus Childsii is the type of another group of hybrids raised by crossing gandavensis varieties with Saundersii. They are vigorous and free-flowering, with very large bright-coloured flowers. Named varieties are offered in bulb lists. Gladiolus primulinus is a comparatively new kind from the Zambesi, with primrose-yellow blooms.

A showy hybrid between Childsii and gandavensis is found in the new Gladiolus America. The flowers are very large and flesh-pink, tinged with lavender. Many of the stronger growing kinds of Gladioli grow between 3 and 4 feet high, and need to be carefully staked.

Glastonbury Thorn.-(See CRATAEgus.)

Glaucium (Horned Poppy). - This group of Poppies (Natural Order Papaveraceae) consists of annual, biennial, and perennial border plants which have showy flowers. They are popularly termed Horned Poppies, and are found wild in Europe and Asia Minor. Seeds of annuals and perennials should be sown in the positions where the plants are to flower, the former being sown in March, to flower the same year, and the others in July, to bloom the following year. The seeds are sown thinly in ordinary garden soil, and the seedlings thimned so that they are 6 or 7 inches apart each way. Two of the commonest species are corniculatum with orange-red flowers, and its variety rubrum with red flowers; and flavum, a yellow-flowered plant which has several varieties, notably fulvum and tricolor. Some of the species included at one time in this family may now be found under Chelidonium. The Horned Poppies may be used with effect as undergrowth for thin shrubberies.

Glaux maritima (Sea Milkwort).--A dwarf-growing perennial, native of Europe, including the British Isles. It belongs to the Primula family (Primulaceae), and is known as the Sea Milkwort. 
It wrows from 6 to ro inches in height, and is found throughout the country in the vicinity of the sea, and is pretty when its pink flowers are open. It is hardly, however, a plant to recommend for gardens.

Gleditschia (Locust Tree).-Trees belonging to the Pea family (Leguminosae), and natives of North America, China, and Japan. The majority have spiny branches and trunks, the spines in some cases being 6 to 9 inches long and many times branched. Even from old trunks of some kinds spines are continually appearing, and they grow to their full size in one season. The trees are ornamental by reason of their handsome leaves being divided into a large number of tiny, bright green leaflets. The July flowers are not showy, but they are succeeded by long, flat pods, sometimes I foot in length, which are brown when ripe. They thrive in the Midlands and southern counties in ordinary garden soil, are increased by seeds, and when young should be pruned regularly in summer in order to reduce excessive side growth and encourage the lengthening of the main axis. Gleditschia triacanthos is the commonest and the hardiest, it forms a moderate sized tree, and is a native of the Eastern United States; aquatica and texana are other useful American species; whilst Delavayi, macracantha, and sinensis from China, and japonica from Japan, may also be grown.

\section{Globe Flower.-(See Trollius.) \\ Globe Thistle.-(See Echinops.)}

Globularia (Globe Daisy).--Herbaceous perennials or dwarf shrubs (Natural Order Selaginaceae). They are known as Globe Daisies, and Globularia vulgaris is sometimes called the Blue Daisy: Several are natives of Europe, and are available for the herbaccous border or rockery. Their flowers are in small, rounded heads and open in June and July. Plant in sheltered and moist positions in light loamy soil, and increase the herbaceous kinds by seeds in spring, or by division in early autumn. Globularia corlifolia is a dwarf plant with blue flowers; nana, trichosantha and v'ulgaris also have blue flowers.

Gnaphalium.-There are several species of Gnaphalium (which belongs to the Daisy family, Compositae), chiefly low-growing plants with grey foliage, the flowers being surrounded by dry hracts which last in good condition for a long period and are sometines called Everlasting Flowers. They grow in ordinary soil, and may be used in the herbaceous border or rock garden. A few kinds are: indicum, luteo-album, and uliginosum. All are widely distributed: None is of much decorative value.

Goat's Rue.-(See GALEGA.) 
Godetia.-The Godetias belong to the Evening Primrose family (Onagraceae), and are closely allied to and sometimes included in Oenothera (the Evening Primrose). They are among the most beautiful of hardy annuals, they require rich soil, and the seeds may either be sown in the position the plants are to occupy, or in boxes under glass in March or early April, the seedlings being pricked out in boxes for permanent planting towards the end of May. Seeds may be sown out-of-doors between the middle of March and the end of April. In either case the plants must not be allowed to stand closer than 9 inches, for they grow $I_{2} \frac{1}{2}$ to 2 feet high and branch freely. Godetia rubicunda, from California, sometimes called Oenothera amoena, is the most important kind; there are several varieties, the following being particularly attractive: Lady Albemarle, crimson, dwarf; Bijou, red and white; Bridesmaid, rose and white ; Duchess of Albany, white; General Gordon, crimson; gloriosa, red; La Belle, rose; Lady Satin Rose, rose; Perle, carmine; Rosamunde, rose; The Bride, white with carmine marks; Princess of Wales, ruby and crimson.

\section{Golden Feather.-(See Pyrethrum.)}

Goodyera.-A group of hardy and tender Orchids (Natural Order Orchidaceae). Several hardy kinds are grown in this country, and one is a native. The British plant is Goodyera repens, found in light, loose soil amongst the fallen needles of the Scots Pine, in Scotland. When in flower in summer it may be anything between 4 and 7 inches high, the fragrant flowers being creamy white. It is a rather difficult plant to establish, and the best way to form a plantation is to convey deep turves containing healthy plants from one Pine wood to another. Two North American sorts, pubescens, the Adder's Violet, and Menziesii, the Rattlesnake Plantain, may be grown in a moist position in peaty soil in the rock garden. Several of the tropical kinds are noted for their beautifully marked leaves.

Gordonia is closely allied to Stuartia and Camellia, and belongs to the Natural Order Ternstroemiaceae. Two kinds, Lasianthus and pubescens, both from the Southern United States, have been introduced to this country, but they are only suitable for out-of-doors in the mildest parts, and there appreciate the protection of a wall. Both are evergreen bushes bearing showy white flowers in July and August, which have a somewhat similar appearance to those of a single Camellia. They may be grown in the same way as the latter, and are usually increased from imported seeds. No regular pruning is necessary. When grown as greenhouse plants they give the best results in a border in a light, airy structure. 
Gorse.-(See Ulex.)

Gourd.--(See Cucurbita.)

Grape Hyacinth.-(See MUSCARI.)

Grevillea.-. This is an interesting and decorative group of scmitencler evergreen shrubs belnnging to the Natural Order I'roteaceac. They are natives of Australia, and about the middle of last century were amonesst the most popular of greenhouse plants. Modern heating arrangements and the introduction of numerous quick-growing plants for greenhouse decoration have almost supplanted them and others which were known collectively to our grandparents as New Holland plants. A few kinds are, however, still grown under glass, while two or three are distinctly popular outcloor shrubs in the warmer parts of the country. Grevillea robusta, a handsome decorative foliage plant, is the commonest greenhouse kind, and may also be used out-of-loors for sub-tropical bedding in summer. It is casily raised from seeds sown in warmth in spring. The two best for outof-doors are the yellow-flowered Grevillea juniperina and the redflowerel rosmarinifolia. Both form wide-spreading bushes 4 to 5 fcet high in ordinarily good garden soil, and require no regular pruning. They are rarely without flowers.

Griselinia.-This group contains two useful evergreen bushes suitable for the warmer parts of the country, which are members of the Dogwood family (Cornaceae). They are Griselinia littoralis and lucida, both natives of New Zealand. The former is the hardier kind, and is one of the most conspicuous evergreens of Cornish gardens; it is usually found as a shapely bush between $\mathrm{x} 2$ and 40 feet high with a considerable diameter, the branches being retained from base to summit with little or no attention to training. The rounded glossy green leaves are about 3 inches long. Ordinary garden soil suits it, and it may be increased by layers, cuttings, or seeds. Numerous seedlings may often he found beneath the old plants. If growing too luxuriantly, the branches may be pruned back during summer. Grisclinia lucida is recognised by its rather stiffer habit and larger and thicker oval leaves, which are sometimes between 5 and 6 inches long. It should only be planted in sheltered places.

Gunnera manicata is the most conspicuous plant in this genus (Natural Orcler Haloraginaceae). Although a native of Brazil, it is hardy in many parts of the British Isles, but should have a little protection in spring just when the new leaves are appearing. In general appearance the plant resembles a gigantic Rhubarb, and in Cornwall and Ireland, where it attains its greatest luxuriance, the leaf-stallis are sometimes from 7 to 9 feet long, and the blades of 


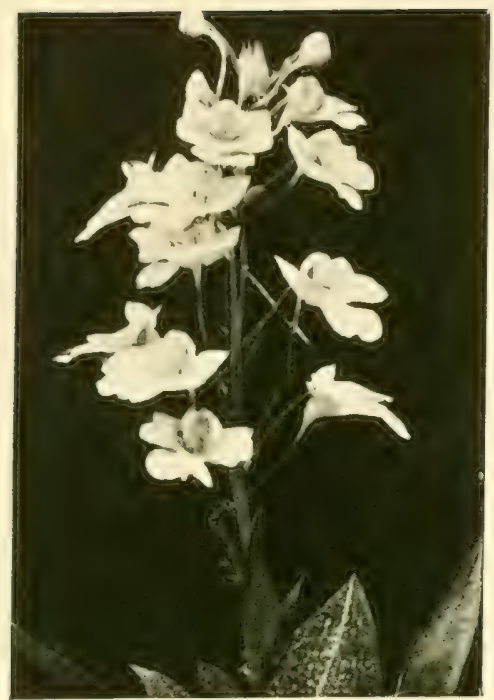

A HARDY ORCHID HABENARIA

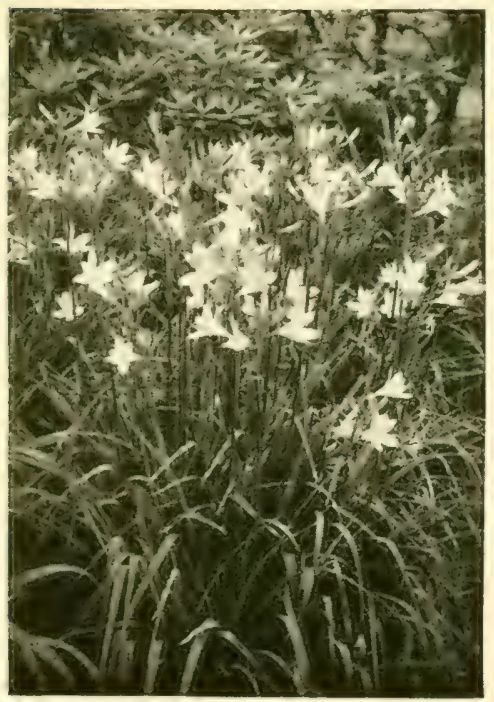

DAX LILY (HEMEROCALLIS FULVA

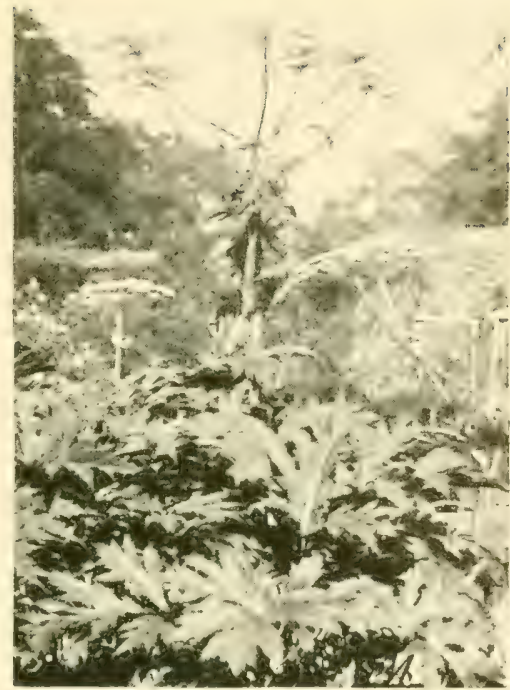

THE STRIKING HERACLEUM GIGANTEUM

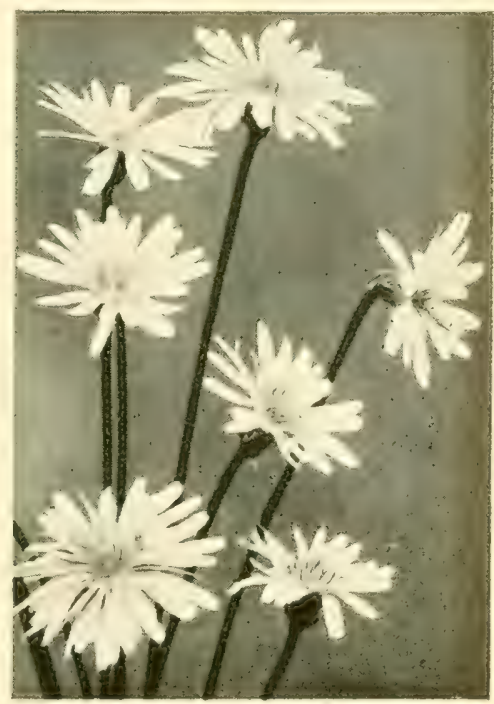

PINK ANNUAL HAWKWEED (HIERACIUM) 

the leaves from 9 to II feet across. In other localities, the leaves are often 6 or 7 feet across. It thrives in rich loamy soil to which cow manure has been added, and should be given a generous topdressing of cow manure each spring. The proper position for it is in moist soil on the banks of a lake or stream, for preference, where the roots can enter the water and the crown stand clear. Propagation is by division of the crowns in spring. Sections containing small dormant buds and a few roots grow readily, but they take several years to attain their finest proportions. Large cone-like inflorescences appear during spring and early summer. They, however, must be removed at once, or they will weaken the plant. Other species are : bracteata, chilensis, magellanica, and perpensa. In the case of hard frost being experienced in winter, it is wise to cover the crowns of Gunnera manicata with leaves and spruce branches.

Gymnocladus.-..There are two kinds of Gymnocladus: canadensis, the Kentucky Coffee Tree of North America, and chinensis, from China; they belong to the Pea family (Leguminosae). The former is the hardier and commoner tree, the other only being available for the milder counties. Gymnocladus canadensis grows from 40 to So fect high, and is remarkable for the white or greyish bark of the younger shoots and for its handsome doubly pinnate leaves. On young specimens the leaves are sometimes 3 feet long. One of the finest examples in the country is growing at Claremont, in Surrey. The seeds have sometimes been used in Canada as a substitute for coffee, whilst those of the Chinese kind have soapy qualities. Warm, well-drained loamy soil is suitable, increase is by seeds, and pruning is confined to regulating the branches of young trees so that they do not interfere with the leading shoots. Such pruning may be carried out during summer.

Gynerium.-(See CORTADERIA.)

Gypsophila (Chalk Plant).--This is a rather large group of plants belonging to the Pink family (Caryophyllaceae), but one kind far exceeds all others in value. That is Gypsophila paniculata, a native of Europe, etc. It is widely grown for decorative gardening, the peculiarly graceful inflorescences of tiny white flowers being very popular in the flower border or for adding lightness and grace to floral decorations composed chiefly of more highly-coloured and heavier flowers. It is of perennial duration, and may be increased either by seeds or division. Any good garden soil appears to suit it, and at maturity it is from 2 to $2 \frac{1}{2}$ feet high with a head of considerable width. Deep soil must, however, be provided, and lime or chalk is an advantage. Once established, a clump will continue to provide a harvest 
of flowers for many years. As the roots are long and woody, it is not advisable to transplant them oftener than is absolutely necessary. In adclition to the type there is a double-flowered form. A few other useful kinds are: Arrostii, libanotica, perfoliata, and repens. The last-named is a chaming low-growing plant for the rockery in welldrained sandy loam. Gypsophila elegans is a pretty little annual with white flowers.

Habenaria.-Many members of this group of Orchicls (Natural Order Orchidaceac), that is to say, those which are natives of the temperate regions of the Northern Hemisphere, are quite hardy in this country. They need a moist, peaty soil, and should be planted in a partially shaded spot. The chief hardy kinds are : bifolia (Butterfly Orchis), native of Britain, which from the centre of two widcspreading leaves sends up a stem I2 inches high, bearing several white, swect-scented flowers; blephariglottis, a North American kind, has white flowers with beautifully fringed lip; another from the same region is ciliaris, with pretty fringed yellow flowers; conopsea has whitish blossoms; the lilac-purple fringed flowers of fimbriata are very pretty, so, ton, are the rich purple blooms of psycodes. An exceedingly curious plant is the British Frog Orchis (Habenaria viridis), with quaint green flowers; it thrives under drier conditions than the others. All the Habenarias grow from I2 to IS inches high, and flower in summer, chiefly in June; they are increased by dividing the roots in late summer.

Haberlea rhodopensis. - A pretty little alpine plant, belonging to the Gloxinia family (Gesneraceae), from the mountains of Greece. It forms a rosette of leaves, and bears in June or July pale lilac-coloured flowers on a spike about 6 inches high. It should be planted in a damp, shady crevice on the rockwork, in sandy peat, and can be increased by seeds sown in the spring in a shady frame.

Habranthus pratensis.-( Sie HIPPlistrum PRATENSE.)

Hacquetia Epipactis.-This, the only member of the genus (which belongs to the Natural (Order Umbelliferae), is a pretty little alpine perennial that reaches a height of about $f$ inches. The leaves are composed of three leaflets, and the small yellow flowers, in tiny umbels, appear in spring. It should be planted in the rockery in light loamy soil, and resents being disturbed; it may be increased by division, which must be very carefully carried out in early spring. Though a native of several parts of Europe, it is very seldom met with.

Hair Grass. - (See AIRA.)

Halesia (Snowdrop Tre).-The best-known member of this group (Natural Order Styraceac) is Halesia tetraptera, the Silver Bell or 
Snowdrop Tree of gardens. Several other kinds have, however, been known for many years under this name, but all are not strictly Halesias. Those from North America are now called Halesia, and those from China and Japan Pterostyrax. Their nearest ally in the outcloor garden is Styrax. The Silver Bell or Snowdrop Tree forms a bushy specimen, usually between I5 $_{5}$ and 25 feet high, although it grows three or four times as high in the United States. It is popular by reason of its profusion of white bell-like flowers, which appear in June. Halesia parviflora, from Georgia and Florida, is quite as beautiful, while it has the advantage of flowering freely as a bush 4 to 6 feet high. Other true Halesias are : tetraptera Mechani, with larger flowers than the type, and diptera, a showy kind from the Southern United States. The Halesias like rich loamy soil, in which a little leaf-mould or peat has been dug. They should be given positions sheltered from cold winds, are increased by seeds or layers, and only require sufficient pruning to keep them shapely, that being carried out after the flowers have fallen.

Halimodendron argenteum, the Salt Tree of Siberia, belongs to the Pea family (Leguminosae). It is of shrubby growth, with many long, thin branches clothed with small greyish leaves, and bears a profusion of pinkish flowers in May. In addition to being a slowy bush, it is well adapted for planting in ground impregnated with salt. In its native habitat it is common on the salty plains. As a rulc, it is grafted standard high in this country upon stocks of the Silerian Caragana arborescens, though it may also be grown on its own roots from seeds. As a bush it is useful for planting amongst rocks over which its branches may ramble at will, and for this purpose it might well find greater use in the vicinity of the sea. When grafted, it may be grown in any ordinary garden soil. Pruning is unnecessary.

Hamamelis (IVitch IIazcl).-A very showy and popular group of hardy shrubs or small trees, natives of China, Japan and North America (Natural Order Hamamelidaceae). The majority blossom during December, January, or February, according to scason, althougl they are usually at their best during the two latter months. One species, virginica, however, blooms during October and November. Although better adapted to the conditions prevailing in southern than in northern gardens, these shrubs are sufficiently harly to survive and give good results in most parts of the British Isles. The popular name of Witch Hazel is applied to the various kinds, although there is really no connection between them and the Hazels. With one exception, the flowers are peculiar by reason of ticir narrow, 
twisted, strange-looking petals; they are produced from buds on all parts of the younger growths, and are in such profusion as almost to hide the leafless branches. Plant in well-drained loamy soil containing a little peat, and provide sheltered positions exposed to full su11. Most of the kinds may be increased by seeds, or the better ones may be grafted upon stocks of the common Hamamelis virginica. The only pruning required is a little now and then to shape the plants. This must be done directly the flowers fall.

A selection of species is as follows: arborea, a Japanese bush or small tree with rich golden blossoms, usually borne during January and February, the calyx lobes are red; japonica, a bushier kind with golden petals and green calyx lobes-the var. Zuccariniana has lemon-coloured flowers. Mollis is a vigorous Chinese bush or small tree, with large oval leaves and handsome, golden, Primrose-scented flowers, which have straight petals with hooked ends: it blooms cluring December and January, and is the best of all. Virginica is a North American kind, which blooms in late autumn before the fall of the leaves; vernalis, also from America, blossoms in spring. The leares of most kinds change to a pretty golden hue before they fall.

Hare Bell.-(See Campanula Rotundifolia.)

Hare Bell, Australian.-(See Wahlenbergia.)

Harpalium.-(See Helianthus.)

Hart's Tongue Fern.-(See Scolopendrium.)

Hawkweed.-(See Hieracium.)

Hawthorn.-(See Crataegus.)

Heartsease.-(See VIOLA TRICOLOR.)

Heath.-(See ERICA.)

Hedera $\left(I v y^{\prime}\right)$.-A popular class of shrubs (Natural Order Araliaceae), usually of trailing habit. The most important kind is Hedera Helix, the Common Ivy of Europe, North Africa, and North Asia, a plant found wild in many parts of the British Isles. There are, however, one or two others in cultivation, though they are sometimes included as varieties of Hedera Helix. The chief are himalaica and coriacea (or colchica, as it is sometimes called); the last-named is the parent of many of those kinds which have very large, thick leaves. The chief attraction of the Iry is its evergreen foliage, though the ycllowish flowers in autumn and dark fruits in winter are also showy. A peculiarity of the Iry is its change of habit under certain conditions. As is well known, it ascends walls and trees by attaching its branches to the surface by means of aerial roots, but when the top of the support is reached the trailing habit disappears, and bush form is assumed. It is in this state that it flowers and fruits, 


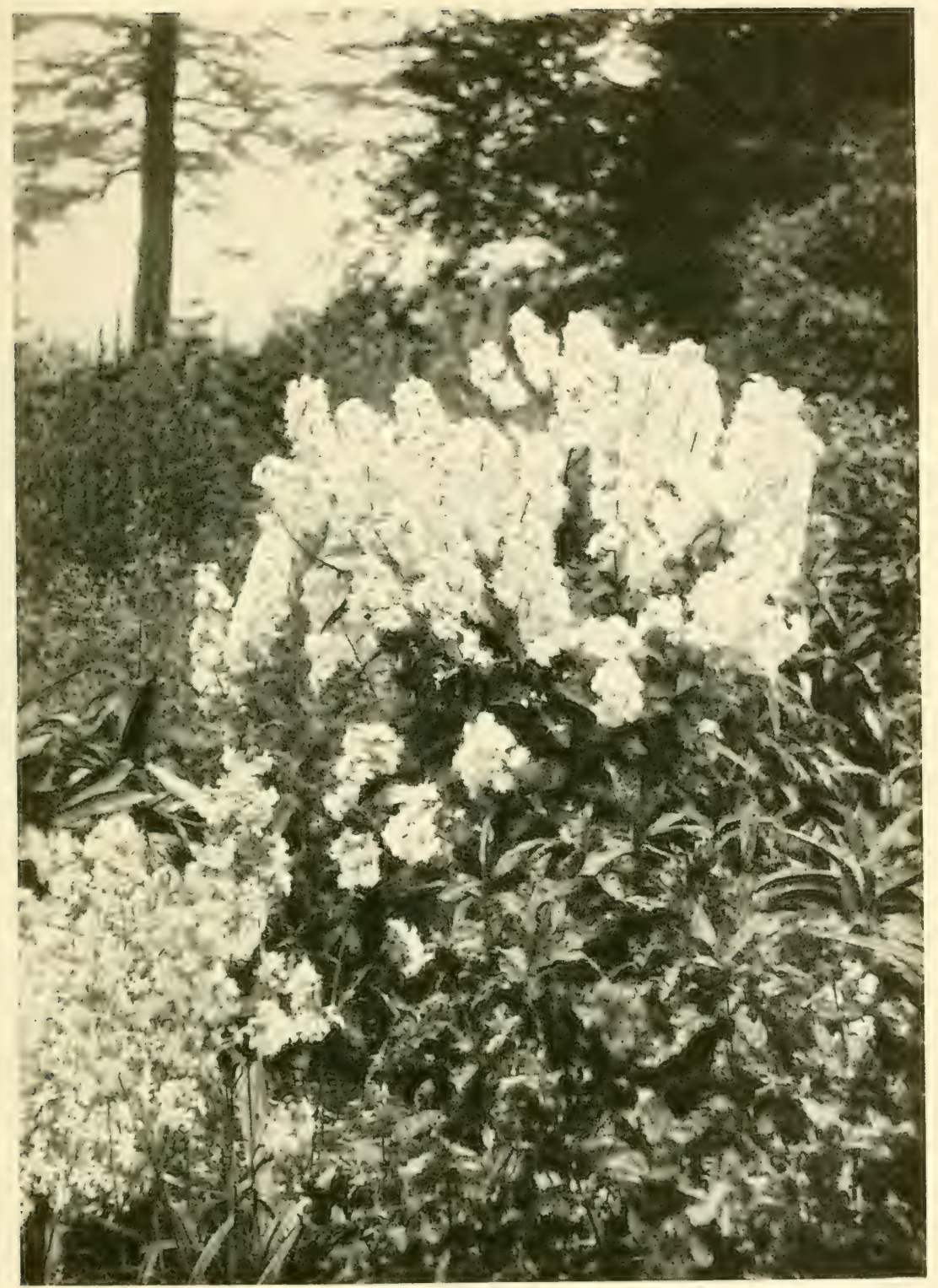

THE OLD DOUBLE WHITE ROCKET 

neither being found on the trailing branches. By propagating from these bushy parts excellent little evergreens have been obtained.

As is well known, the Ivy is a very variable plant, and not only do the leaves differ widely in shape, but also in colouring. Many have been given varietal names, and kinds with green, and gold and silver variegated leaves may be procured. Fortunately, the various kinds of Ivy may be grown in both town and country gardens, and they are available for a variety of purposes. Nothing is better for covering bare walls in bad positions, whether facing north, south, east, or west. They are equally useful for clothing the ground beneath shady trees, where grass will not grow, for planting against pillars, over old tree roots, against dead trees, or as informal fences trained on pillars and chains, etc.; whilst the bush forms may be used about the garden as ordinary evergreens. All kinds of soil come alike to the common kinds, but the less vigorous varieties should be given good loam. Propagation of the trailing sorts is by cuttings, indoors or in an open border. The bush forms may be either rooted from cuttings or be grafted upon rooted cuttings of the strong, trailing Irish Ivy. Ivy grown against house walls should be cut well back early in April each year; that growing against ruins must be left unpruned. When pruning Ivy on walls it should be cut back each year well below the gutters, otherwise it is liable to get between the slates and injure the roofs. Bush Ivies simply require to have the flowering shoots shortened in spring.

The chief sorts are: Helix, of which the varieties algeriensis, angularis, azorica, canariensis (Irish Ivy), and maderensis have large green leaves; Caenwoodiana, conglomerata, crenata, deltoidea, digitata, gracilis, minima, minor, and triloba, small green leaves; nigra and purpurea, purplish leaves; Angularis aurea, aurantiaca, aurea elegantissima, chrysocarpa, and chrysomela, golden leaves, and Crippsii maculata, maderensis variegata and variegata, have silver variegated leaves. The bush forms are found under the name of arborescens; gold, silver, and green kinds of these can be obtained.

Of varieties of other species the following have very large leaves: coriacea, amurensis, dentata, and gigantea. Hedera himalaica is a handsome kind also.

Hedychium.-The Hedychiums, which belong to the Natural Order Scitamineac, are natives chiefly of tropical Asia, and, with one exception, unfit for growing out-of-doors. This is Hedychium Gardnerianum, which passes the winter in a dormant state, and sends up a leafy spike about 4 fect high, terminated by a dense raceme of pale yellow, highly fragrant blossoms in the summer. This plant 
is a near relative of the Canna, and needs a warm spot, such as a narrow border in front of a greenhouse facing south. If the crowns are protected by a few leaves in winter they will be safe. Hedychium may be wintered safe from frost, like the Canna, and planted out in the garden during summer in a warm, sunny spot.

Hedysarum.-Chiefly herbaceous perennials, belonging to the Pea family (Leguminosae), natives of the temperate regions of the Northern Hemisphere. One, Hedysarum multijugum, is a valuable summer-flowering shrub. The more vigorous kinds will thrive in deep, loamy soil, while the smaller ones are suitable for the rockery. Hedysarum coronarium (French Honeysuckle) is most commonly scen; it grows 3 feet high, and bears racemes of deep red flowers during summer. Other species are: neglectum, a dwarf plant with purple-crimson flowers, suitable for the rockery; obscurum, another low growing rock garden plant, with rosy-crimson blossoms, and sibiricum, purple flowered, 2 feet high, suitable for the herbaceous border. The shrubby kind, multijugum, forms a spreading bush about 4 feet in height, with slender zigzag branches clothed with hoary pinnate leaves, and bears, during July, long racemes of purple Pea-shaped blossoms; it flowers best in a warm, well-drained loamy soil. Cut the younger shoots back about half-way in February, and at the same time peg down a number of the branches to within a few inches of the ground. Hedysarums are increased by seeds or by division of the roots in early spring.

Helenium (Snceze Wort).-Hardy perennials, members of the Daisy family (Compositae), and natives of North America. They are valuable for the herbaceous border, where they yield a fine show of bloom late in summer and early autumn. They thrive in ordinary garden soil, and should be divided every two or three years in early spring. The best kinds are: autumnale, pale yellow; autumnale striatum, coppery-crimson striped with orange; Riverton Beauty, with lemon-coloured flowers; and Riverton Gem, terra-cotta tint, changing afterwards to red. The two last-named are very beautiful varieties of autumnale and splendid border plants. All those named srow 5 or 6 feet high. The dwarfer kinds, pumilum and magnificum, reach a height of only 2 feet; their flowers are rich yellow, and freely produced in July. The other species are: Bigelovii, light yellow, brown centre, 2 feet; Bolanderii, pale yellow, black disc, 2 feet; and IIorpesii, the carliest to blom, large, deep yellow flowers, 2 feet.

Helianthemum (Sun Rose).---Low-growing, wide-spreading plants, natives of Europe, ctr. (Natural Order Cistaceac). They are well adlapted for planting on dry, sunny banks, on or in the crevices of 
loose stone walls, for rock gardens, and other places, but they must be given a sunny position. The most familiar kind is the common Sun Rose, vulgare, a yellow-flowered, almost prostrate plant found wild in many parts of the country. Under cultivation it has developed a great many variations from the type, which are distinguished by more vigorous growth; by flowers varying from white to deep golden and from pink to deep red, some being single and others double; or by variegated foliage. The varieties are increased by cuttings inserted in a frame in July, but if seeds from the varieties are sown vigorous plants bearing flowers of many colours are obtained. They give the best results when planted in poor soil, but after 5 or 6 years they usually begin to deteriorate, and should then be replaced by young plants. Pruning should take the form of removing the flower spikes as soon as the flowers fade. The best kinds are: vulgare, of which the following are good varieties: crocatum, croceum, croceum flore pleno, Yellow Standard and serpyllifolium, yellow; cupreum, copper; Fireball, red; venustum, red ; rhodanthum, red ; roseum and roseum multiplex, rose; album, white.

Helianthemum alyssoides grows $\mathrm{I}_{2}^{\frac{1}{2}}$ to 2 feet high, and bears yellow flowers; formosum is quite as vigorous; its flowers are yellow, with a dark blotch at the base of each petal ; ocymoides is a strong-growing, yellow-flowered kind from Spain and Portugal ; polifolium has forms with pink and white flowers; and umbellatum bears white blossoms.

Helianthus (Sunflower).-The Sunflowers, which belong to the Daisy family (Compositae), and are natives of North America, may be divided into two classes: the perennials, valuable border flowers for late summer and in autumn, and the annuals, most familiar of which is the common Sunflower (Helianthus annuus). Among perennial Sunflowers special mention must be made of Helianthus multiflorus and its varieties, particularly the double-flowered forms, which reach a height of 4 to 5 feet. The best are Bouquet d'or and Soleil d'or, both double flowered, quite distinct from each other; a very fine single flower is maximus. Another species, rigidus (Prairie Sunflower), used formerly to be known as Harpalium rigidum. Whereas the root system of Helianthus multiflorus is fairly compact and the plant spreads little, the underground rhizomes of Helianthus rigidus spread rapidly, and soon form a dense, tangled mass, and the plant may prove to be a very troublesome weed if not restricted. Nevertheless, it is decorative and useful for cutting, as the flowers have firm, wiry stems, and keep fresh in water for a long time. The different varieties of rigidus attain a height of 6 to 8 feet; the best are : Daniel Dewar, deep yellow, and Miss Mellish, bright yellow, semi-double: 
Other peremial species are: decapetalus, small, lemon-yellow flowers; mollis, light yellow, black disc; and orgyalis, tall stems, clothed with long, narrow leaves and small bright yellow flowers.

The annual kinds, even when represented only by the common Sunflower, form a striking feature in the garden. There are several pretty and comparatively dwarf varieties now in cultivation, varying from 3 to 4 feet in height; some have single and some double flowers.

A new race of anmual Sunflowers has made its appearance within recent years. It originated in America as a cross between the common annual Sunflower (Helianthus annuus) and the wild Sunflower of North America (Helianthus lenticularis). The basal portion of the florets is of chestnut-red colour, extending in some to such an extent that the yellow is limited to the tips of the petals. The general appearance of the flower suggests at a little distance a large Gaillardia. Annual Sunflowers are readily raised from seed sown in the open ground in spring, while the perennial sorts can be increased to any extent by division of the clumps in autumn.

Helichrysum (Everlasting Flower).-While the Helichrysums (Natural Order Compositae) contain both annuals and perennials, chief interest is centred in the annual kinds, consisting mainly of the numerous forms of Helichrysum bracteatum. These, which grow about 3 feet high, bear a profusion of Daisy-like flowers, in colours ranging from pure white to bright crimson. Apart from their beauty in the flower garden, these blossoms are extremely useful for winter decoration when cut and dried. It is essential that the flowers are cut and hung up to dry while they are still fresh. Helichrysums may be sown out-of-doors in April. A light, warm border suits them best, as might be expected from the fact that bracteatum, the species from whence they have sprung, is a native of Australia. Helichry'sum bellidioides is an alpine of prostrate growth that bears during the summer pretty white Daisy-like flowers. It is of a perennial character, and thrives in well-drained light soil and a sunny spot or in the moraine.

Heliopsis (Orange Sunflower).--Sunflower-like plants (Natural Order Compositae), natives of North America. They are as amenable to cultivation as the different sorts of Helianthus. The chief kinds are: lacvis, bright orange, 4 feet; scabra, orange-yellow, 4 feet; and its varieties, Ladhams, an extra fine sort; Pitcherianus, bright orange, and semi-plenus. All bloom in July and August.

Heliotrope.-(See Heliotropium.)

Heliotropium (Cherry Pic).--The Heliotropes, that form such a delightful feature in our gardens in summer, are all forms of the South American Ifeliotropium peruvianum, and belong to the Borage family 


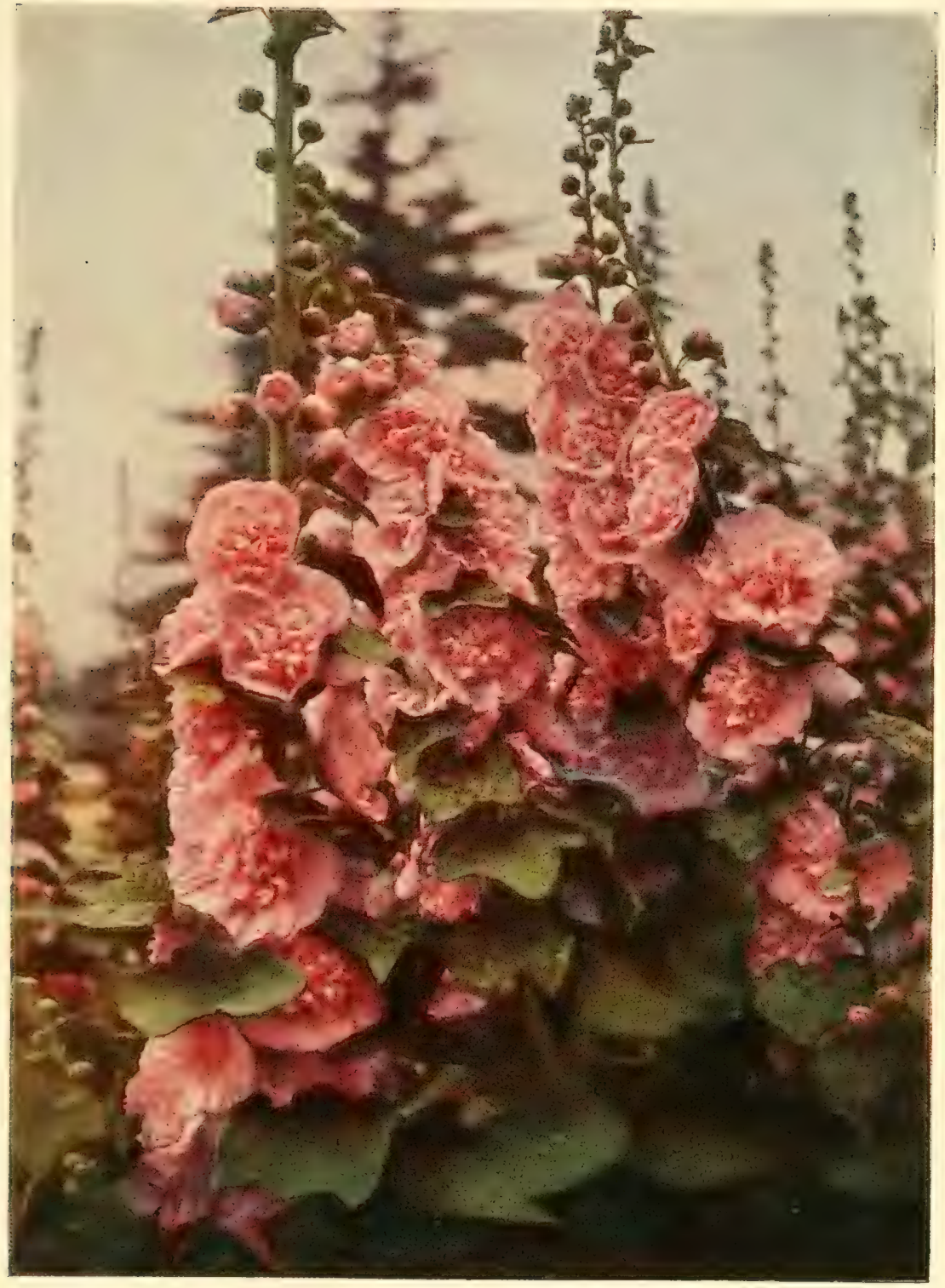

HOLLYHOCK PALLING BELLE 

(Boragineae). Apart from the beauty of their blossoms, which vary in colour from white or nearly so to deep purple, the Heliotropes are also remarkable for their fragrance. They are readily increased by cuttings of the young shoots taken in spring, dibbled in pots of sandy soil, and placed in a closed propagating case. Like the Fuchsia, the Heliotrope will, if kept free from frost during winter, grow rapidly in spring, and a good supply of cuttings is soon available. They are sometimes grown as standards for the flower garden, to obtain which the most vigorous are selected, and all shoots are removed until the desired height of stem is reached; then they are allowed to branch out naturally. Care must be taken to remove any shoots that develop on the stem. When these have done duty in the flower garden during the summer they must be lifted in autumn, potted, and taken into the greenhouse. In spring, before growth recommences, any straggling shoots may be shortened. To obtain pyramid plants the main stem is tied upright, and the branches allowed to develop at will, just pinching out the points of any that are inclined to grow too far. Heliotrope may be raised from seed sown in a warm greenhouse in early spring. The best varieties are: President Garfield, mauve-purple ; Priapo, deep blue ; White Lady, nearly white ; Lord Roberts, metallic violet; Miss Nightingale, dark purple; and Madame de Bussy, blue, with a white centre.

Helipterum (Immortelle).-Annuals belonging to the Daisy family (Compositae), with blossoms of an everlasting character. As a rule, the flowers are smaller than those of Helichrysum. They are very much used for wreaths, hence their popular name of Immortelle Flowers. They are readily dyed and are frequently seen of different colours in florists' shops. A distinct species is Helipterum Manglesii, which, under the name of Rhodanthe Manglesii, has long been a popular plant for growing in pots. It will, however, flower well if sown in a warm, sunny border in April, the bright satiny-pink flowers being very pleasing. All the Helipterums may be cut and dried in the same manner as Helichrysum.

Hellebore.-(See Helleborus.)

Helleborine.-(See EPIPACTIS.)

Helleborus.-The Christmas Rose (Helleborus niger) and its varieties are among the choicest of hardy herbaceous plants, while the Lenten Roses (orientalis) and other species are also very beautiful. They belong to the Buttercup family (Ranunculaceae), and are natives chiefly of Europe and Asia Minor. The Christmas Rose needs a deep sandy loam, enriched with decayed manure, and likes partial shade. Various opinions have been given as to the most 
suitable time of the year for transplanting it, but most agree that some time in summer is most suitable -say July. This plant forms it compact clump, and has stout, thong-like roots. If the clumps are planted whole they often fail to become established, therefore they should be carefully broken up into pieces, each containing several crowns. The colour of the flowers of the various Christmas Roses is white, flushed more or less with rose. The chief varieties of Helleborus niger are: angustifolius, Madame Fourcade, major and maximus, known also as altifolius.

The Lenten Rose (Helleborus orientalis) is less particular in its requirements, and may be transplanted in autumn. A partially shaded situation suits it best. This grows from I2 to I8 inches high, and the flowers, borne in spring as indicated by the popular name, are white, rose, or purplish and freely spotted inside. Another species, virilis, which is a native of Britain, is variable, but the flowers are of some shade of green. Many hybrids between this and orientalis have been raised, and these, with varieties of orientalis, form a selection of beautiful sorts. Chief among them are: Apotheker Bogren, crimson-purple, veined and spotted crimson; C. Benary, white, spotted inside crimson; Cupreus, dark plum; Dr. Moore, bright rose; I. C. Heinemann, purplish-rose, spotted crimson; Frederick, white, pink spots; Gertrude Jekyll, white; Lalla Rookh, rose, spotted purple; Mont Blanc, large white; Ne Plus Ultra, purple; Prince of Wales, rose with dark spots; punctatissimus, purple, frecly spotted deep purple; roseus grandis, fine large rose; and Rubra, deep red. Propagation of hoth Christmas and Lenten roses is by division of the roots at the times recommended for planting. They may also be raised from seeds sown as soon as ripe, but growth is slow.

Helonias bullata. - A strange and rare perennial plant, belonging to the Lily family (Liliaceae), and native of North America; the flower stem, I2 to 18 inches high, bears in June and July a spike of pretty pink flowers. In autumn the leaves turn to a bright red tint before they fall. The plant needs a moist, shady position in a peaty soil; it can be increased by division, carried out in antumn.

Melxine Solierolii.-A dense carpeting plant, very useful for flower herls in summer. It is native of Sardinia, and belongs to the Natumal Order Lrticaeae, and is often planted in the rock garden, where it spreacls quickly. Frost rarely injures it, but in a wet winter it is liable to " limp off." The flowers and fruits are insignificant, its claim to recognition being its dense carpet of bright green. 
Hemerocallis (Day Lily).--A free-growing race of perfectly hardy perennials that will thrive in any ordinary garden soil. They belong to the Lily family (Liliaceae), and are natives chiefly of Japan. They quickly form a tuft of strap-shaped leaves, and the flower spikes are 3 or 4 feet high. The blossoms are chiefly some shade of yellow, and though individually they last but a day in bloom, a succession is kept up for a considerable time. They bloom from June to August: Hemerocallis is readily increased by division, carried out in autumn. The best are: aurantiaca major, rich orange; disticha flore pleno, bronzy-yellow, double; Dumortierii, rich yellow exterior, bronzyorange interior, the dwarfest of all ; flava, bright clear yellow; fulva, bronzy-buff; fulva flore pleno, a double counterpart of the preceding; and Thunbergii, bright yellow.

Hemlock Spruce.-(See TSUGA.)

Hemp.-(See Cannabis.)

Hemp Agrimony.-(See EuPATORIUM.)

Hepatica.-(See ANEMONE HePATICA.)

Heracleum (Cow Parsnip).Herbaceous perennials, belonging to the Natural Order Umbelliferae; few have any refinement, and the best are more fitted for the wild garden than for the border. The chief kinds are:

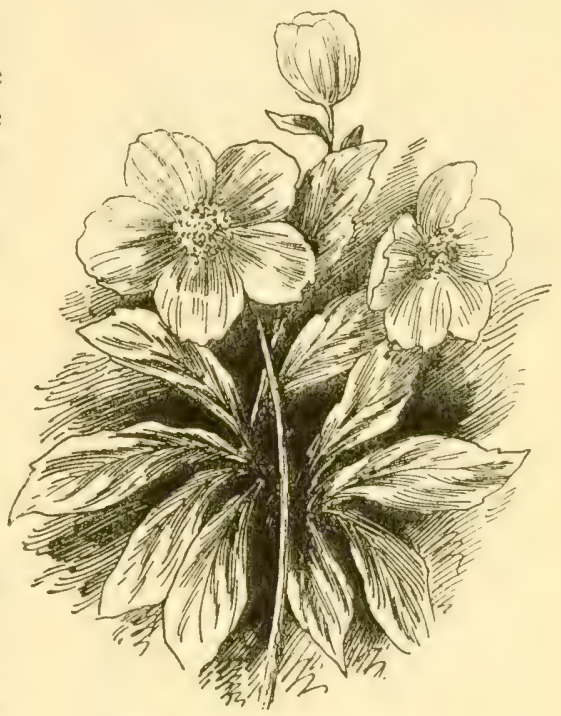

THE CHRISTMAS ROSE

(Helleborus niger) giganteum, which forms a large tuft of much-divided spreading leaves, and in August the stout erect stem, Io or I2 feet high, is terminated by a liuge branching umbel of comparatively small whitish flowers. This plant frequently forms the subject of an advertisement in the newspapers, where it is described as bearing flowers the size of a cart-wheel. Another striking kind is Mantegazzianum, not so tall as giganteum; it is recorded that an umbel of this has been counted containing I0,000 flowers. Both sorts will grow in almost any soil, but as their value depends to a great extent upon their size, manure should be added to the ground. They can be propagated to any extent by means of seeds, or in a lesser degree by division, in autumn; both are natives of the Caucasian region. 
Herb Lily.-(See Alstroemeria.)

Herminium (Musk Orchis).--These are hardy Orchicls (Natural Order Orchidaceac), natives of Europe, including Britain. Iterminium alpinum has Grass-like leaves, and a spike about $u$ inches high of white flowers in early summer. The commonest species is Monorchis, which grows usually in dry, chalky soils: from a pair of basal leaves this pushes up a spike ahout 6 inches high, bearing several small greenish flowers of a pronounced musky odour. Though interesting, these must be regarded more in the light of curiosities than as garden ornaments. A compost of chalky loam with a little leaf-soil is suitable; propagation is by division in late summer.

Herniaria glabra.--This is the only member of the genus (Natural Order Illecebraceae) worthy of recognition; it is native of Europe and Northern Asia, and forms a dense mass of small dark green leaves, and is much used for carpet bedding. Besides this, it may be planted in the rock garden. It is quite hardy, and can be increased to any extent by division, carried out in autumn or spring.

Hesperis matronalis (Rocket).-The only kinds in general cultivation are Hesperis matronalis and its varieties. It is a native of various parts of Europe, belongs to the Wallflower family (Cruciferae), and is a general favourite, especially in old-fashioned gardens; the flowers are fragrant, and their scent is especially pronounced in the evening. Though sometimes treated as an annual, it is really a herbaceous perennial, reaching a height of about 2 feet, and flowering from May to July. The typical kind has single purple flowers, while the varieties include a single and double white, single lilac, and double purple. The double kinds are liable to die out unless young plants are frequently raised from cuttings. The most successful growers propagate annually from cuttings when the young shoots are pushing up in spring. As a rule these require thimning, so that the surplus growths can be inserted as cuttings on a sheltered border and covered with a handlight. In addition to the common name of Rocket, the subject of this note is also known as Dame's Violet, presumably because the blossoms are deliciously fragrant in the evening. The single-flowered Rockets are readily raised from seed. All thrive in ordinary garden soil.

Heuchera (Alum Root).-A charming class of summer-flowering herbaceous plants that have come very much to the fore within recent years. They belong to the Natural Order Saxifragaceae, and are natives of North-IVest America. There are many species, but chief interest centres in Heuchera sanguinea, and the numerous garden forms obtained by crossing it with one or two others, especially 


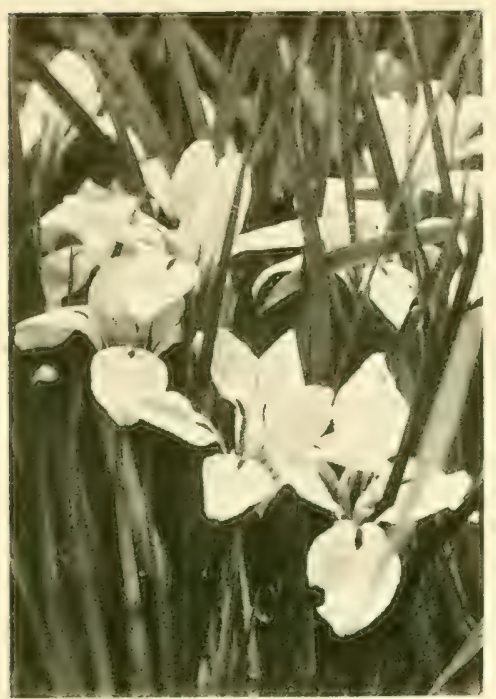

THE ALGERIAN IRIS (IRIS STYLOSA)

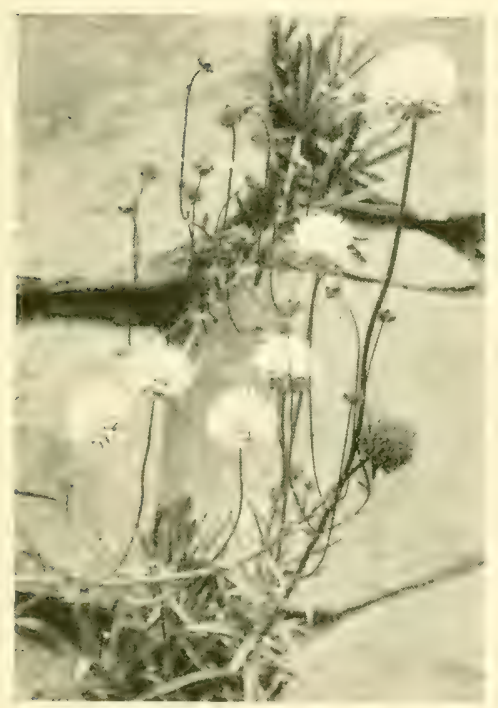

SHEEP'S BIT SCABIOUS (JASIONE JANKAE)

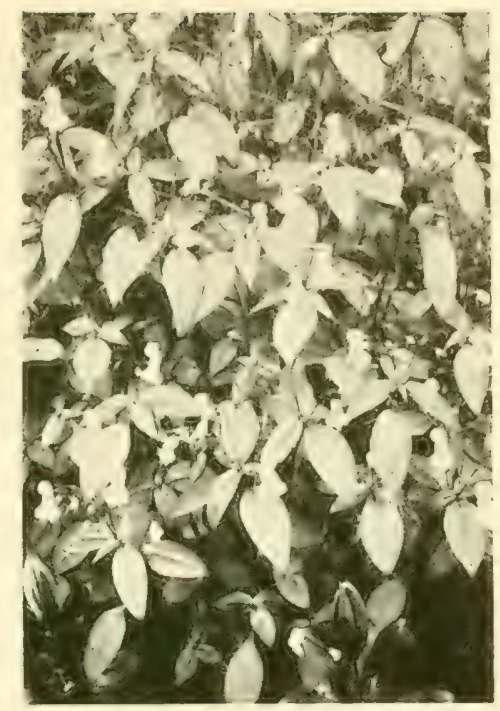

A HARDY BALSAM (IMPATIENS HYBRIDA)

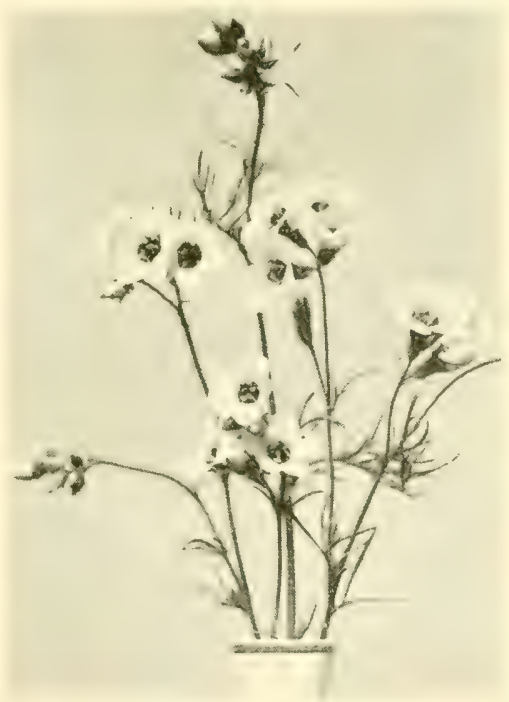

A PRETTY ANNUAL (GILIA TRICOLOR) 



\section{HIBISCUS}

micrantha. The Heucheras form neat tufts of heart-shaped lobed leaves; the flower stems, which reach a height of 2 to 3 feet, bear a profusion of small blossoms, gracefully disposed on slender branching spikes. Of the two species referred to Heuchera micrantha has small white flowers with pink stems, and in sanguinea the blooms are bright red. The best of the garden forms (usually classed as varieties of sanguinea) are : alba, white ; Edge Hall variety, bright rose; Flambeau, rich red; Rosamunde, delicate pink; Rose Queen, rich rosepink; splendens, bright crimson, and Walkerii, the richest coloured of all. Heucheras may be raised from seeds sown in spring in a frame. As this mode of increase cannot be depended upon in the case of the named varieties, these are propagated by division in spring. The plants thrive in well-drained sandy loam in bright sunshine. The long graceful sprays are especially valuable for use in a cut state.

Hibiscus (Mallow).-Hibiscus belongs to the Mallow family (Malvaceae), and comprises a large number of species, the majority being shrubs, though several are herbaceous plants. Few are avail. able for the outdoor garden, the majority being natives of tropical countries. The best shrubby kind, so far as the outdoor garden is concerned, is syriacus, an Oriental species, forming a bush 5 to ro feet or more high, and sometimes met with under the name of Althaea Frutex. Under cultivation it has developed a large number of varieties, some with white, others red or blue, some with single, and others with double flowers. A few good ones are: Hamabo, blush, with dark blotches; Celeste, blue; flore pleno, double; paeoniflora, double; ranunculaeflorus, double; purpurea, purple. All bloom in August and September. They thrive in a sunny position in ordinary garden soil, are increased by cuttings in a cold frame in October, and require no regular pruning.

The greenhouse kinds usually give the best results when planted in a border in a warm greenhouse, but they may also be grown in pots. They are remarkable in many cases for their large brilliantly coloured flowers. A few good kinds are: abelmoschus, large yellow flowers with dark blotches, native of the Tropics; coccineus, a redflowered kind from the Southern United States; Manihot, a vigorous tropical plant, with very large yellow blooms; rosa-sinensis, an evergreen shrub, with large red flowers. There are many varieties of the last-named, of which those with double flowers are highly appreciated.

Hidalgoa Wercklei (Climbing Dahlia).-This near relative of the Dahlia family does not form a tuberous root as they clo, and must be kept during the winter in the greenhouse. It belongs to 
the Daisy family (Compositae), and is native of the mountainous districts of Costa Rica. If planted out when it is safe to do so, the long, flexible shoots grow rapidly, and soon cover a consiclerable space. It climbs by means of the long leaf stalks, which twist themselves around any support. The much-divided leaves are very pretty. When studded over with its bright scarlet flowers like single Dahlias, this plant arrests attention by reason of its showy character and distinct appearance. A bright and warm summer is essential in order to have it at its best. It is propagated by cuttings of the young shoots in spring, and treated like Fuchsia. It will grow in ordinary potting compost, and when planted out in summer prefers a fairly light soil.

Hieracium (Hawkweed).-Many of the Hieraciums (Natural Order Compositae) are troublesome weeds in this country; they have branching spikes of Dandelion-like flowers. Few are of value as garden flowers, the best being Hieracium aurantiacum, I2 to I8 inches high, with bright orange-coloured flowers from July until autumn. The blooms of Hieracium rubrum are orange-scarlet, and in villosum, which is dwarfer than the other two and has whitish, downy leaves, they are bright yellow. Hieraciums are usually planted in the rock or wall garden, but care must be taken that they are not associated with delicate plants. They grow in ordinary soil in a sunny spot, and reproduce themselves readily from seeds, often self sown.

Himalayan Poppy.-(See Meconopsis.)

Hippeastrum.-The Hippeastrums, which belong to the Lily family (Liliaceae), and are native chiefly of South America, are a gorgeous race of bulbous plants, consisting of several species and innumerable garden forms. With one exception, they require glass protection throughout the year. The exception is Hippeastrum pratense, a native of Chili. Though this name is the correct one, the plant is more generally met with in gardens as Habranthus pratensis. The flowers, which are freely borne two or three together on stems from I2 to I8 inches in height, are funnel-shaped, about 3 inches across, and brilliant scarlet with yellowish centre. They are at their best at the end of May and in June. The plant needs much the same treatment as the Belladonna Lily; that is to say, it thrives in a narrow, sheltered border against a greenhouse facing south. The border should be thoroughly prepared by taking out the soil to the depth of 2 feet, on the bottom is placed about 6 inches of drainage material, while the compost is made up mainly of fibrous loam with a mixture of leaf-mould and sand. Planting should be done in autumn, and the bulbs put 6 inches below the surface. So treated, 
they will stand for many years without being disturbed, and flower annually.

Hippocrepis (Horseshoe Vetch).-The only member of this genus (Natural Order Leguminosae) in general cultivation is Hippocrepis comosa, a low-growing, creeping plant with clusters of yellow Peashaped flowers. On a warm, sunny part of the rock garden it will bloom from spring until autumn, and is readily increased by division or by seeds in early spring.

Hippophae rhamnoides (Sea Buckthorn).-This shrub belongs to the Natural Order Elaeagnaceae, and is widely distributed through Europe and temperate Asia, more especially in the vicinity of the sea, where it stands considerable exposure. It is useful for planting on waste land near the sea, and may be used as a screen or shelter for other shrubs. In addition, it is available for planting inland, where it is very effective in winter, when the leafless branches are covered with orange-coloured berries. To procure berries, however, it is necessary to plant both male and female plants together in the proportion of one male to five or six females, and when plants are procured care should be taken to obtain both sexes. Plant in ordinary garden soil. No pruning is necessary. As a rule, it is found between 8 and 12 feet in height. Hippophae salicifolia, from the Himalaya, grows into a tree of moderate size.

Holboellia latifolia is an evergreen climbing shrub from the Himalaya belonging to the Barberry family (Berberidaceae). It is suitable for the milder parts of the country, where its vigorous growth and dark green leathery leaves attract attention. The flowers are not very conspicuous, and the fruits are rarely matured in this country. Plant in ordinary garden soil, and prune fairly hard after flowering.

Holcus (Soft Grass).-The only member of the genus (Natural Order Gramineae) worthy of consideration as a garden plant is Holcus lanatus albus variegatus, a pretty white-striped Grass, useful for the front of or as an edging to the herbaccous border. It is readily increased by division in spring. Holcus lanatus grows wild in Britain.

Holly.-(See ILEX.)

Hollyhock.-(See AlthaEa ROSEA.)

Honesty.-(See Lunaria.)

Honeysuckle.-(See LONICERA.)

Hoop Petticoat.-(See Narcissus Bulbocodium.)

Hop.-(See Humulus Lupulus.)

Hordeum.-From an economic standpoint, by far the most important member of the genus (Natural Order Gramineae) is the Barley (Hordeum vulgare), while as an ornamental Grass, Hordeum 
jubatum, native of North America, is noteworthy. It is sometimes known as the Squirrel Tail Grass, and may be compared to a Barley with very long, conspicuous awns. It grows about if inches high, and thrives in ordinary garden soil. Seed should be sown out-ofdoors in spring.

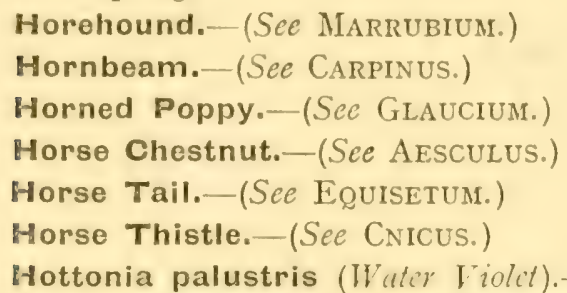
longing to the Primulit family (Primulaceac), which thrives best in shallow water. It is native of Europe. The stems, which are wholly submerged, are clothed with finely divided fern-like leaves of bright green tint. The pale mauve flowers, which are produced during the summer, float on the surface of the water. As with many other aquatics, this can be established by tying the plant to a brick and sinking it in the water. It will soon root in the mud at the bottom and grow quickly.

\section{Hound's Tongue.-(See Cynoglossum.) \\ House Leek.-(See Sempervivum.)}

Houstonia (Blucts). - A delightful race of very dwarf, freeflowering plants (Natural Order Rubiaceac), which bear blue or white flowers throughout the entire summer. They are scen at their very best in a sheltered chink in the rockery. The plants are but from 3 to 4 inches in height when in bloom, the neat, rounded tuft of leaves lying close to the ground. A well-drained, light loamy soil and partial shade suit them best. The various kinds are : caerulea, blue; cacrulea alba, white; purpurea, purplish ; purpurea alba, white; and serpyllifolia, bright blue. They can be increased by division, which must be carefully carried out in September or early spring, or by seeds, which ripen freely; indeed, in the case of Houstonia cacrulea, selfsown seedlings are very frequent.

Humea.- The only species in cultiration is Humca clegans; it belongs to the Daisy family (Compositae), and is native of Australia. It is of biennial cluration, and used for the decoration of the flower sarderi in summer. It forms an erect stem furnished with large oblong, lancenlite, frogrant leaves, and bears a loose janicle of small, reddish flowers in summer; the secondary branches of the panicle are lrooping, and a well-grown plant is most graceful. Seed is sown about midsummer in a pan of light sifted soil, such as a mixture of loam, 


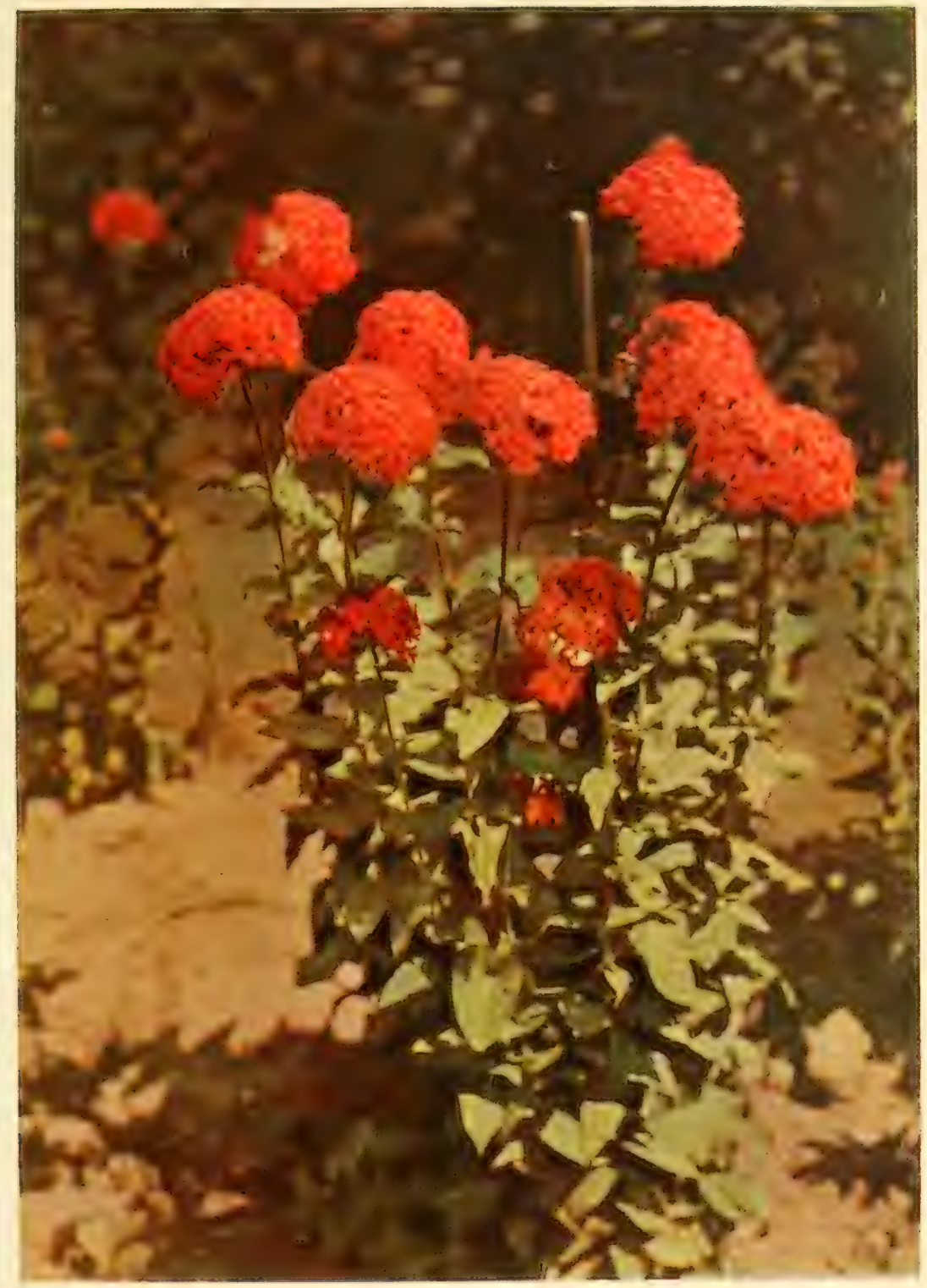

THE OLD SCARLET LYCHNIS CHALCEDONICA 

leaf-mould, and sand, and just covered with a little very fine soil. Germination quickly takes place if the pan of seeds is kept in a shady frame. As the seeds are small, watering through a fine rose must be carefully carried out. When large enough the young plants are pricked off into pans or boxes of soil similar to that described. They are kept in the frame, given plenty of air to ensure sturdy growth, and subsequently are potted singly in small pots, and will be reacly for shifting into pots 5 inches wide in September. They must be wintered in a light, airy grecnhouse just free from frost. Early in spring they should have a shift into larger pots, so that when planted out, about the end of May, they will develop good spikes of blossoms. The handling of the leaves sets up a severe irritation of the eyes of some persons, and this frequently leads to inflammation.

Humulus $(I O p)$. - Apart from its economic value, the common European IIop (Humulus Lupulus), which belongs to the Natural Order Urticaceae, is an ormamental, rapid-growing climber. It is of a herbaceous character, but if planted in good soil will soon cover a considerable space. For quickly clothing arches, trellises, arbours, or pergolas it is well suited. In late summer the plants are laden with clusters of the Hops of commerce. Increase is by division when dormant. The Japanese Hop (Humulus japonicus) is only of annual duration; it is a vigorous climber of considerable ornamental merit, but is in this respect greatly surpassed by its variegated-leaved variety, of which the foliage is delightfully mottled with white. The Japanese Hop may be sown out-of-doors in spring, but the better plan is to raise it under glass and plant out in good soil late in May. If treated in this way the plants are effective much earlicr in the season than if sown in the open ground.

Hunnemannia fumariaefolia. - A showy Californian perennial, momber of the Poppy family (Papaveraceae), with much-clivided gliancous leaves and yellow flowers, suggestive of those of Eschscholtzia californica. It reaches a height of 2 to 3 feet, and requires a light, warm soil. Under these conditions it will flower throughout the summer. It is increased by division when dormant, or by seeds, which are best protected by a frame during their earlier stages.

Huntsman's Cup.-(Sec Sarracenia purpurea.)

Hutchinsia alpina.-(See NoccaeA alpiNa.)

Hyacinth.-(See HyacrntuUs).

Hyacinthus (Hyacinth).--The Hyacinths of our gardens (Natural Order Liliaceac) have been obtained from the South European kind, orientals. The process of selection has occupied many, many years, and new varieties are still being raised. Mlost Hyacinth bulbs are 
grown by the Dutch, for in Holland immense areas are devoted to their cultivation. The bulbs should be planted in October or early in November, and covered with 4 inches of soil. When their season is past and the beds are required for summer flowers, the Hyacinths are liftel, with as little injury to the leaves and roots as possible. and laid in an out-of-the-way border to ripen off graclually. When the leaves have died down the bulbs are dug up and laid out to dry, then cleaned and stored until planting time. The bulbs cannot be

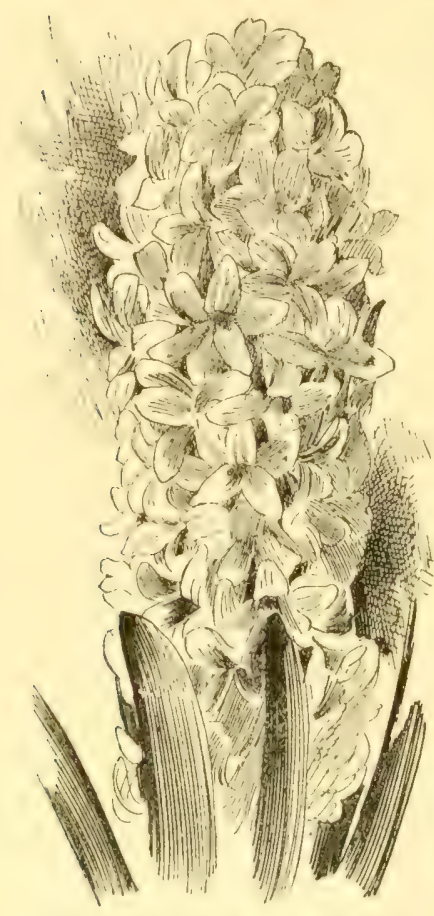

THE FLORIST'S HYACINTH expected to flower so well the second year, and though they cannot be recommended for beds, yet there are many places in the garden, such as in groups in the foreground of shrubberies, where their bright-coloured blossoms will be much appreciated. For outdoor flowering, the very choice varieties need not be employed, a good selection of the cheaper kinds being as follows. Red and pink-Baron Van Tuyll, Cardinal Wiseman, Fabiola, Garibaldi, General Pelissier, Gertrude, Gigantea, King of the Belgians, Moreno, Reine des Fleurs, and Robert Steiger. White-Baroness van Tuyll, La Grandesse, L'Innocence, Madame van der Hoop, and Mr. Plimsoll. Blue-Baron van Tuyll, Charles Dickens, Grand Lilas, Grand Maître, King of the Blues, Leonides, M. de Lesseps, Marie, and Royal Blue.

Other species of Hyacinths are: amethystinus (Spanish Hyacinth), with bright blue flowers (and its white variety, albus), that grows from 6 to $\mathrm{I} 2$ inches high and is very attractive in May; while azureus bears pretty blue flowers before winter has left us.

Several bulbs that have at one time or another been included in the genus Hyacinthus are now placed in other groups, particularly Muscari ancl sicilla. That summer-flowering bulb, with stately spikes of white flowers, formerly known as Iyacinthus candicans, is now Galtonia candicans.

Hydrangea.-Shubby plants bolonging to the Natural Order Saxifragaceac, consisting largely of North American, Chinese, Japanese, 
and Himalayan species. Many have long been popular garden shrubs, whilst one or two sorts are used extensively for greenhouse and room decoration. Some kinds are hardy throughout the British Isles; others can only be grown successfully in the milder counties. Those for outdoors require rich loamy soil, and as they are "rank feeders," a surface dressing of manure occasionally to the ground immediately surrounding the roots, is attended by good results. Hydrangea hortensis, from China and Japan, is used more often than any other kind for greenhouse decoration. Many varieties have developed, the most popular being those where practically all the flowers are sterile, the reproductive organs being displaced by large showy bracts. There are many varieties, however, which bear a mixture of sterile and fertile flowers, which are equally beautiful ; Mariesii, for instance, with large reddish sterile flowers and blue fertile ones, and Veitchii, a similar plant, with white sterile blooms, are very showy. By careful cultivation, the heads of these sterile flowers attain large proportions. Cuttings of the points of shoots are rooted in summer, and the young plants kept in small pots until January. They are then placed in a compost of 3 parts good loam to I part leaf-mould and $I$ part well-decayed manure with a little sand, in 5- or 6-inch pots, and grown on in a greenhouse to produce a single head of flowers each. If such plants are kept for another year they may produce 4 or 6 heads each, and in later years a plant may carry two hundred heads of flowers.

Many large plants are found out-of-doors in the milder parts of the country. A peculiarity of the plant is that although the flowers may be normally pink, the addition of iron to the soil causes them to turn blue. Upon no account prune the shoots of Hydrangea hortensis before they have flowered. As a rule, pruning should take the form of thinning.

The next most popular kind is paniculata, a native of Japan; it is an upright bush, 5 or 6 feet high, which bears terminal panicles of fertile and sterile flowers in August and September. The variety grandiflora differs by reason of all the flowers being sterile. It often forms exceptionally large inflorescences, those on plants growing in rich soil being often between $\mathrm{I} 2$ and $\mathrm{I} 8$ inches long. It is much used for forcing. The young branches may be cut back to within two or three buds of the old wood in February each year. The young shoots must also be well thinned if the finest flower-heads are desired.

Hydrangea arborescens var. grandiflora is another kind which bears handsome, rounded heads of white sterile flowers in July; it 
must have rich soil and be pruned hard back about February. Petiolaris is a useful Japanese plant of climbing habit; it climbs naturally by means of acrial roots, attaching itself to its support in a similar manner to the Ivy, and may be used for walls or for covering tree trunks or the overturned butts of trees; stellata and Lindleyi are well-marked varieties of hortensis. Although there are many other species, those referred to are the best for general use.

Hydrocharis (Frog Bit). - A British plant (Natural Order Hydrocharidaceae) which, rooting in the mud at the bottom of shallow water, will quite cover the surface with curious brown circular leaves. The flowers are not of any particular account.

Hydrophyllum (Water Leaf).-Hardy perennials (Natural Order Hydrophyllaceac), natives of North America. They reach a height of 12 to 18 inches, and prefer a moist soil. The species are: appendiculatum, with blue flowers; Canadense, white; and virginicum, blue. The popular name is derived from the fact that the pinnate leaves become filled with water during spring. All can be increased by division in early spring. The blossoms are borne more or less throughout the summer.

Hymenanthera crassifolia is a dense, low-growing bush from New Zealand, belonging to the Natural Order Violaceae. Attaining a height of $I_{2}$ or 2 feet, it forms a mass of rather rigid shoots clothed with small evergreen leaves. The flowers are not very showy, and the white fruits are not produced in sufficient numbers to make them effective. Plant in ordinary garden soil, increase by seeds or cuttings, and give no regular pruning.

Hypericum (St. John's Wort).-Hardy, shrubby, and herbaceous plants are found in this group (Natural Order Hypericaceae). They are widely distributed through Europe, temperate Asia, and North America, and some occur as weeds in the British Isles. The majority have golden blossoms, but in a few cases the flowers are pale yellow. Most of the shrubby kinds are valuable plants, for they blossom freely from July to October, a time when flowering shrubs are not common. They thrive in good loamy soil, and should usually be given an open position, although one kind, calycinum, gives good results in semishade. The dwarf, shrubby kinds and the best of the herbaceous sorts are worth a place on the rockery, whilst the more vigorous of the perennials should find a place in the herbaceous border. The shrubby kinds are usually increased by cuttings in summer, but some are propagated from seeds or by division. Other kinds may be divided in spring. All the shrubby sorts are benefited by boing pruned rather vigorously in February. Remove old, worn-out 


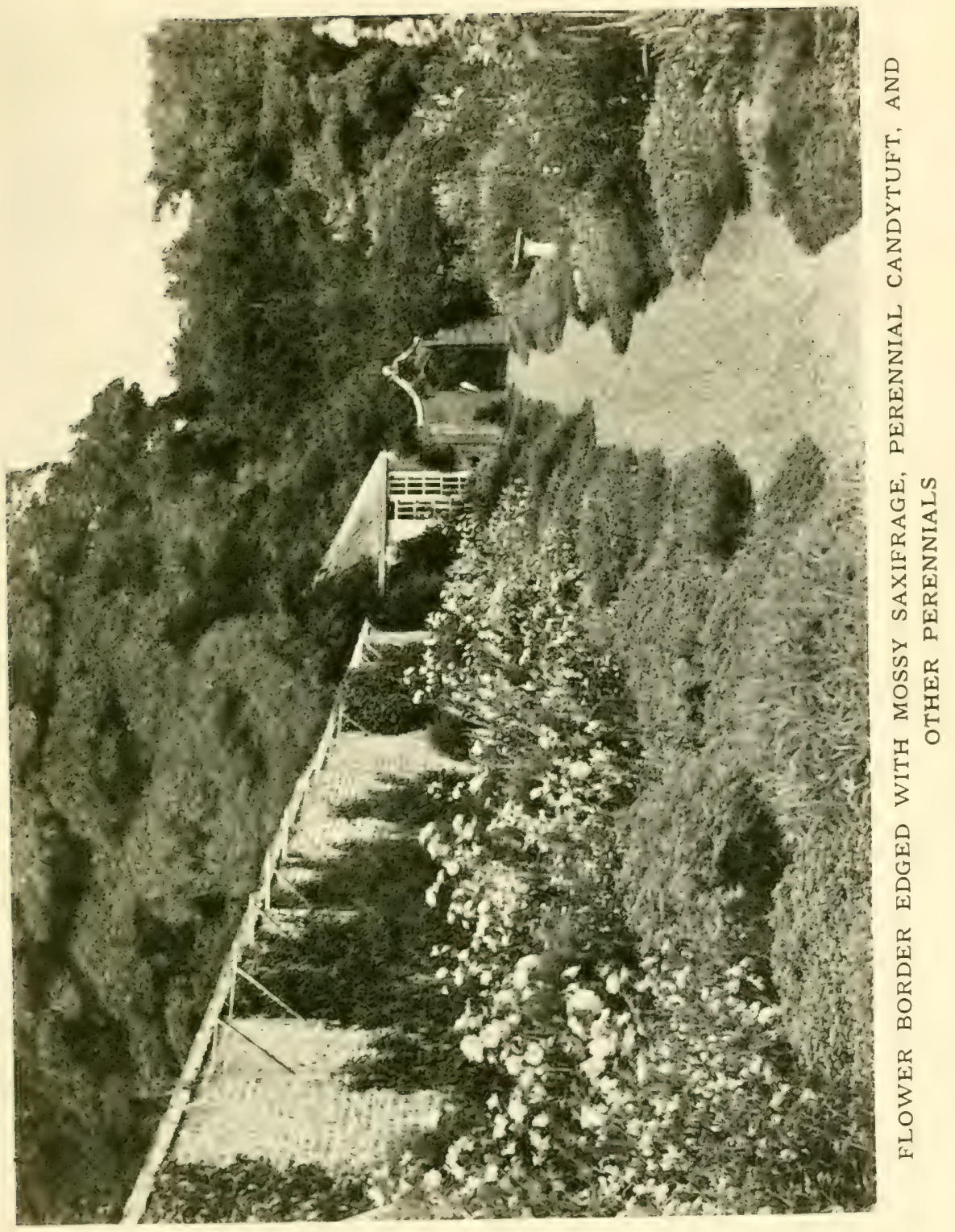



branches and very weak shoots, and shorten the remainder half way. Hypericum calycinum is often grown as a carpet plant beneath trees, and when this is the case it should be cut to the ground each spring.

The chief kinds are: Androsaemum, sometimes called the Tutsan, a European plant I foot to 2 feet high, its yellow flowers are followed by black fruits; aureum, from the Southern United States, is a showy plant; Buckleyi, a dwarf plant, 6 inches high, is from Georgia and Carolina, it is a neat, free-flowering specimen, suitable for the rock garden. Coris, a dwarf herbaceous kind, bears very large flowers, and is grown in the rock garden; calycinum, the Rose of Sharon, has already been mentioned, its flowers are 3 inches across; densiflorum, kalmianum, and prolificum are three dense-growing kinds from North America, they grow about 2 feet high, and produce their small flowers in large heads.

Hypericum elatum is a shrub 3 to 4 feet high, of bushy habit. Hookerianum should be selected when a few kinds only are wanted; it grows $2 \frac{1}{2}$ feet high, and blooms profusely, native of the Himalaya. Moserianum is the best of the dwarf kinds for planting in specimen beds on lawns; growing I foot high, it forms compact plants bearing a profusion of golden blossoms, it is of hybrid origin. Olympicum, from Asia Minor, is conspicuous by reason of its small glaucous leaves and profusion of flowers; its proper place is the rock garden. Patulum var. Henryi is a graceful Chinese kind, 2 feet or so high; it grows freely and blooms profusely. Humifusum, orientale, and perfoliatum may be grown in the herbaceous border. The rock garden kinds need sandy loam and a sunny position.

Hyssopus officinalis (Hyssop). - A well-known aromatic herb (Natural Order Labiatae), that forms a bushy plant about $\mathrm{I} 8$ inches high, and when the bluish-purple blossoms are open in summer it is fairly ornamental. It thrives in ordinary garden soil, and can be propagated either by seeds or cuttings; the latter should be dibbled in a shady border at the end of August, while seed is sown in spring.

Iberis (Candytuft). - The Candytufts, which belong to the Wallflower family (Cruciferae), and are natives chiefly of Southern Europe and Asia Minor, may be divided into two sections, annuals and perennials. The latter are sometimes referred to as herbaceous plants, but they are really shrubs or sub-shrubs, for the stems are permanent, and the foliage is more or less evergreen. As the tallest of them rarely exceed I2 inches in height, they are well suited for the rock garden, particularly Iberis sempervirens, which will drape the front of a large boulder, forming a cascade of white blossom. They flower during April and May and more or less during summer, and are 
increased by cuttings and division in late summer. Seeds also ripen from which, if sown in spring, young plants are easily raised. Perennial Candytufts like a sunny spot and will grow in ordinary welldrained soil. In the front row of the herbaceous border they are seen to advantage, while on dry walls and in the rock garden they are especially charming. A selection of the best includes: correaefolia, Garrexiana, gibraltarica, Little Gem, saxatilis, sempervirens, sempervirens flore pleno, and Tenoreana. The last-named has pale rosylilac flowers, those of the others are white. The dwarfest of all is saxatilis, while Little Gem is a dwarf, compact plant 6 inches high.

The annual Candytufts have been greatly improved within recent years, and different strains, quite distinct from each other, are now to be obtained. The large spikes of the Hyacinth-flowered varieties make a particularly bold show, the range in colour extending through white, rose, carmine, and crimson. Seeds are sown out-of-doors in March and April, and the seedlings must be thinned out well, for a good plant, when at its best, is about 12 inches through. Annual Candytufts flourish in ordinary garden soil, and prefer a sunny spot. They are thoroughly hardy, and seed may be sown in autumn to produce flowering plants in spring. The seedlings do not transplant readily, hence seed should be sown where the plants are to bloom.

\section{Ice Plant.-(See Mesembryanthemum.)}

Idesia polycarpa is a rare ornamental tree from China and Japan, belonging to the Natural Order Bixaceae. Its chief attractions are the large and handsome heart-shaped leaves, which are borne on long reddish stalks. The flowers are rather small and yellowish in colour; they are succeeded, however, by showy, round black fruits in bunches 4 to 6 inches long, resembling bunches of small grapes. It should be given a sunny position on a lawn where the soil is well drained, deep, and loamy. Propagation is by seeds, and any necessary' pruning should be directed towards shaping the tree and keeping the leading shoot clear of rivals.

Ilex (Holly).--This is an important class of hardy trees and shrubs (Natural Order Aquifoliaceac), for it includes the Common Holly, one of our few large-growing native evergreens, and an invaluable plant for the garden. The various species are widely distributed through Europe, North India, China, Japan, and North America, whilst many tender kinds occur in South America and elsewhere. The hardy kinds, however, alone concern us. There are two distinct groups, one of which bears evergreen and the other deciduous leaves; the former group is the more valuable for the garden. The Hollies possess several economic properties, for in addition to the timber 
being hard and useful for turning, carving, etc., the bark of some kinds is of medicinal value, whilst bird-lime is prepared from other sorts. The leaves of some sorts are also used for tea. Those of the South American Ilex paraguensis are of special value for the purpose.

The Common Holly, Ilex Aquifolium, can be grown throughout the British Isles except in water-logged ground, and it often occurs wild in Pine and Oak woods, for instance, in the New Forest and in the Forest of Dean. It is, however, planted largely in the garden both as a decorative tree and as a hedge. For an evergreen hedge it is perhaps the best all-round shrub that can be procured. There are many varieties, some distinct by reason of the shape or spiny character of the leaves and others by the leaf-colouring, for there are many forms with gold- and silver-variegated foliage. Hollies must not be disturbed except at the right season, especially if the soil is to be shaken from the roots, and it is often fatal to move them during winter. Late April and May, and August and September, are the best months for transplanting. People frequently err by over-pruning Hollies. They clip them as they would a hedge, whereas pruning should take the form of thinning the shoots, removing one here and there which is throwing the tree out of shape. This may be done in summer. Holly hedges should be clipped in August.

A few useful varieties of the Common Holly are: Green-leavedangustifolia, a small-leaved kind; camelliaefolia, a handsome uprightgrowing tree with large dark green leaves; Donningtonensis, with narrow leaves; integrifolia and scotica, with almost spineless foliage; and ovata, with distinct leaves of very even size. Golden-leavedGolden Queen, Golden King, aurea marginata, and aurea medio-picta. Silver leaved-Silver Queen, Handsworth Silver, argentea marginata. The yellow-fruited kind (fructu-luteo) and the weeping Holly (pendula) ought also to be grown.

There is another set of Hollies with large broad leaves, which are usually included under Ilex Aquifolium, though many of them are hybrids between Ilex platyphylla or Ilex balearica. Good ones are : altaclarensis, Shepherdii (sometimes called Hodginsii), nigrescens, and nobilis.

Other useful species are: cornuta, a dense evergreen bush from China; crenata, a dwarf, compact evergreen from Japan with tiny evergreen leaves; latifolia, a large-leaved Japanese plant; opaca, the American Holly, with fruits as showy as those of our common kind; Pernyi, a handsome new evergreen species from China, with small leaves; and Veitchii, another new Chinese kind, related to the last-named. 
As the Common Holly is so often grown for its fruits, it must be understood that male and female flowers appear on different trees, therefore the planting of both kinds is essential.

Illicium.-This group, which belongs to the Magnolia family (Magnoliaceae), is composed of a few evergreen shrubs from China, Japan, and North America, which may be grown out-of-doors in the milder parts of the country, but require greenhouse protection elsewhere. They thrive in loamy soil containing a little peat ; are usually raised from seeds, and require no other pruning save what is necessary to shape the bushes. Illicium floridanum, from the Southern United States, has reddish star-shaped flowers, and religiosum, from China and Japan, has cream-coloured blooms. Flowering takes place during late spring and early summer.

Impatiens (Balsam).--Though this is an extensive class, belonging to the Geranium family (Geraniaceae), few are of value for the outdoor garden. The Common Balsam (Impatiens Balsamina) is a popular annual for growing under glass, and occasionally is bedded out during summer. For the latter purpose seed is sown late in March in warmth ; it germinates quickly, and the young plants make rapid progress if potted in light, rich soil. By the second week in June, at which time they should be established in 5 -inch pots, they may be planted out. If the season is favourable they will give a good display, but not for very long. Two shrubby kinds, Impatiens Holstii, with vermilion flowers, and Oliverii, pale mauve, are grown from cuttings in spring like a Fuchsia, and planted out-of-doors early in June. Only in a warm season are they satisfactory in the open. The two following annuals reproduce themselves readily from seeds, namely, amphorata, purple, and Roylei (also known as glandulifera), rosy-purple. Both reach a height of 6 feet or more, and are very striking, but suitable only for the wild garden or woodland.

Incarvillea (Trumpet Flower).-Showy herbaceous perennials (Natural Order Bignoniaceae), natives of China and Turkestan. They form stout, fleshy roots, and in spring produce a tuft of spreading pinnate leaves; the flower spike may be from 18 inches to 3 feet high, and bears trumpet-shaped blooms. Incarvillea Delavayi is the most popular kind, and has rose-red blooms. Somewhat similar is grandiflora, with flowers of deeper shade; Olgae and variabilis have bright rose-coloured blooms; variabilis differs from the others in its finely cut fern-like foliage. All the Incarvilleas flower during June and July. The stout, fleshy roots are remarkably brittle, so that great care must be taken in handling them. Seeds are sometimes produced from which young plants can be raised; it is sown 


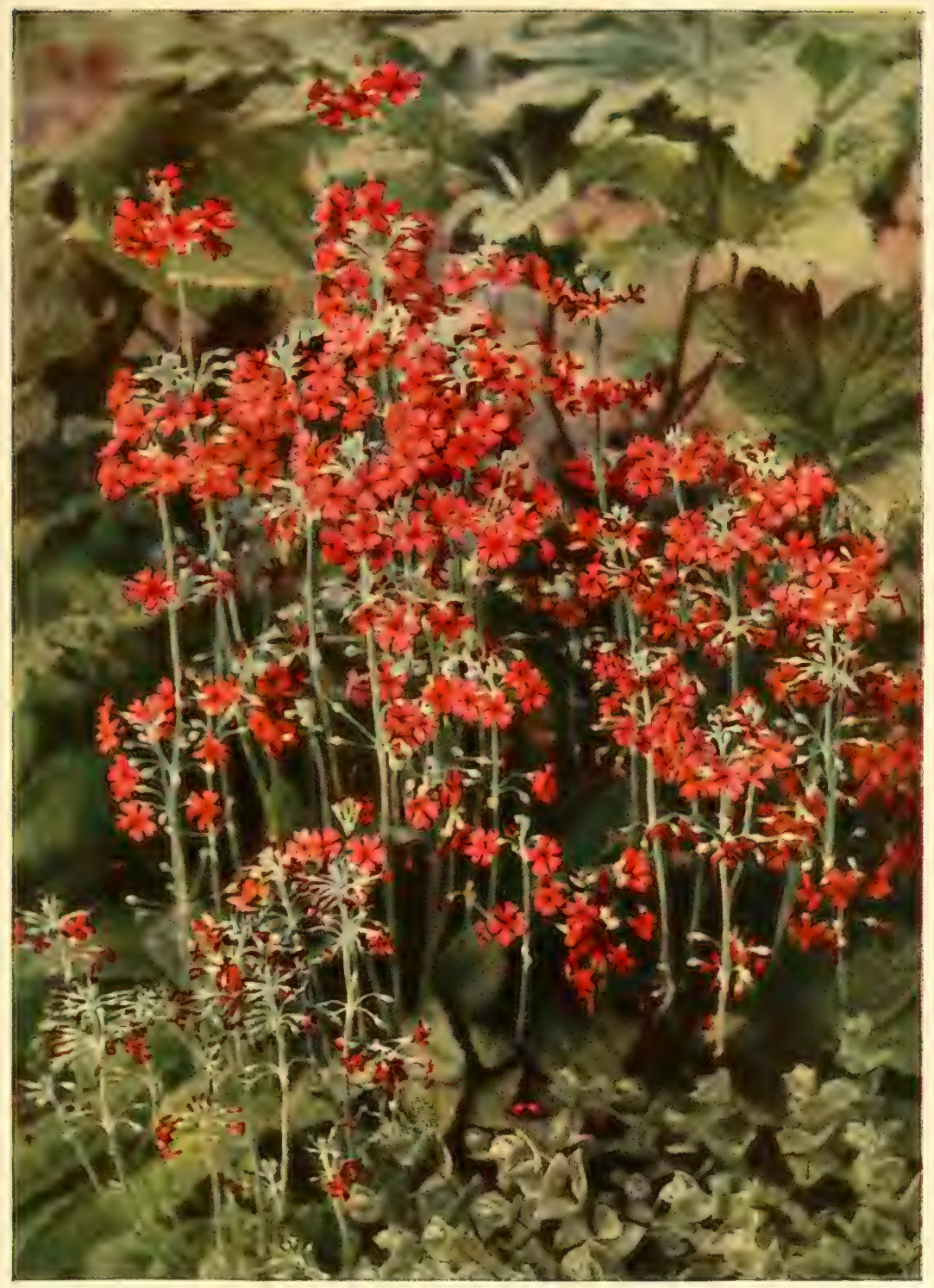

THE BRILLIANT PRIMULA "UNIQUE" 

in sandy soil in spring, and placed in a frame. In the case of established clumps, division may also be carried out in autumn, though they are best left undisturbed as long as possible. In cold gardens these plants should be protected by a heap of ashes over the crowns:

\section{Indian Corn.-(See ZEA.) \\ Indian Cress. - (See Tropaeolum Majus.) \\ Indian Pink.-(See Diantuus Chinensis.) \\ Indian Shot.-(See CanNa.)}

Indigofera Gerardiana is the only shrub in this group with which we need concern ourselves, although Indigofera tinctoria, of the Tropics, is a much more important plant, for it is the source of indigo of commerce. Indigofera belongs to the Pea family (Leguminosae), and the species Gerardiana is a native of the Himalaya. When planted against a wall it grows I $2_{2}$ or I $_{5}$ feet high, the main branches surviving and producing long shoots each year which bear elegant pinnate leaves and dense racemes of rosy-red flowers during July and August. In the open it is usually cut to the ground line each year, but new shoots appear from the rootstock, and grow between 2 and 3 feet long during summer. Flowers are borne quite freely. Pruning of plants in beds should take the form of cutting all shoots to the ground in February. In pruning plants on a wall, cut back the previous year's shoots to within a bud or two of the base. Plant in deep loamy soil, and increase from cuttings.

inula.-Vigorous herbaceous plants, belonging to the Daisy family (Compositae), and natives of the Northern Hemisphere. In late summer and early autumn they bear yellow single flowers. Inulas thrive in ordinary garden soil, and may be increased by division, root cuttings, or seeds. Division is carried out and root cuttings are taken in autumn; the latter are made by cutting the roots into pieces about 4 inches long, which are dibbled into sandy soil or a sheltered border; they will soon form plants. Seeds may be sown out-of-doors in spring. The best are: ensifolia, a neat, compact rock plant, about 9 inches high; glandulosa, 2 feet; glandulosa fimbriata, with fringed petals; grandiflora, 2 feet; Helenium, having large oblong leaves, 6 feet; Hookerii, 2 feet; montana, a little plant, suitable for the rock garden; Oculus-Christii, 2 feet; and Royleana, 2 feet.

Ionopsidium acaule (Violet Cress).-A dainty little annual, member of the Wallflower family (Cruciferae), which grows only about 2 inches high, and bears pretty little lilac-blue flowers throughout spring and summer. It is seen at its best in a half-shaded place in the rock garden. Seed may be sown in spring, where the plants are 


\section{THE BOOK OF HARDY FLOWERS}

to flower. Once established, it will reproduce itself by means of self-sown seeds, which come up freely. The Violet Cress is a native of Portugal and the North of Africa.

Ipomoea (Morning Glory).-An extensive group of chiefly climbing plants (Natural Order Convolvulaceae) which are more numerous in the tropical than in temperate countries. That brilliantly coloured climbing annual, known as Convolvulus major, is classed by botanists as Ipomoea purpurea. The chief annual kinds of Ipomoea that may be grown out-of-doors in a sheltered spot are: rubro-caerulea, a Convolvulus-like plant, with large sky-blue flowers, soon becoming suffused with red; and versicolor, bearing spikes of red flowers which subsequently change to yellow; this is a useful, quick-growing annual. A Mexican tuberous kind, Purga, will survive the winter if the roots are protected from frost and planted at the foot of a south wall; the slender shoots entwine themselves around any support, and soon cover a considerable space. The purplish-rose flowers appear towards the end of summer, and continue into autumn. In the south-west of England it is quite hardy.

Iresine.-The Iresines, which belong to the Natural Order Amarantaceae, and are native of South America, are well-known bedding plants, their chief attraction being their coloured leaves as the flowers are not at all showy. They are easily grown, and if a few plants are wintered in the warm greenhouse they will produce numerous shoots in spring, and thus form roots quickly. If potted and kept in a greenhouse or frame they will form good plants by bedding-out time; they thrive in ordinary potting compost of loam, with a little leaf-mould and sand. Those generally used for bedding are Herbstii, with deep purplish-crimson leaves ; Herbstii aureo-reticulata, leaves veined with gold; and Lindenii, deep red leaves.

Iris.-The different members of the genus Iris (Natural Order Iridaceae) occur over the northern and temperate regions of both hemispheres. The most accommodating race of all is that commonly called Flag or German Iris, which has been obtained from several distinct species, such as amoena, neglecta, pallida, squalens, and variegata. The Flag Irises will thrive in adverse conditions, in shade, in town gardens, on a wall, or a hot bank, though they appreciate good border soil. In planting, the rhizomes should only be just covered; they should be disturbed as little as possible, for they take a year or two to recover fully. The flower consists of the standards or erect petals, and the falls or drooping petals. In some varieties the colours of the two are quite distinct. The standards and falls are here indicated by the initial letter of each: 
A good selection of German Irises is as follows: albicans, white ; atroviolacea, claret ; aurea, golden-yellow ; Black Prince, (s) purplishlilac, (F) almost black; Blue Boy, (S) light blue, (F) purple ; Bridesmaid, (S) pale lavender, ( $\mathrm{E}$ ) white, veined with lavender; Cordelia, (S) deep lavender, (F) rich purple; Duchesse de Nemours, blue, veined white; flavescens, light primrose-yellow; florentina, white, tinged with lavender, this is the species from which Orris Root is prepared; Germania, (S) purplish-blue, (F) purple; Gracchus, (S) lemon, (F) pale yellow, veined purple; Hector, (S) yellow, (F) velvety-crimson; Madame Chereau, white, edged and feathered violet, and pale blue; Maori King, (S) rich yellow, (F) velvety-crimson; Mrs. Neubronner, yellow; Mrs. Reuthe, pale lavender; Poiteau, (s) white, tinged lavender, (F) purple, veined white; and Standard Bearer, (S) rich rosy-purple, (F) purple, veined and shaded white. The list of varieties of this class is a very long one, and some nurserymen are continually raising new varieties. Where the standards and falls are not indicated the flowers are self-coloured. The month of March is a good time to plant the Flag Irises, as the new roots at once take possession of the soil.

Dwarf Flag Iris.- Under the name of Iris pumila there is a charming race of dwarf Irises that flower in early spring; they grow only some 6 inches high, bloom profusely, and are suitable for the rock garden or as an edging to a bed of the larger kinds; for this latter purpose if put in a double row about 4 inches apart they will soon become established. The best are : alba, white; atroviolacea, deep purple; coerulea, light sky blue; cyanea, dark blue; excelsa, yellow; gracilis, pale greyish-blue; and lutea, deep yellow. All of these have rhizomes like the German Iris, but they do not spread to the same extent.

Spanish Iris.-This term is applied to the various forms of Iris Xiphium, and they form an exceedingly valuable race of hardy bulbs. The flowers, produced on stout, erect stems, 2 feet or so high, are of various shades of white, yellow, blue, bronze, and other tints. They are valuable for cutting, and last a long time in water if gathered just as the flowers are opening. The bulbs should be planted during October, preferably in sandy, well-drained loam, 4 or 5 inches deep, and the same distance apart. They may be left undisturbed for three or four years, when they ought to be lifted and replanted. Some good varieties are: Alexander Von Humboldt, rich blue; British Queen, white; Bronze King, bronze; Cajanus, golden-yellow; Excelsior, light blue, late; Jaune, brilliant orange-yellow; King of the Blues, deep blue; La Reconnaissance, bronze and gold; La 
Tendresse, white and yellow; L'Unique, dark blue and white; Ne Plus Ultra, light blue; Ouida, lavender-blue; Sappho, bronzy-yellow ; Souvenir, pale blue, shaded French grey; and Thunderbolt, bronzeyellow, purple, and brown, a striking mixture. All flower in June and early July.

English Iris.-These, which are varieties of Iris xiphioides, belong to the same section as the Spanish kinds, from which they differ in the bulbs, flowers, and tufts of foliage being considerably larger; they should be planted about 8 inches apart. English Irises are about a fortnight later in expanding than the Spanish, and are equally desirable for cutting. Some of the best are: Bleu Mourant, deep blue; Cassandra, lavender-blue; Duke of Portland, white, striped purple; Grand Lilas, lilac-blue; Lord Derby, lavender, spotted dark blue; Madame de Beauharnais, dark blue with deeper blotches; Mont Blanc, white; Nimrod, very deep purple; Perdita, lavender splashed with rose. Plant in October.

Miniature Bulbous Irises.-There is a group of small Irises that bloom in January, February, and March. The flowers of most of them are most exquisitely marked, but are soon spoilt by bad weather, and for this reason are frequently protected by handlights; they need a warm, well-drained border of sandy loam under a south wall and are planted in September. The best are: Danfordiae, yellow; Heldreichii, light sky blue with deep blue falls; Histrio, porcelain blue; histrioides, bright blue; orchioides, deep yellow; persica, silvery-blue and violet; reticulata, dark blue, blotched with gold, sweet-scented; Tauri, violet-purple, deeper coloured falls marked with gold; and Vartanii, light blue.

The Japanese Iris.-While several species of Iris are natives of Japan, the lind to which this name is generally applied is Iris laevigata, more often known as Iris Kaempferii. It is remarkable for the large size and varied colouring of its blossoms, which open in July. Large quantities in many varieties are annually imported from Japan during winter. They have apparently been grown in stiff clayey soil, which serves to protect the rhizomes, so that, if kept away from the boilers during the journey, they reach here in good condition. Imported sorts should be planted in March or April. In this country they need deep loamy soil with leaf-mould and cow manure mixed in ; they are moisture-loving plants and flourish by the side of water, though they need a sunny spot; the crown-that is, the top of the rootstock-ought to be 6 inches above the water. Proximity to water is, however, not absolutely essential; they will thrive in moist loam provided it is well tilled and manured. Many of the 


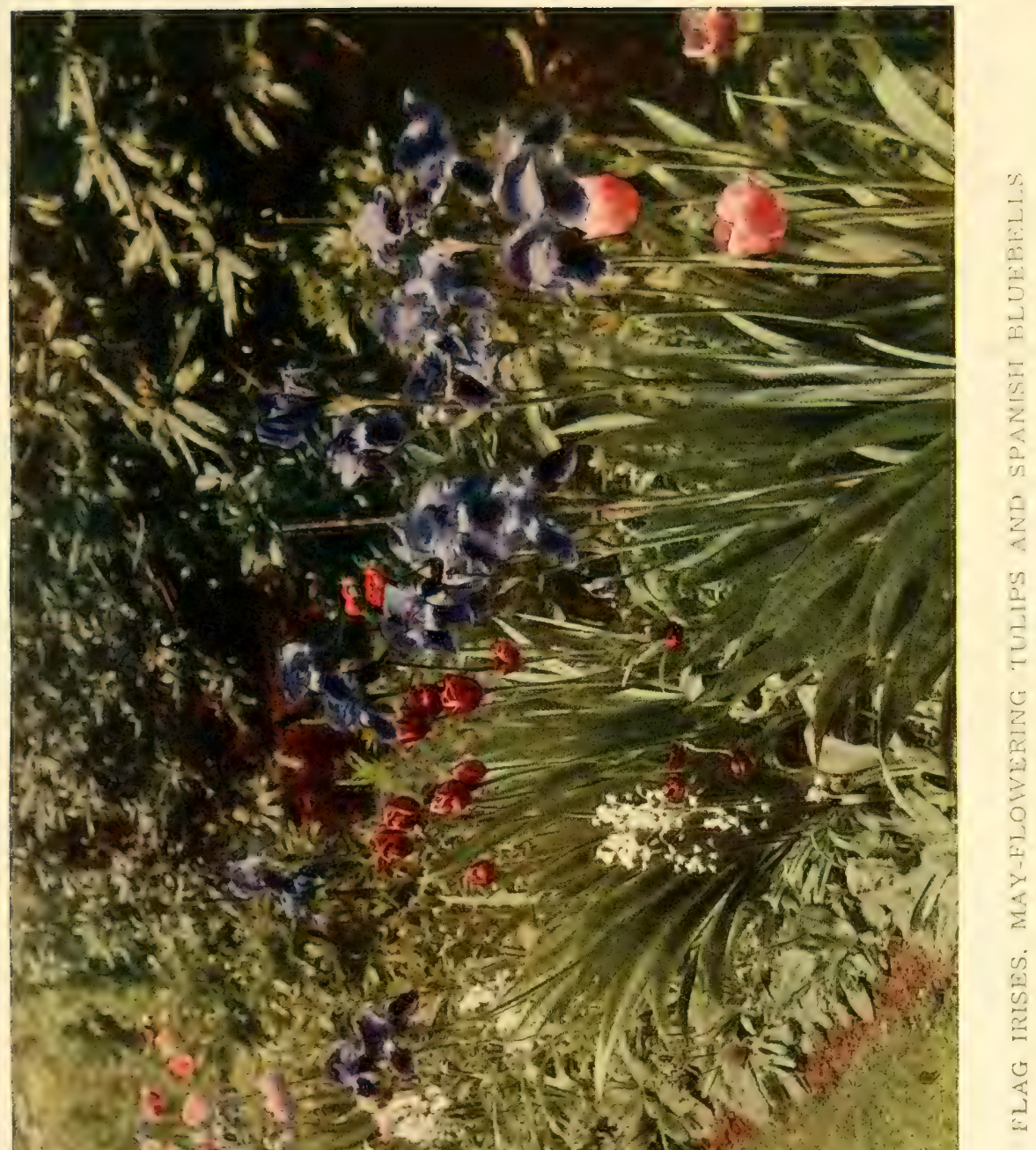



varieties have six large horizontally disposed petals, forming a huge flower, in some cases nearly I2 inches across. Most of them have been raised in Japan, and the names are for the greater part translations from the Japanese. A good selection is as follows: Band of Cloud, lavender, veined with white; Blushing Empress, white, edged rose; Cloisonné, purple; Close of Day, royal blue; Crane, white, veined sky blue; Deep Blue Waters, yellow, surrounded by bright blue, shading to violet-purple; Eastern Queen, reddish-purple; Jewels and Flowers, mauve ground, veined deep purple; Mikado, white, veined lilac; Morning Mists, white, shaded lavender-blue; Nankin, light blue; Peace, rich royal purple; Purple Emperor, a grand purple flower; Rosy Dawn, claret-red; Silver Stars, clear white with yellow blotches; Still Waters, light purple with white veins; White Waterfall, silvery-white; and Wedding Garment, deep blue, veined white.

Other kinds of Iris.-

Irises deserving of special mention are: albopurpurea, white, spotted blue, 3 feet; aurea, golden-yellow, 4 feet; Cengialtii, bright blue, I2 inches; foetidissima (the Gladwyn), greenish, the capsules, which open in autumn and show the bright red seeds, are very pretty; foetidissima aurea, a counterpart of the preceding, but with variegated leaves; graminea, blue and white, 2 feet ; iberica, pearly white, veined black, falls rich brown with purple blotch, I2 inches, when dormant needs to be kept dry for a time; Monnierii, yellow, 5 to 6 feet, needs moisture; orientalis, white and yellow, 5 feet; Pseudacorus, a common British species with yellow flowers, good for waterside; Pseudacorus variegata, striped with creamy-white; stylosa, also known as unguicularis, lavender-blue, winter, needs to be planted at the foot of a south wall; sibirica, of slender growth, 4 to 5 feet high, flowers blue, good for water-side.

Iris Susiana is a quaint flower of great size and greyish colour, covered with dark brown markings; must be treated like iberica, tectorum is a Japanese species, with pale blue flowers, grown in Japan on roofs in the same way as the Houseleek in this country; and tuberosa (Snake's Head Iris), 6 inches, has green and purplish-black flowers in spring. The above kinds, unless otherwise indicated, flower in late spring and early summer.

Cushion Irises.-These Irises, of which Susiana and iberica are examples, are remarkably handsome, but rather special conditions are necessary for their successful cultivation. They are somewhat tender and therefore need a sunny, sheltered position, a bed of welldrained soil, preferably raised a few inches above the ground surface, 
and should be protected by means of a frame when the leaves fade. Light gritty soil is required, and it is essential that the plants are thoroughly ripened, a condition that can only ensue if they are planted in a sunny spot and covered with glass during the dormant season. November is the month advised for planting. These Irises dislike being disturbed. There are now many cross-bred forms of the Cushion Irises.

Isatis (Woad).-The British species belonging to this group (Isatis tinctoria) is an interesting plant (Natural Order Cruciferae) owing to the fact that its juice was used by the ancient Britons with which to dye themselves. From an ornamental standpoint the best is Isatis glauca, from Asia Minor. This forms a freely branched herbaceous perennial with pretty glaucous leaves, and clouds of small yellow blossoms in July and August. It will thrive in the ordinary soil of a herbaceous border, and can be readily increased from seeds sown outside in the spring.

Isopyrum thalictroides.-An exceedingly pretty and distinct little plant, native of Southern Europe and belonging to the Buttercup family (Ranunculaceae); it grows 9 inches high, and is well suited by loamy soil in a shady part of the rock garden. The leaves, which are disposed in a spreading tuft, are deeply cut in a manner suggestive of the fronds of a Maiden Hair Fern, while the tiny white flowers rise above them in slender, much-branched panicles in spring. Isopyrum can be increased by division or by seed sown in spring.

Italian Starwort.-(See ASTER AMELLUS.)

Itea virginica, from the Eastern United States, and Itea ilicifolia, from China, are the only kinds in cultivation in this country. They belong to the Natural Order Saxifragaceae. Itea virginica is a deciduous shrub, 2 to 3 feet high, with short racemes of fragrant white flowers in July; it may be grown in the open in loamy soil, and should be pruned moderately hard in February. Itea ilicifolia is a new evergreen bush suitable for the warmer counties or for planting against walls; its racemes of white flowers are sometimes 9 to 12 inches long. Very little pruning is necessary. Plant in ordinarily good garden soil, and increase from cuttings in summer.

Ivy.-(See Hedera.)

Ivy-leaved Toadflax.-(See Linaria Cymbalaria.)

Ixia.-Pretty bulbous plants, belonging to the Iris family (Iridaceae) and natives of South Africa, that bear slender spikes of showy flowers on stems about I 8 inches high. They are generally treated as greenhouse plants, but may, like many other bulbs from the same region, be successfully grown in well-drained sandy loam, in a narrow sunny 
border, in front of a hothouse or in some similar position. The bulbs are small, and soon suffer if they are kept out of the ground too long, so should be planted in September, or early in October, and covered with 3 inches of soil. With the approach of winter the ground above them must be covered with leaves or some other protecting material. There is quite a long list of varieties, varying in colour from white to crimson and purple. Three of the very best are : crateroides, rich cerise-scarlet; Smiling Mary, deep self pink; and viridiflora, an exceedingly strange kind, green with black centre, very striking.

Ixiolirion.-The only species in general cultivation is Ixiolirion tataricum, known sometimes as Pallasii. It belongs to the Natural Order Amaryllidaceae, and is native of Persia. It is a small bulb, which should be planted in a sheltered spot in autumn, and in the spring will produce a slender flower spike, which bears an umbel of blue or purplish-blue flowers in May or June. Once established, it will increase by self-sown seeds.

Jacobaea.-(See SENECIO JACOBAEA.)
Jacobea Lily.-(See SPREKELIA FORMOSISSIMA.)
Jacob's Ladder.-(See POLEMONIUM CAERULEUm.)
Jalap.-(See IPOMOEA PURGA.)
Jamesia americana is a shrubby plant belonging to the Natural Order Saxifragaceae. It is a native of the Rocky Mountains, and forms a dense shrub 3 to 4 feet high with greyish-green, oval, deciduous leaves, and bears pretty white flowers, each about $\frac{3}{4}$ inch across in May. As it grows freely in any good garden soil and is perfectly hardy it is available for all parts of the country, and may be planted as a specimen bush or as a group in the shrubbery. Propagation may be carried on by means of seeds, and pruning is confined to thinning out a number of the older branches after the flowers have fallen.

Jasione (Sheep's Bit Scabious).-Pretty little herbaceous perennials, natives of Europe, and belonging to the Bellflower family (Campanulaceae). They grow from 6 to 12 inches high, flower throughout summer and often into autumn. The species are Jankae with beautiful blue flowers freely produced from a rosette of leaves: montana, pale blue; and perennis, having compact rosettes of foliage and light blue flowers. All of them thrive in well-drained soil in a sunny part of the rock garden, or may be planted in the chinks of a wall.

Jasminum (Jasmine) is an important group of the Natural Order Oleaceae, embracing chiefly climbing plants which may be grown out-of-doors or in greenhouses, according to the countries of which they are native. The outdoor kinds thrive in loamy soil to which a little leaf-mould has been added and a compost of 2 parts fibrous 
loam, I part leaf-mould or peat, and $\frac{1}{2}$ part sand, is suitable for the tender sorts. Propagation in each instance may be effected by means of cuttings during spring or summer, and pruning takes the form of cutting the secondary branches back to within a bud or two of the main branches. As some bloom on old and others on young shoots, attention must be given to each plant separately. As a rule it is wise to prune as soon as the flowers fade, except in the case of those sorts which bloom during late summer, when pruning may be deferred until winter. The greenhouse Jasmines may be grown in pots or in borders and trained to pillars or rafters; border cultivation is, as a rule, the more satisfactory.

The best of the outdoor kinds are: Beesiana, a new Chinese species with pinkish flowers; fruticans, a dwarf, bushy kind from China, with small, yellow flowers in summer, it requires little pruning; revolutum is a variable yellow-flowered kind from the Himalaya, it flowers in summer, and the variety known as Reevesii is more vigorous than the type. Nudiflorum, a Chinese and Japanese climber, is one of the most useful shrubs of the garden, it flowers profusely in mid-winter in most parts of the country: prune as soon as the flowers fall. Officinale is a white-flowered, fragrant species from Persia and North-West India, it is widely grown for its flowers in summer, and in France it is cultivated for perfumery purposes, it should be pruned during winter; primulinum, from China, has large yellow flowers in winter, it is new to this country and suitable for warm walls.

Jerusalem Sage.-(See Phloms.)

Job's Tears.-(See CoIX LaChryma.)

Juglans (Walmut).--Important timber trees are included in this genus (Natural Order Juglandaceae). They are found in the Caucasus, Himalaya, China, Japan, Manchuria, and North America, and the majority of those introduced are hardy in England and Ireland, whilst some may be grown as far north as Aberdeen in Scotland. They require deep loamy soil such as will grow good wheat or oak trees. As a rule, they are grown solely for ormamental purposes, or in one case for fruit, in the British Isles, but the timber of felled trees usually commands a good price. Propagation of the species is by seeds, and of the varieties by grafting upon their respective types. The best results are obtained when seeds are sown in the positions the trees are intended to occupy, but if they must be sown elsewhere, care should be taken to transplant them every second year in order that a well-developed system of fibrous roots may be procured in view of the final planting. Pruning takes the form of shaping the trees, removing the lower branches, and keeping the leading shoots clear. 


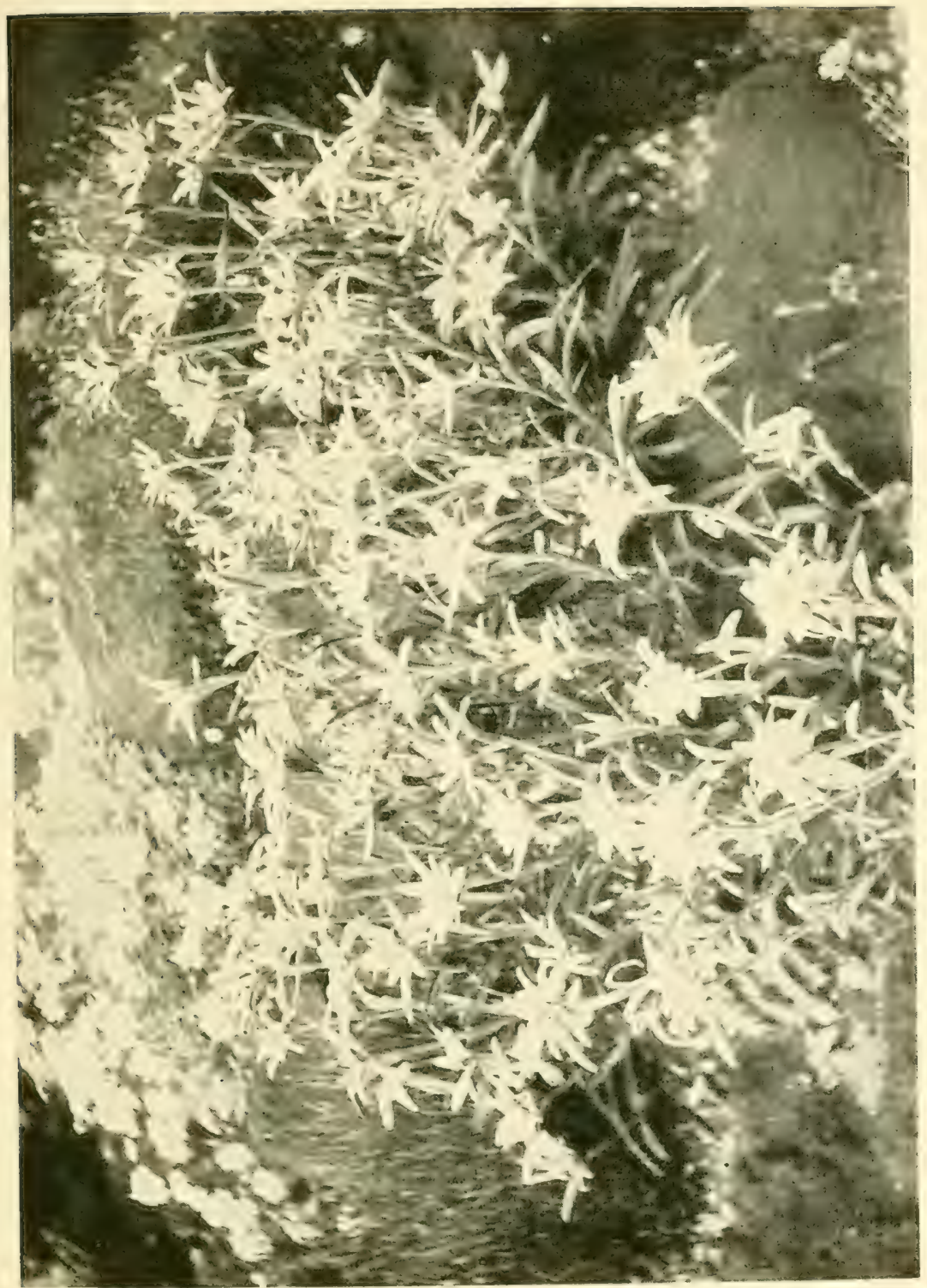



The chief specics are: cinerea, the Butternut of North America, a handsome tree with long, pinnate leaves, the edible nuts are 2 or $2 \frac{1}{2}$ inches long, with deeply ridged shells, and the kernels are sweet and similar in taste to the Common Walnut; cordiformis is a native of Japan and a conspicuous tree by reason of its large handsome lcaves, which are often $2 \frac{1}{2}$ feet long, the male flower catkins are also very striking, for they are frequently more than 12 inches long; mandshurica and Sieboldiana, the former from Manchuria and the latter from Japan, are very similar trees. Nigra, the Black Walnut of North America, is an important timber tree in the United States, whilst it might also be grown as a timber tree in this country: in the south of England it may be seen between 70 and roo feet high, the leaves are handsome, and the timber almost black in colour, the nuts have very hard shells and small kernels. Regia is the Common Walnut, it is widely distributed from the Caucasus to the Himalaya, and is largely grown throughout Southern and Central Europe and in the United Kingdom, its value as an ornamental tree and nut bearer is well known, whilst its timber is extremely popular for the manufacture of furniture, etc. There are several varieties, of which laciniata has finely cut leaves; maxima, large fruits; and monophylla, often single-lobed leaves.

Juncus (Rush).-An extensive group of plants (Natural Order Juncaceae), which occur principally in wet and boggy places. They flourish by the side of water, but many other plants are more effective under similar conditions. A striking plant is Juncus effusus spiralis, in which the leaves are arranged in a peculiar corkscrew-like fashion. What is known as the Porcupine Rush, in which the leaves are banded with white after the manner of the spines of the Porcupine, is now classed as Scirpus, under the name of Scirpus lacustris zebrinus.

Juniperus (Juniper).-This is an evergreen family of trees and shrubs belonging to the Natural Order Coniferae. They are found in Europe, Asia Minor, Asia from the Himalaya northwards, and in North America and the West Indies. Many are hardy and one is a native of the British Isles. They are used largely for garden decoration, and usually give the best results on chalky soil. The tallgrowing kinds form handsome small trees, whilst the dwarfer ones are useful for planting on dry banks. The leaves are of two kinds, one being linear, flat, and sharp-pointed, and the other scale-like and pressed closely to the branch. Both kinds are often found on the same plant. Although they prefer chalky soil, Junipers thrive in moist loam, but are not adapted for planting in or about smoky towns. The species are often increased by seeds, and the varieties 
by cuttings inserted in August in sandy soil in a coldi and closed frame. No regular pruning is required, but a little shaping may be done now and then in summer.

A selection of the chief sorts is as follows: Chinensis, a Chinese tree, which extends to the Himalaya, and is also found in Japan, though the typical kind has green leaves, there are several varieties, e.g. aurca, with golden foliage, and glauca, with bluish leaves. Communis, native of the British Isles, is found as a bush, 2 to 5 feet high, from the South of England to the Highlands of Scotland : there are many varieties, of which alpina aurea, aurea, and fastigiata are distinct. Sabina, the Common Savin, from the mountains of Europe, is a dwarf plant up to 3 feet high, the vars. prostrata and procumbens being scarcely I foot high. Virginiana, an American kind, is interesting as being the tree which is most popular for the manufacture of the casings of pencils; the wood is known as Red Cedar. There are many more species, for descriptions of which textbooks on Conifers should be consulted.

Jussieua.-Most of these, which belong to the Evening Primrose family (Onagraceae), need glass protection, but Jussieua natans, a native of North America, is quite hardy. It is a bog plant, and 4 to 5 feet high, with long Willow-like foliage, which turns deep crimson in autumn, and yellow flowers, suggestive of those of the Evening Primrose, borne in summer.

Kaffir Lily.--(See Schizostylis coccinea.)

Kalmia.-A small class of evergreen and sub-evergreen shrubs belonging to the Heather family (Ericaceae), and native of North America. They give the most satisfactory results when planted in moist, peaty soil, but they also thrive in loam providing it contains little or no lime. They are perfectly hardy, and may be planted almost anywhere in the United Kingdom where the hardier kinds of Rhododendrons thrive. Kalmia latifolia, the Calico Bush of North America, is the most vigorous; growing from 3 to 6 feet high, it is recognised by its large, oval, dark green, Rhododendron-like leaves and heads of white rose-tinged flowers which appear in June. It is usually increased by means of seeds, but seedlings grow very slowly for several years. Isolated specimens are sometimes effective objects on the outskirts of lawns. Kalmia angustifolia is sometimes called the Sheep Laurel in North America, its leaves being considered to be poisonous to sheep; it is a very variable plant, and its numerous varieties are met with from a few inches to 3 feet in height; the type is from 2 to 3 feet high, with evergreen, ovate leaves, each about I inch long, and the rose-coloured flowers appear in May from the 
leaf axils about the points of the shoots. They are very showy, but the vars. rosea and rubra, dwarfer plants, are superior. Nana is of very dwarf habit. Kalmia glauca is also a showy bush with rosecoloured flowers which open in advance of those of the other species; it may be partly evergreen or deciduous, according to the season; the leaves are small and silvery on the under surface. It often blooms in April, and grows from 18 to 24 inches high. Propagation of the last two kinds is by division or seeds. No pruning, but the flower-heads should be removed from Kalmia latifolia when the flowers fade.

Kaulfussia amelloides (Cape Aster). - This pretty little summer flowering annual, which belongs to the Daisy family (Compositae), and comes from South Africa, is invariably referred to under the above name in gardens and seed lists, though, according to botanists, it should be known as Charieis heterophylla. It reaches a height of about 6 inches, and forms a mass of light blue Daisy-like flowers, borne on slender stems in summer; there are white and red flowered varieties. The seed is sown in a warm, sunny spot in April, and the young plants thinned to about 8 inches each way.

Kerria japonica (Jew's Mallow) is a showy, golden-flowered shrub belonging to the Rose family (Rosaceae). It is a native of China, and forms a spreading bush of twiggy branches 2 to 3 feet high; the flowers are about I inch across, and appear during April or early May. There is a double-flowered variety which is much more vigorous and of more erect growth than the type; it grows from 5 to 8 feet high, and its golden flowers are from $I_{\frac{1}{2}}^{\frac{1}{2}}$ to 2 inches across. It was introduced long before the typical kind, and was at first called Corchorus japonicus. There are also varieties with silver and gold variegated leaves; the double-flowered form is, however, superior to the others. Kerrias thrive in well-drained loamy soil, are easily increased by means of soft cuttings in summer, and the old shoots should be well thinned out as soon as the flowers fade. The double-flowered variety is useful for forcing in pots for the greenhouse.

\section{Kidney Vetch.--(See ANTHYLlis.)}

Kitaibelia vitifolia.-A vigorous-growing herbaceous perennial, belonging to the Mallow family (Malvaceae), and native of Eastern Europe. It will reach a height of 6 to 8 feet, and the lobed leaves are of somewhat similar shape to those of a Vine. The flowers, about 3 inches in diameter, are in some cases white, in others rose-coloured. It is more fitted for the wild garden than the herbaceous border; propagation is by division in autumn.

Kniphofia (Torch Lily, Red-hot Poker). - Striking perennials, members of the Lily family (Liliaceae), and native chiefly of South 
Africa; they are known also as Tritoma. There are many species and a large number of garden varieties. The best of all, and one that has given rise to the best garden varieties, is Kniphofia aloides (Uvaria). The large tufts of grass-like leaves of Kniphofia are of striking appearance, and especially when crowned by the erect spikes of bright-coloured blossoms in late summer and autumn. In some districts Kniphofias are none too hardy; wet and frost affect the centres of the plants and cause them to decay. Thus in cold or wet districts, or where the soil is heavy, it is a good plan to treat them as is sometimes done with the Pampas Grass: at the approach of winter the leaves are gathered loosely together and protected by bracken. The drawback to this method is that when the protective material is removed in early spring the plants are liable to be injured by harsh winds, so that the practice is not to be recommended if avoidable. Leaves or bracken placed above the roots and about the base of the plants prove sufficient. By the end of the season the leaves often look rather shabby and are cut off, but this is an unwise thing to do, as they afford a certain amount of protection. Deep, well-drained soil is most suitable for the Kniphofias; it should be dug deeply, well-decayed manure being mixed in. Replanting or dividing the plants should be carried out in spring, as the roots are then active and soon take possession of the soil.

The chief species are: Kniphofia aloides, the ordinary kind, orange-red, which varies somewhat, 5 feet; Burchelli, dark red, passing to orange, 4 feet; caulescens, a kind that forms a decided stem, clothed with broad, glaucous foliage, dusky red flowers shading to buff, 5 fect; Macowanii, light coral-red, 2 feet; Nelsonii, narrow spikes, yellow, $2 \frac{1}{2}$ feet; rufa, yellow, tinted red, in thin tapering spikes, 4 feet, rather tender; and Tuckii, yellow and red, with stiff Yucca-like leaves, 4 feet.

Good garden varieties are: Canary Bird, ycllow, 2 feet; Chrysantha, rich chrome-yellow, 3 feet; Goldelse, thin, tapering spikes, soft yellow; Jolın Benary, rich orange-red, 5 feet; Lemon Queen, lemon-yellow, 5 feet; Nobilis, orange-red, 6 feet ; Pyramidalis, yellow and red; Star of Baden-Baden, bronze-yellow, 6 feet ; and Triumph, yellow and scarlet, 5 feet.

Kochia (Summer Cypress).- This very distinct annual, which is native of Southern Europe, and belongs to the Natural Order Chenopodiaceae, has come very much to the front within recent years, at first under the name of scoparia, though now known as tricophylla. The flowers are insignificant, and the plant depends for its beauty upon the changing tints of its graceful foliage and its symmetrical 


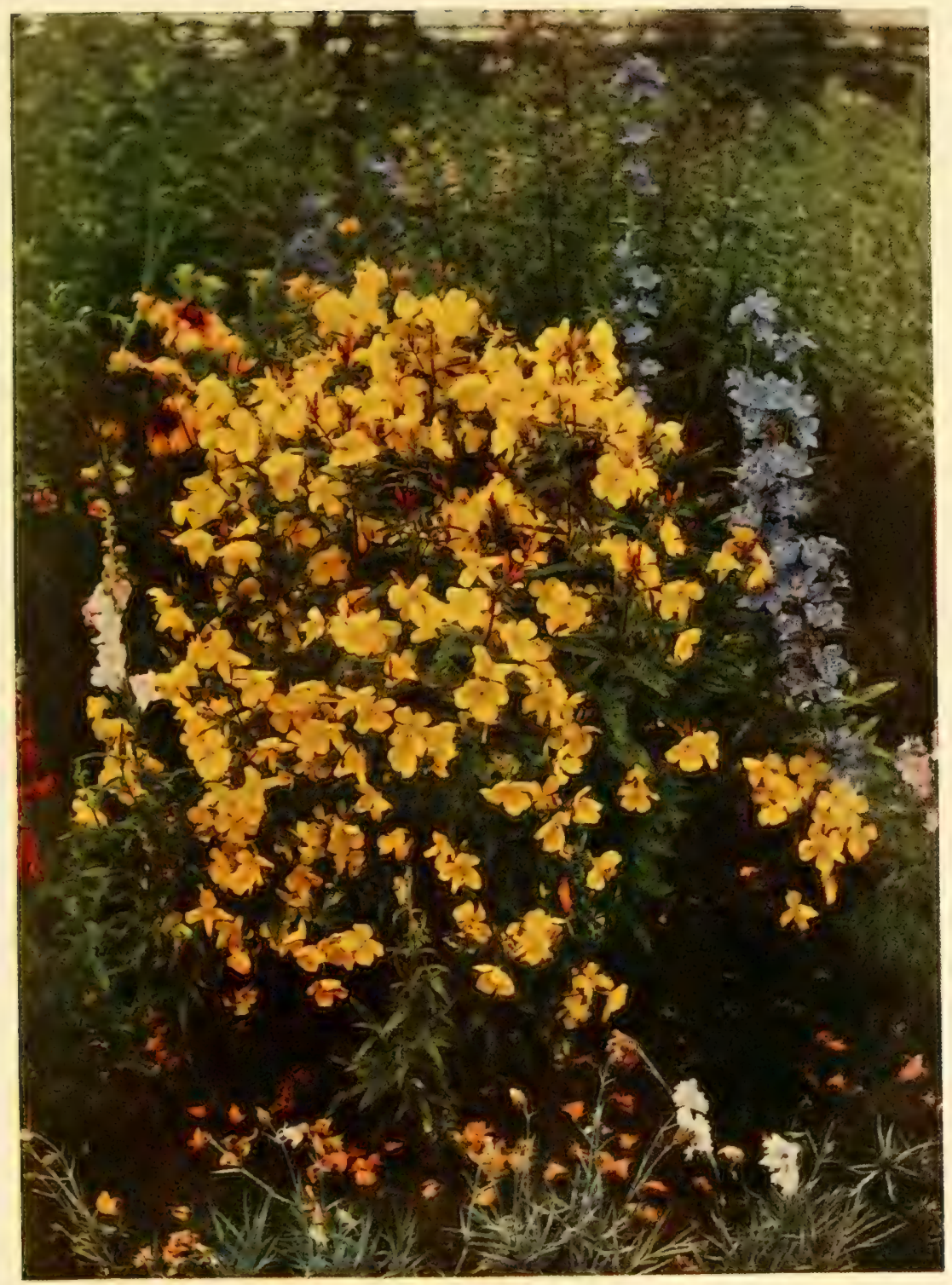

AN EVENING PRIMROSE (OENOTHERA YOUNGIi) 

and uniform growth. Throughout summer the foliage is of a delightful shade of light bright green, and the plants well deserve their popular name of Summer Cypress, but towards autumn it becomes suffused with purple, gradually deepening until it is of a purplishcrimson. The Kochia is generally used as a "dot" plant in the summer flower garden. It is best to sow seeds in a greenhouse in March, and grow the young plants there or in a frame, giving plenty of air. They will then be well established in 4-inch pots by beddingout time, and when planted they grow quickly. Seeds may also be sown out-of-doors in April ; the resulting plants will be very effective late in the season. Ordinary garden soil is suitable.

Koelreuteria paniculata is a tree with handsome foliage, belonging to the Natural Order Sapindaceae. It is a native of China, and quite hardy in the Midlands and South of England, where it forms a wide-headed tree up to 40 feet high. The leaves are divided into numerous segments or leaflets, and on young, vigorous specimens are I 2 to 18 inches long by 9 to $\mathrm{I} 2$ inches wide. Towards the end of July, large terminal panicles of small yellow flowers are produced, which in sunny years are followed by inflated triangular fruits, enclosing hard black seeds. Koelreuteria bipinnata, also from China, is of modern introduction; its leaves are larger than those of the older kind, but it appears to be less hardy. Plant in ordinary garden soil of good quality, increase by seeds, and prune in summer to keep the plants shapely and the leaders clear.

Laburnum.-A popular and important group, belonging to the Pea family (Leguminosae), which contains some of our most ornamental trees. Three kinds are in cultivation: alpinum, a native of Europe, and often called the Scotch Laburnum; caramanicum, a shrubby species from Asia Minor, which bears its yellow flowers in September, and is of little value ; and vulgare, the Common Laburnum, a tree found wild in various parts of Europe. In addition there are many garden varieties and a number of hybrids. The Laburnums thrive in any part of the country in ordinary garden soil, and withstand a fair amount of exposure. The species are increased by seeds, and the varieties and hybrids by grafting upon the Scotch or Common Laburnums. When young, the trees may be pruned sufficiently to keep them shapely, but little pruning should be done to old trees, and it is a mistake to remove old branches. Although usually planted as specimen trees, the Laburnums are sometimes used as hedges and for arches. In such cases the young shoots are cut back annually. Laburnum alpinum is a tree from $I_{5}$ to 40 feet high, and is distinguished from the commoner kind by its larger and darker leaves, 
better habit, and later flowering season. There are several varieties: autumnalis, which often blooms at the normal time in June and again in September; fragrans, with more fragrant flowers than the type; and grandiflorum, with very fine inflorescences, are the best.

Laburnum vulgare grows into a somewhat similar-sized tree, but the foliage is less luxuriant, and the inflorescences, borne in May, are smaller. It also has many varieties, of which Alschingeri, Carlieri, aureum, and Jacquinianum should be grown. The kinds known as Parksii, Vossii, and Watereri are hybrids between these two species; the first-named bears racemes up to 15 inches in length, whilst Watereri produces racemes 8 inches or more long and is very floriferous.

Laburnum Adami is interesting, as it bears racemes of yellow flowers, purple flowers, and shoots, leaves, and flowers similar to those of Cytisus purpureus. It occurred in the first instance as a graft hybrid after Cytisus purpureus had been grafted upon Laburnum vulgare, and its peculiarities have been perpetuated. It is often called the Purple Laburnum.

Lactuca (Flowering Lettuce).-Perennial and annual herbs, native of Europe, and belonging to the Daisy family (Compositae). Comparatively few are sufficiently ornamental to find a place in the garden. They are easily grown in ordinary garden soil in sun or partial shade. Increase is by division of the clumps in autumn or spring and by seeds sown on a border outside during April or May. The name Mulgedium is sometimes used instead of Lactuca for some of the kinds. The chief sorts are: alpinum (Blue Alpine Sow Thistle), which has purple-blue flower-heads in July and August, and attractive foliage, 3 feet; Bourgaei, deep violet, July and August, 3 feet; gigantea, pale bluc, shaded pink, semi-double flowers, 2 inches across, July to September, 5 feet; Plumieri, bright purple or blue, large graceful panicles of bloom from July to September, very striking, 6 to 9 feet.

\section{Lady Forn.-(See Asplenium.)}

Lagenaria (Bottle Gourd).--There is only one species, Lagenaria vulgaris, but there are numerous varieties or sorts differing chiefly in the size and shape of the fruits; they belong to the Natural Order Cucurbitaceae. It is a common climbing annual in the tropics of Asia and Africa, but can be grown outside in this country in summer. Sow the seeds in pots in a cool greenhouse or frame during April, and plant the seedlings late in May or early in June in light, rich soil in a sunny position.

Lagurus (Hare's Tail Grass).-The only kind, Lagurus ovatus, is a hardy annual Grass (Natural Order Gramineae), of considerable value in the flower border and for cutting both in the green state 
and dried for use in winter. Seeds may be sown in a cold frame in August or September, and the young plants set outside in tufts in the border in spring. A second method is to sow the seeds in a cold frame during March, or in April or May where the plants are to flower. The Hare's Tail Grass thrives in ordinary well-drained garden soil in a sunny position; it blooms from June to September, according to when the seeds are sown, and grows about I2 inches high.

Lamium (Dead Nettle).- This is not an important class, yet there are two or three plants which are worth growing. They belong to the Natural Order Labiatae, and thrive in almost any soil in sunny or partially shaded positions. Increase is by division of the roots in autumn or spring. Lamium maculatum has purple flowers from June to September, green and white foliage, grows about 6 inches high, and is native of Britain; the var. aureum has golden-yellow leaves, and is very useful as an edging for borders and summer flower beds and as a groundwork for taller plants. An interesting hybrid is Lamium puralbum, a cross between two of our native wild plants (purpureum and album); it is a free-growing plant with shell-pink flowers.

Lantana (Indian Nettle).-Tender, free-flowering shrubs, members of the Verbena family (Verbenaceae), very useful in beds and borders in summer. In gardens the species are seldom seen, those grown being forms of the South American kind, Sellowiana. Lantanas are readily propagated by cuttings inserted in pots of sandy soil on a greenhouse stage in spring or autumn. Suitable soil consists of 2 parts loam, I part leaf-mould and decayed manure, together with a sprinkling of sand. For summer bedding, cuttings are rooted in August, kept in a greenhouse during winter, and in February are potted singly in small pots; these are put in 5-inch wide pots early in April, and planted outside about the end of May. The tops must be pinched off to induce side shoots to form. When larger plants are required they may be kept for several years in large pots, these being plunged in the beds or borders during summer. In autumn lift and store them under the stage in a cool greenhouse, or in a frost-proof shed or cellar which is not too damp. The flowers are arranged in flattish heads and comprise a fairly wide range of colours. A few of the best sorts are: Chelsea Gem, crimson and amber; Drap d'Or, rich yellow; Eclat, reddish-crimson; Golconda, pink and purple; La Neige, pure white; Magenta King, purple-scarlet; Marquis de Lakorta, yellow and purple; Raphael, yellow and maroon; Rayon de Soleil, deep yellow; salviaefolia (delicatissima), violet-mauve.

Lapageria rosea.-A half-hardy climbing plant (Natural Order Liliaceae) from Chili; it is grown successfully out-of-doors in the 


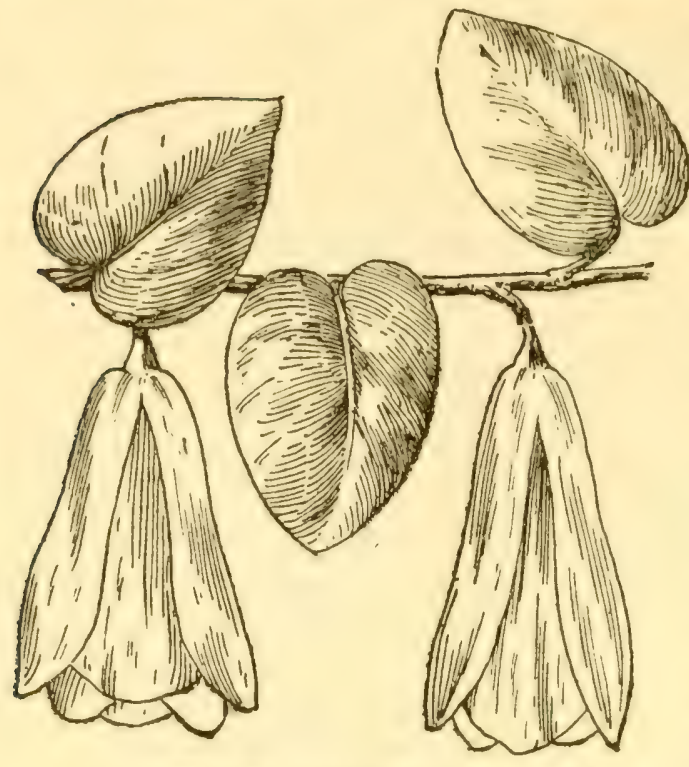

FLOWERING SHOOT OF LAPAGERIA

south and west counties on a cool wall, but in most places needs a cold greenhouse $\mathrm{facing}$ north. It requires well-drained soil of peat, loam, leafmould, and sand. Increase is by layering the shoots whenever convenient. The long wire-like shoots may grow from I2 feet to 20 feet in length. The leaves are thick and dark green. The drooping, bell-shaped fiowers, of wax-like texture, are

rosy-crimson, and last in good condition for some time; the flowering season is summer and autumn. Spring is the best time to plant.

\section{Larch.-(See LARIX.)}

Lardizabala.-The only species grown is Lardizabala biternata, an evergreen climbing shrub from Chili belonging to the Barberry family, Berberidaceae. Though usually grown in a greenhouse, it thrives out-of-doors in mild districts. It needs well-drained compost of sandy loam and peat. The flowers are purple, not very conspicuous, in drooping racemes, and open during early winter. Increase is by cuttings inserted in sandy soil under a bell-glass, or in a frame in late summer and autumn.

Larix (Larch) is an important class of Conifers (Natural Order Coniferae), for it includes those trees which are known popularly as Larches. They are found in the mountains of Central Europe, more particularly the Tyrol, the Himalaya, China, Manchuria, Siberia, Japan, and North America, and in the majority of cases they are good timber trees. The European Larch (Larix europaea) is one of the most important coniferous timbers on the Continent, and is widely grown in the British Isles. Well adapted for growing in dense woods, it forms long trunks of fairly uniform diameter, trees I2 to I5 inches in diameter at the base often measuring 4 or 5 inches at 70 feet 


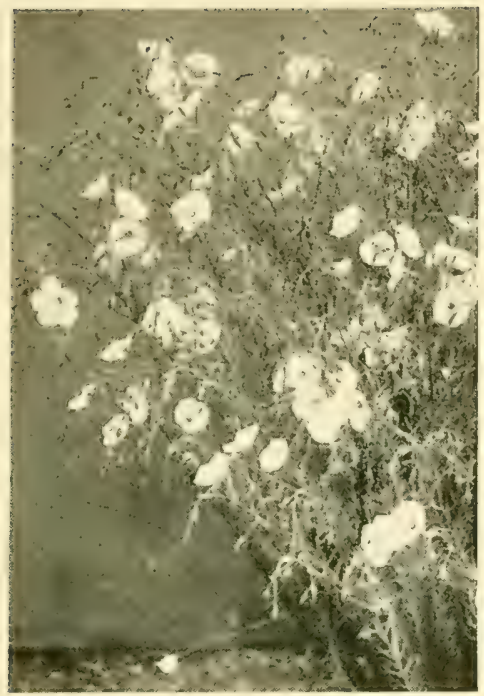

BLUE FLAX (LINUM PERENNE)

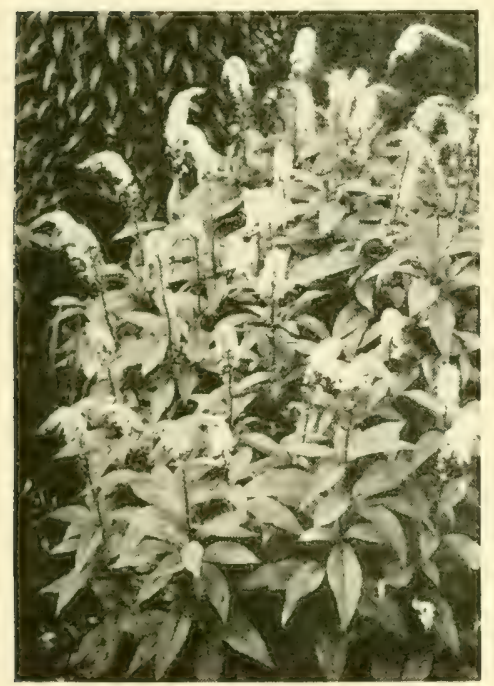

THE SHOWY JAPANESE LYSIMACHIA CLETHROIDES

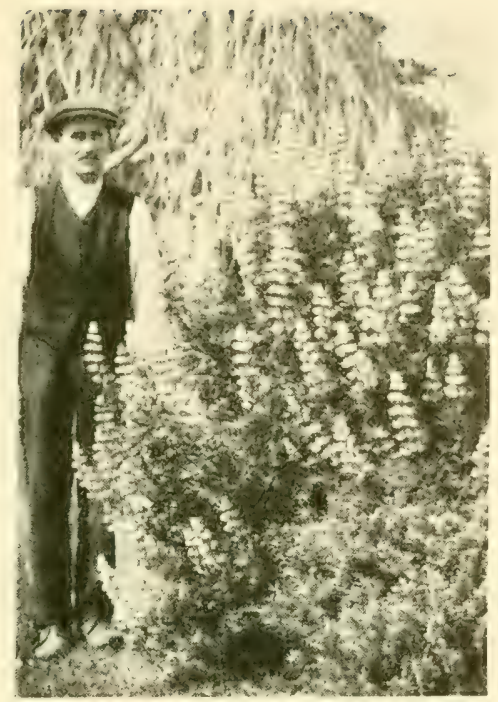

TREE LUPIN (LUPINUS ARBOREUS)

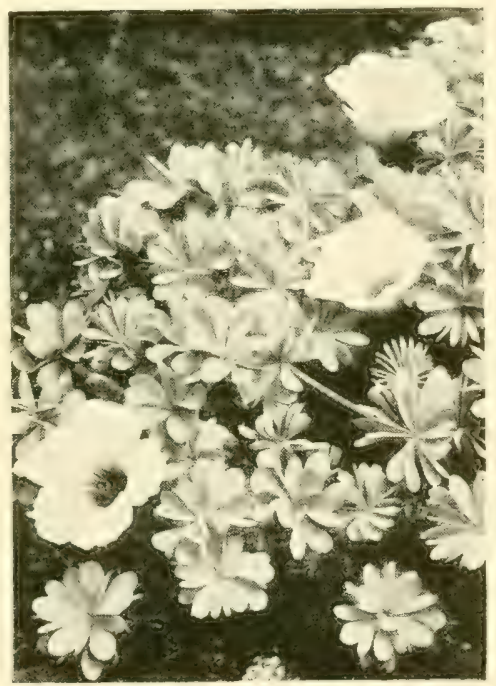

FALKLAND ISLAND WOOD SORREL (OXALIS ENNEAPHYLLA) 

high. This, added to the strength of the wood, makes the Larch peculiarly useful for telegraph and other poles. The timber is, however, employed for many purposes, and is very popular for fencing. Trees growing in open positions are often from 70 to Ioo feet high, with trunk diameters of $2 \frac{k}{2}$ to 4 feet. Apart from their value as timber trees, the Larches are decorative, and few trees are more beautiful in early spring when the fresh green leaves are developing, intermixed with the young bright-pink female cones. Larches must not be planted upon low-lying or wet and heavy land, for under such conditions they often fall a prey to the Larch canker disease, which is due to a fungus, Dasyscypha calycina. On exposed hill-sides, however, where the land is well drained, excellent results are usually - obtained. Decorative trees should be planted in well-drained soil. Increase is by seeds which are usually sown in spring out-of-doors: Pruning of decorative trees is limited to keeping the leaders clear and removing lower branches when necessary.

The chief kinds are: europaea, 70 to I20 feet, large timber tree, European Alps; Griffithii, native of the Eastern Himalaya, an ornamental tree with large cones - it is, however, rather tender. Leptolepis, from Japan, is a vigorous tree, which is often planted under forest conditions; occidentalis, native of Western North America, a very large tree in its native country, but so far has been little grown here; it is, however, being tried as a woodland tree.

Larkspur.-(See Delphinium.)

Lastrea.-(See NEPHRODIUM.)

Lathraea (Toothwort).-Lathraea squamaria is a parasite on the roots of trees, especially on the Alder. It belongs to the Natural Order Orobanchaceae. It has an upright, pale rose-coloured stem 6 inches high, a few fleshy scales instead of leaves, springing from a fleshy rootstock in early spring, with dull-purple or flesh-coloured drooping flowers in spring. It is a perennial, native of Britain, and propagated by sowing seeds on the roots of the host-plant.

Lathyrus (Sweet Pea, Perennial Pea).-Both the annual and Perennial Peas (Natural Order Leguminosae) are among the most beautiful of garden flowers, and the former are especially popular. During comparatively recent years the popularity of the Sweet Pea has increased by leaps and bounds, until at the present time it is more extensively grown than any other annual. To ensure an abundance of good flowers throughout a long season it is essential that the ground be dug quite 2 feet deep in autumn, the surface being left rough until spring. In the lower part of the trench yard manure ought to be mixed together with basic slag at the rate of 6 ounces 
to the yard run; in the upper portion bone meal, soot, lime rubble, and wood ashes are useful. A sunny position is essential for the cultivation of good Sweet Peas. Seeds may be sown in pots early in October, the pots being kept in a cold frame during winter. In warm gardens of light soil seeds may be sown out-of-doors in autumn, though when this practice is adopted some losses must be expected. Most growers sow seeds in small pots in a greenhouse or frame in January, the seedlings being grown in a cool and airy atmosphere. The Sweet Pea is hardy, and the plants, even when quite small, must be grown as hardily as possible. Further sowings may be made out-of-loors in March and early April. Seedlings raised in pots in autumn are planted out in March and will bloom in early summer; those raised in January are planted in April, and will begin to bloom in July. Seeds sown out-of-doors are put about $\mathrm{I}$ inch deep; those sown in flower pots need be covered only by $\frac{1}{2}$ inch or so of soil. There should be at least a distance of 5 or 6 inches between the plants; those who grow for exhibition often put their plants Io inches apart. A fortnight before sowing or planting out-of-doors it is a good plan to apply to each square yard or yard run of row 3 ounces of superphosphate of lime and $I_{2} \frac{1}{2}$ ounces of sulphate of potash, mixing these and forking them into the soil some 6 inches deep. When the plants are growing freely an occasional sprinkling of equal parts of nitrate of soda and sulphate of ammonia, $\frac{1}{2}$ ounce per yard, is helpful. It is essential to stake the plants in good time, otherwise they are apt to get broken. Hazel sticks with numerous twiggy branches are chiefly used when the Peas are grown for garden display; those who cultivate for exhibition often use bamboo canes, Simplicitas netting, or wire or string stretched between strong uprights. Whether Sweet Peas are sown in rows or in circular clumps is a matter for individual choice; they certainly look very charming in either form. Ordinarily, Sweet Peas need little attention during the summer months beyond watering as becomes necessary, hoeing the ground to keep the surface loose, or applying a mulch of manure, and removing dead blooms to prevent the formation of seeds which soon put an end to the blossoming. But those who endeavour to get blooms of the highest quality on long stems pursue somewhat intricate methods of cultivation. Each plant is usually restricted to one or two stems, according to the vigour of the variety (the stronger having the greater number of stems), all side shoots are carefully removed, and artificial manures are used to give size and colour to the blossoms, while, in the first place, the ground is deeply and elaborately prepared for them.

Named varieties are now so numerous that it is a difficult matter 
to make a selection of the best. No two growers would probably agree in choosing a dozen sorts for the garden or for exhibition, and, moreover, new varieties appear annually. The following are good varieties: For the Garden-Clara Curtis, primrose; Elfrida Pearson, pale pink; Etta Dyke, white; Lavender George Herbert, lavender; Mrs. C. W. Breadmore, cream, pink edge; Mrs. Cuthbertson, white and rose; Princess Mary, lavender-blue; Queen of Norway, purplemauve; Rosabelle, rose ; Scarlet Emperor, red ; Thomas Stevenson, orange-scarlet; Zarina Spencer, orange-pink. For Exhibition-Barbara, orange-salmon; Dobbie's Cream, cream ; Edith Taylor, cerise ; Elfrida Pearson, pale pink; Hercules, pink; King Manoel, deep maroon; King White, white; Maud Holmes, crimson ; R. F. Felton, lavender; Scarlet Emperor, bright red; Thomas Stevenson, orangescarlet; Wedgewood, pale blue.

It is interesting to record here that the parent of the garden Sweet Pea is Lathyrus odoratus, a native of Sicily and Sardinia, and thought to have been first introduced in 1699.

The Everlasting or Perennial Peas are favourite climbers for fences, screens, arbours, and porches in many gardens, and may be grown, supported by sticks, in the flower border. The plants thrive in ordinary garden soil, and are propagated by division of the clumps, preferably in spring, and by seeds sown in pots in a cold frame or out-of-doors from April to June. The best-known kind is the European Lathyrus latifolius, 6 to 8 feet high, with rose-coloured flowers from July to September; alba and White Pearl are free-flowering white varieties; and delicatus (Pink Beauty) has blush-pink flowers. The flowers, when cut, last well in water. Lathyrus grandiflorus, 5 to 6 feet high, has dainty crimson flowers during June and July; it is native of South Europe. From the Orient we have Lathyrus rotundifolius, gay with its cherry-carmine flowers during May to July; its height is from 4 to 5 feet.

\section{Laurel.-(See Prunus.)}

Laurus nobilis is the Bay Laurel, or Sweet Bay, of our gardens (Natural Order Lauraceae). It is a native of the Mediterranean region, and although fairly hardy in the British Isles, is sometimes injured by frost, and only attains its finest proportions in the milder counties. It is usually seen as a large bush I2 to 20 feet high, though sometimes it assumes a tree-like habit, and in South Wales has grown upwards of 40 feet in height. Male and female flowers are borne on different trees, the latter being followed by round black plumlike fruits $\frac{1}{2}$ inch in diameter. It is, however, on account of its fragrant, evergreen foliage that this shrub is grown. The var. angusti- 
folia has smaller and narrower leaves than the type, whilst undulata is similar to the last-named except that the margins of the leaves are prettily undulated. Plant in ordinary garden soil, increase by cuttings inserted in a cold frame in July or August, and prune during summer to keep the plants shapely.

Laurustinus.--(See VIBURNum.)

Lavandula (Lavender). - The "Sweet-blooming Lavender" (Natural Order Labiatae) is known to every flower lover. As a neat shrubby bush clothed with grey foliage it is ornamental at all seasons, while in summer the spikes of fragrant flowers are delightful. A dry day in August is the best time to gather these; tie them in small bunches, and hang in a cool, dry place to dry for a few weeks before using. Lavender bushes must have a sunny position and thrive in most soils, preferring that which is light and sandy. Seeds can be sown in a cool greenhouse or frame from April to June, but cuttings form the most popular method of propagation. In October cottagers pull off a few of the side growths with a piece of old stem attached and plant them in the border I foot apart. Another way is to prepare cuttings about 3 inches long in the ordinary way and dibble them in a cold frame or under a handlight in sandy soil during September and October.

There are several varieties of Lavender. The typical kind, Lavandula vera, grows wild in the Mediterranean region; old bushes of this, some 4 feet in height, are fairly common in gardens, but, as a rule, young plants ought to be put in every four or five years and the old bushes discarded. Lavender makes a good dwarf hedge, and should be clipped after the flowers are over. The Dutch Lavender is a dwarf variety I2 inches high; Munstead Variety is a free-flowering sort with long violet-blue spikes; Bowles' Early is dwarf and early flowering, with purple-blue spikes; Old White, or alba, a whiteflowered sort, is worth growing as a novelty.

Lavatera (Mallow).-Annual and shrubby perennials (Natural Order Malvaceae), thriving in ordinary garden soil. Though of perennial character, the shrubby kinds are best treated as biennials, except in the warmer parts of the country, where in time they develop into large bushes. Lavatera arborea (the Tree Mallow), 6 to Io feet high, has large handsome leaves, and is sometimes used in summer bedding; the purple flowers open from July to Septenber; it is native of Europe, including some parts of our sea coast. As a decorative garden plant, the var. variegata, of which the leaves are mottled with creamy-white, is more showy; it is used for summer bedding. Lavatera cashmiriana, native of the Himalaya, 4 to 6 feet high, bears 

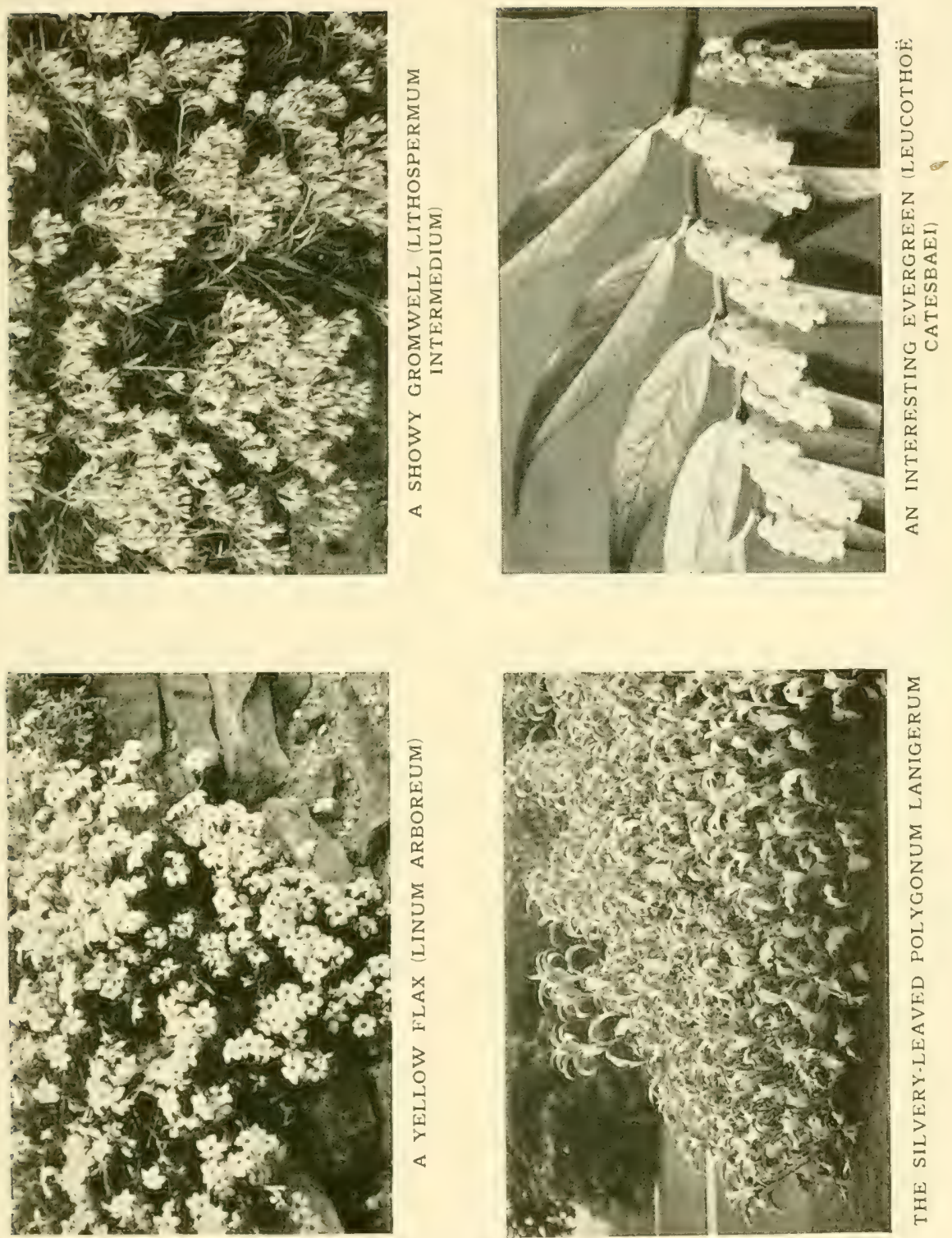

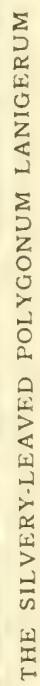



pale rose flowers in summer; while Olbia, 4 to 6 feet, has rose-pink blossoms from June to August--it is wild in Southern Europe. These shrubby Mallows are raised from seed sown in a cold frame during July, and except in the warmer counties need the protection of a cold frame during the winter; those used for summer bedding are also grown from seeds sown in a warm greenhouse in February.

The Annual Mallows are very showy plants, about 3 feet high, and thrive best in rich garden soil. Seeds may be sown under glass in March, but as seedling Mallows do not transplant readily, it is better to sow thinly, in April out-of-doors, where the plants are to flower. They are free-growing, and must not be crowded; a space of from I foot or even 2 feet in good soil is none too much to leave between them. Lavatera trimestris is a native of the Mediterranean region; the best varieties are: rosea splendens, rosy-pink; alba splendens, white; and Loveliness, rosy-red.

\section{Lavender.-(See Lavandula.)}

Layia.-Only one kind, Layia elegans, is grown to any extent. This is a hardy annual, about I foot high, and has large yellow Daisy. like blooms in summer, prettily edged with white. It belongs to the Daisy family (Compositae). The var. alba has white flowers. These plants prefer light, well-drained soil, and last in flower throughout the summer; they are attractive as an edging to a large bed or in groups along the front of a sunny flower border. Seeds are sown late in March or early in April out-of-doors where the plants are to flower.

Ledum.-Three kinds of Ledum are in cultivation, all being perfectly hardy throughout the British Isles; they belong to the Heather family (Ericaceae). They are Ledum glandulosum, from the mountains of California, British Columbia, and Alaska; latifolium, from North America, which is sometimes spoken of as Labrador Tea; and palustre, a native of the northern and arctic regions. They form compact bushes several feet across, and from 6 inches to 2 feet high (the latter height being rare), with small evergreen leaves, which are often covered with a dense mass of felty hairs on the under surface and are pungent when bruised. The white flowers are borne freely in dense, flattened heads during late spring and early summer. As is the case with most other plants allied to Heather, they object to soil containing lime, and show a preference for sandy peat and a moist situation. Propagation is often effected by means of layers, but more vigorous and generally healthier plants are those which have been raised from seeds. Such plants, however, grow very slowly for several years. The Ledums may have a position in the front of the shrubbery, or with the Heaths. Pruning is unnecessary. 
Leiophyllum buxifolium (Sand Myrtle) is a charming little shrub from the mountains of New Jersey, Carolina, Florida, etc., belonging to the Heather family (Ericaceae). It is known under the common name of Sand Myrtle, and has been called various botanical names, including Ammyrsine buxifolia and Ledum buxifolium. Of compact habit, it grows from 6 to $\mathrm{I} 2$ inches high, bearing small dark green Box-like leaves, and in May a profusion of small white pinktinged flowers in close-packed heads. At flowering time little can be seen of the leaves. Soil which will do for Heaths or Rhododendrons suits quite well for this plant. Propagation is often effected by layers or division of old clumps, but better plants are produced from cuttings or seeds. Pruning is unnecessary. The var. prostratum is even dwarfer than the typical kind, and may be planted in the rock garden.

Lemna (Duckweed).-Herbaceous annual floating plants (Natural Order Lemnaceae) without stem or leaf, and bearing inconspicuous flowers. On the approach of cold weather the plants sink to the bottom of the pond or lake; they are common on stagnant water. The Duckweeds increase very rapidly by buds, rapidly forming large floating masses on the surface in warm weather.

\section{Lent Lily.-(See Narcissus.)}

Leontopodium (Edelweiss).--The Swiss Edelweiss, Leontopodium alpinum (Natural Order Compositae), is the most talked-of alpine plant. Countless accidents have resulted from endeavours to collect it in its native Alps. It is not, as a rule, successful in gardens in smoky districts, but in pure country air it thrives excellently on an exposed rockery in well-drained stony soil and a sunny position. Increase is by division in spring and by seeds sown during spring or summer in well-drained pans of sandy soil. Leontopodium alpinum has small yellow flowers enveloped in white, woolly leaf-like bracts and grey leaves; it is about 6 inches high, and at its best in June and July. There are several so-called varieties, which are really geographical variations, namely, altaicum, from Russia; himalayanum, Himalaya; sibiricum, Siberia; and transylvanicum, from Austria.

Leptosiphon.-In some botanical lists Leptosiphon (Natural Order Polemoniaceae) is merged in Gilia, but for garden purposes it is distinct, and the name Leptosiphon is used. All varieties are annuals thriving in ordinary garden soil ; they are useful in the rock garden and as an edging to beds and borders. The seeds are sown outside during August for early flowering, and in April where the plants are to bloom in summer and autumn. The chief sorts are: androsaceus, lilac-purple, 6 to 9 inches, California ; aureus, golden-yellow, 
compact, 3 to 6 inches; hybridus, a mixed strain, including numerous shades of colour, 3 to 6 inches; and roseus, delicate rose, 3 to 6 inches. Snow-white is a pure white variety, 3 or 4 inches high, one of the best for an edging.

Leptosyne.-Californian annuals and perennials (Natural Order Compositae) with Coreopsis-like flowers, very useful for cutting, and of value in the garden. Leptosyne Stillmanni, golden-yellow, I8 inches high, blooms throughout the summer; from seed sown outside in April, the plants flower in five or six weeks; an excellent annual for beds and groups in the border. Leptosyne maritima, 2 feet, has large bright yellow flowers in late summer and autumn; this kind is rather tender in some districts, seed being sown in June, and the plants kept in a frame during winter ; or it may be raised in a heated greenhouse in early spring for planting out-of-doors in May. Rather light soil and a sunny position suit these plants.

Lespedeza.-Only one species, Lespedeza bicolor, is much grown in gardens; this is a shrubby plant belonging to the Pea family (Leguminosae), 4 feet or more high, native of North China and Japan. The small, Pea-like, rosy-purple flowers are freely produced in large terminal panicles in autumn, while the pinnate leaflets add to the beauty of the plants. The annual growths should be cut down to the ground each year in February or March. Ordinary light garden soil is suitable, and increase is by division of the rootstocks in spring or by seeds sown in a cool greenhouse or frame from March to June. This plant is not suitable for cold districts.

Leucojum (Snowflake).-A small group of bulbous plants (Natural Order Amaryllidaceae) with leaves resembling those of the Daffodil, and large fragrant Snowdrop-like flowers. They succeed in light loamy soil, and when once planted should be left undisturbed for some years. They are suitable for the rockery, wild garden, and open woodland. September and October are the best months in which to plant the early flowering kinds; while Leucojum autumnale is planted in spring. Increase is by offsets, which may be lifted and divided at the times recommended for planting. The bulbs should be covered with 3 or 4 inches of soil. The chief kinds are: aestivum (Summer Snowflake), white, tipped with green, several flowers on a stem, May and June, I 8 inches, native of Southern and Central Europe, including Britain; autumnale, white, tinted with rose, September, 4 to 6 inches high, Mediterranean region; pulchellum (syn. Hernandezii), white, May, I8 inches, from the Balearic Isles; and vernum, the Spring Snowflake, white green-tipped flowers in April, native of Southern Europe. 
Leucophyta.-Only one species is commonly grown, Leucophyta (syn. Calocephalus) Brownii, an Australian shrubby plant with attractive, silvery-grey stems and leaves; it belongs to the Daisy family (Compositae). It is a favourite plant for summer bedding. Propagation is by cuttings inserted in pots of sandy soil during August ; the plants are often kept for several years, as they grow slowly. During winter both these and the rooted cuttings must be kept on a shelf in the greenhouse, giving little water; they are planted out in May or early June, and brought under glass again at the end of September. The plants reach a height of 2 feet or more in time.

Leucothoë Catesbaei is the best-known plant in this group, which is a member of the Heather family (Ericaceae). It is an evergreen shrub from the South-East United States, and often grows about 2 feet high, but under good conditions it sometimes attains a height of between 3 and 4 feet. The branches are arching and clothed with ovate, long-pointed leaves 3 to 4 inches long; the white flowers appear in axillary, pendent racemes, 2 to 3 inches long, in May and June. This is a peat-loving shrub, but can be grown in loam if lime is not present, and gives the best results under conditions favourable to Heaths and Rhododendrons. It increases by stems from the rootstock, and these are sometimes detached and used for propagation, but seedlings form the most vigorous plants. A few old branches may be thinned out each year after the flowers have fallen. A second kind is Leucothoë axillaris, which is also found in the South-East United States.

Lewisia.-Californian rockery plants, belonging to the Natural Order Portulacaceae, of considerable beauty and interest. They have fleshy leaves and richly coloured flowers in summer and autumn. A sunny position and a well-drained soil are essential, for while the plants delight in moisture in summer, it is harmful in winter; a compost of sandy loam, peat, and small picces of stone is suitable. Increase is by seeds sown in slight warmth under glass in spring, and by division of the roots during March. The chief kinds obtainable are: Cotyledon, rosy-pink, leaves in a rosette; Howellii, rosy-pink, in long, graceful panicles, thick leathery leaves; Tweedyi, soft salmon-rose, thick leaves in a rosette; oppositifolia, pure white, on slender stems, linear leaves, and rediviva, satiny-rose, dark green succulent leaves.

Leycesteria formosa (Pheasant Berry). $-\Lambda$ vigorous-growing shrub from the temperate Himalaya, belonging to the Honeysuckle family (Caprifoliaceae). It has several attractions, for some people cultivate it in large groups for the sake of its bright green bark in 


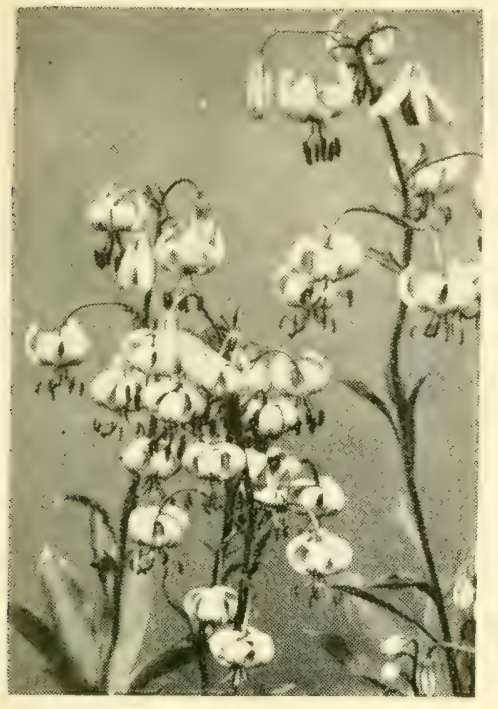

THE MARTAGON LILY (LILIUM MARTAGON)

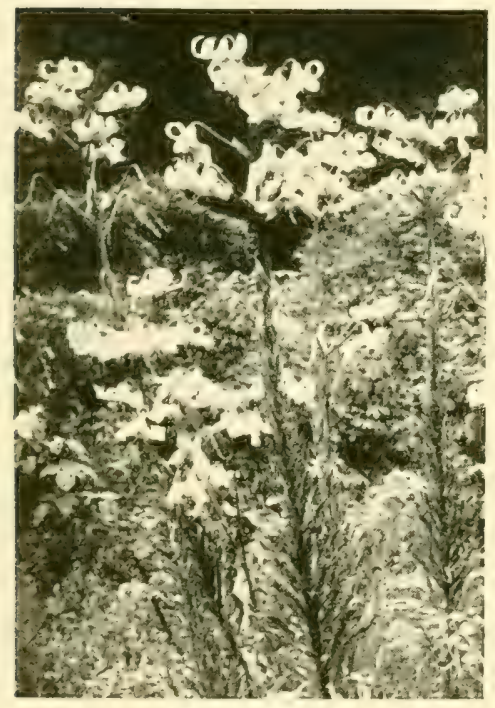

THE NANKEEN LILY (LILIUM TESTACEUM)
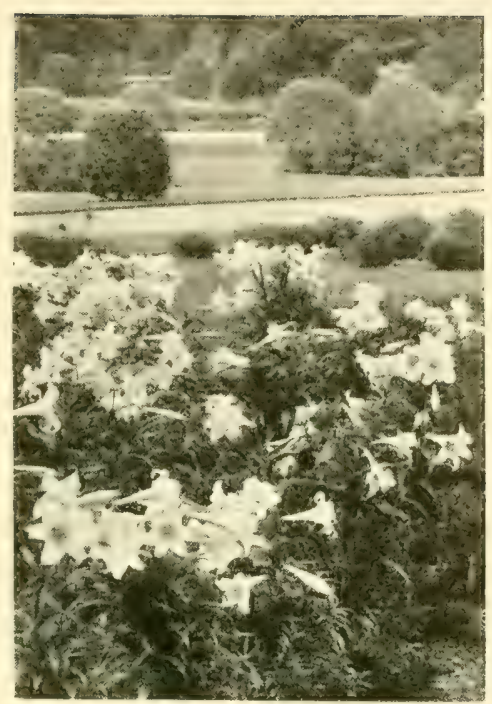

THE WHITE TRUMPET LILY

(LILIUM LONGIFLORUM)

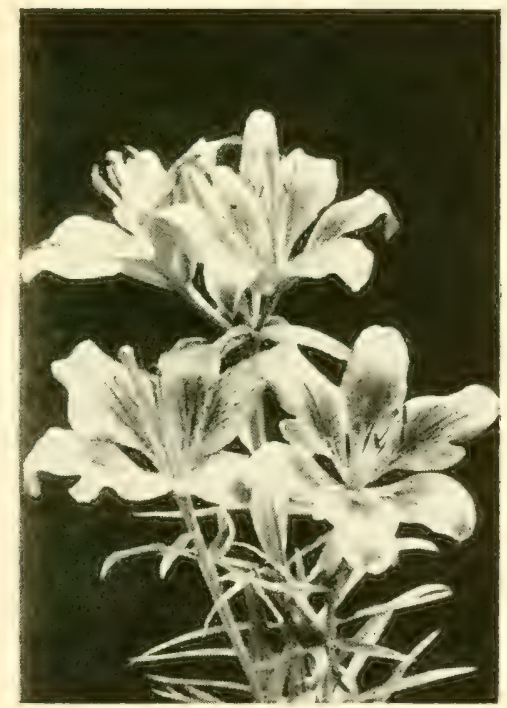

THE ORANGE LILY (LILIUM CROCEUM) 

winter-time, while others prefer its showy inflorescences of creamywhite flowers, which appear amongst prominent dark-red bracts during several weeks in summer; the bracts are persistent and set off the bright black fruits at a later date. It is better adapted to the warmer than the colder parts of the country, though it is usually only the ends of the branches which suffer from cold. Any good garden soil suits. Propagation is by cuttings or seeds, and pruning depends largely upon the object for which the bushes are grown. Those grown for their bark are cut down each spring, whilst bushes are thinned at the same time.

Liatris.--Handsome border perennials, natives of North America, thriving in rich, well-drained, light soil; they are members of the Daisy family (Compositae). Increase is by division of the fleshy roots in spring and by seeds sown in a cold frame as soon as ripe or in spring. Plant in a sunny open border. Liatris graminifolia bears spikes of rosy-pink flowers in August and September, 2 to 3 feet, (the var. dubia has slender stems, thickly furnished with rosy-purple flowers); pycnostachya (Kansas Grey Feather) is crimson-purple, 4 feet, one of our best autumn border plants; punctata has rosypink blooms in August and September, I2 inches; scariosa, bears dark purple flowers in September, 2 to 3 feet; spicata, rosy-crimson, 2 feet, blooms in September and October.

Libertia (New Zealand Satin Flower).-The Libertias, which belong to the Iris family (Iridaceae), have grass-like foliage and beautiful spikes of white flowers. As they are natives chiefly of New Zealand, it is desirable to plant in rather a sheltered position in a well-drained compost of sandy loam and peat. Propagation is by careful division of the clumps in spring, and by seeds sown as soon as ripe in early autumn in a cold frame. Even when the plants are not in flower the evergreen grass-like leaves are attractive. The three most useful species for outdoor cultivation are: formosa, spikes of large white flowers, May, 2 to $2 \frac{1}{2}$ feet, Chili; grandiflora, pure white in spike-like panicles, June, July, $2 \frac{1}{2}$ to 3 feet, New Zealand; and ixioides, white, yellow stamens, June and July, 2 to 3 feet, New Zealand.

Libocedrus. - This is a group of evergreen trees belonging to the Natural Order Coniferae. Four species are grown: chilensis, from the Chilian Andes; decurrens, from Western North America (Oregon to South California); macrolepis, a new kind from China; and Doniana, from New Zealand. Libocedrus decurrens is the most useful tree, the others being better adapted for the milder counties. It may be grown almost anywhere, where cool, moist soil and moist 
and pure atmospheric conditions prevail. Under such conditions it forms a tall, upright column of dense branches clothed with dark green leaves, specimens 50 feet high being often less than ${ }_{5} 5$ feet wide and always imposing. Increase is by seeds, and pruning is unnecessary.

\section{Ligularia.-(See SENEcio.)}

Ligustrum (Privet).-The indiscriminate way in which various kinds of Privet have been planted has brought some discredit upon these shrubs, yet among them are many useful kinds, and even those that have been planted most widely have certain qualifications lacking in many other shrubs. They belong to the Natural Order Oleaceae. Ligustrum ovalifolium grows quite well beneath the shade of trees, whilst there are few cheaper or more rapid-growing hedge plants. It is, however, a "gross feeding" shrub, and soon impoverishes the ground if the roots are not cut well back once a year. It is a native of Japan, whilst various other kinds are found in the same country, China, and Europe. They are increased by cuttings, the hardier kinds placed out-of-doors in autumn and others in sandy soil under glass in summer. When outgrowing their positions they may be pruned vigorously during April, whilst hedges should be clipped several times between May and September if they are to be kept compact and neat.

The following are the chief kinds: Delavayi, a graceful Chinese Privet of recent introduction, with small, evergreen, oval leaves and good-sized inflorescences of showy white flowers, suitable for the southern counties; japonicum, from China and Japan, is a useful evergreen bush with bold handsome leaves, growing from 3 to 5 feet high, and bears upright panicles of white flowers during summercoriaceum and involutum are compact varieties of rather stunted growth; lucidum is a vigorous and useful evergreen from China, growing from $\mathrm{I} 2$ to 20 feet high and blooming freely; ovalifolium, already alluded to, is widely grown for hedges, and its golden-leaved var. aureum is a showy and largely grown shrub, being a great favourite with owners of small gardens.

Ligustrum sinense, from China, is a large bush or small tree up to 20 or 25 feet high; its light green leaves are sub-evergreen, or sometimes quite evergreen, and the white flowers are succeeded by clusters of small black fruits; massalongianum and strongylophyllum are of neat growth and suitable for the southern counties; vulgare, the common British kind, is planted beneath trees, and is also used for hedges.

Lilac.-(See SYRINGA.) 
Lilium (Lily).-The Lilies (Natural Order Liliaceae) are the most beautiful of all hardy bulbous plants; they vary in height from a few inches to Io or even 12 feet, while the blooms are remarkably diverse in shape and rich in colour, and open throughout a long season, from May to October. A few amateurs make the Lily family their special hobby, and are able to cultivate some sixty species and varieties in various soils and positions. Some kinds grow freely in full sun in ordinary border soil, while others require some shade and special soil. The usual method of increasing Lilies is by offsets taken off at the seasons recommended for planting. Home-grown bulbs are best planted during October and November; bulbs imported from Japan and elsewhere in February and March. The most important exceptions to this rule are candidum and testaceum, which should be planted during August or early September. So far as concerns the depth at which to plant Lily bulbs, they naturally divide into two groups, namely, those that root from below the bulb only and those that root from the base of the stem as well as from the bulb; the former are covered with about 3 inches and the latter with 5 or 6 inches of soil.

Some Lilies are readily raised from seeds, and flower in from two to five years from sowing. Several kinds produce bulbils on the stems, which form a ready means of increase, notably tigrinum, sulphureum, and bulbiferum. Others must be propagated by means of the scales that go to form the bulb; they are broken off carefully, laid on pans of light soil, and covered with a sprinkling of sand; young bulbs grow from the bases of the scales. Notes with regard to the soil and position best suited to individual kinds are given in the following pages. Lilies which prefer partial shade and a peaty, leafy compost, may be grown in association with hardy ferns. A few of the dwarf sorts are useful for planting in the rock garden.

Lilium auratum, the Golden-rayed Lily of Japan, has large, fragrant flowers, white, marked with yellow and purple, in August; it needs a compost of peat, leaf-mould, and sandy loam, and the bulbs should be covered with 6 inches of soil. It grows from 4 to 6 feet high, and prefers partial shade; the plants are not usually long-lived. A few fine varieties are rubro-vittatum, macranthum, and Wittei. Lilium Brownii, a Chinese Lily, bears trumpet-shaped blooms, white inside and purple-brown outside, in July; it thrives in peat, leaf-mould, and sandy loam, in a sunny or partially shaded spot, the bulbs being planted 5 or 6 inches deep; it grows about 3 feet high. Lilium bulbiferum, with orange-red flowers in May and June, grows in ordinary border soil in a sunny spot; it is from 3 to 4 feet high, and comes 
from Central Europe. Lilium candidum (Madonna Lily), having pure white flowers in June, thrives in any ordinary border soil, preferably containing lime. It requires a sunny position, and should be planted in August, the bulbs being covered with 2 or 3 inches of soil. It attains a height of from 3 to 5 feet, and is a native of Southern Europe.

Lilium chalcedonicum (Scarlet Turk's Cap), a native of Greece, will grow in ordinary ground in a sunny border, and should be covered with 2 or 3 inches of soil. It grows 3 to 4 feet high, and bears rich wax-red flowers in July. Lilium concolor, from China and Japan, bears orange-red blooms in July; it thrives best in peat in a somewhat shady spot in the rock garden, and should be planted 3 inches deep; its height is from I2 to I8 inches. The var. Coridion has rich yellow blooms. Lilium croceum (Orange Lily), native of Southern Europe, bears orange-red flowers in the latter part of June and throughout July. It grows from 3 to 5 feet high, and should be planted 5 inches deep. Lilium davuricum or umbellatum (Dahurian Lily) grows from 2 to 3 feet high, and will thrive in ordinary soil in a sunny border; its orange-red upright flowers are in terminal clusters. The bulbs should be planted at a depth of 5 to 6 inches. This Lily is native of Siberia and has numerous varieties, mostly of Dutch origin. Aurantiacum, multiflorum, erectum, Cloth of Gold, Incomparable, Sappho, and Tottenhami are some of the most distinct, and all are easily grown.

Lilium elegans (Thunbergianum) is a Japanese Lily, possessing numerous varieties that will thrive in the open border in light garden soil. They vary in height from 6 to 36 inches, and flower in June, July, and August, the colours ranging from yellow to rich crimson. The bulbs should be planted 4 inches deep. The following bloom in June and July: Prince of Orange, atrosanguineum superbum, bicolor, Orange Queen, Othello, Peter Barr, sanguineum, Van Houttei, and Willie Barr. The best August flowering ones are Batemanniac, venustum, and Wallacei.

Lilium giganteum, a remarkable Himalayan Lily, forms a tuft of unusually large leaves and produces a thick flowering stem that may reach a height of 10 feet; the immense tube-shaped blooms, which are white with green tinge and shaded with purple inside, open in July and August. This Lily needs a sheltered, partially shaded spot and deep soil consisting of loam, leaf-mould, peat, and sand. The bulb dies after flowering, though offsets are produced which may be used to increase the stock. If small bulbs are planted they take several years to reach flowering size; larger ones may be expected to bloom in one or two years. The bulbs ought to be covered with 4 or 5 inches of soil. 
Lilium Hansoni, from Japan, bears yellow flowers, marked with brown spots, in June, and should be planted 4 to 5 inches deep, in ordinary border soil in sun or partial shade. Its average height is from 3 to 4 feet.

Lilium Henryi, a handsome Chinese Lily, bears orange-yellow flowers in August and September. It grows from 5 to 8 feet high in ordinary border soil, and likes partial shade; the bulbs should be planted 6 to 8 inches deep. Lilium longiflorum (Trumpet Lily), native of Japan, grows from 2 to 3 feet high, and may be planted 4 to 5 inches deep in ordinary, light border soil, to which a little peat and leaf-mould have been added.

Lilium Martagon (Turk's Cap Lily), from Central and Southern Europe, bears reddish-purple blooms in June and July. It needs merely ordinary soil in a half-shady position, and grows from 3 to 5 feet high. The bulbs must be covered with 3 inches of soil. The var. album is a lovely white border Lily. Lilium monadelphum Szovitzianum (colchicum), having citron yellow blossoms in May and June, grows well in ordinary border soil in a sunny position, the bulbs being planted 3 or 4 inches deep. It grows from 4 to 6 feet high and is native of Caucasus and North Persia. Lilium pardalinum (Panther Lily), from California, with yellow blooms, shaded with orange and red, in July and August, needs a deep soil consisting chiefly of leaf-mould and peat, and requires shade from the midday sun. It grows from 5 to 8 feet high, and the bulbs should be covered with 3 inches of soil. Lilium pomponium, a Lily from Lombardy, growing 3 to 4 feet high, bears flowers of sealing-wax red shade, in June; the bulbs should be planted 4 inches deep in ordinary soil in a sunny border. Lilium pyrenaicum, whose home is in the Pyrenees, will grow in ordinary soil in either sun or shade. It reaches a height of 3 feet, in its flowering season in May and June, when it bears greenish-yellow blooms marked with dark spots. It should be planted 2 to 3 inches deep.

Lilium speciosum (lancifolium), a popular Japanese kind, thrives in ordinary soil to which a little peat and leaf-mould have been added, in sun or partial shade. It grows some 3 to 5 feet high, and has numerous varieties, varying from rosy red, through pink to white. Its flowering season is during late summer and autumn. A few distinct sorts are: album Kraetzeri, magnificum, Melpomene, punctatum, roseum, and rubrum. The bulbs should be covered with 4 or 5 inches of soil. Lilium sulphureum, a Burmese Lily, bears in September and October very large trumpet-shaped flowers, sulphurcoloured, with brownish shading outside. It grows from 5 to 7 feet 
high in ordinary, well-drained border soil in a sunny spot. The bulbs should be planted 6 to 8 inches deep. Lilium superbum, native of the United States, grows about 5 to 7 feet high, and the bulbs need planting 4 inches deep in a soil made up of sandy loam, peat, and leaf-mould in a somewhat shady position. The graceful reflexed flowers, which are at their best in July and August, have an orange yellow centre shading to reddish-crimson, and are prettily spotted.

Lilium tenuifolium is a graceful Siberian Lily, from 12 to 18 inches high, with narrow leaves, slender stems, and waxy-scarlet blooms in Nay and June; it requires light loamy soil to which leaf-mould has been added. The bulbs must be covered with 2 inches of soil, and are preferably planted in a sheltered position in the rock garden: Lilium testaceum (Nankeen Lily) (also known as isabellinum and excelsum) bears fragrant citron-yellow blossoms in June and July, on stems 4 to 5 feet high. This kind is supposed to be a hybrid between candidum and chalcedonicum. It thrives in ordinary border soil in a sunny place, and the bulbs should be covered with 3 inches of soil, planting being done in August.

Lilium tigrinum (Tiger Lily), from China and Japan, bears orangered, black-spotted flowers, with reflexing segments in August and September. It grows about 3 to 5 feet high, and thrives in ordinary soil in a sunny border. The bulbs should be covered with 4 or 5 inches of soil. There are several varieties: Fortunei, with woolly stem, flowers somewhat later than the typical kind; giganteum, has rich orange-scarlet flowers; flore pleno has double blooms; and pseudotigrinum (Maximowiczii) is a late-flowering (October) variety without bulbils in the axils of the leaves:

\section{Lily of the Valley.-(See Convaliaria.) \\ Lime Tree.-(See Tilia.)}

Limnanthemum peltatum (Fringed Buck Bean). - Though wild in Britain, this is a beautiful water plant; it belongs to the Gentian family (Gentianaceac), and is sometimes known as Villarsia nymphaeoides. The roundish leaves float on the surface of the water frecly, and in summer and early autumn the fringed yellow blossoms are very attractive. The Buck Bean thrives in shallow water where the roots can reach the mud; if planted by a muddy bank it will gradually spread out into the water. Propagation is very easy by division, while seeds may be collected when ripe, and sown in mul along the water's edge. Though a pretty plant, it increases rapidly under congenial conditions, and is apt to encroach on choicer kinds:

Limnanthes.-- The only species grown in gardens is Limnanthes Douglasii, a hardy annual, native of North-West America, and 
member of the Geranium family (Geraniaceae). It thrives freely in ordinary soil and is one of the best dwarf annuals for autumn sowing. Sow seeds in autumn or spring where the plants are to flower. Selfsown seedlings may often be found. It grows 6 inches high, is of spreading growth, and bears fragrant yellow flowers edged with white.

Linaria (Toadflax).-Annual and perennial plants, of dainty character, belonging to the Snapdragon family (Scrophulariaceae); valuable in the rock garden and border. Propagation of the perennial kinds is by cuttings inserted in a cold frame during August and September in pots of light sandy soil, by division of the clumps in March, or by seeds sown in a frame during April or May. The annual Toadflaxes should be sown during April where they are to flower. Well-drained, rather light soil suits the Toadflaxes best.

The chief perennials are: alpina, purple and orange, a charming trailing plant for the rock garden and old walls, flowers freely from June to September and sows itself, native of Europe (there are white, alba, and rose-coloured, rosea, varieties); Cymbalaria (Kenilworth Ivy or Ivy-leaved Toadflax) bears lilac-blue flowers freely from May to September; though a British wild plant, this is pretty in the rock garden and on old walls (the vars. alba and rosea are attractive). Dalmatica (syn. macedonica) has blossoms with orange-yellow lip, from June to August, a valuable border plant, 3 to 4 feet high, native of Dalmatia; genistifolia is a showy border kind with light yellow flowers from June to September and pretty glaucous foliage, 4 feet, Europe and Asia Minor; hepaticaefolia, a dainty trailing alpine for the rockery and old walls, with lilac blossoms, from June to August, Corsica ; origanifolia, violet flowers, orange throat, June to September, 4 inches, rockery, South Europe.

Linaria pallida, bearing violet flowers from June to August, is only 3 inches high and suitable for the rockery or edge of the bog garden, Italy; purpurea bears maroon-purple blossoms on slender, graceful stems in July and August, it has glaucous leaves and grows about 3 feet high, Europe; vulgaris Peloria is a curious form of our Wild Toadflax, 2 feet high, with pale yellow and orange blooms in July and August.

The chief annual Toadflaxes are bipartita, lilac-purple and yellow, I 2 inches, North Africa; maroccana White Pearl, a beautiful Toadflax with white flowers, I2 inches (the var. Yellow Prince has yellow flowers); reticulata aureo-purpurea, purple-crimson and orange, 9 inches.

Lindelofia (Himalayan Hound's Tongue).-One species and two varieties of this blue-flowered perennial are grown in a few gardens. 
They belong to the Borage family (Boraginaceae). Ordinary welldrained border soil and a sunny position supply their needs. Pro. pagation is by division in autumn or spring, and by seeds sown under glass in spring or out-of-doors during April and May. Lindelofia spectabilis bears purple or violet-blue blooms from June to August, I8 inches, Himalaya; the var. afghanica, deep purple, is summer blooming; and praecox has bright blue flowers from April onwards.

Lindera.-This is a group of shrubs belonging to the Natural Order Lauraceae, their near relative in the outdoor garden being the Sweet Bay (Laurus nobilis). Although of no special decorative value, their fragrant leaves make them interesting, wnilst the small golden flowers of some kinds are produced with sufficient freedom to render the plants attractive. Plant in light loamy soil or in loam containing a little peat. Increase is by seeds or cuttings, and pruning is carried out in summer merely to keep the bushes shapely. A few good kinds are: Benzoin, the Spice Bush or Benjamin Bush of the United States; and glauca, hypoglauca, and triloba, from Japan:

Linnaea (Twin Flower).-Linnaea borealis, the only species, is a trailing or creeping evergreen shrub belonging to the Honeysuckle family (Caprifoliaceae), native of Britain and other countries. This dainty little plant needs a rather shady position and peaty soil. The flesh-coloured, fragrant, pendulous flowers are in pairs, and open from May to July. It is propagated readily by division in autumn or spring, and by cuttings inserted in pots of sandy peat in a frame during August and September.

Linum (Flax).- Hardy perennial and annual plants (Natural Order Linaceae) notable for their graceful growth and free-flowering. They should be grown in a sunny position in rather light, well-drained soil. Some are suitable for the rock garden, others for the border. Seed forms a ready means of increasing both perennial and annual Flaxes, and is generally the most satisfactory method of propagation, as these plants dislike being disturbed. A few, notably arboreum, are increased by cuttings inserted in sandy soil in a cold frame during August; while perenne is easily raised by division of the roots in spring: Sow seeds of the perennials out-of-doors during April and May, and the annuals in April where the plants are to flower. The annual sorts are: grandiflorum, brilliant red, I2 inches, summer, native of Algeria (var. rubrum, which is of richer colour, is generally grown); usitatissimum (Common Flax), pale blue, IS inches to 3 feet, July and August, found wild in Europe.

The most showy perennials are alpinum, blue, trailing, 4 to 6 inches, June to August, suitable for the rock garclen, native of Europe, etc. ; 


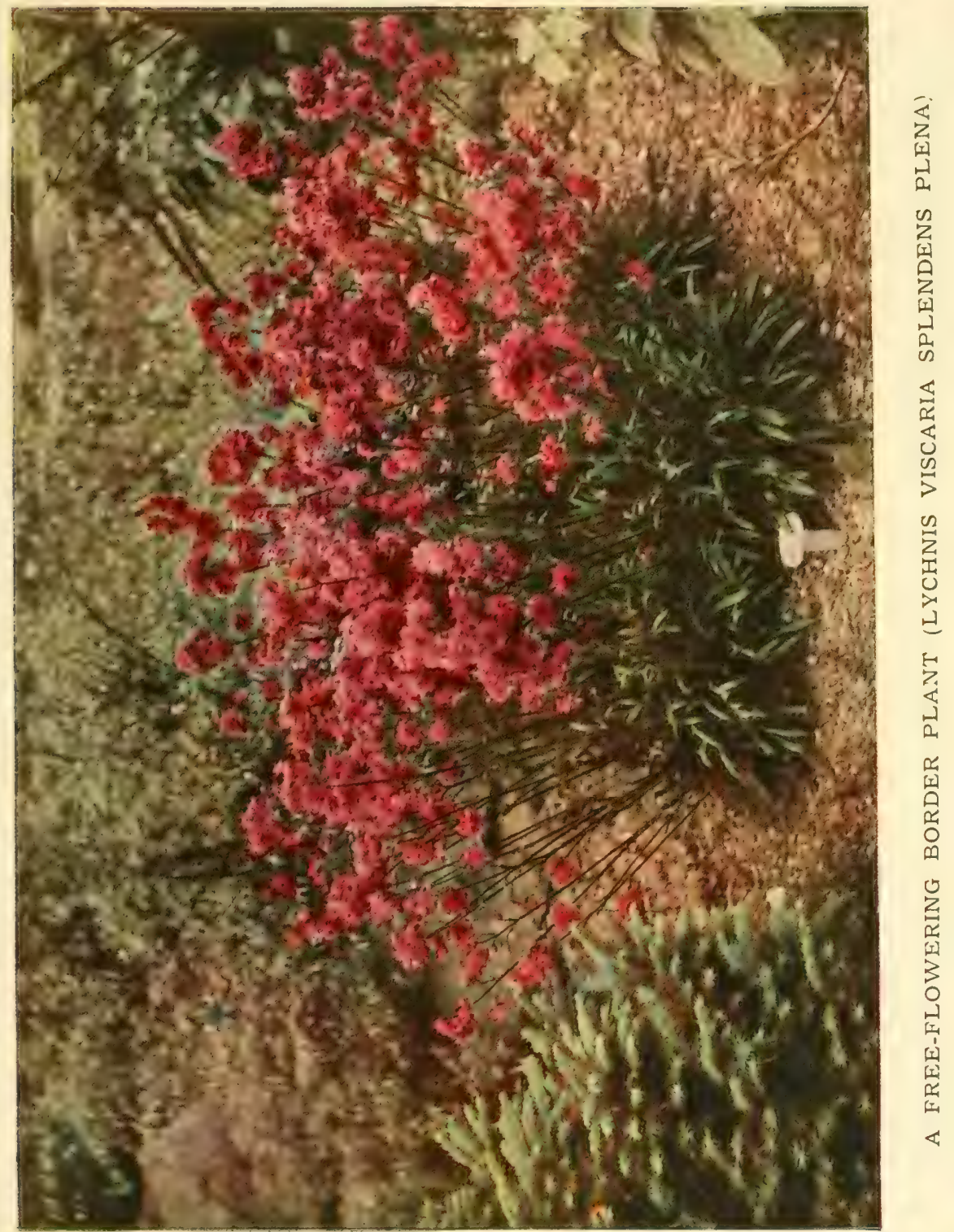



arboreum, lemon-yellow, $\mathrm{I} 2$ inches, a showy shrubby kind, best planted in the rock garden, native of Crete; austriacum, pale blue, I 2 inches to 2 feet, June and July, Europe; flavum, golden-yellow, I2 inches, June to September, Southern Europe, very effective in the rock garden; monogynum, white, I 8 inches, June to August, New Zealand; narbonense, blue, I8 inches to 2 feet, June to August, Southern Europe; perenne, pale blue, the most popular and easily grown perennial Flax, I2 to I 8 inches, June to August, northern temperate regions; perenne album is a pretty white variety.

Lippia citriodora (Scented Verbena).-A popular shrub on account of its lemon-scented leaves; it belongs to the Natural Order Verbenaceae. It is native of South America, and is not generally hardy in the British Isles, although it might profitably be planted in more gardens, especially if placed at the foot of a warm wall. It thrives and makes a good-sized bush in the south and west counties and on the west coast of Scotland. Bushes 3 or 4 feet high have even been known to grow for many years in Essex gardens. It is also grown as a greenhouse and as a room plant. Cuttings may be rooted in sandy soil during spring and summer, and it thrives in ordinary garden soil. Cut the longer branches back in spring in order to keep the plants shapely.

Liquidambar (Sweet Gum Tree).-Three kinds, all trees, have been introduced: formosana, from China and Japan; orientalis, from Asia Minor; and styraciflua, from the United States. They are members of the Witch Hazel family (Hamamelidaceae). The lastnamed is the only one of any value in the British Isles, where it grows from $5^{\circ}$ to 80 feet high, and is distinguished by silvery bark, glossy Sycamore-like leaves, and Plane-like fruits. Its chief asset is the rich autumnal colouring of the leaves, and at that season it is one of the showiest trees in the garden. It is known as the Sweet Gum Tree in America, and it is there valuable on account of its timber, which has a wide use for cabinet work, etc., being used under the names of Red Gum, Yellow Gum, and Satin Walnut. The last name is usually applied to the wood in this country. This tree is raised from seeds or layers, may be planted in ordinary garden soil, and should be pruned in summer to keep the trees shapely whilst young.

Liriodendron Tulipifera (Tulip Tree).--This was for long considered to be the only representative, but within recent years a new kind has appeared from China under the name of Chinensis. They belong to the Magnolia family (Magnoliaceae). Liriodendron Tulipifera is found in the United States, where it forms a very large tree and produces valuable timber. Here, it often exceeds roo feet in 


\section{THE BOOK OF HARDY FLOWERS}

height, with a trunk diameter of 3 feet. It is commonly known as the Tulip Tree, and is popular alike, for its handsome, curious-shaped leaves and yellow and green Tulip-shaped flowers. The timber is imported into this and other countries under the names of White Wood and Yellow Poplar, and it is largely displacing Deal for the backs of cabinets, drawers, and other kinds of work. Plant in good, deep, loamy, well-trained soil, increase by imported seeds, and prune when young to keep the trees shapely. There are several variegated varieties, but they are no improvement on the type. The Chinese tree, Chinensis, appears to be quite as vigorous as its better-known relative.

Liriope.-Only one species is grown in gardens, namely, Liriope spicata (syn. graminifolia), a native of China and Japan. It is a member of the Natural Order Haemodoraceae. The plants are evergreen with arching leaves Io or I2 inches long; the deep violet-blue flowers are small, closely arranged on the upper part of a stem 9 to $\mathrm{I} 2$ inches high, and open from September to November. The Liriope thrives in ordinary garden soil, and prefers a sheltered, half-shady position. Increase is by division of the clumps during March and April, which is also the best time for planting. Even more beautiful than the type is the variety variegata, with yellow leaves striped with green; this is frequently used as a summer bedding plant. Lift the plants in autumn and store in a cold frame, planting out-ofdoors again during May. Ophiopogon spicata variegata is another name for Liriope spicata.

Lithospermum (Gromeell).-Dwarf alpine or rockery perennials, belonging to the Borage family (Boraginaceae). They thrive in well-drained sandy, peaty soil, and need a sunny spot. Increase is by seeds sown as soon as ripe or in spring in pots in a cold frame, by division of the clumps in autumn and spring, and by cuttings inserted in a cold frame during August. The most useful species are angustifolium, bright yellow, June, narrow foliage, 9 to 12 inches, North America; canescens, rich yellow, June and July, grey foliage, 9 inches, North-West America; Gastoni, azure blue with white centre, I2 inches, Pyrenees; graminifolium, deep blue drooping flowers, June to August, tufts of grass-like leaves, Italy; prostratum, dark Gentian-blue flowers from spring to autumn, a dwarf evergreen of great beauty, the most popular kind for the rockery, native of South-West Europe - the var. Heavenly Blue has lovely azureblue flowers.

Loasa.-This is a comparatively little-known though a rather large group of hardy and greenhouse annual and perennial plants (Natural Order Loasaceae). Only three are worthy of mention here : 
hispida, yellow, a free-flowering half-hardy annual, July to August, I2 inches, Peru; lateritia (Chili Nettle), coral or brick-red, July and August, a twiner or climber for warm walls and fences, 6 feet or more high, a half-hardy perennial, but usually treated as a half-hardy annual, the plants being raised under glass in spring and put out-ofdoors early in June; vulcanica, white with red and yellow centre, July and August, half-hardy annual, I2 inches, New Grenada. The Loasas are readily raised from seeds sown under glass in spring, either in a warm greenhouse or cold frame, the former for preference. Plant out on a warm, sunny border in well-drained soil early in June.

Lobelia.-This is a very large class of tender and hardy perennials and annuals, belonging to the Bellflower family (Campanulaceae). The best known are the dwarf summer bedding sorts. Lobelia cardinalis and fulgens, which blossom in autumn, are also very popular.

The herbaceous perennials are propagated by division of the roots or clumps in March, by cuttings made of the young shoots during April and May, inserted in pots of sandy soil in a frame; a third method of increase is to sow seeds in a greenhouse during February to produce flowers in summer, or in a cold frame in May to give plants the following year. They delight in rich, moist soil and a partially shaded position. In cold and wet soil it is desirable to lift the roots in October and store them in boxes of light sandy soil in a frost-proof shed for the winter. Another method of protection is to place little mounds of old coal ashes over the clumps from November to March. The four perennial species generally cultivated are cardinalis, scarlet, August to October, dark green leaves, $2 \frac{1}{2}$ to 3 feet, North America; fulgens, brilliant scarlet, August to October, dark bronze-red foliage, Mexico; syphilitica, blue, July to October, 3 to 4 feet, North America; Tupa, reddish-scarlet, August to October, 4 to 6 feet, Chili. For garden decoration the following sorts obtained by cross-breeding are very showy ; the plants produce slender graceful spikes of flowers, 3 to 4 feet in height, clothed with blossoms of various shades from August to October; Queen Victoria, Gloire de St. Anne's, Firefly, Lord Ardilaun, Carmineus, caerulea grandiflora, Gerardi, Magnificent, multiflora, Milleri, Orion, Jupiter, and Purple Emperor.

The dwarf Lobelias are popular flowers for summer bedding. Lobelia Erinus, from South Africa, a tender perennial, is the parent of the numerous named varieties. There are two methods of propagation: by seeds sown in a heated greenhouse during February or early March, and by cuttings taken in August and kept on the greenhouse shelf during winter. In February further cuttings may be rooted by taking off the young shoots and putting them in pots 
of sandy soil in a case in the greenhouse. Lobelias grow rapidly in spring, and in a month from inserting cuttings the tops of these can be taken off to form others. From fifty stock plants as many as a thousand can be obtained in spring ready to plant outside by the end of May. The plants thrive in rich, light garden soil in sunny beds and borders. The following are good named sorts, which must be jropagated by cuttings: Barnard's Perpetual, rich blue, white centre; Emperor William, deep violet; Kathleen Mallard, deep blue, double; Queen of Whites, dwarf, compact white; Swanley Blue, bright blue; Waverley, rich blue. Bedding Lobelias, taller and of spreading growth, are: speciosa, dark blue; gracilis, blue (or white); and Hamburgia, a lovely blue trailing sort. These are especially useful for window boxes, vases, and hanging baskets.

Lobelia tenuior (ramosa) is a beautiful half-hardy annual kind from Australia. It grows 12 inches high, and flowers freely from June to September. Seeds are sown in a heated greenhouse during February and March, the plants being put out-of-doors in beds and borders, or in window boxes and vases late in May. There are varieties, seeds of which are sold separately, with rich blue, pale blue, pure white, and rose-coloured blooms.

Loiseleuria procumbens is a dwarf, prostrate shrub belongings to the Heather family (Ericaceae), closely allied to Rhododendron, and sometimes called the Alpine Azalea or Azalea procumbens, It is a native of the European Alps and other cold parts of the Continent, Asia, and America, whilst it also occurs in the Highlands of Scotland. Scarcely rising a couple of inches above the ground when at its tallest, it is frequently quite prostrate. The evergreen leaves are very small, and the white or pinkish flowers, each $\frac{1}{1}$ to $\frac{1}{3}$ inch across, appear during early summer, often in June. It should be planted in peaty soil in the rock garden, and increased by cuttings or seeds. Pruning is unnecessary.

Lomaria (Hard Fern).--These are interesting and distinct ferns (Natural Order Filices) of dwarf growth. Division of the clumps is the usual means of increase, though if many plants are required they may be raised from spores. March is a good time to lift, divide, and replant. Plant in a shady spot in ordinary, well-drained soil containing a little leaf-mould. The best-known species is Lomaria Spicant, our native Hard Fern, sometimes grown as Blechnum Spicant. It has barren fronds, 8 or 9 inches, and fertile fronds, I2 inches long. There are numerous varieties, the best known being Aitkinianum, crested; concinnum, crenulated margins to fronds; cristatum, crest at endis of fronds; plumosum, prettily divided fronds; and trinervum coronans, divided pinnae, and crested. 


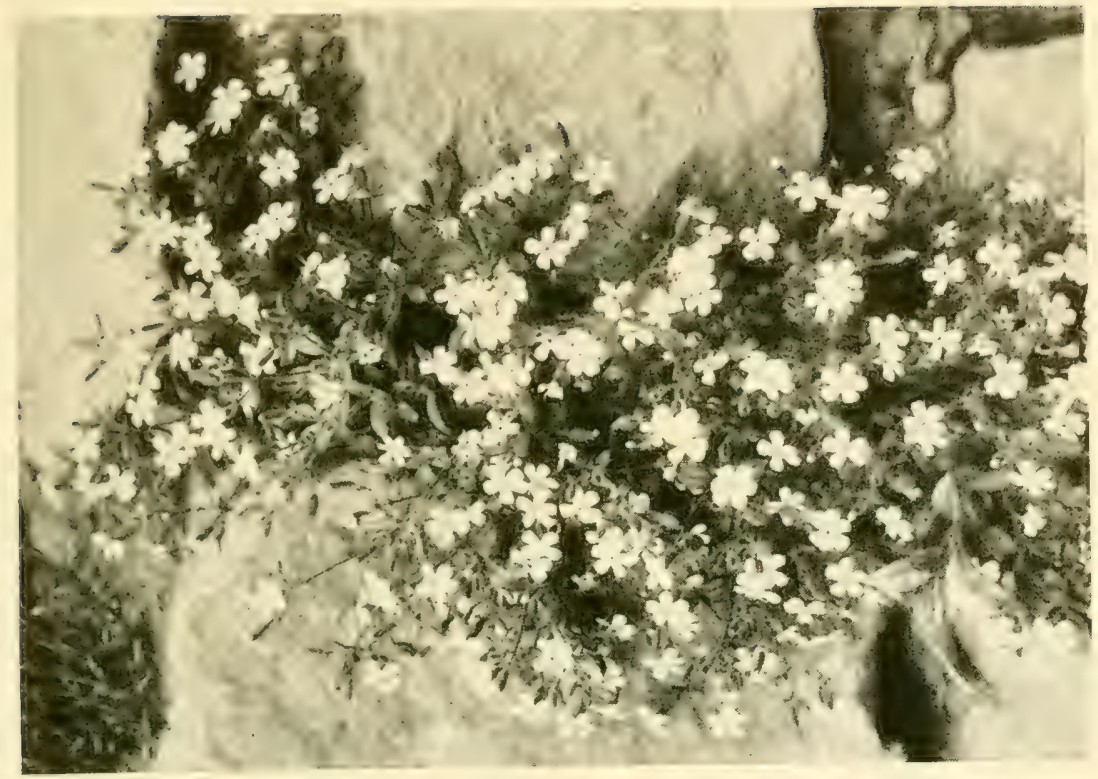

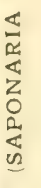
k $\frac{8}{2}$ प्र zo 잔

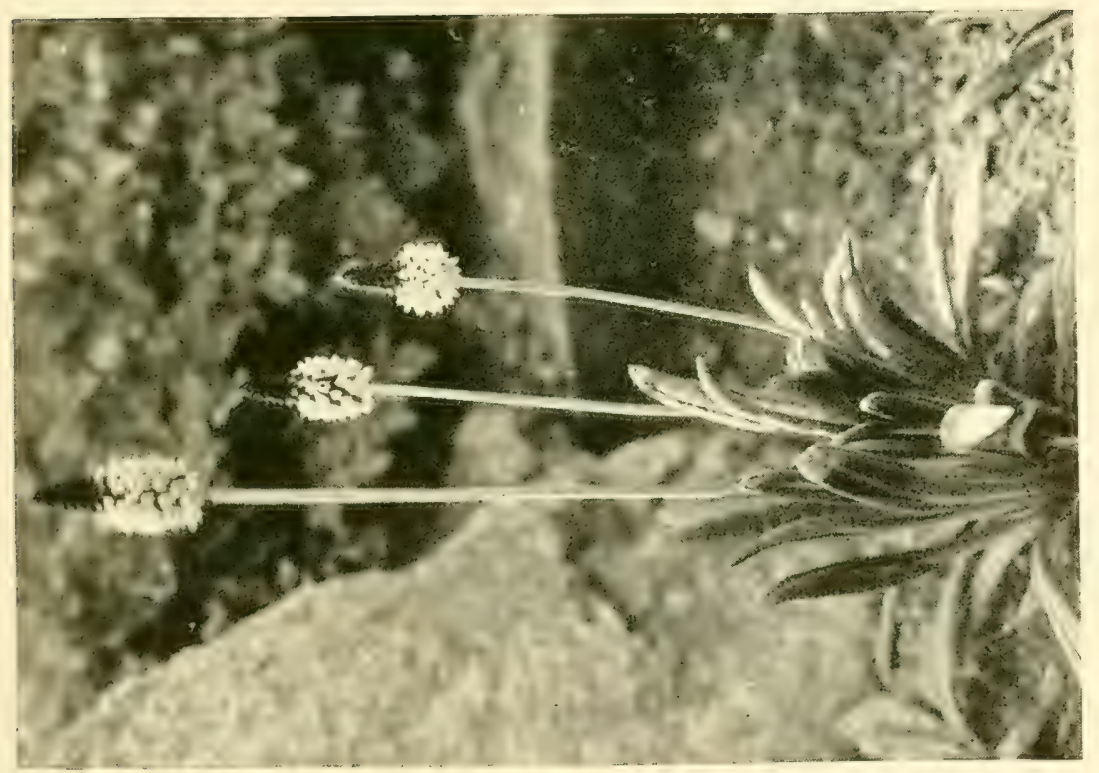





\section{LONICERA}

Lonicera (Honeysuckle).-This group (Natural Order Caprifoliaceae) includes the climbing and bushy shrubs which are known popularly as Honeysuckles. They are found in Europe, Asia, and North America, and two species are included in the British Flora. As a rule, the bushy kinds produce their flowers in pairs from the leaf axils of young shoots from the previous year's growth, whereas the blossoms of the climbing sorts are in fairly large bunches in the upper leaf axils or from the points of similar growths. The bushy kinds are suitable for planting in shrubberies or for forming specimen bushes, while those of climbing habit can be used on pergolas, fences, walls, or other supports. The last-named, with a few exceptions, such as sempervirens and etrusca, which are rather tender, are better adapted for northerly gardens than for those in the south, for in gardens in the warmer counties they often become covered with greenfly: Bush Honeysuckles are, as a rule, seen to the best advantage when planted in sunny positions where the shoots become thoroughly ripened. Pruning should take the form of thinning the branches after the flowers have fallen. Loamy soil is the most satisfactory, and increase is by seeds and cuttings.

The chief kinds are: Caprifolium, a climbing kind with showy, fragrant, yellowish flowers; etrusca is a very vigorous climbing plant from Southern Europe, it flowers with great freedom, the ends of the branches for a length of 3 feet being often covered with yellowish flowers : the var. superba is an improvement on the type, and may be grown out-of-doors in the southern counties and in a cold, sunny greenhouse elsewhere. Fragrantissima and Standishii are two Chinese bush kinds that bear white and cream-coloured flowers respectively during January and February; Heckrotti is a climber which bears red flowers freely; involucrata, one of the best of the bush kinds, is from North-West America, its golden tubular flowers are enclosed by dark reddish bracts which remain until the black fruits are ripe; japonica is a free-flowering Chinese and Japanese climber bearing yellow fragrant flowers; flexuosa and Halliana are good forms, whilst aureo-reticulata has golden variegated leaves; Maackii is a freeflowering bush kind from China.

Lonicera Periclymenum, the Common Woodbine or Honeysuckle, is one of the best climbers; the vars. belgica and serotina are often grown. Two other useful plants are: sempervirens, a climber, and tatarica, a bush.

Loranthus is a parasitic plant closely allied to the Mistletoe, belonging to the Natural Order Loranthaceae. Loranthus europaeus is a native of Southern Europe and the Orient ; it grows upon the Olive 
and various other plants, and may be introduced to gardens in the south-west counties.

Loropetalum Chinense is a semi-tender Chinese shrub belonging to the Witch Hazel family (Hamamelidaceae). It may be grown out-of-doors in the warmer counties, but must have the shelter of a greenhouse elsewhere. Nature specimens may be from 3 to 5 feet high. The flowers are white, with narrow thread-like petals, reminding one of those of the Witch Hazels, and are borne in winter or early spring. It should be planted in warm, well-drained loamy soil containing a little peat or leaf-mould, and in the southwest may either have a place in the open or against a wall. Cuttings may be rooted during summer, and regular pruning is unnecessary.

Lotus (Bird's foot Trefoil). - The only hardy kind worth growing is Lotus corniculatus flore pleno, a double variety of the wild Bird'sfoot Trefoil; it belongs to the Pea family (Leguminosae). The

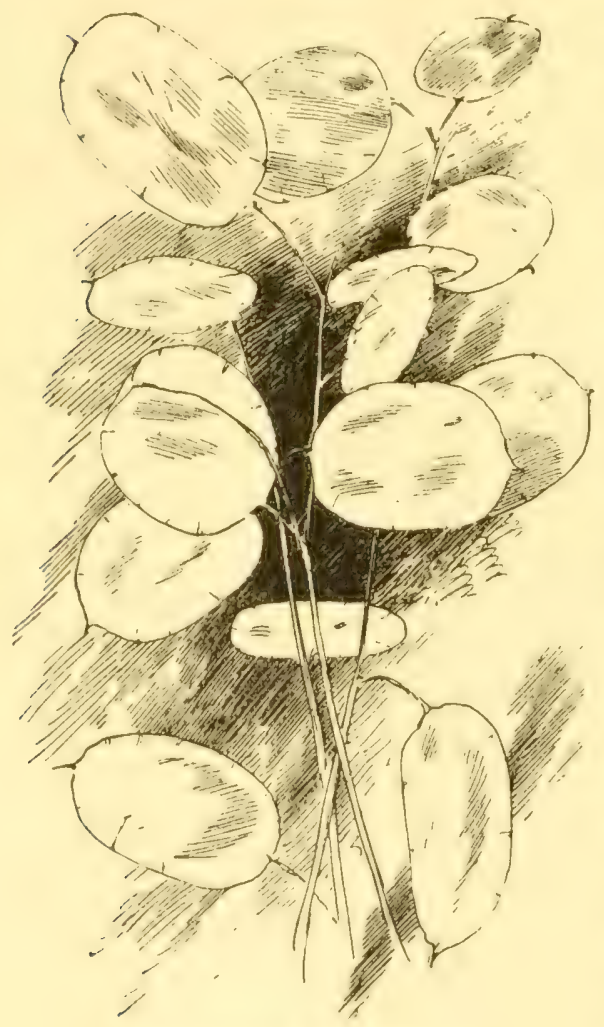

SEED PODS OF HONESTY

(Lunaria biennis) flowers, opening in summer and autumn, are yellow striped with red, and are effective in a sunny rock garden or old wall. A second kind from the Canary Islands, Lotus peliorhynchus, is really a greenhouse plant, but is grown outof-doors in warm gardens; it has long trailing growths, greyish stems and foliage, and crimson-scarlet Pea-like flowers in summer; on account of its grey leaves and stems it is sometimes used as a carpeting plant in summer bedding. Increase is by seeds sown in a greenhouse in summer.

Lunaria (Honesty).-Lunaria annua or biennis, member of the Wallflower family (Cruciferae), is a favourite plant in old-fashioned gardens ; it is biennial, and thrives in almost any soil and position, even in shade. It is a native of Northern Europe. Sow the 


\section{LUPINUS}

seeds outside during April and May on a border, and transplant in autumn where the plants are to flower. Self-sown seedlings usually come up freely every year. The plants grow about 2 feet in height, and have lilac-purple flowers in early summer, followed in autumn by silvery seed pods which are much valued for winter decoration when cut and dried; there is a beautiful white variaty. Lunaria rediviva, a perennial, native of Europe, has fragrant purple flowers in May and June, smaller than those of the common kind.

Lupinus (Lupin).- The Lupins, which belong to the Pea family (Leguminosae), comprise hardy annuals, herbaceous perennials, and shrubs. All thrive in ordinary garden soil, and prefer a sunny position. They are equally valuable for large and small gardens, being showy and easy to grow.

The Annual Lupins are suitable for groups in borders and for beds; they vary from 12 inches to 3 feet in height, and flower from late June or early July until the end of September. Seeds are sown in a heated greenhouse or cold frame during March, and out-of-doors in April, where the plants are to flower. The Mexican Lupin (Hartwegii) grows about 2 feet high and has blue and white flowers; the vars. alba and azurea, azure-blue, are distinct and attractive. Lupinus subcarnosus, from Texas, I2 inches high, has violet-blue flowers with white centre; mutabilis, 3 to 4 feet high, has blue and white or pink and cream flowers, its native home is New Grenada; densiflorus (Menziesii) is a lovely yellow Lupin, I8 inches high, from California; from the same country comes nanus, I2 inches high, having dainty lilac and blue flowers. Then we have a few garden Lupins, for instance : hybridus atrococcineus, scarlet and white, $2 \frac{1}{2}$ feet; Dwarf Blue and White, I foot; Dwarf Yellow, fragrant, I foot; Dwarf Carmine and White, I foot; Dwarf Pink, I foot; and Tall Dark Blue, 3 feet.

The Perennial Lupins are invaluable hardy border flowers. They are of easy cultivation in ordinary soils. In addition to the old blue kind, Lupinus polyphyllus, from California, and its white variety, many sorts have been raised in gardens during recent years. A few of the best of these are: Moerheimi, pink ; Blue Cloud, lavender-blue ; Butterfly, purple and white; Dusky Prince, dark violet-purple; Excelsior, mauve; Rosy Gem, rose; and Taplow Purple, purple: The plants grow from 3 to 5 fect high, according to the quality of the ground, and bloom in May and June; or, if seedlings are also grown, one can have Lupin flowers until frosts spoil their beauty. September or early October is the best time to plant or to replant. Seeds sown in a heated greenhouse during February will produce plants to bloom in late summer and autumn, or they may be sown 
out-of-doors from April to June to obtain flowering plants a year later. A great variety of shades of colour can be raised from a packet of mixed seeds. Lupinus nootkatensis is a North American Lupin, 2 feet high, bearing purple, white, and yellow blooms in early summer.

The North American Tree Lupin (Lupinus arboreus) forms a large shrubby bush, 3 to 5 feet or more in height and as much in diameter. In exposed positions the young shoots are cut during frosty weather, but, as a rule, this natural pruning only seems to make the plants flower more freely the following summer. In fact, to secure good, shapely bushes it is desirable to prune if the long, straggly growths escape harm from frosts. Increase is by cuttings inserted in sandy soil in a cold frame during late summer, and by seeds sown in a frame when ripe or in spring. The typical kind has pale yellow flowers; varieties are Snow Queen, pure white; Somerset, yellow; Golden Spire, deeper yellow; Milkmaid, primrose-yellow and white; and Dorothy, blue and white. These beautiful Tree Lupins flower throughout the summer, and are fragrant. In exposed gardens, where these plants sometimes suffer in winter, they should be planted at the foot of a sunny south wall ; in fact, they need a sunny position and welldrained soil in all gardens.

Lychnis (Campion).-In this group, which belongs to the Pink family (Caryophyllaceae), there are several useful annuals and numerous beautiful perennials with richly coloured flowers. They thrive in ordinary garden soil which has been well dug and manured. Propagation of the perennials is by division of the roots in autumn or spring, by seeds (of the single-flowered kinds) sown on a border outof-doors from April to June, and by cuttings made of young growths in spring and inserted in light, sandy soil in a frame. Lychnis alpina, 4 to 6 inches, purple-red, April to June, native of Europe, is a pretty little plant for a sunny spot in the rock garden; Haageana, from Japan, is one of the most showy Campions on light, well-drained soil ; there are scarlet, white, rose, and pink sorts that flower during July and August, the plants are about 12 inches high, and are suitable for the rock garden or the front of a sunny border. Lagascae, a Spanish kind, is a charming alpine, 4 inches in height, with dainty, rose-coloured, white-centred flowers from May to July; rosea, deep pink, and alba, white, are desirable varieties; pyrenaica, from the Pyrences, is a lowgrowing, glaucous-leaved plant bearing white flowers, May to July, suitable for the rock garden. The European Lychnis Viscaria grows about $\mathrm{I} 2$ inches high, and bears rosy-red flowers during June and July ; better than this for the rockery and front of the border are the varieties 
alba grandiflora, white, splendens, rich red, and splendens plena, a most valuable plant with double, rosy-red flowers.

The best perennial species for the flower border are : chalcedonica, the Jerusalem Cross, a slender-growing kind, 3 to 4 feet high, with showy scarlet flowers during July and August-an invaluable plant. The Crowned Campion from Southern Europe, coronaria (Agrostemma coronaria) will thrive in sun or partial shade, even among hardy ferns in the shady border; it has grey leaves and stems, grows 2 to 3 feet high, and bears rosy-crimson flowers in summer ; alba, white; atrosanguinea, rich crimson-purple; oculata, white, rose centre; and Walkeri, blood crimson, are distinct varieties. From a packet of mixed seeds a number of colours can be raised. Two varieties of our native Ragged Robin (Flos-cuculi) are grown in gardens; alba plena, double white; and rubra plena, double rose ; these are I 8 inches high, flower freely from June to September, thriving particularly in moist soil and the bog garden. Lychnis Flos-jovis, the Rose Campion, IS to 24 inches in height, has bright pink flowers in summer. One of the most beautiful Campions is Lychnis vespertina alba plena; it is a double white-flowered variety of our native Evening Campion, 2 to 3 feet high, with fragrant flowers, from June to September.

The annual Campion, Lychnis Coeli-rosa (syn. Agrostemma Coelirosa), the Rose of Heaven, is native of the Levant ; it grows $I 8$ inches high, and bears rosy-purple flowers during summer. There are several varieties of distinct colours which come true from seeds, or seeds may be purchased in mixture. Dwarf Carmine, 6 inches high, is valuable as an edging; the seeds are sown outside during April on a sunny border, where the plants are to flower.

Lycium Chinense is the well-known Box Thorn or Tea Tree, a strong-growing Chinese shrub with trailing branches, belonging to the Potato family (Solanaceac). It is often planted where a quick and dense-growing plant is required to mask unsightly objects. Its attractions centre in the small purple flowers, each about $\frac{1}{2}$ inch across, and in the bright red fruits which are very showy in autumn. Lycium pallidum, from New Mexico and Arizona, is not so well known ; it is a loose-growing bush 4 feet high, with glaucous leaves, greenish flowers, and orange-coloured fruits. Plant in ordinary garden soil, give a sunny position, increase by means of seeds in spring, and thin out the shoots of the former kind occasionally.

Lycopodium (Club Moss).-There are seven native British Club Mosses (Natural Order Lycopodiaceae); they are more interesting than beautiful, and appeal to the botanist rather than to gardeners. They revel in a moist, peaty soil in the bog garden, or in low parts 
of the rockery. The plants are increased by division, spring being the best time; they are flowerless evergreen plants, allied to ferns, and produce spores instead of seeds. The species are: clavatum, a fairly common plant in the North of England, Scotland, and Wales; annotinum, fairly common in Scotland, and found in one or two places in England and on Snowdon; complanatum, found in Gloucestershire and Worcestershire; alpinum, common in Scotland and North of England; inundatum, selaginoides, and selago, the Fir Club Moss.

Lycoris.-Bulbous plants (Natural Order Amaryllidaceae), suitable for planting on a well-drained, sunny border in sandy loam, peat, and leaf-mould. Plant the bulbs 3 to 4 inches deep in September or October and 6 inches apart. They grow 12 to 24 inches in height. The best species are: aurea, golden-yellow, August and September, China; radiata, a Chinese species with pinkish-red flowers in June and July; squamigera, a Japanese plant, with fragrant, rosy blossoms in July and August.

Lyonia ligustrina is a North American bush, from 2 to 3 fcet high, belonging to the Heather family (Ericaceae). It is of rather dense growth, and produces racemes of white flowers freely during late spring and early summer. Conditions similar to those required by Rhododendron are necessary. Increase is by seeds or cuttings in summer, and pruning is limited to the occasional thinning out of the older branches.

Lysimachia (Loosestrife, Crecping Jenny).--Several very useful hardy perennials are found in this group, which belongs to the Primula family (Primulaceae). The plants thrive in ordinary garden soil, including that of a rather wet, boggy nature. Increase is by division from October to March, while seeds may be sown in a cold frame, or outside from April to June. A sunny or partially shaded spot is suitable. Lyismachia clethroides, a Japanese plant, 2 to 3 feet high, has spikes of white flowers in July and August and prettily tinted foliage in autumn; Ephemerum, from Southern Europe, grows 3 feet high, has grey leaves and erect spikes of white flowers in July and August, it is a useful water-side plant; Henryi is a new Chinese species of low growth with large yellow flowers in summer, and is suitable for the rock garden; longifolia, from North America, reaches a height of 2 feet, and bears showy yellow blooms in July and August. Lysimachia Nummularia (Creeping Jenny, Moneywort), the best-known kind, is a native trailing plant that will grow anywhere, and its yellow blooms in summer are familiar; it spreads very rapidly; the golden-leaved var. aurea is very handsome, and much used as a carpet for summer bedding; punctata (syn. verticillata), a European kind, 
3 feet high, has spikes of yellow flowers in July and August; it is useful for the water-side.

Lythrum (Purple Loosesirife).-The Loosestrifes (Natural Order Lythraceae) are good-natured plants, thriving in sun or partial shade and in ordinary soil. While attractive in the mixed flower border, they are particularly suited for cultivation by the water-side, the north border, and wild garden. Increase is by division of the clumps from October to March, by cuttings inserted in pots of sandy soil in a frame in April, and by seeds sown in a heated greenhouse during February to flower the same year, or outside from April to June to blossom the following year. The Common Purple Loosestrife (Salicaria) is a British wild plant, and the plants cultivated in gardens are varieties of this. Three good ones are : rosea, rich rose; superba, deep rose ; and Brightness, rose-pink, which grow 3 to 4 feet in height and flower freely from July to September. Also flowering during the same period is Lythrum virgatum Rose Queen, $3 \frac{1}{2}$ feet high, having long graceful spikes of bright rose-coloured flowers; alatum, 2 feet high, bears crimson-purple flowers from June to September.

Maclura aurantiaca, the Osage Orange of the Southern United States, is a tall deciduous tree armed with ferocious spines. It belongs to the Natural Order Urticaceae, and is allied to the Mulberry. Neither flowers nor leaves are of special interest, but the round, orange-like fruits are ornamental. The leaves are sometimes used in America as food for silkworms, whilst the spiny branches, and the fact that the plant withstands severe pruning well, make it a good hedge plant, and as such it might be used in this country. It grows well in ordinary garden soil, and may be pruned during winter. Male and female flowers are produced on different trees.

\section{Macrotomia.-(See ARNEBIA.)}

Magnolia (Lily Trec).-This group (Natural Order Magnoliaceae) is a very important one to gardeners, for it includes a large number of ornamental trees and shrubs, many of which are hardy in numerous parts of the United Kingdom. Others are only suitable for the milder counties or for planting against walls, but the majority which have been introduced may be grown in one part or another of the British Isles. The head-quarters of the Magnolia is in China, but some occur in the Himalaya, Japan, and the United States. The various kinds thrive in warm, well-drained loamy soil, but appreciate a little peat or leaf-mould, especially in the soil placed immediately about the roots at planting time. It is advisable to put the largergrowing sorts in permanent positions carly in life, for they are rather difficult to transplant after they have attained a moderate size. Plant- 
ing should be conducted cither early in autumn (say in September), or during April or carly May. Propagation is effected by seeds, grafts, or by layering branches. Pruning should be directed toward shaping the bushes, but the plants need not be pruned very severely. Summer is the best time for the work.

A selection of the best kinds is as follows: Magnolia acuminata is a tall tree with large handsome leaves, native of the United States, where it is called the Cucumber Tree or Mountain Magnolia; its greenish-white flowers are not very showy. Campbellii, a native of the Eastern Himalaya, is one of the showiest of all, but, unfortunately, it can only be grown in the mildest districts; forming a large tree in its native country, it grows between 20 and 30 feet high here. the flowers often exceed 9 inches across, and are rich red without and white flushed deeply with rose within. Delavayi is a new evergreen species from Yunnan, bearing very large leaves and cream-coloured flowers; it must be planted against a wall in the southern counties.

Magnolia conspicua, the Yulan of China and Japan, is one of our earliest flowering trees, and it is often at its best during late March and early April ; the white, cup-shaped, fragrant flowers cover every part of the leafless branches. There are numerous trees between 15 and 40 feet high in the neighbourhood of London. It is sometimes grown against walls. Crossed with obovata, a bushy, purple-flowered Magnolia from China, a number of very beautiful hybrids have been produced; these bloom profusely, the fragrant flowers usually being white, more or less decply stained with purple. Good ones are: Alexandra, Norberti, and Soulangeana. Fraseri is a deciduous summer-flowering species from the Southern United States; its flowers are 6 to 8 inches across and buff-coloured. Glauca, the Swamp Bay or Laurel Magnolia, from North America, may be either evergreen or deciduous; it forms a large bush with white flowers.

Magnolia grandiflora, the Bull Bay of the Southern United States, is often grown as a wall plant in this country, although in the south and west it forms a handsome bush or small tree in the open ground. Its large evergreen leaves are very attractive, but during summer attention is diverted to the handsome white blossoms which are often 9 inches across; of the several varieties, that known as gloriosa is probably the best. Hypoleuca is a comparatively new Japanese species, with large deciduous leaves and white flowers. Lennei is a hybrid, it is said, between conspicua and obovata, but from the shape and colouring of its flowers the first-named and Campbellii appear to be the most likely parents; it blooms in May, the flowers being crimson on the outside with very large shapely petals: 


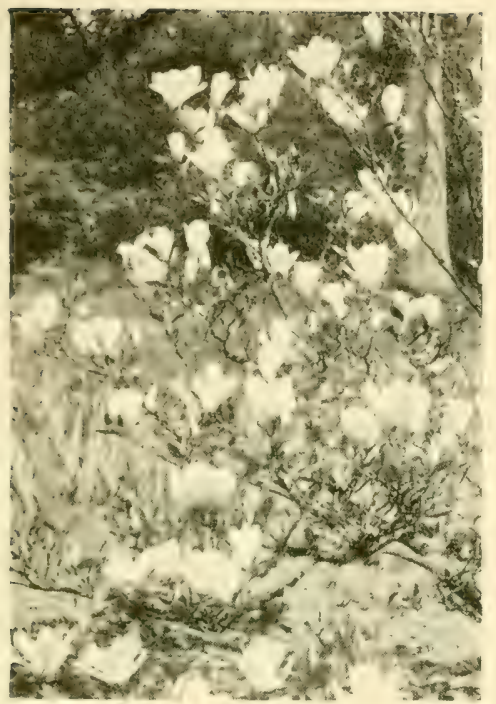

A LILY TREE (MAGNOLIA SOULANGEANA)

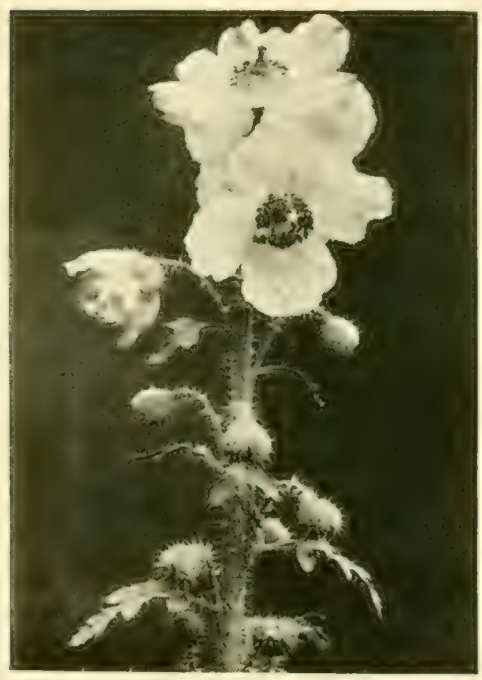

Photo: II. H. Waitc

HIMALAYAN POPPY (MECONOPSIS ACULEATA)

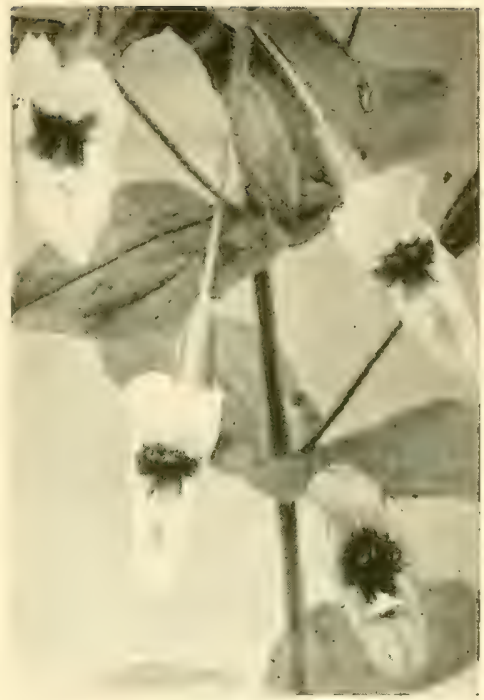

THE MONKEY MUSK (MIMULUS CARDINALIS)

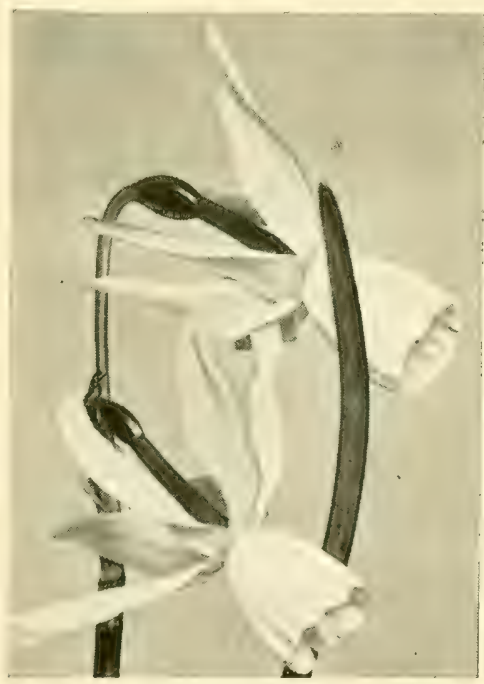

NARCISSUS JOHNSTONI QUEEN OF SPAIN 

Magnolia macrophylla is only available for the southern counties, but it is a magnificent plant both by reason of its handsome foliage and large buff-coloured flowers; it forms a small tree, and is native of the Southern United States. Parviflora, from Japan, is a deciduous bush with white shapely flowers enclosing a mass of crimson stamens; the flowers appear in May and June. Watsoni, from the same country, is a somewhat similar shrub, though larger in all its parts.

Magnolia stellata is a handsome Japanese bush 4 to I 2 feet high, with a similar diameter; its glistening white star-like blooms are borne with exceptional freedom in April (var. rosea has rose-tinted blooms). Salicifolia, a new Japanese bush or small tree, bears pretty white flowers 3 to 4 inches across in May. Tripetala, the Umbrella Tree of the United States, is distinguished by large foliage, white flowers, and red fruits

Mahonia.-(See BERBERIS.)

Maianthemum (Two-leaved Lily of the Valley).--The only kind available for our gardens is Maianthemum Convallaria, a native of the north temperate regions; it is of herbaceous habit, and belongs to the Lily family (Liliaceae). The plant is generally hardy in the British Isles, and should be planted in shady or semi-shady places in soil rich in humus, such as is found in an Oak or Beech wood, and it is a good plant for naturalising in wild gardens, its requirements being very similar to those of the Lily of the Valley. It spreads by means of underground stems, and may be easily propagated by digging up and dividing the roots or rhizomes any time between the fall of the leaves in autumn and the beginning of growth in spring. In height it rarely exceeds 9 inches, and the white flowers appear in May. In some parts of the British Isles it is found wild.

Maidenhair Tree.-(See GINKGo.)

Maize.-(See ZEA MAYS.)

Malcolmia (Virginian Stock).-The plants found in this group of the Wallflower family (Cruciferae) are mostly of annual duration, the best known being the common Virginian Stock (Malcolmia maritima), from the Mediterranean region. There are, however, other species, some confined to Greece and others being more widely distributed in Southern Europe. They thrive in any good garden soil, and are excellent for groups along the front of the herbaceous border, or for large masses upon ground which it is wished to clothe quickly. Seeds are sown out-of-doors where the plants are to bloom; those sown in March or early April will bloom during June and July, whereas those sown late in May or in early June will bloom in August and September. It is wise to thin the seedlings to a distance of 3 inches 


\section{THE BOOK OF HARDY FLOWERS}

apart. Malcolmia maritima grows from 6 to 9 inches high and bears white, lilac, rose or red flowers. Good varieties are: alba, white; and Crimson King, crimson. Mixed kinds are, however, very efiective. Other useful sorts are: bicolor, 6 inches, pink and yellow, Greece; Chia, 6 to I2 inches, purple or lilac, Greece; and littorea, 6 to 12 inches, purple or reddish-purple, Southern Europe. The flowers of the various kinds are fragrant, especially in the evening.

Mallow.-(See Malva.)

Malope.-The Malopes, which belong to the Mallow family (Malraceae), contain one species of considerable decorative value, namely Malope trifida, an annual, native of Spain and North Africa. It grows to a height of 2 feet, and branches freely, each shoot bearing a number of large crimson flowers, upwards of 2 inches across, which resemble those of a single Hollyhock. There are several varieties, that known as grandiflora being really a glorified form of the typical kind, whilst grandiflora alba has white flowers and rosea, rosy-pink blossoms. Malopes are among the most beautiful of hardy annuals, and are of the easiest possible cultivation providing they are given deeply-dug, loamy soil, enriched with manure. It is wise to sow the seeds, where the plants are to flower, during the latter part of March or early in April. Sow thinly and cover the seeds with about one-third of an inch of soil. As soon as the seedlings are large enough to handle, thin them to at least Io inches apart. They mature seeds freely which may be kept from year to year if they are stored in a drawer in a cool room.

Malva (Mallow).-Numerous hardy herbaceous plants of annual, biennial, or perennial duration are found among Malva (Natural Order Malvaceae). Several are natives of the British Isles, two common oncs being moschata, the Musk Mallow, and sylvestris, the Marsh Nallow. Although several of them bear showy flowers in profusion, they cannot be considered to be amongst the most attractive herbaccous plants, and are certainly of less decorative merit than Malope trifida and the Hollyhock. But they have advantages, for they thrive in poor soil, and the British kinds are effective amongst wild plants. The kinds usually found in gardens are Alcea, a European perennial growing 4 fect or more high, with pink or reddish flowers, commonly called the Vervain Mallow; crispa, an annual, native of Europe, 2 to 4 feet high, flowers white; moschata (Musk Mallow), perennial, 2 to 3 feet, rose; the variety alba has white flowers. They are easily grown from seeds, which may be sown as soon as they are ripe, or they may be kept in a cool room and sown in March. In either case they can be sown in an open border. 
Malvastrum (False Mallow).-Most of the species of this group of the Mallow family (Malvaceae) are natives of the New World, being found in Western North America, Parana, Uruguay, and Chili, though one or two kinds are widely distributed through the warmer regions of the world. They are not very hardy, but a few kinds can be grown in the herbaceous border and rock garden in the South of England. They thrive in warm, loamy soil, and are increased by seeds sown under glass in February. Their decorative merits are not pronounced. Malvastrum coccineum, 6 inches, scarlet, NorthWest America; Gilliesii, 6 inches, red, Parana ; lateritium, 6 inches, red, Uruguay; and campanulatum, I to $I \frac{1}{2}$ feet, purplish-rose, Chili, are amongst the best. All bloom during summer.

Mammillaria.-Mammillaria belongs to the Cactus family (Cactaceae), and consists of a large number of quaint-looking leafless plants, which are thickly armed with spines. They are found largely in the arid regions of Mexico, Arizona, and Texas, and are usually dwarf and compact in habit. Some kinds do not grow more than I inch or 2 inches high, whilst others may attain a height of 6,9 , or 12 inches. The stems are usually round and divided into numerous regular-sized, cushion-like excrescences from which the small tufts of spines, which in some species are short and in others of considerable length, are produced. The flowers in most cases are very attractive, being red, rose, yellow, or white in colour, whilst they are followed by pretty red fruits. They require a sunny greenhouse to bring them to perfection, but fairly good results can be obtained by growing them in a sunny window, and the strongergrowing kinds can be plunged in beds out-of-doors for the summer months. Cultivation is simple, for they thrive in well-drained pots in a compost of 2 parts good loam to I part of broken lime rubble, and coarse sand with a little leaf-mould. They can be left in the same pots for several years. During winter practically no water should be given. Of the large number of species available, the following is a selection: barbata, a dwarf plant with rose flowers and white spines; bicolor, dwarf, purple, covered with small spines; dasyacantha, 3 inches, red; elongata, 3 to 4 inches, yellow; formosa, red; Missouriensis, dwarf, yellow or red, Southern United States-this is one of the hardiest kinds, and can be grown out-of-doors in a few places in the British Isles.

Mandragora (Mandrake),-Herbaceous plants of perennial duration, which belong to the Potato family (Solanaceae). They are peculiar on account of their thick, fleshy rootstocks which frequently bear a resemblance to the human form. Probably on this account, together 
with their medicinal properties, many weird legends are attached to the plants. In some countries people would not upon any account pull the plants from the ground, for such work could not be done without some breakage of roots, which was said to cause the plants such pain that they screamed, and bad luck was sure to dog the footsteps of any person who injured them. As the roots were required, however, the collectors dug round the plants to loosen them, and then tied an animal to each plant, causing it to pull the plant from the ground. They are not of any great value for decorative purposes, but are sometimes planted in semi-shade, where the soil is moderately deep. Propagation is by division of the crowns in spring or by seeds sown out-of-doors, or in a frame during February or March. Mandragora autumnalis grows about I foot high and bears purplish flowers in early autumn, and officinarum (the Medicinal Mandrake) bears white or blue flowers in May. Both are found in the region bordering the Mediterranean.

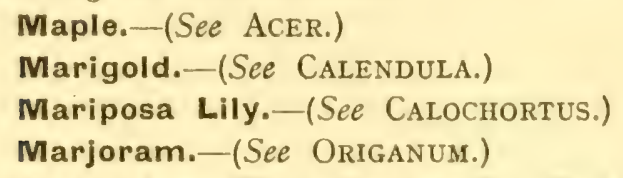

Marrubium (White Horehound).-Herbaceous perennials, remarkable for their somewhat pungent odour and bitter taste. They belong to the Sage family (Labiatae), and few of them have any decorative value. One species, however, the Common Horehound (Marrubium vulgare), a native of Europe (including the British Isles) and North Asia, is usually grown amongst collections of medicinal plants and herbs, for at one time it possessed a considerable reputation as a simple domestic medicine by reason of its tonic properties. Except in some country places, however, it appears to have fallen largely into disuse. Plant in ordinary garden soil, increase by division in February or March, or by cuttings dibbled in sandy soil in a frame, when the shoots are 2 or 3 inches long, in April.

Marsdenia erecta.-This is a climbing shrub (Natural Order Asclepiadaceae) from Eastern Europe and Asia Minor, suitable for planting in the milder counties. Its slender stems are clothed with broadly ovate or heart-shaped leaves, and the small white flowers are produced from the upper leaf axils and the points of the current year's shoots towards July or August. Plant in ordinary garden soil against a wall for preference. Cuttings can be rooted during summer if inserted in sandy soil in a close frame. Pruning should take the form of cutting the previous year's shoots well back in February once the plant has covered the available space. 

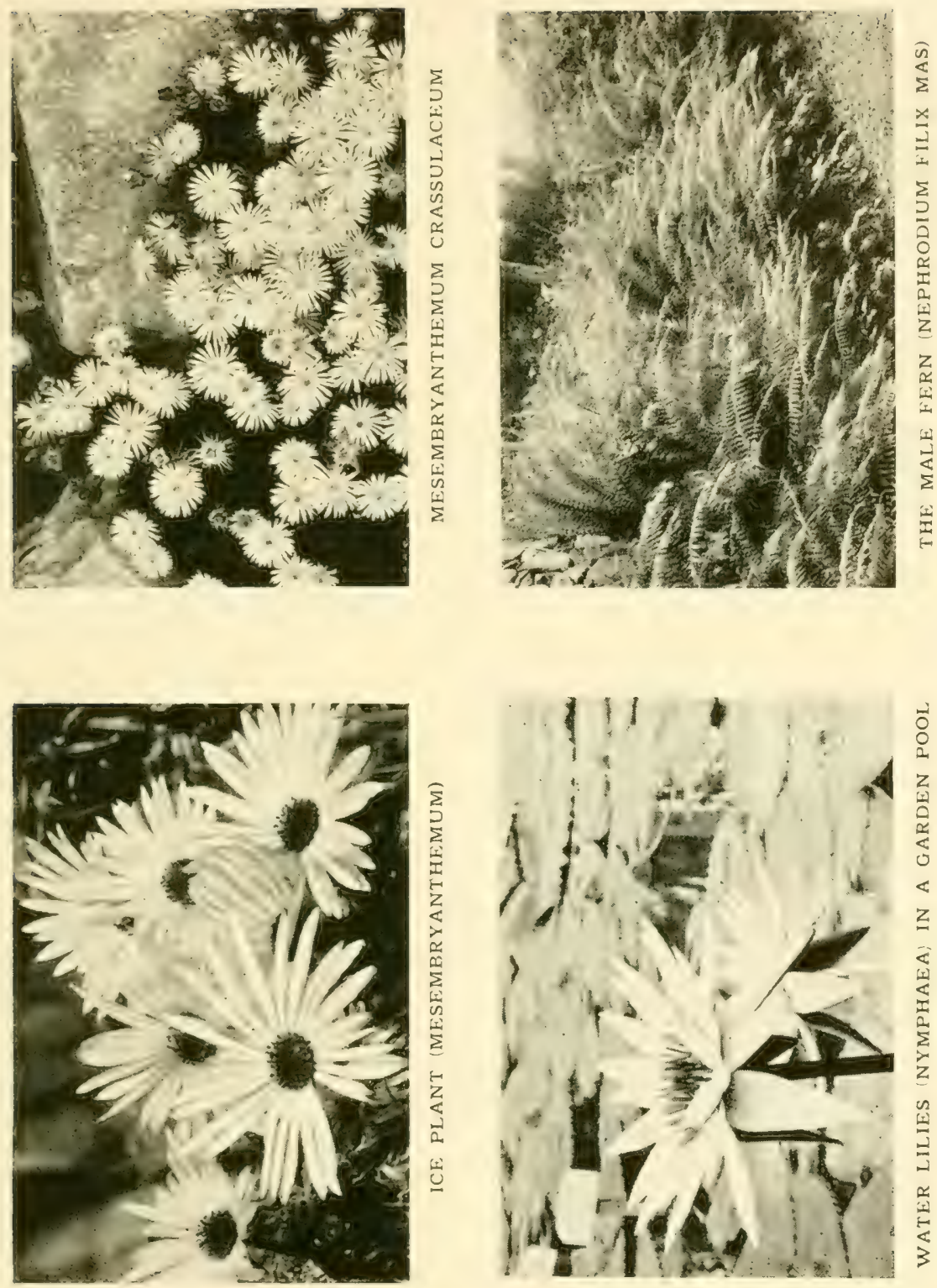



\section{Caltha.) \\ Marvel of Peru.-(See Mirabilis.)}

Marsh Marigold.-(See

Matricaria (Mayweed).Annual and perennial herbs, often of a weedy character, are found in this genus of the Daisy family (Compositae). Some of them are rather pretty when in flower, and they thrive in poor soil. Matricaria inodora, a white-flowered native plant, grows on waste ground in most parts of the country, and is sometimes a troublesome weed on cultivated land; Tchihatcheffii, a dwarf, white-flowered species from Turkish Armenia, is one of the best kinds for the garden, and is sometimes planted in the rock garden; it is increased by seeds sown in spring or by division in February or March. Matricaria Chamomilla, a widely distributed European plant, is known as the Wild Chamomile; its flowers have tonic properties similar to the true Chamomile (Anthemis nobilis), for which they are sometimes substituted.

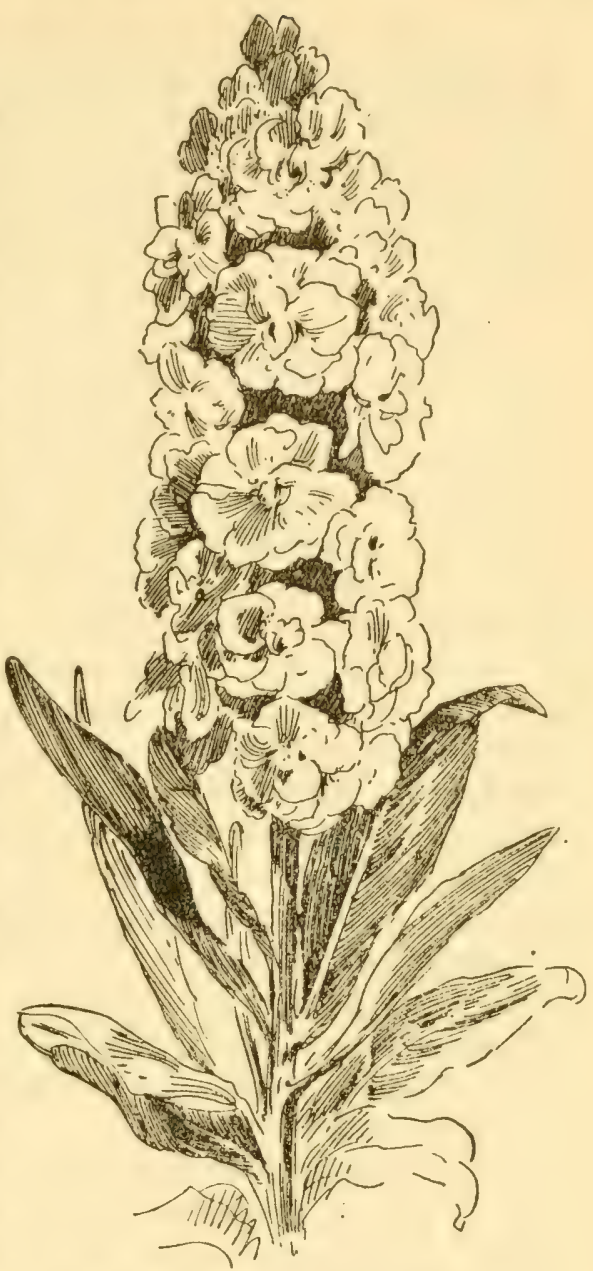

THE TEN.WEEK STOCK (Matthiola)

Matthiola (Stock).-A number of very useful and ornamental annual, biennial, and perennial border plants are included in this group of the Wallflower family (Cruciferae). They are well known under the name of Stock, and various species have produced such kinds as Ten-Week, East Lothian, Brompton, Night-scented, etc. Matthiola incana (sometimes called annua), a native of Southern Europe, etc., is perhaps the most important species, for it is the parent of most of the garden Stocks. It may be either of annual or biennial duration, whilst occasionally, in the case of the Brompton Stock, plants may live for two or three years; for this reason incana and 
anmua were at one time kept separate, the former being credited with the production of the Brompton and the latter with the Ten-Week kinds. Now, however, all are grouped under incana, a plant which is sometimes found wild near the coast in the South of England. The typical kind grows I foot to 2 feet high, and bears purplish flowers, but the cultivated forms vary greatly not only in growth, but in the colour and form of the flowers.

Seeds of the Ten-Week Stock should be sown under glass in March. When large enough to handle prick out the seedlings 2 or 3 inches apart in a compost of 3 parts loam, I part leaf-mould, and I part well-rotted manure, in boxes, or a bed in a frame. About the middle of May plant them permanently in good soil. The chief consideration should be to keep them growing without a check from the seedling to the flowering stage. Many varieties are offered by seedsmen, good ones being: Canary-Yellow, Crimson, Purple, White, Rose; all are double. Packets of mixed colours, however, usually give quite good results. A large-growing strain of Ten-Week Stock is known as Giant Perfection, and a dwarf strain as Dwarf German. Both can be procured in all the colours mentioned above. A class of Stocks which may be grown either as Ten-Week or winter-flowering for pots under glass is known as New Admiration; white, rosylilac, flesh and crimson-coloured kinds can be obtained.

The Brompton Stock is a biennial, though it sometimes lives to bloom a second or even a third time. Seeds should be sown in June or July of one year, out-of-doors, to produce flowering plants the following year. Double-flowered kinds with purple, scarlet, white, or rose-coloured flowers can be procured.

The Intermediate or East Lothian Stock is a biennial. Seeds are sown in summer to obtain plants that will bloom the following year. In the warmer parts of the country the plants may be left out all winter, but in colder places they should be kept in a frame until spring. These kinds are useful for flowering in the greenhouse. Varieties with double crimson, scarlet, purple, and white flowers can be procured. Crystal White is a very attractive white-flowered variety, whilst a good group is known as May Queen; it can be obtained in scarlet, purple, or white. Wallflower-leaved Stocks are simply Ten-Week varieties, with leaves resembling those of the Wallflower. As a rule it is not advisable for the amateur to save his own seed. By sowing seeds of Intermediate Stocks under glass in February and growing them without a check, they can often be got to flower out-of-doors in August and September.

Matthiola tristis, the Night-flowering Stock, is a native of Southern 
Europe, forming a sub-shrub with red or purplish flowers. It is not very hardy, and should be given a sheltered position. Matthiola bicornis, the Night-scented Stock, is a free-flowering annual, about x2 inches high, with lilac blooms that are very fragrant in the evening. Seeds are sown in March or April where the plants are to bloom:

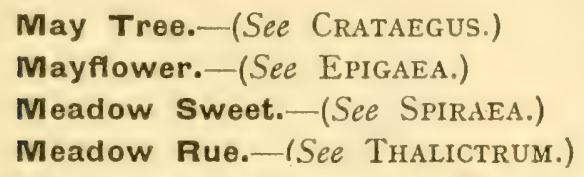

May Tree.-(See Crataegus.)

Mayflower.-(See EPIGaEA.)

Meadow Sweet.-(See SpIRAEA.)

Meadow Rue.-(See Thalictrum.)

Meconopsis (Poppywort).-Biennial and perennial herbaceous plants belonging to the Poppy family (Papaveraceae) : they are represented in the British Flora by the Welsh Poppy (Meconopsis cambrica), a perennial plant 9 to $I 2$ inches high, which bears yellow flowers freely during late spring and early summer. It is useful for naturalising on stony ground, for planting on walls, or for the rock garden. Seeds are sown in spring from which plants may be pricked out in beds in June and be planted permanently in autumn. Meconopsis aculeata is a very beautiful plant from the temperate Himalaya; it is of biennial duration, and seeds sown in May or June produce good plants with considerable tufts of hairy leaves by autumn. In spring they grow vigorously if in moist and good soil, and a strong inflorescence appears from the centre of each plant, reaching 2 to 3 feet high, and bears large blue or purplish flowers. Meconopsis bella is a rare species from the Himalaya, growing from 4 to 6 inches high and bearing solitary blue flowers in June; it should be planted in the rock garden.

Meconopsis integrifolia is a remarkable plant from China; it is a biennial, and blossomed for the first time in this country in 1905. From seedlings raised in May or June a strong central flower spike appears the following May or June, which produces large flowers of a pretty, soft yellow colour. Another attractive Chinese species of recent introduction is punicea. This is correctly a perennial of dwarf habit, which produces large red, solitary, Sarracenia-like flowers on slender stalks $I_{2} \frac{1}{2}$ to 2 feet high in May. It is raised from seeds sown as soon as ripe, but is rather difficult to keep owing to its dislike of a damp atmosphere in winter.

Meconopsis Wallichii, from the Himalaya, is one of the most beautiful of all when at its best. Plants raised from seeds sown in June flower in the following June; the inflorescences rise to a height of 3 or 4 feet and bear large numbers of blue or purplish flowers, each one about 3 inches across: Some people prefer to sow seeds of this 
and other kinds under glass in March to plant out in June, but such plants are apt to bloom prematurely. Meconopsis nepalensis, also a Himalayan species, is sometimes called the Nepaul Poppy. Its flowers are yellow: heterophylla is an annual from California, its flowers are copper or crimson-coloured. The biennial sorts should have welldrained soil, for they are liable to suffer from damp in winter. It is a wise plan to cover large plants with a sheet of glass in order to throw off the worst of the rain. All the Meconopsis (except the annual kind, heterophylla) like a shady place and peaty, loamy soil.

Medeola (Indiun Cucumber Root). - The only species known of this North American genus of the Lily family (Liliaceae) is virginica, a hardy herbaceous plant growing about 9 inches high and bearing small yellowish-green flowers in June. It increases by means of fleshy underground stems which have a Cucumber-like flavour, hence the common name. Division of the clumps in February or March forms a ready means of increase, and the plant thrives in ordinary garden soil. It, however, has little decorative value.

Medicago arborea (Moon Trefoil).-A showy shrub from Southern Europe belonging to the Pea family (Leguminosae). Growing 3 or 4 feet high, it bears bluish-green leaves and a profusion of golden flowers in summer. It is essentially a sun-loving plant, and should be given the sunniest position available, preferably against a south or west wall, for it is not very hardy ; or in the extreme south it may be given a place in the rock garden. Plant in loamy soil, increase by means of seeds, and confine pruning to shaping the bushes or shortening shoots which may have been injured by frost. There are numerous herbaceous species of Medicago, which are valuable as fodder plants, especially sativa, which is known under the common name of Lucerne. It is a very deep-rooting plant, and keeps green in times of drought when most other fodder plants are burnt up. Medicago Echinus, the Calvary Clover, is sometimes grown in gardens on account of its legendary associations. This is an annual, bearing yellow flowers in July, and is raised from seed sown in pots in April, the plants usually being grown in a greenhouse; the leaves are marked with dark purplish blotches, and the fruits are curiously curled.

Medlar.-(See Crataegus.)

Melianthus (Honey Flower).-Two species, major and minor, are grown of this genus of the Sycamore family (Sapindaceae). Both are natives of South Africa and are semi-tender plants of loose, bushy habit, although major is often grown out-of-doors in summer with other bedding plants for the sake of its large, glau. Jus green, pinnate leaves. When planted against a pillar in a conservatory its long, 


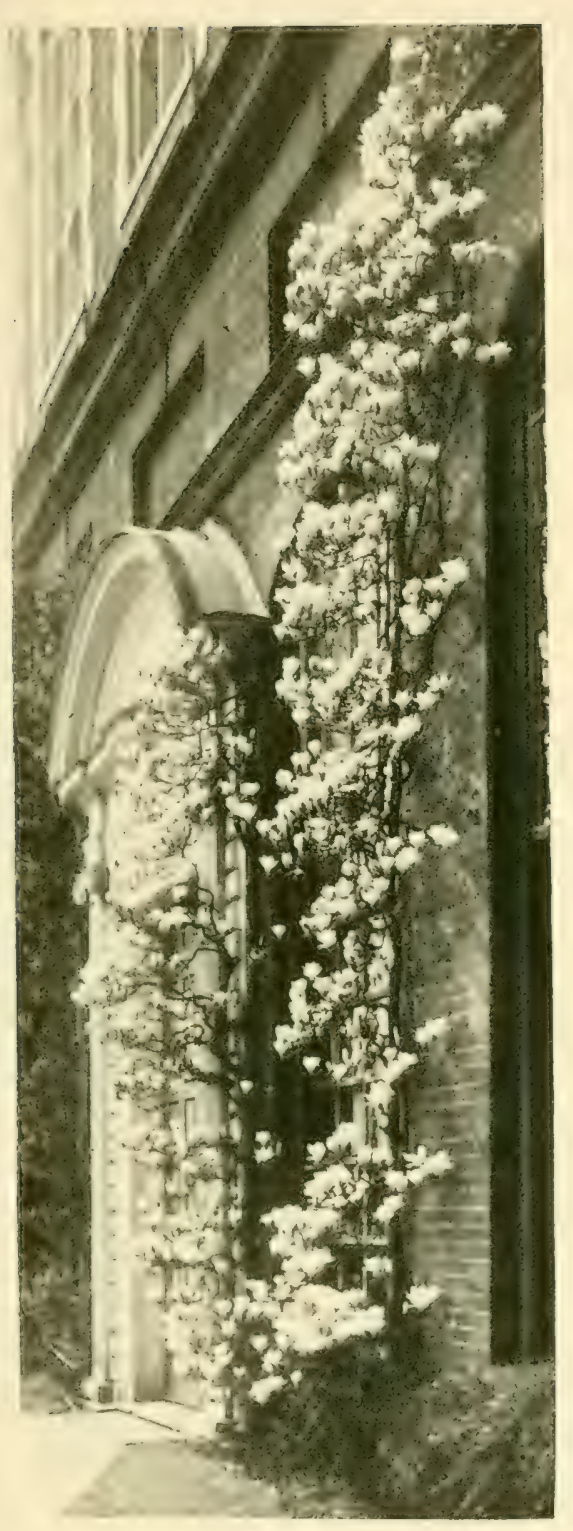

THE YULAN (MAGNOLIA CONSPICUA)

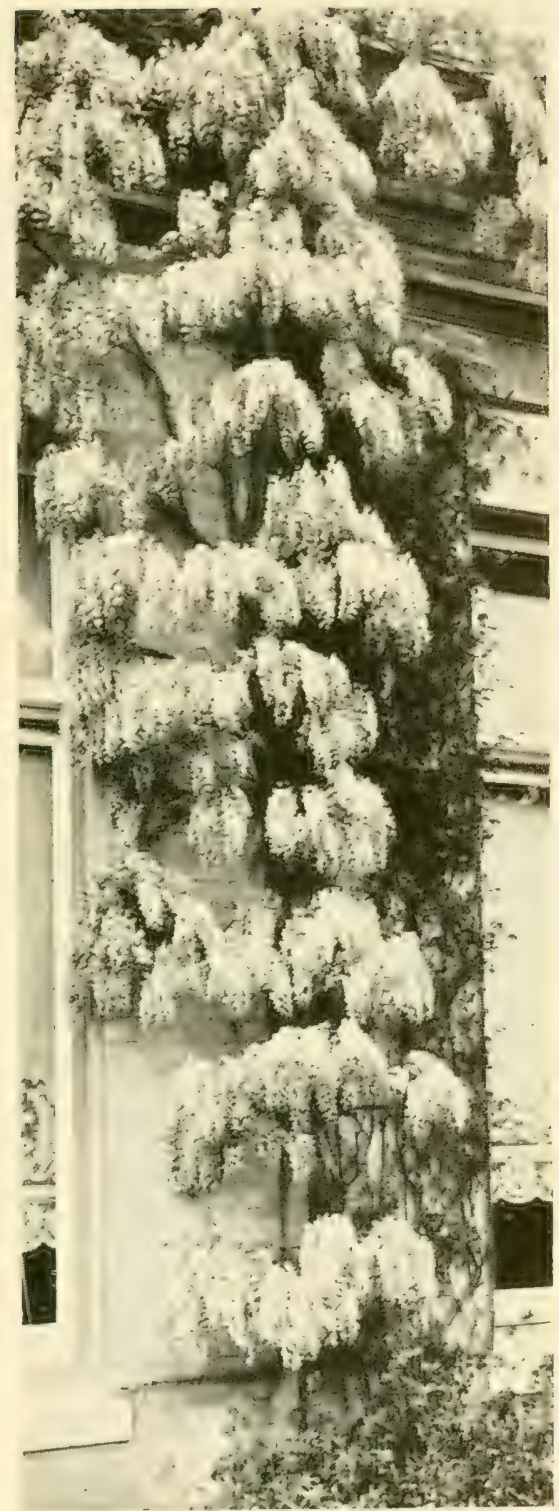

THE FAVOURITE WISTARIA

SINENSIS 

rather gaunt branches grow Io to 20 feet high, but out-of-doors it is often but 3 or 4 feet high. In the milder parts of the country it survives the winter out-of-doors, especially when planted in warm, well-drained soil at the foot of a wall. In other districts the rootstock can be saved by covering it with ashes, though the branches may be killed. Cuttings inserted in light soil in a warm and close frame in August root quite easily, and may be stored in a cool greenhouse for winter to supply more cuttings in March. By the end of May they will be ready for planting out-of-doors. It may also be raised from seeds sown under glass in February. Plants which are kept on from year to year may be cut back a little in February to keep them bushy. The reddish flowers are borne in summer in long racemes. Minor, with flowers of reddish-brown, grows about 4 or 5 feet high, and is much smaller in all its parts. Similar treatment to that recommended above suffices.

Meliosma.-Two or three kinds of Meliosma (Natural Order Sabicaceae) have been known for many years, but little attention was paid to the family before the early years of the present century, when several kinds were introduced from China from districts with a climate very similar to that of the British Isles. So far as it is possible to tell at present, the Chinese plants will fulfil early expectations, and be hardy enough for general cultivation except in the coldest parts of the country. The Meliosmas have usually conspicuous oval or oblong leaves and large inflorescences of small creamcoloured flowers. They should be planted in good, well-drained loamy soil, are usually increased from seeds, and require no regular pruning. Where they cannot be grown out-of-doors their cultivation had better not be attempted, for they are too coarse growing for an ordinary greenhouse. Meliosma myriantha, native of China and Japan, one of the older kinds, is suitable for the south and west counties.

Melissa (Balm).-One species, officinalis, of this group of the Sage family (Labiatae) is usually included in collections of herbs, principally for the sake of its fragrant leaves. Sometimes truly herbaceous, it is more often met with as a sub-shrub I foot or 2 feet high, or sometimes taller; the leaves, when bruised, emit a very pleasant odour, owing to the liberation of an essential oil, and they are considered to possess slight medicinal properties, being one of the old-fashioned remedies for colds when steeped in water or made into " tea." The white or yellowish flowers are borne during summer, but are not very showy. Propagation is by seeds, sown either under glass or outdoors in March, or by cuttings placed in a cold frame in May; division of the plants in spring may also be practised. Varie- 
gata is a variety with variegated leaves; it is grown from cuttings inserted in a cold frame in autumn or by division in spring, and is grown as a border and bedding plant. It is easily kept dwarf by pruning.

Melittis (Bastard Balm or Honey Balm).-Melittis Melissophyllum, a handsome herbaceous perennial, native of Europe, including the British Isles, is the only cultivated species of this group, which belongs to the Sage family (Labiatae). Growing from I2 to I8 inches high, it forms a dense plant, and produces showy flowers in May. A few blooms only are borne upon each inflorescence, but they are about $I_{\frac{1}{2}}$ inch long and creamy-white with a purple lip. It enjoys a certain amount of shade, and may be included with good results amongst plants for naturalising in thin woods. It is not very fastidious regarding soil, as it grows in any kind that is moderately good. Increase is by division during February or March and by seeds sown out-of-doors during the latter month. The variety grandiflora has rather larger and brighter-coloured flowers than the type.

Menispermum.-Two climbing plants belonging to this genus (Natural Order Menispermaceae) are sometimes found in gardens. They are Canadense, the Moonseed, from North America, and dauricum, from Siberia, China, and Japan. Both are perfectly hardy and thrive in ordinary garden soil, either against walls or trellises or over rough posts or bushes in the open garden. The foliage is rather distinct by reason of its bright green colour and peculiar shape, but the flowers are not showy. The round black fruits are, however, conspicuous, for they resemble small bunches of grapes. Increase is by seeds or by division of the clumps. Superfluous growth may be cut out during February.

Mentha (Mint).-Several valuable herbs are found in this group of the Sage family (Labiatae), and there are few gardens throughout the country which do not contain one or more representatives. The Spearmint (viridis) is widely grown for flavouring purposes, a sprig or two being usually boiled with new Potatoes and Peas, whilst it is in great demand for Mint sauce. Groups are easily established by taking cuttings of young shoots when they are about 4 inches long in spring; they should be removed below the ground, in order to secure a few roots, and be dibbled into ordinary garden soil. Growth is rapid by means of underground stems. Division of the roots is also a means of increase, but cuttings are usually preferred. Mentha Pulegium is the Pennyroyal of gardens, grown for its aromatic properties; it, like the former, is a native of Europe, including Great Britain, and can be grown under similar conditions. Mentha piperita 
and its variety officinalis are, however, the most important Mints from a commercial point of view. They are known by the common name of Peppermint. Mentha Requieni (known also as Thymus corsicus) is a charming, low-growing, creeping plant for the rock garden bearing purplish blossoms in July.

Mentzelia.-This group of New World herbaceous plants is included in the Natural Order Loasaceae. It comprises several showy kinds which are usually of biennial duration, but they are rather difficult to grow successfully. The seeds should be sown under glass in May or June in light sandy soil, the seedlings being pricked out in boxes in a compost of 3 parts light fibrous loam to I part each of leaf-mould and sand. When large enough they are potted singly in 3 -inch pots, and as soon as established are plunged in ashes in a sunny position until autumn; they are removed to a cold frame for winter, and planted on a warm, sunny border in April. Good kinds are: Lindleyi, 8 to I 2 inches, yellow, California ; laevicaulis, 2 feet, yellow, California; oligosperma, 2 feet, orange, Louisiana; ornata, 2 feet, white, North America. Some people treat all these kinds as annuals by sowing the seeds during early February in a greenhouse and growing the plants under glass to plant out in May.

Menyanthes (Bog Bean).-Menyanthes trifoliata, which belongs to the Gentian family (Gentianaceae), is the only kind; it is a widely distributed plant throughout the Northern Hemisphere and is wild in the British Isles, in shallow pools and streams, growing in mud a few inches below the surface of the water, and is also found in bogs and marshes. It is easily recognised by the Broad Bean-like leaves produced on strong stems a foot or more high, and by its racemes of prettily fringed flowers, which are white, suffused with pink. By lifting the rhizomes and placing them in baskets of soil it is easy to establish plantations by sinking the baskets in ponds or streams. Such work must be done in spring.

Menziesia globularis is a shrubby plant belonging to the Heather family (Ericaceae). It is found in the Alleghany Mountains, from Pennsylvania to Georgia, where it forms a small bush sometimes several feet high. Here it is often less than 2 feet in height. Its small bell-shaped flowers are white or pinkish in colour, pendent, and appear in summer, but they are amongst the least conspicuous of those of the various plants of the Heather family. Conditions which suit the Heath will suit this shrub also. Increase is by seeds and no pruning is needed. There is a variety called ferruginea or hirsuta.

Merendera. - Bulbous plants, belonging to the Lily family (Liliaceae); they are allied to the Colchicum, and some blossom in 
autumn, others in spring. Well-drained, light loamy soil is suitable, and they may be planted in beds, borders, or as clumps in the rock garden. They can be transplanted any time after the fall of the leaves, and increase is by division of the clumps of bulbs, and by sceds sown in boxes in a frame as soon as ripe. Good sorts are: Bulbocodium, 4 inches high, flowers large, pinkish-lilac, autumn, Spain, etc. (the var. bulbocodiodes produces larger flowers and is more vigorous); persica, 2 to 3 inches, lilac, autumn, Persia and Afghanistan; sobolifera, 3 inches, lilac, spring, Asia Minor and Persia.

Mertensia (Smooth Lungwort).-These plants are of herbaceous habit, and resemble the ordinary Lungwort or Pulmonaria, but may be easily distinguished by their smooth leaves, those of Pulmonaria being rough and hairy. Most are natives of North America, but a few are found elsewhere, one inhabiting Siberia and another being widely distributed through the north temperate and arctic regions. They belong to the Borage family (Boraginaceae), and the more vigorous kinds are suitable for the herbaceous border, the weaker ones being more at home upon the rockery. They require moderatcly light and well-drained soil, and are increased by division in February or March or by seeds sown in a frame in March. Mertensia alpina, from North-West America, is a charming little plant suitable for the rock garden; its flower-stems, terminated by pretty blue flowers, appear in May or June; maritima is found in the maritime regions of the British Isles, and is widely distributed through the north temperate and arctic regions; it is quite a dwarf plant, and bears pretty blue flowers; in some places it is called the Oyster Plant.

Mertensia paniculata, I $\frac{1}{2}$ feet, blue, July, North America; pulmonarioides (Virginian Cowslip), I $\frac{1}{2}$ feet, blue, May, North America; and sibirica, $I_{2}^{\frac{1}{2}}$ feet, blue, May, Siberia, are other good kinds.

Mesembryanthemum (Fig Marigold).- Trailing or bushy plants with succulent leaves, and often showy flowers, are found in Mesembryanthemum (Natural Order Ficoideae). They are natives of South Africa and require the sunniest possible position. Few kinds are thoroughly hardy even in the South of England, although in the milder parts of Cornwall a good many can be grown as ordinary rockery plants, and Mr. Dorrien Smith cultivates nearly a hundred kinds in his famous garden at Tresco Abbey in the Scilly Islands. There they are planted out upon rockwork, and provide a most brilliant display during summer. The Common Ice Plant, crystallinum, is one of the hardiest kinds: it is of annual duration, seeds being sown in warmth in February or March, and the young plants grown in pans or boxes to be planted out in May. Growth is very rapid, and 


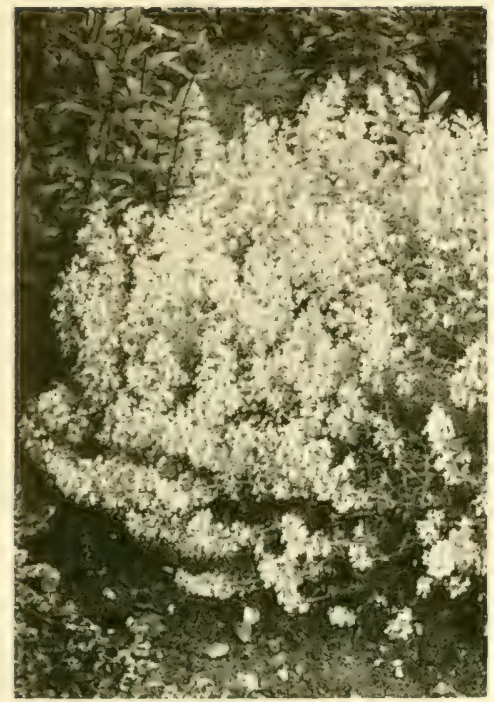

NEPETA MUSSINI. A FREEFLOWERING PLANT

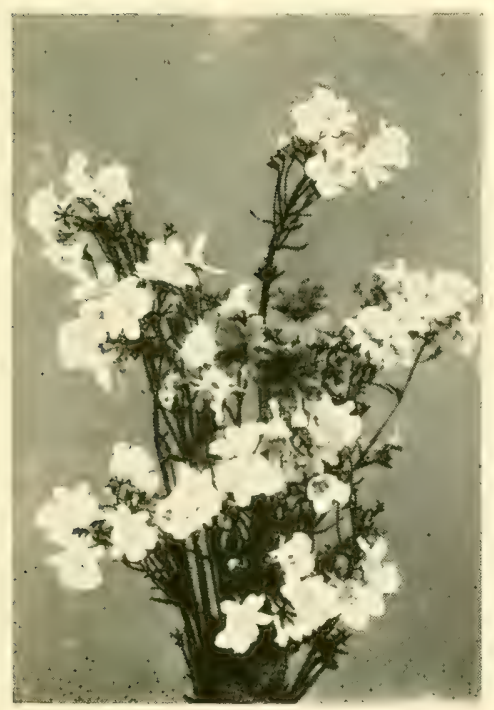

NEMESIA STRUMOSA. A BEAUTIFUL ANNUAL

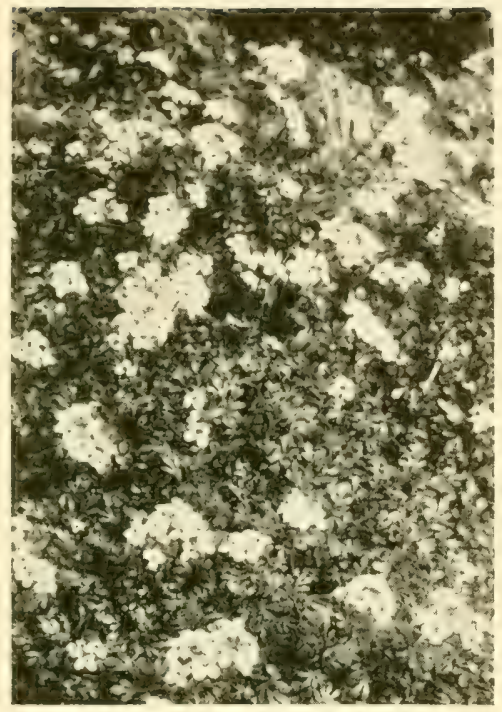

A PRETTY ALPINE (NOCCAEA ALPINA

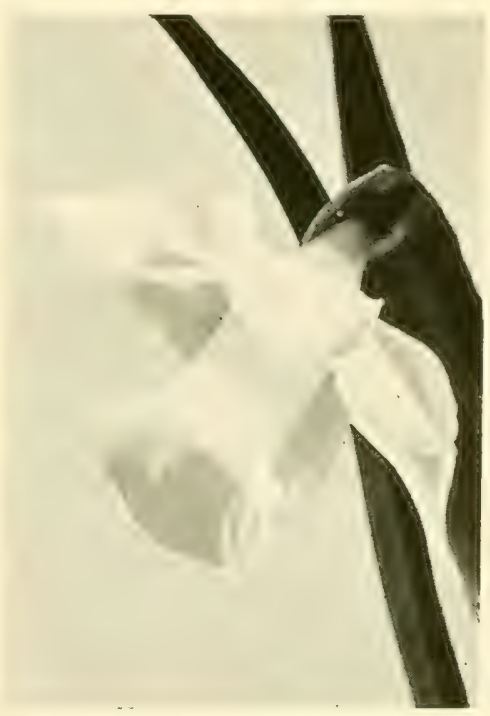

WHITE TRUMPET DAFFODIL

(NARCISSUS LADY OF THE SNOWS) 

it may be planted in borders or upon walls or rockwork; its chief attractions are the cool-looking leaves and glandular stems and foliage, which give the plants a jewelled appearance. The flowers may be red or white, but are not so showy as those of other kinds. Mesembryanthemum cordifolium variegatum is often grown for carpet bedding, its heart-shaped leaves being prettily variegated with gold. It is a perennial plant, and cuttings are rooted in August under glass, and kept in pots until January, when they are potted singly. Growth is rapid, and the points of the shoots are removed on several occasions during spring and used for cuttings. The young plants are put out with other bedding plants during late May and early June. Mesembryanthemum tricolor, or pyropeum, as it is sometimes called, is one of the Fig Marigolds; it is an annual plant of bushy habit, growing freely from seeds sown under glass in March or out-of-doors in April. The flowers are an inch across, and various shades of purple, rose and white in colour. Other kinds, such as edule (yellow), albidum (white), floribundum (red), roseum (rose), spectabile (red), and violaceum (purple), may be rooted from cuttings under glass in August, and be kept in a sunny greenhouse throughout winter to plant on the rockery or in a sunny border in May.

Meum (Baldmoney or Spigncl).- The only kind commonly grown is Neum athamanticum (Natural Order Umbelliferae). It is a very pretty herbaceous plant, about $\mathrm{x} 2$ inches high, and is found wild in many parts of Europe, including the British Isles. It is of neat growth and available for border or rockery, where its finely-cut leaves and white flowers during early summer render it a conspicuous object. It is quite hardy, and thrives in ordinary garden soil, and is easily increased by division in February and early March.

\section{Michaelmas Daisy.-(See ASTER.)}

Michauxia.-This is a small but attractive group of the Bellflower family (Campanulaceae). Two species may be grown, campanuloides and Tchihatcheffii, both natives of Asia Minor. At their best they rank amongst the most stately and beautiful of herbaceous plants, but are rather difficult to manage and the best results cannot be looked for with any degree of regularity. Although they may continue to live for three or four years, like the Foxglove, they are usually grown as biennials, seeds being sown during the summer of one year to produce plants that will flower in July of the succeeding year. It is wise to sow the seeds in pots or boxes under glass, and to grow the young plants in a frame until they are well established. Some of them should then be planted out in light, well-drained loam, and the remainder kept in a frame to put out in spring. As the plants 
are a little tender, a well-sheltered but not heavily shaded position is desirable. Campanuloides produces large branched inflorescences, 3 to 4 feet tall, and bears large, bell-shaped, white blossoms, which are shaded on the outside with purple. Tchihatcheffii is a rather more vigorous plant, which also bears white flowers. In the event of dry weather being experienced in May, it is wise to mulch the plants with well-rotted manure.

Michelia.--Trees or shrubs belonging to the Natural Order Magnoliaceae, and closely related to the Magnolias, with which they are sometimes included. At least three species are in cultivation, compressa, an evergreen bush or small tree from Japan; fuscata, a Chinese bush; and Champaca, a tree from the Malaya. The first two are grown out-of-doors in the South of England and Ireland, but have nowhere attained any considerable size. Michelia fuscata is a very interesting shrub, for in addition to being evergreen, it produces flowers freely from the leaf axils during summer. The flowers are small for a Magnoliad, reddish within and buff without; they are peculiar by being fragrant at certain times of the day, and whereas the scent can rarely be detected before eleven o'clock in the morning, it is very pronounced from that time until late afternoon. They should be treated as advised for the Magnolias, but need a little more peat in the soil. They, with the early flowering Magnolias, can bc grown in pots or tubs for greenhouse decoration.

Micromeria.-This is a group of herbs and woody plants belonging to the Sage family (Labiatac). Many have little garden value, but a few can be grown for the herbaceous border or rockery. They succeed in any good garden soil providing it is moderately well drained. The herbaceous kinds can be increased by seeds or by division in February or March, seeds being sown in pots in a frame or greenhouse, and those of a shrubby character are propagated by cuttings in July and August, or by sceds in February or March. They require a little thinning and the removal of the points of the shoots in February. Micromeria croatica, of herbaccous habit, bearing rose and violet flowers in July, is native of Croatia ; graeca is a sub-shrub producing pink flowers in June, native of Greece, etc.; rupestris, I 2 inches high, has flowers in June, and is from Carniola ; and Juliana, 6 inches, with red blossoms in July, comes from the Mediterranean region.

\section{Mignonette.-(See RESEDA.)}

Milla.-Bulbous plants belonging to the Lily family (Liliaceac), though now usually included in Brodiaea; the kinds here mentioned are classed as Brodiaca by botanists. They are all moderately low- 
growing plants, being usually less than 12 inches in height. In most cases the flowers are showy, and the flowering time depends largely upon whether the plants are grown under glass or out-of-doors. They are not very hardy, and can only be grown with success out-of-doors in the milder parts of the country, and even then it is wise to plant them in a border of well-drained, rather light soil at the foot of a wall. It is usual to obtain imported bulbs and to plant them in October or November about 3 inches below the surface of the ground. Where groups have been established, surplus bulbs or offsets may be removed to plant elsewhere, lifting being done as soon as the leaves die. The chief kinds are: biflora, I2 to I5 inches, white, May, Mexico ; Leichtlinii, 4 inches, white, autumn, Chilian Andes; macrostemon, I2 inches, lilac, May, Buenos Ayres; porrifolia, I2 inches, blue and white, summer, Chili; and uniflora, 6 inches, white, February to April, Buenos Ayres. When grown under glass they should be placed several together in $5^{-}$or 6-inch pots, and be given full sun.

Mimulus (Monkey Flower, Musk).-A number of very attractive herbaceous plants and sub-shrubs are found in Mimulus (Natural Order Scrophulariaceae). Perhaps the best known is the sweet-scented Musk (moschatus), a herbaceous perennial native of North America; it is well known by reason of its viscid, fragrant leaves, its yellow flowers, and its habit of spreading rapidly by underground stems.

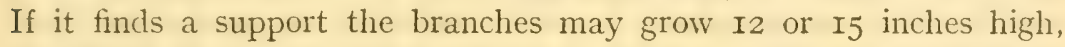
though it is usually much dwarfer. It is popular for growing in pots, and is usually one of the flowers grown in cottage windows. Good potfuls can be made up by dibbling half a dozen pieces, each with a few roots, into 5-inch pots filled with a compost of 3 parts loam to I part each of leaf-mould and sand, in March. The var. Harrisonii, with flowers an inch across, is also useful for pots, but is less hardy than the type. One form of Mimulus moschatus appears to have lost much of its fragrance, and when patches are being planted care should be taken to secure the fragrant kind. Mimulus luteus, also from North America, is another popular Musk ; it is very hardy, and suitable for planting in moist soil about the margins of lakes or streams. Under favourable conditions it becomes naturalised, and is very effective over a considerable period in early summer by reason of its profusion of yellow blossoms which are borne on stems I2 to I8 inches high. It is easily raised from seeds sown in light soil as soon as ripe or kept in a cool room and sown in spring; the var. alpinus, also known as cupreus, is very distinct by reason of its large flowers, which are heavily spotted with brown. By crossing it with the other variety of luteus, which is variously called guttatus 
and variegatus, a handsome race of hybrids has been obtained which are remarkable for their large, handsome, spotted flowers. As a rule, the ground colour is white, cream, or yellow, with large irregularshaped blotches of brown or reddish-brown. These hybrids are known under the common name of Monkey Musk, and are very popular for summer bedding. Seeds are usually sown under glass during February or early March, and the seedlings are pricked out in pans or boxes for planting out-of-doors in May. They blossom throughout summer. In some gardens they are used for greenhouse decoration, and are grown in shallow pans.

Mimulus cardinalis is a red-flowered perennial from North America, growing from 2 to 3 feet high and blooming during early summer. It can be grown in the herbaceous border and in pots. Mimulus Lewisii grows 9 inches high and bears rose-coloured flowers in August; it is a native of North-West America. A very different plant is found in Mimulus glutinosus, for it is of shrubby habit. As it is not very hardy it must be grown under glass except in the milder parts of the country. It forms a bushy plant 4 to 6 feet high, and bears brownish flowers freely throughout a great part of the year. It is a native of California, and easily increased by cuttings during spring and summer. Plants which have bloomed for some considerable time should be cut back and allowed to form new growth from the lower parts of the shoots during early spring.

Mina.-Mina lobata is the only species of this group of the Bindweed family (Convolvulaceae), and it is now included in Ipomoea, under the name of Ipomoea versicolor. It is, however, so well known in gardens as Mina lobata that the name is retained here. It is a climbing plant with showy crimson and yellow flowers, a native of tropical America, and of annual duration. Seeds may be sown in pots under glass in February, the young plants being put out in good soil in May, or the seeds can be sown in late March where the plants are to bloom. It may be used for covering fences or trellises, or be given a circle of Birch branches over which to climb. Vigorous plants bloom from June onwards for two or three months.

Mirabilis (Marvel of Peru).--Showy herbaceous perennials belonging to the Natural Order Nyctaginaceae. Mirabilis Jalapa, a tropical American species, is the best known. In two years it forms a plant $I \frac{1}{2}$ to 2 feet high, and nearly 3 feet across, producing its flowers for a considerable period from the end of May onwards. Red, white, yellow, and lilac flowers are borne by different plants, whilst red and white or striped blossoms may be found on the same plant. In warm, well-drained soil in the warmer parts of the country it withstands 
the cold of winter without injury, but in other places it is wise to lift the roots and place them in a frame covered by ashes or leaves for the winter. It can, however, be grown as an annual, for, from seeds sown in warmth in February, young plants can be obtained to plant out in May, and they will flower finely all summer. Seeds are produced freely and a few should be collected each year. Other good kinds are: longiflora, 2 to 3 feet, white, pink, or violet, summer, Mexico; and multiflora, $I \frac{1}{2}$ feet, crimson-purple, July and August, California. When a position in full sun, in a border at the foot of a wall can be provided, these plants are especially attractive.

Miscanthus.--Vigorous and decorative herbaccous plants are found in these members of the Grass family (Gramineae). They are desirable for isolated clumps in conspicuous positions, but are specially suitable for moist places such as the bank of a lake or stream, and are peculiarly adapted for associating with Bamboos. Rich soil must be provided, and when preparing for planting it is a good plan to add cow manure when the ground is light or horse manure when it is heavy. Established plants also benefit by a surface dressing of decayed manure each spring, and they appreciate an occasional application of liquid manure. Plants which are not growing near water must be kept moist at the root during dry weather. Propagation is by division of the clumps in March or early April. The best kinds are: japonicus, 3 to 6 feet, native of Japan; its var. variegata has silver variegated leaves, whilst zebrina has leaves mottled with gold; saccharifer, also from Japan, grows I2 feet high, with glaucous leaves; while the Chinese and Japanese kind, Sinensis, is a very graceful, green-leaved plant between 3 and 4 feet high. All should be cut down before new shoots commence to grow in spring.

\section{Mistletoe.-(See VISCUM.)}

Mitchella (Partridge Berry).-Mitchella repens (Natural Order Rubiaceae) is a crecping plant from North America, and is suitable for a position in the rock garden, its attractions being the pretty, white, purple-flushed, fragrant blossoms which appear in summer, the bright red berries in autumn and the evergreen leaves in winter. Rather light peaty soil and a semi-shaded position should be provided. Propagation is by division in February or March and by seeds sown about the same time in light soil in a frame or greenhouse. It can be associated with the dwarf Gaultheria with satisfactory results.

Mock Orange.-(See Philadelphus.)

Moltkia petraea.-This very pretty little shrub belongs to the Borage family (Boraginaceae), and possesses pretty rich bluish flowers. It is a native of Dalmatia, and forms a stiff bush 12 inches 


\section{1) 2

to 2 feet high, which, when out of bloom, is rather suggestive of Lavender. The flowers, which open in June, however, at once show that it is quite distinct. It gives the best results in a sunny position in the rock garden, preferably in a crevice between stones or rocks. Loamy soil suits it, and increase is by seeds or cuttings. Except for the removal of the old flower-heads, pruning is unnecessary.

Monarda (Horscmint, or Horsebalm).--Several showy and perfectly hardy herbaceous plants are included in this group of the Sage family (Labiatae). They are natives of North America, and are characterised by fragrant leaves. All are amongst the easiest of plants to cultivate, for if planted in any good garden soil they spread rapidly and bloom profusely over a considerable period from early Junc onwards. Propagation is by division of the clumps any time during late autumn, winter, or early spring. It is unwise to leave plants more than two or three years in one position. When dividing the plants the outer parts should be chosen for replanting, for they are usually more vigorous than the centre. Monarda citriodora, Lemon-scented Balm, from North-West America, grows 2 feet high and bears pink flowers; didyma, the Oswego Tea, is the best known kind ; it is $I_{2}^{1}$ to 2 feet high, and bears bright red blooms (the variety called Cambridge Scarlet is finer); fistulosa, Wild Bergamot, grows 2 to 4 feet high, and its flowers may be red or rose, its var. mollis is recognised by its hairy leaves. All bloom in summer.

\section{Monkshood.-(See Aconitum.)}

Miontañoa.-Tender or half-hardy shrubs, members of the Daisy family (Compositae). They are only available for planting out-ofdoors in the mildest parts of the country, but in many other gardens they can be grown out-of-doors during summer. Cuttings of young shoots root quite well if inserted in sandy soil in a closed frame in April or July. Plants in pots should be given a compost of 3 parts loam, I part leaf-mould, and I part sand. Those grown out-of-doors require well-drained, rather light loam. Montañoa bipinnatifida grows 3 to 4 feet or sometimes more in height, and bears yellowish flowers during summer, it is a native of Mexico; tomentosa, 3 feet high, bears white flowers in September, it is also from Mexico. Both may be cut back well in February.

Montbretia.-Bulbous plants belonging to the Iris family (Iridaceae). Though the name Montbretia is still kept up in gardens, these plants are now called correctly Tritonia. They are generally very showy, and blossom during July and August; they give excellent results when planted, about 3 inches deep, in a well-drained border of light loamy soil which is moderately rich. The bulbs may be planted 


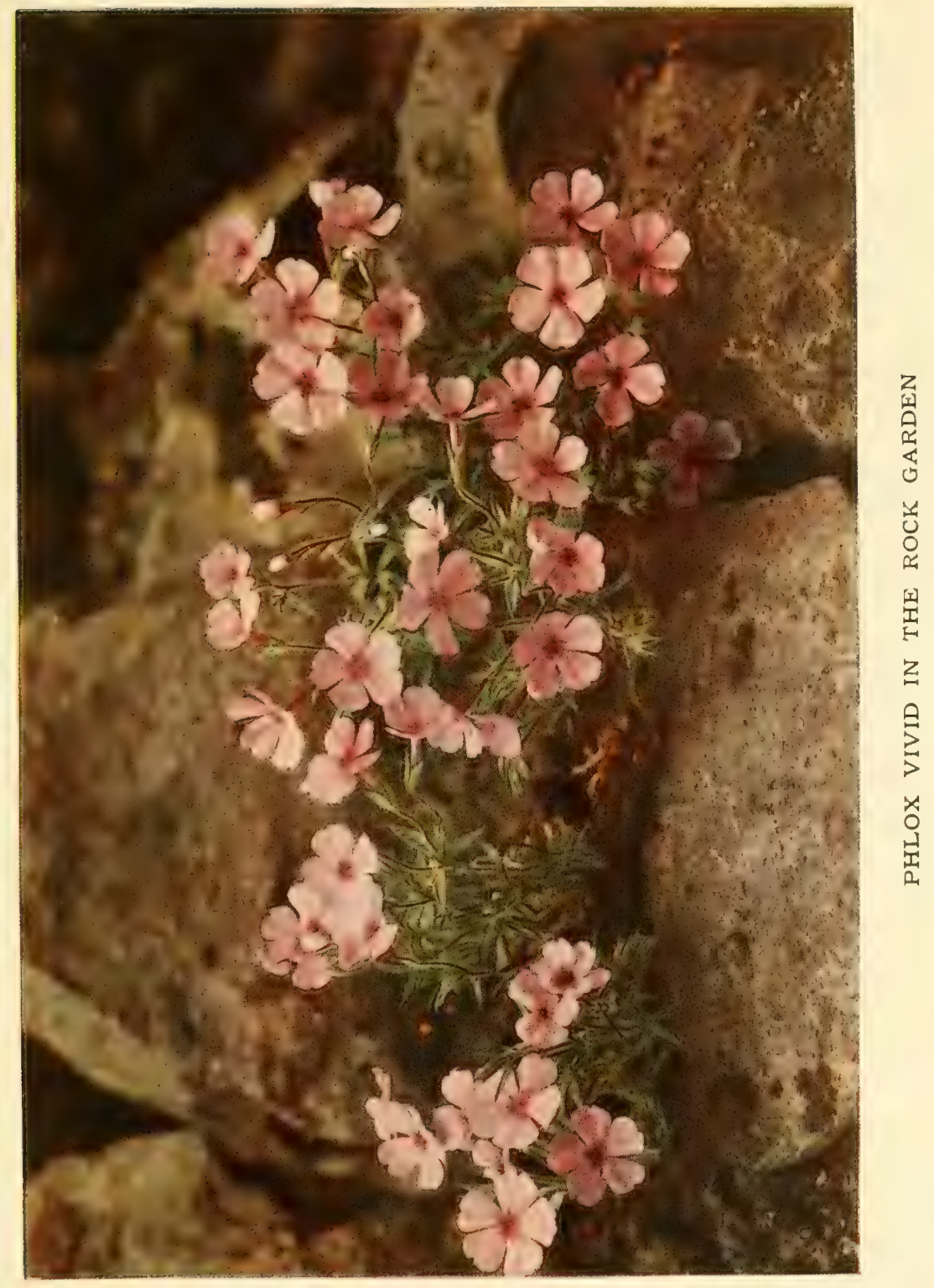



in autumn or not until February or early March; most kinds can be allowed to remain undisturbed for several years. Offsets are produced freely and they are usually used for increase of stock, although seeds sown as soon as ripe in a bed of sandy soil in a sunny frame produce flowering plants in the course of two years. Like other plants of South African origin, they require all the sun available, and it is little use planting them in shady places if they are to thrive really well. Montbretia aurea, 2 feet, yellow, and Pottsii, orange shaded red, are two of the best known kinds. Between them a hardy and vigorous hybrid has been raised, called crocosmiaeflora, 2 to $2 \frac{1}{2}$ feet high, with orange-scarlet flowers, but there are also many more sorts, remarkable for their large and brightly-coloured flowers. Good ones are: America, orange-red ; Anneau d'Or, orange-yellow, purple base ; California, yellow and purple; Congo, dark orange-red; George Davison, golden-yellow; Le Pactole, apricot; Prometheus, orange and crimson; Westwick, orange, maroon ring.

Moon Daisy.-(See Chrysanthemum.)

Moraea.-The Moraeas are Iris-like plants (Natural Order Iridaceae), natives of South Africa. They are not very hardy, but a few kinds thrive when exposed to full sun in a border of welldrained, light loamy soil, at the foot of a wall for preference. They are increased by division of the clumps in spring. The hardiest kinds are iridioides, 6 to $\mathrm{I} 2$ inches, white, with brown or yellowish spots, summer; and Spathacea, I2 inches, yellow, spring. A very fine greenhouse kind is found in Robinsoniana; it grows 5 feet high, and has long and wide, strap-shaped, evergreen leaves and large inflorescences of white flowers. It is sometimes called the Wedding Flower.

Morina.-This group of the Natural Order Dipsaceac is allied to the Teasel family and consists of a number of perennial herbaceous plants chiefly from the Himalaya. They are of vigorous growth and have usually large and ornamental leaves, and rather curious but attractive Thistle-like flowers. Their proper place is towards the middle or back of the herbaceous border, and they should be planted in fair-sized groups. During severe weather in winter it is well to cover the crowns with dry leaves and Spruce or other evergreen branches. They like good deep soil which is moist, but well-drained, and are increased by seeds sown in light sandy soil in a close frame as soon as ripe. It is wise to keep the young plants in a frame until they are at least six months old. Good kinds are: Coulteriana, 3 feet, yellowish, summer; longifolia, 3 feet, purple or reddish-purple, summer ; persica, 3 feet, red and white. All are found in the Himalaya, but the last-named extends to Persia as well. 
Morisia.- Hypogaca is the only kind available for cultivation; it belongs to the Wallflower family (Cruciferac). This dainty little herbaceous plant is suitable for the rock garden, and grows scarcely 3 inches high, but forms a distinct rosette of pretty little pinnate leaves, from amongst which yellow flowers, about $\frac{1}{2}$-inch across, appear on stout upright stalks during late spring and early summer. Although introduced from its home in Sardinia and Corsica as long ago as 1833 , it is not very common ; it requires light soil, and should be given a position where it will be sheltered from excessive damp during winter. Increase is by seeds sown as soon as ripe and by detaching side growths and inserting them as cuttings in pots of sandy soil in a closed frame in spring. It is especially attractive when grown in shallow pans to bloom in a cold greenhouse in spring. A few small pieces of sandstone should be placed between the plants when they are grown in this way.

\section{Morning Glory.-(See IPOMOEA.)}

Mlorus (Mulberry).- Trees of considerable importance in their native countries and in other places where they have been introduced; they belong to the Natural Order Urticaceac. There are three distinct kinds: alba, from temperate and sub-tropical Asia, which is a very variable plant, and of which the Chinese have distributed numerous varieties; nigra, the common Mulberry of our gardens, which has been in cultivation from time immemorial, and of which the native country is unknown; and rubra, the Red Mulberry, of North America. The last-named is not sufficiently hardy for general cultivation, even in the South of England; but the other two are both grown. Morus alba is cultivated in practically all silk-producing countries, for its leaves form one of the most suitable foods for silkworms. The American Nulberry is used for the same purpose, but is not considered to be so good as the white kind. Morus nigra, as is well linown, is grown both as an ornamental and fruiting tree, and many fine examples are to be found throughout the Midlands and South of England. There is one oljection to it as a lawn tree, for its fruits fall in quantities when ripe and are apt to stain children's and ladies' clotling. It is very tenacious of life, and fine trees may often be found cooped between high walls in smoky towns. In fact, such a one exists and fruits annually almost within a stone's throw of the Guildhall in London. The Mulberries like well-drained luamy soil, are easily increased by cuttings in autumn, and only require sufficient pruning to keep the trees in shape. That can be done during summer.

Mountain Ash.-(See Pyrus.) 
Muehlenbeckia.-This group (Natural Order Polygonaceae) is made up of a number of shrubs of erect or climbing habit, except Muehlenbeckia axillaris, which is of dwarf, prostrate growth. They are natives of New Zealand, Australia, the Solomon Islands, and South America. Some are hardy in the South of England, and those are the only ones that demand attention. The dwarf kind, axillaris, may be planted on the rockery; adpressa, complexa, and varians are climbers with an abundance of slender growths clothed with tiny dark leaves, the flowers are small and yellowish. They must only be planted where they can have plenty of room and should be placed at the foot of a large bush over which they may ramble at will. Increase is by cuttings. Plant in ordinary garden soil and prune in spring to keep within bounds.

Mullein.--(See Verbascum.)

Musa (Banana).-The Banana belongs to the Ginger family (Scitamineae), and two kinds are sometimes grown for the outdoor garden in this country. They are Basjoo, a native of Japan, and Ensete, from Abyssinia. Musa Basjoo grows Io or I2 feet high, and is hardy in a few of the most favoured parts of Cornwall; it has been grown for many years in gardens in Falmouth and also in the Scilly Islands. Elsewhere it must be kept in a cool greenhouse for the greater part of the year, but can be placed out-of-doors in summer. At its best it is seen with a stout stem surmounted by leaves 3 to 4 feet long and 7 to 9 inches wide; the flowers are not very ornamental, and the stems die after the death of the flowers or after perfecting seeds. Constant renewal of stems is, however, going on from the rootstock, and stems in all stages of development may be found on a clump. It is not a very satisfactory plant, as the leaves are easily injured by wind. It requires rich soil, and is increased by division of the clumps in spring. Musa Ensete is also grown now and then in Cornish gardens, but, as a rule, it is planted in large pots or tubs and used for sub-tropical bedding in summer, spending the rest of the year under glass. When planted out in rich soil in a greenhouse it forms a magnificent specimen, with a stout trunk Io or I2 feet high and $I_{2}$ or $I_{5}$ inches through, surmounted by an immense head of leaves, each one of which may be 12 feet in length and 2 feet wide. The leaves of pot-grown plants are smaller, but very ornamental. Unfortunately, they are easily injured by wind, and when placed out-of-doors often look very ragged before the end of summer. This species does not produce suckers, but dies after seeding. Propagation is thus entirely by seeds which are imported. They should be sown in loamy soil in warmth as soon as received. 
Muscari (Grape Hyacinth).-A considerible number of very pretty and easily grown bulbous plants are found in Muscari (Natural Order Liliaceac). They are widely distributed through Southern Europe and Asia Hinor and accommodate themselves very well to conditions in the British Isles, growing and flowering well, even where the soil is poor. The flowers are usually some sharle of blue, though a few bear purple, yellow, or white flowers. All are dwarf, the tallest being about 9 or 12 inches high ; others, however, rarely grow more than 6 inches, whilst some are but 3 inches high. The weaker kinds should be planted in a border where they can be readily looked after, but some are excellent for carpeting beds of shrubs. One of the best for this purpose is conicum, native of Europe, and often called Heavenly Blue; it grows 6 inches high and bears its spikes of rich blue flowers freely in April. Very effective displays can be made by carpeting beds of white-flowered shrubs, such as Magnolia stellata or Amelanchier Canadensis oblongifolia, which bloom at the same time, with this plant. It increases with great rapidity both by forming new bulbs from the old ones and from self-sown seeds. Other good ones are: botryoides, 6 inches, blue, April, Italy, with its vars. album, white and pallida, pale blue; comosum, 6 inches, blue, April, Southern Europe (the var. monstrosum, 9 inches, has curious but ornamental, malformed, pale blue inflorescences of large size). Muscari commutatum, 6 inches, bears blue flowers in April and is native of Italy; grandifolium, 9 to $\mathrm{I} 2$ inches, is dark blue, its habitat is unknown; micranthum, 6 inches, bears violet flowers in April, its habitat, too, is unknown; moschatum grows 9 inches high and has blue flowers in April, it is native of Asia Minor (the var. flavum is yellow); racemosum (Starch Hyacinth), 3 to 4 inches, has blue flowers in April and is native of Europe. All should be planted as early in autumn as possible, for they soon begin to form new roots.

Musk.-(See Mimulus.)

Myosotidium nobile (Chatham Island Forget-me-not).-This, which belongs to the Borage family (Boraginaceae), is a fine herbaceous plant from the Chatham Islands. It is one of the most beautiful of all hardy plants when seen at its best, for it forms large, glossy, evergreen leaves I2 to IS inches high, from amongst which, during late spring and early summer, stout inflorescences appear which bear large and beautiful blue Forget-me-not-like flowers well above the leaves. Unfortunately it is difficult to grow and only gives really good results in a few localities. It appears to thrive most satisfactorily in the mild and moist climate of the south-west counties within a comparatively short distance of the coast. There, in borders, often 
at the foot of a wall, it is found in rude health and flowering magnificently, giving the happy owners the idea that it can be grown as easily as a Cabbage, whereas a few miles away it may fail entirely. Propagation is by seeds sown as soon as possible after they are ripe, and by division of the clumps in spring. It has been noted in firstrate condition in Cornwall, planted in loamy soil. It has been tried in cold frames in some places, with little success, however.

Myosotis (Forget-me-not).-Annuals, biennials, and perennials are included in this familiar group of the Borage family (Boraginaceae). Some are distinctly alpine plants, and others are found in woods, grassland, and marshes at low elevations, several being natives of the British Isles. All are easily raised from seeds sown as soon as ripe, or they may be kept until the following May. Seeds of the commoner kinds can be sown out-of-doors, but those of rare sorts should be sown in pots of sandy soil in frames. Common Forget-me-nots are excellent for undergrowth for thin shrubberies, beds, or borders, and should always be included amongst spring bedding plants, but rare kinds give the most satisfactory results when planted in the rock garden. In most cases the flowers are a delicate shade of blue, but there are varieties with white and rose flowers. Myosotis alpestris is a very beautiful kind from

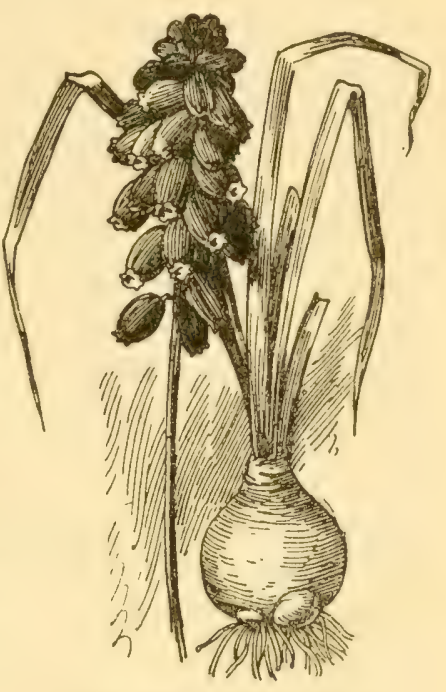

THE GRAPE HYACINTH

(Muscari) the Swiss Alps; it forms dense rosettes of growth and produces inflorescences 3 to 6 incles high of charming blue flowers in spring. It suffers a little from damp in winter, and should be planted on the rockery in gritty soil amongst small bits of sandstone; the var. albus has white flowers, whilst Victoria is a garden kind with pretty blue flowers. Myosotis azorica is a very beautiful but rather tender perennial from the Azores; it grows 6 to 9 inches high, and bears rich blue flowers. Plant in a well-drained position in the rock garden. Myosotis dissitiflora is the Common Early-flowering Forget-me-not, an excellent plant for naturalising, and its varieties for spring bedding. Seeds are sown in May or June to produce flowering plants for the following summer. Good garden varieties are: Blue King, deep blue: White Queen, white; Princess 
Rose, rose; Blue Pyramid, blue; Star of Love, blue. Myosotis palustris is the Water Forget-me-not, a pretty blue-flowered plant; repens is a dwarf, blue-flowered kind, native of Britain; and sylvatica is the Common Wood Forget-me-not of the Briti-h Isles.

Myrica.-A group of hardy shrubs, mostly from North America, but one kind, Myrica (iale, the Boy Myrtle or Swect Gale, is found throughout the Northern Hemisphere, and is a familiar object in boggy land in the British Isles. Myrica cerifera, the Wax Myrtle of the United States, is so called by reason of its fragrant leaves and a waxy exudation from the fruits. Myrica californica is the Californian Wax Myrtle. Perhaps the most attractive plant is the North American Myrica asplenifolia, which has elegant pinnate leaves; it is, however, clifficult to grow if not given moist peaty soil. Other kinds do better in the ordinary garden, but are best adapted for boggy land. Increase is by seeds and no regular pruning is needed. Anyone who has to deal with wet peaty land at a considerable elevation would do well to remember the hardier kinds of Myrica. These plants belong to the Natural Order Myricaceae. Several tender species are natives of Africa and Asia.

Myricaria germanica, belonging to the Tarnarisk family (Tamaricaceae), is a native of Europe and other countries, and is closely allied to the Tamarisk. It has sometimes been called Tamarix germanica, but is a distinct shrub. Growing at least 4 or 5 feet high, it is noticeable by reason of its graceful growth and tiny leaves, and by its terminal panicles of pinkish or sometimes almost white flowers in June. Like the Tamarisks, it may be planted in exposed places near the sea, but also thrives inland. Plant in ordinary garden soil, increase by cuttings of ripened shoots inserted out-of-doors in October, and cut back the previous year's shoots in February.

Myrrhis (Swect Cicely).-Myrrhis odorata, a native of the British Isles, is the only member of this group (Natural Order Umbelliferae) available for our gardens. It was at one time grown as a pot-herb and for salads, but is rarely now used for that purjose?. It is, however, sometimes grown for its aromatic foliage; it grows 2 to $2 \frac{1}{2}$ feet high and produces white flowers in May. Any kind of soil suits and increase is by seeds or division during early spring.

Myrsine.-Several shrubs from South Africa, Australia, Mexico, India, and New Zealand are comprised in Myrsine (Natural Order Myrsinaceae), but they are not of sufficient interest to warrant their being grown under glass, although one kind, africana, is a useful evergreen for out-of-doors in the South of England. It is a low-growing bush of rather attractive appearance, with small dark green foliage 
and tiny brownish flowers in spring. A position in the rock garden suits it, whilst propagation is by cuttings of half-ripe shoots in summer. Pruning is unnecessary.

Myrtus (Myrtle). - This is an important and popular group of shrubs (Natural Order Myrtaceae), for it includes the Common Myrtle. The various kinds are distributed through New Zealand, Australia, Brazil, Peru, Chili, Southern Europe, etc., those from the cooler countries being of the greatest use in the British Isles. Though not generally hardy, several kinds give excellent results in the south and west counties, whilst further north they may be grown against walls, or in tubs to stand out-of-doors in summer, being kept in a cold greenhouse or outhouse in winter. In many instances the white flowers are exceedingly beautiful, whilst they find a capital setting amongst the evergreen leaves. They thrive in loamy soil to which a little peat or leaf-mould has been added, and are increased by means of cuttings of half-ripe shoots inserted in sandy soil in a closed and warm frame during summer. Pruning is sometimes required to shape the bushes and to rejuvenate those which are becoming thin and leggy; this should be done in April. Myrtus communis, the Common Myrtle of Southern Europe, is a fragrant-leaved evergreen with white flowers and black fruits; it grows quite well against a wall about London. The var. tarentina has neat growth and small leaves; it is popular for mixing with flowers at weddings. Myrtus Luma is a handsome evergreen from Chili, and is one of the chicf attractions of Devon and Cornish gardens in September when covered with its white flowers. Myrtus Ugni is also from Chili ; it grows well in the gardens of the south-west. Other useful sorts are: bullata, myrsinoides, and obcordata.

Nandina domestica.-This is an interesting shrub, from China and Japan, belonging to the Barberry family (Berberidaceae). Though rather tender, it may be grown with success out-of-doors in the south and west counties of England and in Ireland. The most satisfactory position for it is a sheltered corner at the foot of a south or west wall, where the stems can become thoroughly ripened. Its attractions are the large pinnate leaves which are produced in clusters about tire points of the branches, and its large panicles of white or pink flowers in July. Many forms are recognised by the Chinese and Japanese, with whom it is very popular. Here it has never been planted extensively. Plant in ordinary garden soil, and increase by seeds or division of the clumps. Prune away old shoots when necessary.

Narcissus (Daffodil).- The Narcissi, which belong to the Natural Order Amaryllidaceae, and are native of various European countries, 
form an extensive group of popular flowers. Apart from their great value for the cmbellishment of the outdoor garden, they are also largely grown in pots or bowls for flowering under glass. Exhibitions of Narcissi are now commonly held during spring, and large sums are often obtained for bulbs of the choicer varieties. It does not, however, follow that these are the best for garden display, for many of the cheapest kinds are unsurpassed for this purpose.

The soil best suited to Narcissi in general is sandy loam that has been enriched with some manure a year or so previously. Fresh manure ought never to be used when planting. The best substitute is bonemeal, a little of which should be scattered in the soil beneath the bulbs, or if a bed or border is being planted, the bonemeal may be scattered on the surface at the rate of 6 ounces to the square yard, and dug in. Most amateurs plant the bulbs of Narcissus too near the surface; there should be 3 inches of soil over the largest ones and 2 inches or so over those of medium size, while the smallest ought to be covered by at least I inch of soil. If possible, the bulbs should be planted not later than September, though those who grow to produce the finest blooms for exhibition plant in July and August. In the outdoor garden Narcissi are planted in various ways. Frequently they are put in beds that have contained tender plants during the summer months, either alone or grouped with other spring flowers. In masses or clumps in the front of shrubberies they are seen to advantage, and there may remain undisturbed and thus become established; whereas in beds they must be cleared away to make room for the tender plants in summer. In the latter case the bulbs must be carefully lifted in May, disturbing the roots as little as possible, and laid in some out-of-the-way spot until the leaves have turned yellow; they are then taken up, cleaned, and stored ready for planting in late summer or early autumn.

Another purpose for which many kinds of Narcissus are adapted is for planting in grass that is not often cut, and where they may come up year after year. The grass must not be cut until the leaves have died away, or the bulbs will deteriorate quickly. In planting bulbs in turf, one needs to be careful to arrange them as naturally as possible; straight lines must be avoided. A good plan is to scatter the bulbs broadcast, and plant them exactly where they lie, subsequently adding a few small irregular groups here and there on the margin.

Narcissi are, according to the classification of the Royal Horticultural Society, grouped in eleven divisions, and the length of the cup or trumpet portion of the flower is the chief factor in their classification. 


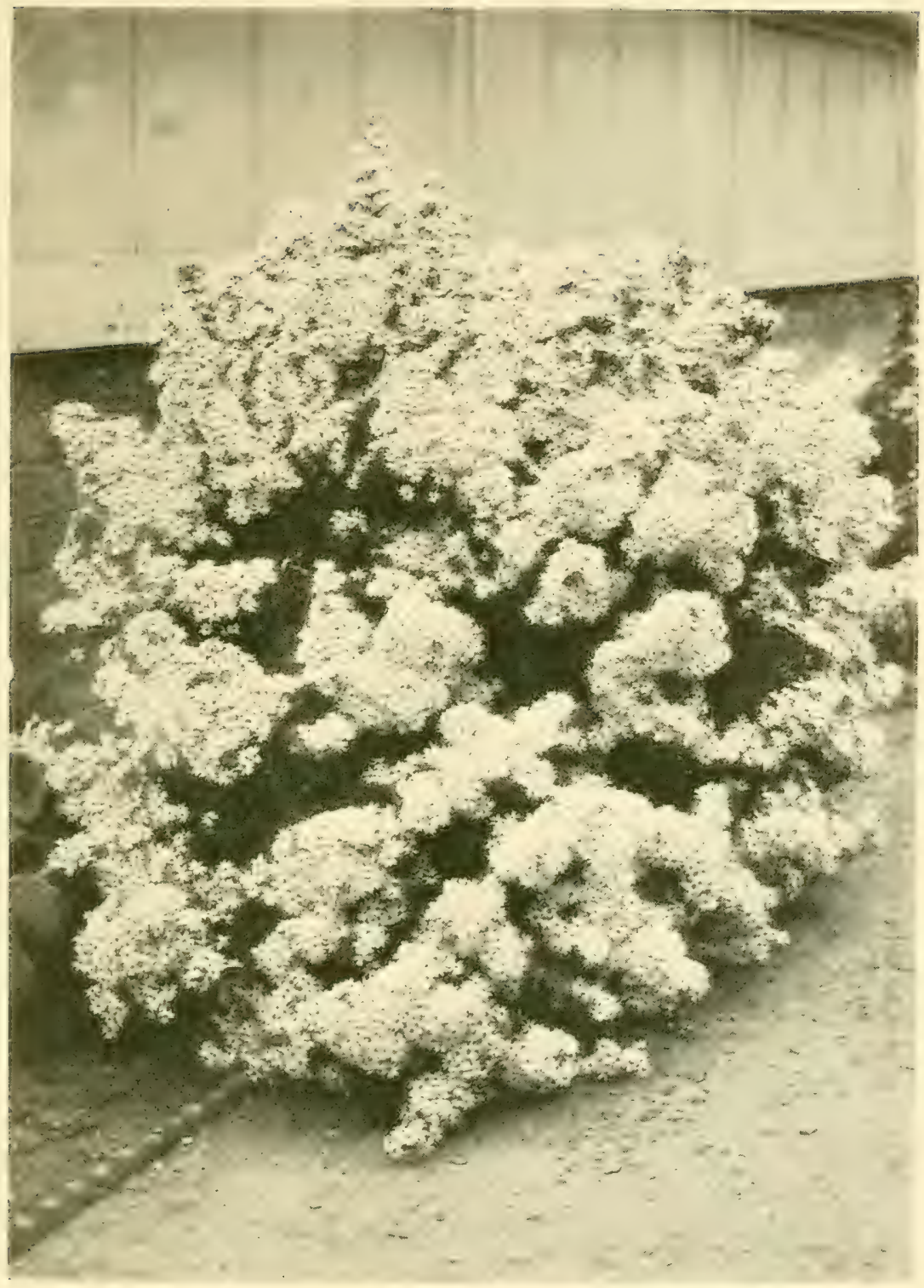

A NEW ZEALAND DAISY BUSH (OLEARIA STELLULATA 

First, there are the Trumpet Daffodils, in which the central trumpet is as long as, or longer than, the perianth or spreading portion of the flower. This section is subdivided into White, Yellow, and Bicolor Trumpet Daffodils, according to their colour.

The following are some of the best: Yellow-Admiral Togo, Emperor, Glory of Leyden, Golden Spur, Henry Irving, King Alfred, Lord Roherts, Maximus, Minimus (a tiny Daffodil), Obvallaris, P. R. Barr, Vin Waveren's Giant. White-Albicans, Cernuus, Madame de Graaff, Lady of the Snows, Mrs. Thompson, Pallidus Praecox, Peter Barr, W. P. Milner. Bicolor-Apricot, Duke of Bedford, Empress, Glory of Noordwijk, Grandis, Horsfieldii, J. B. M. Camm, Irs. Walter Ware, Princeps, Victoria, Weardale Perfection, William Goldring.

In the incomparabilis or chalice-cupped Narcissi, the cup is not less than one-third of the length of the perianth segments, but never equal in length.

A few of the best varieties are: Autocrat, Beauty, Blackwell, C. J. Backhouse, Frank Miles, Gloria Mundi, Lucifer, Orangeman, Red Star, Sir Watkin, Stella Superba, White Wings.

In the section known as Barri (which includes varieties formerly classed as Burbidgei), the central cup is of a length less than onethird of the rest of the flower. Some of the best are: Agnes Barr, Albatross, Beacon, Conspicuus, Crown Prince, Dorothy E. Wemyss, Falstaff, Flora Wilson, John Bain, Seagull.

The Leedsi section comprises those varieties of chalice-cupped (incomparabilis) and star Narcissi (Barri), which have white or creamywhite perianth, and a white, cream, or otherwise pale cup. Among the best are the following: Ariadne, Bianca, Duchess of Westminster, Elaine, Katherine Spurell, Mary Magdalene de Graaff, Minnie Hume, Mrs. Langtry, Peach, Salmonetta, Waterwitch, White Lady.

Those kinds known as Triandrus hybrids have been derived from Narcissus triandrus; they are distinguished by reflexed or spreading perianth and long, narrow cup, and usually have more than one bloom on a stem. Triandrus albus is the lovely Angel's Tears Daffodil, suitable for gritty soil in the rock garden or for growing in flower pots; triandrus calathinus has much larger blooms. Queen of Spain is a charming Narcissus of clear yellow colour, suitable either for the rock garden or pots. A few of the kinds raised during recent years are: Agnes Harvey, white; Cingalee, cream, with more deeply coloured trumpet; J. T. Bennett Poë, cream, with primrose trumpet; and Little Queen, which is remarkable for the fact that the trumpet is white and the perianth pale yellow. 
The Cyclamineus or cylamen-flowered Narcissi have reflexing perianth and long, narrow tube, and have been derived from Narcissus cyclamineus, a charming little flower of rich yellow colouring, the earliest of all the Daffodils to open. It likes a soil of loam and peat and a somewhat shady spot in the rock garden, while it is delightful for growing in flower-pots for the cold greenhouse.

The Jonquil, and those Narcissi that have been raised from it, give the name to another section known as Jonquilla. The single yellow Jonquil is a favourite kind, for it is easy to grow, and has fragrant yellow blossoms late in the season or in early Nay. The Campanclle Jonquil, with very narrow leaves and fragrant yellow blooms, and odorus rugulosus, with sweet-scented flowers of similar colour, are others of this class. A particularly fine new sort is called Buttercup; the bloom is of greatly improved form, and has some of the Jonquil scent.

The Tazetta (Polyanthus or Bunch-flowered) Narcissi are great favourites both for out-of-door cultivation and for growing in pots and bowls. A few of the best are: Grand Monarque, white, pale yellow cup ; Grand Solcil d'Or, yellow, orange cup; and Mont Cenis, white, with yellow cup. The favourite variety for forcing, the Paper White Narcissus, belongs to this group. The Poetaz Narcissi, raised by cross fertilisation between the Poet's and the Bunch-flowered kinds, are in this class and comprise some splendid kinds, such, for instance, as Aspasia, white, with yellow cup; Elvira, white, with orange-yellow cup; Jaune à Mcrveille, pale yellow, with deep yellow cup; and Triumph, white, with yellow cup. The flowers are in bunches on tall, stout stems.

The Poet's Narcissi (Poeticus) form another group; they have usually a white perianth and a small, flat crown, in the newer varieties often of vivid colouring. Among the large number now existing some of the best are the following: Almira, Cassandra, Epic, Homer, Horace, Lycidas, and Virgil. The old Poct's Narcissus and its var. poetarum, which has an orange-red crown, are still invaluable; they are among the last of the Narcissi to bloom.

The next group consists of Double Daffodils, and contains, among others, the Old Double Yellow kind (Telamonius plenus), Butter and Eggs, Codlins and Cream, and Orange Phoenix.

The last group comprises various species of Narcissus, many of which are very charming. The Hoop Petticoat Daffodil (Narcissus Bulbocodium and varieties), which are delightful for pots, or may be grown in loam and peat in the rock garden; juncifolius (the small Rush-leaved Daffodil), with dainty little yellow flowers; serotinus, 
that bears quite small blooms, white, with yellow cup, in October; and viridiflorus, the green Narcissus, which has little green blossoms in late autumn.

Prominent among the newer kinds are those known as Engleheartii Narcissi, which are distinguished by broad, spreading, perianth segments and flat, large crown, often of bright colouring. The larger varieties are now classed as incomparabilis or chalice-cupped Narcissi.

Narthecium ossifragum (Bog Asphodel).-This pretty plant, which belongs to the Lily family (Liliaceae), and is native of Europe (including Britain), thrives only in boggy spots and where it is fully cxposed to the sun. It produces grass-like leaves, while the yellow flowers are borne towards the end of the summer on stems about I2 inches high. Propagation is readily effected by division in early spring.

Nasturtium (Water Cress).-The only species to mention is the Common Water Cress (Natural Order Cruciferae), a well-known British plant which will thrive in boggy spots. In many districts it is much cultivated for the sake of its tender shoots, which are largely eaten as a salad. It is increased by cuttings, division, or by seeds in spring.

Nasturtium.-(See Tropaeolum.)

Navel Wort.-(See OMPHALODEs.)

Neillia is a group of shrubs closely allied to Spiraea; they belong to the Rose family (Rosaceae). A number of the species are coarsegrowing shrubs, but a few are of graceful appearance. The bestknown kinds bear white flowers in May, but there are one or two new Chinese sorts which bear pink flowers. Neillia opulifolia is perhaps the best known; a native of North America, it grows from 6 to 9 feet high; there is a golden-leaved form called lutea, which is valued for its yellow foliage. Neillia capitata and Neillia Amurensis are other vigorous sorts suitable for the back of a shrubbery. Neillia Sinensis, from Central China, is a new shrub of graceful growth with pink flowers; thyrsiflora, from the Himalaya, is also a graceful bush, but not very hardy. Plant in ordinary garden soil and cut out old branches sometimes. Increase by cuttings in summer.

Nemesia.-The chief interest in the members of this genus (which belong to the Snapdragon family, Scrophulariaceae, and are natives of South Africa) is centred not in the half-dozen species or so, but in the splendid race of hardy annuals that have been obtained from them. The kind that has played chief part in the production of the modern varieties is Nemesia strumosa, of which the flowers are of yellow or orange tint. New varieties with blooms in shades of 


\section{THE BOOK OF HARDY FLOIVERS}

bluc, white, yellow, orange, pink, carmine, scarlet, and crimson, can be obtained. Those with the larger flowers grow $\mathrm{I} 2$ inches or more high, but there is a dwarf strain with smaller blossoms, borne in profusion, the best being Blue Gem of Forget-me-not blue. For early flowering the seeds of the Nemesia are usually sown under glass in March, and the young plants put out when danger from frosts is over. The possession of a glasshouse is not necessary for the cultivation of these beautiful flowers, as seed sown out-of-doors late in April germinates frecly, and produces a wealth of blossom in July and August. Seedlings of the ordinary varieties may be put 6 or 8 inches apart, the dwarf kinds being somewhat closer. The Nemesias are not of vigorous growth, and are uscful, for example, for carpeting the ground beneath tall plants, such as Standard Roses. They are seen at their best in well-dug sandy loam, and in a sunny position.

Nemophila (Californian Blue Bell).--One of the most delightful of our hardy annuals (Natural Order Hydrophyllaceae) is Nemophila insignis, which was introduced from California as long ago as I8z2. It is of a free, spreading growth, and a succession of blossoms is kept up for a long time. The ordinary kind has blue flowers with white centre, but there are several varieties. Another species, commonly known as Nemophila atomaria, but which botanists tell us should be Menziesii, has spotted flowers; so, too, has the nearly allied Nemophila maculata. The Nemophilas may be sown in autumn for May flowering, and in spring for July blossom. Like most Californian annuals they need light soil and a sunny spot; they may be planted in a bed to themselves, or used as an edging or carpeting.

Nepeta (Catmint).-Some of the Nepetas are little more than weeds, though a few kinds are attractive. They belong to the Sage family (Natural Order Labiatae). Included among the best are Nepeta (ilechoma variegata, a variety of our own British Ground Ivy, of which the leaves are margined with white; it is a pretty creeping plant for moist spots in the rock garden. Nepeta macrantha is a good border plant that reaches a height of about 3 feet, and bears spikes of deep lavender-blue flowers from July to September. The most useful of all is Tepeta Mussinii, from the Caucasus, which forms a much-branched tuft about is inches high; the leares are greyish and fragrant. A continuous display of pretty pale-blue flowers is kept up throughout the summer. The last to mention, Nepeta spicata, is a pretty blue-flowered perennial, from the Himalaya, that reaches a height of about 2 feet and blooms during summer. The Nepetas named are perennial and will thrive in ordinary garden soil, and can be readily increased by division in autumn. Nepetal 


\section{NEPHRODIUM}

Mussinii is well suited for planting on an exposed sumny part of the rock garden, for there the grey foliage takes on its finest colouring.

Nephrodium (Male Forn).-Most of the Nephrodiums (Natural Order Filices) are natives of the Tropics, and therefore require the temperature of a warm greenhouse for their successful cultivation. The finest of all the hardy kinds is our own native Nephrodium Filixmas or Male Fern (often called Lastrea). It often forms quite a stem or trunk, from the apex of which the fronds are developed in a regular circular manner. Under cultivation many varieties have been raised, so that a selection of the varieties of Nephrodium Filixmas alone is sufficient to form an interesting fernery. Some of the crested kinds are very fine. Nephrodium dilatatum (Prickly Buckler Fern), which is more spreading than the Male Fern, with triangular shaped fronds; Goldieanum, with spreading bright green fronds; montanum, a pretty mountain species; and Thelypteris, with slender creeping stems, are other kinds. Nephrodium Thelypteris is known as the Marsh Shield Fern, and needs a shady, moist, somewhat boggy spot. All the others thrive in shade or half shade in soil with which leaf-mould has been freely mixed. These ferns may be increased by division during winter.

Nertera depressa (Bead Plant).-A charming little plant (Natural Order Rubiaceae), native of the mountainous regions of South America. It forms a dense tuft of creeping shoots, clothed with tiny, ovate, fle hy leaves; the flowers, which appear in summer, are insignificant, being of a dull greenish colour, but they are succeeded by berries which, when ripe, are of beautiful orange tint, and last in beauty for a considerable time. Nertera is more generally grown in pots or pans than in the open ground, but it will thrive in a partially shaded spot in the rock garden provided it is protected from wet in winter. It is readily increased by division carried out in spring. Until the plants are nicely rooted they should be kept in a slightly warm greenhouse, but subsequently a semi-shady airy frame is the place in which fruits are likely to form.

Neviusia alabamensis, sometimes called Snow in Summer, by reason of its profusion of fluffy white blossoms, is a native of Alabama and belongs to the Rose family (Rosaceae). In ordinary garden soil it grows into a wide-spreading bush 3 to 4 feet high. The flowers are borne in profusion during May or June, and out-of-doors are white or greenish-white in colour. When forced, however, they are pure white, and a well-flowered bush is a charming object. Propagate by means of cuttings in July, and thin the plants after flowering, cutting away some of the older shoots. 
New Zealand Bur.-(See ACAENA.)

New Zealand Flax.-(See Phormium.)

Nicotiana (Tobacco).-Some of the Tobaccos, which belong to the Natural Order Solanaceae, and are natives of South America, are grown for the sake of their handsome summer flowers, while others are remarkable for their large and striking foliage. They are usually looked upon as half-hardy annuals, though there is some doubt as to the correctness of this point of view. At all events, for the outdoor flower garden they should be treated as such; that is to say, the seed is sown in warmth early in March, and the young plants are potted and finally hardened off ready for planting out late in May. They need rather rich soil and a sunny situation. The best kinds are : affinis (also known as alata), of which the long tubular white flowers exhale such a delicious perfume in the evening; there are now many forms or varieties with colours ranging from white to violet and crimson, through various intermediate shades, all grow about 3 fect high. Nicotiana colossea and colossea variegata have huge leaves. and reach a height of 6 feet. Nicotiana Sanderae has deep rose or carmine flowers, and is about 3 feet high. Nicotiana sylvestris is of bold growth with large deep green leaves and pendent clusters of white flowers, 5 feet. Nicotiana Tabacum, interesting as yielding the Tobacco of commerce, is a handsome foliage plant, 4 to 6 feet high.

Nierembergia. - Though several species of Nierembergia, which belong to the Potato family (Solanaceae), and are natives of South America, are known to botanists, there is only one kind in general cultivation, namely, Nierembergia rivularis, a pretty little trailing plant which, though reaching a height of only two or three inches, soon covers a considerable space. It should be grown in the rock garden, in loamy soil with which a little leaf-mould and sand are mixed. The comparatively large, erect, bell-shaped flowers are borne throughout the summer. A second kind is Nierembergia frutescens; this, which is of a compact, somewhat shrubby habit, reaches a height of I 8 inches, and bears pretty blue flowers. Nierembergia rivularis can be readily increased by division in spring, while frutescens should be propagated by cuttings put in sandy soil and protected by a frame in August:

Nigella (Love in a Mist).-A charming class of hardy annuals, belonging to the Buttercup family (Ranunculaceac), and natives of the Mediterranean districts. Nigella damascena, known popularly as Love in a Mist and Devil in a Bush, has been long popular in this country. It grows from $x 8$ inches to 2 feet high, and has finelycut Fennel-like leaves, some of which surround the pale blue flowers. 


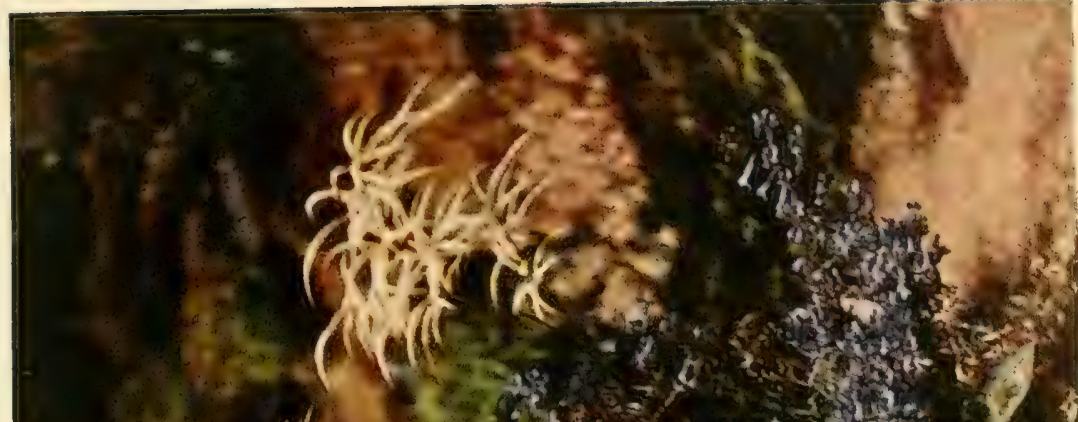

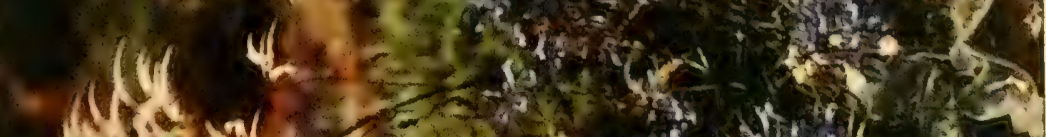

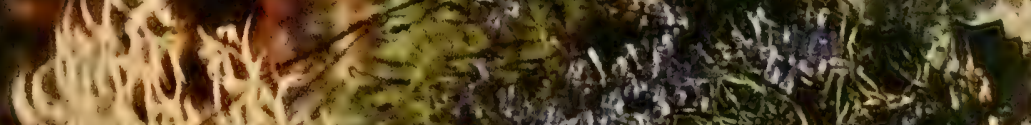
7. 1 .

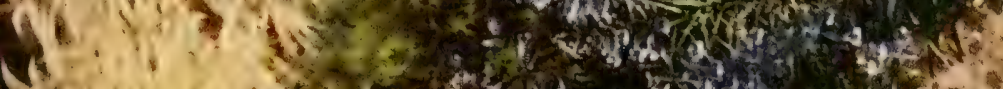
(a)

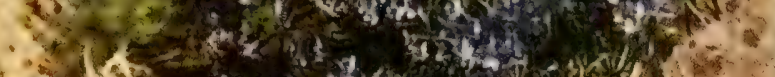

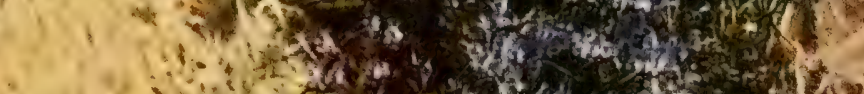
a.

3

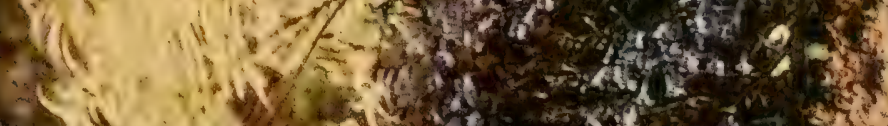

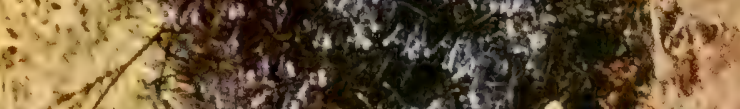

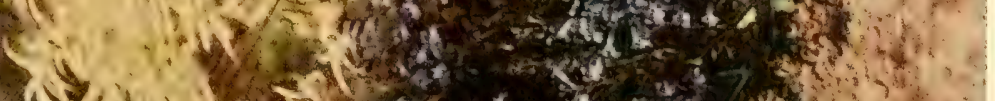

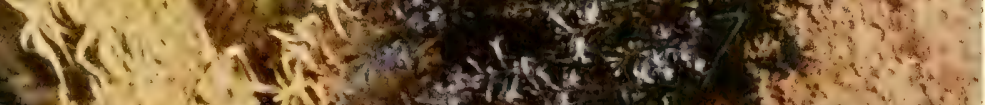

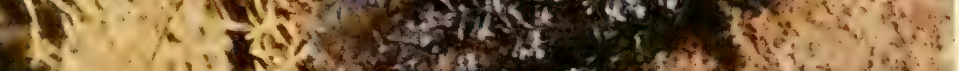
(5) 

There is a greatly improved variety known as Miss Jekyll, of which the blossoms are of deeper colouring. There is also a white variety (alba). The only other species of any value in the garden is Nigella hispanica, with purplish-blue flowers. The Nigellas are quite hardy, hence seed may be sown in autumn for an early display, and in April for a succession thereto. They do not transplant readily, for which reason they should be sown where they are to flower.

Noccaea (Hutchinsia).-Noccaea alpina is a pretty little European plant somewhat like a small Iberis, belonging to the Wallflower family (Cruciferae). It needs a warm, sunny spot and sandy soil in the rock garden, and bears white flowers throughout the summer. Noccaea petraea is a tiny plant of annual duration and of no particular value.

Notospartium Carmichaoliae, belonging to the I'ea family (Leguminosae), is a curious and rare bush native of New Zealand. Growing but a few feet high, it has curious slender rush-like branches, hearing dry-looking scales in place of leaves, but in June it produces a profusion of small Pea-shaped blossoms of a very pretty shade of pink. It can only be grown out-of-doors in the southern counties, and even then must have a sunny position. A place at the foot of a wall, where it can grow freely without being trained to the wall, is excellent. Give loamy soil and increase by seeds. Pruning is not required.

Nuphar (Yellow Water Lily).--A genus of free-growing aquatics with yellow blossoms. They belong to the Natural Order Nym. phaeaceae, are widely distributed in north temperate countries, and are very nearly related to the Nymphaeas. Nuphar advena, the large Water Lily of America, is too vigorous for small spaces of water. The leaves, and the flowers which are yellow outside and reddish within, rise considerably above the surface of the water. Nuphar lutea may be looked upon as the European form of the preceding. Nuphar minimum, sometimes known as Kalmianum, being of far less vigorous growth, may be planted in small ponds. If there is sufficient soil or mud at the bottom of the water all that is needed in planting is to tie the plant to a brick or some other weight, and drop it in the water at the spot where it is to grow. The weight will soon cause it to sink into the mud, where, pushing forth roots of its own, it quickly becomes established. Planting is best done in the spring:

Nuttallia cerasiformis.-This is the Oso Berry of California, belonging to the Rose family (Rosaceae), and one of our earliest flowering shrubs, for its blossoms often expand in February. It attains a height of 5 or 6 feet, and adds to its width fairly rapidly 
by means of suckers from the rootstock. Male and female flowers are borne by different plants, and it is necessary to plant the two sexes together if a crop of the red Cherry-like fruits is desired. The flowers are white, but not very showy. Ordinary garden soil suits; increase is by seeds or division of the clumps, and regular pruning is not required.

Nymphaea (Water Lily).-The genus Nymphaea (Natural Order Nymphacaceae) contains but few hardy species, but there are many varietics. Few phases of gardening have made so much advance in popular favour within the last decade or two as Water Gardening, and a great deal of this is no doubt owing to the numerous and manycoloured Water Lilies that have been raised. In nurseries where these beautiful Water Lilies are grown for sale, they are kept in pots for convenience of transit. When it is desired to establish them in ponds or spaces of water having a certain amount of soil at the bottom, the Lilies are usually planted in turfy loam in a loose, shallow wickerbasket that will easily decay; the basket is merely to hold the soil in position until the plants are well-rooted. To prevent the plant from floating a few pieces of string should be run across from side to sirle of the basket to hold the roots in place. The months of April and May are the best times to plant. A suitable depth of water for Nymphaeas is from I2 inches to 3 feet, according to their vigour. A running stream is not suitable for them, for the water is too colcl.

Some of the most desirable Water Lilies are Nymphaea alba, the common White Water Lily; Andreana, bright red; candidissima plenissima, double white; Carisbrookii, blush pink; colossea, fleshcoloured; Frocbelii, deep crimson, passing to carmine-purple; Gladstonii, pure white, semi-double; James Brydon, pink; Marliacea chromatclla, yellowish; Marliacea ignea, carmine-red; Marliacea rosea, bright rose; Robinsoniana, violet-purple, shaded red; sanguinca , bright crimson; W. Doogue, deep pink; and W. Falconer, ruby-red Less vigorous sorts suitable for small ponds and pools are: candida, white; Ellisiana, purplish; Laydekeri fulgens, amaranth; Iaydekeri rosea, carmine-rose; Laydekeri lucida, rose-red; odorata, white, fragrant, and pygmaea, white, the smallest of all.

Nyssa is a group of trees belonging to the Dogwood family (Comaccae). The species are natives of North America, where they often occupy wet land, and are known under the common name of Tupelo. Their principal attraction here is the brilliant autumnal colouring of the leaves, and for this reason they deserve more extended notice in the South of England. The two kinds most suitable for the British Isles are: aquatica and sylvatica. Plant in moist 
land, such as the bank of a lake or stream where the roots can enter the water, and choose a position exposed to south and west. Increase by seeds in spring and prune in summer to shape the trees.

Oak Fern.-(See Polypodium Dryopteris.)

Ocimum (Basil).-Annual or perennial plants belonging to the Sage family (Labiatae), few of which have any particular horticultural value. The best known is the Sweet Basil (Ocimum Basilicum), a well-known fragrant herb with white blossoms; it is readily increased by means of seeds sown in spring.

Oenothera (Evening Prinrose).-An extensive group of plants (Natural Order Onagraceae), natives chiefly of North America. Some are annuals and others biennials, but the majority are of perennial duration. By far the best known is the common Evening Primrose (Oenothera biennis), of which the golden-yellow blossoms are so conspicuous towards the close of the day. Though some kinds are suitable for the rock garden they are not particular as to soil, and will thrive in sandy loam, provided they are in a sunny spot. The common Evening Primrose and some of the other strong-growing kinds are well suited to the wild garden or woodland. Oenotheras may be increased by seeds, division, or by root cuttings. Seeds should be sown in spring, division being practised and root cuttings taken in autumn.

The chief kinds are: acaulis (also known as taraxacifolia), with large white flowers on trailing stems throughout summer, and leaves like those of the Dandelion, 6 inches; biennis, common Evening Primrose, 4 to 5 feet; eximea (caespitosa), large white flowers in July and August, changing to pink with age, I2 inches high; Fraserii (glauca), golden-yellow flowers all summer, 2 feet; fruticosa major, deep yellow, June until autumn, 2 feet; Missouriensis, with rich yellow blooms in summer, is a charming trailing plant for the rock garden; ovata has 4-inch high tufts of narrow leaves and golden-yellow flowers from April to June; pumila is a tiny plant, 4 inches high, with yellow flowers in summer; speciosa bears satiny-white blossoms from June to September, 2 feet, and tetraptera rosea bears rose-coloured blooms all the summer, I2 inches high. The annual kinds of Oenothera are more commonly known as Godetia, and are described under that name.

Olea (Olive) is a group of evergreen trees and shrubs (Natural Order Oleaceae), the most familiar of which is the Common Olive (Olea europaea). This is cultivated extensively in Southern Europe, South Australia, California, and elsewhere for the sake of the oil expressed from the pulp of the fruits. This oil is known as olive oil, and is used for culinary purposes, the manufacture of the higher grades 
of soap, and other things. l'ure olive oil is very valuable, but it is often adulterated for minor uses. The Common Olive can be grown out-of-doors in Devonshire, Cornvall, and other places with a similar climate ; elsewhere it needs the protection of a wall. Plant in ordinary garden soil, increase by seeds or cuttings, and prune only to keep the bushes shapely. Plants grown for fruit in Southern Europe are often pruned into bush form to facilitate the collection of the fruits, and resemble bush Apple trees. Olea glandulifera, from the Himalaya, and verrucosa, from South Africa, may also be grown out-of-doors in the milder counties. The Common Olive is the host of several kinds of Mistletoe, one with red and another with yellow berries being effective in winter.

Olearia (Daisy Bush).- This is an interesting and useful group of evergreen shrubs, natives of New Zealand and Australia, belonging to the Daisy family (Compositae). Only one species can be said to be genuinely hardy throughout the British Isles, but many may be grown in the south-west counties, and others thrive in selected situations elsewhere. They are often called Daisy bushes by reason of their Daisy-like heads of flowers which are borne with considerable freedom during summer. They thrive in ordinary garden soil, preferably rather light. Some kinds are increased by cuttings in summer and others by seeds. Pruning is usually confined to shaping the bushes and keeping them from outgrowing their positions. As a rule they stand severe pruning well, providing it is done in spring, April being a good time. Less severe pruning may be conducted after the flowers have fallen.

The chief kinds are: Haastii, a New Zealand species, the hardiest of all and one of the most generally useful shrubs we possess; it usually grows from 3 to 4 feet high, forming a shapely bush with little attention to pruning. The ovate leaves are deep green, about $I$ inch long and thick in texture, and the white flowers appear with great freedom in July. It may be used for large masses, groups in shrubberies, isolated specimens or hedges, either inland or fully exposed to sea air. Olearia macrodonta, from the same country, is a more vigorous bush, sometimes exceeding 6 feet in height ; its oblong leaves have prettily wrinkled margins; it thrives fairly well in many parts of the country. Olearia stellulata is an exceedingly pretty little bush 2 feet or so high, with small greyish-green leaves, and bears a profusion of white flowers in May or June; an excellent plant for the rock garden, or for a sheltered position elsewhere; it may also be grown in pots for greenhouse decoration: Olearia argophylla, from Australia, is familiarly termed the Muskwood by reason of its Musk- 


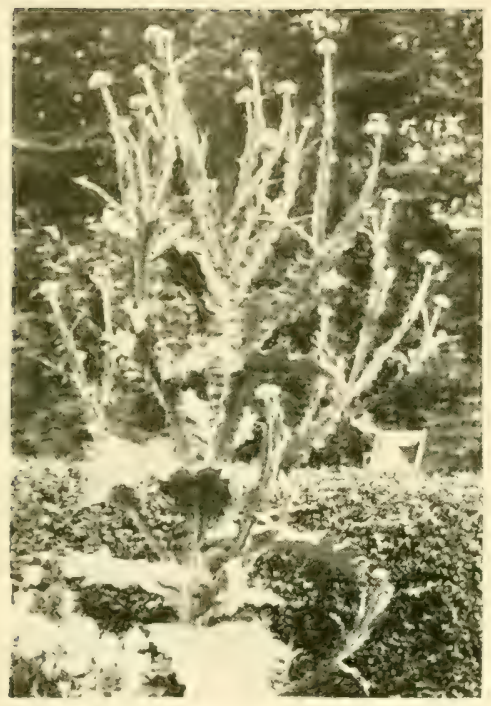

THE COTTON THISTLE

(ONOPORDON ACANTHIUM)

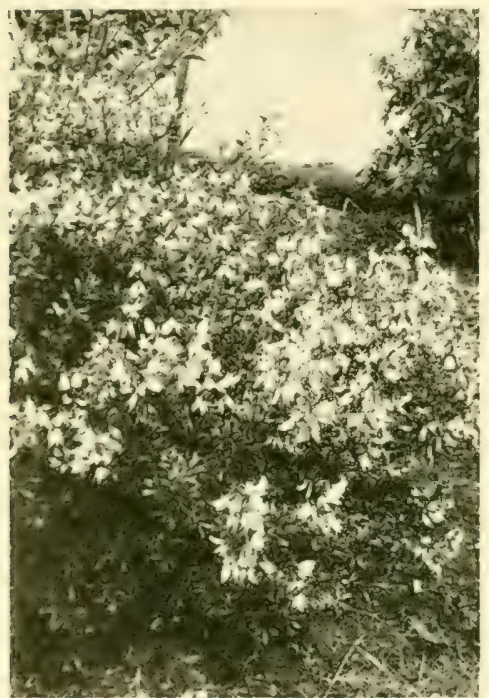

REST HARROW (ONONIS FRUTICOSA)

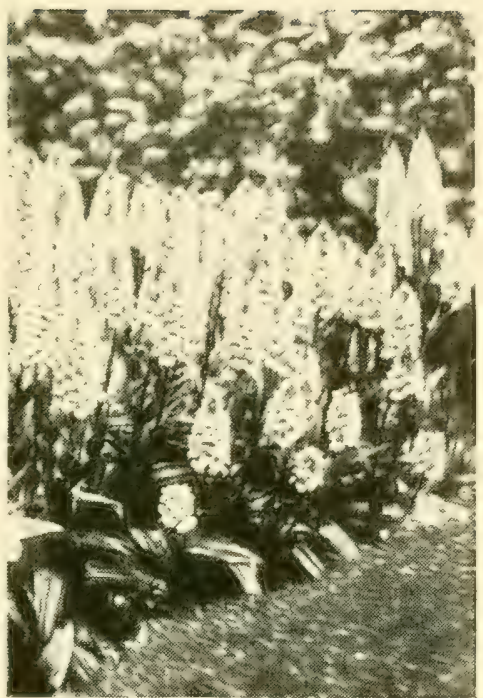

THE MADEIRA ORCHIS (ORCHIS FOLIOSA)

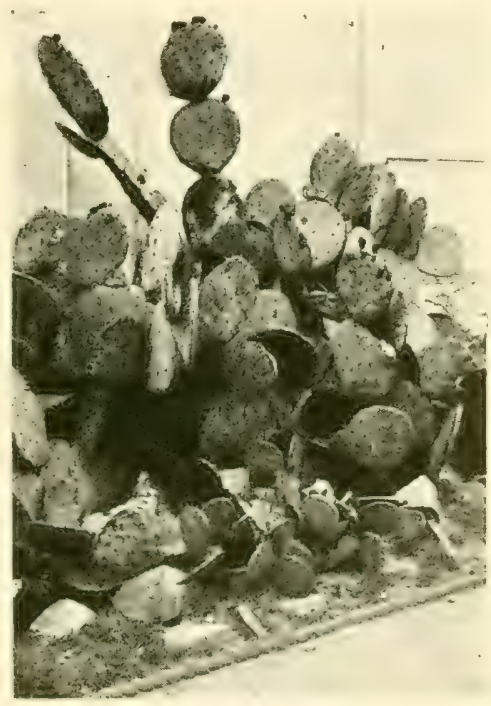

THE PRICKLY PEAR (OPUNTIA) 

scented leaves; it attains the dimensions of a small tree, but is only of value for the warmer counties. Other useful kinds for warm gardens are: compacta, Forsteri, insignis, nitida, nummularifolia, pannosa, and Traversii.

Omphalodes (Navel Wort).-These attractive plants belong to the Borage family (Boraginaceae), and are natives principally of the Mediterranean region. Omphalodes linifolia is a charming little hardy annual, which is seen to advantage in a sheltered, partially shaded spot in the rock garden; it is usually somewhat less than I 2 inches high, and the neat white flowers are freely produced; once established from seeds sown in spring it very often reproduces itself from selfsown seeds. Of the perennial species the best are cappadocica (cornifolia), from Asia Minor, with rich blue Forget-me-not-like flowers in early summer, I2 inches; nitida, native of Portugal, with bright blue flowers from March to June, 12 inches; verna, from Southern Europe, intense blue, May to August, 6 inches; and Luciliae, from Greece, with glaucous leaves and lilac-blue flowers in June. The perennials need a sheltered position in the rock garden and welldrained sandy loam. The most difficult to grow is Luciliae, which needs gritty loam and half shade; nitida ought to be kept in a frame during winter, for it is not very hardy. Seeds sown in autumn or spring afford a ready means of increase.

Onoclea sensibilis. - A very pretty hardy fern (Natural Order Filices), native of North America, nearly related to the Royal Fern (Osmunda), and, like this, bearing its spores on separate fronds. It attains a height of 18 inches to 2 feet, and grows freely in good soil in a moist and moderately shaded spot. It is increased by division of the creeping rhizomes before growth recommences.

Ononis (Rest Harrow).-Shrubby, sub-shrubby, or herbaceous plants from temperate climes, belonging to the Pea family (Leguminosae). Ononis spinosa is the British plant which is known familiarly as the Rest Harrow; it is a pretty half-shrubby kind with showy pinkish Pea-shaped flowers, and is found in dry pastures and sandy wastes near the sea throughout the country. One of the best of the shrubby kinds is Aragonensis, a dense bush I to 2 feet high, native of the Pyrenees; its Pea-shaped flowers are golden and borne in profusion during May and June; it is a sun-loving plant, and excellent for an exposed position on the rockery. Propagate by cuttings or seeds and remove the old flower-heads after the flowers have faded. Ononis fruticosa and rotundifolia are showy shrubs with rather soft wood; both produce pinkish flowers in profusion during early summer. They are natives of Southern Europe, and require full sun with light 
loamy suil. Increase is carried out by means of seeds. Pruning may take the form of shortening the longest shoots in spring. They are equally at home in the rock garden or border.

Onopordon (Cotton Thistle).--Some of these striking plants are well worth a place in the wild garden or woodland, or even in a large borler; they belong to the Daisy family (Compositae), and are natives of Europe and Asia Minor. The best are Onopordon Acanthium (Scotch Thistle), bracteatum, and opolucephalum. The flowers of each are purplish-white, the plants reach a height of 6 to $S$ feet. They are readily raised from seeds and will grow in ordinary soil. Seed should be sown in spring.

Onosma (Golden Drop).--Pretty plants belonging to the Borage family (Boraginaceae) with flowers chiefly of some shade of white or yellow. They thrive in sandy loam, but are apt to suffer unless the soil is well drained, for which reason they are seen at their best in the rock garden in a spot fully exposed to the sun. They grow from 6 to I2 inches high, and bear their tubular-shaped flowers in terminal, partially drooping, racemes. The principal species are: albo-roseum, white, changing to pink; Bourgaci, pure white; echioides (often known as taurica), golden-yellow; and stellulatum, Jellowish. They all bloom more or less throughout the summer, and can be increased by seeds or by division. Seeds should be sown in spring and division carried out in early autumn. All have hairy foliage, and they must be in a sunny spot; it is wise to protect the plants from rain in winter by a pane of glass supported some inches above them. They are natives of Southern Europe and Asia Minor.

Ophioglossum (Adder's Tongue).-This strange-looking plant, which grows wild in Britain, would not be looked upon by the uninitiated as a member of the Fern family (Natural Order Filices), as in general appearance it is widely removed from plants of that order. In a wild state it frequently occurs in grassy meadows, where in a moderately moist situation it will grow 12 inches high, but in lrier uplands its height is much less. It is deciduous, and forms a bud, not a tuber, from which fleshy horizontal roots are produced. These occasionally develop a bud, and thus form a plant some inches from the parent. The simple barren fronds of Ophioglossum are borne on long stalks, and are similar in shape to an arrow-head. The fertile frond is like a tongue, the spore cases being arranged in two opposite rows. Wonderful medicinal values were formerly attached to Ophioglossum. It will thrive in a cool, fairly moist part of the rock garden in loamy soil.

Ophrys (Bie Orchis). - A group of Orchids (Natural Order Orchidaceae), found wild in Britain, that form roots of a more or less tuber- 
ous nature. They are not at all showy, but are extremely interesting from the fact that the flowers bear a certain resemblance to insects, etc.; hence their popular names. They succeed best in chalky loam and in a partially shaded position. Some of them occur freely on the chalky downs in the South of England. The chief kinds are : apifera (Bee Orchis), flowers green and rose; Arachnites (Black Spider Orchis), rose-purple and green; aranifera (Spider Orchis), green and brown; bombilifera (Humble Bee Orchis), chocolate-brown and green; lutea, yellow and purple; speculum, green, yellow, and blue; and muscifera (Fly Orchis), green and dark red. All bloom in early summer.

Opuntia (Prickly Fig).--The hardy kinds, of which there are very few, are dealt with under the heading of Cactus.

Orchis. - The various kinds of Orchis (Natural Order Orchidaceae) are terrestrial Orchids, native chiefly of Europe and Asia Minor, while some are found wild in Britain. Orchis foliosa, which comes from Madeira, is one of the most handsome of all. In peat and loam, in a cool, moist spot, the flower stems will reach a height of from IS to 24 inches; the blooms are purplish-rose and open in May. The Marsh Orchis (latifolia) is a showy native plant, about I2 inches high, bearing purplish blossoms in June. The Spotted Orchis (maculata), also found wild in Britain, has handsomely spotted leaves and rose-purple blooms in early summer. A variety of this, known as superba, is especially fine. Others are: mascula, 4 or 5 inches high, with purplish flowers in April-one may sometimes find a meadow carpeted with this kind; pyramidalis, I2 inches, having rose-coloured flowers in June; and the Soldier Orchis (militaris), which grows about 15 inches high, and bears purplish blooms in April. All these kinds may be grown in loam and peat with which sand is mixed, and need a fairly cool spot; they dislike being disturbed, and should be planted as early in autumn as the roots can be obtained.

Origanum (Marjoram).-One species of Origanum (Natural Order Labiatae), namely vulgare, is a well-known herb, being extensively grown under the name of Marjoram. It is of no particular ornamental value, but the others are exceedingly pretty little bushy plants, about I foot high, that form a pleasing feature on a sunny part of the rock garden where they bloom during summer. The little ovate leaves are densely hairy, and the popular name of pink Hops conveys a good idea of the general appearance of the inflorescence. The best are Dictamnus (Dittany of Crete), and hybridum, both with pink flowers, and pulchrum, in which the blooms are pale rose. Origanums thrive in ordinary sandy soil, and may be increased by division when 
dommant, or hy cuttings of the goung shoots taken when they are about 3 inches long, inserted in pots of sandy soil, and placed in a close frame until they root, after which they can be planted out-ofdoors.

Ornithogalum.-An extensive group of bulbous plants (Natural Order Liliaceae), natives principally of the Mediterranean region and South Africa. The South African kinds can only be planted in a well-drained border, close to a warm wall, such as is recommended for Babiana. Many of the others, however, are quite hardy and of considerable value in the garden. The best are: arabicum, having large white flowers with dark centre, on spikes I 8 inches high; nutans, with drooping Blue Bell-like flowers of silvery-grey and greenish tint; pyramidale, pure white, striped with green at the back; pyrenaicum, greenish-yellow; and umbellatum (Star of Bethlehem), whitish starry flowers, borne close together on a short sturdy spike. The lastnamed flowers in spring, the others in early summer. The bulbs should be planted by the end of September in sandy loam. Ornithogalum umbellatum is a most accommodating plant, and thrives excellently in a shady border, or may be planted in grass.

Orobus.-(See LATHYRUS.)

Orobus vernus (Spring Vetch). - This is a pretty little border plant, native of Europe, and member of the Pea family (Leguminosae); it grows about I2 inches high, thrives best in sandy, welldrained border soil, and bears purplish-blue flowers in April.

Orontium (Golden $C l u b$ ). - A plant belonging to the Natural Order Araceae, and native of North America; in general appearance it is similar to Arum. It has a fleshy rootstock, from which thick, dark green, ovate leaves are produced, while in May the golden clublike blossoms are produced. This Orontium is an aquatic, and if planted in good soil at the bottom of 6 to I2 inches of water, it will grow rapidly.

\section{Orris Root.-(See IRIS FLORENTINA.)}

Osmanthus.-. This is a useful family of evergreen shrubs be. longing to the Olive family (Oleaceae). The commonest species is Osmanthus Aquifolium, from Japan; it forms a shapely bush, 3 to 5 feet high, with Holly-like leaves, possessing the peculiarity of those of the Common Holly, namely, of being spiny-margined on young plants and almost spineless on aged specimens. The flowers are white, fragrant, and borne during winter. The variety purpureus differs from the type by having purplish leaves, whilst variegatus has silver variegated foliage, and rotundifolius small and more rounded leaves than the typical kind. There are other kinds, such as lati- 


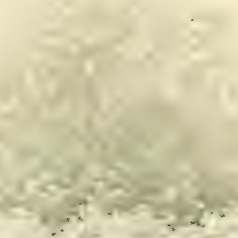

-

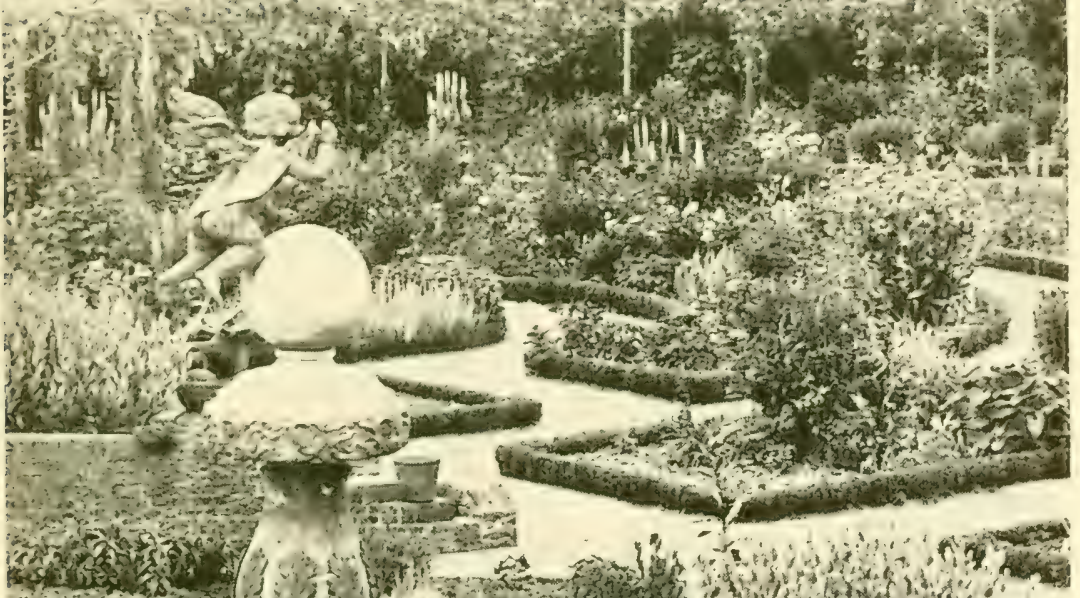

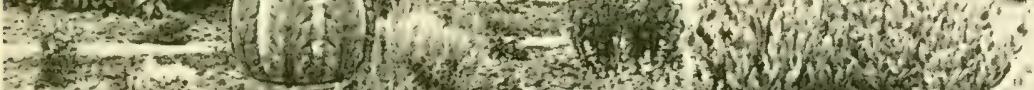

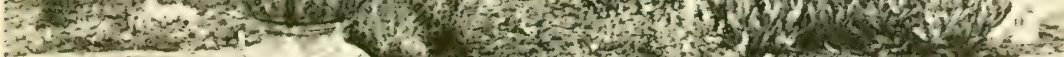

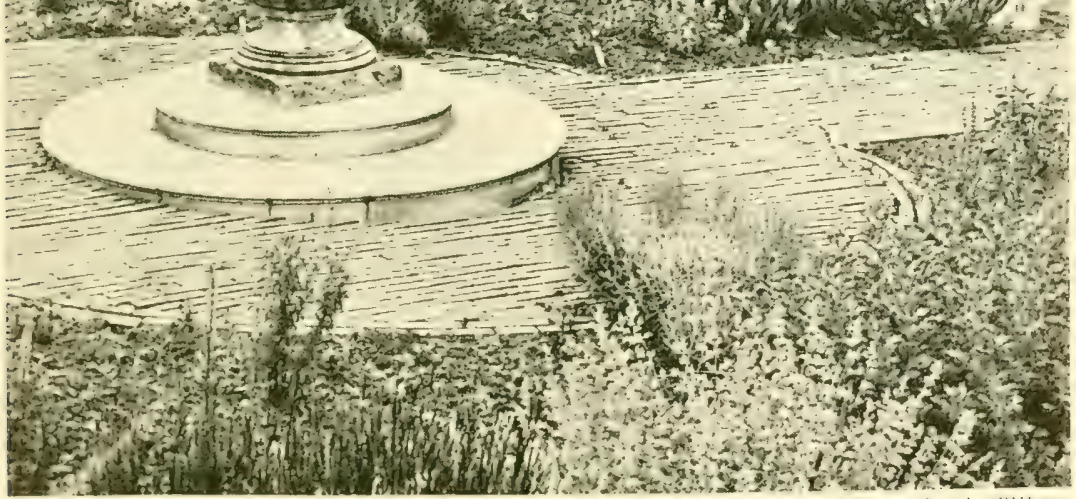

HARDY HERBACEOUS FLOWERS IN A FORMAL GARDEN 
folius, with larger leaves; and Delavayi, a smaller bush, with rather small leaves and pretty white flowers. All thrive in loamy soil containing a little peat, and may be increased by cuttings inserted in sandy soil in a warm and closed frame in summer. Pruning to shape the bushes may be done during summer.

Osmunda (Royal Forn).-Of our various hardy Ferns, Osmunda regalis (Natural Order Filices), is unsurpassed, for, given a suitable position, it will grow from 6 to 8 feet in height, or even more. It is popularly termed the Royal Fern, and certainly that title is well deserved. This fern, which is found wild over the greater part of the globe, is seen at its best in this country in wet, marshy districts. There it forms a mass of solid rootstocks, bound together by stout black wiry roots, totally unlike those of any other fern. The fronds -which are bi-pinnate or twice divided-are from 3 to 6 feet in length. The spores are borne, not at the back of the fronds, but on spike-like masses towards the upper part of the fronds in the centre of the plant. For waterside planting this fern is one of the best plants we have. Two North American species are also very beautiful, but they do not need so moist a spot as the Royal Fern, although they must be watered freely in summer. They are: cinnamomea and Claytoniana, which form handsome tufts 2 feet high and twice as much through; the fronds are but once divided instead of twice, as in Osmunda regalis. Strange to say, when only barren fronds are produced cinnamomea and Claytoniana are difficult to distinguish from each other, but the fertile fronds of the former are wholly spore-bearing, while in Claytoniana the capsules are confined to the middle of the frond, both the lower and upper part being barren. A pretty small Osmunda is japonicum corymbiferum, which grows only about I2 inches high, while the points of the spreading fronds are prettily crested; it is not adapted for planting under such conditions as the others, but for a damp spot in the rock garden it is well suited.

Ostrowskia magnifica (A siatic Bell Flower).-When well grown this must be regarded as one of the most striking of herbaceous perennials. It belongs to the Natural Order Campanulaceae, and is native of Central Asia. The roots, which are thick, fleshy, and excessively brittle, produce stout stems 4 to 5 feet high, terminated by numerous open bell-shaped flowers, about 6 inches across, mauve and white. The plant should not be disturbed; the best results are obtained by planting it in deep, rich, well-drained loam with which some old mortar has been mixed. A warm and sheltered position, such as at the foot of a south wall, is essential. Ostrowskia can be raised from seeds sown in sandy soil as soon as ripe, and placed in a frame. 


\section{THE BOOK OF HARDY FLOWERS}

The young plants, when sufficiently advanced, should be planted in their permanent quarters.

Ostrya.-This is a group of trees allied to the Hornbeam and belonging to the Natural Order Corylaceae. The commonest species is carpinifolia, the Hop Hornbeam, of Southern Europe and the Orient. The common name refers to the general aspect of the tree, which resembles that of the Hornbeam, whereas the fruit has a Hop-like character. It forms a moderate-sized round-headed tree with exceptionally hard and heavy wood. Ostrya japonica, a native of Japan, is less well known, and quite young trees are its only representatives in the British Isles; the fruits are rather ornamental and Hop-like. Ostrya virginica, the Ironwood of North America, is a distinct tree suitable for park planting. All thrive in ordinary garden soil, preferring that of a loamy nature. They are increased by seeds and pruning is directed towards keeping young trees in shape and the leaders clear. This may be done in summer.

Othonnopsis cheirifolia.-The only member of the genus Othonnopsis in general cultivation is cheirifolia, which forms a spreading plant about 12 inches high, clothed with grey, thick evergreen foliage. It belongs to the Daisy family (Compositae), and has yellow Marguerite-like flowers on long stems. It is a first-rate plant for a dry, sunny position in the rock garden, where it will flower from June until August; a thoroughly drained spot is necessary. It can be propagated by division, or by cuttings of the young shoots in spring as soon as they are sufficiently advanced. They must be protected by a frame or hand-light until rooted.

Ourisia coccinea.-A charming perennial that will keep up a succession of its scarlet Pentstemon-like blossoms from summer until autumn. It belongs to the Snapdragon family (Scrophulariaceae), and is native of the island of Chiloe, South America. It grows from 9 to $\mathrm{I} 2$ inches high. The conditions most favourable to its success are a moist soil and a partially shaded spot. It is increased readily by division in early spring.

Oxalis (Wood Sorrel). - The Wood Sorrels form an extensive group of low-growing plants, native of South America, South Africa, and other countries, and belonging to the Geranium family (Geraniaceae). Many of them have tuberous roots. A few of the hardy kinds are favourite rock garden flowers. The British Wood Sorrel, or, as it is sometimes called, Shamrock (Oxalis Acetosella), is a pretty little native wild flower, found wild in partially-shady spots and in leafy soil ; its dainty white flowers open in April ; it is charming for grouping here and there in odd corners of the rockery or the wood- 
land. Oxalis adenophylla, pink, and enneaphylla; white, reined with lilac, are invaluable flowers for the rock garden; they have grey, deeply-cut, rounded leaves, and in summer bear their beautiful blooms in profusion. Rosea is an attractive variety of Oxalis enneaphylla, having rose-coloured blooms. A half-shady spot and a compost of loam and leaf-soil, together with a free sprinkling of sand and grit, suit them well. Both kinds are natives of the Falkland Islands. Oxalis corniculata rubra is a free-growing creeper with bronze leafage and yellow flowers in spring; it spreads very quickly, and should not be grouped among choice plants.

Oxycoccus is a group of shrubs (Natural Order Vacciniaceae), allied to Vaccinium. Two species are sometimes grown: macrocarpus, the American Cranberry, and palustris, the Common Cranberry of the Northern Hemisphere. Both are of shrubby character, but of more or less prostrate growth, the branches rarely rising more than 9 inches above the ground. Essentially bog-loving plants, they do little good in dry positions, though they may sometimes be kept alive in borders by giving the soil a mulch of sphagnum moss to conserve the moisture. The flowers are pinkish, and the red fruits are showy in autumn and winter. Increase is by seeds or division. Pruning is not required.

Oxydendron arboreum is the Sorrel Tree or Sourwood of North America. It belongs to the Heather family (Ericaceae), and here is seen as a bush or sometimes as a small tree I2 to I5 feet high. The leaves are deciduous, and turn to a brilliant scarlet or orange-scarlet tint in autumn, while about July or early August the large panicles of white flowers are also attractive. It is a somewhat fastidious plant, and only gives the best results when planted in naturally moist peat or sandy loam containing a little peat, and in a sunny position. Its beauty, both as regards flowers and autumnal colouring, however, entitles it to consideration. It is increased by seeds. The flowerheads should be removed when the flowers fade; regular pruning is unnecessary. It gives good results in some parts of Surrey.

Oxytropis.-Dwarf Vetch-like perennials, belonging to the Pea family (Leguminosac), growing about $\mathrm{x} 2$ inches high. They thrive best in hot, dry soils, and bloom during summer. The chief kinds are: alpestris, cream; argentea, white; Lambertii, rosy-carmine ; and ochroleuca, yellowish. They can be raised from seeds sown in spring and placed in a frame until the seedlings are sufficiently advanced to be removed to the open ground.

Pachysandra.-A small group of low-growing evergreen shrubs, belonging to the Spurge family (Euphorbiaceae). Two species 
are sometimes grown, procumbens, from North America, and terminalis, from Japan. They usually grow about I foot high, and spread hy means of shoots from the rootstock. Plant on the rockery or in a border in light loam, increase by division, and do not prune regularly. These plants are of no great value.

Paeonia (Pacony).-As far as actual species or wild types are concerned, the genus Paeonia, which belongs to the Buttercup family (Ranunculaceae), is not a particularly extensive one. There are, however, innumerable garden varieties which serve to place Paeonies in the front rank of hardy herbaceous plants. The Paconies are divided into two classes, firstly, those that are herbaceous-i.c. dying to the ground during winter-and secondly, the so-called Tree Paeonies. These are not strictly trees, but they are of a woody character, and form permanent shrubs.

l'rominent among the herbaceous kinds are: albiflora, white, the parent of many garden varieties; anomala, from Siberia, prettily cut leaves, rose-coloured flowers; arietina, native of the Orient, rose; Emodi, from China, white; officinalis, native of Europe, rich crimson; peregrina, from the Orient, bright crimson; tenuifolia, dark crimson; and Wittmanniana, yellowish.

Paconia officinalis, the commonest of all, is a magnificent plant and among the earliest of the Paeonics to expand, being at its best towards the end of May and early June; it is, however, forestalled by Paconia anomala. Even before the blossoms appear Paconia officinalis is attractive, as the young foliage and leaf stalks are heavily tinged with red; by the time the flowers expand the leaves acquire their normal deep green tint. This species is one of the most vigorous, and will hold its own under varied conditions. In the herbaceous border it forms a striking feature, but is seen to even greater advantage in boid groups in the shrubbery or other conspicuous places. The fact that this magnificent Paeony can be purchased cheaply is another point in its favour.

Of the garden varieties of herbacenus Paconies there is a very long list, from which a selection serves to maintain a display in late May and throughout June. All the following are good: Abel de Pujol, clear rose; Albatross, white; Ambrose Verschaffelt, violetcrimson; Canary, yellowish; Caroline Allain, soft pink; Constance Devret, ruby-carmine; Duchesse de Nemours, white, shaded in the centre with lemon; Faust, pale pink; Festiva maxima, white; Gloire de Douai, rich amaranth red; Henri Demay, crimson-rose; Jules Lebon, rich rose; Marie Lemoine, creamy-white; Madame Emile (jalle, rich pink; Millais, amaranth red; Octavie Demay, 


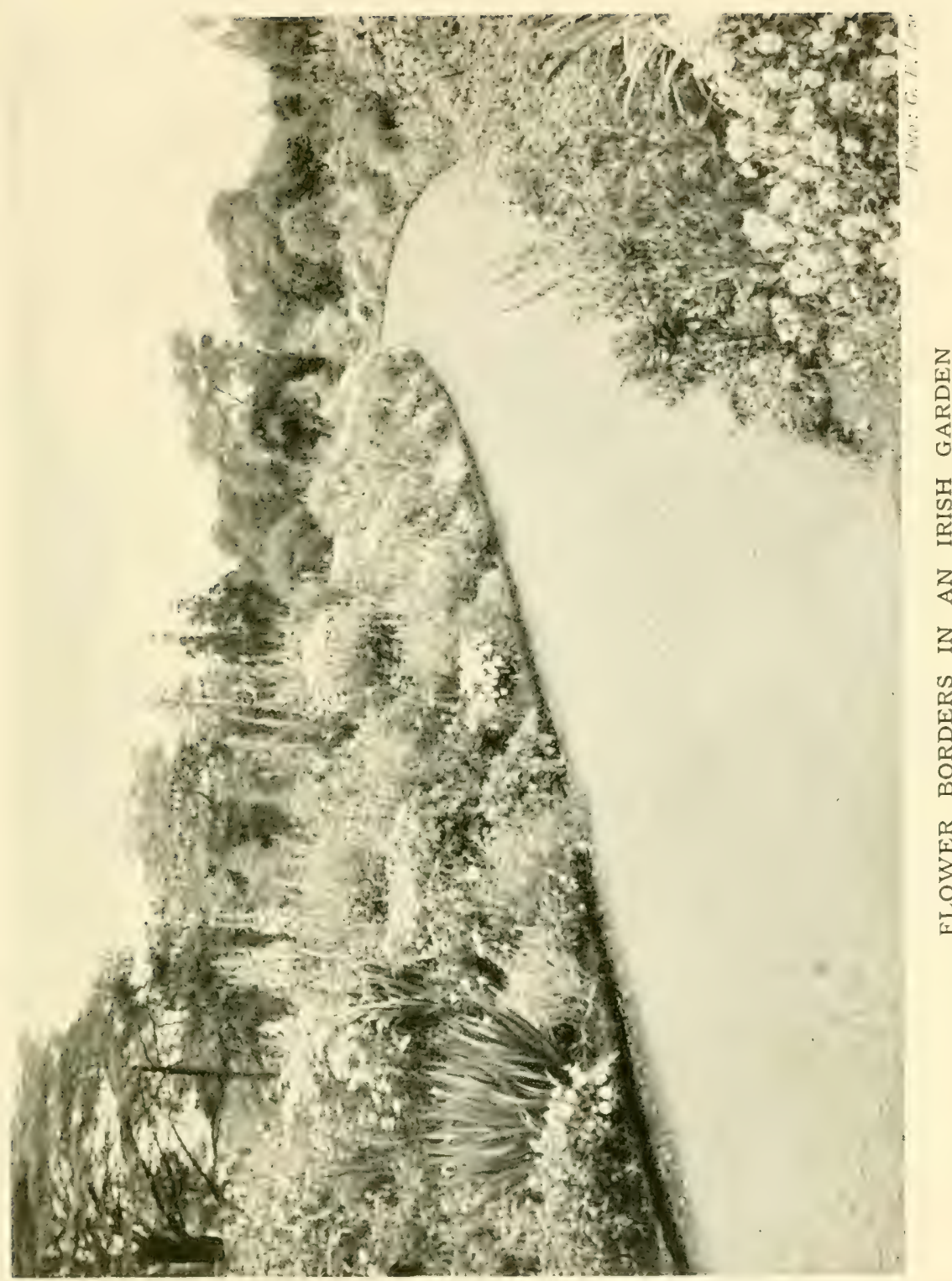



pink, very early; Reine des Roses, rose; Surpasse Pottsii, dark crimson; Tricolor, rose, yellow, and lilac; Vicomte de l'Alma, violetred; Victor Lemoine, carmine; and Virginie, light lilac-rose. The above-named varieties have double or semi-double flowers.

The following are single: Abyla, rose ; albiflora carnea, pale pink ; albiflora simplex, white; Dorothy, silvery-pink; Enchantress, rich rose; Kathleen, rose, shaded white; Rosy Morn, pale blush; and Twynham Glory, pink.

In order to have Paeonies at their best the soil should be deeply dug, some well-decayed manure being mixed in, though the ground must not be made too rich. The most suitable soil is sandy loam ; it is far preferable to heavy land, though this may be improved by adcling sand, wood ashes, and fine mortar rubble. The time and manner of planting are of some importance. Paeonies ought not to be transplanted often, for once established they will continue to flower in a satisfactory manner for years, especially if given a mulching of decayed manure in early spring. Transplanting should be done towards the end of September and in October, not later. In transplanting old clumps of Paconies, success cannot be looked for if they are simply lifted and planted undisturbed in their new quarters. The clumps should be broken up into pieces, consisting of four or five crowns. It is not sufficient to chop them into pieces with a spade ; the way to proceed is to take two garden forks placed back to back and drive them into the roots well below the crowns; by pressing the handles outwards the clump will be wrenched asunder without injuring the shoots. After this a strong knife, carefully used, will do the rest. The roots must be planted at such a depth that the crowns are about 2 inches below the surface, while 2 feet apart is a suitable distance to place them.

Tree Paeony. - The only Tree or shrubby Paeony in our gardens for many years was the Japanese Paeonia Moutan. This has been supplemented by Paeonia lutea, a yellow-flowered kind from China, at present rare. Rarer still and very costly are some hybrids between the two. Paeonia Moutan and its varieties need deep loamy soil, and a situation where the morning's sun does not shine on them; though perfectly hardy they start into growth early, and the young shoots are liable to injury by late frost. The damage is all the more severe if the sun shines on them when frozen. The typical Paconia Moutan has large white flowers, with a blotch at the base of the petals; the varieties vary in colour from white to deep crimson: Most of these are of Japanese origin and bear Japanese names, such as Adsuma-saki, Bunbudo, Kami-asobi, Tokiwadsu, etc. 
Paliurus australis (Christ's Thorn).-This shrub belongs to the Natural Order Rhamnaceae, and is a native of Southern Europe. Its popular name applies to its legendary associations with the "Crown of thorns," used at the Saviour's Crucifixion. It may be found as a dense bush 6 to 12 feet high, or as a small tree upwards of 20 feet in height. The small twiggy branches are clothed with pale green leares and with many sharp thorns. The small yellow flowers are produced freely in spring, and are succeeded by circular fruits, the central seed being surrounded by a curious membranous wing. Plant in ordinary garden soil and increase by sceds. Pruning does not require regular attention. Simply reduce plants which are outgrowing their positions.

Pampas Grass.-(See Cortaderia.)

Pancratium.--There are several tender kinds of Pancratium (Natural Order Amaryllidaceae) in cultivation, the only hardy ones being two from Southern Europe: illyricium and maritimum. Both are bulbous plants, and produce a number of strap-shaped leaves; the flower stem, which appears in carly summer, is terminated by an umbel of white, fragrant, funnel-shaped blossoms. The plants need

fairly warm spot, such as a narrow border in front of a greenhouse facing south or at the foot of a wall with a similar aspect. The bulbs should be planted in September or October, and protected in winter.

Panicum. - An extensive group of Grasses (Natural Order Gramineae), some of which are of considerable economic value. One of the most prominent in this respect is The Millet (Panicum miliaceum). Some of them are very ornamental, especially capillare, plicatum, tonsum, and virgatum. They are generally included in collections of ornamental Grasses, and may be sown out-of-doors in a warm border in April, where they are to flower.

Pansy.-(See VIOLA TRICOLOR.)

Papaver (Poppy).-The Poppies (Natural Order Papaveraccac) are natives of the temperate parts of Europe and Asia, and consist of annual, biennial, and perennial kinds. Of perennials the chief is Papaver orientale, from Asia Minor. This grows about 3 feet high, and bears large scarlet flowers, with black blotch at the base of each segment. In the many varieties the blossoms vary in colour from white to deep crimson, through pink, salmon and terra-cotta. The Oriental l'oppy and its varieties thrive in ordinary garden soil in a sunny spot or even in half shade. They bloom from May to July, while a few flowers are often produced during autumn.

of liennial kinds the best are: Papaver alpinum (Alpine Poppy), a plant about 6 inches high, with silvery leaves and summer flowers 
that vary in colour from white to orange; it is a charming kind for the rock garden in light soil and a sunny spot. Papaver nudicaule (Iceland Poppy) is somewhat similar, but taller, and altogether more vigorous; the flowers are of different shades of white, yellow, orange, and scarlet, exceedingly useful for cutting. The seed of these two kinds should be sown in early summer to flower the following year; they are strictly perennial, though short-lived, and are best raised from seed each year.

Annual Poppies should be sown in March or April where they are to flower. Care must be taken not to sow too thickly; healthy plants need to be 18 inches or 2 feet apart. One of the principal annual species is Papaver somniferum (Opium Poppy), of which there are numcrous garden forms that differ markedly from each other and from the typical kind. Many of them have popular names, such as Cardinal, Mikado, Mephisto, White Swan, Mauve Queen, etc. All are remarkably showy. Another favourite set of annual Poppies has been obtained from our common Field Poppy (Papaver Rheas); they are known as Shirley Poppies, and in growth are similar to the Field Poppy, except in the colour of the blossoms, which are of almost endless shades and very dainty.

Paradisia Liliastrum (Saint Bruno's Lily). - This plant, which is more generally known as Anthericum Liliastrum, is a showy perennial, native of Southern Europe, and belongs to the Lily family (Liliaceae). From a thickened rootstock several grass-like leaves are produced, and in June the flower-spike, about 3 feet high, bears several flowers of the purest white; they are broadly funnel-shaped and somewhat suggestive of those of the Madonna Lily (Lilium candidum). Paradisia will thrive in ordinary garden soil.

Pardanthus chinensis (Leopard Flower).-An Iris-like plant (Natural Order Iridaceae) that reaches a height of 2 feet and in June and July bears numerous flowers about 2 inches across, orange spotted with purple; the individual blooms last but a short time. This plant needs a warm, well-drained soil ; it should be planted in spring, and can be increased by division carried out at that season. It is also known by the name of Belamcanda punctata.

Paris (Herb Paris).-A strange plant (Natural Order Liliaceae) that grows about I2 inches high and in early summer bears yellowishgreen flowers; usually four leaves are produced by each plant. This is a native of Europe, including Britain. A second species, Paris polyphylla, from the Himalaya, has blossoms of much the same colour, but with an increased number of leaves. Both prefer a moder. ately light, moist soil and a shady spot. 
Parnassia (Grass of Parnassus).-One species, namely Parnassia palustris (Natural Order Saxifragaceae), is a native of Britain, in some parts of which it is popularly termed the Grass of Parnassus. It is essentially a bog plant, under which conditions it reaches a height of 6 inches or more, and bears towards the latter part of the summer a great number of pretty little white flowers. Other species are: asarifolia, caroliniana, and fimbriata, all of which greatly rescmble each other. These last three are all natives of North America.

Parochetus communis (Bluc-flowered Shamrock).-A charming little trailing plant for a warm, sunny, well-drained spot in the rock garden, where it flowers in late summer, and often into autumn. It belongs to the Pea family (Leguminosac), and is native of the Himalaya. The blossoms are Pea-shaped, and of a delightful shade of blue. Increase is by division carried out in spring or by sceds sown at the same time.

Paronychia (Nail Wort).-Small plants (Natural Order Illebraceae) for a sunny rockery; they flower usually in June, and are fairly pretty, but their ornamental qualities do not rank very high. The best are: Paronychia capitata and serpyllifolia; both have white flowers, and can be readily increased by division.

Parrotia.-There are two species of Parrotia, which belong to the Witch Hazel family (Hamamelidaceae). Both are small trees, but they are quite distinct in other respects. Parrotia Jacquemontiana is a native of the Western Himalaya, and blooms during early summer after the development of the leaves. The flowers are small and inconspicuous, and they are arranged in short dense spikes attended by white bracts an inch or more across, which are the showy part of the inflorescence. The other species is Parrotia persica, from Persia; it blooms on the leafless branches in February, the small flowers appearing freely in clusters from buds on all parts of the branches, the showy part being the bright red stamens. A wellflowered tree is a very conspicuous object. There is a second ornamental period in autumn, for the leaves colour brilliantly before they fall. Both kinds require sunny positions in well-drained loamy soil. Propagation is by seeds, and pruning is directed towards shaping the trees, the most suitable time being summer.

\section{Parsley Fern.-(See Allosorus CRISpus.)}

Parthenium (Feverfere). - This, which some authorities now grouj in the genus Chrysanthemum under the name of Chrysanthemum Parthenium, is a Chamomile-like plant (Natural Order Compositae), with flowers suggestive of Daisies. There is a free-flowering variety 


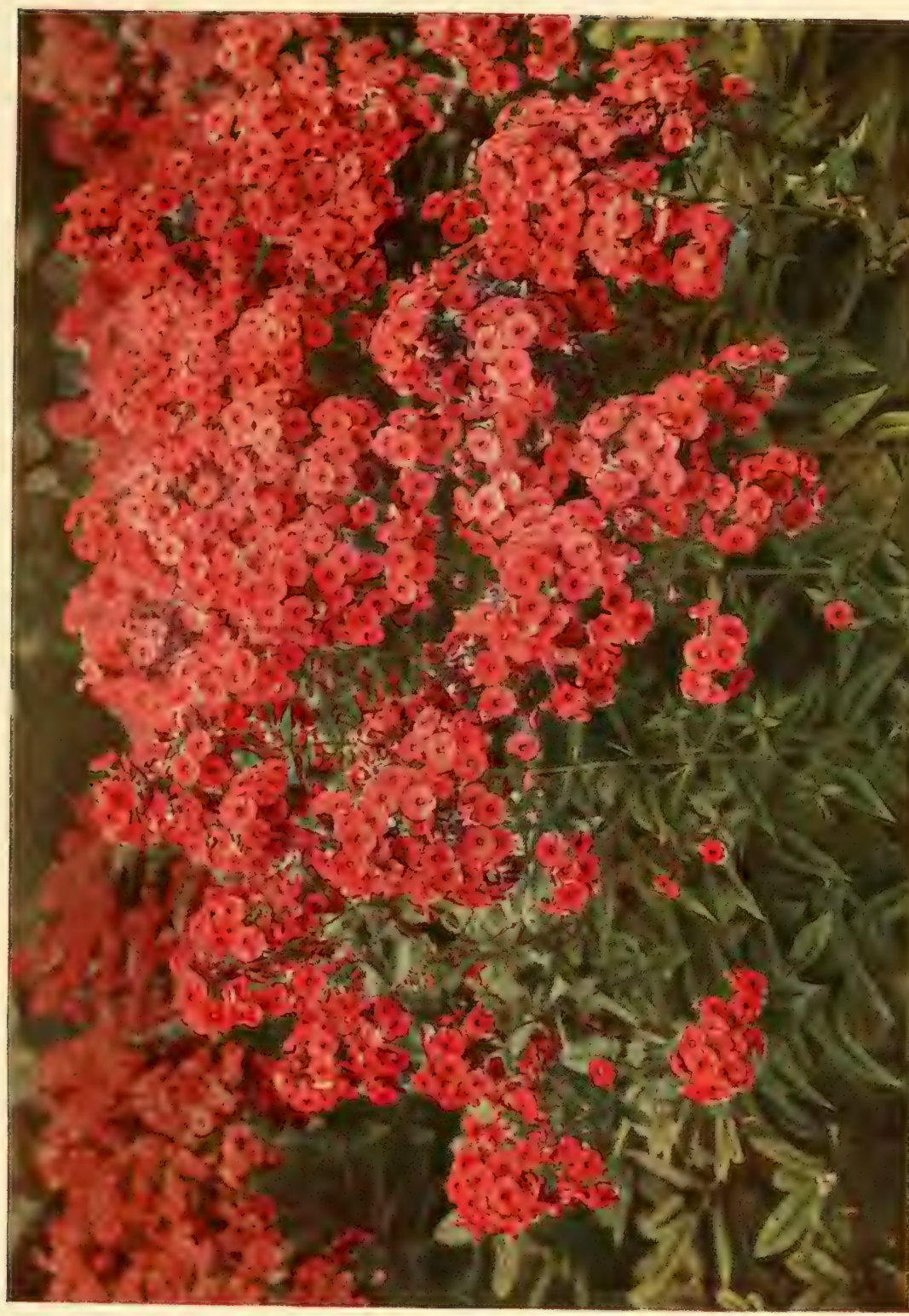

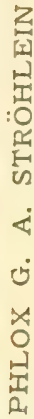



with double blossoms, which, if sown out-of-doors in spring, will flower for a considerable period in the summer. It thrives in any ordinary garden soil.

\section{Partridge Berry.-(See Gaultheria.)}

Pasque Flower.-(See Anemone Pulsatilla.)

Passiflora (Passion Flower).-Of the numerous Passion Flowers (Natural Order Passifloraceae), the only kinds that can be considered hardy in this country are the Brazilian Passiflora caerulea and its white-flowered variety Constance Elliott. Both are delightful and rapid-growing shrubby climbers. They prefer a warm, sunny position, and will thrive in ordinary garden soil. Given a bright, hot summer, the fruits, in addition to the flowers, are decidedly ornamental; they are somewhat egg-shaped, hang suspended by long stalks, and when ripe are bright yellow. When seed ripens young plants can be readily obtained in this way. The best results are obtained by sowing the seeds in spring, in a well-drained pot of sandy soil, and putting the young plants in single pots as soon as they are large enough. Seedlings, however, do not flower so freely when young as those propagated by means of cuttings, which are formed from young shoots in early summer; they are cut 4 inches in length, and dibbled in pots of sandy soil, placed in a frame kept close and shaded. Providing there is ample space for their development, Passifloras require practically no pruning, but when they have covered the position assigned to them, the shoots of the preceding year may be cut back to two or three buds in spring, old and exhausted or muchtangled shoots being cut out altogether.

\section{Passion Flower.-(See Passiflora.)}

Patrinia.-These are free-flowering border plants nearly related to the Valerian; they belong to the Natural Order Valerianaceae, and are natives of Northern Asia. They reach a height of about 2 feet, and the flowers are in terminal corymbs in June and July. The two kinds generally cultivated are scabiosaefolia and villosa, both having yellow flowers. They thrive in ordinary garden soil, and can readily be increased by division when dormant. Seeds, too, afford a ready means of propagation; they should be sown in a sheltered border out-of-doors in spring.

Paulownia imperialis is a handsome tree, native of Japan, belonging to the same family as the Snapdragon (Scrophulariaceae). It is ornamental alike by reason of its large broad leaves and handsome flowers. On young vigorous plants the leaves are sometimes upwards of 2 feet across, and for that reason people sometimes plant groups of young trees in rich soil and cut them down to the ground 
each spring. During summer, pole-like shoots, $\delta$ or 9 feet high, are formed which are clothed from base to summit with their handsome leaves. On older specimens the leaves may be less than 9 inches across. The violet-blue or purplish flowers are tubular in shape and borne in terminal panicles in spring. Unfortunately, the tree is only hardy enough for the southern counties. Plant in loamy soil, increase by seeds, and limit the pruning to shaping the trees and keeping the leaders clear whilst young. A new species has been introduced from China which, it is thought, will be hardier than the old one. It is called Fargesii, and is similar in general appearance to the Japanese tree. Good examples of Paulownia imperialis are sometimes seen about London, but they rarely flower.

\section{Pea, Everlasting.-(See Lathyrus latifolius.)}

Pea, Sweet.-(See Lathyrus odoratus.)

Pelargonium.--Of the several sections into which the South African Pelargoniums (Natural Order Geraniaceae) are divided, practically the only two that are employed for the outdoor garden are the Zonal and Ivy-leaved sorts. The Zonal Pelargoniums embrace those commonly termed Scarlet Geraniums, though the colour of the blossoms ranges from white to deep crimson. Large numbers are grown for flowering under glass, but it does not necessarily follow that the best for this purpose are most suitable for bedding out during summer. Of scarlet varieties Paul Crampel is undoubtedly the most popular bedding Pelargonium of the present day; its growth is good and the flower trusses are large, while the blossoms are rarely affected by the weather. Other bright-coloured varieties, suitable for bedding, are Beauty, cerise; Henry Jacoby, crimson; King of Denmark, salmon; King Edward VII., crimson; Maxime Kovalevsky, orange-salmon; Salmon Paul Crampel, salmon; West Brighton Gem, scarlet; and Vesuvius, scarlet. Good pinks for this purpose are : Constance, Henry Compton, and Mrs. Robert Hayes. The best whites include Queen of the Belgians and Snowdrop.

Many varieties are grown not for the sake of their flowers but for their ornamental leaves. Though less popular than they were a generation ago, these are still used for bedding. Of those of which the green leaves are edged with white, the most useful are Bijou, Dandy, Flower of Spring, and Nadame Salleroi; the last-named, a dwarf compact variety, with roundish leaves, never flowers, and is much used as an edging. Varieties with yellow or yellowish leaves are: Creed's Seedling, Crystal Palace Gem, Robert Fish, and Verona. Bronze-leaved varieties include: Bronze Queen, Her Majesty, Maréchal 
MacMahon, and Swanley Bronze. The tricolor-leaved varieties, at one time exceedingly popular, are now not much grown, as they do not thrive satisfactorily during unfavourable summers; still, they are admired by some. Good varieties are: Brilliant, Dolly Varden, Empress of India, Enchantress, Lass o' Gowrie, Macbeth, Mrs. Turner, and Mrs. Pollock. A variety that always arouses interest is known as Black Vesuvius: it is of dwarf, compact habit, with dark, almost black, leaves and scarlet flowers. As an edging to light-coloured varieties it is very effective.

Ivy-leaved Pelargoniums increase in popularity year by year; owing to their free, drooping growth, they are much used for balconies, window-boxes, vases, etc., as well as for bedding out. Large pyramids or standards are often seen, and they can be used as an edging to beds, the growths then being pegged down. There are many varieties, but the three best are: Galilee, soft pink; Madame Crousse, silverypink; and Souvenir de Charles Turner, rich reddish-rose. Others that may be grown for the sake of variety or to suit individual tastes are: Beauty of Castle Hill, soft rose ; Corden's Glory, scarlet; Col. Baden Powell, delicate mauve; Giroflée, magenta-purple; Jeanne d'Arc, white; Murillo, dark crimson; and Willy, scarlet.

Practically all the above-named Pelargoniums require the same treatment. The only difference is that the tricolor-leaved varieties are more delicate than the others, and require to be kept in a dry, airy greenhouse during winter; it is, of course, absolutely necessary that all are kept safe from frost. To grow Pelargoniums for summer bedding, the best time to take cuttings is during the first three weeks of August. At that time the cuttings root readily out-of-doors, whereas a month later success in this respect is far less certain. In taking the cuttings, select those that will be the least missed, so that the general appearance of the flower bed is not spoilt. They should be 3 or 4 inches long and cut off below a joint and the bottom leaf removed. If the cuttings are very succulent they may with advantage be laid out to dry for a few hours before being inserted. If put in shallow boxes these should be drained by boring holes in the bottom and covering them with crocks. Loam, leaf-mould, and sand form suitable soil ; it must be pressed down moderately firmly, and the cuttings put 2 to 3 inches apart. Keep the soil only slightly moist. The boxes may then be placed on a hard surface out-of-doors in a sunny spot; if put on soil, worms will enter and disturb the cuttings. In October the boxes must be taken under glass, either in the greenhouse or in a frame. While an unheated frame, if covered with mats, will keep out a certain amount of frost, Pelargoniums cannot 
be safely wintered without fire heat, clamp as well as frost being a great enemy. Whether the cuttings, when rooted, are potted singly either in autumn or spring will depend upon the space available, though those potted in autumn will, of course, make the best plants. Throughout the winter a light, airy position in the greenhouse is best for them.

Pennisetum.-These Grasses (Natural Order Gramineae), which are natives of the warmer regions of the globe, contain few kinds of any ornamental value; the only one in general cultivation is a very pretty annual Grass, Pennisetum longistylum, which grows about I8 inches high, and bears fluffy purplish flower spikes from 4 to 6 inches long. It is a native of Abyssinia. Seeds may be sown in spring in ordinary garden soil.

Pennyroyal.-(See Mentha Pulegium.)

Pentstemon.-There are many species of Pentstemon in cultivition but these are far outnumbered by the garden varieties; in fact, as with the Snapdragon, it is almost useless to keep them separate, as splendid kinds can be raised from seed. Still, most dealers have a few of the very best of their own raising, which are named and kept separate and increased by cuttings. The Pentstemons belong to the Snapdragon family (Scrophulariaceae), and are natives of North America. Of the true species the following may be mentioned: acuminatus, lilac-purple, July to September, I2 inches; barbatus, scarlet, summer, 3 to 4 feet; caeruleus, blue, July and August, I2 inches; Coboea, large inflated purple flowers, July and August, I8 inches; confertus, pale yellow, summer, I2 inches; cyananthus, purple and blue, July and August, I2 inches; glaber, blue, July to September, I2 inches; heterophyllus, light blue, July to September, I8 inches; laevigatus, white, June to August, 2 feet; ovatus, blue, July to September, 2 feet; spectabilis, blue, summer, 2 feet; and Watsonii, deep purple, July to September, 9 inches.

Of late years a small-flowered race of garden varieties have become general favourites. They are known as the "Gem" class, are dwarfer than the other kinds, and of bushy habit, while the flowers are borne in great profusion throughout the greater part of the summer. Botanists tell us these are but forms of Pentstemon Menziesii, a native of North-West America. At all events, they are a charming addition to flowering plants for the outdoor garden in summer. The varieties are: Myddleton Gem, carmine-pink, with white throat; Newbury Gem, of which there are pink, scarlet, and white forms; and Southgate Gem, of which the flowers are larger than those of Newbury Gem. 


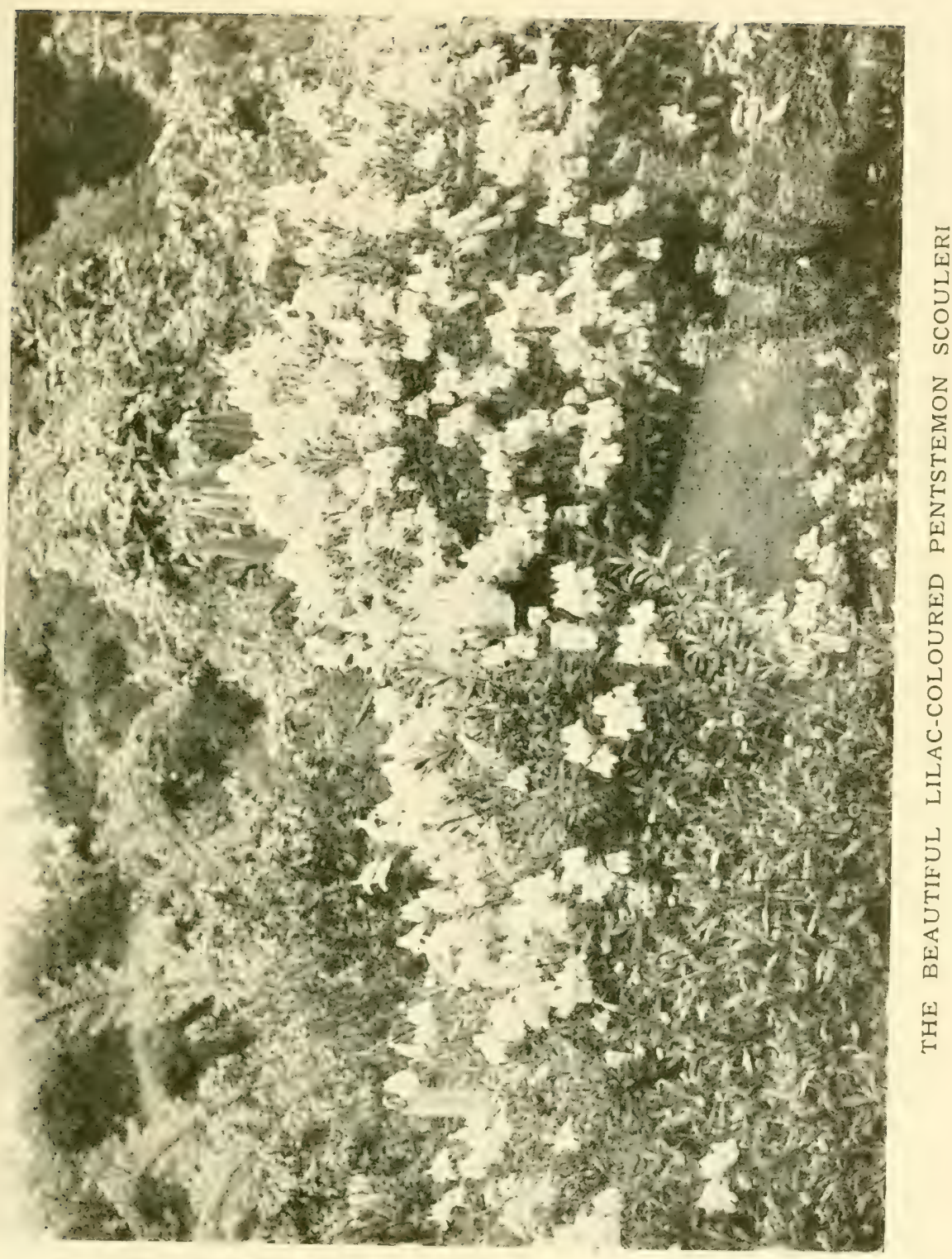



The florists' varieties almost rival the Foxglove in size of bloom, and the flowers are in long bold spikes; all shades of scarlet-pink, carmine, and purple are represented; the scarlet varieties with white throat are remarkably showy. These Pentstemons are seen to great advantage in the herbaceous border, especially where it is backed by shrubs, or when planted in a bed by themselves:

Pentstemons will thrive in ordinary garden soil, but are none too hardy during a severe winter, for which reason the choicer kinds are often raised from cuttings in autumn, and wintered in a frame. The best cuttings are furnished by plants that have not been allowed to flower, as they produce shoots more freely. As soon as these are about $2 \frac{1}{2}$ inches long they are taken off and inserted in pots of sandy soil and placed in a frame. There they will soon root, and with a little protection in severe weather will be safe throughout winter. Seed sown in the greenhouse in February will yield plants that may be safely planted out in June to flower during the summer. Though in some places there is a risk in leaving the choicer kinds of Pentstemon out during the winter months, this is not everywhere the case. The most favourable conditions are a rather light, well-drained soil, and a sunny position. Heavy clayey ground is not so suitable.

Perilla.-Only one member of this genus is valuable from a decorative standpoint. This is known generally as Perilla nankinensis, but by botanists it is referred to as Perilla ocymoides crispa. It belongs to the Sage family (Labiatae), and is native of China. The flowers are of no value, but the dark blackish-purple leaves are very effective in association with other plants in beds in the flower garden. It can be readily raised from seeds sown in the greenhouse in February or March. The young plants make rapid progress, both when under glass and in summer when planted out. In certain flower bed designs it is necessary to continue " stopping " the growths to keep the plants to the required height.

Periploca graeca is a vigorous climbing plant belonging to the Natural

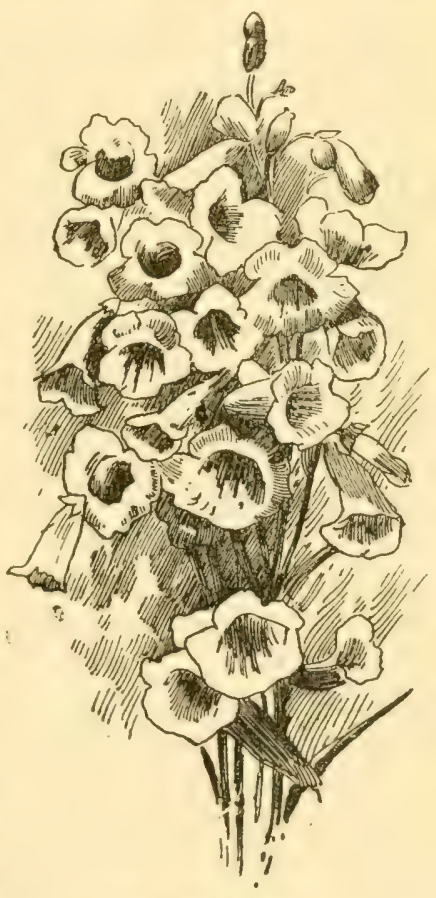

THE PENTSTEMON 
Order Asclepiadaceac. It is a native of South-East Europe and the Orient, and has long been known in our gardens. Planted in ordinary garden soil it grows rapidly, forming long slender shoots, clothed with dark green ovate leaves, and bearing purplish flowers in July. It should be planted against a wall, trellis, or pergola, but is not suitable for cold districts. It may be increased by cuttings of young shoots inserted in sandy soil in a warm frame during summer, and any necessary pruning should be attended to in spring. This usually takes the form of shortening branches which are outgrowing their space.

\section{Periwinkle.-(See VInCA.)}

Pernettya mucronata is a very beautiful little bush, belonging to the Heather family (Ericaceae), which has three distinct uses: first, its leaves are evergreen; secondly, the white flowers are decidedly pretty in May; and lastly, the berries are ornamental through autumn and part of the winter. It is a native of the Magellanic region, whence it was introduced in $I 828$. As seen in our gardens, it forms a spreading bush 12 inches to nearly 3 feet in height, increasing in width by means of underground stems; the tiny ovate leaves are scarcely more than $\frac{1}{2}$ inch long, and the flowers are borne from their axils. The fruits vary considerably in size and colouring, the larger ones being $\frac{1}{3}$ inch in diameter, and the colour varying from white to pink, purple, and deep red. A number of well-marked forms have been given varietal names, denoting the colour of the berries; very often the fruits are in such profusion as to make it necessary to stake the branches. Plant in moist soil free from lime, but the ground must not be waterlogged. Propagation is by division, layers, cuttings, or seeds, and pruning is limited to the removal of a few of the older branches now and then, the work being done in spring.

Perovskia atriplicifolia.-A half-shrubby plant belonging to the Sage family (Labiatae), and native of the Himalaya; it has only come into prominence within recent years. It forms a shapely bush from 3 to 4 feet in height, with greyish leaves and spikes of lavender-blue flowers, at their best in July and August. Seen in a mass, it is remarkably effective. The Perovskia can be propagated by division when dormant, or by cuttings of the young shoots when they are about 3 inches long, in spring, inserted in a frame or hand-light. Light, well-drained soil and a sunny spot provide suitable conditions.

Peruvian Lily.-(See Alstroemeria.)

Petasites (Butter Burr).-The best-known plant of this group (Natural Order Compositae) is the Winter Heliotrope (Petasites fragrans), with white, sweet-scented flowers in February. It must, 
however, be planted sparingly, for, once established, it is a terrible weed, being as difficult to get rid of as its near relative, the Coltsfoot. In the wild garden, however, a place may often be found for it. Two others, namely, the European Butter Burr (Petasites vulgaris) and the Japanese (Petasites japonica), are more noteworthy for the sake of their large roundish leaves. They are seen to the best advantage in the bog garden, though they will thrive under drier conditions.

Petunia.-The many forms of Petunia (which belongs to the Potato family, Solanaceae) that we have now in our gardens have all originated from Petunia nyctaginiflora and violacea, both natives of South America. From these a beautiful race of flowering plants has been obtained, which are of great value in the outdoor garden in summer. Though perennials, and at one time increased largely by cuttings, they are generally grown as annuals, from seed sown in February, in a warm greenhouse. If the young plants are transferred to pans or boxes and afterwards potted singly, they will be well established by bedding-out time. The double-flowered kinds, though much used for the greenhouse, are less suitable for outof-door planting than the single ones, which are less affected by wind and rain. Some of the single ones are very large, with the edges crisped and undulated; in colour, too, they vary greatly, but generally the self-coloured crimson, rose, and purple sorts are most admired. There is also a race of small-flowered kinds, of which Countess of Ellesmere is an example; this bears a profusion of rose and white flowers throughout the season. The very double kinds are propagated from cuttings formed from the young shoots in spring. They are dibbled in pots of sandy soil, and placed in a close propagating case in the greenhouse, and will soon root.

Phacelia.-The Phacelias, which belong to the Natural Order Hydrophyllaceae, and are natives of California, are pretty flowering annuals, with chiefly blue blossoms. By far the best known is Phacelia campanularia, with bell-shaped flowers of intense blue; it is of somewhat spreading growth, and reaches a height of about 9 inches. Others are : divaricata, violet, I2 inches; Menziesii, purple, I2 inches ; Parryii, violet, 9 inches; tanacetifolia, rose, 2 feet; viscida (also known as Eutoca viscida), intense blue, 9 inches; and Whitlavia (also known as Whitlavia grandiflora), violet, 12 inches. The Phacelias thrive in any fairly good garden soil, but, like most Californian annuals, prefer a warm, sunny spot. The young plants do not transplant well, hence the seed is best sown in the open border in April, where the plants are to flower; they should be thinned to about 6 inches apart: 
Phalaris. - By far the best known of this group of Grasses (Natural Order Gramineae) is the Ribbon Grass, or Gardener's Garter, Phalaris arundinacea variegata. It grows about 2 feet high, and the gracefully recurving leaves are freely striped with white. It is a familiar object in cottage gardens, and sprays of it form a part of country nosegays. It will thrive in almost any soil, and can be readily increased by division when dormant. Another well-known kind is canariensis, which furnishes the canary seed so much appreciated by those who keep cage birds; it is of annual duration, the pretty inflorescence being in a globe-like head.

\section{Pheasant's Eye.-(See ADonIs.)}

Phellodendron.-The members of this group (Natural Order Rutaceae) form small ornamental trees suitable for planting on lawns. The two kinds obtainable are amurense, from Amurland, and japonicum, from Japan. Their beauty centres in the large pinnate leaves and clusters of black fruit, the flowers being greenish, and not easily seen. They must be given deep loamy soil, and if the natural soil of the vicinity be poor, several loads of better material should be provided at planting time. A sunny position is advisable. Propagation is by seeds, and pruning should take the form of training the leading shoot in an upward direction and reducing side growths at the same time. This is only necessary whilst the trees are young.

Philadelphus (Mock Orange).-This group (Natural Order Saxifragaceae) is made up of a number of ornamental shrubs, many of which have fragrant flowers, and all are showy. They are natives of Asia and North America, and exhibit considerable diversity of growth, the greatest extremes being noticeable between grandiflorus, a bush I5 to 20 feet high and as far through, native of the Southern United States, and microphyllus, from Colorado, which scarcely attains a height of 3 feet. This little shrub, in conjunction with the common Asiatic Mock Orange (coronarius), has, however, exerted a considerable influence upon the whole race, for quite a new type of shrub has been evolved. Not only are the hybrids distinct in flower and growth, but they require different cultural treatment. The species or wild types, as a rule, thrive most satisfactorily in rich loamy soil, and pruning is limited to an occasional thinning of the branches after flowering, although bushes may be left unpruned for many years. But the hybrids (i.e. those raised by florists) must be pruned every year if the most satisfactory results are desired. As soon as the flowers fade, cut the flowering branches back to the point from which vigorous young shoots are springing. In many cases they may be cut back almost to the ground line. During summer, shoots 2 to 3 feet 


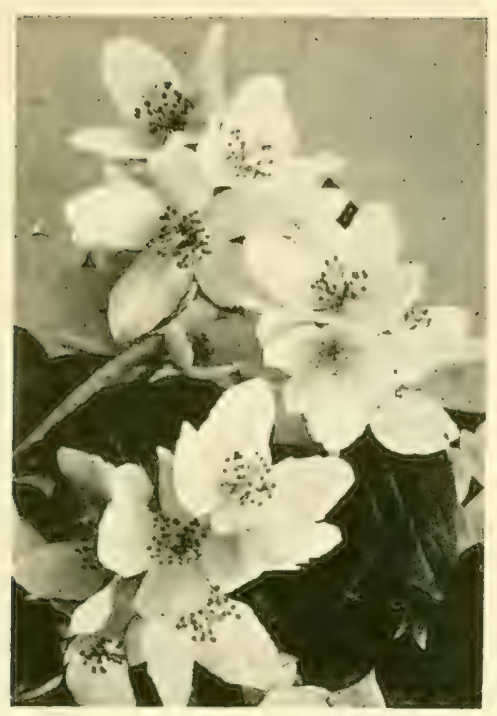

THE MOCK ORANGE

(PHILADELPHUS CORONARIUS)

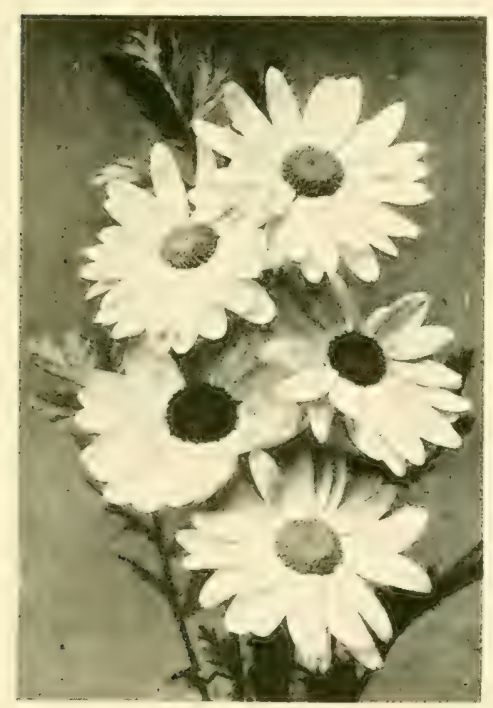

FLOWERS OF SINGLE PYRETHRUM PINK PEARL

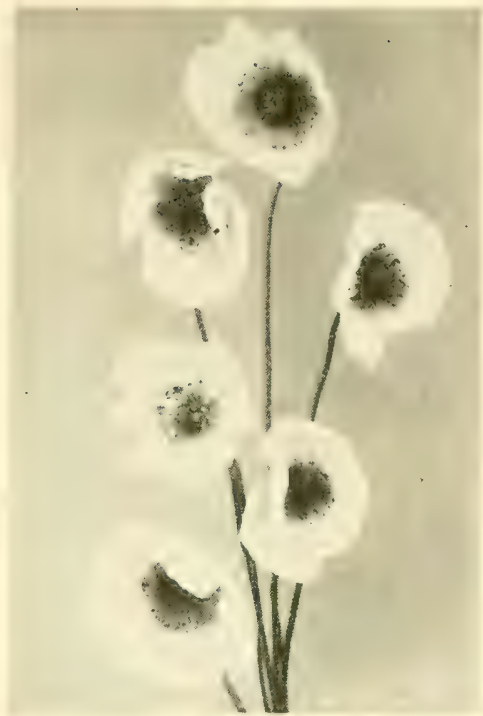

THE ICELAND POPPY (PAPAVER NUDICAULE)

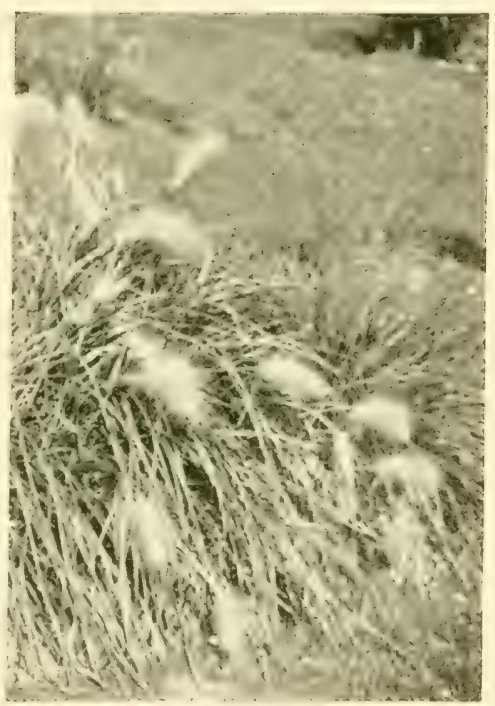

A CURIOUS HARDY GRASS

(PENNISETUM LONGISTYLUM 

long will be formed, which at the proper time-the following Junewill bloom from end to end. Like the stronger-growing sorts, they require rich loamy soil, and are improved by a yearly surface dressing of well-decayed manure. Propagation may be carried out by means of green cuttings inserted in sandy soil in a warm and closed frame in summer, or by cuttings of ripened growths inserted out-of-doors in autumn. The former method is the better one.

A selection of hybrids (those raised in gardens by cross fertilisation) includes the following: Lemoinei is typical of this group: if left unpruned, it forms a dense bush 3 to 4 feet high, but is less beautiful and flowers less freely than pruned plants; the var. erectus is better than the type, its fragrant flowers are about I inch across. Other good ones are: Avalanche, very large flowers; Boule d'Argent, double ; Fantasie, a very fine kind; Candelabre; purpureo-maculatus, white flowers with purple centre; Pavillon Blanc, flowers large and white; Rosace, flowers double, 2 to 3 inches in diameter; Virginal, flowers double.

Among the best species or wild types are : coronarius, native of Asia, often called Syringa or Mock Orange, a vigorous bush, Io to I5 feet high, with a profusion of creamy-white flowers in June, there are many varieties, some with double flowers and one with yellow foliage. Grandiflorus is a very beautiful and vigorous bush, the flowers are between 2 and 3 inches across, pure white, and less fragrant than those of the common Mock Orange, the vars. floribundus and laxus are more free-flowering than the type. Lewisii is a wide-spreading, shapely, free-flowering kind from Western North America; microphyllus is a charming little bushy kind, with small greyish leaves and very fragrant white flowers; mexicanus is the most tender kind, and is only suitable for the warmer counties, its white flowers are large and shapely.

Phillyrea.-Evergreen bushes, belonging to the Natural Order Oleaceae, chiefly natives of the Mediterranean region; the majority have long been known in our gardens. Phillyrea decora, from Lazistan, is, however, of more recent introduction, although it has been known for upwards of twenty-five years; it was at one time known as Vilmoriniana, and in its early years obtained a bad reputation, for plants had an unaccountable way of dying when apparently in good health a few days before; this was eventually found out to be due to grafting upon stocks of Privet. Now that it is grown from cuttings and from seeds it gives excellent results. Nature bushes are 4 to 5 feet high, and sometimes as much as Io feet across; the dark green leaves are like those of the Bay in shape, and the white 
flowers, followed by dark fruits, are produced from their axils. Phillyrea angustifolia from the Mediterranean region has very narrow leaves about 2 inches long and its var. rosmarinifolia has still smaller leaves; both form shapely bushes at least 5 feet high. Then there are two other species, latifolia and media, each of which claims several varieties; they grow into fine bushes or small trees up to $I 8$ or 20 feet high. Plant in ordinary, fairly good garden soil, increase by means of cuttings of young shoots inserted in sandy soil in a closed frame in July, and prune in summer, the pruning being directed towards shaping the bushes.

Phlomis.-The different species of Phlomis (Natural Order Labiatae) occur principally in Southern Europe and Asia Minor. They are of shrubby or sub-shrubby character, and bear a certain amount of resemblance to the common Sage. The most pronounced shrubby kind is Phlomis fruticosa, known popularly as the Jerusalem Sage. This forms a sturdy bush 4 to 6 feet in height, clothed with rough greyish leaves, and bears spikes of bright yellow flowers disposed in whorls throughout the summer months. Other species are: cashmeriana, pale lilac, 2 feet; Russelliana, golden-yellow, 3 feet; and samia, yellow, 3 feet. All flower during the summer months. They prefer a light, well-drained soil and full exposure to sunshine. Some may be increased by division, while cuttings of the young shoots may also be rooted if taken when from 3 to 4 inches long and protected by a frame or handlight.

Phlox.-The Phloxes (Natural Order Polemoniaceae) may be divided into three distinct sections: (I) the dwarf alpine kinds; (2) those of annual duration, the best known example of which is Phlox Drummondii ; and lastly, those usually referred to as herbaceous Phlox, among the finest of all border flowers in August and September.

Herbaceous Phloxes show a wide range of colour, from white, through various shades of pink, salmon, violet, and scarlet. They will thrive in any deep garden soil, but prefer a trenched border of sandy loam, with which well-decayed manure has been mixed. Propagation is by division and by cuttings. Division must be carried out in early autumn or spring, and if carefully done will result in good well-rooted plants. If possible, each portion should have three shoots, and in this way flowering plants can be obtained the first season. Cuttings may be taken in spring as soon as the young shoots are about 3 inches in length; they are twisted off so that the base of the shoot is detached also. If dibbled in pots of sandy soil placed in a frame they will soon form roots. The transplantation of estab- 
lished plants should be carried out as soon as possible in autumn after the flowers have faded.

Some of the best varieties are: Brilliant, carmine-rose ; Coquelicot, orange-red; Elizabeth Campbell, salmon-pink; Etna, orangered; Eugène Danzanvilliers, lilac-rose; G. A. Strohlein, orangered ; General von Heutz, salmon-red ; Iris, purplish-blue; Le Mahdi, violet-blue; Pantheon, pink; Paul Bert, lilac and white; Salmonea, salmon-rose; Selma, pink; Tapis Blanc, white, dwarf; William Ramsay, purple; and Wonder, white with rose flush, dwarf.

Phlox Drummondii, which is practically the only annual species, is among the best annual flowers. From the typical kind, of which the blossoms are red, varieties have now been obtained varying in colour from white to deep crimson and purple, through many intermediate shades. They vary in height from I2 to I8 inches. Annual Phloxes are much appreciated in the outdoor garden in summer, and if the old flowers are cut off they produce a succession of bloom longer than many annuals. The taller kinds may, if desired, be pegged down. Seed of Phlox Drummondii is usually sown under glass in early spring for the first display of blossoms; the plants will, however, flower finely if sown out-of-doors in April.

The dwarf Phloxes are among the showiest of rock garden flowers, while some of them are used largely for spring bedding. They form masses of spreading evergreen shoots, and in spring yield their blossoms in profusion, often to such a degree that the leaves are hidden. The dwarf Phloxes are natives of hilly districts in some of the States of North America. Chief favourite among them is the Moss Pink (Phlox subulata), of which there are several charming varieties, as, for example, Vivid, rose; G. F. Wilson, mauve; Fairy, lilac; The Bride and Nelsoni, white; and Little Dot, white with blue centre. The typical plant, Phlox subulata, forms a compact leafy tuft, and in April and Nay bears pink blossom. Phlox amoena, which bears rose-coloured flowers, is another pretty trailing kind and one that blooms freely. Of a different type is Phlox divaricata, which reaches a height of about 12 inches, and bears pale lilac-blue flowers; the var. Laphami is an improved form. Others are Phlox procumbens, lilac; ovata, rose-purple; and reptans or verna, the creeping Phlox, with comparatively large rose-coloured blooms. Phlox stellaria, white, and its lilac-coloured var. lilacina, are vigorous, and soon form large masses which blossom profusely in early summer.

Some care is needed in the cultivation of the dwarf Phloxes if they are to give of their best, and the conditions most likely to ensure success are a fairly cool position, such, for example, as one facing 
west, thorough drainage, and a soil consisting of loam with which leaf-soil and grit are mixed. They look best when planted at the top of a wall or rock ledge down the face of which the shoots may trail. Some of them, notably the white vars. Nelsoni and The Bride, are apt to die off during a wet winter, and for this reason are benefited by the protection of a pane of glass raised a few inches above them. If the plants become straggling and bare in the centre they lose much of their attractiveness, but this may usually be obviated by cutting back the growths as soon as the flowers have faded, at the same time working a top-dressing of gritty compost among the shoots. Phlox reptans is increased by pegging down the trailing shoots in summer; when they are well rooted the shoots may be cut off and transplanted. The other kinds are propagated by cuttings inserted in sandy soil in a frame in June. Old plants that have lost their compactness may be taken up at the same season and divided, the portions being planted in well-prepared gritty soil in partial shade, there to remain until early autumn, when they can be planted permanently.

Phormium (New Zealand Flax).-A noble plant, belonging to the Lily family (Liliaceae), that forms a stout tuft of strap-shaped leaves from 4 to 6 feet long. These contain a strong fibre, which is of considerable commercial value. As an ornamental plant in moist soil near water it can be recommended. There is a variety with leaves of bronze-purple tint, and two or three variegated sorts. While Phormium tenax will hold its own in many parts of the country, the variegated kinds are more tender, and need protection from frost. Loamy soil is suitable. Increase is usually by division ; seeds, too, sometimes ripen, and these should be sown as soon as possible in pots of loam, leaf-mould, and sand placed in a greenhouse.

Photinia serrulata is the most important species of this group of shrubs (Natural Order Rosaceae), so far as this country is concerned. It is a fine evergreen bush or small tree, native of China, with large, oblong leaves resembling those of a Laurel, but more refined. In spring, when the young leaves are developing, they are of a pretty reddish tint, and are attended by red bracts. Later on, towards June, the white flowers appear. Unfortunately it is too tender for borders except in the milder counties, and it is seen at its best in Devonshire, Cornwall, and Ireland. There, planted in loamy soil, it forms a handsome lawn specimen, I2 or If feet high. About London it grows well, but is sometimes injured by frost. Elsewhere it is best on a wall. Systematic pruning is unnecessary, but a little shaping may be done during summer when required. 


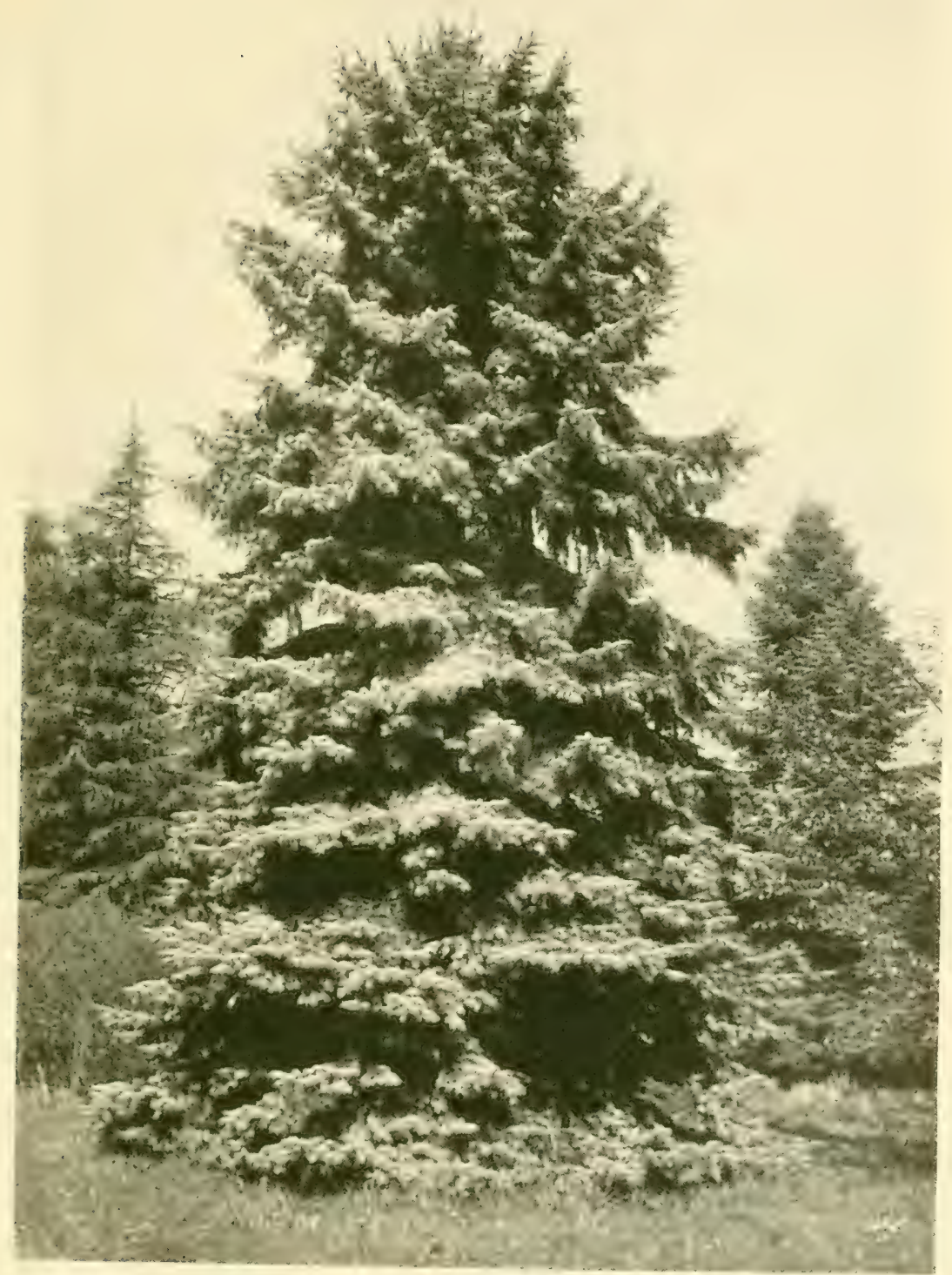

A HANDSOME SPRUCE FIR (PICEA PUNGENS GLAUCA) 


\section{PHRAGMITES COMMUNIS AUREUS}

Increase by seeds or layers. Other species are Benthamiana, from China, and variabilis, from China and Japan. The last-named is the hardiest of the three.

Phragmites communis aureus.-A stately Reed (Natural Order Gramineac), which reaches a height of about 5 feet, and of which the leaves are prettily marked with yellow. It is a very effective plant for bog or waterside planting, and can be readily increased by division.

Phygelius capensis (Cape Figwort).-A striking, sparely-branched plant belonging to the Snapdragon family (Scrophulariaceae) that will reach a height of 4 to 5 feet. The tube-shaped flowers, which are produced in whorls from the upper part of the plant, are of bright scarlet colour and open in late summer and early autumn. This Phygelius is a native of South Africa, and needs as warm a spot as possible, such as a position at the foot of a south wall. It can be readily increased by division in early spring.

Phyllocladus, a small class of Conifers (Natural Order Coniferae) includes some very curious and interesting shrubs or small trees, which are only available for outdoor planting in the mildest parts of the country. They require moist yet well-drained soil, a clear and moist atmosphere, and a mild, equable temperature. One or two species have been noted in good condition in gardens in the vicinity of Penzance where the soil is very fertile, and made up largely of humus and disintegrated granite. Propagation may be effected by means of cuttings inserted in sandy soil in a close frame in summer, and pruning is limited to shaping the plants. Phyllocladus rhomboidalis, the Adventure Bay Pine, from Tasmania, and trichomanoides, are sometimes grown.

Phyllostachys (Bamboo) belongs to the Natural Order Gramineae, and is one of the two most important groups of hardy Bamboos. They may be distinguished from Arundinaria and Bambusa by their glossy, smooth, and shining stems, and by the side branches always being in groups of three, as a rule two large ones and one very small. The small one is usually in the centre and sometimes falls away early in life. They also differ from the other Bamboos by casting their leaf or stem sheaths very early in life, whereas these may be noted on Arundinaria for a considerable period, sometimes for more than a year. The cultural requirements are the same as for Arundinaria in every particular. The culms or stems are generally very close together, and long running rhizomes are not so prevalent as in Arundinaria. This causes the clumps to become very dense, and it is necessary to remove the old canes to the ground line. As 


\section{THE BOOK OF HARDY FLOWERS}

a rule, plants dic after flowering, but it is said that the death of these and other Bamboos may be prevented by cutting all the canes down to the ground line when the first sign of flowering is noticed. Subsequent shoots are said to show no signs of flowering. We cannot, however, vouch for the accuracy of this.

The chief kinds are : aurea, native of Japan, a rather erect-growing kind, 12 or 15 feet high, with golden stems; Castillonis, sometimes classed as a variety of Quilioi, is a Japanese plant 12 feet or more high, with occasionally variegated leaves and golden stems, the flattened parts of which are bright green. Fastuosa, although usually classed as a Phyllostachys, is correctly an Arundinaria, it is one of the hardiest and most decorative of all hardy Bamboos; its erect, handsome plumose stems rise to a height of 20 feet or more, and the leaves keep their colour better than those of any other species. Filexuosa, from North China, is a handsome kind with graceful plumose branches, and the same may be said of the Japanese Henonis. Nigra is a vigorous, graceful kind with dark brown or almost black canes; the var. punctata has mottled canes, both kinds, with the var. Boryana, are very useful Japanese Bamboos. Ruscifolia is a curious dwarf kind with short wide leaves, it rarely exceeds 2 feet in height; viridiglaucescens, from China, is one of the hardiest species, it grows $I_{5}$ feet or more high, and is of graceful outline.

Physalis (Winter Cherry).-The plants of this group (Natural Order Solanaceae) are remarkable for the large bladder-like calyces that contain the fruits and which, when ripe, are of bright orangered colour. When cut and dried they are much used for indoor decoration in winter. The best are: Bunyardii and Franchetii. They thrive in a sunny spot in any good garden soil, and can be increased to any extent by means of seeds or by division carried out in early spring.

Physostegia virginiana.-A vigorous-growing North American herbaceous perennial belonging to the Sage family (Labiatae), 3 feet high, with erect stems, terminated by spikes of pink flowers from July until autumn, which are very useful for cutting. There is a white variety alba, and another, speciosa, taller than the type. All thrive in ordinary garden soil, and can be increased by division in early spring.

Phyteuma (Rampion).-Chiefly hardy herbaceous perennials, members of the Bellflower family (Campanulaceae), natives of the Mediterranean region and Asia Minor. While they are nearly related to the Campanulas, the flowers are quite different, being borne in curiously crowded heads on comparativcly long stalks. They are 
fitted for planting in a sunny part of the rock garden in gritty soil, where they flower from June to August. The best are : anthericoides, slaty-blue, 9 inches; canescens, lilac-blue, I2 inches; comosa, deep blue, tipped white, 3 inches; orbiculare, deep blue, I2 inches; and Scheuchzeri, purplish-blue, I2 inches. They are propagated by means of division, carried out in spring, or by seeds sown under glass at the same season.

\section{Phytolacca d e c a n d r a} (Poke Weed).-This is the only member of this group (Natural Order Phytolaccaceae) that can be looked upon as ornamental, and it is certainly a striking object in the herbaceous border towards the end of the summer and in early autumn. It produces a stout stem from 4 to 8 feet in height, and branches freely from the upper portion. The little white flowers are borne in long racemes, and are succeeded by closely packed dark purple berries, the weight of which causes the clusters to droop. A well-grown plant laden with berries is very striking. This Phytolacca is readily raised from seeds sown in a sheltered border in spring. The plant is poisonous.

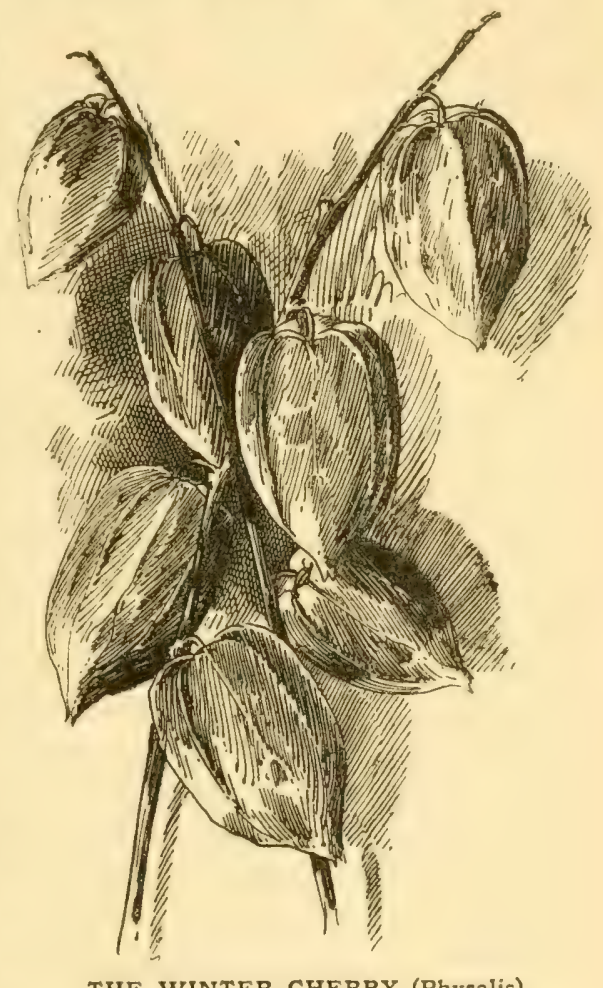

THE WINTER CHERRY (Physalis)

Picea (Spruce).-This group of Conifers (Natural Order Coniferae) includes all the trees which are popularly termed Spruces. Several of them are very important timber trees. Thus, Picea excelsa, the Common Spruce, supplies white deal, and is the most important European pulp wood. Picea alba is the great pulp wood of Eastern North America, in addition to being used for the same purposes as our white deal; whilst Western North America supplies another valuable kind in the Sitka or Tideland Spruce (Picea sitchensis). They may be distinguished from the Firs, or Abies, with which they are often confused, by the leaves being usually needle-like and surrounding the branches, and by the cones being pendulous and remain- 
ing intact after shedding the seeds, those of the Abies being erect and falling to pieces as soon as the seeds are ripe. The Spruces, as a rule, thrive in wet soil, and the Sitka Spruce has been found invaluable for cold and wet bog land, thriving where even the Common Spruce fails to exist. It is also useful for planting near the sea, and may be used with the Austrian, Corsican, and Scots Pines for reclaiming sandy wastes and fixing sand dunes. Propagation of all the species is by seeds, and of the varieties by cuttings or by grafting upon stocks of their respective types. The pruning of ornamental specimens takes the form of removing dead wood and rival leaders. Those grown for commercial purposes are planted close, and side branches are suppressed naturally. Several kinds of insects are troublesome at times. One, Chermes abietis, forms a Pine-applelike gall on the branches, and another, a small greenish aphis, causes leaf-shedding. They may be destroyed by spraying the trees with paraffin emulsion during April, May, and June.

Picea alba is a very hardy tree from Eastern North America, sometimes from 60 to Ioo feet high in a wild state, but often less than 60 feet; it does not grow very large here. Engelmanni is a British Columbian Spruce, and its var. glauca forms a handsome lawn tree. Excelsa, the Common Spruce, grows I30 feet high in Central Europe, less farther north, and is grown extensively as a forest tree in this country; there are many dwarf, bushy forms, a few are: Clanbrasiliana, compacta, diffusa, dumosa, pygmaea, and Remonti. Nigra is the Black Spruce of North America, it is grown here as an ornamental tree. Orientalis, from the Mountains of the Taurus and the Caucasus, is distinguished from the Common Spruce by its smaller leaves and neater leaf arrangement, both it and the common kind are grown largely for Christmas trees.

Picea pungens, a native of Utah and California, is a handsome tree; the var. glauca is known as the Blue Spruce by reason of its beautiful glaucous leaves; Smithiana, often called Morinda, is an elegant Himalayan kind, with pendent branches and long leaves.

Picea Omorica and sitchensis are included in the so-called Flatleaved Spruces. The former is the Servian Spruce and an excellent, decorative, fast-growing tree; and the other is from Western North America, where it extends along the coastline from Central Alaska to South California, often growing in brackish land. It is being planted extensively under forest conditions in this country.

Picotee.-(See Dianthus.)

Picrasma quassioides is a decorative tree of middle height belonging to the Natural Order Simarubaceae, and having for one 
of its allies the better-known Tree of Heaven (Ailanthus glandulosa). It is found wild over a considerable area in China, Japan, and the Himalaya, where it forms a wide-headed tree 35 to 45 feet high: Its attractions are its ornamental pinnate leaves which are up to I3 inches long; its reddish-brown, mottled bark, and bluish fruits. This tree is sufficiently hardy to grow in many districts of the British Isles, and ought to be found as a lawn specimen more frequently than at present, for it thrives in loamy soil and can be increased by either seeds or cuttings. Young trees should be pruned to keep them shapely, the chief object being to maintain clear leaders.

Pieris.-Although there are numerous species of Pieris, which belongs to the Heather family (Eriaceae), three kinds stand out so prominently that the others are hardly worth considering. The three most useful ones are : floribunda, from North America; formosa, from the temperate Himalaya and China; and japonica, from Japan. All are evergreen shrubs with white flowers. Pieris floribunda grows from 2 to 4 feet high, forming a dense bush with rather dull ovate leaves; the flowers appear in upright panicles from the middle of March to early May. Pieris japonica is a more vigorous bush, but it does not grow much taller; it is recognised by the handsome, glossy, dark green oblong leaves, 3 to 4 inches long, and by its large terminal pendent panicles of flowers borne between March and May. Both kinds are quite hardy. Pieris formosa is a larger-growing bush, sometimes approaching $I_{5}$ feet in height; it has large, handsome, deep green leaves and dense upright panicles of flowers which appear during May and June. It is less hardy than the other two, and is only suitable for borders in the south and west counties of England, the western maritime counties of Scotland and for Ireland. A special attraction of this kind is in the bright reddish colour of the young leaves. The cultural requirements are similar to those of Rhododendrons, for they dislike lime and thrive most satisfactorily in moist, sandy soil containing peat. Propagation is by layers and by sceds, seedling plants being preferable, although growth is slow for a few years. Systematic pruning is unnecessary, but the flower heads should be removed as soon as the flowers fade.

Pimpernel.-(See Anagallis.)

Pine.-(See PInus.)

Pinguicula (Butter Wort).--Pretty little plants (Natural Order Lentibulaceae) with a rosette of leaves from which are produced flowers, on slender stalks, somewhat suggestive of those of a Violet. The whole plant is but a few inches high, and grows, best in a moist spot among moss and low herbage. The flowers appear in May and 
June. The chief hardy kinds are: alpina, white; grandiflora, violetblue; and vulgaris, violet.

Pink.--(See Diantrus.)

Pink Hops.-(See Origanum.)

Pinus (Pinc).-A group of Conifers (Natural Order Coniferac) made up chicfly of evergreen trees, but a few kinds are of bushy growth: Many are well adapted for planting in dry, wind-swept regions, and are the best available trees for forming the first line of defence against wind from the sea. Moreover, they may be planted at higher elevations than any of the broad-leaved trees, with the exception of Common Birch. The dense-leaved kinds are useful for wind-breaks around gardens or fruit or flower farms, and may also be planted to block out unsightly objects. They are not, however, adapted for planting in or about large towns where the atmosphere is charged with smoke or chemical fumes. The Pines are widely distributed through Europe, Asia Minor, Asia (from Siberia to the Himalaya, one or two kinds being found south of the Himalaya), Japan, North America, and the Canary Islands. Moreover, they have been planted largely in Australia, New Zealand, and South Africa. Possessing valuable economic properties, the timber of a number of species is more largely used for general building purposes than that of any other group of trees. Thus the Common Scots Pine (Pinus sylvestris), a native of Siberia and Northern Europe, including the British Isles, is the most important building timber of Northern Europe, where it is known as redwood, red deal, yellow deal, etc. Then the well-known Pitch Pine of the Southern United States is the timber of Pinus palustris, and the white pine of North America is the wood of Pinus Strobus. The seeds of various kinds-e.g. Pinea, Cembra, edulis-are edible. Resin and turpentine are other important products of the wood of Pines, and France in particular benefits largely from her turpentine and resin industry which has developed through planting waste and continually shifting sand dunes in Western France.

Many kinds of Pines are known, and they are divided into three wcll-marked groups by the way in which the long needle-like leaves are arranged in twos, threes, or fives; in one case, however, they are borne singly. It is not within the scope of this work to indicate the nice distinctions between the various species, but the student will find them clearly defined in various works upon Conifers.

l'ines must be placed in permanent positions while quite small, particularly if they are to be subjected to considerable exposure. As a rule, it is better to place the trees permanently when between I and 2 feet high, those 3 or 4 feet taller often transplanting badly. As a 


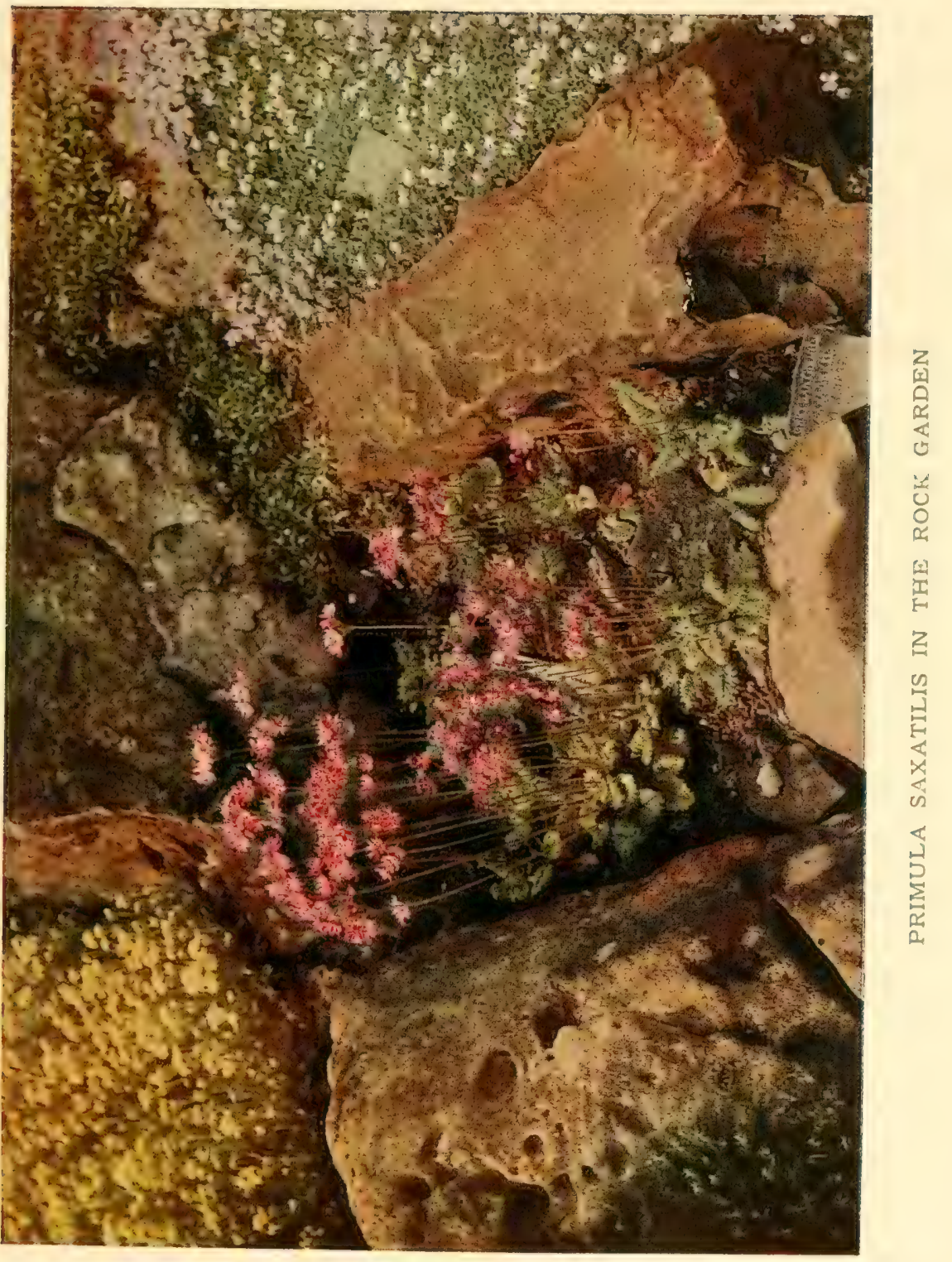




\section{PINUS}

rule, a plant $\mathrm{I}_{2}^{1}$ feet high put in at the same time as another 5 feet in height will have outgrown the latter one at the end of five years. Propagation of all species and well-marked varieties is by seeds and of other kinds by grafting upon stocks of their respective types. Pruning is directed towards shaping trees which are becoming unshapely. The work may be done in late autumn. Pines are useful for decorative specimens as well as for forest planting.

In the following kinds the leaves are in twos or threes: Pinus Bungeana, the Lace-bark Pine of China, is distinct by reason of its bright green leaves and the way in which the bark is shed each year in thin flakes, a rather rare tree suitable for lawns. Coulteri is a native of California, and is grown as an ornamental tree for its long handsome greyish leaves, sometimes more than 9 inches in length; its remarkable cones are sometimes produced here, they are 9 to I2 inches long, thick, woody, and armed with strong curved spines; densiflora is a Japanese species somewhat similar to our Common Scots Pine.

Pinus insignis, the Monterey Pine, is a native of California; its leaves are a brighter green than those of most other Pines, and they are in groups of three. Although not very hardy, it thrives amazingly in the south and west maritime counties, where the rings of annual growth are often from $\frac{1}{2}$ to $\frac{3}{4}$ inch apart. It is an excellent windbreak, and stands exposure to sea air. Pinus Laricio is known as the Corsican Pine. It is found in Southern Europe and the Taurus Mountains, and is planted widely in this country; growing very rapidly, it gives good results in poor sandy soil. The var. nigricans is the Austrian Pine, the best of all wind-breaks in this country. It may be planted on sand dunes just above high-water mark. Both trees have very dark foliage and a sombre appearance. Montana is found as a bush in the European Alps; it is useful for massing on dry banks in garden or park; muricata, a Californian tree, is remarkable for the length of time the cones remain upon the branches, sometimes thirty years or more.

Pinus Pinaster, the Cluster or Maritime Pine, may be planted near the sea in the south and west, also inland; it has showy redbrown bark; Pinea is the Stone Pine or Umbrella Pine of Southern Europe, a flat-topped, ornamental tree often used in gardens.

Pinus sylvestris, the Scots Pine, is a native tree, and the remains of several natural forests are still to be found in the Highlands of Scotland; it frequently grows between 80 and IIo feet in height, that height being exceeded by 20 or 30 feet in some European forests. Standing considerable exposure, it is often found on very bleak 
hillsides and close to the sea. There are several well-known varieties, one of which has golden leaves.

In the following Pines the leaves are in groups of five: Pinus Armandi is a new Chinese kind, with handsome glaucous-green leaves. Ayacahuite, the Hickory Pine of Mexico, forms a handsome specimen; it is much like Pinus excelsa, from the Himalaya, but has downy shoots and recurved scales at the base of the cone. Cembra, the Swiss Stone Pine, is of close pyramidal habit and of decorative presence; excelsa, the Blue or Bhotan Pine, from the Himalaya, forms a fine tree with glaucous green leaves; it is not adapted for windswept places; Lambertiana is the Sugar Pine of California, suitable only for the milder counties; Strobus, the Weymouth Pine, may be planted for ornament or profit, but is subject to insect attacks, which sometimes injure young trees.

Piptanthus nepalensis, sometimes called the Himalayan Laburnum, belongs to the Pea family (Leguminosae). A native of the temperate Himalaya, it forms a large bush in the milder parts of the country, but requires the protection of a wall elsewhere. It, however, exhibits some curious differences of behaviour in various parts of the country. About London it thrives against a wall, but does little good in the open, yet at Forres, in North-East Scotland, it thrives as a bush in the open ground. Its principal attraction is in the golden Pea-shaped flowers in May and June. Give well-drained loamy soil, increase by means of seeds, and let pruning take the form of removing the unripened ends of the shoots in February.

Pistacia is a group of large-growing shrubs or small trees (Natural Order Anacardiaceae), natives of the region bordering the Mediterranean Sea. Several species are sometimes found in gardens in the South of England with their near allies the Sumachs or Rhus. Some have economic properties, for a rare oil-like resin is obtained from incisions made in the trunk of Pistacia Terebinthus in the Island of Scio. This substance is called Chian Turpentine, and is sometimes used in medicine and as a preservative for wine. This is one of the kinds that can be grown out-of-doors here. Others are Lentiscus, chinensis, and atlantica. Plant in a sunny position in light, welldrained loamy soil. Increase is by seeds or root cuttings, and systematic pruning is unnecessary.

Pittosporum.--This is a useful family of evergreen shrubs or small trees, natives of New Zealand, Australia, China, Japan, and other countries, belonging to the Natural Order Pittosporaceae. Many of them are hardy in the south-west counties of England, in Ireland, and in the West of Scotland, but about London even the 
hardier kinds need the protection of a wall. Although usually grown for their evergreen leaves, the flowers of some kinds are showy, those of a few being fragrant. They thrive in ordinary garden soil, preferring well-drained loam in which a little peat has been dug. Propagation may be conducted by inserting cuttings of half-ripe shoots in a sandy compost in a close and warm frame in summer, or seeds may be sown. Pruning is directed towards shaping the bushes, and may be attended to during summer. The chief sorts are: crassifolium, a New Zcaland shrub with thick, oval, greyish-green leaves and claret-coloured flowers, which are borne singly from the leaf axils during late spring. Eugenioides is a big evergreen bush, bearing large inflorescences of pale yellowish, fragrant flowers during March and April ; in Cornwall it forms a bush 12 to 20 feet high, well furnished with branches from base to summit. Eriocarpum is a decorative kind from the Himalaya with yellow flowers; nigricans, sometimes called tenuifolium, is recognised by its oval or ovate leaves and small dark purple or almost black flowers; Tobira, from China and Japan, and undulatum from Australia, are useful evergreens with showy white, fragrant flowers.

Plagianthus Lyallii, a New Zealand shrub, is the best known of its group, which belongs to the Mallow family (Malvaceae). It, however, is quite an uncommon shrub, although its great beauty warrants extended cultivation. Like most other New Zealand shrubs, its proper place is the gardens of the south-west counties and Ireland, but it is hardier than many and thrives both against a wall and in the open ground at Kew, a garden which is not particularly well placed for the cultivation of somewhat tender shrubs. It forms a bush 6 to Io feet high, with a similar width; the deciduous leaves are ovate and 4 or 5 inches long, whilst the flowers are white, $I \frac{1}{2}$ inches across, and borne in clusters from the leaf axils of the young shoots in June or July. When in flower it is difficult to conceive a more charming plant. Cuttings may be rooted in summer, but they are rather difficult to deal with, and better results often follow layering the lower branches. No systematic pruning of bush plants is necessary, but those growing against walls must be pruned after flowering. Give rich loamy soil. Another useful species is Plagianthus betulinus, from the same country; it also has white flowers.

\section{Plane Tree.-(See Platanus.)}

Plantain Lily.-(See FunkIA.)

Platanus (Plane).-A small but important group of trees belonging to the Natural Order Platanaceae. There are three species, two natives of the Orient and the third of North America. Some people 
make a fourth species of Platanus acerifolia, popularly termed the London Plane, but it is considered to be of hybrid origin, though no data exist of its original appearance. All the Planes possess the peculiarity of shedding their bark each year, and upon that account they are excellent trees for towns. There is no better tree than Platanus acerifolia for towns, and its rude health and vigour under trying circumstances has caused it to be planted more freely than any other tree in and about London, hence the common name. It cannot, however, be used to the same extent in the North of England. The two kinds usually met with are acerifolia and orientalis, whilst cuneata is also grown sometimes. The true occidentalis, the Buttonwood of North America, however, is rarely seen in this country, although acerifolia is often distributed under that name. It is not very hardy here.

Platanus orientalis may be distinguished from the London Plane by its smaller and more finely-lobed leaves. Both grow into extremely ornamental trees of the largest size. When planted in narrow streets they have of necessity to be pruned hard back periodically; they, however, withstand the somewhat barbarous treatment better than most trees. In gardens, pruning is directed towards keeping the leaders clear and removing lower branches when necessary. Ordinary garden soil suits, and propagation is often by cuttings of ripened wood placed out-of-doors in winter, or by layers.

Platycodon grandiflorum (Chinese Bell Flower).-A very pretty and distinct Campanula-like plant (Natural Order Campanulaceae) with blue flowers; indeed, by some authorities it is classed as Campanula. It is striking by reason of the curious balloon-shape of the buds; it grows about I 8 inches high, and flowers from July to September. Distinct varieties are : alba, white; autumnale, blue, vigorous ; Mariesii, deep blue, I2 inches; and Mariesii alba, white. They are suitable for the rock garden or front of the herbaceous border, and need well-drained sandy loam. All can be increased by division carried out in spring.

Platystemon californicus (Californian Poppy). - A very pretty hardy annual belonging to the Poppy family (Papaveraceae), that may be sown out-of-doors where it is to flower, either in autumn or spring. It is of spreading growth, and has prettily-cut, glaucous leaves. The flowers are about 2 inches across, and of pale yellow colour. The young plants should be thinned out about 4 to 5 inches apart. Ordinary garden soil and a sunny spot meet its needs.

Plumbago (Lead Wort).- The chief hardy plants in this group (Natural Order Plumbaginaceac) are Plumbago europaea, a herbaceuts 
perennial, native of the South of Europe, and bearing clusters of violetrose blossoms in late summer; it reaches a height of about 3 feet, while an annual, Plumbago micrantha, is dwarfer. Neither is particularly ornamental, but Larpentae (known also as Ceratostigma plumbaginoides) is an attractive plant for a sunny spot in the rock garden in well-drained sandy loam; the bunches of blue flowers appear at the ends of the shoots in late summer. Both this and Plumbago europaea are increased by division in autumn or spring. The South African Plumbago capensis, a greenhouse shrub, is largely used for bedding out during the summer months. The bunches of light blue flowers are very beautiful. There is a white-flowered variety (alba), but the blossoms are less showy than those of the typical kind. The plants must be wintered in the greenhouse and given comparatively little water. Propagation is easily effected in spring by cuttings of the young. shoots put in sandy soil in warmth. Before growth recommences, straggling branches on old plants should be cut back, and old and exhausted shoots cut out. Hard pruning, however, is to be avoided, as this leads to the production of vigorous shoots that do not flower freely.

Plume Poppy.-(See Bocconia.)

Poa (Meadow Grass).--These Grasses (Natural Order Gramineae) are, as a rule, of no particular ornamental value. The best is Poa trivialis variegata, a neat, compact Grass about 6 inches in height, the leaves being freely striped with white; it is effective as an edging, will thrive in ordinary soil, and can be readily increased by division in spring.

Podocarpus.-Evergreen Conifers (Natural Order Coniferae), some are large trees, others trees of moderate height, and a few are shrubs. They are widely distributed in Tasmania, South Africa, China, Japan, Himalaya, Java, New Zealand, Chili, and elsewhere. A few are hardy and form handsome bushes in the milder counties; and one or two can be grown in many parts of the country. They are seen at their best when planted in moist, but well-drained soil, either of loamy or peaty character, in places where a clear atmosphere and moderately mild, equable climatic conditions prevail. Increase is by seeds or cuttings, plants of the larger-growing kinds raised from seeds being preferable. A little pruning in summer is necessary now and then in order to shape the bushes, but severe pruning must not be attempted.

The best kinds for out-of-doors are: alpina, a low dense-growing bush from Tasmania, growing 3 or 4 feet high, with very small Yewlike leaves, the hardiest of all; chilina, from the Andes of Chili, is 
a handsome large-growing bush suitable for the southern counties; it grows at least ${ }_{5}$ feet high, and bears handsome dark green leaves 2 to 3 inches long. Nageia, from Japan, may be grown out-of-doors in Cornwall; it has rather short, wide leaves. Nubigena, from Chili, is suitable for the south-west counties. Totara may also be grown in some parts of Cornwall; it is one of the largest and most important timber trees of New Zealand.

Podophyllum (Duck Foot).-A small class of hardy perennial plants, members of the Barberry family (Berberidaceae), with creeping rootstocks and thick fibrous roots. Only three kinds are in cultivation: Emodi, native of the Himalaya, grows about I2 inches high, has handsome, lobed, pale green leaves, marbled with bronze, the white flowers, about $I_{2}$ inches in diameter, borne in July, being succeeded by large fruits, which are bright red when ripe. Peltatum, from North America, has whitish flowers, borne on erect stems bearing two one-sided leaves, the flowerless stems terminating in a large, round seven- to nine-lobed leaf of umbrella-like shape, and being particularly attractive. Pleianthum, a Chinese kind, has purple flowers and fruits and six- to eight-lobed leaves; it grows from I to 2 feet high. These plants thrive in damp, boggy soil, and are increased by division carried out in spring, or by seed.

Poet's Narcissus.-(See Narcissus Poeticus.)

Poke Weed.-(See Phytolacca decandra.)

Polemonium (Jacob's Ladder).-Pretty, frce-flowering, herbaceous perennials (Natural Order Polemoniaceae), most of which have flowers of some shade of blue. The different kinds vary in height from 6 inches to 3 feet, and all bloom during summer. The chief kinds are : caeruleum, 2 feet; caeruleum grandiflorum, $2 \frac{1}{2}$ feet ; confertum, I2 inches; himalaicum, 3 feet; himalaicum album (white), 3 feet; humile, 6 inches; reptans, 9 inches; Richardsonii, IS inches; and Richardsonii album, I8 inches. All thrive in ordinary soil; the smaller kinds are well suited to the rock garden, and the others to the herbaceous border. They need a sunny spot, and flourish in ordinary, well-drained soil.

\section{Polyanthus.-(See Primula.)}

Polygala.-In this group (Natural Order Polygalaceae) are several ornamental vigorous shrubs suitable for the gardens of the warmer parts of Cornwall and the Scilly Islands, and for the greenhouse elsewhere, including also one or two pretty little alpine plants available for general cultivation in rock gardens, and several weeds. The tender kinds are natives of South Africa, California, India, and elsewhere, the most useful being those from 
South Africa. Polygala myrtifolia and its var. grandiffora are typical kinds. When planted out they form bushes ro or I2 feet high, but are amenable to cultivation in pots, and flower freely when small bushes 12 or 18 inches high, in 5- or 6 -inch pots. They have small oval leaves about $I$ inch in length, and bear reddish-purple flowers, which are suggestive in general appearance of those of the Pea family, though structurally distinct. Increase is by cuttings during carly summer; the young plants are grown in a light and airy greenhouse in a compost of 2 parts loam, I part peat, and $\frac{1}{2}$ part each of leafmould and silver sand. It is necessary to remove the points of the shoots occasionally to encourage bushy growth. Old plants may be pruned rather severely after flowering. Other useful South African species are oppositifolia and virgata. Probably the best alpine kind is Chamaebuxus: it grows but a few inches high, with small evergreen leaves and creeping stems. The flowers are large for the size of the plant, and the colour is cream and yellow; there is, however, a variety with rich purple blooms. It blossoms in spring, and should be planted in sandy peat.

Polygonatum (Solomon's Seal).-Of the several kinds of Polygonatum (Natural Order Liliaceae), the most ornamental is the Common Solomon's Seal, Polygonatum officinale. Good plants of this produce shoots 3 to 4 feet high, clothed with bright green leaves; the stems arch over gracefully, and from the lower side the longstalked greenish-white flowers hang in small clusters in May or early June. Other species are: biflorum, multiflorum, oppositifolium, roseum (with pinkish flowers), and verticillatum. The flowers of the above kinds, with the exception of roseum, greatly resemble each other. The Solomon's Seal thrives best in sandy loam, though it will grow in quite ordinary soil, and likes shade; it is never seen to greater advantage than in a woodland glade.

Polygonum (Knot Grass).- This is an extensive group of plants (Natural Order Polygonaceac), some of which are but weeds, while others are highly ornamental. They vary greatly, from vaccinifolium, 6 inches or so high, to sachalinense, Io or I2 feet high, while in baldschuanicum we have a vigorous climber of considerable value for the beauty of its blossoms. The chief kinds are: affine, rose, July to October, 6 inches ; alpinum, white, June to August, 3 feet ; amplexicaule, rosy-red, end of summer, 3 feet; baldschuanicum, feathery panicles of white rose-tinted flowers, in May and September, climber ; Bistorta, rose, July to September, 2 feet; capitatum, pink, July and August, 6 inches; compactum, white, autumn, 2 feet; cuspidatum (also known as Sieboldii), creamy-white, late summer and autumn, 
8 to Io feet; sachalinense, whitish, end of summer, Io to I2 feet; and sphaerostachyum, deep red, late summer and autumn, iz inches.

Of those mentioned the dwarf kinds are desirable for the rock garden, while the others will thrive in the open border in ordinary soil. Great caution must be observed in planting cuspilatum and sachalinense, for though a good clump of either forms a striking feature, they are a nuisance in cultivated ground; their creeping underground stems choke all other plants, and once they take possession of a spot it is almost impossible to eradicate them. They are handsome in the wild garden or woodland, but there and there only should they be planted. An annual kind, orientale, 5 feet high, with drooping clusters of rosy-red flowers, during summer, is well worth growing; while a tender kind, lanigerum, if raised in warmth in early spring, and planted out in June, forms a large, spreading, bushy plant 4 or 5 feet high, with leaves of an intense silvery whiteness. Polygonum Bistorta and affine are very attractive in the rock garden, in summer for their spikes of pinkish flowers, and in autumn and winter for their brilliantly coloured leaves, which, however, fall before spring.

Polypodium (Polypody Fern).-The Polypody (Natural Order Filices) is a common British Fern, while it is also found over the greater part of Europe, Asia, Africa, and North America. There is no danger of confounding it with any other kind, though it varies a good deal in height, according to the situation in which it is growing. It forms a creeping rhizome, from which arise fronds from 6 to 12 inches long and from 3 to 6 inches wide; the yellow masses of spores form a distinctive feature of this Polypody. It is exceedingly prolific in varieties, in some of which the pinnae are twicedivided, e.g. cambricum, cornubiense, and elegantissimum. In a wild state Polypodium vulgare is to be found on old walls, rocks, and trees, especially where a little vegetable debris has collected; it also grows freely on the ground, especially in hedge banks and similar places. From the evergreen character of its firm, leathery fronds this Polypody forms an attractive feature on the rock or wall garden. In planting it there its liking for leafy soil must be remembered, while the creeping rhizome must not be buried in the soil, but so arranged that it lies flat upon the surface with the roots in the soil. One half leaf-mould or peat, the other half made up of loam and silver sand, form a suitable soil. Once planted, it must be allowed to remain undisturbed, as the clumps improve in beauty year by year; it should have a fairly shady, cool, and moderately damp position. There are two other species of Polypolium hardy in this country, 


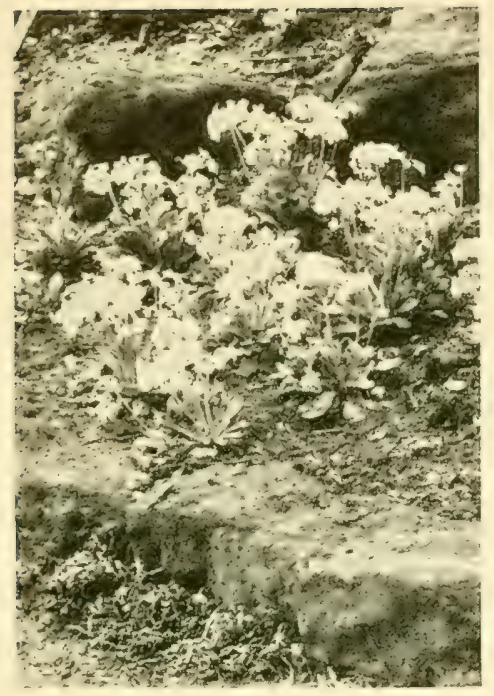

A ROCKERY GROUP OF PRIMULA FRONDOSA

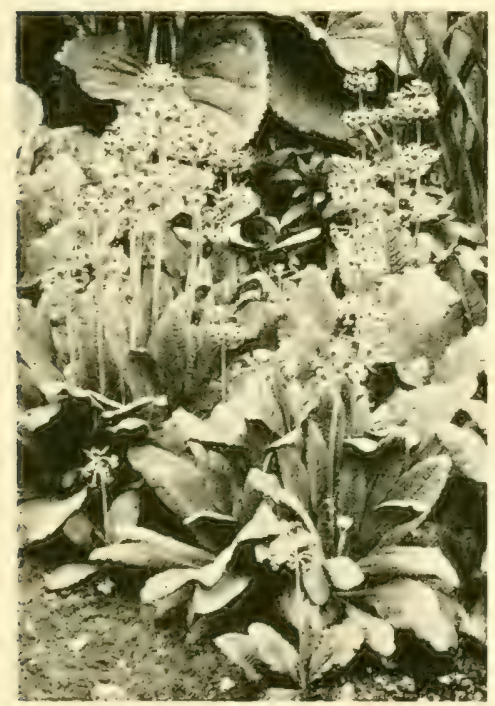

THE ORANGE-YELLOW PRIMULA BULLEYANA

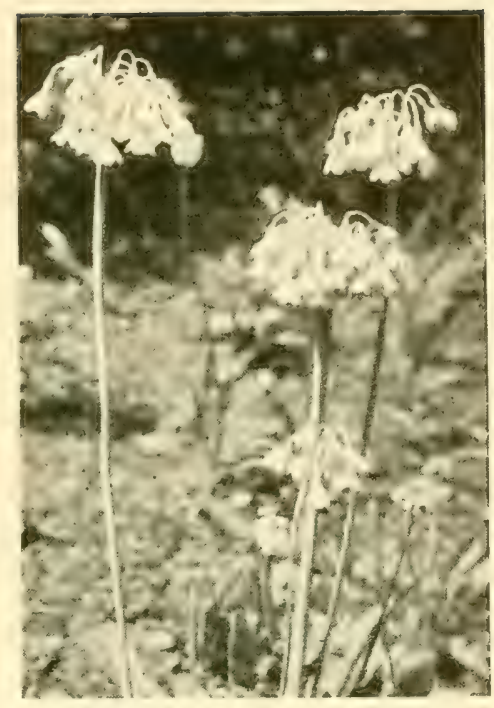

THE SIKKIM PRIMROSE (PRIMULA SIKKIMENSIS)

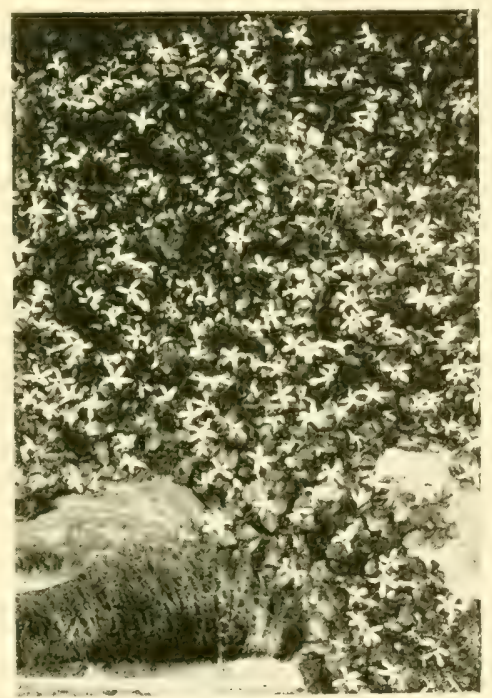

PRATIA ANGULATA ON THE ROCKERY 

namely, Dryopteris (Oak Fern) and Phegopteris (Beech Fern). Their popular names are based on the supposition that they occur principally in woods of these trees. Both are deciduous and both bear much-divided fronds about 9 inches long. They need similar treatment to that outlined.

\section{Pomegranate.-(See PunICA.)}

Pontederia cordata. - A North American plant (Natural Order Pontederiaceae) which forms a tuft of arrow-head-like lcaves of a dark green colour and firm texture; it needs about I2 inches depth of water. The spikes of closely set light blue flowers appear in summer and autumn. On the margin of a pond this forms a striking feature; it can readily be increased by division in spring.

Poppy.--(See Papaver.)

Poppy, Horned.-(See Glaucium.)

Populus (Poplar).- This is an important genus of usually fastgrowing trees belonging to the Natural Order Salicaceae, their closest allies being the Willows. The Poplars, as they are commonly called, are widely distributed through Europe, Northern and Central Asia, North Africa, and North America, where they are usually found occupying moist land in the vicinity of lakes and streams, even where it is sometimes flooded. They are well adapted, therefore, for planting in wet land where many other trees would fail. Many kinds form large timber trees at fairly rapid rate, and the timber, though soft, can be used for a variety of purposes; it is not very inflammable, therefore it is largely used for brake blocks, where there is likely to be considerable friction. It is also used extensively for box-making and the bottoms of trucks and carts, for it does not easily fracture. All except the Aspens (which include tremula, tremuloides, and grandidentata) are easily rooted by means of large cuttings inserted in an outdoor border during autumn or winter. The exceptions are increased from suckers, seeds, or layers. Poplars withstand pruning well and are sometimes cut back annually to form a wind-break. As a rule, though, pruning is confined to shaping the trees and keeping the leaders clear. Poplars stand a fair amount of exposure even near the sea, and are often used for wind-breaks.

Populus alba, the White Poplar or Abele of Europe, North Africa, etc., is a very common, moderate-sized tree; its timber is used largely for making clip baskets in which to pack fruit and flowers. The var. pyramidalis is of narrow, pyramidal habit, and is a very useful tree ; the var. nivea differs from the type by being of bushy habit and bearing very silvery leaves. Balsamifera, the Balsam Poplar of North America, is a striking tree which emits a balsam-like fragrance, 
especially after rain ; canescens has greyish bark, and is often called the Grey Poplar; it forms a large tree of distinct appearance. Eugenei is a fast-growing hybrid Poplar of narrow, erect habit; it is used largely in France as a field tree.

Populus scrotina is a large, fast-growing North American tree, there is a golden-leaved variety often called deltoidea aurea. Nigra grows into a very large tree, and is frequently used as a wind-break, the var. pyramiclalis is the well-known Lombardy Poplar of our gardens, one of the most striking of narrow, pyramidal trees. Tremula, a native of Europe, North Africa, and North Asia, is well known as the Aspen, its dainty, rounded, quivering leaves make it a striking tree; tremuloides is the North American equivalent for the Aspen, the var. pendula, called "Parasol de St. Julien," is a fine pendulous tree, and very showy when laden with long male catkins in February.

Portugal Laurel.-(See Prunus.)

Portulaca (Purslanc).-The Portulacas (Natural Order Portulacaceac) form an exceedingly pretty race of summer flowering annuals. By a continual process of selection they have been raised from l'ortulaca grandiflora, native of Brazil ; this has purple or yellow flowers, but in the garden varieties the blossoms vary from white, through various shades of yellow and scarlet, to purple, while there are both single and double-flowered sorts. They are seen to the best advantage during a hot summer; if the weather is wet and cold, they are usually a comparative failure. They need a warm, well-drained soil, and a spot fully exposed to the sun, indeed, the hottest part of the garden in the best place for them. They are of a spreading growth, and reach a height of about 6 inches; the stems and leaves are succulent, so that they will stand drought well, providing the soil is fairly deep. Seed may be sown under glass in spring, the young plants being placed outside carly in June where they are to flower. They may also be sown about the end of April in the open border, and thinned out to 6 inches apart.

Potentilla (Cinquefoil):- These are for the most part hardy herbaceous perennials (Natural Order Rosaceae), but a few are shrubs. Chief among them are: alba, white, 6 inches; ambigua, yellow, 3 inches; argyrophylla, yellow, I2 inches; formosa or Nepalensis, cherry rose, 12 inches, spreading growth; formosa Miss Willmott, bright cerise, 9 inches; formosa Gibson's Scarlet, intense scarlet, I2 inches; formosa Hopwoodiana, rosy-buff, I5 inches; fruticosa, yellow, 3 fect, shrub; nitida, pale pink, 6 inches; nitida alba, white, 6 incless; nivalis, white, 6 inches; rupestris, white, I2 inches; Thurberii, reddish-brown, 9 inches; Tonguei, orange-yellow, flowers in 
autumn, 9 inches; and Veitchii, white, 3 feet, shrubby. The dwarf kinds are well suited for planting on a sunny part of the rock garden in well-drained soil of sandy loam. The more vigorous kinds may be planted in the herbaceous border. They can be increased by division carried out in spring, the shrubby kinds from cuttings taken in August and protected by a frame or handlight. All flower from June onwards to the end of the summer. Potentilla nitida is a delightful rock garden plant; the silvery leaves are all the better for protection in winter by a pane of glass raised a few inches above the plant.

The border varieties form a very showy class of hardy, herbaceous perennials, that reach a height of $I 8$ inches to 2 feet, and flower during June, July, and August. The blossoms, which are mostly semidouble, are of various shades of yellow, scarlet-crimson, and maroon, almost black. A good selection is : Congo, dark maroon; Dr. André, golden-yellow, suffused with vermilion; Drap d'Or, orange; E. R. Cutler, scarlet, splashed with yellow; Fulton, rich red and yellow; Gold Prince, golden-yellow; Jupiter, vivid crimson, marked with yellow; Le Vesuve, bright crimson, flushed yellow; Nigra plena, very deep maroon; Ophir, vermilion; Vesuvius, scarlet; Vulcan, coppery-red; and William Rollisson, mahogany-red and orange. The foliage of all these much resembles that of the Strawberry.

Pratia.-Pretty little creeping plants (Natural Order Campanulaceae) for the rock garden, where they thrive in a moist, partially shaded spot, and in a mixture of loam, leaf-mould, and sand. Those in general cultivation are: angulata, white; begoniaefolia, blue, succeeded by purple berries; and repens, white, red berries in autumn. These little plants only grow about 2 inches high, and bloom during the summer. They can be propagated by division in spring.

Prickly Pear.-(See Opuntia.)

Prickly Thrift.-(See Acantholimon.)

Primrose.-(See Primula vulgaris.)

Primrose, Evening.-(See Oenothera.)

Primula (Primrose).- The hardy Primulas (Natural Order Primulaceae) form one of the most attractive and fascinating groups of garden flowers, and a representative collection ought to be considered indispensable. The various kinds are distributed throughout a wide area; the majority grow wild in China, Japan, the Himalaya, and other parts of Asia. Others are native of Europe and America, while some of the hardy kinds, such, for example, as the varieties of the Common Primrose, the Polyanthus, Auricula, and Primula japonica, are grown in beds and borders. Most of them are planted in the 


\section{THE BOOK OF HARDY FLOWERS}

rock garden, where they blossom chiefly in spring and early summer. In recent years many beautiful varieties and cross-bred sorts have been raised by florists, and they form a valuable addition to the species or wild types. The innumerable varieties of Primula sinensis are important greenhouse flowers. So, too, are Primula Kewensis, verticillata, floribunda, Forbesi, and obconica.

So far as their cultivation in gardens is concerned, hardy Primulas may be grouped in three chicf classes, namely, rock-loving Primulas, which are essentially plants for the rock garden; those that need moist soil and are suitable for the bog garden or cool border; and finally those used in spring bedding, the Common Primrose, Polyanthus and others. Most of the hardy Primulas are perennial; some are biennial, or usually die or deteriorate after flowering.

Bog or moisturc-loving Primulas.--Many of those included in this group are vigorous plants bearing tall flowering stems on which the blooms are usually disposed in whorls or tiers a few inches apart; their blossoming season is thus a long one, for as the stems lengthen so do the flowers continue to open. They prefer moist, peaty or leafy soil and a cool position, such, for example, as in the bog garden or by the sicle of a small stream, but most of them can be grown without difficulty in any cool, half-shady spot in a mixture of loam, peat or leaf-soil with sand. The most satisfactory method of propagation is by means of seeds sown as soon as ripe in boxes in a cold frame or in spring in a slightly heated greenhouse. The seeds are small, and need to be sown thinly and covered only with a sprinkling of sand. By late summer the seedlings will be large enough to plant out-of-doors where they may be expected to flower the following year. The herbaceous kinds can be increased by division in late summer, and some of the rock Primulas by cuttings in summer.

Primula Beesiana is one of the newer kinds from Western China; it is of vigorous growth, and in early summer bears purplish, yellowcentred blossoms on a strong stem, 2 feet or more high.

Another kind of recent introduction from Yunnan is Primula bulleyana, an especially handsome plant. It is of strong growth, and in May and June bears flowers of orange-yellow colour arranged in tiers on a thick stem similarly to Primula japonica. Its needs are simple, for a partially shaded position and deep soil of the kind already describer suit it admirably. Primula cashmiriana is a variety of Primuli denticulata, and differs from that kind in that the lower surface of the leaves is covered with yellow "powder," and the flowers are usually paler in colour. It needs similar treatment to denticulata. 
A particularly showy kind is Primula cockburniana, native of Western China. It is far less vigorous than those already named, and bears orange-red blossoms on slender stems in early summer. Although perennial in some gardens, it is more often treated as a biennial, seed being sown each spring to provide flowering plants for the following year. It likes a cool spot and moist, yet well-drained soil. Two splendid Primulas, closely allied to cockburniana, have been raised in gardens, namely, Unique (shown in one of the coloured plates) and Lissadell Hybrid; both are more vigorous than cockburniana, have flowers of similar colour, and need the same conditions.

Primula saxatilis (cortusoides) is an attractive kind from Siberia, with prettily cut leaves, and bunches of rose-coloured blossoms on stems some Io to I2 inches high. There are numerous varieties both of this and of Primula Sieboldii, of which the blooms are similar. They are quite easy to grow in half shade, and a mixture of loam and peat or leaf-soil.

The Himalyan Primula capitata blossoms in July and later, when most kinds are over, and for this reason is more than ordinarily valuable. The flowers, which are in round heads on white stems, are of violet or purple colour. Seeds must be sown each summer, for the plants die after flowering. In common with others of this section it needs shade and a moist, well-drained soil. The Bird's-Eye Primrose (Primula farinosa) is a charming little native kind for a cool, moist spot, though it is far less dependable than Primula frondosa, which may be described as a larger form of farinosa.

Primula Forresti is another of the newer kinds from Western China ; it is of vigorous growth, and bears yellow fragrant blossoms, and is suited by limy loam. It has not proved generally hardy, and should be protected in winter by a handlight or cloche. A dainty little plant bearing whitish flowers on slender stems some 6 inches high is Primula involucrata; it is quite happy in moist, peaty soil in half shade. A very closely allied kind is Primula sibirica.

One of the most striking of the newer Chinese Primulas is littoniana; it is remarkable for the fact that the buds are red and the flowers lilac-purple. It blooms in July, and thrives in moist, deep soil in partial shade.

The Japanese Primrose (Primula japonica) is among the easiest and most handsome of all ; it soon forms a strong tuft, from which, in May, rise stout stems bearing blossoms of crimson, rose, white, or other shade according to variety. Primula pulverulenta is a close relative, but is even more handsome owing to its white, powdery stems and finer flowers. Both thrive in moist loam and peat in partial shade. 
The Himalayan Primula rosea is a charming little plant, forming a close leafy tuft, and bearing in April intense rose-coloured blooms on 6 inch high stems. It is easily grown in peaty soil in the bog garden or other moist spot. Seeds form a ready means of increase, or the plants may be divided after flowering. The Sikkim Primrose (Primula Sikkimensis) is one of the most graceful of all, bearing sulphur-yellow drooping blossoms on stems some 2 feet high in early summer. A cool position and moist soil are essential.

Rock Primulas.- Some of the choicest rock garden plants are found in this section of Primula : they are of low growth, natives chiefly of the European Alps, and generally need partial shade and decp, well-drained soil, the composition of which must be varied according to the requirements of the species. Primula Auricula (illustrated in one of the coloured plates) is well known by reason of its having been one of the parents of the race of garden Auriculas which are referred to on page 53. It is a lovely plant, with thick mealy leaves and yellow flowers, and is found wild on limestone in the European Alps; it thrives best in loam containing lime, and should be planted firmly in partially shaded rock crevices, preferably flat against the rock. The roots descend deeply, and a fair depth of well-drained compost is essential.

The dainty little Primula Allionii, from limestone cliffs in the Maritime Alps needs more than ordinary care; a sunny crevice in limestone rock, firm planting, and good depth of soil provide ideal conditions. The lilac rose-coloured flowers, large for the size of the plants, open in late spring. Primula carniolica from the Carinthian Alps bears rose-purple blooms in April from an attractive tuft of glossy green leaves; it needs to be planted firmly in moist soil containing grit, and is best suited by a partially shaded spot. Primula clusiana from the Austrian Alps is a delightful little plant with attractive deep green leaves and large rose-carmine flowers, the petals of which are deeply cleft. Primula glaucescens (calycina) is similar, though possessing distinctive characters in the glaucous tinge of the leaves and less deeply cleft flowers. Both bloom in April, and thrive in well-drained loamy, gritty soil in partial shade.

One of the most popular of the Rock Primulas is hirsuta (usually described in catalogues as viscosa), which is native of the Alps of SouthEast Europe; it has somewhat downy, saw-edged leaves, and in early summer bears heads of rose-coloured bloom. A lovely variety of this plant is the white-flowered hirsuta alba, more generally known as nivalis. Both kinds must be planted firmly in rock crevices in gritty loam and peat in slight shade. Primula integrifolia, native of 
the high Alps of Europe, though a small plant, bears unusually large blooms of rose colouring; it thrives under similar conditions to Primula hirsuta.

Primula marginata, native of the Maritime Alps, is one of the most charming of Rock Primulas; the leaves are greyish with yellow margin, and the dainty flowers, which open in April, are of deep lavender shade. A sunny crevice, and loam containing grit and limestone, fulfil its needs. Primula minima is a tiny plant which forms a dense tuft, and in early summer bears comparatively large rosecoloured blooms. Care is necessary that this kind does not get parched in summer, and a moist soil of peat and loam is suitable. Primula pedemontana from the Piedmont is particularly showy when its heads of deep rose or crimson flowers are at their best in April ; it prefers a partially shaded crevice and gritty soil. The true Primula viscosa is a native of the Maritime Alps, and, in April, bears flowers of pale violet-purple on stems several inches high; the var. Mrs. J. H. Wilson has rich violet-coloured blooms, and is especially handsome. These are not difficult in deep gritty soil in partial shade among rock-work.

Garden Primulas.-The Common Primrose (Primula vulgaris) is too well-known to need more than passing reference to its value as a flower for the woodland, streamside bank, shady walk, and spring beds. Together with the Oxslip (Primula elatior) it is, in its many varieties, especially those of blue colouring, delightful also in the rock garden. However, so far as spring flower gardening is concerned, the Polyanthus (which is considered to be a variety of the Primrose) is now more largely grown. The varieties of Polyanthus have been improved wonderfully during recent years, and their showy flowers provide a rich display in April and May. Both Primrose and Polyanthus are easily raised from seed sown in drills on a shady border during May or June, the seedlings subsequently being transplanted. Well-dug, loamy soil, with which some leaf-mould is mixed, and a position in partial shade are all they need, and there they will thrive if watered as becomes necessary and kept free from weeds.

\section{Privet.-(See Ligustrum.)}

Prumnopitys elegans (Plum-fruited Yew).-This belongs to the Conifers (Natural Order Coniferae), and is a native of Chili. In a wild state it forms a tree 40 or 50 feet high, but here it is usually seen as a large bush. Of Yew-like character, it is preferable to the Common Yew for gardens, for its leaves are of a more cheerful shade of green ; they are small, from $\frac{1}{2}$ to $\frac{3}{4}$ inch long, and softer than those of the Common Yew. The fruits are whitish when ripe and resemble a small plum or large cherry in appearance. Plant in ordinary moist, 
garden soil, where lime is not prevalent, and increase by means of cuttings, or seeds when obtainable. Seeds are not often matured here, however. No systematic pruning is necessary, but if the bushes become unshapely a little cutting may be done in summer.

Prunella (Silf Heal).---These are free-growing carpeting plants (Natural Order Labiatae), well suited for clothing rough, moist, rocky banks. The chief kinds are: grandiffora, violet-purple, 9 inches; vulgaris, purple, 9 inches; and Webbiana, rosy-purple, 9 inches. They can be increased to any extent by division. Prunella vulgaris is a common wild plant in Britain, and is sometimes a weed on lawns.

Prunus. - This is a very important group of the Rose family (Rosaceac), for it contains a considerable number of handsome decorative trees and shrubs and also includes several of our best fruitbearing trees; the species are widely distributed, being common throughout Europe, Northern and Central Asia, Japan, and North America. The cultivated kinds are divided into a number of wellmarked groups. Thus, Amygdalus includes the Almonds and Peaches; Armeniaca, the Apricots; Prunus (proper), the Plums; Cerasus, the Cherries; Padus, the Bird Cherries; and Laurocerasus, the Laurels.

The treatment of the different groups does not vary to any considerable extent, except in the case of that last mentioned, the members of which are evergreens. All thrive in good loamy soil, such as is found in an ordinary garden. They do not like deep planting; simply place about $\frac{1}{2}$ or I inch of soil over the upper roots; fresh manure placed immediately about the roots is detrimental, although it may be put over the soil as a mulch in summer. The species are increased by means of seeds and the varieties by grafting or budding upon Plum, Cherry, or Almond stocks. Some kinds can, however, be propagated by cuttings or by layers.

Pruning of the tree kinds needs to be done with care, especially when it necessitates the removal of large limbs, for all the members of the Prunus family are liable to attack by a disease known as "gumming," which often originates from wounds and eventually kills the trees. Any wounds that are made must be immediately protected by coal-tar. When pruning is confined to the shortening of the previous year's shoots, however, the fear of injury is not so great. The Laurel group also stands pruning well. For special cultural remarks relative to this group, see "Laurocerasus."

Several diseases are rather prevalent among the Prunuses, and perhaps the most prominent one at the present moment is that known as "Silver Leaf Disease." This is most common amongst cultivated Plums, but it also attacks Cherries, Laurels, and other kinds. It is 


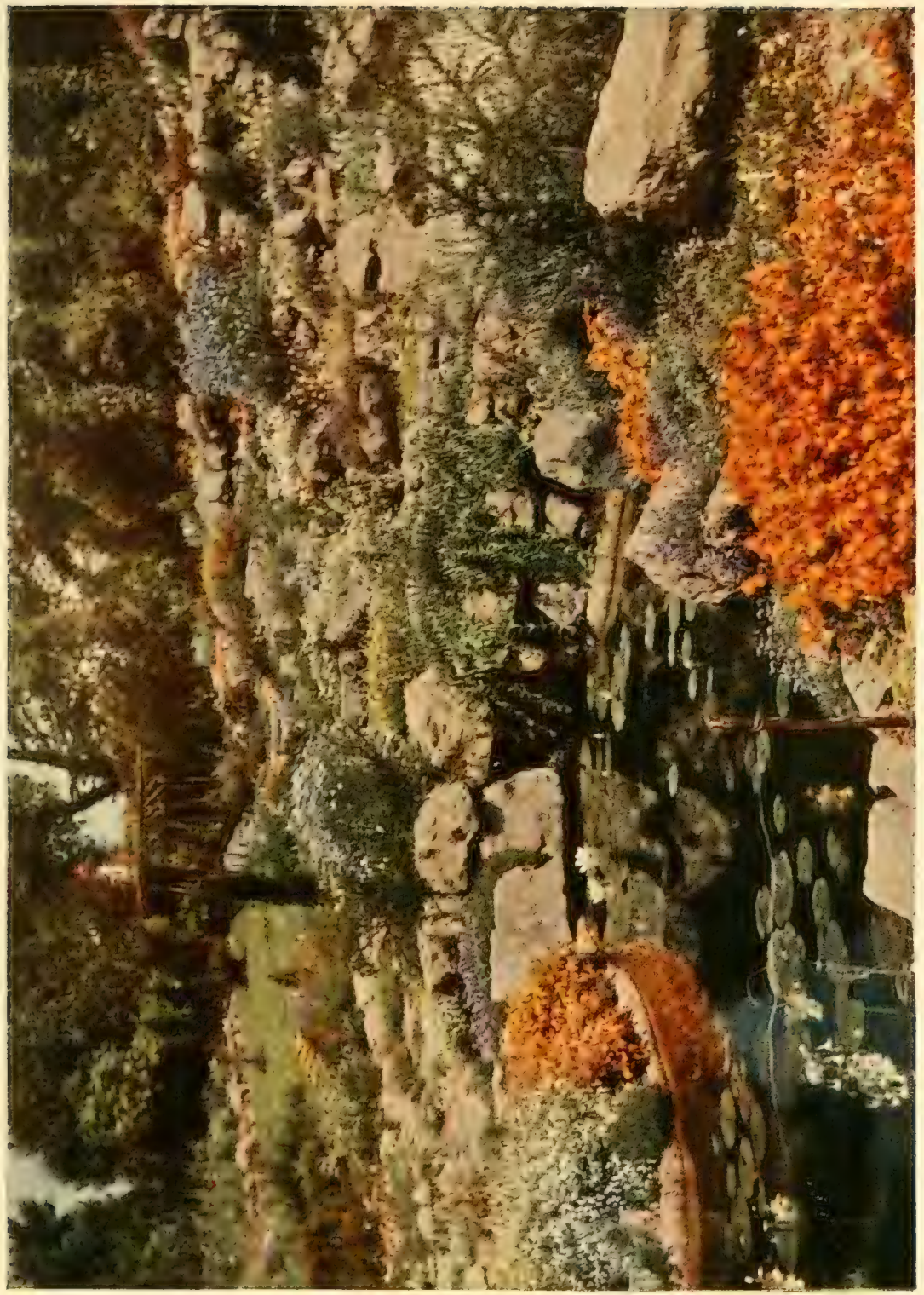

돌 

easily detected by the sickly, anacmic, silvery appearance of the leaves, due to an air space forming beneath the epidermis. It has been of peculiar interest to scientists, for they were unable to account for the disease for a long time, and even now there remains much to learn concerning it, and a remedy for a diseased tree has yet to be found. There are enemies in the form of aphis which attack the young leaves and shoots; these may be kept in check by spraying with paraffin emulsion. Scale insects are also found, particularly on the Peaches; they may be attacked by spraying in winter with a caustic wash, or in April and May with paraffin emulsion. Several members of the Prunus group are of the greatest value for forcing for greenhouse and conservatory decoration in spring. The best are those with double flowers, such as japonica flore pleno; triloba flore pleno; and the various varieties of Cherry and Peach. If lifted from the open border in October and potted, they may be placed in the forcing-house in January. Few plants better repay the little trouble given.

In the following notes attention is directed to a few of the best kinds in each group: Amygdalus (Almonds and Peaches).-Prunus Amygdalus is the Common Almond, one of the most beautiful of March flowering trees in the South of England. It is native of Southern Europe, the Levant, etc., and has long been grown here, where it is known as a tree I5 to 35 feet high, bearing a profusion of rose-coloured blossoms. There are numerous varieties, of which dulcis produces the Sweet Almonds, and amara the Bitter Almonds, of commerce. The var. persicoides blooms 2 or 3 weeks in advance of the type, and macrocarpa has very large flowers and fruits. Prunus Davidiana is a Chinese tree which blooms in February, bearing either rose-coloured or white flowers; nana is a miniature Almond from Southern Russia, 2 or 3 feet high, forming a spreading bush and bearing rose-coloured flowers freely; georgica and Gessleriana are richly coloured varieties.

Prunus Persica is the parent of our garden Peaches; it is considered to be a native of China, and has been cultivated for many centuries. The double-flowered varieties are the most useful for decorative gardening; they form trees up to 20 feet high, but may be kept dwarf by cutting the previous year's shoots back each year after flowering. Good kinds are : camelliaeflora, magnifica, chrysanthemum, and flore rubro pleno, with double red flowers; flore roseo pleno and Clara Meyer, with double rose flowers; and flore albo pleno, double white.

Prunus (True Plums).-The most important species in this group is Prunus communis, from which the fruiting Plums of our gardens 


\section{THE BOOK OF HARDY FLOWERS}

have been evolved by cultivation; as a wild plant it is showy by reason of its white flowers, but it is not worth growing for decoration. Prunus cerasifera, the Cherry Plum or Myrobalan of the Caucasus, is very showy, for it forms a low, wide-headed tree which blooms with considerable freedom in March or early April, the flowers being white; the fruits are bright red, but are not borne freely here. Atropurpurea is a purple-leaved variety (sometimes called Prunus Pissardi). The Cherry Plum can be used as a hedge plant. Prunus divaricata is a similar tree with yellow fruits; maritima and americana are American Plums, which have been used to some extent by the hylbridist ; spinosa flore pleno is a double-flowered form of the Common Sloe or Blackthorn, and an admirable bush for the garden; it is usually grafted upon the typical kind.

Prunus triflora is a native of China and other countries, but is usually called the Japanese Plum; its white flowers are conspicuous in spring here, but the fruits are not produced. It is the parent of a race of Plums, though probably some American kinds have been used with it, which are grown largely in California, Australia, and South Africa, and are received in British markets from the last-named country in winter.

Cerasus (Cherries).-Prunus Avium, the Common Cherry, and Prunus Cerasus, the Morello Cherry, are the two species which are most largely cultivated for fruits, although both have, of course, been very much improved. Prunus Avium is found wild in many parts of the country as a tree 40, 50, or sometimes 90 feet high; the timber is of a pretty reddish hue, and is used for furniture. The double-flowered form, flore pleno, is the one often grown for decorative purposes, and it is a beautiful object when every branch is wreathed in May with pure white pendent blossoms; the single-flowered var. pendula, with weeping branches, is also worth growing. Prunus acida is another useful kind, native of Europe, forming a small tree of compact growth; Dumosa, humilis, and Marasca are dwarf forms which flower freely and are suitable for small gardens. Semperflorens is another variety, but very unlike others: its branches are rather pendent, and the blossoms borne in drooping clusters in May and again in July; it is often called the All Saints' Cherry. Cerasus Rhexii flore pleno is a double-flowered form of the Morello, though not quite so beautiful as Avium flore pleno.

Prunus japonica was for many years only known by its doubleflowered varicties, flore albo pleno and flore roseo pleno, but the single-flowered kind was introduced from China a few years ago. The double-flowered ones are better garden shrubs, although they 
have not the additional attraction of bright red fruits which the single one possesses. These should be planted in good soil and cut back every second year; they are only 3 to 4 feet high. Prunus Pseudocerasus and serrulata are allied kinds from China and Japan which are often mistaken one for the other; the varieties of the former have, however, hairy, and those of the latter smooth, leaves. There are varieties of both with very large double flowers; of the former Watereri, with pink flowers, is the best, and of the latter, flore albo pleno, flore luteo pleno, roseo pleno, and James H. Veitch are all good. The last-named has large rich red double flowers.

Armeniaca (Apricots).-Prunus Armeniaca, the Apricot, is more popular for its fruit than as a flowering tree: Mume, the Japanese Apricot, though, is showy when in flower, especially the varieties with double white and double pink blooms. Prunus triloba flore pleno is, however, the most popular flowering plant of the group : it forms a large shrub and bears charming pink flowers I inch across in April. The flowering branches may be pruned hard back as soon as the flowers fade. Prunus triloba is a native of China.

Padus (Bird Cherries).-Prunus Mahaleb, the St. Lucie Cherry, is a European tree with a large rounded head; its white flowers are borne during late May in profusion in small flattened heads. Pendula is a good variety with pendent branches. Prunus Padus, the Common Bird Cherry, is wild in the British Isles; its white flowers are borne in May in dense racemes 3 inches long, but some of the varieties have inflorescences twice as long; Alberti and flore pleno are two of the best varieties.

Laurocerasus (Laurels).-Prunus Laurocerasus, the Common Laurel, or Cherry Laurel, a native of Eastern Europe and the Orient, and Prunus lusitanica, the Portugal Laurel, from Spain and Portugal, are the most important species in this group. Both are well-known vigorous shrubs which form handsome specimens if left unpruned, but are often ruined by incessant cutting back. The Portugal Laurel is a difficult plant to transplant, and should be placed in permanent positions while quite small. May and September are the best times to plant. Of the Common Laurel the following are the best of the many varieties: Camelliaefolia, caucasica, latifolia, Otinii, schipkaensis, and versaillensis. Of Prunus lusitanica the vars. Azorica, ormstoniensis, and myrtifolia are the best. Variegated-leaved kinds must be avoided.

Pseudolarix Fortunei (Golden Larch).--This Chinese tree is also known as Pseudolarix Kaempferi. It belongs to the Natural Order Coniferae, is included in the leaf-losing group, and is allied to the 
Larches. In China it sometimes grows over roo feet high, but it is not likely to attain, at its best, more than half that height here. It was introduced by Fortune in I846, and is still uncommon. It differs from the ordinary Larches by its longer and wider leaves, and its cones are also distinct, being much larger and breaking up as soon as ripe. A decorative feature of the tree is the golden autumnal colouring of the leaves. It is best adapted for good, deep, moderately moist soil, and is increased by seeds. Pruning is necessary now and then to keep a clear leader.

Pseudotsuga Douglasii (Douglas Fir). - One of the most important timber trees of Western North America. It belongs to the Natural Order Coniferae, and is closely allied to the Firs, but may be distinguished by its softer leaves and pendent cones which do not break up when the seeds are ripe. Under natural conditions it attains an enormous size, trees being frequently more than 200 feet high, and 6 to 8 feet in diameter. It grows rapidly in many parts of the British Isles, attaining its greatest luxuriance in the moist and sheltered valleys of South-West England, Wales, Ireland, and Scotland. It has great merits as a decorative tree, and is also grown under forest conditions. There are two distinct types grown, one bearing green and the other glaucous leaves; the former is considered to be the hardier. There are also several varieties, but they are of little account. Another species, Pseudotsuga macrocarpa, is sometimes grown, but its merits are quite overshadowed by the other. Plant in loamy or peaty soil where lime is not abundant. Increase is by seeds, though it is not likely that the amateur will wish to raise his own trees, for they can be purchased cheaply. Systematic pruning is not required.

Psoralea.--Shrubs and herbaceous plants belonging to the Pea family (Leguminosae), very few of which are in cultivation. Two of the commonest bushy kinds are glandulosa, from Chili, and pinnata, from South Africa. They may be grown out-of-doors in the southwest counties, but require protection elsewhere. They grow from 4 to 6 feet high, and the former bears blue and white and the latter blue Pea-shaped flowers during late spring or summer. Give loamy soil, and increase by seeds. Pruning is restricted to shortening the branches a little after flowering. A few kinds sometimes grown in the herbaceous border are acaulis, Onobrychis, and tenuiflora.

Ptelea trifoliata, the Hop Trce of the United States, is the bestknown kind in this group, which belongs to the Natural Order Rutaceae. Here it forms a small round-headed tree, with three parted deciduous leaves, and bears panicles of green, but very fragrant flowers in early summer. The fluwers are followed by clusters of quaint fruits, the 
central seed being surrounded by a dry membranous wing, the whole fruit being about $\frac{3}{4}$ inch across. The fruits have a bitter Hop-like taste and possess tonic properties. Although less showy than many of the earlier flowering trees, its interesting character warrants its planting in the garden, particularly as it is easily grown in ordinary soil. There are several varieties, of which aurea, with golden leaves and fastigiata, of stiff, erect growth, are the most distinct. The typical kind is increased by seeds and the varieties by cuttings or by grafting. Regular pruning is unnecessary. Ptelea Baldwinii is a second kind from Northern California.

Pteris Aquilina (Brake Fern or Bracken). - This is by far the most common of our British Ferns (Natural Order Filices), for in many places it covers wide areas. In an open sandy loam and a partially shaded moist spot, it attains its greatest luxuriance. Under such conditions the feathery fronds are of a beautiful light green tint, but where fully exposed to the sun and under drier conditions they often acquire a reddish tinge ; this is most pronounced towards autumn. There are places in the wild garden or woodland where Bracken proves effective; the creeping rhizomes do not penetrate deeply, and the best way to establish them is to dig out some turf-like blocks containing the roots or rhizomes, and plant in their new quarters as taken up. The wide geographical distribution of the Brake Fern is particularly noteworthy, for it extends from Lapland and Siberia to the Cape of Good Hope. In the Western Hemisphere it also occurs from the extreme north to Mexico. There are several varieties, but the departures from the normal type are much less pronounced than is the case with many British Ferns.

Pterocarya is a group of trees allied to the Hickories and Walnuts, belonging to the Walnut family (Juglandaceae). They are distinct from those trees, however, by reason of their small nut-like fruits being attended by dry membranous wings. In all cases the leaves are pinnate and ornamental, and male and female flowers are borne on different inflorescences. The female inflorescences often elongate after the death of the flowers, and the catkins of fruits sometimes exceed a foot in length. They require moist, loamy soil, and are happily placed upon the bank of a stream or lake, where the roots can enter the water. Propagation is by seeds, and pruning is limited to shaping the trees when young and keeping the leaders clear. Pterocarya caucasica, from the Caucasus, is the commonest species; it grows into a wide-spreading tree 30 to 50 feet high here, but is taller in a state of nature. It fruits freely in this country. Pterocarya rhofolia, from Japan, is a rare kind, but occasionally met with, as 
also is stenoptera, from China. The most showy species of all is considered to be Paliurus, a Chinese tree introduced I2 or I4 years ago ; it has decorative foliage and large circular fruit an inch or more across. It is very rare at present.

Pterostyrax. - This group, which belongs to the Natural Order Styraceae, comprises two hardy shrubs or small trees. They are: corymbosa, from Japan; and hispida, from China and Japan. Both are decorative and suitable for borders in the Midlands and South of England, and for walls in cold districts. They differ from Halesia by their smaller cream or white flowers being disposed in pendent panicles. Plant in warm, loamy soil or in soil containing a little peat. Propagation is by seeds and cuttings, and pruning is confined to shaping after flowering and thinning the inside branches.

Pulmonaria (Lung Wort).-A group of European plants (Natural Order Boraginaceae), nearly related to the Borage, and, like this, having flowers of some shade of blue or rose-purple; the hairy leaves are marked with white. They are of comparatively dwarf growth, and may be planted in the rock garden, while they are also suitable for the front of the flower border. The chief kinds are: angustifolia, blue, March to June, I2 inches; angustifolia azurea, deeper blue; arvernensis, rich blue, spring, 9 inches; arvernensis alba, white, spring ; rubra, brick-red, March to July, I2 inches; and saccharata, rose and blue, April and May, I2 inches. Pulmonarias can be increased by division carried out in early autumn or spring, the first-named for preference.

Punica Granatum (Pomegranate).-This belongs to the Natural Order Lythraceae, and is sometimes grown out-of-doors against sunny walls in the milder parts of the country, where it frequently perfects its showy scarlet flowers and sometimes matures fruit. There are two distinct varieties in addition to the type; one, flore pleno, with double scarlet flowers nearly 3 inches across, and nana, with small scarlet flowers. The last-named flowers more freely than the others, and gives excellent results near London if placed against the warm wall of a greenhouse facing south. The various kinds are sometimes grown in tubs and stood out on terraces during summer. Generally, however, we have insufficient sun to warrant their being grown outof-doors. Plant in loamy soil and give what little pruning is necessary in winter. The Pomegranate is a native of Persia.

Purslane.-(See Portulaca.)

Puschkinia scilloides (Striped Squill).-A delightful little, springflowering, bulbous plant, from the Orient, that reaches a height of 6 to 8 inches. It belongs to the Lily family (Liliaceae), and the 
flowers are white striped with rich blue. It will thrive in a welldrained border, and forms a very pleasing feature in the rock garden. The bulbs ought to be planted in September or October.

Pyrothrum.-Botanists now class these plants (Natural Order Compositae) with the Chrysanthemum, the original species from which the garden varieties have sprung being known as Chrysanthemum coronarium. The name of Pyrethrum is, however, in such general use that in order to avoid confusion it is used here. Both the single and double varieties are well-known border plants, while the long firm stems render the blooms suitable for cutting. The flowers are, as a rule, at their best in May and June. The Pyrethrum delights in well-manured soil; in too light ground it does not grow freely, whereas in clayey soils it is apt to die during the winter. Just as the young leaves appear a sharp look out must be kept for slugs, which soon do a good deal of damage. Division, which should be carefully done, is best carried out in early autumn or in March.

Some good double varieties are: Ajax, purple-crimson; Aphrodite, pure white; Captain Nares, bright, glowing crimson; Celia, bright pink; Duchess of Edinburgh, rosy-mauve; Lady Derby, silvery flesh ; La Vestale, blush ; Lord Rosebery, brilliant scarlet; Melton, bright crimson-scarlet; Mont Blanc, white; niveum plenum, white, quilled flower; Queen Mary, salmon-pink; rubrum plenum, rosypurple; Triomphe de Mai, carmine-rose; and Virgo, creamy-sulphur. Single-flowered sorts are: Agnes Mary Kelway, bright rose; Albert Victor, crimson-scarlet; Alexis, amaranth ; Beatrice Kelway, cherryrose; Carmen Sylva, blush white; Coccinea, reddish-purple; Fairy, rose-pink; Hebe, pure white; James Kelway, vivid scarlet; Mrs. Bateman Brown, rich crimson; Mrs. William Kelway, flesh-pink; Standard, rosy-carmine; and Vivid, crimson-amaranth.

Pyrola (Wintergreen).--Low-growing, half-shrubby plants, belonging to the Heather family (Ericaceae). The chief kinds are: elliptica, white, June and July, 6 inches; media, white, tinged red, July, 4 inches; rotundifolia, white, June and July, 6 inches; and secunda, greenish-white, June and July. They thrive in peaty or leafy soil in a moist, half-shady portion of the rock garden.

Pyrus. - This is a very important class (Natural Order Rosaceae), for it includes two of our most valuable fruits in the Apple and Pear, while many kinds are decidedly ornamental and amongst the most beautiful flowering trees of the garden. Moreover, the majority are hardy and thrive throughout the British Isles. They are widely distributed through the Northern Hemisphere; Europe, Asia, and North America all contributing numerous kinds. Several species are 


\section{THE BOOK OF HARDY FLOWERS}

found wild in the British Isles. The group is divided into several sections under different sub-headings. Thus, Pyrophorum includes all the Pear family; Malus, the Apples; Sorbus, the Mountain $\Lambda$ shes ; Aria, the White Beams; Adenorachis, the Choke-berries; and Mespilus, the Medlars. Some botanists split up the different groups and give each one generic rank, whilst others include the Quinces (Cydonia). With these matters, however, we have little to do, and for our purpose we give them as above.

All require somewhat similar methods of cultivation. They thrive in ordinary garden soil; the species may be increased by seeds, and the varieties by grafting or budding. A few kinds may be propagated by cuttings, but, as a rule, that method is not recommended. Pruning takes the form of keeping the centres of the trees open and removing branches which are in the way. All wounds so made must be coated with tar. Some of the kinds are liable to attacks by various insect pests, notably by scale insects, and the Malus group by American Blight. It is a good plan to spray the trees with a caustic wash in winter. This kills many insects and helps to remove dirt, moss, and rough bark under which insects may lurk. In summer, American Blight may be attacked with paraffin emulsion. In the following notes attention is directed to a few of the best kinds in each group.

Pyrophorum (Pears).--This group is made up chiefly of whiteflowered trees which bloom in April and May, the commonest example being Pyrus communis, the ordinary Wild Pear. As a wild tree or an occupant of park or shrubbery it possesses considerable beauty by reason of its wealth of blossom; the fruits are small, rather dry, and gritty. Garden Pears have originated by many years of cultivation and selection. Pyrus auricularis, though usually included amongst the Pears, is strictly a hybrid between communis and Aria; it is intermediate in character between the two trees, and the flat heads of white flowers are followed by scarlet and gold pear-shaped fruits. Betulaefolia is the Birch-leaved Pear from China and Japan, growing at least 20 feet high, and forming a decorative tree; longipes, from Algeria, is handsome alike for its white flowers and tiny brown fruits; Pashia, an Indian Pear, differs from other kinds by having flowers suffused with pink.

Pyrus salicifolia, the Willow-leaved Pear, has narrow, Willowlike, silvery leaves, white flowers, and small green fruits: Sinensis is interesting, in addition to being a showy tree, for it is the parent of the cultivated Pears of China and Japan; the var. Simonii is curious, as the fruits are exactly the reverse in shape to other Pear fruits. Tschonoskii is one of the newer Pears, for it has been received from 


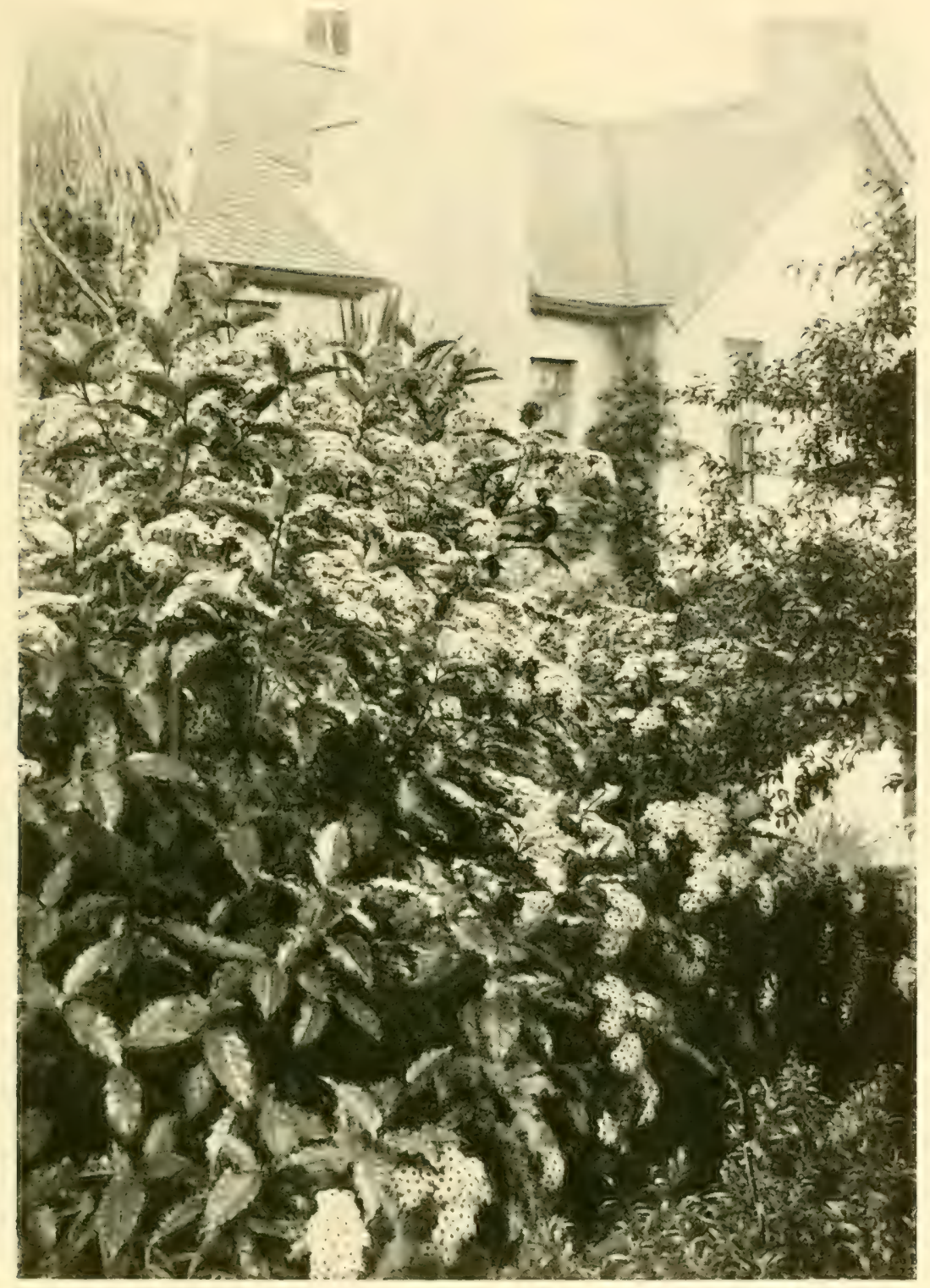

A DAISY BUSH (OLEARIA MACRODONTA) IN SOMERSET 

Japan within the last twenty years: it is a tall, upright-growing tree, bearing white flowers shaded with pink, and small, hard green and red fruits.

Malus (Apples and Crab Apples).-This is the most important group so far as ornamental trees are concerned; it includes numerous species, amongst which the following are conspicuous: Pyrus baccata, the Siberian Crab, a widely distributed tree from the Himalaya to Siberia and Japan, forms a large bushy specimen which bears a profusion of white rose-flushed flowers in May; they are followed by round fruits which are usually red when ripe. The fruits are esteemed for jelly making, but if allowed to remain on the tree they frequently hang until March. Pyrus prunifolia is a closely allied tree from Northern Asia ; it differs from baccata by its fruit ripening earlier and by the persistent calyx lobes which remain in the same way as those of the Apple, whereas those of baccata fall. The var. cerasiformis has rich red fruits as also has fructu coccinea, whilst xanthorcarpa has yellow fruits. Pyrus coronaria, the American Crab Apple, is a native of the Eastern United States, and is distinguished by large Apple-like blossoms succeeded by bright green fruits $I$ to $I \frac{1}{2}$ inches in diameter. The double-flowered var. flore pleno is, however, superior to the type for ornamental planting. Its flowers are borne late in May, and are often 2 to $2 \frac{1}{2}$ inches across.

Pyrus floribunda forms a large bush or small tree, often from I2 to I6 feet high; its branches, which sweep the ground, have a diameter of 15 or 20 feet. The pink-flushed flowers are in such profusion as almost to hide the branches during late April and early May. Atrosanguinea is really an improvement on the type, its flowers being more richly coloured. Halliana is considered to be a hybrid, it has large bright rose and white semi-double flowers, which appear with great freedom.

Pyrus Malus, the Common Crab Apple, is found wild in some parts of the British Isles. Several varieties have been given names, and all are showy when in flower, but they are usually passed over for the large-fruited kinds, such as John Downie, Dartmouth, and other garden forms, which are equally beautiful in flower and infinitely more so in fruit. Pyrus Niedzwetzkyana is sometimes included as a species, but it is really either a variety of Malus or a hybrid, for a small percentage only come true from seed. It is said to come from the Caucasus, and its interest centres in its red flowers, a colour which also tinges leaves, wood, roots, and fruits.

Pyrus Ringo is a small tree from Japan, which bears a profusion of white rose-flushed flowers followed by golden fruits; Scheideckeri, 


\section{THE BOOK OF HARDY FLOWERS}

said to be a hybrid between prunifolia and floribunda, produces semidouble flowers in such profusion as to check growth, and is excellent for places where a free-flowering but slow-growing tree is necessary. Spectabilis, from China and Japan, grows as large as an ordinary Apple tree, and produces fine large flowers, but is outclassed by its double-flowered var. flore pleno; this never fails to bear a wealth of blossoms of a bright pink hue; the var. Kaido is also very attractive.

Aria (White Beam).--Pyrus alnifolia is a rare Japanese and Chinese tree with Alder-like leaves and white flowers in flattened heads; the small, scarlet oval fruits ripen in August. Aria, the Common White Beam Tree of northerly regions, is found in many parts of the British Isles, particularly on chalky ground; it forms a bush or tree up to 45 feet high, and is handsome alike by its oval greyish leaves, white flowers in large flat heads, and orange and scarlet fruits. There are numerous varieties, of which chrysophylla, with golden leaves, graeca, a very free-flowering and free-fruiting form, and majestica, with handsome leaves and particularly large and showy red fruits, are the best. Pyrus crataegifolia, sometimes called Cormus florentina, is a dwarf bushy tree from North Italy; it is very handsome by reason of its deeply lobed leaves, fine flowers, and fruit. Pyrus intermedia, a European species, is distinguished by its leaves being distinctly pinnate about the lower part, it is a very good town tree. Pinnatifida is a somewhat similar tree, but the divisions of the leaves do not extend to the midribs; both it and its var. fastigiata are excellent town trees; rotundifolia is very similar to Aria, with rounder leaves and larger fruits; Torminalis, the Wild Service, is found wild in some parts of the British Isles; the brown fruits are not very attractive; vestita is a handsome, silvery-leaved tree from the Himalaya.

Sorbus (Mountain Ash).--Pyrus Aucuparia, the Rowan or Mountain Ash, is the best-known tree in this group; growing from I $_{5}$ to 35 feet or more in height, it is well known by reason of its pinnate leaves and handsome scarlet fruit; it stands exposure well, and thrives in quite poor soils. The var. fructu luteo has yellow fruit, asplenifolia has cut leaves, fastigiata is of upright habit, and pendula has weeping branches. Pyrus americana is the American form of the Mountain Ash; it is of somewhat stiffer habit than the European species, with larger heads of fruits; the var. nana is useful for small gardens. Pyrus Sorbus, the Service Tree, is also included in this group, as are also such showy kinds as lanuginosa and thianschanica.

Adenorachis (Choke-berry).--Two North American kinds, both bushes, are included in this group; they are arbutifolia and nigra. 
Their attraction lies in their white flowers in May, small red or black fruits later, and the beautiful tints of their foliage in autumn.

Mespilus (Medlar).-Pyrus germanica, the Common Medlar, is the best of this group; it is a well-known garden tree. The tree sometimes called Pyrus lobata is really a hybrid between germanica and the Common Hawthorn.

Pyxidanthera barbulata (Pink Barren Beauty).-A pretty little plant from North America (Natural Order Diapensiaceae) that grows only 2 inches high. The short bell-shaped flowers, white or pink, are borne in May and June. The foliage is somewhat Heath-like, and acquires a purplish tinge with exposure. It thrives best in sandy peat kept fairly moist, yet in a sunny spot.

Quaking Grass.--(See BrIZA.)

Quamash.-(See CAMASsia Esculenta.)

Quercus $(O a k)$. - This is an important group of trees and a few shrubs (Natural order Cupuliferae), for it includes all the true Oaks. A large number of kinds have been described, which, with a few exceptions, are hardy in the British Isles. They are natives of Europe, Asia, and North America, and a few of North Africa. Many are important timber trees, such as the Common Oak of the British Isles and Europe, the Red and White Oaks of North America, and certain Japanese and Himalayan species. The bark in most cases is rich in tannin, and was at one time the most approved subject for tanning leather. The acorn cups of some kinds, particularly of the Valonia Oak (Quercus Aegilops), are used for the same purposes, whilst it is from the bark of Quercus Suber that the cork of commerce is obtained.

Generally, the Oaks require good, deep loamy soil in order to attain their finest proportions, but they also do fairly well in some soils of poorer quality. When planting Oaks for ornamental purposes, however, care must be taken to provide really good soil, and if the natural ground is poor, large holes 8 to I 2 feet square and 2 to $2 \frac{1}{2}$ feet deep should be prepared for them by removing the poorer material and filling up with good soil. This is expensive work, but it pays in the end, for it must be remembered that Oaks are only beautiful when grown well, and that their prospects of life may be calculated in centuries. When the soil is good, it simply needs trenching before the trees are planted. All kinds must be increased by seeds, which, whenever possible, should be sown where the trees are to grow. Varieties are increased by grafting upon stocks of their respective types, two or three years' old wood being used for scions. Pruning takes the form of keeping leading shoots free from rivals, removing 
lower branches occasionally, and thinning out branches where the branch system is too dense. If the trees are properly looked after whilst they are young they will require little pruning in after life.

Quercus acuta is an evergreen kind from Japan, a tree in its native country, but a bush here; the glossy leaves are attractive. Ballota, the Sweet Acorn Oak, is a native of Spain and Portugal; its evergreen leaves are easily distinguished from those of the Common Evergreen Oak by being rounder, shorter, and rather thicker; the sweet acorns are used as an article of food in Soutl-West Europe; it is only suitable for the south and west. Quercus castaneaefolia, from the Caucasus and North Africa, has leaves resembling those of the Swcet Chestnut; it is vigorous and attractive.

Quercus Cerris, the Turkey Oak, grows fairly rapidly into a large ornamental tree, and is distinguished by its deeply cut leaves and mossy acorn cups. There are many varieties, one or two with silver variegated leaves. Lucombeana is sometimes included as a variety, but it is really a hybrid between this species and Quercus Suber. As a rule, it keeps its leaves until late winter. Seedling forms show a great deal of variation, some being near the Turkey Oak and others near the Cork Oak.

Quercus coccinea, the Scarlet Oak of North America, is grown for the sake of its brilliant autumn colouring: at that season the leaves are rich deep red for a period of several weeks; conferta is a rigorous tree with bold foliage, native of Italy, Hungary, etc.; cuspidata, from Japan, is grown for its evergreen leaves, and the var. variegata has handsome variegated foliage; glauca is another evergreen Japanese kind, which forms a useful bush in the South of England.

Quercus Ilex, the Evergreen or Holm Oak of the Mediterranean region, is a valuable evergreen tree. It gives excellent results over a considerable part of England, and is a good tree for the maritime counties. Few trees are better suited for blocking out unsightly objects, whilst it forms a handsome specimen tree, and also grows into a good hedge, standing clipping well. It is difficult to transplant, and must be planted permanently when quite small. May is a good time to plant.

Quercus macranthera, from Armenia, is grown for its large handsome leaves. Mirbeckii, a sub-cvergreen from Spain, Portugal, and North Africa, is a very handsome species with large leaves; it is suitable for a lawn:

Quercus pedunculata, the Common Oak, and sessiliflora, the Durmast Oak, are our two British kinds. Both form handsome trees, and are too well known to require further recommendation: there 


\section{RAMONDIA}

are numerous varieties of both. Rubra, the Red Oak of North America, is a vigorous tree with large decorative leaves; the var. aurea has golden leaves.

Quercus Suber, the Cork Oak, should be planted in gardens in the South of England, for its evergreen leaves and corky bark are always interesting. Velutina, var. rubrifolia, is perhaps the largest-leaved of all Oaks, for the leaves are sometimes I3 inches long and $\&$ inches wide; it is called the Champion Oak, and is a native of North America.

Ramondia.--Pretty little plants, natives of the South of Europe, and belonging to the Gloxinia family (Gesneraceae), that form a rosette of broad crinkled hairy leaves, and have violet-like flowers on stems a few inches high in June. They should be planted in a shady crevice in the rock garden flat against the rock to prevent water lodging in the centre of the crowns; a compost of loam and leaf-soil with sand is suitable. They are increased by division in September, or by seed sown as soon as ripe or in spring. The chief kinds are: Ramondia (Jankaea) Heldreichii, blue; pyrenaica, violet-purple; pyrenaica alba, white; and Nathaliae, deep purple. All are charming flowers.

\section{Rampion.-(See Phyteuma.)}

Ranunculus (Buttercup).-An extensive group of plants (Natural Order Ranunculaceae), natives for the most part of Europe and Asia, one or two occurring in New Zealand. The different kinds vary considerably, for some are troublesome weeds, while others are handsome border flowers. In addition, some are delightful alpine plants. For the bog and water garden some of the kinds are well suited, but most popular of all are the tuberous-rooted florists' varieties, which were at one time the pride of the garden, but are now not so much grown. Ranunculus aconitifolius flore pleno (Fair Maids of France), bearing double white flowers in May and June, grows from I 8 to 2.4 inches high, and is a delightful plant for the waterside. alpestris, from the Pyrenees, is a rock garden plant, some 5 or 6 inches high, and bears somewhat large white blossoms in June, their beauty being enhanced by the cluster of yellow stamens in the centre; it needs deep loamy soil in which leaf-soil and grit are freely mixed, and in common with most other kinds must not suffer from lack of moisture in summer. Amplexicaulis is a handsome, grey-leaved, white-flowered kind that is at its best in May; it grows Io or I2 inches high, and offers no difficulty in moist soil. A charming alpine is found in glacialis, quite a dwarf plant, with attractive deep green leaves and white flowers in June; it needs a cool spot and a soil of 
loam, leaf-soil, and grit. Ranunculus Lingua is an attractive marsh plant, growing 2 to 3 feet high, and bearing yellow blooms in summer. An attractive and easily grown kind is gramineus, with narrow leaves and bright yellow blooms in April; it grows about I2 inches high. Others worthy of mention are: parnassifolius and pyrenaeus, from the European Alps, bearing large, white blooms in May and needing cool, gritty loamy soil; and Seguieri, another Alpine, only about 4 inches high, bearing white flowers in May.

The florists' varieties of Ranunculus asiaticus are usually referred to under the heads of Persian, French, and Turban varietics. In the Persian the flowers are as regularly imbricated as a show Dahlia, and the colours vary from pure white, through various shades of pink, yellow, orange, scarlet, and crimson, to almost black. The small curious-shaped tubers should be planted in the autumn 2 inclies deep in sandy loam, and need to be protected from sharp frost, or they may be planted in early spring. The proper way is so to arrange the roots that the claws are placed downwards, and to cover them with about 2 inches of soil. It is advisable to lift the roots when the leaves have facled and store them until planting time. The French varieties are of stronger growth, with equally showy flowers, while the Turban kinds with less formal flowers are earlier in blooming than the other two. The Ranunculus may be raised from seed sown in boxes of sandy soil in March.

Red Hot Poker Plant.-(See Kniphofia aloides.)

Rehmannia.--The kind chiefly grown is Relmannia angulata, a Chinese plant of comparatively recent introduction (Natural Order Scrophulariaceae). It is a herbaceous perennial, and produces spikes to a height of 4 fcet, which from June to August bear Foxglovelike flowers of rosy-purple colour with ycllow throat. It is largely grown for greenhouse decoration, but will thrive out-of-doors in a warm, sheltered spot in the southern part of the country. The var. Pink Perfection is without the purplish tone of the typical kind. A distinct species, less showy and dwarfer in habit, is Chinensis, with blush-coloured flowers having dark markings. The Rehmannias may be divided in spring, or seeds sown at that season under glass to produce flowering plants the following summer. They thrive in ordinary, well-drained sandy loam with which a little leaf-soil should be mixed.

Reseda (Mignoncttc).--Of the several perennial species of Resedia (Natural Order Resedaceae) the only one of any account as a border plant is Reseda glauca, with glaucous foliage and spikes of whitich flowers during the summer months. It is native of Europe. An 


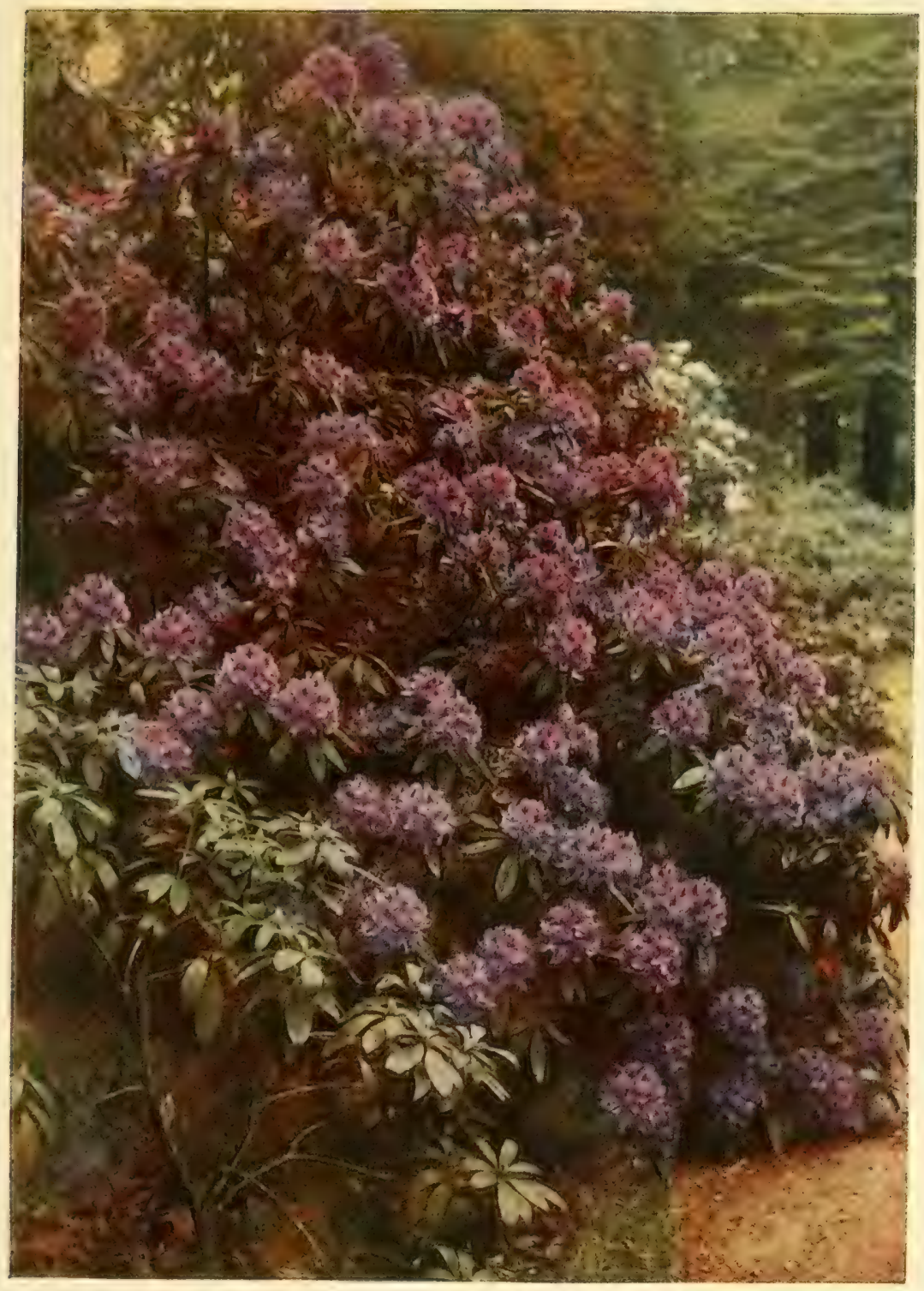

RHODODENDRON PURPUREUM ELEGANS 

annual kind, however, occupies a foremost position among flowers of this class. This is the fragrant Mignonette (Reseda odorata). By a process of selection several varieties have been obtained with creamy white, red, and yellow flowers. The Mignonette will thrive in ordinary garden soils, except those deficient in lime, which must be added either in the shape of old mortar rubble or lime itsclf. The seed should be sown outside during the month of $\Lambda$ pril and the soil made firm.

\section{Rest Harrow.-(See OnONIS.) \\ Retinospora.-(Sce CUPRESSUS.)}

Rhamnus.-Numerous hardy shrubs are found in this group of the Natural Order Rhamnaceac. Several species have considerable economic value, but very few are of any decorative importance. They are widely distributed through Europe, including the British Isles, Asia, and North America, and are easily grown. Ordinary garden soil suffices for successful cultivation, and propagation is most easily practised by sowing seeds as soon as ripe, or in the following February, in boxes or pots of light loamy soil in a frame or greenhouse. Regular pruning is unnecessary, but when severe cutting back is required it should be done in March. The flowers are in no case showy, but in several instances the black fruits are attractive. The following species are of interest: Alaternus is a large-growing evergreen bush from South-West Europe, with oval or oblong leaves I inch to 2 inches long; it grows at least Io feet high, and as far through, and can be used in shrubberies or as isolated specimens; the var. maculata has golden variegated leaves, and variegata has leaves margined with silver. The latter variety is difficult to transplant. Cathartica, the common Buckthorn of our hedgerows, is a spiny, deciduous bush, sometimes 15 or 20 feet high; its black berries are conspicuous in September. If desired, it can be used as a hedge plant. Frangula, the Alder Buckthorn, is a native bush or small tree up to 20 feet or so high; its bark has laxative properties, but it is chiefly valued on account of the wood being very valuable for charcoal, used in the better qualities of smokeless gunpowder. Grown for this purpose, it should be planted in large plantations and treated as coppice. Purshiana is the source of the drug Cascara Sagrada. It is a Californian tree, between 20 and 40 feet high, with deciduous leaves, tiny greenish flowers, and black fruits. The bark is removed from the branches in spring, dried, and ground to powder; it is then used for its laxative properties. It grows well in this country, and the drug has been prepared from English-grown bark. Cuttings of young shoots may be rooted in a warm frame during summer. 
Rheum (Rhubarb).-Natives principally of the temperate parts of Asia. The Common Rhubarb (Rheum Rhaponticum) is a wellknown plant, and apart from its economic value, a decidedly ornamental one. It belongs to the Natural Order Polygonaceae, and is native of temperate Asia. There are, however, others which surpass it in decorative value, notably Alexandrae, with small compact tufted leaves, and large pale yellow bracts, which are disposed up the flower stem, and form a very striking feature in early summer. Collinianum has very large leaves and spikes of bright crimson flowers ; Emodii, large red-veined leaves and spikes of whitish flowers; officinale, one of the sources of Turkey Rhubarb, possesses very large leaves and small greenish flowers; palmatum, has very deeply cut leaves with whitish flowers; while in palmatum tanghuticum the blossoms are of rich red tint, and produce a striking effect. All the Rheums can be readily increased by division or seed, and will thrive in ordinary garden soil.

\section{Rhodanthe.-(See Helipterum.)}

Rhododendron.-This (which belongs to the Natural Order Ericaceae) is at the same time one of the most beautiful and important groups of shrubs, for not only is almost every species a showy flowering plant, but large numbers of hybrids and varieties have originated which are popular everywhere where plants of the Heather family thrive. Only one adverse criticism can be made, that being the general dislike of the Rhododendrons to lime, which makes it impossible to cultivate any, cxcept a very few kinds, in places where lime is present in the soil to any appreciable extent. The head-quarters of the family was at one time considered to be the Sikkim Himalaya, whence the late Sir Joseph Hooker introduced many lovely kinds about the middle of last century. Recent explorations in Central and Western China have, however, revealed the fact that China contains a great many more kinds than the Himalaya. Then some are found in Japan, North America, Java, and Europe.

In a genus or group containing about 200 species we naturally expect to find considerable variation in habit of growth, and this is the case with the Rhododendron. Some are of tree-like proportions, whilst others rise but a few inches above the ground. The majority are found in moist, peaty, or loamy soil, but some grow in swamps and others are epiphytes, finding their homes between the branches of trees and growing freely wherever decayed leaves and other humus can collect. Some kinds are hardy throughout the greater part of the British Isles, whereas others may only be grown successfully outof-doors in the milder counties, a cold house being required elsewhere. 
The majority of these commence to grow early and are injured by late frosts rather than by winter cold. Then there is another set of subtropical kinds from the Malaya, which can only be grown in warm greenhouses.

As a rule, Rhododendrons thrive most satisfactorily in light loam or peaty soil which is naturally moist but well drained. They will, however, grow in quite heavy soil, providing lime is absent. As the roots are fine and fibrous, they bind the soil into a compact mass, and are amongst the most convenient plants we have for transplanting. Autumn and spring are the best times to transplant, but it is possible to carry on the work during every month of the year providing ordinary care is exercised. As the best roots are usually near the surface of the soil deep planting must be avoided, and to keep the roots moist provide a surface dressing of leaves. Should old plants show signs of becoming weak they may be invigorated by being watered with cow-manure water two or three times during the growing season. A point to remember during transplanting is that the new soil must be made quite firm about the roots, otherwise a difficulty will be experienced in keeping them moist.

Several methods of propagation are adopted. Many of the species and all new varieties are raised from seed. This should be sown thinly on the surface of sandy peat made firm in pans or boxes. Cover with sheets of glass and brown paper until germination takes place. Gradually inure to light and air, and when the seedlings can be handled prick them off in a prepared bed in a cold frame, I inch apart each way. Many of the smaller-growing sorts are easily increased by cuttings of short, half-ripe shoots taken during July or August and inserted in sandy soil in a close and warm frame. Then the largegrowing kinds and most of the hybrids are increased by grafting or by layers. Grafting takes place under glass in February, March, and April, each kind being grafted upon seedling stocks of the species to which it is closely related. The kind of graft known as "saddle" is used, and the plants are kept in a close, warm, and shaded frame until the union is complete.

Pruning of young plants is necessary to ensure a sturdy foundation. This must, however, be done early so that the plants do not waste time in making growth which will need to be removed eventually. Therefore remove the ends of young shoots whilst they are quite soft, and a further set of shoots will be formed in summer. Pruning in later life consists of regulating the size and shape of bushes, cutting down "leggy" plants, and removing the flower-heads before seeds can form. When a vigorous cutting back into old wood is necessary, 
it must be done in early April, for by sacrificing the season's blooms a longer flowering period is gained. Pruning at other times must be done as soon as the flowers fade.

There are two well-marked groups of Rhododendron. One group, of which the majority of kinds are deciduous, was at one time known as Azalea, the remaining one being Rhododendron. The difference was made in the first instance by reason of certain of the earlier-known kinds of the former group having but five stamens to each flower, whereas in the group known as Rhododendron each flower had ten stamens. Subsequent introductions, however, proved that these features could not be relied upon, and Rhododendron is now applied to all kinds. For garden purposes, however, Azalea will always remain.

Azalea.-The best-known kinds in this group are the Indian Azalea (Rhododendron indicum), the Ghent Azaleas (hybrids from various North American and one Caucasian species), and the. Mollis Azaleas (Rhododendron sinense). Rhododendron indicum is a well-known evergreen greenhouse plant, which is found in many single- and double-flowered varieties, the blossoms varying in colour from white to pink, salmon-pink, rose, and deep red. Vast quantities are grown in Holland every year to supply the Continental and English markets. They thrive most satisfactorily in a quite cool greenhouse on a moist, ash-covered stage. A few of the hardier varieties are grown out-ofdoors in Cornwall. The small-flowered variety amoenum is hardier than the rest; it gives very good results out-of-doors in the neighbourhood of London. The variety known as amoenum splendens is an improvement, the flowers being a brighter red. Rhododendron Kacmpferi is sometimes given as a variety of indicum, though now considered distinct; it is a native of the mountains of Japan and like amoenum in habit and in size and shape of flowers; the colour of the flowers varies from reddish-purple to brick-red. It may be grown out-of-doors about London.

The Ghent Azaleas are hybrids between the North American Rhododendron calendulaceum and nudiflorum and the Caucasian Rhododendron flavum. They may be procured in a wide range of colours from white to pink, yellow to orange, and scarlet to red. Iew plants flower more profusely or exhibit such a range of delicate colouring. Horeover, the flowers are deliciously fragrant, and the plants quite hardy. The Mollis group is made up of forms of the Chinese and Japanese Rhododendron sinense, crossed with the Ghent varieties. The flowers are, as a rule, larger and more uniform in outline. They exhibit a wide range of delicate colouring, and are 


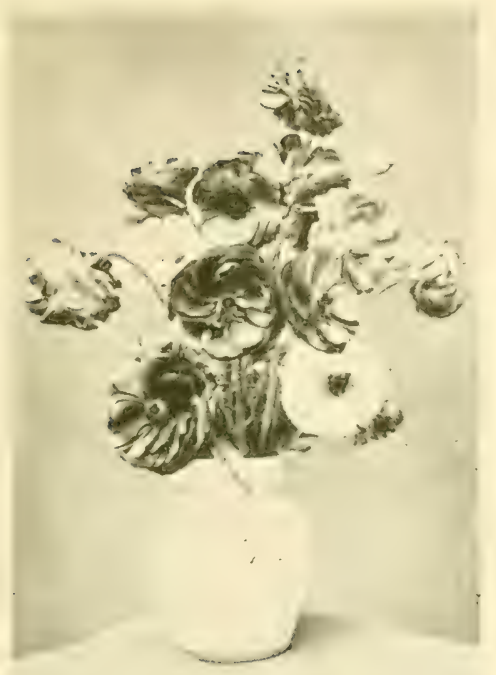

FLOWERS OF THE FLORISTS RANUNCULUS

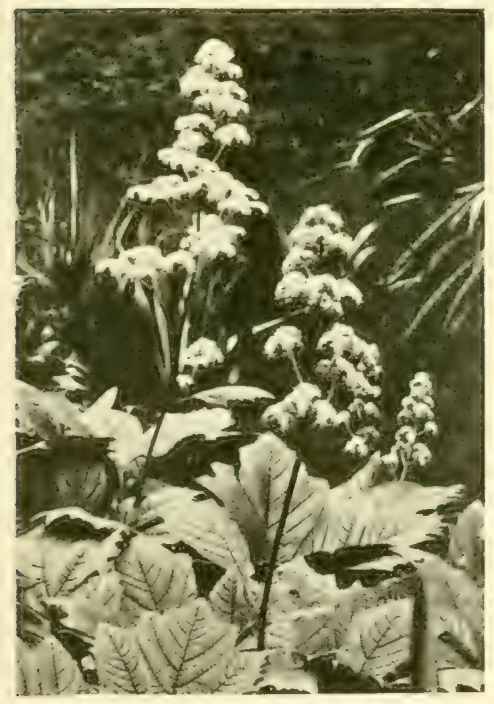

FOR THE BOG GARDEN (RODGERSIA PODOPHYLLA)

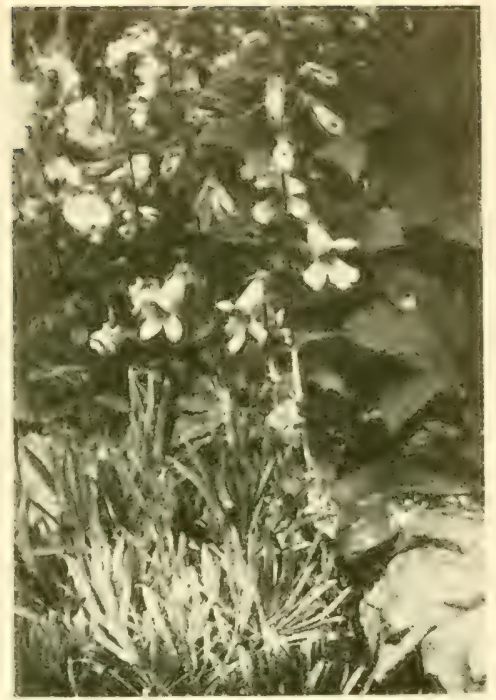

REHMANNIA ANGULATA, GROWING ON TOP OF WALL

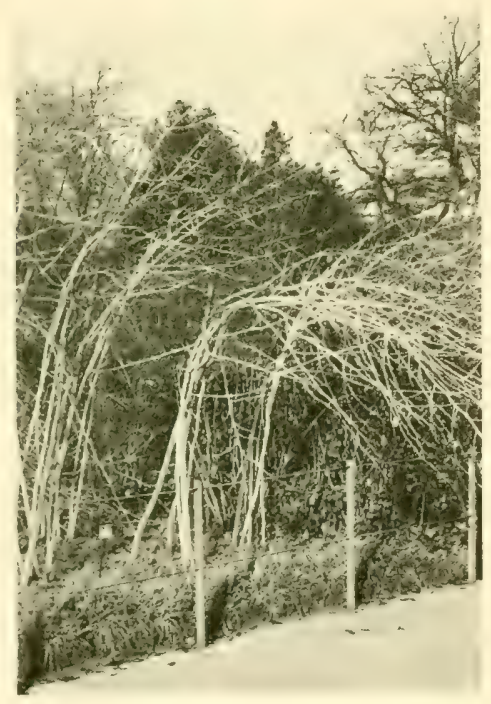

A WHITE-STEMMED BRAMBLE (RUBUS BIFLORUS) 

very free-flowering. The flowers are borne a week or two in advance of those of the Ghent kinds, and are sometimes injured by late spring frosts. The various kinds are very popular for forcing, and large numbers are grown on the Continent for that purpose alone. Other useful kinds in the Azalea group are Vaseyi, with white and pink flowers; rhombicum, with reddish-purple flowers; occidentale and arborescens, with white or pink flowers; and the white-flowered viscosum, which blooms in July nearly a month after the Ghent kinds are over.

Evergreen Rhododendrons suitable for the milder counties and for indoors elsewhere.--Rhododendron arboreum is a Himalayan species which in Cornwall sometimes attains a height of 35 feet with a trunk I 2 to 15 inches in diameter. The flowers vary from rich crimson to pink and white; as a rule, they are borne in shapely compact heads. The varieties with a silvery under surface to the leaves are often the best kinds. Many hybrids from it and other species have been raised in Cornish gardens. Rhododendron Griffithianum (sometimes called Aucklandii) is a handsome kind with large white flowers, sometimes five inches across. It has been used largely by the hybridist, and there are many very showy kinds suitable for the milder counties. Beauty of Tremough, pink; Gill's Triumph, red; and Glory of Penjerrick, red, are specially worthy of note. Rhododendron campylocarpum, although succeeding in sheltered places about London, gives better results farther south and west; its yellow flowers, each 2 inches or more across, are its special attraction.

Rhododendron ciliatum, a bush 4 to 5 feet high, is famous for its profusion of white pink-flushed flowers; argenteum is a noble Himalayan plant, forming a bush quite I5 $_{5}$ feet high, with large leaves, sometimes a foot long, and immense heads of large creamy-white flowers produced in February and March. Falconeri is also a magnificent bush, its leaves are often more than a foot long and 6 inches widle, covered beneath with rusty down; the creamy-white flowers are in very large shapely heads. Other useful kinds are found in barbatum, glaucum, Thomsoni, cinnabarinum, and the rich red hybrid Shilsoni.

Evergreen Rhododendrons suitable for general planting.-Although numerous species are available for this purpose, they are usually neglected for the sake of the many garden hybrids which have been raised by crossing such hardy, vigorous kinds as the North American catawbiense, and the European ponticum with the more tender Himalayan sorts. Those which approach most closely to catawbiense usually bloom in June, and are recognised by their dense, 
shapely inflorescences, whereas those which more closely resemble the Himalayan species often bloom in April and early May, whilst in many instances their trusses of bloom are rather loose.

Hundreds of such varieties are to be obtained, and of them a select list is appended: Auguste van Geert, large truss, reddish-purple ; Baroness Schroeder, white, finely spotted; B. de Bruin, scarlet; Bronghtonianum, vigorous plant, fine truss of rosy-red flowers; Charles Bagley, cherry-red; Charlie Waterer, scarlet, light centre; C. S. Sargent, scarlet; Doncaster, bright scarlet; Duchess of Connaught, white, with lemon-yellow markings; fastuosum flore pleno, mauve, semi-double; Frederick Waterer, crimson; Gomer Waterer, large white; H. H. Hunnewell, crimson; King of Purples, purple; Lady Clementine Mitford, peach; Lady Grey Egerton, French grey; Madame Carvalho, white; Marchioness of Lansdowne, rose, with dark spots; Michael Waterer, scarlet; Minnie, white; Mrs. Holford, salmon-pink; Mrs. S. Simpson, white; The Queen, white.

Amongst other species and hybrids the following well deserve attention: Augustinii, Central China, mauve; campanulatum, Himalaya, lilac, early ; caucasicum, Caucasus, dwarf, rose ; dauricum North Asia, rosy-purple, January ; ferrugineum, "Rose des Alpes," rose, Alps, June ; Fortunei, China, fragrant, a large bush ; Kewense, a large-flowered fragrant hybrid; lepidotum, dwarf, red-purple, Himalaya; Manglesii, white, a hybrid, large trusses; nobleanum, an early flowering red-flowered hybrid, very suitable for forcing; ponticum, a vigorous purple-flowered species suitable for undergrowth; intricatum, a new Chinese, violet-flowered kind, suitable for the rock garden; moupinense, a compact growing, new kind with white flowers; racemosum, a charming plant 2 to 3 feet high, with small whitish or pink flowers, borne from axillary buds; Yunnanense, white with brown spots, 3 to 4 feet, or more high.

Rhodothamnus Chamaecistus is a dwarf Ericaceous plant from the Austrian Alps. It is one of the few plants belonging to the Heath family which thrive on a limestone foundation, and its correct place is the rock garden. Of shrubby growth, it is usually less than 9 inches high, with tiny evergreen leaves and flat pink and white flowers I inch across, which have something of the appearance of Rhododendron flowers. Plant in crevices between large stones in light loamy soil, increase by seeds or cuttings, and remove the flower-heads as soon as the flowers fade, leaving sufficient only for the production of a few seeds if such are required.

Rhodotypos kerrioides.-This plant is sometimes called the White-flowered Kerria, and it belongs to the Rose family (Rosaceae). 
It is a native of China and Japan, and forms a shapely bush 3 to 4 feet high with Kerria-like leaves and white flowers $I$ to $I \frac{1}{2}$ inches across. Planted in ordinary good loamy soil, it grows vigorously and blossoms freely in May. Increase is by cuttings of young shoots inserted in a warm frame during summer, and pruning is limited to thinning out the old branches after flowering.

Rhubarb.-(See RHEUM.)

Rhus (Sumach).--This group (Natural Order Anacardiaceae) is composed of European, Asiatic, and North American trees and shrubs which have often ornamental leaves and poisonous sap. They are planted for the sake of their summer and autumn effect, for in addition to the leaves being of a showy character earlier in the year, they often colour brilliantly in autumn. Planted in loamy soil or even in that of a light character, they usually give good results, autumn colour in some cases being most brilliant where the soil is poor. Propagation is by seeds or root cuttings, the latter being made from pieces $\frac{1}{4}$ to $\frac{1}{3}$ inch diameter and 4 inches long, in spring. Little pruning is necessary except when the plants are grown for a special purpose, such as very large foliage. They are then cut down to the ground each year.

Rhus Canadensis from North America is a dwarf-spreading bush with three parted leaves which colour brilliantly in autumn; cotinoides, sometimes called the "Chittam Wood," is a native of the Eastern United States, at least I2 feet high, and its oval leaves change to brilliant orange-scarlet in autumr. Cotinus is the Venetian Sumach of Southern Europe, and is recognised by its bushy habit and broadly oval leaves, also by the curious plumose inflorescences, the slender stalks of which remain after the flowers fall. Their misty appearance has suggested the name of Smoke Bush.

Rhus Toxicodendron should be known, to be avoided. Its branches are often of semi-scandent habit, and they are clothed with large three-parted leaves which take on very bright colours in autumn. The plant is, however, very poisonous to the touch of many people, but not to all; it is a native of North America and Japan, and known as Poison Oak and Poison Ivy. Trichocarpa, from China and Japan, turns scarlet in autumn. Typhina is the Staghorn Sumach of the Eastern United States; it forms very large handsome leaves up to 3 feet long, and is sometimes cut hard back each year to encourage additional vigour; laciniata is a pretty cut-leaved variety. With this species may be classed Rhus glabra and its variety laciniata. They are much alike except that the former has hairy and the latter glabrous leaves. 


\section{Rhynchospermum.-(See TRACHELOSPERMUM.) \\ Ribbon Grass.--(See Phalaris.)}

Ribes (Currant).--This group (Natural Order Saxifragaceae) is an important one owing to the fact that it contains a number of decorative flowering kinds, and also several important fruits. The fruits are the Gooseberries and Rel, Black, and White Currants. The garden Gooseberries have been raised by the careful cultivation and selection of varieties of the common wild Ribes Grossularia, a spiny bush found in many parts of the Northern Hemisphere. As a wild plant its fruits are small and of little value, but everyone is familiar with the fine fruits of the garden. Similar remarks apply to the Currants, for the fine cultivated kinds have originated from various wild types. Thus the Black Currants are the progeny of Northern Europe and North Asiatic Ribes nigrum. The Red Currants owe their origin to Ribes rubrum, a native of the Northern Hemisphere, whilst the White Currants are fine forms of Ribes rubrum var. album. In this work, however, we have little to do with the fruiting kinds, but those which produce showy flowers claim our attention. They are of the easiest cultivation, thriving well in moderately good loamy soil, and being multiplied by cuttings of ripened wood 9 to I2 inches long inserted in the open ground during autumn or winter. No systematic pruning is necessary, though it is a good plan to look over the plants every second or third year and remove a few of the older branches to make room for young shoots from the base. The work must be done as soon as the flowers fade.

Ribes alpinum, a native of the Northern Hemisphere, is not a showy kind, but it is worth growing on account of its close, compact habit and its ability to withstand a considerable amount of sharle; the var. aureum has golden leaves. Ribes aureum, sometimes called the Misscuri or Buffalo Currant, is a native of Western North America, and is an important April and May flowering shrub. Growing from 3 to 5 feet high, it bears deliciously fragrant, deep yellow blooms in racemes 2 to 3 inches long. There are several varieties, such as the early-flowering praccox, the loose-racemed tenuiflorum, and the rich-coloured and free-flowering aurantiacum. The last-named is the best of all; it grows about 3 feet high. Ribes bracteosum from the Western United States forms a bush 4 to 5 feet high, remarkable for its long pendent racemes of yellowish flowers; cereum bears small whitish flowers; and lacustre, brownish blooms.

Ribes sanguineum, a native of California, etc., is known under the common name of Flowering Currant, and is easily one of the finest shrubs of the garelen. Its rose, pink, or reddish flowers, borne in 


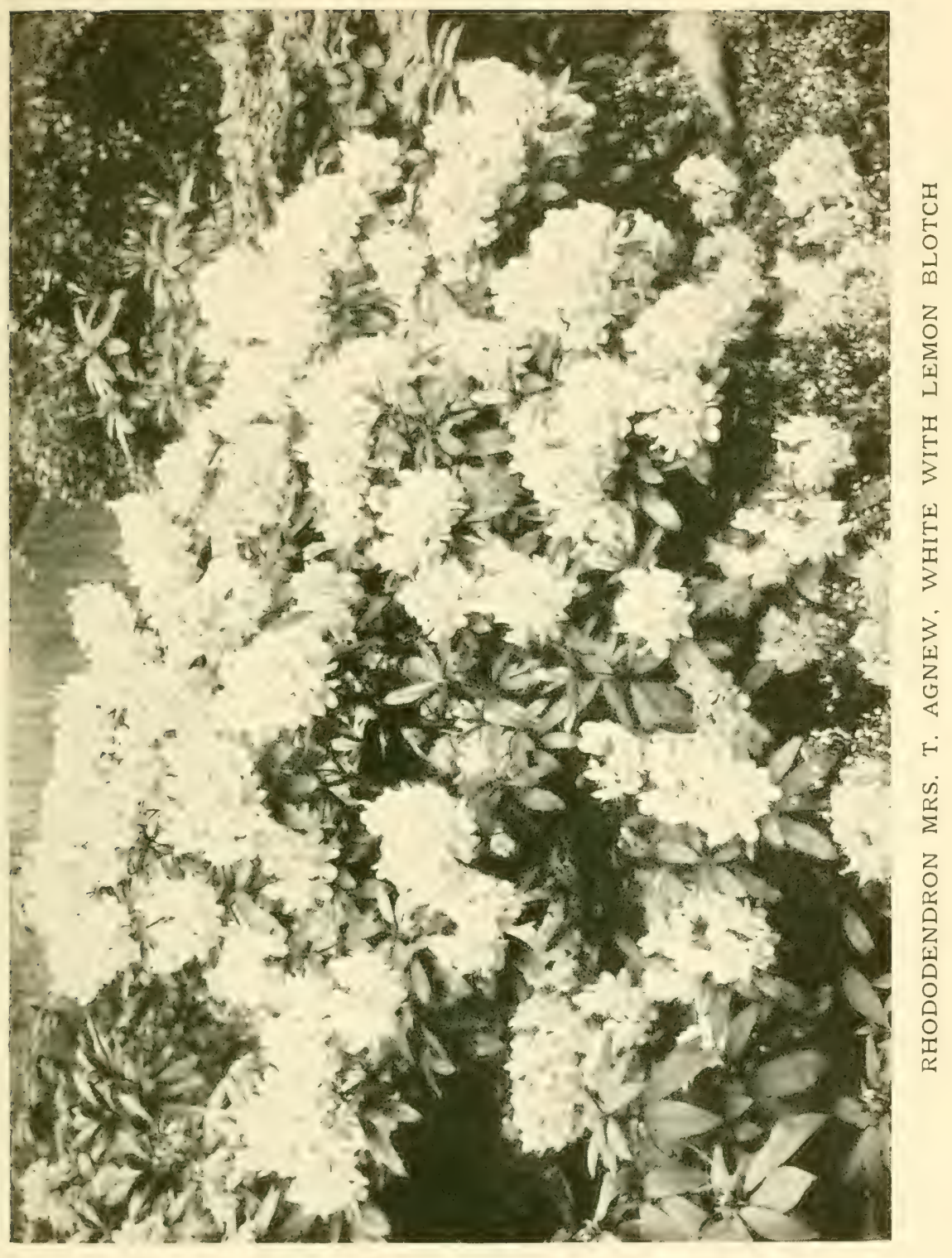



pentent racemes, are very conspicuous during late March and early April. There are numerous varieties, all of which are showy : albidum is recognised by its white rose-tinged flowers ; atrorubens, or splendens, as it is sometimes called, by its rich red blooms; carneum by flesh. coloured blossoms; flore pleno by deep red double flowers; whilst Davidianum, glutinosum, and malvaceum are other distinct forms. Albidum is somewhat difficult to keep in good health, and does not appear to be a very long-lived plant. Ribes Gordonianum is a hybrid between aureum and sanguineum; it is intermediate in character, but is no improvement on either. Ribes speciosum, the Fuchsiaflowered Gooseberry, is a native of California and a very beautiful shrub, with brown spiny branches which bear, from axillary buds in early spring, long cylindrical scarlet flowers with long exserted stamens. It is a little tender, however.

Richardia (Arum Lily).-The South African Arum Lily (Richardia africana or aethiopica, as it is often called), which belongs to the Natural Order Aroideae, is usually regarded as a greenhouse plant, and in most parts of the country it must be looked upon as such. In the mildest districts, such as in the extreme south-west of the country, it withstands the winter out-of-doors, and then forms a striking feature if planted at the edge of a pond or some similar position. The kinds with yellow or yellowish flowers, namely albo maculata, Elliottiana, and Pentlandii, go to rest during the winter. They may be started into growth in pots in the greenhouse, and when all danger from frost is over be planted out in a sheltered spot in good soil; they must be lifted in autumn before sharp frosts set in. They are, however, not so well adapted for outdoor planting as the common kind.

Ricinus communis (Castor Oil Plant). - This, which belongs to the Spurge family (Euphorbiaceae), is mainly employed for sub-tropical bedding during summer. From seed sown in warmth in early spring, the young plants make rapid progress, and become well established in 5 -inch pots by the bedding-out season. Then, if planted in some rich soil, they will soon reach a height of 5 to 6 feet, the stout erect stems being plentifully furnished with large, handsome lobed leaves. There are several varieties with variously coloured leaves: africanus, light green; Cambodgiensis, dark crimson; Gibsonii, bronze; sanguineous, dark stems, reddish leaves; and Zanzibarensis, green.

Robinia (False Acacia) is an important class of trees and largegrowing shrubs belonging to the Pea family (Leguminosae). They are of North American origin, and the tree kinds are known as Locusts or False Acacias. In America the hard wood of the commoner species 
is esteemed for many kinds of work, being specially favoured for posts on account of its great durability. All thrive in loamy soil, but whilst some are increased by seeds, others require to be grafted and others again raised from root cuttings. Pruning is necessary to shape the trees, and attention must be paid to keeping the leading shoots free from rivals.

Robinia hispida, the Rose Acacia of the Southern United States, forms a loose bush, 8 to I 2 feet high, with bristly branches, spreading by suckers; the rose-coloured flowers are as large as those of a garden Pea, and are borne in clusters of four to six. Better than the type, however, is the var. inermis; it is of more compact habit, and bears larger racemes of flowers. The typical kind is increased by root cuttings, and the variety by grafting upon stocks or roots of the Common Robinia Pseudacacia. Robinia neo-mexicana, from the Rocky Mountains, is a medium-sized tree bearing dense racemes of pinkish flowers in June and again in August. Kelseyi is a new pink-flowered species which forms a bush or low tree. It is very beautiful, and well worth consideration. Increase by seeds or by grafting.

Robinia Pseudacacia is the best known of all ; it forms a moderatesized or large tree, and can be used with effect both as an isolated specimen and as an avenue or street tree. Its attractions are its elegant pinnate leaves and dense racemes of white flowers, which are borne freely in May and June. There are many varieties, of which angustifolia, with very pretty leaflets; aurea, with golden leaves; bella-rosea and Decaisneana, with rose-coloured flowers; gigantea, of very robust habit ; fastigiata, with the habit of a Lombardy Poplar ; monophylla, with few leaflets; and robusta Vignei, are amongst the most distinct. Robinia viscosa, the "Clammy Locust" of the Southern United States, may be distinguished by its viscid inflorescences and warted or burred trunk. Its flowers have a pinkish tinge.

\section{Rock Cress.-(See ARABIS.) \\ Rock Rose.-(See Cistus.) \\ Rock Spray.-(See Cotoneaster.) \\ Rocket.-(See HESPERIS MATRONALIS.)}

Rodgersia.-A small group of bog plants (Natural Order Saxifragaceae) with very handsome leafage. They are Rodgersia aesculifolia, large bold leaves, somewhat resembling those of the Horse Chestnut, and spikes of white Spiraea-like flowers in summer. Rodgersia pinnata has handsome bronze leaves and white blossoms; and in podophylla the foliage is of purplish-bronze tint. They grow from 2 to 3 feet in height, and can be increased by division in spring. 


\section{ROMNEYA COULTERI}

Romneya Coulteri, belonging to Papaveraceae, is sometimes called the Tree Poppy on account of its bushy habit and close relationship to the Poppies. Although in reality a shrub, it is often treated as a herbaceous plant, for the branches are killed to the ground line in winter in many places. The rootstock is, however, capable of sending up new and vigorous shoots year after year, which often bear larger flowers than those produced from older wood. It should be planted in well-drained loamy soil at the foot of a wall with a south or west exposure, and except in the milder parts of the country, it is a good plan to cover the rootstock in winter with cinders or some other protective material. Watch the young shoots in spring and protect them from slugs and frost. They may then be expected to attain a height of 5 or 6 feet and bear showy glaucous leaves and handsome white flowers 6 inches across. Propagation is easily effected by root cuttings, sections 4 inches or so long being taken in spring and inserted in sandy soil indoors. There is a second species called Romneya trichocalyx. The most marked difference from the other species is the hairy calyx of the latter. Both are natives of California.

Romulea.-Pretty little bulbous plants, with Crocus-like flowers during the spring months. They are native of Southern Europe and belong to the Iris family (Iridaceae). They require well-drained sandy soil and a warm, sunny position. The chief kinds are: Bulbocodium, blue and yellow; Clusii, lavender; Columnae, white; and speciosa, rosy-violet. They should be planted in early autumn.

Rosa.-This important group (Natural Order Rosaceae) includes a very large number of species or wild kinds, in addition to all the garden Roses. The species are, as a rule, characterised by shrubby habit of growth, pinnate leaves, with well-developed stipules at the base, and spiny stems. There are, however, one or two exceptions in which all these characters are not present. They are widely distributed throughout temperate Europe, Asia, and North America, several being included in the British Flora. The majority are hardy in the British Isles, but the wild kinds are frequently ignored, preference being given to the varicties which have been raised by the intercrossing of several species.

Although the value of the Rose is simply decorative in this country, a few varieties are of considerable commercial importance in South and South-East Europe and Persia on account of the oil which is extracted from the flowers, known in commerce as Attar or Otto of Roses. The principal kinds employed for the purpose are gallica and vars. damascena and centifolia. The fruits of some kinds, such as the Japanese rugosa, are sometimes used as a conserve, but, 
as a rule, they are more highly appreciated from a decorative standpoint.

The garlen Roses are divided into a number of well-marked groups, such as Hybricl Perpetual, Tea, Hybrid Tea, Noisette, Bourbon, Rambler, Polyantha or Multiflora, Wichuraiana, Scotch, and Rugosa.

The IIybrid Perpetuals originated, it is said, by crossing the Provence Roses or forms of Rosa gallica with the Damask Rose (Rosa damascena), and perhaps some other species. The earlier varieties appeared between 1837 and 1840 , and additions have been made regularly until the present date. They are characterised by fine, fragrant, shapely flowers, which vary in colour from white to pink, rose, red, and crimson. There is usually a big burst of flowers in June and carly July, and a second and much smaller crop in August and September. They are generally increased by grafting or budding upon Briar or Mancti stocks, the former being the most lasting. Rich loamy soil gives the best results, and pruning is carried out in March. Some of the best varieties are: Captain Hayward, light red; Charles Lefêbvre, crimson; Commandant Félix Faure, crimson and red; Dr. Andry, bright crimson; Duke of Edinburgh, scarlet-crimson; Fisher Holmes, crimson with red shading; Frau Karl Druschki, white; Géneral Jacqueminot, bright red; Hugh Dickson, crimsonred; Mrs. John Laing, pink; Mrs. R. G. Sharman Crawford, rosepink; Ulrich Brunner, rose-red.

The Tca Roses have originated from the China or Monthly Rose, Rosa indica. The varieties are characterised by delicate colouring and exquisite fragrance. Most of the kinds are in their greatest beauty during the expanding stage, the fully open flowers being semi-double and loose in appearance. They have a very long flowering period, for they commence blossoming in June and are only stopped by frost. In the neighbourhood of London it often happens that flowers can be catherel at or about Christmas. It is, however, the most delicate group, and the branches are frequently cut back by frost. In cold districts it is usual to place a little bracken or a few branches of cvergreens amongst the plants during a cold period. Although usually budded on briars, the best plants are often those raised from cuttings, which root readily on a sheltered border if inserted in late September. Twelve good varieties are: Anna Olivier, pale rose and buff; Gloire de Dijon (climbing), salmon-buff and yellow; (. Nabonnand, pale rose shades; Harry Kirk, sulphur-yellow; Lady Hillingdon, yellow, fawn shading ; Lady Roberts, apricot and yellow; Madame Antoine Mari, white, shaded rose; Madame Hoste, cream-yellow; Mrs. 


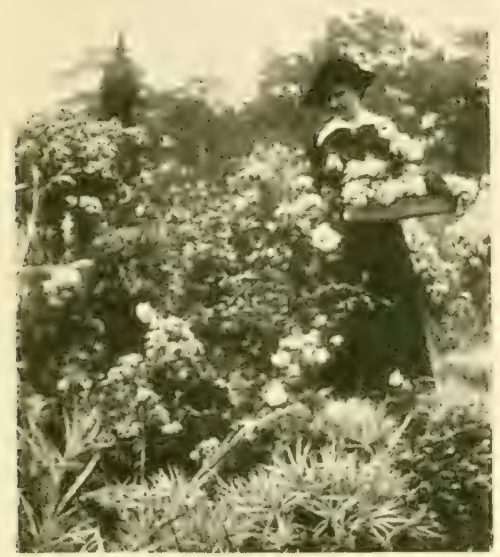

AUTUMN ROSES AND MICHAELMAS DAISIES

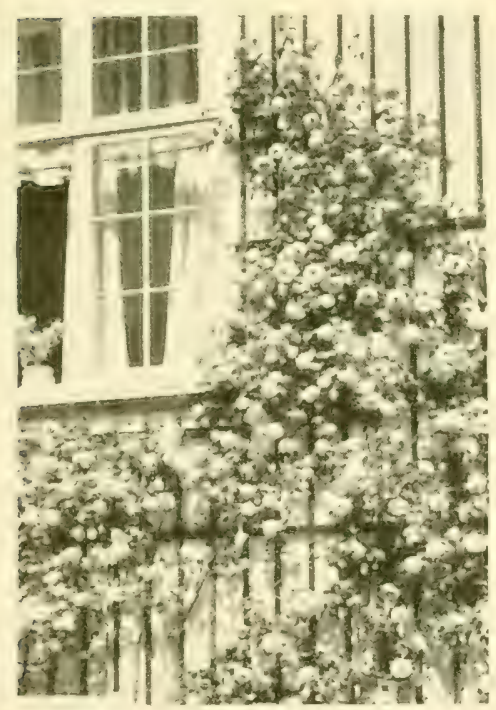

ROSE GLOIRE DE DIJON ON WALL, TRELLIS

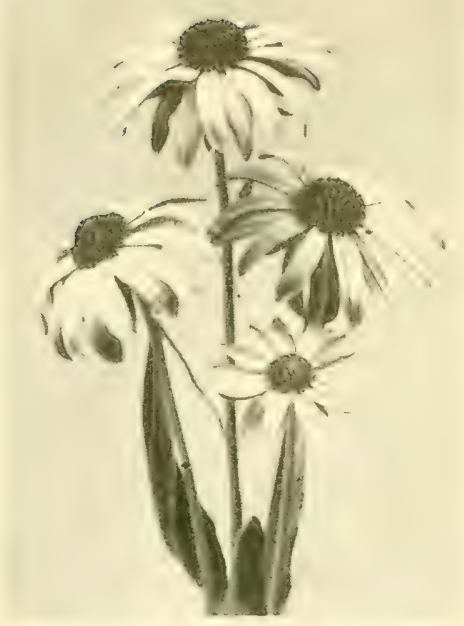

ONE OF THE CONEFLOWERS

(RUDBECKIA PURPUREA)

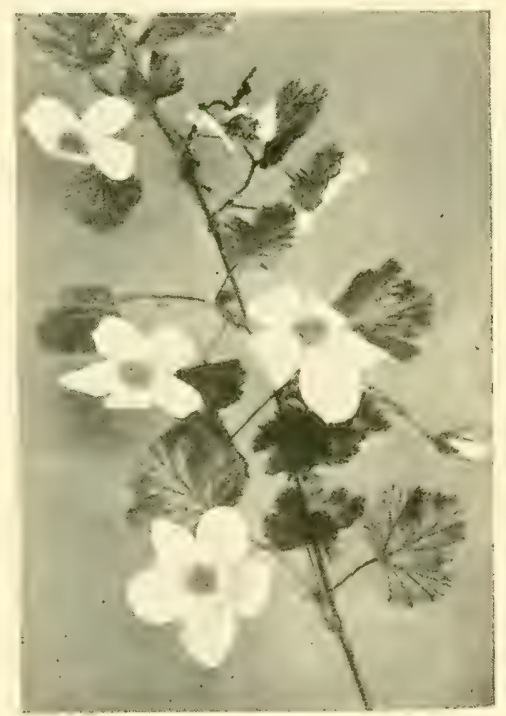

A BEAUTIFUL BRAMBLE (RUBUS DELICIOSUS ) 

Herbert Stevens, white; Nita Welldon, white, tinged blush; Noëlla Nabonnand, crimson (climbing); W. R. Smith, blush white.

The Hybrid Teas are a comparatively modern group, for many of the best kinds have appeared within the last twenty years. They have been raised by crossing varicties of the two former groups, the object being to secure the long flowering period and delicate colouring of the Tea varieties with the shapely flowers and general health and vigour of the Hybrid Perpetuals. This object has been attained, and many of the most popular garden Roses are now included in this group. Unfortunately some of them lack the fragrance of the parent varietics. They are propagated by the various methods adopted for other varieties, but should be raised from cuttings whenever possible. A modification of this group appears in various varieties known as Pernetiana Roses, in the raising of which the Austrian Briar (Rosa lutea) and its var. bicolor were used. The rich yellow of the former and the brown and yellow of the latter have resulted in some very rich yellow and terra-cotta kinds. Among the best varieties are: Augustine Guinoisseau, blush white; Caroline Testout, bright pink; Duchess of Wellington, orange-yellow; Duchess of Westminster, bright rose; G. C. Waud, rose with orange tinge; General McArthur, bright red; Gustav Grunerwald, pink; Lady Ashtown, deep pink; La Tosca, blush and rose; Madame Abel Chatenay, salmon-pink; Mrs. David McKee, cream-yellow; Pharisaer, white and salmon; Prince de Bulgarie, rose and yellow shades; Richmond, bright red.

The Dwarf Polyantha.-Another group of Roses, which belongs to the China or Indica set, is that made up of the Dwarf or Baby Polyanthas, which, though often less than I 8 inches high, form shapely bushes and blossom with wonderful freedom, the flowers being small, double, and produced in very large terminal inflorescences. There are white, pink, and some fine red varieties, for example: Aennchen Müller, pink; Cecile Brunner, blush white and rose; Jessie, bright red; Léonie Lamesch, copper-red and yellow; and Mrs. W. H. Cutbush, deep pink.

The Rugosa Roses have been raised by crossing the very hardy Rosa rugosa from Japan with various Hybrid Perpetuals. They are of vigorous growth, usually free flowering and fragrant, and very hardy; in fact, they can be grown successfully in climates which are too cold for the other garden kinds. They are rather difficult to increase from cuttings, and are often grafted or budded upon stocks of Rosa rugosa. The fruits of the single sorts are showy in autumn. Some handsome sorts are: Blanc double de Coubert, white; Conrad F. Meyer, pink; Rose à parfum de l'Hay, dark red; rugosa alba, 


\section{$38_{4}$ THE BOOK OF HARDY FLOWERS}

white; and rugosa atropurpurea, crimson; the two last-named are single, and bear showy fruits.

The Scotch Roses are cultivated forms of Rosa spinosissima, a wild Rose which appears in some parts as a dwarf plant but a few inches high or as a dense bush up to 3 feet in height with intensely spiny branches and usually white flowers. The varieties have single or double flowers in many colours, white, pink, yellow, and red all being represented. They are useful for planting in places where the neater and wilder parts of the garden meet. In this class pruning is limited to thinning out some of the older shoots after the flowers have fallen.

The Noisette Roses consist of a number of very charming varieties, usually of climbing habit, with a pleasant fragrance. They were raised by crossing Rosa indica varieties with the Musk Rose (Rosa moschata). As a rule, they are not very hardy, and are often planted against a wall or in a greenhouse. When pruning these kinds thin the weak wood out and leave the young vigorous shoots their full length. By bending the branches into a horizontal position the lower buds are induced to break into growth more freely than would otherwise be the case. The famous Roses Naréchal Niel and William Allen Richardson belong to this group. Others are: Climbing Aimée Vibert, white; Lamarque, white, with pale yellow shading; L'Idéale, red, shaded with yellow; and Rêve d'Or, buff-yellow.

The Bourbon Roses are also related to Rosa indica, the other parent being Rosa gallica. The varieties consist of both bush and climbing forms, the flowers, as a rule, being borne in considerable profusion and being very fragrant. The dwarf kinds should be pruned in the ordinary way in spring, whilst those of climbing habit should be thinned out instead of having the long shoots shortened. Mme. Isaac P'ereire, rose-carmine, is one of the best varieties.

The Moss Roses consist of a set of varieties with fragrant flowers which are peculiar by reason of their crested or mossy calyx. There are many varieties, all of which are attractive. The parent of the group is Rosa gallica var. muscosa. The best of the varieties are: Blanche Moreau, white; Common Moss, pale rose; Crested Moss, pink; and White Bath.

The Provence Roses are rarely seen nowadays, although their large flowers are perhaps more deliciously fragrant than those of any other kind. They include all the various forms of Rosa gallica.

The Polyantha or Multiflora group is made up of climbers which are usually of vigorous habit. The type of the group is Rosa multiflora, and most of the varieties or hybricls have appeared within the last twenty-five years, or since the advent of the famous Crimson 
Rambler. They flower in June and July, the blossoms appearing in large clusters from short growths from the side buds on the previous year's shoots. The chief pruning is usually practised as soon as the flowers fade. The old flowering shoots are then cut out, leaving the vigorous young branches, which generally grow freely from about the base. Such varieties thrive splendidly from cuttings. Some of the chief are: American Pillar, rose; Blush Rambler, blush rose; Crimson Rambler, bright red; Hélène, blush tinged with violet; Leuchtstern, rose and white; Mrs. F. W. Flight, deep pink; Rubin, crimson-rose; Tausendschön, rose-pink; Tea Rambler, copper and pink ; Trier, white, single, perpetual flowering.

The Wichuraiana group is made up of climbing kinds, which are usually of a semi-evergreen character. They form very long slender branches, and have been raised by crossing the Chinese and Japanese Rosa Wichuraiana with various garden Roses, particularly Teas and those of the multiflora group. They are invaluable for covering rough fences and banks, whilst they may also be planted at the bases of rough bushes and low trees over which they can spread their branches. Grafted on tall stems, they form very effective weeping plants. Cuttings root quite easily and form the best means of increase. Pruning is the same as in the multiflora group. The well-known Dorothy Perkins is a good example of this class. All have appeared within the last twenty years. Among the many varieties are: Alberic Barbier, yellow fading to white; Aviateur Blériot, yellow; Dorothy Perkins, rose-pink; Excelsa, red; François Guillot, yellow, white, and pink; Hiawatha, crimson; Jersey Beauty, cream-yellow; Joseph Billiard, crimson, pale centre; Lady Godiva, blush pink; Minnehaha, pink; Réné André, yellow and rose; and Shower of Gold, yellow.

The Penzance Briars.-These are vigorous kinds with the leaf fragrance of the Sweet Briar (Rosa rubiginosa), but with a variety of bright-coloured fiowers. They were raised by Lord Penzance by crossing the Sweet Briar with various garden Roses. As all are strong growers, they must be given plenty of room. They do not require regular pruning, but are improved by an occasional thinning. A few of the best are: Amy Robsart, rose; Anne of Geierstein, crimson-rose; Flora MIcIvor, rose-white; Julia Mannering, pink; Lady Penzance, copper and yellow; Meg Merrilies, crimson; and Rose Bradwardine, rose.

The species of Rosa are beautiful in flower and fruit, though the modern varieties have quite ousted them from many gardens. Some kinds, however, deserve special notice, and such as Rosa moschata, 
a vigorous climber with fragrant white blossoms; alpina and its var. pyrenaica, red-flowered kinds with brilliant scarlet fruits; Banksiae, the Banksian Rose, remarkable for its wealth of yellow or cream flowers, in the milder counties; bracteata, a semi-evergreen with huge white blossoms, suitable for warm counties; macrophylla, with long scarlet fruits; rugosa, with large flowers and Apple-like red fruits; lutea, with rich yellow flowers and various other kinds, are all worth growing.

The subject of the Rose and its cultivation is a wide one, to which full justice can only be done in a volume devoted to it, of which "The Rose Book" is one of many. Readers desiring full details on the cultivation of the Rose and its innumerable modern varieties are therefore referred to such works.

Roscoea.-For many years the only Roscoea in cultivation was Roscoea purpurea (Natural Order Scitamineae), native of the Himalaya. This forms a thickened rootstock, from which leafy shoots rise to a height of about I2 inches. Each shoot bears during the summer several purple flowers, of which the large-spreading lip is suggestive of an Orchid. The plant is quite dormant during the winter, and needs a warm, sheltered spot, such as a narrow border in front of a greenhouse or some similar position. A second species, hardier than the preceding, is the comparatively new Roscoea cautlioides, from China ; the flowers are soft yellow and freely borne. It has proved to be hardy in many parts of the country, where the precaution was taken of planting the fleshy roots 5 or 6 inches deep in sandy loam.

Rose, Christmas.-(See Helleborus Niger.)
Rose, Lenten.-(See Helleborus ORIEntalis.)
Rose of Jericho.-(See Anastatica.)
Rosemary.-(See Rosmarinus OfFicinalis.)

Rosmarinus officinalis (Roscmary), is a native of South Europe and belongs to the Sage family (Labiatae). It has been in cultivation since $\mathbf{5 4 8}$, and is a popular garden shrub in the milder parts of the country, where it is grown as a specimen bush and as an informal hedge. Mature bushes are often 4 to 5 feet high and attractive alike for the small fragrant leaves and lilac or mauve flowers. The essence or oil of commerce, known as Rosemary oil, is obtained from this plant. Cuttings of young shoots can be rooted by inserting them in sandy soil in a close frame in summer. Pruning need not be made an annual task, but when the bushes appear to be getting ragged they may be shortened after flowering. Any ordinary garden soil suits. There is a golden-leaved variety known as foliis aureis; it appears to be rather more tender than the typical kind. 


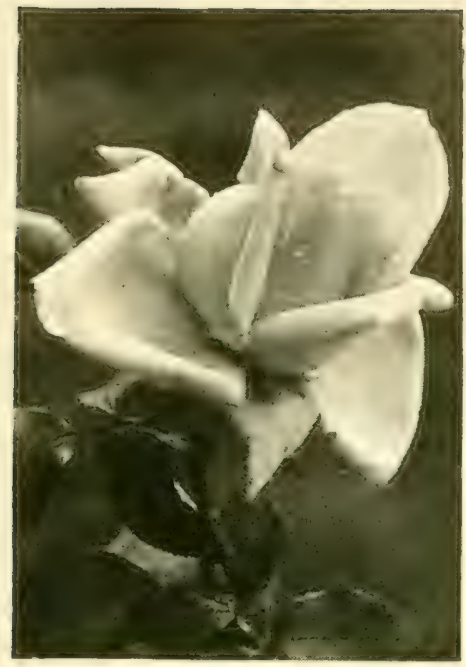

DUCHESS OF WELLINGTON (H.T.). A SPLENDID ORANGE-YELLOW VARIETY

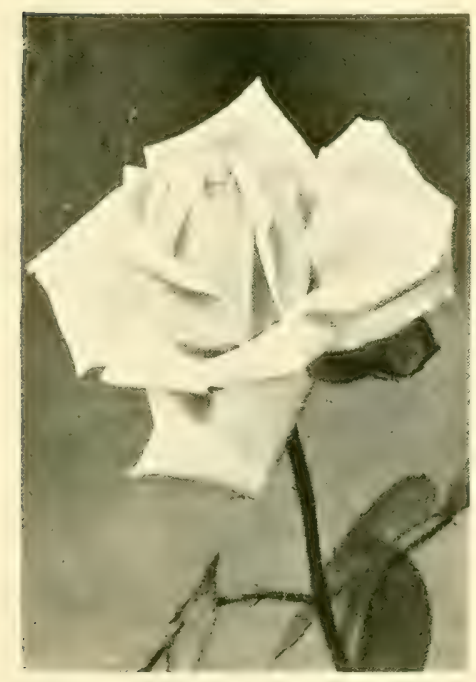

MAY MILLER (H.T.' ROSE AND PEACH SHADES. A FINE NEW ROSE

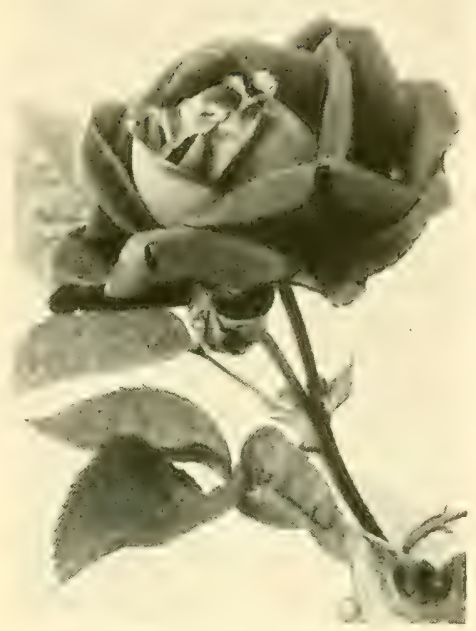

FRANÇOIS COPPEEE (H.T.), AN EXCELLENT DARK CRIMSON ROSE

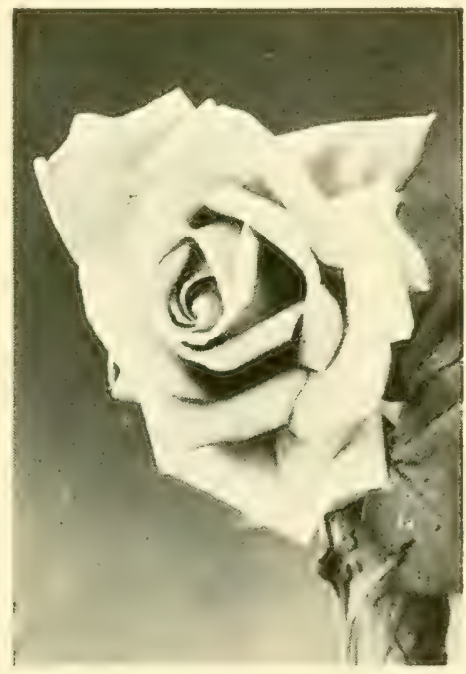

A PRETTY ROSE, MRS. ALFRED TATE (H.T.), COPPER AND FAWN SHADES 

Royal Fern.--(See OSMUNdA REgalis.)

Rubus (Bramble).-This extensive group (Natural Order Rosaceae) includes both upright-growing and climbing shrubs which exhibit great diversity of habit, some being but a few inches high and others forming branches quite 20 feet long. The branches of many are armed with thorns, whilst in other cases the thorns or spines are reduced to mere bristles, or they may be absent altogether. The leaves, too, may be either simple or made up of a number of leaflets, whilst on some kinds they are persistent and on others deciduous. Several kinds are valuable garden fruits, as is instanced by the Raspberry and Blackberry, and the more recent Hailshamberry, Loganberry, and Lowberry. A large number may be grown for decorative purposes, the group with white stems being specially valuable for the purpose.

Good loamy soil should be provided, and the species may be increased by seeds and layers, and the varieties by the latter means. Branches are not layered in the ordinary way, but they are bent over and the points pegged down into the soil. A swelling takes place near the apex, which after a while emits roots and shoots. Many of the kinds are benefited by having the old branches removed to the hase each year. In the case of sorts grown solely for decorative purposes it is wise to do this as soon as the young growths are a foot or so long, but in the case of the fruiting kinds pruning must be left until after the fruit has been gathered.

The Brambles are very widely distributed in the Northern Hemisphere, Europe, Asia, and America, each country providing numerous species. They are, however, not confined to these Continents. Within the present century a very large number have been received from Western and Central China. A few are likely to prove useful fruiting plants and most of the others are of decorative worth.

Fruiting kinds.-Rubus Idaeus, the Wild Raspberry of Western Asia and Europe, including the British Isles, is the parent of all the cultivated Raspberries. The fine fruits of the garden have been obtained by cultivation and selection. Rubus fruticosus, in a wide sense, includes all the wild Blackberries or Brambles of the British Isles. There are, however, numerous kinds included under this one heading, but no good purpose will be served by describing them here; the Blackberries of gardens are usually fine selected forms. Rubus laciniatus, a form with finely cut leaves and large luscious fruits, is a popular kind, whilst the Wilson Junior Blackberry, an American production from the North American Rubus villosus, also produces large fruits. 
The Loganberry is a hybrid between a cultivated Raspberry and Blackberry, whilst the Lowberry has been obtained by further intercrossing. Rubus phoenicolasius, from China and Japan, is known as the Japanese Wineberry; its bright scarlet fruits are borne in profusion, and they have a pleasant flavour. A peculiarity of the plant is the stiff, viscid bristles which appear on the branches. Rubus caesius is the Common Dewberry, the fruit of which in some places is collected for use; the same is done with the fruits of the Cloudberry, Rubus Chamaemorus, and other kinds.

Kinds with white stems. - These are so distinct and useful by reason of their white or glaucous stems that they are worthy of special note. Rubus biflorus, from the temperate Himalaya, is perhaps the most familiar plant; growing 8 or Io feet high, its branches have the appearance of being whitewashed, from which the common name of "White-washed Stemmed Bramble" has arisen. Amongst recent introductions is a variety of this, called quinqueflorus, which is more vigorous and striking than the type. The annual branches are often I2 to I5 feet high, and I inch to $I_{2}^{1}$ inches in diameter near the base. Rubus Giraldianus is, however, even more imposing, not that it is more vigorous, but that it is of such a good colour and distinct habit. A dense mass of shoots is formed from a common rootstock which grow erect to a height of 5 or $5 \frac{1}{2}$ feet; they then suddenly bend over and gradually grow downwards until they touch the ground. It is a new species from China. Rubus lasiostylus, from the same country, is imposing by reason of its white stems, whilst its fruits are large with a pleasant flavour. Other white-stemmed kinds are leucodermis, and thibetanus, a handsome kind of recent introduction.

Other useful sorts.--Rubus bambusarum is an elegant Chinese plant, with long slender branches and three or five parted evergreen leares, the leaflets being long and narrow, dark green above and grey beneath. It is a useful subject for planting on a pergola. Rubus chroosepalus, a species recently acquired from Central China, has evergreen, broadly ovate leaves, green above and grey beneath, and long slender branches. Rubus corchorifolius is a very vigorous kind, with tall, strong green stems bearing a few scattered spines, Iierria-like leaves, and conspicuous white flowers usually in pairs from the leaf axils in April. Introluced from China about fourteen years ago.

Rubus deliciosus, from the Rocky Mountains, is a handsome bushy kind with white flowers as large as those of a Dog Rose ; the branches are not spiny, and they keep on growing and flowering for a number of years; inopertus, a new Chinese kind, is remarkable for its vigorous 
branches I2 to I5 feet high, which are covered with red bark and a light coat of glaucous bloom, the Rose-like leaves are pretty. Lambertianus, another new Chinese species, is recognised by its long slender branchlets and broadly ovate or heart-shaped leaves which are almost evergreen; nobilis is a showy hybrid between the Common Raspberry and the American odoratus, it grows 6 to 8 feet high, with brown stems and large, ornamental leaves; odoratus, the Purpleflowered Raspberry of North America, is handsome alike by its large foliage and purple flowers, 2 inches across, it grows 6 to $\delta$ feet high ; parvifolius, from China and Japan, is chiefly remarkable for its profusion of bright red fruit ; Playfairianus is a vigorous Chinese plant, with three to five parted evergreen leaves.

Rubus spectabilis, from California, throws up vigorous bright brown branches which, in April, bear showy rosy-purple flowers; Thumbergii glabellus, from China, grows I 2 or I 5 feet high, with green, conspicuously angled stems and Rose-like leaves; thyrsoideus flore pleno is a handsome kind, with large bunches of double-white flowers borne in August; ulmifolius flore pleno is a popular and ornamental kind, its semi-double reddish flowers are borne with considerable freedom during July and August; the var. inermis is remarkable for its spineless branches.

Rudbeckia (Cone Flower).--Easily grown herbaceous perennials, natives of North America, and belonging to the Daisy family (Compositae); their yellow flowers are borne during the latter part of summer and in early autumn. Not only do they make a good show in the herbaceous border, but owing to their firm, wiry stems they are very useful for cutting. They are readily increased by division when dormant. The chief kinds are: californica, 6 feet; columnaris, 4 feet; Golden Glow, double, 8 feet; grandiflora, 5 feet; laciniata, $\delta$ feet; maxima, 7 feet; speciosa (also known as Newmanni), 2 feet ; and subtomentosa, 4 feet.

Rue.-(See RUTA.)

Rue, Wall.-(See Asplenium Ruta-muraria.)

Rumex (Dock).--Most of the species of Rumex (Natural Order Polygonaceae) are troublesome weeds, but one of them is, if rightly placed, decidedly ornamental. This is the Great Water Dock (Rumex Hydrolapathum); it forms a tuft of large bold leaves on tall, upright stems, and is very effective in shallow water, where it can have space for development, as on $n o$ account must it be placed in proximity to choice plants.

Ruscus is a shrubby class belonging to the Lily family (Liliaceae), made up of several low-growing evergreens which bear showy 
red fruits. Three kinds are in cultivation: aculeatus, the Common Butcher's Broom of Europe, including the British Isles; Hypoglossum, from Southern Europe; and Hypophyllum, from South-West Europe and North Africa. The first named grows 2 to $2 !$ feet high, and is familiar by reason of its stiff, upright growth carrying spiny, flattened, modified branches, which are often called leaves, and tiny flowers. As male and female flowers are borne by different plants, it is necessary to plant both together to obtain fruit ; the latter should predominate. The other two kinds are really more attractive, for the so-called leaves are of a brighter shade of green and larger. All are excellent for planting in semi-sharly positions, and form a good ground covering for plantations or for beds of strong growing shrubs. Propagation is usually by division of the clumps in spring. They may be broken up into quite tiny pieces, but each piece must have root and a good bud at the base. Seeds may also be used for increase. Pruning should consist of the removal of a number of the older shoots each year.

\section{Rush.-(See Juncus.)}

Rush, Flowering.-(See Butomus umbellatus.)

Ruta (Rue).--Practically the only Rue (Natural Order Rutaceae) met with in gardens is the Common Rue (Ruta graveolens), a wellknown strong-smelling herb, native of Southern Europe. It is not without ornamental value, for it forms a much-branched bush 3 feet or so in height, clothed with trifoliate leaves of bluish-green tint and yellow flowers in early summer. Other species are bracteosa, divaricata, and patavina. The Rues will thrive in ordinary soil that is well drained, and can be increased by seeds sown in spring or by cuttings 4 or 5 inches long, taken in summer and dibbled in sandy soil on a shaded border.

Sage.-(See Salvia.)

Sagina (Pearlicort).-Only one kind, Sagina glabra (pilifera), and its golden-leaved variety, aurea, are much grown. Both are very dwarf evergreen plants, belonging to the Pink family (Caryophyllaceae), closely carpeting the ground, and thrive in sun or shade. Sagina glabra is useful to plant as a groundwork for early springflowering bulbs in the rock garden, or as an elging to beds and borders. The var. aurea is extensively used for carpet bedding, forming a goldenyellow carpet. In early summer both plants are thickly studded with myriads of small starry white flowers. The Pearlwort can be rapidly propagated by division in autumn or spring, and thrives in ordinary garden soil ; it is a native of Corsica, and is also known as Spergula pilifera. 


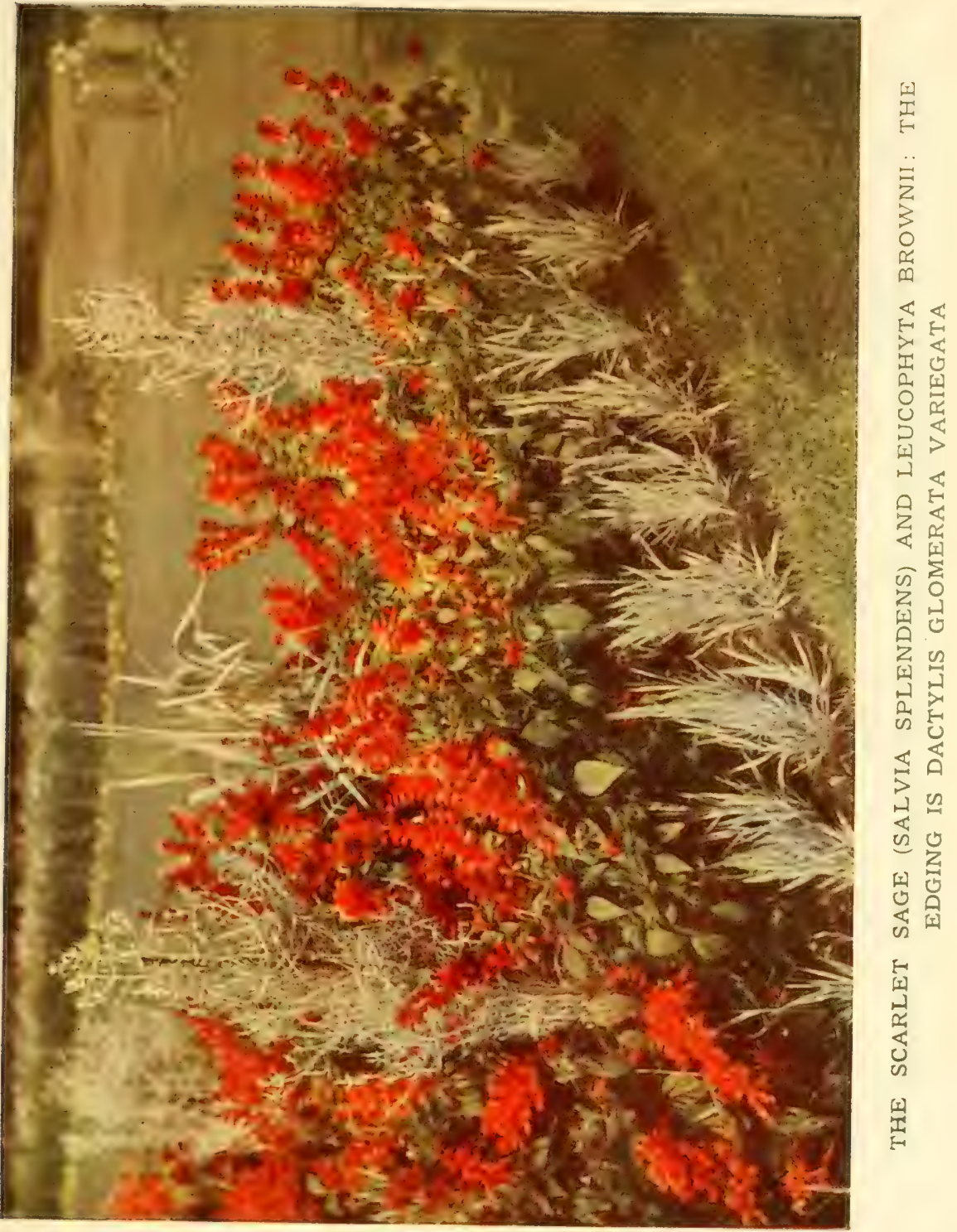



Sagittaria (Arrow Head).-Attractive water plants (Natural Order Alismaceae), with arrow-shaped leaves and pleasing spikes of white flowers from July to October. Our native Arrow Head, Sagittaria sagittifolia, is well known; it has rich, green, arrow-shaped leaves on long stalks, and tall spikes of white flowers. For water gardening the double var. flore pleno is a much more useful plant, the pure white flowers lasting longer in beauty. The North American Arrow Head, Sagittaria variabilis, is very beautiful, having large white flowers. There is also a double variety, flore pleno, which is generally considered indispensable in an aquatic garden. Water from 6 to $\mathrm{I} 2$ inches deep is most suitable, and the roots are planted, in pots or baskets of soil, in the mud alongside a pond. The single kinds may be increased by seeds sown in pots, and submerged in water as soon as convenient after gathering; the others by division in April.

Salix (Willow).--The Willows (Natural Order Salicaceae) are important both from decorative and commercial aspects. They are widely distributed through Europe, Asia, and North America, whilst they have been planted widely in other countries. Some are tiny prostrate shrubs, and others large trees. Several of the latter are of peculiarly graceful habit, and are used extensively for planting in the vicinity of water. Most of the kinds are well adapted for planting in wet ground, although the best results are not obtained where the ground is continually waterlogged; occasional flooding, however, is not disadvantageous. Some Willows have brightly coloured bark, and for that reason they are planted in large groups for their winter effect. The best colour is obtained from young branches, therefore they are cut hard back each year, usually in March. Many kinds are grown for basket-making, whilst the wood of Willow is the most popular of all woods for the manufacture of cricket bats. One Willow, however, is liked better than any other for the purpose; that is an upright-growing female tree with bluish leaves, of hybrid origin, variously called Salix alba caerulea and Salix caerulea, and anyone who plants trees for timber should be careful to procure this kind, and plant it in moist soil near a stream or lake. The side branches must be removed whilst quite young, and any which may appear from the trunks of later date must be pulled out when but a few inches long. Willows are often pollarded at a height of I2 to I4 feet from the ground, the branches being cut back every 8 or Io years. The wood is used for a variety of purposes, such as for splitting for hurdles, charcoal for gunpowder, etc. All the kinds may be easily increased by cuttings made I foot long and inserted out-of-doors in winter. 
The best tree kinds, other than that already referred to, are the following: Salix babylonica, the Weeping Willow, native of China, is of peculiarly graceful outline, and forms a handsome tree in the milder parts of the country; elegantissima and Salamoni are other weeping trees of rather more vigorous habit, and hardier. Salix fragilis is the Crack Willow, a large tree common in many parts of the country: its wood is used for the rims of sieves and for other purposes. Salix alba is another handsome tree.

The Bush Willows, most frequently grown for basket-making, are selected varieties of Salix purpurea, triandra, viminalis, hippophaifolia, and daphnoides. They are met with under a great variety of names, and each one is made up solely of male or female bushes, which indicates that each has sprung from one original plant.

Salix vitellina and cardinalis are varieties of Salix alba, with yellow and red bark respectively. Although usually grown as bushes, they will attain tree-like proportions if allowed to grow freely. Salix vitellina pendula is a graceful tree with pendent golden branches; daphnoides has purplish bark covered with a glaucous bloom; Caprea and cinerea are two common British kinds, the male catkins of which are familiarly known as Palm.

Salix magnifica is a very showy Willow recently received from China; it has very large and thick oval leaves of glaucous green colour, and produces long catkins of flowers.

When Willows are grown for the sake of the catkins the male kinds only should be selected. Such as herbacea, Paulinae, and retusa are very dwarf, and suitable for moist places in the rock garden.

Salpiglossis. - The present-day strains of Salpiglossis, which belongs to the Potato family (Solanaccae), are the progeny of a Chilian species, sinuata. They are half-hardy annuals, growing 2 to 3 feet in height, with large, prettily veined, funnel-shaped flowers. The great improvement in the size and colour of the flowers brought about by florists during recent years renders the Salpiglossis very desirable for beds and groups in the border. Seeds are sown in a warm greenhouse or frame during March, the seedlings, when large enough, being transplanted to shallow boxes and planted out-of-doors, about 6 inches apart, towards the end of May. The plants prefer light, rich soil and a sunny position, when they will flower from early in July until September. Seeds of Salpiglosis are sold separately to colour and in mixture. Different seedsmen give varying names to their strains of seeds, such as variabilis, large-flowered, grandiflora, superbissima, and Emperor. As a rule, for the distinct colours the name of the colour is used; for instance: atrococcinea (blue and gold), purpurea 
(rich purple), Kermesiana (crimson), aurea (golden-yellow), rosea, and coccinea (orange-red). The stem and leaves are viscid or sticky, and the flowers are not of pleasant scent.

Salvia $(S a g c)$. - Among the Sages (Natural Order Labiatae) are hardy perennials, tender shrubby plants, and annuals. Salvia Horminum (The Clary) is a hardy annual worthy of a place in every garden; it thrives in ordinary soil. Self-sown seedlings often come up annually, otherwise seeds are sown in September and the end of March or early April, where the plants are to flower. If this is not convenient, seedlings may be raised on the reserve border and moved to the flowering positions during May. The plants grow about $I_{2}^{1}$ feet high. Salvia Horminum depends for its beauty upon the coloured bracts enclosing the small flowers; they are purple, white, or rosecoloured; the best variety is Blue Beard, with rich purple bracts. The plants last in beauty from June to September, the autumn-sown plants being at their best in the former month.

The best perennial border Sage is virgata or nemorosa, native of Europe; it forms a bush 3 to 4 feet high, with showy violet-blue flower spikes from June to September. This Sage thrives in good garden soil, and is readily increased by division in autumn and spring. Cuttings made of the young shoots late in spring root readily in a close frame. The Mexican Sage, Salvia patens, is a half-hardy tuberous-rooted species. It thrives out-of-doors in the southern and western counties, but in the London district and farther north the roots should be lifted, placed in sand, and stored in a frost-proof cellar or shed. During March or April they are started into growth in a greenhouse like the Dahlia. The young shoots may be inserted as cuttings in a close frame, hardened off, and planted outside late in May. Its lovely gentian-blue flowers make this plant invaluable for the border from July to September; rather light soil and a sunny position are necessary. Salvia pratensis, the Meadow Sage, is a rare British plant, worthy of a place in the garden; it has leafy bracts and rich purple flower spikes. Useful varieties are alba, white; Baumgarteni, violet-blue ; and rosea, rosy-red. It thrives in ordinary soil, in sunny borders, and partial shade, and is increased by division of the roots in autumn or spring, or by seeds sown on a border outside in April or May. The plants grow $2 \frac{1}{2}$ to 3 feet high, flowering from June to August.

For beds and borders in summer the best of the shrubby kinds is the Scarlet Sage, Salvia splendens. This is really a greenhouse species, but it is a splendid summer bedding plant. Seedlings are raised under glass by sowing in a warm greenhouse in February, 
but the usual plan is to take cuttings in August and keep the young plants on the greenhouse shelf during winter, planting outside early in June. For bedding, the best sorts are Fireball, 2 feet; Pride (Glory) of Zurich, I5 inches; and splendens grandiflora, 3 to 4 feet; all have brilliant scarlet flowers lasting from the end of June until September. Ordinary garden soil, well tilled and manured, is suitable. The Scarlet Sage is a native of Brazil.

Sambucus (Elderberry).-Sambucus, which belongs to the Honeysuckle family (Caprifoliaceae), includes the slirubs or small trees known as the Elderberries, and a few herbaceous plants. They thrive in moist soil of almost any description, and appreciate a little shade. The Common Elder, Sambucus nigra, is found through Europe, Western Asia, and North Africa. In the British Isles it often springs up as a weed and soon takes possession of considerable tracts of ground if not uprooted. It has a value near the sea, for it stands sea air well, and is often used as a wind-break for choicer plants. There are numerous varieties, of which aureo-marginata and aureo-variegata (with golden variegated leaves), leucocarpa (with whitish fruit), and laciniata (with cut leaves) are the best.

Sambucus racemosa is the Red-berried Elder of the Northern Hemisphere; it is distinct by reason of its flowers and fruits being in dense racemes or corymbs instead of the more familiar flat heads of the ordinary Elder. There are many varieties, some of which have very beautiful leafage: foliis aureis and plumosa aurea have very prettily cut leaves of a bright golden hue; whilst plumosa and tenuifolia have also very prettily cut leaves. The golden varieties show the best colour when cut back well each spring.

Sambucus canadensis is a North American species, with larger leaves than nigra; its golden-leaved variety is very showy, and is useful for planting in large groups; the tranches should be cut down to the ground in March each year, the variety maxima has immense flower-heads. Sambucus glauca, also a North American shrub, produces very large flower-heads in July. All these kinds may be increased by stem or root cuttings, and the species by seeds.

Sambucus Ebulus, the Ground Elder, of Europe and the Orient, is the best-known herbaceous kind. It grows 2 to 3 feet high, and may be planted in the wilder parts of the garden or woodland, but is too coarse for the herbaceous border.

Sanguinaria (Bloodroot).--The only kind, Sanguinaria canadensis, belongs to the Poppy family (Papaveraceae), and is native of North America. It has a thick fleshy rootstock, and is increased by division preferably in early autumn. The plants are 4 to 6 inches 


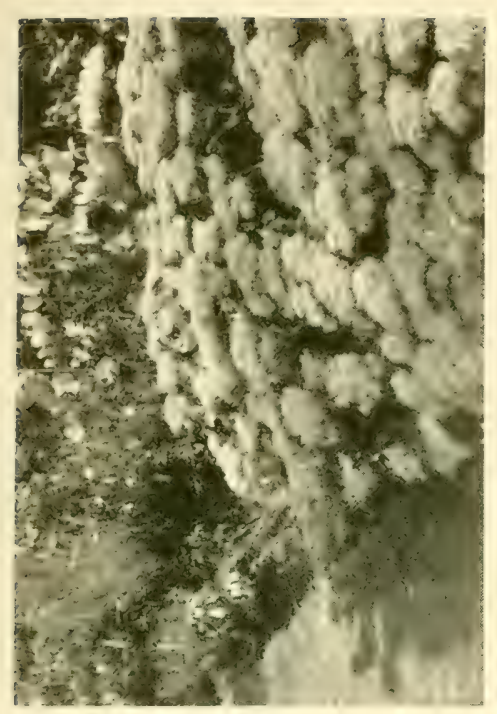

告
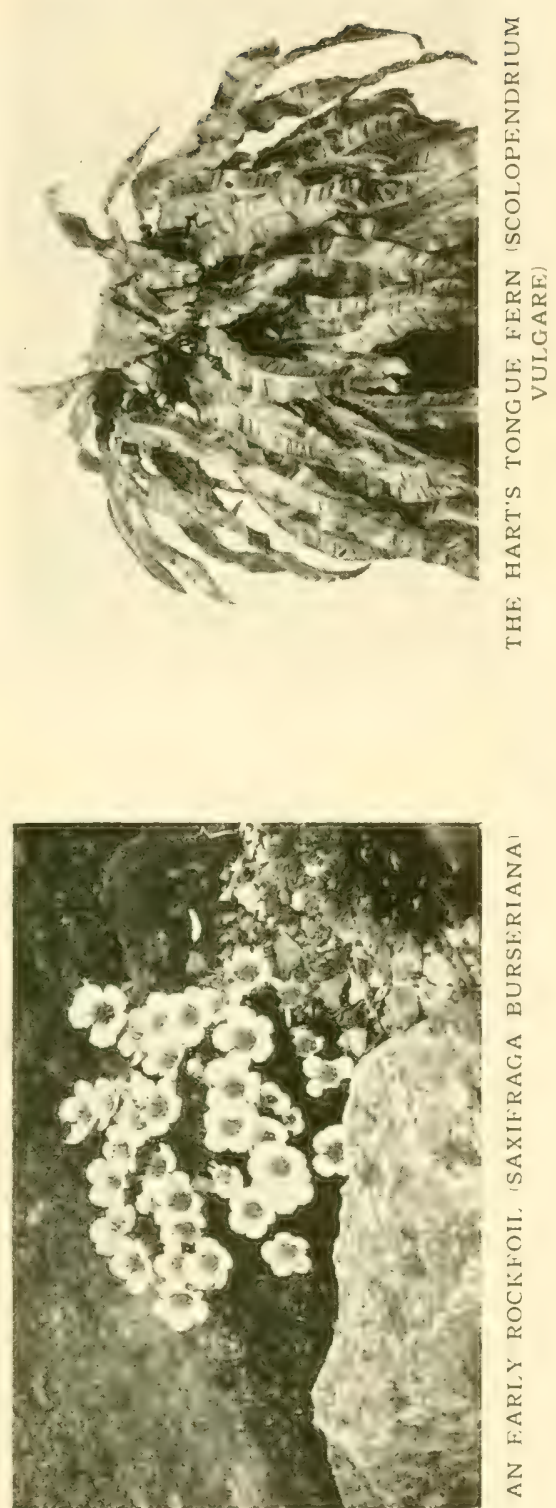

high, with rounded, reined leaves, and during May and early June the pure white flowers with yellow centres are very attractive. The Bloodroot thrives best in semi-shaded positions, in the rock garden, among hardy ferns, or beneath deciduous shrubs, in a peaty compost, and may be associated with Rhododendrons.

Santolina (Lavender Cotton).-These are dwarf, hardy, shrubby perennials, with pleasingly fragrant foliage; they belong to the Daisy family (Compositae). The two best known are: Chamaecyparissus, with silvery-grey foliage, and yellow flower-heads at their best in July, I2 to 24 inches in height; and viridis, with rich deepgreen foliage and creamy-white flowers in July, I $\frac{1}{2}$ to 2 feet high. Both are natives of Southern Europe. They thrive in ordinary garden soil, and are readily increased by cuttings inserted in a cold frame during August and September. In addition to their beauty and value for the front of the shrubbery border, the plants make very pleasing dwarf hedges, and may be trimmed into shape with shears.

Sanvitalia.--The only kind to record here is procumbens (Natural Order Compositae), a Mexican hardy annual. It is a dainty trailing plant some 6 inches high, with yellow, Daisy-like flowers and dark centre. Ordinary light garden soil is suitable. For preference, sow the seeds in autumn or spring where the plants are to flower; these two sowings will give flowers from the end of May or June to September. There is also a double-flowered variety which is readily raised from seeds.

Saponaria (Soapwort).--Showy annuals and perennials, members of the Pink family (Caryophyllaceae). They thrive in ordinary garden soil and a sunny position. The annual kinds are : calabrica, bearing a profusion of small, deep rose-coloured flowers throughout summer, 6 inches high, native of Italy; alba is a pretty white-flowered form. Saponaria Vaccaria grows 2 to $2 \frac{1}{2}$ feet high, producing dainty pink flowers from June to September, much valued for cutting in company with the white-flowered variety alba. Sow the seeds in September or early April where the plants are to flower.

The best-known perennial is the double-flowered variety of our Common British Soapwort, Saponaria officinalis flore pleno. It grows I 13 to 2 feet in height, producing from July to September lovely loose sprays of double rosy-pink flowers; it is suitable for a sunny or halfshaded position. Saponaria ocymoides is a European trailing plant, 6 inches high, quickly forming a carpet in the rock garden or front of the border, covered in early summer with innumerable small bright pink blossoms. There are several varieties of this kind: splendens, rosy-crimson; versicolor, pink and white flowers; and alba, white. 
One of the best Alpine Soapworts is Saponaria caespitosa, from the Pyrenees, a plant of tufted habit, some $\sigma$ inches high, with pretty clusters of rose-coloured flowers in summer. Ordinary well-drained soil suits the perennials. Propagation is by division of the tufts or clumps in autumn or spring. Seeds may be sown in a cold frame from April to June.

Sarcococca.-This is a small group of low-growing or mediumsized evergreen shrubs from the Himalaya and China, belonging to the Spurge family (Euphorbiaceae). They thrive in light loamy soil, and are increased by seeds, cuttings, or by division. Regular pruning is unnecessary, but the occasional removal of old branches is attended by good results. They may be planted in fairly sunny places or in moderate shade, and are useful for small groups in the front of the shrubbery, while those of low growth can be grown in the rock garden. Sarcococca ruscifolia is one of the most compact and most useful species; it is a new Chinese kind. Other useful sorts are coriacea, humilis, prunifolia, saligna, and trinerva.

Sarracenia (Huntsman's Horn).-This is one of the Pitcher plants (Natural Order Sarraceniaceae) which are natives of Nortl America. Only one species is quite hardy, namely Sarracenia purpurea ; this has bladder or inflated horn-like leaves, 6 to I2 inches long, red, prettily veined, and having a curious lid-like appendage at the top. The rich purple flowers are borne on stems about I2 inches high towards the end of April and during May. Propagation is by division in spring, which is also the best time for planting. The Sarracenias revel in moisture; in fact the roots must never be allowed to become dry. A bog garden is the place for them, or, failing this, the wettest position in the rock garden. Suitable soil consists of peat, sphagnum moss, and pieces of charcoal. The hardiest of the remaining kinds are: flava, psittacina, and Stevensii. In warm and sheltered bog gardens these are worthy of a place; they should be covered with a temporary frame in winter, if thought necessary.

Sassafras officinale.-This rare and interesting tree is a native of the United States and belongs to the Laurel family (Lauraceac). It is hardy in the South of England, and a very fine specimen exists in the gardens at Claremont in Surrey. As in other members of the same family the various parts of the plant are aromatic, and a fragrant oil is obtained from the root-bark and wood which is used in perfumery and for flavouring purposes. It requires good, well-drained loamy soil and a fairly sunny position. Increase is by imported seeds, and pruning is limited to keeping the leading shoot clear of rivals and otherwise shaping the tree, which may be done in summer. 
Young plants are inclined to be tender by reason of late, ill-ripened growth, but older trees withstand a considerable amount of frost without injury.

\section{Satin Flower.-(See Sisyrinchium.)}

Saxegothea conspicua (Prince Albert's Y Cw) belongs to the Natural Order Coniferae, and in addition to being of decorative value is interesting by reason of its various parts having affinities to several different families, yet it cannot be said to be very closely related to either. Thus, an eminent botanist, the late Dr. Lindley, described it as having the male flowers of a Podocarp, the female flowers of a Dammara, the fruit of a Juniper, the seed of a Dacrydium, and the general aspect of a Yew. It is a native of the Andes of Valdivia and Patagonia, and was introduced in I849 and named in honour of the late Prince Consort, hence the common name "Prince Albert's Yew." It is only suitable for the south and south-west counties, but it there makes a handsome specimen of elegant Yew-like habit, growing up to a height of 40 feet. Plant in moist, but well-drained soil, increase from cuttings, placed in sandy soil in a close frame, and prune when young to keep the leading shoot clear.

Saxifraga (Saxifrage or Rockfoil).-Of plants cultivated in the open air in these islands, none show greater variation or exhibit such extraordinary beauty as the numerous kinds of Saxifraga (Natural Order Saxifragaceae). The popular name of Rockfoil is only descriptive of those that are truly mountain plants, and is misleading when applied to such as peltata, which grows 3 feet high.

The majority of Saxifrages grown in gardens are native of the mountains of Europe. Some are only found in restricted localities, while others are widely distributed.

Saxifrages are, on the whole, not difficult plants to manage, provided we recognise the conditions that make for success and take the necessary trouble to supply them ; failure will result if soil be used that has become sour, or is close and sticky, holding moisture for a long time. Really well-drained soil is essential, and a compost that suits the majority consists of 2 parts loam, I part each of coarse grit and crushed mortar; if, in addition, stone or granite chips are mixed with the soil, an ideal rooting medium is obtained. The amateur rockgardener will often have to make shift with other material, as for instance, crushed bricks in place of grit. Again, those who garden on chalk, or can easily procure this or limestone, have something far superior to mortar rubble, for nearly all the Rockfoils need soil containing lime.

A shallow bed of soil is little better than none at all ; "pockets" 
and crevices intended for the finer Saxifrages should be opened to a depth of 2 feet, 6 inches of rough drainage being placed in the bottom. Then fill up the next 9 inches with the compost already advised, working in some of the larger pieces of rubble, and bring the ground to the original level with the compost, leaving out the rubble. This gives a good depth of well-drained soil, and even in the hottest weather the roots find moisture there. With the mossy Saxifrages and those like Saxifraga Geum and umbrosa, together with a few of the stronger and more vigorous encrusted kinds, this elaborate preparation is not essential. They thrive in ordinary garden soil to which some gritty material is added; all, however, insist on having thorough drainage.

One of the most important groups in the garden is formed by the Encrusted or Silver Saxifrages; they are easily recognised by the white encrustation that is present on the leaves, which are regularly arranged upon short stems and form a circular outline; hence they appear like rosettes of silvery-green. The flowers are generally borne in plume-like heads; the stems, short or tall, are at first erect, but as the flowers expand, these by their weight cause the stem to arch over gracefully. With one exception (Saxifraga florulenta) all the plants contained in the group can be recommended to the notice of amateurs, as they present no insuperable difficulties in cultivation. All prefer plenty of lime and grit in the soil and a sunny position. They also succeed in aspects facing east or west, while they are equally at home in the rock garden or dry wall. One of the easiest and most variable species in this group is Aizoon (common on mountains of Europe and north arctic regions), characterised by dense mounds of small silvery rosettes all clustered together; in balcana, the leaves are broad, the flowers white, heavily spotted with pink on $I_{5}$ inch stems. Baldensis, from Mount Baldo, is neat, with compact silver rosettes and white flowers; pectinata has blunt, toothed, silvery leaves, and in rosea the flowers are distinct, being rose ; in flarescens and lutea the flowers are of yellow tint.

Saxifraga cochlearis from the Maritime Alps capitvates alike by its dainty spoon-shaped leaves and tiny mounds of silver rosettes, and the grace of the wiry flower stems, 6 inches high, that carry big flowers of purest white; in the variety minor the rosettes and flower stems are smaller. In Saxifraga Cotyledon, which ranges from the Pyrenees and Alps to Lapland, the broad strap-like leaves form large rosettes, the branched inflorescence of white flowers occupies the upper half of the stem, while in the varicty pyramidalis the whole stem is branched from the base upward. The side shoots of the last-named are frequently grown into plants for the cool grecnhouse; to get the best results no 


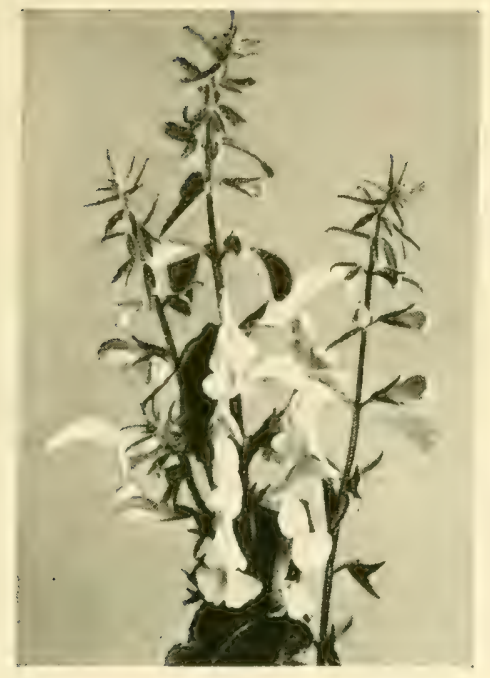

THE BLUE SAGE (SALVIA PATENS)

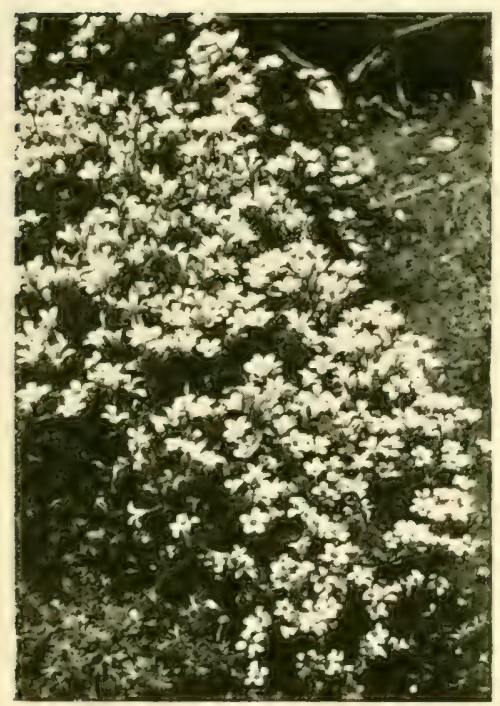

MOSSY ROCKFOIL (SAXIFRAGA WALLACEI)

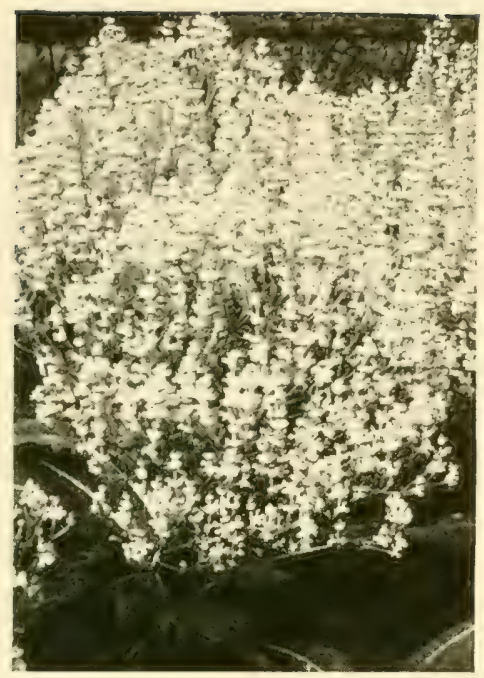

A FREE-FLOWERING SAGE (SALVIA GLOBOSA)

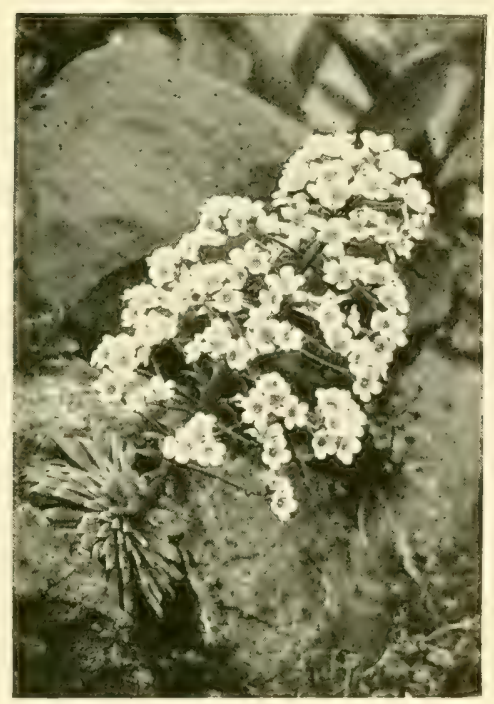

THE QUEEN OF ROCKFOILS (SAXIFRAGA LONGIFOLIA) 

side growths should be allowed to develop on the pot specimens, all the energy of the plant being concentrated in one rosette.

Saxifraga Hostii, from the Alps of Central Europe, is also a strong growing, tall kind with panicles of yellowish flowers, faintly spotted with pink. Macnabiana, another of the tall kinds, is one of the best, with light arching stems, up to 24 inches high, and white flowers heavily spotted with pink. Kolenatiana is an Asiatic species with tapering, strap-shaped leaves, and delicately coloured pink flowers borne in graceful plume-like heads, in summer; it is a charming sort, and prefers a cooler, less sunny position than the others. Lingulata is one of the most handsome Saxifrages, and is represented by numerous forms, all native of the Maritime Alps, the names of which are somewhat confused in gardens. In the typical plant the leaves are long and narrow, and the margins heavily encrusted; the flowers, which are large and white, are borne by 15 -inch stems that are only slightly arched, giving a dense and substantial appearance. In the var. lantoscana the leaves are shorter and distinctly spoon-shape, the flower stem is arching, and the flowers are chiefly on the upper side. There is also a form of lantoscana named superba; this is recognised by its large white flowers.

Saxifraga longifolia, from the Pyrenees, is the most remarkable of the encrusted kinds, it never forms offsets, hence must always be raised from seed; the plants, however, must have a covering of fine gauze material over them when in flower, otherwise the blooms become fertilised with pollen from other species by insect agency. This kind forms the largest rosette of any; well-developed specimens measure 9 to 12 inches across. The magnificent flower spike, which reaches a height of 24 to 30 inches, forms a towering pyramid of white blossom. Some years elapse before it attains flowering size.

The group of Saxifrages known as the Kabschia section embraces some delightful kinds; they bloom in the opening months of the year, and present, in striking combination, large flowers surmounting plants of minute growth. They form low mounds or carpets of short, grey or green rosettes formed of leaves that are sharp and needlelike or blunt, and slightly thickened at the base. In planting this section keep the plants well into the ground, and make certain that they are thoroughly firm, while around them, on the surface, employ rough grit in quantity. Propagation may be carried out by division in spring, splitting the plants into pieces having roots, and planting in the usual way; this, however, should only be practised under compulsion or after some experience has been gained with easier members. Cuttings can also be made of single shoots in summer, 
inserting several in pots of gritty soil, placing these in a close, cool frame.

An easy and satisfactory plant to grow is Saxifraga apiculata; it spreads into a broad, bronze-green mass, and the flowers are lemonyellow, several on a stem, and appear as early as March ; there is also a white form, similar to the type in all but colour. Boydii has deep yellow flowers in March; it is not one of the easiest to manage. A far better garden plant is that known as Boydii alba; this has large, handsome flowers of white, while it is as easy to grow as apiculata. Burseriana, from the Southern and Eastern Alps, is a plant of uncommon beauty, and gives generously of its flowers during February. The plant is variable; in the type the leaves form close, spiny tufts of dull grey green and the flowers are on 2-inch stems, usually opening about the beginning of March. In the var. major the leaves are larger and of a greyer tint, with a corresponding increase in the size of the flowers; in the forms known as "Gloria" and "Magna" we have the largest flowered of all, while the var. tridentina is particularly attractive, the margins of the petals being waved. A sunny position or an east or west aspect suits these; in the south the hottest exposure should be avoided. Diapensoides, from the Tyrol, etc., is one of the smallest, with close, imbricated, hairy leaves that form silvery tufts, from which rise 3 -inch hairy stems that carry the big white flowers in clustered heads.

Saxifraga Elizabethae is a free-growing hybrid, that forms a solic mat of dense green; the flower stems are some 2 inches high, tinted red, while the clustered flowers are yellow; it only blooms freely where it receives abundance of sun. Ferdinandi-Coburgi, from Macedonia, has clustered flowers of yellow during April. Faldonside is an early-flowering hybrid, taking pride of place among yellows; the colcur is really sulphur yellow, the petals being rounded and full with crimped margins. Growth is free but slow, the stiff leaves forming a close, hard carpet of greenish-grey. L. G. Godseff is a vigorous hybrid producing fine lemon-coloured flowers on 3-inch stems, the latter tinted red; it is a good grower, and spreads freely in gritty soil, in sun.

Saxifraga marginata, from Southern Italy, produces its large white flowers in clusters of three or more; the stems are some 3 inches high; the leaves are not of the spiny kind, but resemble a small silvery Saxifrage having the margins encrusted by lime; it flowers in Harch. Rocheliana, native of the Balkans, has small encrusted leaves and white bunched flowers on 2 -inch stems; the var. coriophylla usually gives a more gencrous display. Sancta, a Macedonian species, has yellow 
flowers on 2-inch stems, and dense mats of dark green shoots. Paulinae is a hybrid with lemon flowers, on 2-inch stems.

The Porphyrion Saxifrages are represented by oppositifolia. In the typical kind the flowers are purple, but the variation found in this kind is very great. In the var. splendens the flowers are purplecrimson, and produced in March; the var. alba has white flowers, while in the var. W. A. Clark they are bright carmine-red. All are close growing with evergreen, opposite leaves, succeeding best in cool, gritty soil with the foliage and stems fully exposed to sun.

Saxifraga Fortunei, from Japan, is the best representative of the Diptera group, and is valuable in being the last to flower; the leaves are large, rounded, and with toothed margins, while the stout, I8-inch stems carry large panicles of white flowers; its flowering season is late September or early in October. It is only hardy in favoured districts, succeeding in rich gritty soil with plenty of moisture. Saxifraga sarmentosa, or Mother of Thousands, so often seen in cottage windows, belongs to this group:

In the Robertsonia group the best-known representatives are Geum and umbrosa (London Pride); of the former the vars. crenata and dentata are worth growing, while the latter should be represented by the vars. Colvillei, serratifolia and minor. All are green-leaved plants, easy to grow in any good soil.

A charming and lovely plant of the Engleria group is Saxifraga Griesbachii; this lovely Macedonian plant has blue-green, silvered leaves which form rosettes of handsome and distinct character. As early as January the centre begins to swell up showing a blood-red, club-like stem; but not until early March is the infloresence fully developed, and the inverted flowers of purple-crimson reveal the yellow stamens within; the stems supporting these are also coloured and covered with leafy bracts of the same shade. It looks charming in a vertical fissure, and must have a cool, well-drained spot and soil of grit, limestone chips and loam.

The Dactyloides group embraces the mossy Saxifrages; these are among the most useful and reliable, forming snowy sheets, or masses of colour when in flower. Of the white flowered kinds hypnoides, found in the alpine parts of Britain, is the plant familiar in gardens as Eve's Cushion; it makes a dense, close, springy mass of vivid green, and bears its flowers on 6-inch stems in spring. Exarata, also of this type, produces flowers in such profusion that the foliage can scarcely be seen ; these are on firm, wiry stems some 3 inches in height. Camposii, of gardens, is really Wallacei ; it is a plant of great merit, with big white flowers on branched stems some 6 inches high, and one of the 
most effective of the mosses of larger growth. Decipiens, from Northern Europe, is also a large growing kind with leaves that are deeply lobed; the flowers are large, and on 6-inch stems; of this plant there are several varieties. Caespitosa, from Northern Europe, and sponhemica, a species found along the West of Ireland, have also white flowers, and generally have much in common with decipiens.

Saxifraga muscoides is an important mossy plant of dwarf growth (found widely distributed over the European Alps); from this kind the popular strain of red-flowered mossy Saxifrages has originated. One of the oldest and best is Guildford Seedling, with close carpet of green, and bright red flowers on 6-inch stems. Fergusoni is similar, with rather deeper coloured flowers; Bakeri, also of small growth, has flowers of rich carmine-red ; sanguinea superba is one of the richest coloured of all. Among the taller red-flowered varieties are Lady Deane, white, with pink centre; decipiens grandiflora, reddlish-pink; Clibrani, crimson; and Bathoniensis, deep crimson. All red-flowered forms retain their colour best in half shade; in full sun they are more or less washy before they fade: the prettiest effect of all is produced while they are in bud.

The Megasea group is the last of importance in the garden to notice. The kinds are readily recognised by the large, round, leathery leaves, of an evergreen character. Although the flower spikes are beautiful when seen in quantity, it is for their foliage effect that they are most cherished in gardens; the autumn and winter tints of ruddy purple and bright red are extremely pleasing. The best are cordifolia and crassifolia, both Siberian plants that differ from each other chiefly in the leaves. Ligulata is the earliest to flower, but is not the hardiest, and should have a warm position in cold districts; it is a showy plant in spring, and gives noble effects when boldly grouped with large rocks on steep banks or ledges; it is native of the Himalaya.

Almost all Saxifrages are readily increased by division, which is best carried out in early spring. With the free-growing kinds all that is necessary is to dibble in pieces or tufts, leaving only the actual crown or rosette exposed; the better and scarcer sorts should be grown in pots as recommended for the Kabschia section. When offsets or cuttings are not obtainable, resource must be had to seed, which is sown either in autumn or spring, in pans of gritty soil, the seedlings being grown under such conditions as described for cuttings. Unless great care has been taken to ensure self-fertilisation in the plant that produced seed, the seedlings will probably be of mixed parentage, as Saxifrages intercross very readily. 


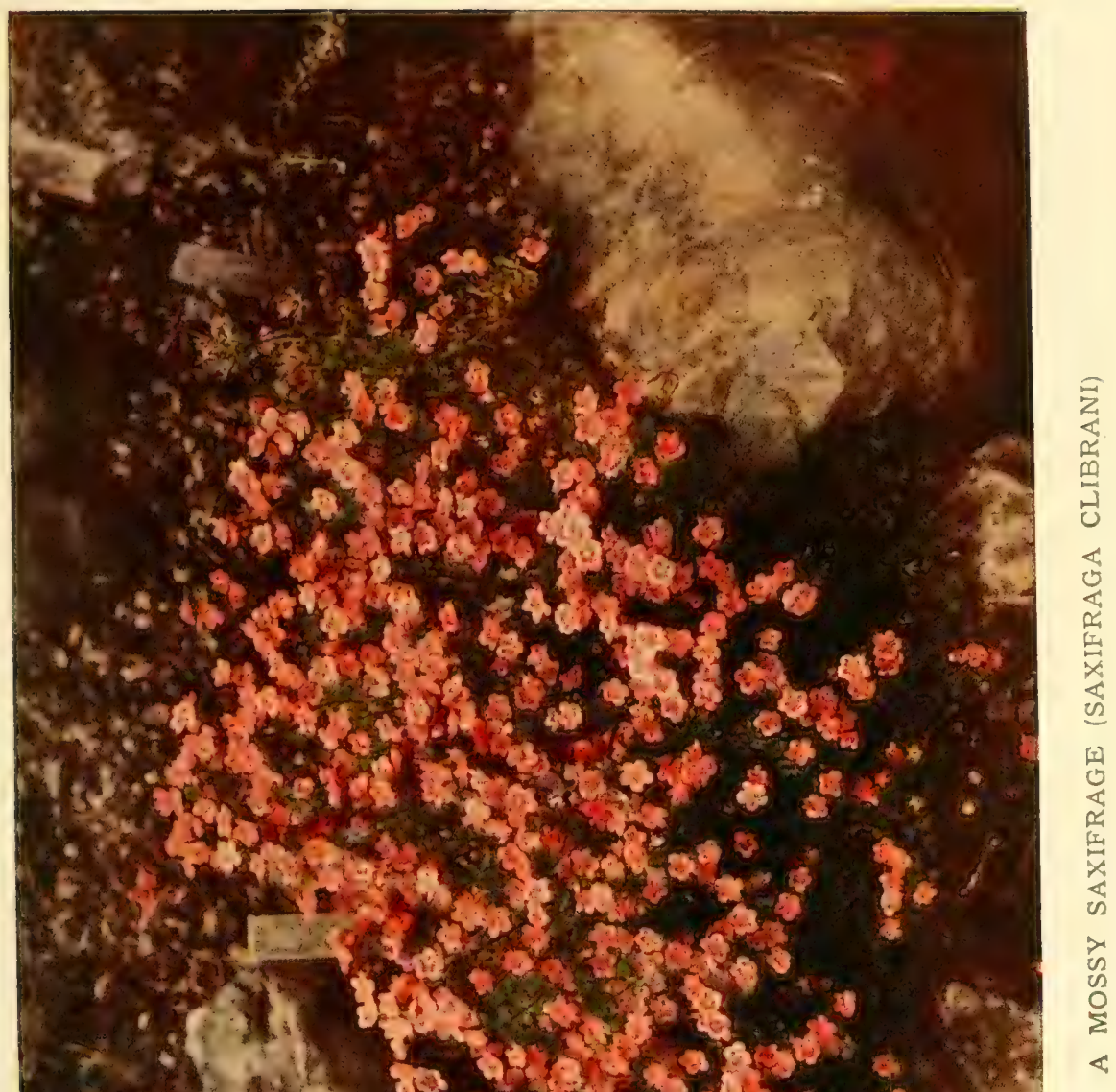

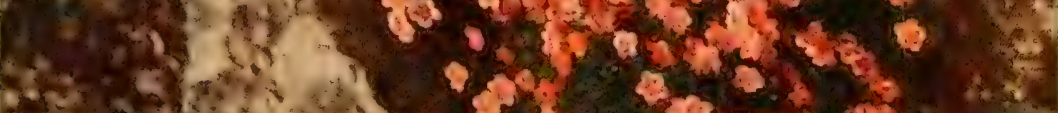

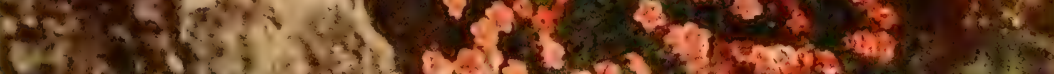

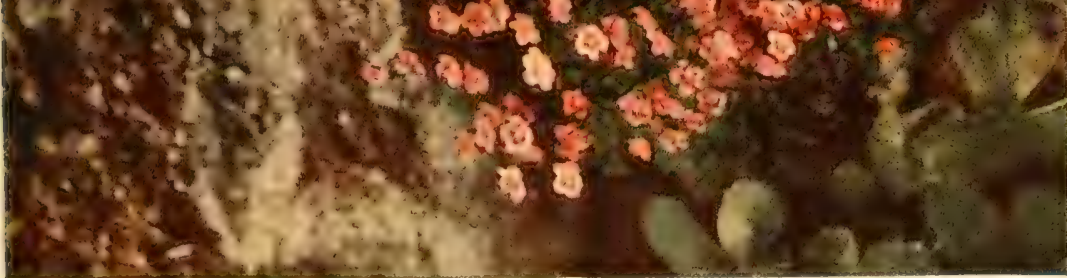



Scabiosa (Scabious).-Pretty annual, biennial, and perennial plants (Natural Order Dipsaceae), often known in cottage gardens as Pincushion Flowers in reference to the shape of the flower-heads. The most popular is the Sweet Scabious, Scabiosa atropurpurea, native of Southern Europe, of which the varieties are numerous. They may be treated as biennials and sown in May or June for planting in their flowering positions in autumn; or they can be treated as annuals and raised from seeds under glass in spring. The plants thrive in good garden soil, grow about 3 feet in height, and flower freely from May to September, according to the time of sowing. Distinct sorts - seeds of which are sold separately-include : Snowball, white ; King of the Blacks; Marginata, lilac and white; Pink, Mauve, and Cherry Red. There is also a dwarf strain, nana flore pleno (Tom Thumb), I2 inches, in mixed colours.

The best-known perennial is Scabiosa caucasica, the Caucasian Scabious; it grows about 2 feet high, has dainty lilac-mauve flowers in quantity during June and July, and fewer in August and September. Desirable varieties are: alba, white; Pride of Riverslea, delicate lilac-mauve; perfecta, pale mauve; and Diamond, dark mauve. On fairly light soils and in large rock gardens the plants last for some years, and may be increased by division in September or spring. In gardens where the soil is rather heavy and moist this Scabious is treated as a biennial, seed being sown on a border outside from April to June. The ycllow Scabious, Scabiosa lutea, is a tall plant for the herbaceous border, 5 feet high, flowering from July to September; still taller is the var. gigantea, with primrose-yellow flower-heads. In the rock garden Scabiosa Pterocephala (syn. parnassiaefolia) is a charming plant, 6 inches high, from Greece, with mauve-purple flowers in summer and autumn, and greyish-green foliage. It is increased by division or seeds. All the Scabious need a sunny position.

Scabious.--(See Scablosa.)

Schinus is a group of evergreen shrubs (Natural Order Anacardiaccae), closcly allied to the Sumach (Rhus). Two species are sometimes grown: Bomplandianus, from South Brazil, and dependens, from Chili. Both are evergreen, fast-growing shrubs, which are rather tender and only suitable for the southern counties; the small white flowers are sufficiently plentiful to be attractive, but there are many more ornamental shrubs. They, however, grow well in poor soil, and for that reason are worth encouragement. Increase is by seeds and cuttings. An occasional cutting back is necessary to keep the plants within bounds. This may be done in summer. It is wise to plant them in a sunny position. 
Schizanthus (Butterfly Flower).-Although perhaps better known as a greenhouse plant, the Schizanthus (Natural Order Solanaccae) is also a lovely annual for the garden. Three kinds-Grahami, pinnatus, and retusus, natives of Peru and Chili---have been used by the florist in creating the beautiful sorts in cultivation to-day. The colours include white, pink, mauve, lilac, and rosy-red, all more or less blotched and spotted. Good strains of seeds in mixture are: Wisetonensis, large-flowered hybrids; and hybridus grandiflorus. The prettily cut pinnate foliage enhances the beauty of the plants which grow from I foot to 2 feet high. Seeds are sown under glass towards the end of March or outside during April, where the plants are to flower. The stems should be supported with twigs from an old birch broom when a few inches high. The flowering season is from the end of June to September.

Schizocodon.-The only species, Schizocodon soldanelloides, (Natural Order Diapensiaceae) is a native of Japan; it grows only 3 or 4 inches high and forms a tuft of shining evergreen leaves, among which appear the elegantly fringed, rose-coloured flowers in spring and early summer. Increase is by division in September, at which time planting ought also to be done. Peat and coarse sand form the best soil. This is one of the daintiest flowers for a warm, sheltered nook in the rock garden where the soil is fairly moist.

Schizopetalon (Lace Flower).-Only one kind is grown, Sclizopetalon Walkeri, a Chilian plant with prettily fringed white flowers, belonging to the Wallflower family (Cruciferae). It is a half-harcly annual, growing 9 to $\mathrm{I} 2$ inches high, raised from seeds in light soil on a warm border during April and early May, where it will flower in July and August. The blossoms have an Almond-like fragrance.

Schizophragma.-Climbing plants belonging to the Saxifrage family (Saxifragaceae), and closely allied to Hydrangea. Two species have been introduced, hydrangeoides, from China and Japan, and integrifolia, from China. Both are rare plants of climbing habit, and they resemble Hydrangea petiolaris (with which the former plant is often confusel) by having acrial roots on the branches by means of which they cling to their supports, tree trunks, rocks, or fences: They, however, show a considerable difference from Hydrangea by the sterile flowers, those of Schizophragma having but one large bract, whilst in Hydrangea there are four. The white sterile flowers are few in number, and they appear here and there amongst the numerous fertile flowers in the large flat head. Plant in good loamy soil against an upturned tree butt, tree trunk, or wall. Propagation is by layers and pruning is unnecessary. Of the two kinds integrifolia is likely 
to form the most showy plant. The single bracts of the sterile flowers are up to 3 inches long and $I_{2}^{\frac{1}{2}}$ inches wide.

Schizostylis (Kaffir Lily).-The only kind is Schizostylis coccinea, a South African bulbous plant belonging to the Iris family (Iridaceae), and flowering from October to December. The plants grow about 2 feet high, have Iris-like foliage and vivid scarlet-crimson flowers. The best position is at the foot of a sunny south wall or fence. Suitable soil consists of 2 parts fibrous loam and I part each of peat, leaf-mould, and sand. Increase is by division of the offsets in spring. The clumps ought to be divided, and replanted about every three years.

Sciadopitys verticillata (Umbrella Pine).-An attractive Conifer (Natural Order Coniferae), known in its native country, Japan, as the Umbrella or Parasol Pine, by reason of the narrow evergreen leaves being arranged on the branch in the same way that the ribs of a parasol or umbrella are arranged. It has been in cultivation since I86r, about which date it was introduced by two persons, Mr. J. G. Veitch and Mr. R. Fortune. In its native country it forms a timber tree of the largest size. Here, however, it does not appear as if it will ever attain its average size, although it forms a stately, well-furnished specimen clothed with branches from base to summit. The largest specimens are to be seen in the south-west counties, where some are 20 feet high; it thrives in light, well-drained though moist, loamy soil containing a little peat, and gives the best results where the atmosphere is pure and moist. Although it thrives best in the milder counties, it cannot be called tender, for it withstood the severe winter of $1894-5$ without injury in the neighbourhood of London. I'ropagation is by seeds, which are ripened freely in this country, and pruning consists of keeping the leaders clear, shaping the plants, and removing any cones, whilst still very small, which are not required for seeds.

Scilla (Squill, Bluebell).--In small and large gardens the Squills (Natural Order Liliaceae) are equally valuable. They thrive in any garden soil, except that which is heavy and wet, and may be increased rapidly by offsets, while seels also provide a ready means of propagation; in fact, if these are allowed to ripen, self-sown seedlings of most kinds spring up readily. Autumn is the best time to plant the bulbs of those kinds that bloom before midsummer; peruviana and autumnalis should be planted in spring. A suitable depth to plant is such that the smaller bulbs are covered with 2 inches of soil and the larger ones with 3 or 4 inches. The flowering season is from February to April. The earliest are : bifolia, deep blue, native of 
Europe and Asia Minor; and sibirica (Siberian Squill), porcelain blue; there are white varieties of both, while bifolia carnea has pale pink blooms. All these grow about 3 inches high.

During May Scilla italica (Italian Bluebell) bears dainty pyramidal flower spikes of lavender tint, 6 inches high; this and the white var. alba should find a place in the rock garden, together with Scilla peruviana (Peruvian Squill), which bears a dense raceme of from fifty to one hundred light blue flowers in June. This plant, which is native of the Mediterranean region, has the largest bulb of all hardy Scillas; light sandy loam and leaf-mould form a suitable compost. In late summer, July to September, we may look for the blossoms of Scilla autumnalis, from Europe and North Africa, purpleblue, and the var. japonica, rose, both with pretty spikes 6 inches high, and suitable for the rock garden.

While most of us are familiar with our native Bluebell, Scilla festalis (nutans), few flower lovers recognise its value for shady borders and odd corners unsuited to choice plants. Varieties are obtainable in half a dozen distinct shades of colour: festalis, violet-blue; alba, white; azurea, porcelain blue; Blush Queen, delicate pink; carnea, blush pink; rosea grandiffora, rosy-pink; and rubra, lilac-rose. Allied to these and suitable for similar positions and for the flower border are the Spanish Bluebells, varieties of Scilla hispanica (campanulata). The flower spikes, about I5 inches high, are stiffer and the flowers a little larger than the British Bluebell; distinct varieties are alba, white; Bleu Coeleste, deep blue; Blue Qucen, porcelain blue; Rosalind, rose-pink; and Rose Qucen, lilac-rose. Once planted in sunny or shady positions, the bulbs of both Bluebelis and Squills may be left undisturbed for years unless required to be lifted for propagation.

Scirpus (Club Rush).-Numerous members of this group (Natural Order Cyperaceae) grow by the waterside and swamps in this country. The two best for the garden pool are the Common Scirpus lacustris, with green leaves and reddish-brown inflorescences, in July and Angust, several feet in height, and the var. Tabernaemontani zebrinus (Banded Rush), of which the stems are banded or ringed with pale yellow. Increase is by division preferably in spring.

Scolopendrium (Hart's Tongue Fern).--The British Hart's Tongue, Scolopendrium vulgare (Natural Order Filices), is one of our commonest native ferns. It is an attractive evergreen plant with shining green leathery fronds, curled, crested, or much divided in the numerous varieties. Some have quite small leaves, others grow from $I \frac{1}{2}$ to 2 feet in length. The Hart's Tongue Ferns thrive in sun 


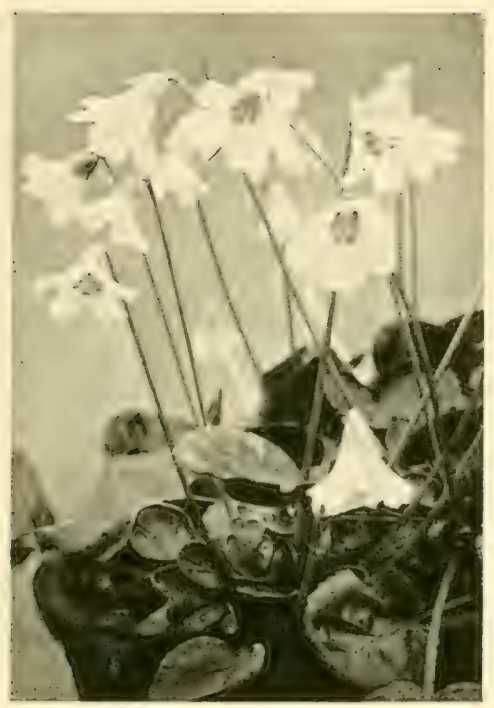

FOR THE ROCKERY (SHORTIA GALACIFOLIA)

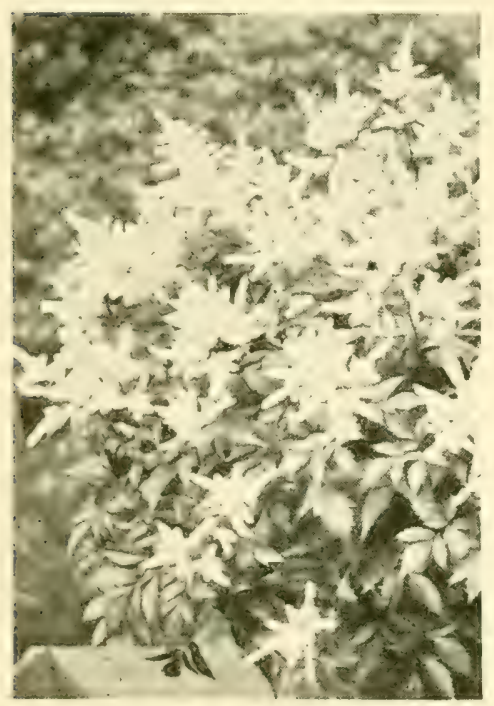

THE JAPANESE SPIRAEA (SPIRAEA JAPONICA)

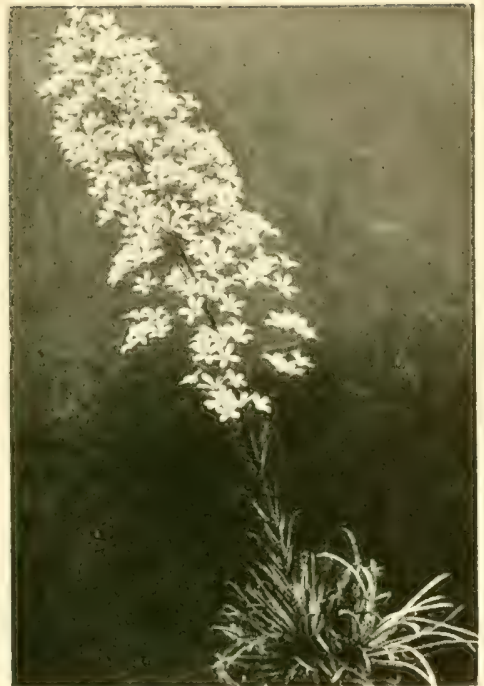

A HANDSOME ROCKFOIL

(SAXIFRAGA LINGULATA)

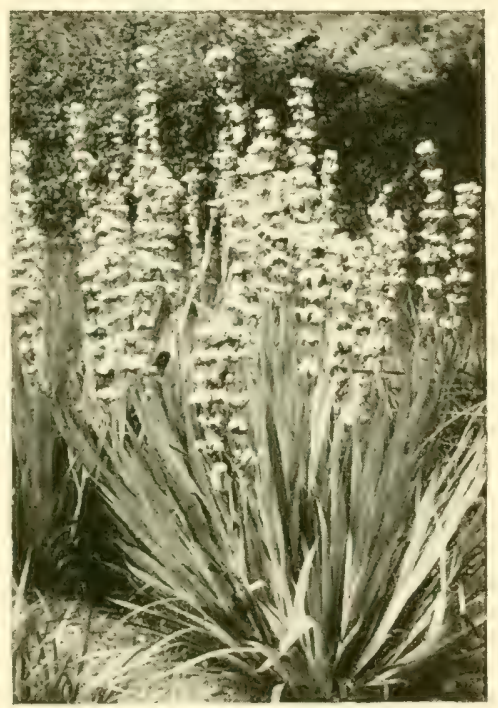

THE SATIN FLOWER

(SISYRINCHIUM STRIATUM) 

and shade, by the waterside, in the bog garden, on the rockery, in a shady border, and in the chinks of an old wall. While they grow well in ordinary garden soil, they are benefited by mixing a little peat, leaf-mould, and old mortar rubble in the ground previous to planting. Propagation of the varieties is by division in autumn or spring. They may also be increased by spores, but do not come true. It is only possible here to give a list of a dozen of the 400 or 500 varieties which have been given clistinctive names: crispum, crispum fibriatum, cristatum, cristatum Kelwayi, cristulatum, grandiceps, laceratum, marginatum, ramo-cristatum, ramo-marginatum, sagittato-cristatum, undulatum cornutum.

Scolymus (Golden Thistle).-Useful plants for large flower borders and the wild garden; they belong to the Natural Order Compositae. As the popular name suggests, the plants have Thistle-like leaves and flowers. Increase is by seeds and division in autumn or spring. They are usually treated as biennials and raised from seeds sown outside in May or June. Ordinary garden soil is suitable, and they prefer a sunny position. Scolymus grandiflorus bears golden-yellow, solitary flower-heads in May and June, and has greyish leaves; it grows 3 feet high, and is native of the Mediterranean region. Scolymus hispanicus (Spanish Oyster Plant) has yellow flower-heads, in clusters, from July to September ; it is 3 feet high, and native of South-West Europe.

Scots Pine.-(See PINUs.)

Scutellaria (Skull Cap). - Those who like to cultivate little-known plants will find Scutellaria interesting and desirable for the rock garden and front of the border. It belongs to the Sage family (Labiatae). Propagation is mostly carried on by division of the roots in spring. When seeds are available these should be sown in a frame in spring or early summer. Ordinary garden soil and an open, sunny position supply their needs. The following are the best: albida, from Greece, with white flowers; alpina, native of Europe and Central Asia, purple and yellow; altissima, a

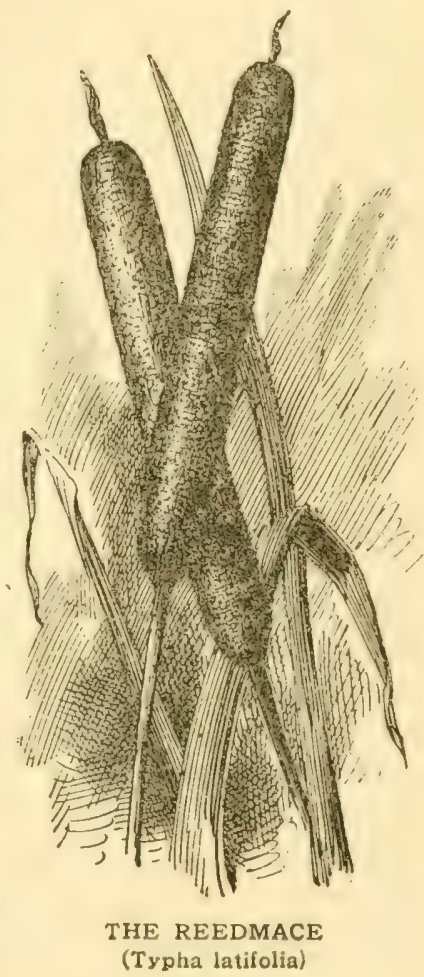




\section{S THE BOOK OF HARDY FLOWERS}

Caucasian plant with dark purple flowers; and baicalensis, native of Siberia, purple. Scutellaria orientalis, from Central Asia and Southern Europe, is a very desirable trailing kind, 9 inches high, with yellow flowers. These plants bloom in July and August, and grow about 12 inches high.

Sea Buckthorn.-(See HippopiAE.)

Sea Holly.-(See ERYngium.)

Sea Lavender.-(See Statice.)

Sedum (Stonecrop).-These are important plants (Natural Order Crassulaceae), chiefly suitable for the rock garden. Many thrive in dry, sunny positions in crevices of old walls, crannies between boulders in the rock garden, and between rough paving-stones. A few are popular plants for carpet bedding, and others deservedly find a place along the front of the flower border. Well-drained soil is essential, and plenty of mortar rubble mixed in is advantageous. Propagation by division is fairly general, though some kinds can be rapidly increased from cuttings, while others are easy to raise from seeds. Planting may be done in autumn or spring, which is also the best time to divide the clumps; cuttings are inserted in sandy soil, preferably in a frame during summer and autumn, while seeds are sown in a cold frame from April to June.

Sedum acre, the Biting Stonecrop or Wall Pepper, is a familiar British plant, about 3 inches high, with yellow blossoms in early summer. Though a native plant it is useful in the rock garden; the var. aureum, with yellow foliage, is used for carpet bedding. Sedum album, also British, grows 4 to 6 inches high and bears white blossoms in June and July. In the South of England Sedum dasyphyllum (glaucum) is found wild on old walls; it is 2 inches high, and has white flowers tinged with pink in June and July. The Siberian Sedum Ewersii has silvery leaves, trailing stems, and rosy-purple flowers lasting from July to September; height about 4 inches. Sedum kamtschaticum (Orange Stonecrop) is a showy evergreen plant with trailing stems, rich green leaves, and bunches of yellow flowers from June to August; it is native of Kamtschatka and about 6 inches ligh. Sedum lydium, from Asia Minor, grows 3 inches high, with tiny pink flowers in summer; during winter the plants assume a bronzy-red tint. From Amurland comes the distinct Sedum Middendorfianum, 4 inches high, with yellow flowers from July to September, followed by heads of red seed vessels; a beautiful rock plant. The Californian Stonecrop, Sedum obtusatum, 4 inches high, has succulent foliage of bronze-green shade, yellow flowers in August. Sedum pulchellum (Bird's-foot Stonecrop) is charming in the rock garden; 
the dainty pink flowers attract attention from July to September; it is 3 inches or rather more in height, and native of North America. Sedum rupestre grandiflorum has blue-green foliage which becomes tinged with red in winter, and yellow flowers in July and August; 6 inches high; native of Europe.

An important kind from Japan is Sedum Sieboldii, 6 inches high, with greyish-green leaves edged with red, and rose-coloured flowers from July to September. It is spreading in habit and in addition to being planted in the rock garden is sometimes used for summer bedding, as also is the var. variegatum. Sedum spathulaefolium from Western North America is a lovely picture in June when aglow with yellow flowers, rosettes of glaucous green leaves, and pink-tinted stems; it is from 4 to 6 inches high. Sedum spurium is a procumbent Caucasian Stonecrop with evergreen leaves and pink-white blossoms in July and August; 4 to 6 inches high.

Several kinds, from I foot to 2 feet high, in addition to their value in large rock gardens, are worth planting in a sunny flower border. Sedum Aizoon, from Siberia, bears yellow flowers in July and August, and Sedum Maximowiczii, from Japan, having flat, yellow flowerheads, is at its best in July. A very striking species is the European Sedum maximum, with white flower-heads spotted with red, from July to September; the var. atropurpureum (purpureum) has purple foliage and rosy flower-heads. The Japanese Stonecrop, Sedum spectabile, is one of the most showy and valuable kinds; it is easy to grow, and a splendid plant for small gardens, thriving in sun or partial shade; for a north border it is unsurpassed as an edging. The large flat heads of rose-purple flowers are in full beauty in late August and September; the var. roseum (atropurpureum) is brighter in colour. For dry positions the Orpine, Sedum Telephium, a British species, is valuable; it has erect stems I2 inches high and purplish-pink flowers from July to September ; it is a very variable plant, and some of the most distinct forms have been given names; three of the best are Munstead Red, Borderi, and haematodes.

Selaginella.-These are moss-like plants (Natural Order Lycopodiaceac) allied to the Fern family. They need a moist, half-shaded position in the rock garden, bog garden, or on a sloping bank by the side of a shady walk or stream. The most suitable soil is one containing peat and leaf-mould, but this is not essential. Increase is by division in spring; the dwarf trailing growths spread rapidly over the ground in genial surroundings. Cuttings also form a ready means of propagation; they are inserted in sandy soil in a close frame from March to August. Selaginella helvetica, from the Alps, is the 
hardiest kind, forming a thick green carpet; denticulata, native of the Mediterranean region, is rich green at first, but changes to a reddish tint in autumn when planted in exposed positions. Kraussiana is stronger in growth, forming a rich, dark green carpet in sheltered nooks; it is not so hardy as the other two, being a South African kind, and is often grown in the greenhouse in winter and planted outside as a carpet for some of the summer bedding plants.

Sempervivum (Houseleck).-In hot and dry positions these plants (Natural Order Crassulaceae) thrive where few will exist. In country districts we see mounds of their evergreen rosettes on the sloping roofs of buildings; they are suitable for planting on the top of or in the crevices of old walls, on the bare surfaces of stones in the rock garden, or as an edging to beds and borders. They thrive in very gritty and well-drained soil, with which old mortar rubble is freely mixed. Country people, when planting little hillocks on the roofs, mix clay and mortar rubble together in which to start them. Houselecks increase rapidly by offsets, the best time to divide them being in spring, though if an increased stock is not required they may be left undisturbed for years. Sometimes Houseleeks are raised from secds, but the plants produce offsets so freely that this method

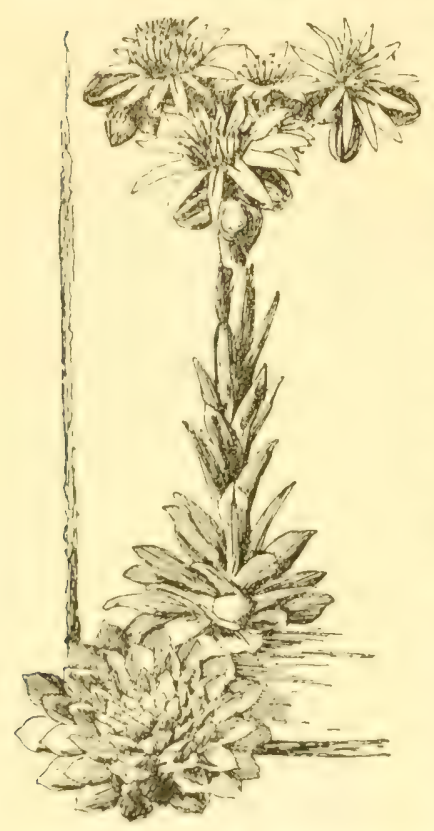

ONE OF THE HOUSELEEKS (Sempervivum) is seldom worth while. The plants vary from $\frac{1}{2}$ inch to 9 inches across, and the leaves are of various shades of green, often edged with red. In early summer, mostly from May to July, the plants produce their spikes of red and yellow flowers, some flowering much more freely than others. A few of the best hardy species are the Common Houseleek, Sempervivum tectorum, of which there are half a dozen distinct forms; triste, known as the Red-leaved Houseleek; arachnoideum, the Cobweb Houseleek, having small rosettes covered with white cobweb-like down, quite the daintiest kind; and calcareum (californicum), the Chalk-loving Houseleek from the Alps of Dauphiny, with glaucous leaves, tipped with red-brown. From the Alps and Pyrenees we have Sempervivum montanum, with rosettes I inch to 2 inches across; while glaucum, globiferum (Hen 


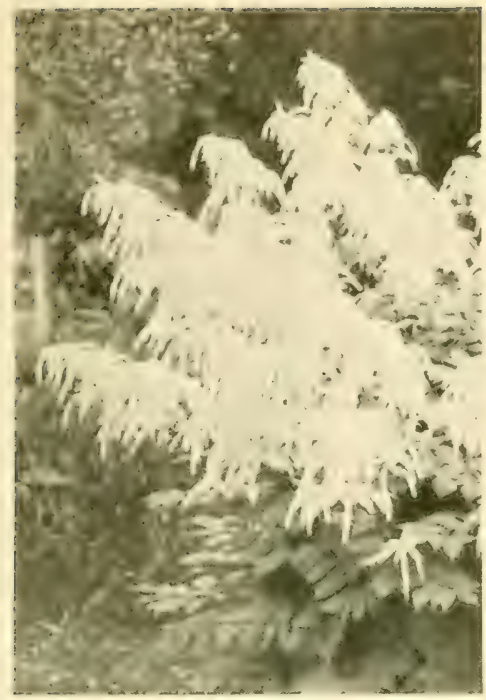

GOAT'S BEARD (SPIRAEA ARUNCUS)

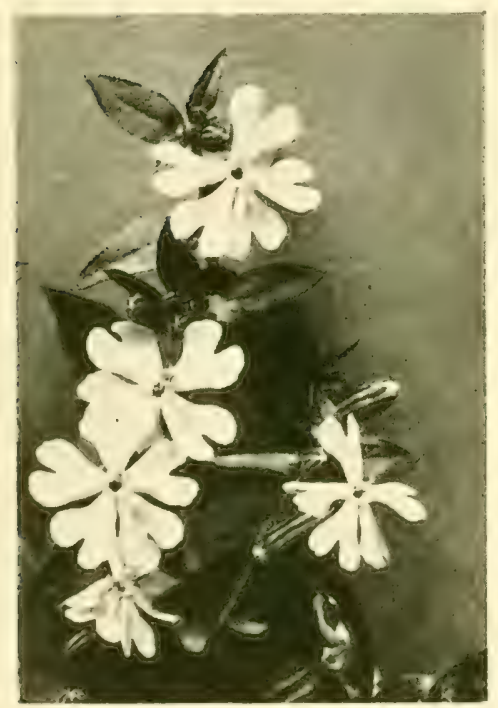

A FAVOURITE FOR SPRING BEDS (SILENE PENDULA)

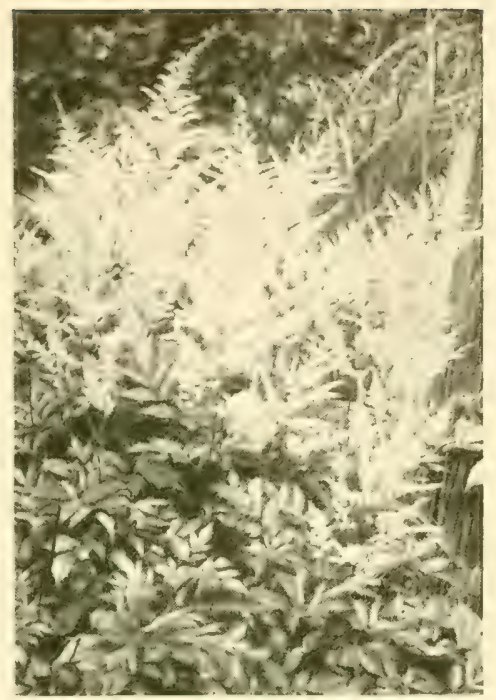

THE BEAUTIFUL ASTILBE (SPIRAEA) CERES

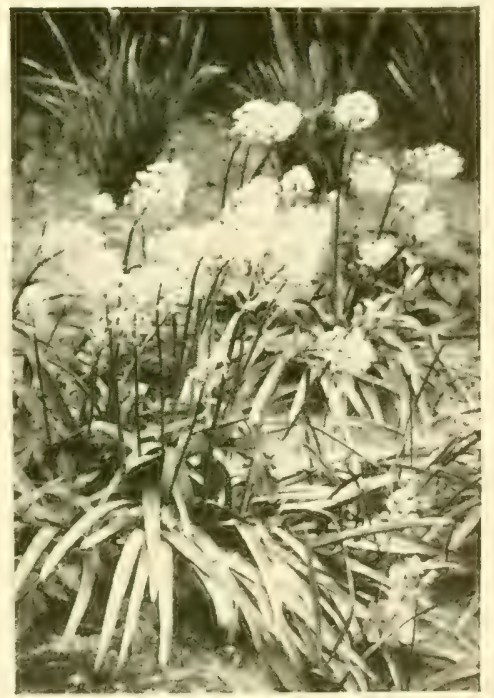

THE SPANISH BLUEBELL (SCILLA HISPANICA) 

and Chicken Houscleck), and fimbriatum should also be grown. For summer bedding the Madeira Houseleek (tabulaeforme) is a great favourite for edging carpet beds; it has very large flat rosettes, light green in colour, but is rather tender and needs to be lifted in autumn and kept in a cool greenhouse during winter.

Senecio (Groundsel, Ragwort).- The Senecios (Natural Order Compositae) are very numerous, but comparatively few are grown in gardens. The best known annual kind is Senecio elegans (Jacobaea), native of South Africa; seeds are sown under glass in March or April or out-of-doors on a sunny border towards the end of April. There are two strains, the tall (I8 inches high), and dwarf (9 inches in height). Both are obtainable in distinct colours, red, purple, lilac, and white sorts being sold separately or in mixture. A select collection of perennial species should include the following: Senecio pulcher, with purplish-red flowers, in autumn, 2 feet or more in height, is an attractive plant for the rock garden or a sunny border; Doronicum, a European species, grows I2 inches high, and has golden-yellow flowers from June to August. From China we have three distinct and beautiful plants all with yellow flowers in late summer; clivorum, 4 feet, large leaves; Wilsonianus, 4 feet, large cordate leaves; and tangutica, 5 feet. All three are delightful freegrowing plants for large borders, the waterside and wild garden.

Senecio macrophyllus, the Large-leaved Caucasian Groundsel, is a noble plant some 5 feet high, with large heads of yellow flowers in July and August, particularly happy in moist soils. Senecio japonicus (Ligularia japonica), from Japan, has handsome divided leaves, I2 inches across, and bears orange-yellow flowers on stiff stems in August, 3 to 5 feet high. Senecio Kaempferi aureo-maculata is a half-hardy kind with large green leaves beautifully marbled or spotted with yellow; it is a Japanese plant, hardy in the milder counties, and elsewhere may be used in beds and borders outside in summer. The perennial Senecios thrive in ordinary garden soil, well tilled, and manured. Increase is by division from autumn to spring when the weather is favourable. Most of them produce seeds which should be sown on a border out-of-doors from April to June; and Senecio pulcher may be propagated from root-cuttings, pieces of the fleshy roots, I inch to 2 inches long, being placed in sandy soil in a cold frame during the spring.

Sequoia.-This is an interesting group of Conifers (Natural Order Coniferae), for it contains two unique hardy trees and the largestgrowing Conifers. Amongst the known trees of the world their height is said to be surpassed only by some of the Eucalyptus of Australia. 
The kinds in question are : gigantea, the Bigwood, and sempervirens the Redwood, both natives of California. The last-named is the commoner tree, the former now being restricted to a comparatively few groups, most of which are, however, safe from the woodcutter, the land on which they stand being strictly under the control of the United States Government. Secpuoia gigantea, sometimes called Wellingtonia, was discovered in I852; its trunk sometimes exceeds 300 feet in height with a diameter near the base of $\mathrm{I}_{5}$ to 20 feet. The older specimens are said to be quite 3,000 years old. In this country trees already exceed Ioo feet in height where they are growing under favourable conditions. Young specimens are of rather stiff outline, with a somewhat formal, conical habit; the cones are small and borne freely here. Several varieties have been given names, notably pendula, with pendent branches, and aurea, with variegated leaves. None is of any value.

The Redwood (Sequoia sempervirens) is a more ornamental tree, and attains somewhat similar proportions; it is much more common in its native habitat than the other kind, and its timber is a regular and important article of trade. It is one of the few Conifers which reproduce themselves from sprouts from the cut-back trunks. A considerable difference is noticeable in the leaf arrangement of the two Sequoias, the leaves of the Bigwood being somewhat like those of Cryptomeria, though shorter, whilst those of the Redwood are more like those of Taxodium, but evergreen. The cones of the latter are usually less than $\frac{3}{4}$ inch long.

The most satisfactory results are obtained by planting them in good, moist, but not waterlogged, loamy soil, where the atmosphere is pure and moist. They thrive well in the South and West of England, Ireland, and Scotland. Propagation is best carried out by seeds, and pruning is confined to shaping the trees and keeping them to single leaders. Shelter from wind is an advantage.

Serapias.-A small group of hardy Orchids (Natural Order Orchidaceae), natives of the Mediterranean region; they grow about 2 inches high and flower in May. Choose a sheltered, partially shaded position in the rock garden and plant in a soil composed of peat, sandy loam, leaf-mould and sand. Increase is by division of the tubers in August and September. Scrapias cordigera, lilac and red, purple-brown lip, and Lingua, brownish-purple, red lip, are the most showy kinds.

Shasta Daisy.-(See Cirmsanthemum Maximum.)

Shield Fern.-(See Aspidium.)

Shirley Poppy.-.(See PaPAver.) 
Shortia (Crimson Lcaf).-Two species of this desirable rock garden plant (Natural Order Diapensiaceae) find a place in our gardens: galacifolia, from North America, and uniflora, from Japan. Propagation is by division in September or March. The plants love a cool, moist, and sheltered spot in the rock garden, and need sandy peaty soil; they are evergreen, grow about 6 inches high, and flower from April to June. Shortia galacifolia has somewhat drooping flowers, white at first, changing to pink, the petals are prettily fringed, and the flower stalks rosy-red; in summer the foliage is deep glossy green and changes to bronze-crimson in autumn. Shortia uniflora has delicate rosy-pink flowers and rather smaller leaves than the other.

\section{Siberian Crab.--(See Pyrus.)}

Sibthorpia (Moncy-wort). - Sibthorpia europaea is a pretty crecfing plant, scarcely $\frac{1}{2}$ inch high, belonging to the Snapdragon family (Scrophulariaceae), native of Britain, and called the Cornish Moneywort. It needs a rather moist, half-shady position in the rock garden in ordinary soil. The tiny, pale, flesh-coloured flowers which open from June to September are not very conspicuous; the small leaves are roundish, prettily notched, and hairy. There are two varicties: aurea, golden-leaved, and argentea variegata, of which the leaves are margined with creamy-white. Spring is the best time for propagation, which is carried out by dividing the tufts, the creeping stems rooting frecly on the underside and forming a dense carpet.

Sidalcea (Greck Mallow).-Hardy perennials belonging to the Mallow family (Malvaceae), which are easy to grow and flower freely in ordinary well-drained soil. Increase is by division at any favourable opportunity from October to March, and by seeds sown on a border out-of-doors in April or May to secure flowering plants the following year. Sidalcea candida, from New Mexico, has beautiful satiny white flowers, freely borne in summer and early autumn on plants 3 feet in height. Flowering at the same season is Sidalcea Listeri, a plant raised in gardens, with prettily fringed, rosy-pink blossoms, 3 to 4 feet high. From North-West America we have Sidalcea malvaeflora, a showy plant, 3 to 4 feet high, with rosy-purple flowers, lasting in beauty from July to September. There are several varieties, the best being Rosy Gem; atropurpurea, dark rosy-red; and Mariana, rosy-crimson.

Silene (Catchfly, Campion).-Much could be written in praise of these plants which belong to the Pink family (Caryophyllaceae). Both the hardy annuals and perennials are extensively grown; they thrive in ordinary soil, and are best in a sunny position. The annuals 
are casy to grow; in fact, under favourable conditions, self-sown seedlings are plentiful. The best known are the varieties of Silene pendula, from the Mediterranean region; the typical plant grows 9 to $\mathrm{I} 2$ inches high, and bears rose-coloured blossoms freely in spring and early summer. Selected varieties which come true from seeds are Double Salmon I'ink, Double Delicate Pink, and Bonetti, deep rose with dark foliage. For spring bedding or as an edging to a border the dwarf Silenes are very showy. Good varieties are: Dwarf Rose, Dwarf White, Double Dwarf Rose, Double Delicate Pink, and Golden Bedder, with golden-yellow leaves and delicate, rose-coloured flowers. The seeds are sown on a border out-of-doors in July, the seedlings being transferred to their flowering positions in September or October; these are for spring flowering. If desired, a second sowing may be made in April to secure plants that will bloom in autumn. Silene Armeria (Lobel's Catchfly) is a native of Switzerland and some parts of France; it is from I2 to I8 inches high, and has rose-coloured fragrant flowers from July to September. Seeds are sown in April, where the plants are to flower.

The perennial species are numerous. Silene acaulis (Moss Campion), a European species, forms a dwarf cushion, and bears small rosypink flowers in April ; it thrives best in very gritty soil or the moraine, and is difficult to flower well. Silene alpestris (Alpine Catchfly), from the European Alps, is a dainty white-flowered plant, some 6 inches high, for the rock garden, easily grown in sandy soil.

Silene maritima flore pleno has double white blooms resembling Pinks; it is 4 to 6 inches high, and flowers in summer. Silene Saxifraga is a pretty tufted alpine with white flowers. Silene Schafta, the Caucasian Campion, some 6 inches high, is one of our best late summer plants for the rock garden; the flowers are bright rose. The North American Fire Pink, Silene virginica, grows 9 inches high, having fiery-scarlet blossoms from July to September. Most of the Perennial Campions bear seeds freely, which should be sown on a border outside, or in a cold frame during April and May. They may also be propagated by division in autumn or spring.

Silk Vine.-(See PERIPLOCA.)

Silver Fir.-(See ABIES.)

Sisyrinchium (Satin Flower).--Useful plants, with fibrous roots and grass-like foliage, for a warm, sunny border and the rock garden. They belong to the Iris family (Iridaceae), and thrive in light sandy loam, in which peat and leaf-mould are freely mixed. Propagation is by division in September or March. The most showy species is the North American Sisyrinchium grandillorum, with rich druping 

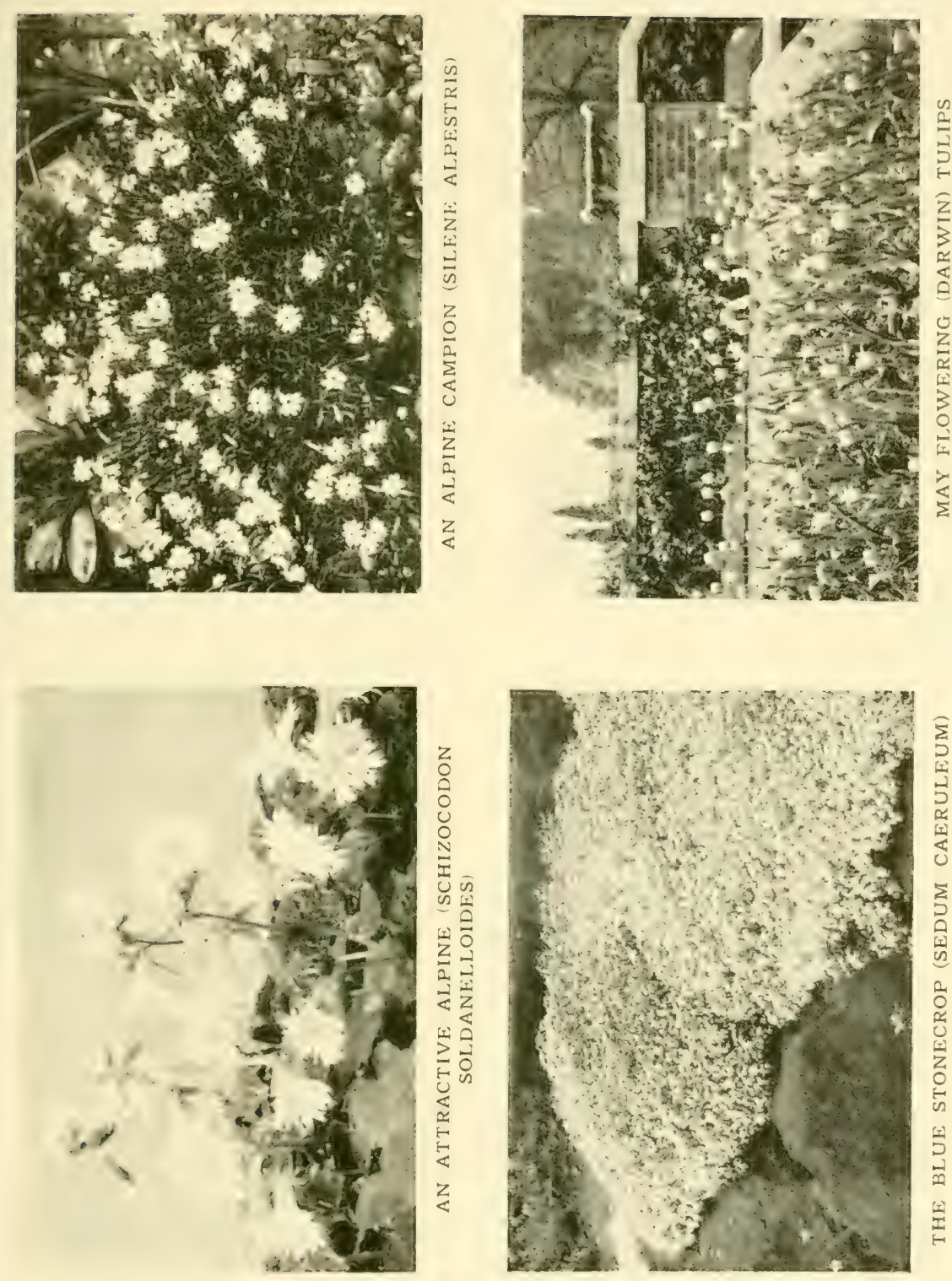

purple flowers on slender leafy stems, I2 inches high, from March to May; album is a pretty white variety. Sisyrinchium angustifolium (Blue-eyed Grass) has elegant grassy leaves and pale blue flowers in terminal clusters from May to July; it is 6 to 9 inches ligh and native of North America; there are two varieties, bellum, slatyblue, and Nuttallii, blue and white. Sisyrinchium Bermudianum (Bermuda Satin Flower), I2 inches or so high, has deep blue flowers from May to July. Sisyrinchium striatum, from the Argentine and Chili, is a taller-growing plant, 2 feet or more in height, with yellow flowers on leafy stems from May to July.

Skimmia.--Evergreen shrubs from China, Japan, and the Himalaya, belonging to the Rue family (Rutaceae). Three kinds are grown: Fortunei, from China; japonica, a native of Japan; and Laureola, from the Himalaya. There are, in addition, several wellmarked varieties. The flowers are white, fragrant, and showy, whilst in some instances they are succeeded by showy-red fruits which last throughout winter. All plants do not, however, produce fruits, for male and female flowers are borne by different plants. It is therefore necessary to place a male plant here and there amongst those of the other sort to insure fertilisation and consequently fruit; pollen is often conveyed to the female flowers by artificial means. As a rule, all three kinds are found between $I$ foot and 2 feet in height, the plants spreading into broad and dense specimens. Plant in good, well-drained loamy soil in which a little peat has been dug. Propagation is carried on by means of seeds or by layering the branches. Cuttings are sometimes used, but they are rather difficult to root. Special varieties are sometimes grafted upon stocks of their respective types; that called Foremanii is considered one of the best. Regular pruning is unnecessary.

\section{Slipperwort.-(See CALCEOLARIA.) \\ Sloe.-(See Prunus.)}

Smilax is an interesting group of climbing shrubs which have usually evergreen leaves and spiny branches; they belong to the Lily family (Liliaceae). Some are hardy, others tender, but they are not often grown in gardens. The cultivated kinds are found in Southern Europe, Asia Minor, North America, Mexico, the East Indies, Australia, and other countries. The roots have medicinal properties and furnish the Sarsaparilla of commerce. A popular trailing plant which is often grown indoors under the name of Smilax, is really a species of Asparagus, its correct name being Asparagus medeoloides. Most of the Smilax are of vigorous growth, and only give satisfactory results when allowed plenty of room. The hardy 
ones should be planted at the foot of a fence or bush over which they can ramble at will and become a luxuriant tangle. The best kinds for outdoors are aspera, from the Mediterranean region, and its vars. maculata and mauritanica, all of moderate growth; Boxa-nox, from the Southern United States; excelsa, laurifolia, and rotundifolia. Plant in good loamy soil in a fairly open position, increase by detaching sections from the rootstock in autumn, and confine pruning to keeping the plants within bounds.

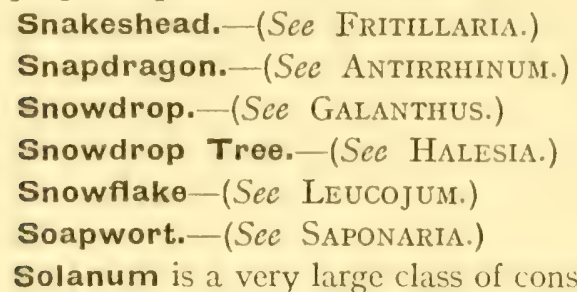

Order Solanaceae), for amongst its members it includes the common Potato, Solanum tuberosum. The various species are widely distributed throughout the world, and they show great diversity in growth. Some are climbers, others shrubs, many are herbaccous, and a large number weeds. Several kinds are very showy and popular garden plants with pretty flowers or fruits, and one or two of our best glasshouse climbers belong to this family. Some kinds are poisonous, and it is wise to avoid eating the fruits of all kinds which are not well-known and well-tricd plants. An instance of the poisonous character of the fruit is found in the common, wild, climbing Bitter Sweet (Solanum Dulcamara) of our hedgerows; its brilliant red oval berries are well known and generally admired, but the berries have proved fatal to children on several occasions. A few years ago a new fruit obtained considerable advertisement under the name of "Wonder Berry." That was found to be a form of another Solanum, which is a common weed with us, Solanum nigrum. The Egg plant (Solanum Melongena), which is grown for its fruits, is widely distributed througin the Tropics of the Old World, and is treated as an annual in gardens. Solanum capsicastrum is the well-known Winter Cherry, so-called by reason of its round Cherry-like fruits which last throughout winter. A native of Brazil, it forms a bush 3 or 4 fect high. As a rule, it is grown from cuttings each spring.

Solanum crispum, a native of Chili, is a very showy shrub, suitable for a wall about London or as a bush in the open in the southwest counties. In the Victoria I'ark, Bath, it thrives excellently in the open ground, growing freely to a height of 6 or 8 feet and flowering magnificently. The deep mauve or bluish flowers are over an inch 
across and borne in large heads. Solanum jasminoides is a very pretty climbing plant, which bears elegant bunches of white flowers throughout summer and early autumn. A native of Brazil, it is often grown as a wall plant in Devonshire, Cornwall, and Ireland; in other places it is worth training to a greenhouse rafter or wall. Solanum Wendlandii is easily one of the most beautiful of glasshouse climbers, while in one or two places in Cornwall it has met with a certain amount of success on a sunny wall in the open. It is a native of Costa Rica and is of vigorous growth, easily attaining a height of 20 feet, with large deeply-lobed leaves and fine heads, sometimes I2 inches or more across, of beautiful deep mauve flowers.

All the climbers may be pruned back fairly close to the old wood in winter or early spring.

Several annual kinds, such as Balbisii, may be grown for the sake of their ornamental fruits, and are sometimes used for summer bedding: They are raised from seed sown in warmth in February.

Soldanella (Blue Moon-wort).--Small and dainty alpine plants (Natural Order Primulaceae), forming dwarf tufts of rounded leaves some 3 or 4 inches high among which the nodding, bell-shaped flowers appear in April and May. They need a half-shady nook in the rock garden and a soil of sand, loam, peat, and leaf-mould. In winter place sheets of glass raised above the plants as a protection from excessive moisture, but do not cover them with a handlight. Increase is by division in September or February and early March. Sometimes one can save seeds of Soldanella alpina, which should be sown in a cold frame as soon as ripe. This has violet-coloured, prettily fringed flowers, and is a native of the Alps of Europe. Soldanella minima, blue, and its var. alba are European plants with solitary flowers. Soldanella montana, a native of Eastern Europe, has very pretty blue flowers; and pusilla, from the Alps, bears solitary, nodding violet blossoms.

Solidago (Golden Rod).-This is a group of mostly North American hardy perennials with yellow flowers (Natural Order Compositae). They thrive in ordinary garden soil in a sunny or partially shaded border or by the waterside, and may be naturalised in the open woodland or wild garden. Division of the clumps from November to March is the general method of propagation, though seeds are sometimes sown on a border outside in April or May. The flowering season extends from August to October. The most useful border plants are : Canadensis, 4 to 5 feet; Golden Wings, 5 feet; neglecta, 5 feet; Shortii, 5 feet; spectabilis, 3 to 4 feet, fragrant; and ulmifolia, 5 to 6 feet. Several dwarf sorts of our native Golden Rod (Solidago 
Virgaurea) are useful for planting in odd corners of the rock garden and in the hardy Fernery, notably alpestris, a Swiss kind, 6 to 9 inches ; cambrica, the Welsh Golden Rod, I2 inches; prostrata, from Norway, 9 inches; and Buckleyi, a North American sort, I2 inches high.

Sollya (Australian Blucbell Creeper). - Two species of this slender climbing Australian plant (Natural Order Pittosporaceae) are cultivated in gardens. Though perhaps better known as greenhouse twiners, those who have not seen the Sollyas growing out-of-doors would be surprised to find how well they thrive on a sheltered wall, particularly in the southern and western counties. Propagation is by cuttings inserted in a frame or under a bell-glass during July or August. The soil should be well drained and consist of sandy loam, peat, and leafmould. Support the slender twining shoots with twiggy pea-sticks instead of nailing them to the wall. The flowering season is summer and early autumn. Both kinds have nodding blue flowers: heterophylla is the stronger, parviflora (Drummondii) being smaller and more slender in growth.

Solomon's Seal.-(See Polygonatum.)

Sonchus (Sow Thistle).-Four kinds of Sonchus (Natural Order Compositae) grow wild in Britain: palustris, the Tall Marsh Sow Thistle; arvensis, the Milk Thistle; oleraceus, the Annual Sow Thistle; and asper, the Fringed Annual Sow Thistle. Only one is deserving of note here, and that is palustris, a stately plant for the wild garden and waterside, 6 feet high; it has prettily cut leaves and yellow blossoms in August and September. It is perennial, and may be increased by division, though seeds are usually sown in early summer where the plants are to flower.

Sophora.-There are several hardy or half-hardy kinds of Sophora, all showy trees or shrubs, belonging to the Pea family (Leguminosae). The two hardiest are : japonica, from China and Japan, and viciifolia, from China. The first-named forms a large tree, if planted in the open, often with a low trunk and large, wide-spreading head of branches, but when crowded by other trees the trunk elongates and the head is smaller. The pinnate leaves are dark green, and the creamcoloured flowers are borne in large panicles in September or earlier in sunny years. It forms a very good lawn tree in the South of England. Loamy soil suits it; increase is by seeds, and the pruning of young trees is directed towards maintaining equality of growth. Sophora viciifolia is a new shrub of considerable worth; it forms a dense bush at least 6 feet high of rather rigid, somewhat spiny growth, bearing elegant, small pinnate leaves and white flowers tinged with violet. The flowers appear with great freedom in May, and it is an 


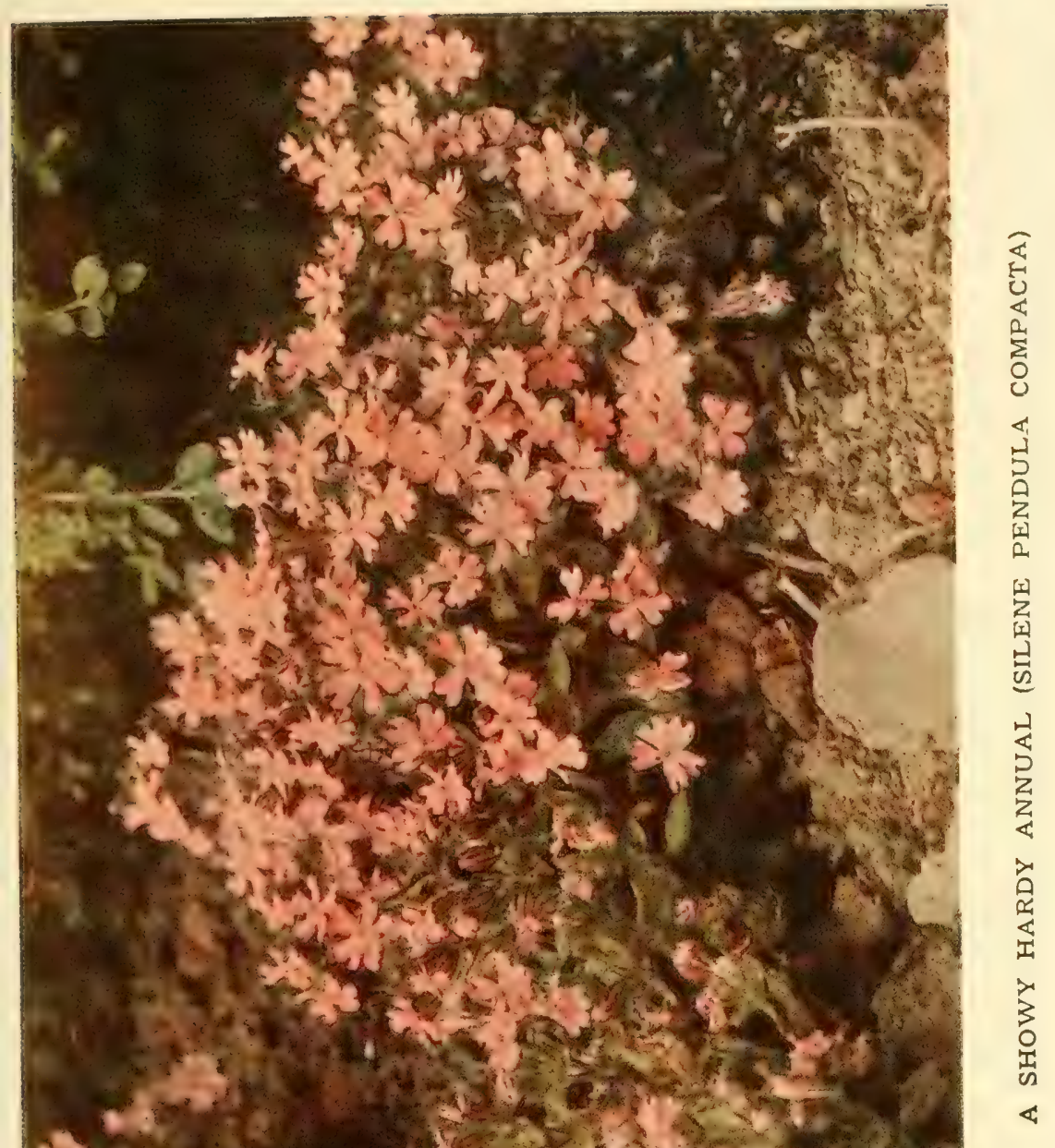



excellent lawn or shrubbery plant. Loamy soil with a little peat suits it, and propagation is by sceds or cuttings. As it transplants badly, it must be given a permanent position while quite small. Regular pruning is unnecessary. Sophora tetraptera is a New Zealand shrub or small tree, which is sometimes called Edwardsia. Although too tender for general outdoor planting, it gives excellent results against a wall, and sometimes in the open in Devonshire and Cornwall. The tiny pinnate leaves are pretty, but the large golden blossoms are the more attractive feature of the plant. They are at their best in May or June, according to season. Plant in ordinary garden soil. Regular pruning is not required.

Spanish Bluebell.-(See ScILLA.)

Spanish Broom.-(See Spartium.)

Spanish Chestnut.-(See Castanea.)

Spanish Iris.-(See IRIS XIPHIUM.)

Sparaxis.-These are showy and interesting bulbous plants (Natural Order Iridaceae) from South Africa. They should be grown on a sunny south border in a raised, well-drained bed of sandy loam, peat, and leaf-mould. Plant the bulbs in autumn or February, 2 to 3 inches deep, and 3 inches apart. Increase is by offsets, the bulbs multiplying fairly rapidly in favourable surroundings. They may be left for several years without lifting and replanting. During winter, if the ground is likely to become very wet, it is advisable to place a light over the bed. Sparaxis have narrow Iris-like leaves and slender flower spikes, I2 to I8 inches high, in May and June. As may be seen by the following list there is considerable variation in the colour of the flowers: alba, white, rosy-lilac outside of petals; Fire King, scarlet, black, and yellow; grandiflora, crimson and black, yellow eye; lutea, sulphur-yellow; Nain, deep yellow, outside of petals striped brown; tricolor, scarlet and black, yellow eye. The two species are Sparaxis grandiflora and tricolor, from which the other varieties named, and many more, have been raised in gardens.

Spartium junceum (Spanish Broom). - This is a decorative shrub, native of South-West Europe, and belonging to the Pea family (Leguminosae). It is known by its long, slender, Rush-like branches, which contain a large amount of pith. The small oval leaves are not produced very freely, and their functions are partly fulfilled by the bright green bark. The shrub is of rather loose growth when left to itself, and it is a good plan to prune the shoots of young plants frequently in order to encourage a bushy growth. Older plants may be pruned once a year, in spring, for the flowers appear on the current year's shoots; they are large and bright yellow, and borne over a 
considerable period during summer and early autumn, when flowering shrubs are particularly useful. As it grows well on dry, sunny banks, the Spanish Broom is doubly welcome in the garden, for it can be placed to advantage where many other plants would fail. Seeds are produced freely, and form the best means of increase. Young plants must be kept in pots until planted permanently, for they transplant badly. As it is not very long-lived, it is wise to raise young plants frequently. There is a variety flore pleno, with double flowers, but it is worthless in comparison with the type.

Specularia (Venus' Looking Glass).-The only kind commonly grown is Specularia Speculum (Campanula Speculum), a hardy annual growing wild in some parts of Southern Europe. It belongs to the Bellflower family (Campanulaceae). The plants grow about 9 inches high and bear purple bell-shaped blossoms with white throat in summer. Sow the seeds in autumn or in spring, from March to May, where the plants are to bloom. From several sowings made during these periods an extended season of flowering may be expected from June to September. The plants thrive in ordinary soil, on a sunny or partially shaded border.

Speedwell.--(See VERONICA.)

Spergula.-(See SAGINA.)

Spiraea. - The Spiraeas, which belong to the Rose family (Rosaceae), form an important group of flowering shrubs and herbaceous plants, several of which are of the greatest value for shrubberies and herbaceous borders. They are found in Europe, Asia, and North America, and one or more kinds are to be found in flower from March to September.

The shrubby kinds vary from dwarf bushes, which rise scarcely I2 inches above the ground, to handsome wide-spreading specimens I2 to I5 feet high. In some instances the blossoms are in small flat heads I inch or so across, and in others they are in large terminal panicles up to I8 inches long. All thrive in rich loamy soil, and are improved by an occasional surface dressing of well-rotted manure. They may in most cases be increased by cuttings of young shoots inserted in sandy soil in a closed frame in July. A few kinds, such as arguta and Thunbergii, are, however, rather difficult to increase in this way, but respond quite well if layered. For the purpose of pruning. shrubby Spiraeas are divided into two groups. Those that bloom in spring from short growths from the previous season's stems, such as Thunbergii, arguta, media, Van Houttei, canescens, etc., require no regular pruning, but may be cut hard back after flowering if they are outgrowing their positions. But another group, which 
blooms during summer requires vigorous pruning. This group is represented by such kinds as japonica, salicifolia, Menziesii, and Douglasii. They must be pruned in spring; all weak shoots being cut away, and the strong ones shortened to within I2 or I5 inches of the ground. As a rule, these kinds produce shoots from the ground line freely, and may be divided occasionally. Vigorous sorts such as Lindleyana and Aitchisoni may also have the younger shoots shortened back fairly hard in spring, for in their cases also the flowers terminate the current season's shoots. The spring-flowering Spiraeas may be used with advantage for forcing.

The following are the chief early-flowering kinds: arguta, 3 to 4 feet, one of the best of all April-flowering shrubs; bracteata, a vigorous June-flowering kind from Japan; canescens, a vigorous shrub with a profusion of bloom in May; confesta, a showy garden hybrid; decumbens, from Europe, a dwarf sort, suitable for the rock garden ; Henryi, a new, June-flowering species from China; media; Thunbergii, the earliest of all to bloom, and an elegant bush in summer by reason of its slender shoots and dainty foliage; and Van Houttei, a fine free-flowering bush, Io feet high. All bear white flowers.

Good late-flowering kinds are: Aitchisoni, a vigorous species from Afghanistan, growing quite I5 feet high and bearing very large, terminal inflorescences of white flowers in August ; Lindleyana is a very similar shrub, but the flowers are cream-coloured; arborea is another of the same set, characterised by pinnate leaves and large inflorescences; discolor, a large-growing decorative kind from North-West America, bears a profusion of cream-coloured flowers in July. All these are best increased by seeds. Spiraea japonica is a free-flowering kind from India, China, and Japan; its reddish flowers are borne in large flat heads; the varieties Bumalda, ruberrima, and Anthony Waterer, with red flowers, are handsome; alba has white flowers; and glabrescens is very vigorous. Spiraea Menziesii, from North-West America grows very strongly, and bears dense heads of red flowers: the variety triumphans is the best of all, but there are numerous other free-flowering forms. Spiraea salicifolia, with white flowers, is also worth growing.

Of herbaceous Spiraeas, the red-flowered palmata from Japan is a handsome kind, suitable for planting near water; Aruncus, with immense inflorescences of creamy-white flowers; Filipendula, and Ulmaria, the Common Meadow Sweet, are all useful kinds. Plant in rich soil and increase by division in early autumn. The plant often grown in greenhouses as Spiraea japonica, is correctly Astilbe japonica, the true Spiraea japonica being a shrub. 


\section{THE BOOK OF HARDY FLOWERS}

Spiranthes (Lady's Tresses).- This is a widely distributed group of terrestrial Orchids (Natural Order Orchidaceae). Three kinds grow wild in Britain, but are not confined to these islands. They are: aestivalis, flowers white, on spikes 15 to 18 inches high, in July and August; autumnalis, white, fragrant blooms on slender spikes, 6 to 9 inches high, in August and September; Romanzoviana, the largest of the three, which bears white flowers in August and September on a stem 6 to Io inches high. Propagation is by division of the rootstocks in spring, when new growth is about to start. Plant in an open position in fibrous loamy soil containing chalk and a little leaf-mould.

Sprekelia (Jacobean Lily). - The only species to mention is Sprekelia formosissima (Natural Order Amaryllidaceae). It is a half-hardy bulbous plant from Mexico flowering in June or July. The crimson flowers resemble an Amaryllis; in fact, the plant has been included by some botanists in that genus; the flower stems are 12 inches or more high. Select a warm, sunny position at the foot of a south wall, and make up a well-drained bed of loam, leaf-mould, sand, and a little well-decayed manure. Plant the bulbs in February or March, covering with 3 to 4 inches of soil. Increase is by division of the offsets at this time. Do not disturb the bulbs for some years unless required for propagation.

\section{Spruce Fir.-(See PICEA.) \\ Spurge.-(See Euphorbia.) \\ Squill.-(See ScIlla.)}

Stachys (Woundwort).-Hardy perennials (Natural Order Labiatac) having flowers something like those of the Dead Nettle, but more showy, while one in particular, Stachys lanata, is excellent for edging beds and borders. The plants thrive in ordinary soil in sun or partial shade, and are readily increased by division in autumn or spring, at which times replanting should also be done. Stachys lanata (Lamb's Tongue), from the Caucasus, has silvery-white woolly leaves, and forms an excellent permanent edging for a bed or border, as it is only 3 or 4 inches high. It has purple flowers in June and July, but these are not very showy. As a flowering plant the Mexican Stachys coccinea is the most showy; it grows I2 inches high, and has brilliant scarlet flowers from July to September; it must be grown on a warm, sunny border, and except in mild districts the roots should be lifted and kept in a frost-proof frame in winter. This difficulty is often overcome by sowing seeds in a heated greenhouse during February and treating it as an annual. Stachys (Betonica) grandiflora, from Asia Minor, is a showy plant with violet flower spikes 
I2 to IS inches high, from May to July; superba is a variety with rich purple-violet flowers.

Stachyurus.-A group of shrubs native of China and Japan and belonging to the Natural Order Ternstroemiaceae. Until within quite recent years one species only, Stachyurus praecox, was grown, and that was a very rare shrub; now several kinds are available, of which the chief are praecox and Chinense. They are all deciduous with often reddish-brown bark and ovate leaves 5 or 6 inches in length. The flowers are yellow, and borne in pendent racemes from axillary buds in April. The immature racemes may, however, be seen throughout winter, for they are formed at the end of the growing season and remain dormant until early spring. All the kinds require warm, well-drained loamy soil, in which a little peat or leaf-mould has been dug. They may be increased by cuttings in summer inserted in sandy soil in a close and warm frame, or by layers put down in spring: Regular pruning is unnecessary.

Staphylea.-Shrubby plants, belonging to the Natural Order Sapindaceae, several of which are handsome when in flower and of considerable value for the shrubbery and for forcing for greenhouse decoration in spring. Although few kinds can be grown in the open, they come from widely separated countries; thus one is from North America, one from Japan, one from the Caucasus, and one from Southern Europe. All have pinnate leaves, and the white flowers are followed by inflated bladder-like fruits, which contain the hard brown seeds. They must be planted in rich loamy soil in a sunny position, and propagation may be effected by means of layers or seeds. Except when the plants are outgrowing their positions, it is not necessary to prune them regularly, but those used for forcing are usually pruned to keep them dwarf and bushy. Such pruning is carried out after the flowers have fallen.

Staphylea Bumalda, from Japan, is a bush 3 or 4 feet high, with small white flowers; it is tender and not so useful as other kinds; colchica, a native of the Caucasus, is a vigorous bush up to I2 feet high, it bears handsome inflorescences of white flowers in May; pinnata, from Southern Europe, is known as the Bladder-nut, it forms a large bush with white flowers. A hybrid between pinnata and colchica, called Coulombieri, is of very vigorous growth, and bears handsome heads of white flowers; this and colchica are the best for forcing. Staphylea trifolia, the American Bladder-nut, is a large bush with few-flowered inflorescences and rounded fruits.

Star of Bethlehem.-(See ORNithogalum.)

Starwort.-(See ASTER.) 
Statice (Sea Lavender). - The Sea Lavenders include annuals, biennials, and perennials, and belong to the Natural Order Plumbaginaceae. They have elegant corymbs or panicles of flowers which, when cut and dried, are very useful for indoor decoration in winter. A sandy, well-drained loam is the most suitable soil, and they must have a sunny position, where they last in flower for a longer period than most plants. The perennials are best raised from seeds sown in a frame or on a border out-of-doors from April to June; sometimes also they are propagated by division in autumn or spring. Statice latifolia (the great Sea Lavender), 2 to $2 \frac{1}{2}$ feet high, is the best perennial for the border; it has light and graceful inflorescences of small lavender-blue flowers from June to September; it is native of Bulgaria and Southern Russia. The Caucasian Sea Lavender, Statice Gmelini, grows 18 inches high, and has dainty, purple-violet flowers from June to August. Statice incana, a native of Tauria and Siberia, I 2 inches, has pleasing reddish-pink flowers from July to September. Statice Limonium, though a native plant, may worthily occupy a place in the garden; there are bluish-purple and white varieties. The dense-spreading panicles are about I 8 inches high, and last in beauty from July to September. Some of the most useful flowers for cutting are provided by the florists' varieties, several of the best-notably Beauty, Lavender, and Lilac Queen - have been given distinctive names.

The annual Sea Lavenders are grown in enormous quantities and sold as "Everlasting Flowers" in shops, and by street hawkers. These are mostly coloured varieties of a European species, sinuata. The Algerian Sea Lavender, Statice Bonduelli, with yellow flowers, is also popular. The seedlings should be raised under glass during March or sown on a sunny border outside in April. The last to mention is Statice Suworowi, from Central Asia, which is best treated as a biennial, sowing the seeds in a cold frame during July, though it can be grown as an annual from seeds sown in a heated greenhouse in February. This is the most beautiful of all the Sea Lavenders, having feathery spikes of delicate rose-coloured flowers lasting from June to September or October, according to the time of flowering.

Stauntonia hexaphylla is an evergreen, climbing shrub belonging to the Barberry family (Berberidaceae). It is a native of Japan and China, and suitable for the southern counties, where it may be planted against a wall or trellis. The flowers are small, white, and appear during late spring or early summer. Plant in loamy soil ; increase by imported seeds, or by cuttings of half-ripe shoots inserted in sandy soil in a close and warm frame in summer. The surplus shoots should be cut well back after flowering. 
Stenanthium (Mountain Fleece).-Only one species is worth growing, Stenanthium robustum, from Carolina. It belongs to the Lily family (Liliaceae), and is a stately plant, from 4 to 6 feet in height, with feathery, white flower plumes during August and September. It is tuberous-rooted, and thrives in deeply dug and wellmanured garden soil, in not too sunny a spot. Liquid manure is beneficial in summer to assist in the development of the large plumelike inflorescences. Increase is by lifting and dividing the tuberous roots in spring, which is also the best time for planting.

Stephanandra is a group of shrubs belonging to the Rose family (Rosaceae). Two species only are grown; they are flexuosa, from China and Japan, and Tanakae, from Japan. Although closely allied to Spiraea, they do not possess such showy flowers, for although blossoms are borne freely the colour is dull. The growth of each plant, however, is to its advantage, for the branches have a graceful poise. In winter the bright brown bark is very attractive, and a group or two of plants in the front of the shrubbery is desirable. Plant in ordinary garden soil ; increase by means of summer cuttings placed in a close frame, and thin out a number of the older shoots each spring.

Sterculia.-An extensive class of trees and shrubs (Natural Order Sterculiaceae) found in Australia, India, Brazil, and other countries. Only one species is suitable for out-of-doors here, and that can only be grown in the warmer counties. It is Sterculia platanifolia, from China and Japan, and is chiefly noticeable by reason of its large and decorative leaves. It may be planted in a sunny position in the ordinary soil of Cornish gardens. Sterculia rupestris, from Australia, is a curious tree often called the Bottle Tree on account of its short swollen trunk, resembling a bottle in shape. The trunk is surmounted by a large, wide-spreading head. A few kinds, which are sometimes grown in greenhouses, are: acerifolia, caudata, diversifolia, lurida, and neocaledonica.

Sternbergia (Lily of the Field).- These are pretty bulbous plants (Natural Order Amaryllidaceae) with yellow Crocus-like flowers, for a warm, sunny border or southern slope of the rock garden. Make up a bed of light, sandy, gritty soil, and see that it is well drained. The bulbs are planted 4 or 5 inches apart and 3 inches deep in light sandy soil; those of the autumn-flowering kinds, in June or July, and those which flower in spring, in October. Increase is by offsets, the bulbs being lifted and divided at the times recommended for planting. The Sternbergias named below grow 6 to I2 inches high and have strap-like foliage : lutea (Winter Daffodil), from the Mediter- 
ranean region, flowers in September and October; the var. major (angustifolia) has rich golden-yellow flowers; minor is a dainty, small-flowered sort for the rock garden; macrantha, from Asia Minor, opens its canary-yellow flowers in October. For flowering in April, grow Fischeriana, a native of Asia Minor, with clear yellow flowers.

Stipa (Feather Grass).-A group of perennial grasses (Natural Order Gramineae), several of which are hardy and attractive for border decoration, as well as being useful to cut and dry for winter decoration. Increase is by division of the tufts in autumn or spring, and by seeds sown on a border outside in April or May. It is worth while lifting and dividing the clumps about every third year; rather light garden soil is suitable. The flowering season is from June to August. The most ornamental are: gigantea, 3 feet, a native of Spain; and pennata (pinnata), 2 feet, Europe.

Stock.-(See MatThiola.)

Stock, Virginian.-(See Malcolmia.)

Stokesia (Stokes' Aster).-Only one kind is grown, Stokesia cyanea (Natural Order Compositae), a hardy perennial, native of North America. It has lavender-blue Aster-like flowers from August to October, and grows from $I_{\frac{1}{2}}$ to 2 feet in height. There is a white variety alba and an early-flowering sort, praecox. Increase is by division in March or by seeds sown in a heated greenhouse during February, or a cold frame in May and June. Fairly light, rich soil and a sunny border meet the needs of this plant.

Stonecrop.-(See SEDUM.)

Stranvaesia, which belongs to the Rose family (Rosaceae), is a new group to most gardens, for the two species have only been in general cultivation a few years, although one has been known for a considerable period in scientific collections. They are glaucescens, from the Himalaya, and undulata, from China. Both are evergreen shrubs, bearing white flowers in May and red fruits towards the end of summer. They are better adapted for the south and southwest counties than for less-favoured localities, but are worth trying against walls where they do not succeed in the open ground. Any good garden soil is suitable for them, but that of a loamy character is most desirable. Seeds form the best means of increase, although branches may be layered. Regular pruning is not required, but a little is necessary now and then to keep the bushes in shape, and to keep those which are planted against walls in bounds.

Stratiotes (Water Soldier).- Though a British water-plant, the Water Soldier (Natural Order Hydrocharidaceae) is worth introducing to the sides of our lakes and ponds. The only species is Stratiotes 
aloiles, which has long sword-like leaves with spiny margins, and bears white flowers in summer. Increase is by division in spring, the pieces being planted in the mud at the bottom of shallow water during April. During the winter the plants are submerged; they rise to the surface for the flowering season and sink again in autumn: The roots must be kept within bounds, for though a most interesting and uncommon plant, it sometimes increases too rapidly.

\section{Strawberry Tree.-(See ARBUTUS.)}

Streptosolen (Jameson's Browallia).-Streptosolen Jamesonii, from Columbia, is a free-growing greenhouse plant (Natural Order Solanaceae), having brilliant orange-coloured flowers, and is used extensively in some gardens for summer bedding. As a climber of moderate height for clothing sunny fences and low walls in summer, this plant is strongly recommended. It thrives in ordinary potting soil, a mixture of loam, leaf-mould, and sand. Increase is by cuttings inserted in pots of sandy soil during July and August in a close propagating frame. Grow the plants in a cool greenhouse during winter, and plant out-ofdoors in early June. When space in the greenhouse permits, the old plants may be lifted in autumn and returned under glass for the winter.

Stuartia.-This group of hardy shrubs, which belongs to the Camellia family (Ternstroemiacea), is composed of a number of rare and showy kinds, which are worthy of more extended cultivation. Three species are grown, two from the Southern United States and one from Japan. All grow into large shrubs, if planted under favourable conditions, and blossom during July and August, a time when flowering shrubs are scarce. They are rather difficult to propagate by any means other than seeds, and should be kept in pots until it is possible to plant in permanent positions, for they dislike being disturbed at the root. Well-drained loamy soil, containing a little peat or leaf-mould, forms a suitable rooting medium, and it is wise to select a sunny position sheltered from cold north and east winds. Regular pruning is unnecessary. Stuartia pentagyna, from the Southern United States, grows from 5 to 8 feet high in this country; it bears ovate, deciduous leaves and large white flowers, 3 inches across, of which one or more petals are deep red on the outside. Stuartia Pseudo-camellia grows into a small tree in Japan; here it attains a height upwards of $I_{5}$ feet. Both its leaves and fowers are smaller than those of the American kinds; the flowers are white, about 2 inches across, and appear in July and August. Stuartia Malachodendron (sometimes called virginica), a native of the Southern United States, takes its name from the old generic term of Malachodendron. 
It grows more than 8 feet high, and bears white flowers upwards of 3 inches across, with clusters of purplish stamens.

Stylophorum (Greater Celandine).-There are two or three kinds known, but only one is grown in gardens, and that is Stylophorum diphyllum, native of North America. It belongs to the Poppy family (Papaveraceae), and has elegant pinnate leaves, and in summer and autumn produces a succession of deep yellow blossoms ; it is a hardy perennial, growing about 12 inches high, and thrives in ordinary soil in a sheltered position in the rock garden or on a partially shaded border. Increase is by division in March, or by seeds sown on a border out-of-doors in April or May.

Styrax.-Useful hardy shrubs or small trees (Natural Order Styraceae) with showy flowers during June and July. Of the known kinds some are natives of China and Japan and others of North America, Southern Europe, and Asia Minor. They are increased by seeds, and give the best results when planted permanently direct from pots. The most suitable soil is well-drained loam in which a little peat or leaf-mould has been dug. A sunny position sheltered from cold north and east winds should be chosen, and regular pruning is not desirable; simply shorten branches here and there which may be outgrowing others and spoiling the symmetry of the plant. Increase is best carried out by means of seeds. Styrax americanum, a native of North America, forms a dense bush several feet high, bearing small white flowers. Styrax japonicum is one of the most decorative kinds ; it is a native of Japan and China, and forms a small tree or large bush, with small ovate leaves and showy white flowers borne from axillary buds, on long pendent stalks, during June or July. Plants 20 feet high are to be found in this country. Styrax Obassia, from Japan, forms a small tree with large, handsome, broadly oval leaves and conspicuous inflorescences of white flowers; it is a very beautiful plant. Styrax officinale, a native of Southern Europe and Asia Minor, is known as the Storax, on account of its producing a fragrant gumresin known by that name; it forms a good-sized dense bush, and bears white flowers. One or two new species have been introduced from China of late, but they are too uncommon to be available for general cultivation.

Suaeda fruticosa is a bush widely distributed through the northern temperate regions, belonging to the Natural Order Chenopodiaceae. It grows about 3 feet high, branches freely, and is densely clothed with small greyish leaves. Although of no special garden interest, it is valuable as being one of a small number of shrubs which grow freely on land impregnated with salt, and in places where a saline atmo- 
sphere prevails. For this reason it is useful for planting on land in the vicinity of the sea, and is one of the plants that can be used for the clothing of sand dunes. Propagation is by seeds or cuttings, and pruning is limited to cutting back the ends of the branches in spring to encourage dense growth.

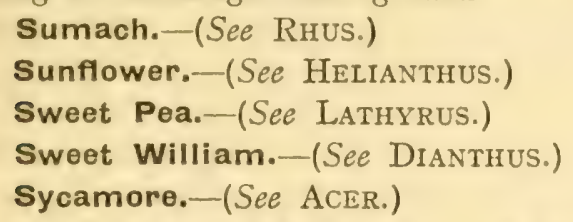

Sycopsis sinensis belongs to the Witch Hazel family (Hamamelidaceac), and is a comparatively new introduction from China. It forms a shrub several feet high, of rather loose growth, and bears ovate, evergreen leaves $I$ inch to 2 inches long. As a flowering shrub it has not yet given evidence of its worth, whilst there are other evergreens of more decorative appearance. Plant in well-drained loamy soil. Regular pruning is unnecessary.

Symphoricarpus racemosus (Snowberry). - This is the bestknown kind in its group, which belongs to the Honeysuckle family (Caprifoliaceae). It is native of North America, and well known as a bush 3 to 4 feet high, with oval, deciduous leaves, racemes of pinkish flowers in May, and white fruits which ripen in autumn. As it thrives well in sun or shade, it is an excellent shrub for undergrowth, and is often used for that purpose in woods. Propagation is lisually by division of the clumps, though seedling plants are often more vigorous and bear larger fruits. A plant of rather more graceful habit, with large quantities of fine fruits, has recently been grown under a variety of names, including Symphoricarpus mollis; it, however, appears to be but a well-marked form of racemosus. Symphoricarpus orbiculatus, from North America, is known as the Indian Currant or Coral-berry, by reason of its small reddish fruits; there is a variety variegatus with golden variegated leaves. Other kinds are: mollis, Heyeri, and occidentalis, all from North America. All grow well in ordinary garden soil, and give little trouble after they are once established. Pruning is not necessary except when the plants are becoming too large. Symphoricarpus racemosus stands cutting back well.

Symphyandra. - These are pretty plants, members of the Bellflower family (Campanulaceae), mostly treated as biennials, though sometimes under favourable conditions the roots are perennial. Sow the seeds from May to July, preferably in a cold frame. Plant in September or October and March in ordinary, well-drained soil in 
positions sheltered from the mid-day sun. They may be planted in the border or rock garden. Symphyandra Hofmanni has white bellshaped blossoms from June to August, the plants grow $I_{2}$ to 2 feet high, and are natives of Bosnia; pendula, from the Caucasus, grows I2 inches high, having pale yellow flowers in leafy racemes during July and August; and Wanneri is a rich, blue-flowered, rock garden plant, about 6 inches high, from Transylvania, flowering from June to August.

Symphytum (Comfrey).-These are hardy perennials of rather coarse growth, suitable for the shrubbery border, wild garden, woodland, or waterside; they belong to the Borage family (Boraginaceac). Propagation is by division in autumn or spring. In the matter of soil they are not particular. Symphytum asperrimum, from the Caucasus, is the Prickly Comfrey, it grows 3 to 5 feet high and has bluish-purple flowers in May; caucasicum, 2 to 3 feet, has handsome foliage, and azure-blue flowers in May. The Scarlet Comfrey, officinale bohemicum, is a variety of the British Comfrey, with brilliant red flowers in May and June, height 2 to 3 feet; tauricum, the White Comfrey, grows about 3 feet high, and has pretty creamy-white blossoms from April to June.

Synthyris.-Dwarf perennial plants (Natural Order Scrophulariaccae) from the Rocky Mountains, thriving in ordinary, welldrained soil in the rock garden. Increase is by division in autumn. Synthyris pinnatifida has rich purple flowers in attractive spikes, about 9 inches high, from June to August ; plantaginea alba is a freeflowering white sort; and reniformis has spikes of violet-blue flowers opening in June and July; it is about 9 inches high, and prefers rather a shady position.

Syringa (Lilac).-This is one of the most popular of all classes of shrubs, for it includes the Common Lilac, one of the finest flowering shrubs. Syringa belongs to the Natural Order Oleaceae, and consists of numerous species. Syringa vulgaris, the Common Lilac, is a native of Eastern Europe, from whence it was introduced about 1597; it is well known as a vigorous bush up to 20 feet high, or sometimes as a small tree with a distinct trunk, the large panicles of fragrant flowers appearing from terminal buds and from side buds near the points of the branches in May. It often forms many suckers from the base, and to this reason may frequently be traced the inferior flowering of certain bushes. Such suckers should be cut away, and weak shoots from the inside of the bushes must also be removed in order that the full vigour of the plants may be concentrated upon the perfection of the main shoots. Thorough ripening of the wood is 


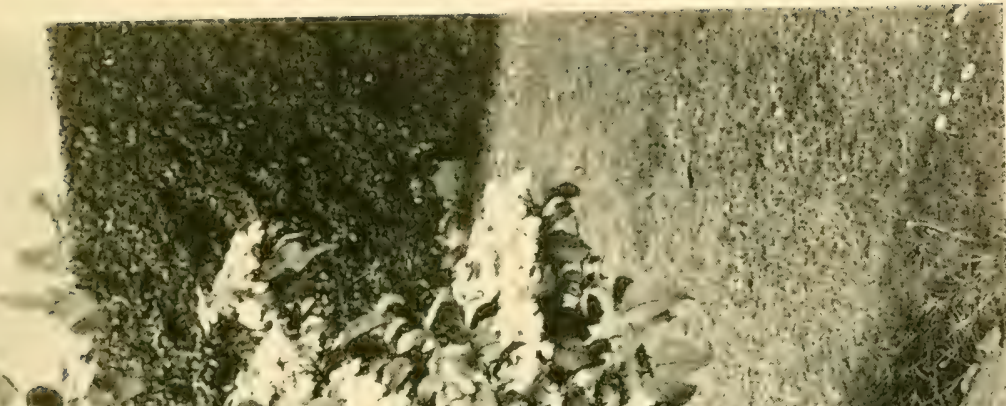

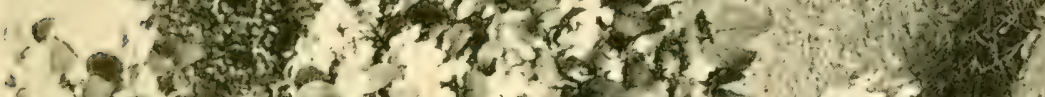
* 4 .

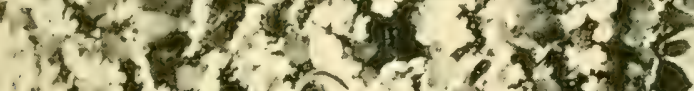

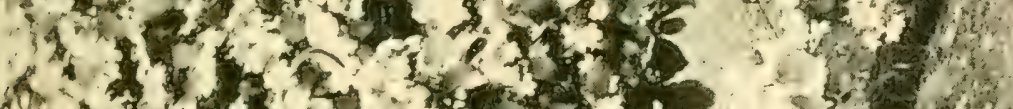

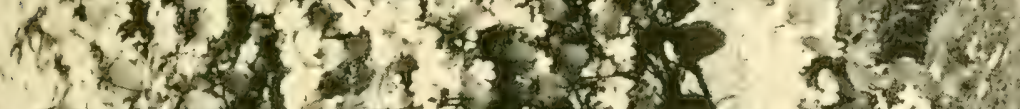

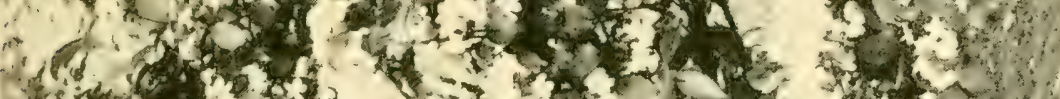

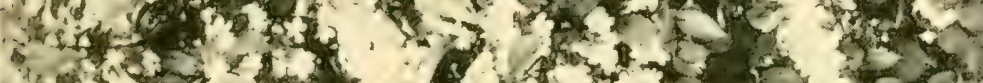

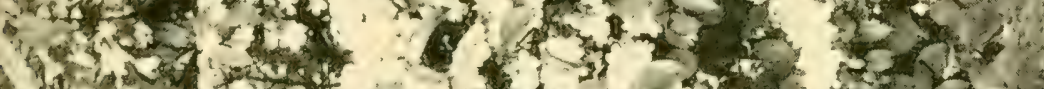

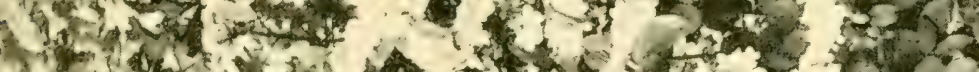

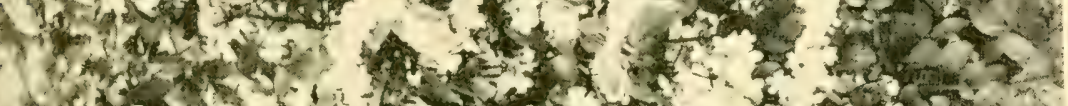

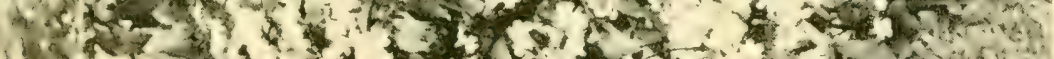

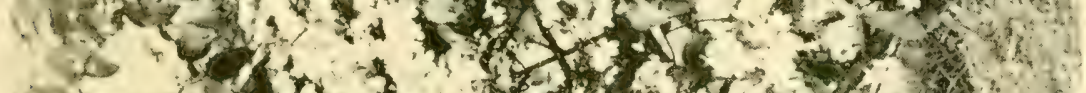
Nota

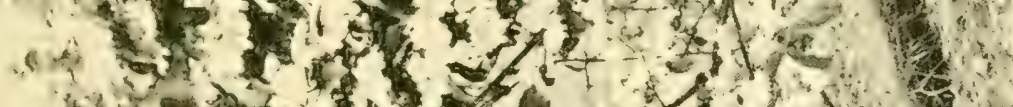

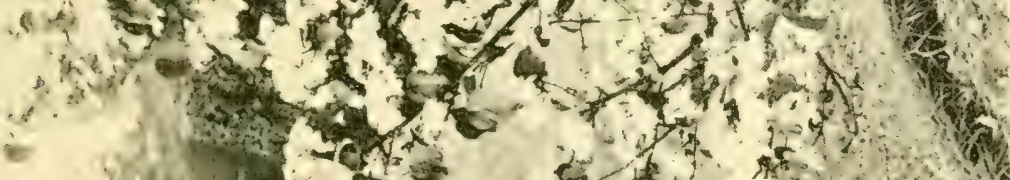

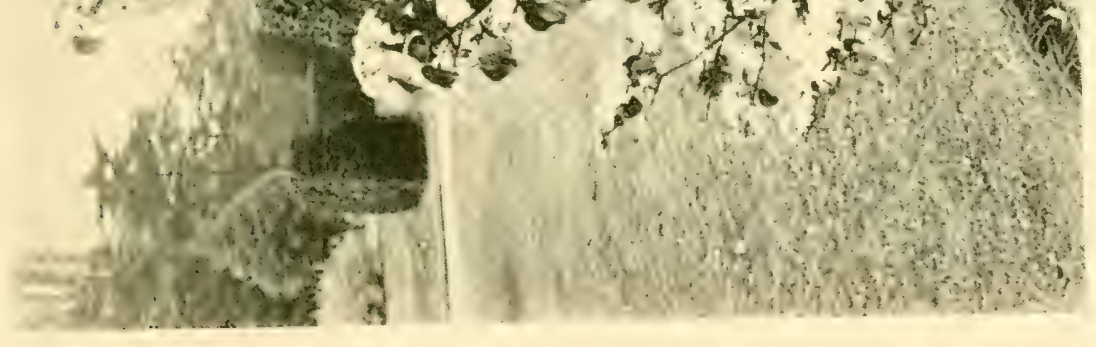



also essential to success, therefore light and air must have free access to all parts. Pruning must be conducted on two occasions during the year. Look over the plants when the young shoots are about 4 or 6 inches long, and remove any that are not required. Then, about July, look over them again and remove suckers (those from the base) and weak secondary shoots. The old flower-heads should also be cut off to prevent seed production; this is specially necessary in the case of the garden varieties. Lilacs require rich loamy soil, and they may be further assisted by surface dressings of well-decayed manure and two or three applications of cow manure water during the season of growth. Propagation of the garden varieties is by grafting upon seedling stocks or by layers. Those raised from layers are the best, for the others are apt to produce vigorous suckers which weaken the plant. Lilacs are often used for forcing, and for this purpose they are grown specially, all weak shoots being carefully removed. They may only be forced successfully every second or third year.

Of the many garden varieties, the following are worthy representatives. Singles.-Alba grandiflora, Marie Legraye, Noisettiana, white; Aline Marqueris, reddish-purple ; Charles X., rosy-purple; Géant des Batailles, dark red; Madame Kreuter, bright rose; Philemon, dark red; Souvenir de L. Spath, dark crimson.

Doubles.-Alphonse Lavallée, bright rose ; Charles Joly, dark red ; Dr. Masters, lilac; Madame Abel Chatenay and Madame Lemoine, white; Michael Buchner, lilac; President Carnot, lilac.

Syringa Chinensis, the Rouen Lilac, is considered to be a hybrid between vulgaris and persica; it forms a shapely bush, I2 feet or more high, with handsome inflorescences of lilac flowers. Syringa Emodi, from the Himalaya, grows 15 to 20 feet high, and bears heads of white, pink-flushed flowers in June; japonica, a native of Japan, bears large heads of cream-coloured, Privet-like flowers in June; Pekinensis is a small tree from Northern China, with cream-coloured blossoms in June. Syringa persica is a dwarf, very bushy kind, growing 3 to 4 feet high, native of Afghanistan, and often called the Persian Lilac; the lilac-coloured flowers are very fragrant, and the elegant inflorescences are borne in profusion. Syringa villosa, from Northern China, is remarkable for its very large inflorescences of rosy-red flowers. None of these species requires regular pruning.

Tagetes (Marigold).-The principal species of this group of the Daisy family (Natural Order Compositac) are erecta and patula, known respectively as African and French Marigolds. They are natives of Mexico, and their cultural requirements, are simple. They are raised from seeds sown under glass in February, the 
seedlings being planted out-of-doors in May. Other useful kinds are: Tagetes lucida (Mexican Marigold), 12 inches, yellow, summer, Mexico ; and signata, $x_{2}^{\frac{1}{2}}$ feet, yellow, summer, Mexico.

\section{Tamarisk.-(See TAMARIX.)}

Tamarix (Tamarisk).--Shrubby plants or small trees (Natural Order Tamaricaceae) which have a peculiar liking for sea air, and may be planted in places fully exposed to the sea. However, they succeed well in inland gardens, and are often grown for their decorative qualities. The branches, as a rule, have a graceful poise, and are clothed during summer with delicate, bright green, tiny leaves. Some of the commoner kinds, more particularly anglica and gallica, are used for hedges in seaside towns. They stand clipping well and may be used in exposed places; considerable use is made of Tamarix as a hedge plant in Southport about the shore gardens. All thrive well in poor soil, but appreciate that of a loamy character. Although regular pruning of all kinds is not absolutely necessary, those grown for flowering do better if cut back somewhat each year. Springflowering kinds should be cut back after flowering, and those which bloom on young wood are pruned in February. Propagation may be effected by cuttings of ripened shoots made 9 to 12 inches long and inserted deeply in an outdoor border during winter. As a rule, the whole cutting is buried except the upper 3 or 4 inches.

Tamarix anglica, the common Tamarisk of the sea shores of Western Europe, sometimes attains the dimensions of a small tree with a trunk I 2 or $I_{5}$ inches in diameter; its pinkish flowers are borne freely; gallica is a very similar plant. Tamarix Chinensis is a handsome kind from China and Japan; its branches assume a plumose habit, and its bright green leaves and pinkish flowers are very effective: Pentandra blossoms in July and August, the upper 2 feet of each shoot being a handsome inflorescence, 2 feet long; it should be planted in good soil, grown as a bush 3 to 4 feet high, and cut well back each spring; it is sometimes known as hispida aestivalis.

Tamarix tetrandra forms a large, wide-spreading bush, and bears a profusion of pinkish flowers in May; it is native of the Mediterranean region.

Tanakaea.-The only cultivated kind in this genus of the Rockfoil family (Saxifragaceae) is Tanakaea radicans. Of herbaceous habit, it is a low-growing plant of Japanese origin, suitable for a rather moist position, in sandy loam or peat, in the rock garden. Its white flowers are borne in summer in elegant inflorescences, and it is increased by seeds or by division during February or March. Seeds may also be sown in summer under glass as soon as ripe, and the tiny plants wintered 


\section{TAXODIUM DISTICHUM}

in a cold frame. Even in spring it is wise to sow the seeds in pots of light soil under glass.

Taxodium distichum (Deciduous Cypress).-A very useful Conifer (Natural Order Coniferae) for planting in moist ground in the vicinity of water. In a state of nature it occupies swampy land, which is often flooded, in the South-East United States. It there grows more than Ioo feet high, with a considerable bulk, the lower part of the trunk being often peculiarly swollen, whilst woody growths, 2 to 3 feet high, spring from the roots round about the trees. Specimens over roo feet high are found in several parts of the South of England, notably in the gardens at Syon House, Brentford, and Whitton Park, near Hounslow. Some of these trees have also developed the peculiar knees or root growths for which the species is famous. At Kew a tree may be seen which for many years has been growing entirely in water. When young, Taxodium distichum has a pyramidal outline, but the head becomes wide-spreading with age. During summer it is a conspicuous object by reason of the pleasant green foliage, whilst it is also attractive in autumn, for at that period the leaves turn brown previous to falling. Propagation is by imported seeds, and pruning is limited to keeping the leaders of young trees clear. In America the timber is of considerable importance for structural work.

Taxus baccata (Common Yew) is the best-known representative of this group of Conifers (Natural Order Coniferae). It is native of Europe, and one of the three chief evergreen trees of the British Isles. It has been famous for many centuries, for when bows and arrows were important instruments of war, Yew wood was selected for the manufacture of bows. The Yew lives to a very great age, and many old trees are known which range between 500 and $I, 000$ years of age. Nany of these old trees are growing in churchyards, whilst others are found in the grounds attached to old abbeys. In such places they have usually short but very stout trunks and widespreading heads of branches, but when drawn up by other trees the trunk clongates and is often less than $I_{2}^{1}$ feet in diameter. The wood is very hard and heavy, and takes on a very fine polish. As an evergreen, the Yew is of a rather gloomy appearance by reason of its dark sombre foliage, but it has numerous varieties with golden leaves. A pleasant feature of the Yew is seen in the showy, coral red fruits which ripen in August; these are only produced, however, by certain trees, for male and female flowers are not borne by the same tree. The branches and leaves, especially when partly withered, are poisonous, and numerous cases of cattle poisoning have been recorded through cattle eating cut branches. 
Taxus baccata stands clipping well, and is often used for hedges and for topiary work. Yew hedges exist for a very long period, but are hardly so attractive as those of Holly. The Yew thrives in any good garden soil providing it is not subject to flooding, and may be increased by seeds or cuttings. The latter method of increase is preferred for hedge plants as a certain amount of variation often exists amongst seedlings. The clipping of hedges or topiary specimens may be attended to any time during summer.

The most distinct form of the Yew is the Irish Yew, Taxus baccata fastigiata; this is of stiff, upright habit. There is a variety with golden leaves; and other good ones are fructu luteo, with golden fruits; adpressa, with small leaves and rather dense habit, it has a variegated form with pretty golden leaves; aurea and Barroni are both showy golden-leaved kinds; Dovastoni is of pendent habit; clegantissima is of graceful outline, with golden variegated leaves; horizontalis elegantissima is another pretty variegated kind; whilst imperialis and procumbens should also be grown. Taxus canadensis is the North American Yew; it differs little from the common kind. Taxus cuspidata is a native of the Mountains of Japan; it has rather larger and brighter leaves than baccata.

Tchihatchewia.-These interesting plants belong to the Wallflower family (Cruciferae). One species only is available for the outdoor garden, that being isatidea, a native of Asia Minor, where it was originally found at an elevation of between 5,000 and 6,000 feet about the source of the Euphrates. Of perennial duration, it forms a small plant of tufted habit with narrow leaves $I_{2}^{\frac{1}{2}}$ to 2 inches long, and in May produces a dense head of pinkish flowers in an inflorescence 6 to Io inches high. It can be increased by means of seeds sown in light loamy soil, as soon as ripe, in a cold frame, and the young plants should be kept under glass for the first winter, planting them out in well-drained loamy soil, in a sunny position, in the rock garden during April or May.

Teasel.-(See Dipsacus.)

Tecoma (Trumpet Flower).-Handsome climbing plants (Natural Order Bignoniaceae), some of which are evergreen and others deciduous. They are usually of vigorous habit with pinnate leaves and goodsized tubular flowers. Two species are grown out-of-doors, but the majority require the shelter of a greenhouse. They are found in the West Indies, South America, Australia, China, and Japan, and South Africa. Tecoma grandiflora, a native of China and Japan, is a very strong-growing plant suitable for a wall with a south or west aspect in the South of England, whilst it also does moderately well in some 
parts of the Midlands. It grows 15 or 20 feet high and bears tubular flowers, 3 inches long, of an orange-scarlet colour. Plant in good loamy soil and prune the side branches back in spring, for the inflorescences terminate the current year's wood in September. Sanguinea is a red-flowered variety. Tecoma radicans, the Trumpet-flower of North America, is another showy, hardy kind which blooms in September. Cuttings from young shoots may be rooted in spring under glass.

Tecophilaea (Chilian Crocus).- - These are beautiful bulbous plants of small stature (Natural Order Haemodoraceae), natives of Chili. They are not very hardy in this country except in the warmest parts, and the best results are obtained by planting them in warm and thoroughly drained, light loamy soil at the foot of a warm greenhouse wall. In the colder parts of the country it is wise to cover them with a handlight for the winter months. Propagation is usually by offsets from the old bulbs, though they may also be raised from seeds sown as soon as ripe in beds or boxes of light soil in a garden frame. Bulbs should be planted in October, on a shallow layer of sand about 3 inches below the surface of the soil. The chief kinds are: cyanocrocus, 6 inches, blue, spring (the var. Leichtlini is deeper blue than the type); and violaeflora, 6 inches, blue, spring. Now and then nice little clumps may be seen in the rock garden in the southern counties.

Tellima.-Hardy herbaceous plants, belonging to the Rockfoil family (Saxifragaceae). They are allied to Heuchera (Alum Root), but are less ornamental than the best of these. Two kinds are generally grown: grandiflora, of Heuchera-like growth, with a dense cluster of prettily veined leaves and flower spikes of small yellowish flowers which rise to a height of $I_{2}^{\frac{1}{2}}$ or 2 feet in April and May; and parviflora, an inferior plant, I2 inches or so high, which bears pinkish flowers in May. Both are natives of Western North America; they require rather moist, peaty soil, or a mixture of light loam and leafmould. Propagation is by division in February or March and by seeds sown under glass about the same time.

Teucrium (Germander).--This rather large group of the Sage family (Labiatae) is made up chiefly of neat-growing, hardy herbaceous plants with fragrant foliage, and some plants of shrubby or subshrubby growth. They are generally moderately hardy and succeed in ordinary garden soil, whilst propagation of the herbaceous sorts can be effected by division in February, and those of shrubby and subshrubby growth are increased by cuttings inserted in light soil under a handlight in summer. Several kinds are useful for small groups 
in the front of the herbaceous border; others may be planted upon old walls, and the dwarfer kinds in the rock garden. Some of the principal species are: canadense, 2 feet, herbaceous, purple flowers, August, North America; Chamaedrys (Germander), 9 inches, purple, summer, Europe, etc., suitable for walls, rocky ground, and ordinary borders (the var. foliis aureis has golden leaves); flavum, 2 feet, yellow, summer, Mediterranean region; this should only be planted in the southern counties. Teucrium fruticans is a loose-growing shrub, I2 feet high, with lilac flowers in summer and autumn, Southern Europe, suitable for walls and trellises in the Midlands and South; Marum (Cat's Thyme), a tiny shrub of dwarf, Thyme-like habit from South-West Europe, 6 to 9 inches high, with purple flowers in summer ; Polium (Poly Germander), 3 to 6 inches, is a shrub with yellow blooms in summer, it is native of the Mediterranean region, and should be grown in the rock garden; Scorodonia (Wood Sage), I2 inches high, with yellow flowers in summer, is native of Great Britain:

Thalictrum (Meadow Rue).-Hardy herbaceous plants with light and graceful foliage and inflorescences; they belong to the Buttercup family (Ranunculaceae). They are widely distributed, for some are found wild in Europe, others in the Himalaya, China, North America, and other countries. The more vigorous kinds should be grown as groups in the herbaceous border, or be arranged on a more ambitious scale in the wild garden. Those of dwarfer growth may be given a place in the rock garden in a moderately moist position. The foliage of several kinds is useful for cutting for decorative purposes. They thrive in ordinary, good garden soil, and are increased by division of the clumps in February. Seeds may also be sown under glass at the same time, or as soon as they are ripe towards the end of summer. The following is a selection of the many kinds in cultivation: anemonoides, 3 feet, yellow, April, North America; angustifolium, 3 feet, yellow, June, Europe; aquilegifolium, 3 feet, purple, June, Europe (the var. atropurpureum has dark purple flowers); Chelidonii, 2 to $2 \frac{1}{2}$ feet, purple, June, Himalaya; Delavayi, 2 to 3 feet, purple, June, China; flavum, 3 to 4 feet, yellow, June, Europe ; minus, I2 inches, yellow, June, Europe-this has very pretty foliage, and there are numerous varieties, all of which are of peculiarly graceful habit : adiantifolium, affine, concinnum, flexuosum, and purpurescens are all attractive.

Thermopsis.-Hardy herbaccous plants belonging to the l'ea family (Leguminosae). The majority of the cultivated kinds are natives of North America, though one, Thermopsis barbata, a very beautiful plant, growing 12 inches high and bearing purple flowers 
in June, is a native of the Himalaya. Useful North American sorts are: caroliniana, 2 feet high, with yellow flowers during June and July; lanceolata, also a yellow-flowered plant, which grows I 2 inches high and bears yellow blossoms in June; montana, 2 feet, yellow, June; and rhombifolia, $x_{\frac{1}{2}}$ to 2 feet, yellow, June. In all cases the flowers are large and Lupin-like in appearance. Good loamy soil, which has been well manured, is suitable, and propagation is best effected by means of seeds sown under glass in February. As they do not care for root disturbance, it is better to dig round them rather than lift them when renovating the herbaceous border, which is the correct place for these plants. For the same reason it is not wise to try to increase the stock by division of the clumps.

Thladiantha. - The only species of Thladiantha, which belongs to the Cucumber family (Cucurbitaceae), available for growing outof-doors is dubia. A native of China, it is a half-hardy climber of annual duration, bearing yellow flowers, succeeded by ornamental red fruits which ripen in autumn. Seeds should be sown in pots in a warm greenhouse during March, and the young plants grown in good soil to plant out in rich, well-manured loamy ground during late May or early June. When once established growth is very rapid, and a fence, trellis, or group of tree branches may soon be clothed with luxuriant growth.

Thorn.-(See CrataEgus.)

Thrift.-(See ARMERIA.)

Thuya (Arbor-Vitac). - This is a group of Conifers (Natural Order Coniferae) composed of several important evergreen trees natives of China, Japan, and North America. They are closely allied to the Cupressus, from which they may be distinguished by their longer cones. Some of them are important timber trees in their native countries, and although usually grown for decorative purposes here, one kind is sometimes planted under forest conditions. In some cases the species are inclined to vary, and a number of varieties have been given names. These are usually increased by grafting upon stocks of their respective types. In other cases increase is by seeds. The Thuyas give the most satisfactory results when planted in moist, but weil-drained soil, and are most at home in places where the climate is pure and the atmosphere moist. In addition to being planted as decorative trees, some are occasionally used for hedges. They are not, however, so useful as many other shrubs for this purpose.

Thuya dolabrata, a native of Japan, is sometimes sold as Thuyopsis dolabrata. In its native country it grows into a large tree; here it forms a small pyramidal specimen clothed with ornamental green 
branches to the ground line; the variety variegata is dotted over with patches of silver; it is no improvement on the type. Japonica is a Japanese tree of medium height, less beautiful, however, than the previous kind; orientalis, the Chinese Arbor-Vitae, forms a dense pyramidal bush 20 feet or more high, with the secondary branchlets standing at right angles to the trunk; it has numerous varieties, of which aurea, with golden foliage, compacta, and densa, of dwarf habit, and glauca, with glaucous foliage, are very distinct.

Thuya occidentalis is a very variable species from North-East America; it is often called the American Arbor-Vitae, and is a tree of moderate growth. The varieties aurea and Ellwangeriana aurea have golden foliage, while there are many other varieties which differ in growth and colour of foliage from the type. Thuya plicata, often called gigantea and Lobbi, is a native of North-West America, where it forms a tree of the largest size and is known as the Red or Canoe Cedar; its wood is very valuable in its native country, and the tree is planted under forest conditions here. As an ornamental tree it sometimes exceeds Ioo feet in height. The leaves of this and Thuya occidentalis have a turpentine odour when rubbed.

Thyme.-(See Thymus.)

Thymus (Thyme).-Dwarf, fragrant-leaved shrubs or sub-shrubs are found in this group of the Sage family (Labiatae). The principal kinds are natives of Europe, one or two being included in the British Flora. The ordinary Thyme is grown in every kitchen garden, and its leaves and young shoots form one of the most poular flavouring herbs for culinary purposes. But the Thymes have other uses, for as flowering plants they have much to commend them while they are also planted for the fragrance of their leaves. They succeed in almost any garden soil, are well adapted for planting on stony ground, give good results in the rock garden, and are useful for planting in the crevices of walls. They are sometimes used with good results between the stones of paved paths, and form a distinct feature when planted in informal paths in the rockery or wild garden, providing the paths are not subjected to heavy traffic. Propagation may be by cuttings placed under a handlight in summer or by layering the shoots in fine soil, in spring or summer. A few stones are often used to keep the shoots down. The following are all desirable kinds: azoricus, 3 inches, purple, summer, native of the Azores, forms an attractive mass in the rock garden; Chamaedrys, 3 inches, purple, summer, Europe, including the British Isles, a very useful kind for the rock garden, paths, walls, etc.; var. montanus is a very dwarf kind from mountainous regions. Thymus Serpyllum (IVild Thyme), 
I to 3 inches, purple, summer, native of Europe, including the British Isles, may be used for all kinds of sunny places, and is very attractive when in flower; its variety citriodorus is the Lemon Thyme; another, with golden variegated leaves, is very pretty, whilst the variety lanuginosus is remarkable for its woolly leaves and shoots. Thymus villosus, 3 to 6 inches, purple, summer, is a native of Portugal, and should be given a place on the rockery; vulgaris is the Common Garden Thyme which is in such demand by housewives; Zygis, I to 2 inches, purple, summer, native of Spain, is a very dwarf kind, suitable for the rock garden.

Tiarella (Foan Flower). -The best known Tiarella, which belongs to the Rockfoil family (Saxifragaceae), is cordifolia, a native of North America. It is a hardy herbaceous perennial, growing about I2 inches high, and is renowned for the elegance of its branched inflorescences of white flowers, which are at their best during April. It is suitable for the herbaceous border or rock garden, where it should be given a moist position in light soil enriched by the addition of leaf-mould.

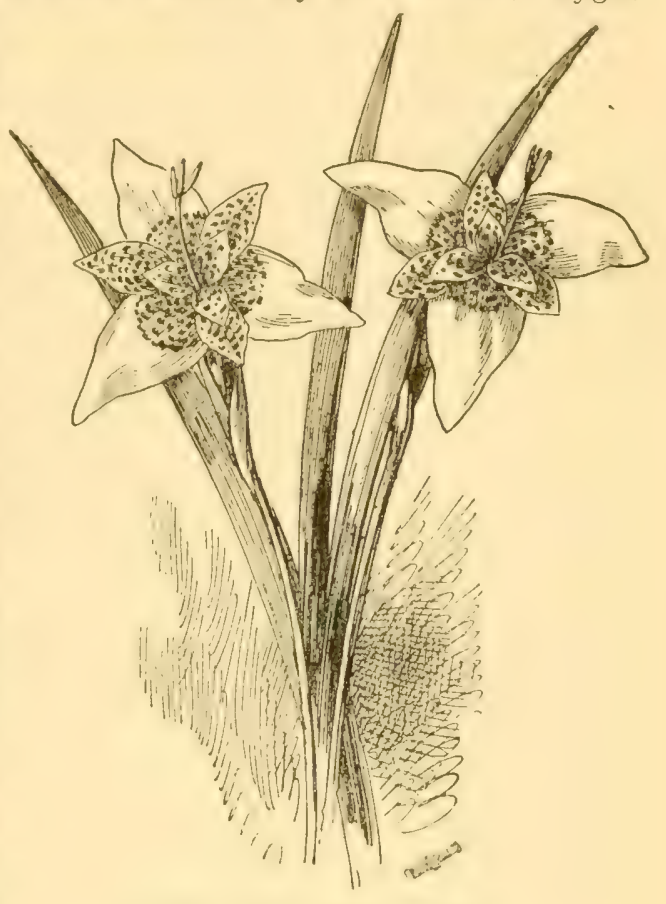

THE TIGER IRIS (Tigridia) Propagation is by seeds sown in a pan of light soil in a cold frame in spring, or by division of the clumps in February. Tiarella unifoliata is also available; a native of Western North America, it bears its light-coloured flowers in April. Similar conditions are required to those recommended above.

Tigridia (Tiger Iris).-Very beautiful bulbous plants are included in this group of the Iris family (Iridaceae). Tigridia Pavonia, the Peacock Tiger Iris, a native of Mexico, is the best-known species. Its flowers are amongst the most gorgeous of all garden flowers; they are roughly triangular in outline, often 5 inches across, and scarlet, spotted with crimson, or in the various varieties, yellow, 


\subsection{THE BOOK OF HARDY FLOWERS}

orange, or white, spotted with red. Unfortunately, the individual flowers are very fugitive, lasting but a short time at their best, but a succession of blossoms is kept up for several weeks during July and August. It grows from $I_{2} \frac{1}{2}$ to 2 feet high, and gives good results when planted in well-drained, but rich loamy soil in a position shaded from the fiercest midday sun. It is usual to plant the bulbs during March or April on a layer of sand 3 or 4 inches below the surface of the soil. In some places they are left in the ground for several years, but are usually lifted in the same way as Gladiolus and stored in a frost-proof but cool room for the winter. Offsets are produced frecly, and they usually suffice for increase of stock, but seeds may also be sown as soon as ripe in a bed of sandy soil in a cold frame. Tigridia Pringlei, $I_{2}^{\frac{1}{2}}$ feet, scarlet, orange, or cream, summer, Mexico; and violacea, I2 to I8 inches, rosy-purple and white, early summer, Mexico, are other kinds which thrive under similar conditions to Pavonia. Several named varieties of Pavonia are offered by bulb merchants.

Tilia (Lime).- The Limes (which belong to the Natural Order Tiliaceae) are found in Europe, North and Central Asia, and North America. They are known under the popular names of Lime or Linden, and the white soft wood is often called Bass Wood. Although the wood is not of great value it is popular for various kinds of work, such as carving, the sounding boards of musical instruments, keys of pianos, etc. The Limes thrive in light, dry soil, although the best results are secured by using soil of better quality. Propagation of some kinds is by sceds, and of others by layers of year-old shoots produced from coppiced plants. Pruning is necessary to keep the leading shoots free from rivals, and to check the undue development of side branches.

Tilia americana, the American Bass Wood, is distinct by reason of its very large leaves; it is sometimes grafted on a European kind, but is not a great success except when on its own roots; argentea is the White Lime of Europe, and is distinguished by the grey or silvery undersurface of its leaves. Tilia dasystyla (euchlora), from the Caucasus, is one of the best of all Limes; its leaves are bold, dark green, and glossy, and they keep their colour until late in the year, a trait not possessed by all the Limes; the flowers have the familiar Lime fragrance. It is an excellent kind for avenues or for isolated specimens. Henryana and Miqueliana are new Chinese species, which promise to form ornamental trees; mandshurica is not recommended, for it commences to grow very early, and often falls a prey to late frosts.

Tilia petiolaris is one of the best of the European Limes. It forms 
a handsome tree, and retains its leaves well, the powerfully fragrant blossoms have a stupefying effect upon insects; platyphyllos is one of the Common Limes; it (together with vulgaris) has a serious failing as an ornamental tree, for the leaves commence to turn yellow very early, often in August, and litter the ground for a considerable time. Moreover, the leaves often become very dirty during summer. There are numerous varieties of Tilia platyphyllos, of which asplenifolia and filicifolia nova have curiously lobed leaves.

\section{Toadflax.-(See LiNARIA.)}

Tobacco.-(See Nicotiana.)

Tofieldia (False Asphodel).-Marsh-loving herbaceous plants are included in this group of the Lily family (Liliaceae). A few kinds are sometimes grown in gardens, but they are usually confined to botanical collections, although they might well be planted more extensively than at present in bog gardens, especially where the soil is of a peaty character. Propagation is by division of the clumps in February. Tofieldia calyculata, 4 to 6 inches, greenish-white, summer, Europe; glutinosa, 6 inches, whitish, North America; and palustris, 3 to 6 inches, pale green, summer, north temperate and arctic regions, also a native of the British Isles, are the available kinds.

Tolmiaea.-The only kind is Tolmiaea Menziesii ; it is a member of the Rockfoil family (Saxifragaceae). A native of North-West America, it is allied to, and somewhat resembles in the leaves, the Heuchera, although at maturity a distinct difference may be noted, for the Tolmiaea produces tiny plants from dormant buds at the junction of the blade and stalk of each leaf. These tiny plants can be pegged down into sandy soil and be used for increase of stocks The greenish flowers are borne in inflorescences as in Heuchera, but they are not very attractive, and the plant is grown more on account of its peculiar leafage than for any beauty it may possess. It thrives in ordinary garden soil.

Topiary Work.-This term is applied to the clipping of various kinds of small-leaved evergreen trees or shrubs into fantastic shapes: It was very popular between the sixteenth and early part of the nineteenth centuries, and specimens a couple of hundred years old are still to be seen in some gardens. Fortunately, a more natural style of gardening came into vogue during the early part of last century, and topiary work died out except in a few old gardens. There has, however, been a disposition to revive it of late, which is a great pity, for this hard clipping of plants into all kinds of abnormal shapes, which bear a more or less grotesque likeness to certain birds and beasts, pillars, tables, chairs, etc., is condemned by all true lovers of 
Nature. The shrubs usually selected as victims are the various varieties of the Common Yew and the Common Box. It is necessary merely to select healthy, bushy plants, and clip them hard back several times a year into the desired shape, training young growths into the various directions where extra development is required. The old Yew trees at Hampton Court and the large one in Harlington Churchyard, Middlesex, were at one period clipped into formal shapes, but they have been allowed to grow freely for a century or more.

\section{Torch Lily.-(See Kniphofia.)}

Torreya.-This is a small group of Conifers (Natural Order Coniferae) made up of evergreen shrubs or small trees suitable for planting in the warmer parts of the country. Three species are known, californica, commonly called the Californian Nutmeg by reason of its nut-like fruits; nucifera, from Japan, the seeds of which are eaten in that country; and taxifolia, from Florida, which is there called the Stinking Cedar. All bear a resemblance to the different kinds of Cephalotoxus, and their fruits are similar in shape. The leaves are from I inch to 3 inches long, dark green, and borne freely enough to make the bushes of decorative value. Increase is by seeds. Welldrained loamy soil suits, and pruning is limited to shaping the bushes. In the warmer parts of the country they grow into handsome specimens, and deserve extended planting in place of the Common Yew, for their leaves are of a less sombre character.

Trachelospermum.-Two of these plants, which belong to the Periwinkle family (Apocynaceae), can be grown on a wall or trellis in the warmer parts of the British Isles. Both are climbers with evergreen leaves and fragrant flowers, the flowering time being summer. They require light and well-drained loamy soil to which the addition of a little leaf-mould at planting time is an advantage. Either a west, east, or south exposure is suitable, and propagation is by cuttings of half-ripe shoots, 3 or 4 inches long, inserted in light soil in a closed frame in July or August. The species are crocostomum, I2 to I5 feet high, flowers yellowish-white in heads nearly 3 inches long; and jasminoides, I2 feet high, flowers white, in rather smaller heads. This is sometimes called Rhyncospermum jasminoides. Both are natives of China. The only pruning required is a little trimming into shape during early spring.

Trachycarpus (Chusan Palm). - Trachycarpus excelsus is a fairly hardy Palm (Natural Order Palmae), a native of Japan, and sometimes called Chamaerops excelsa or Fortunei. In the neighbourhood of London it has been known to withstand 30 degrees of frost; although the leaves were injured, the plants grew quite well 
the following spring. It is, however, in the more southerly and westerly counties that it gives the best results; there it may be seen as a vigorous tree $I_{5}$ or 20 feet high, with a stout trunk and fine head of large fan-shaped leaves. The yellow flowers, though small individually, in combination form very attractive and large inflorescences, and in some gardens quantities of the small, hard, pea-shaped seeds are matured each year. When they fall on suitable ground they usually germinate freely and form a good means of propagation; seeds may, however, be collected and sown under glass if desired. In either case young plants should be placed in permanent positions as early as possible. Deep and rich loamy soil is required, and an occasional top-dressing of well-rotted cow manure is attended by good results. Dead leaves must be removed each spring, but the fibre on the trunk should not be taken off.

Tradescantia (Spider-wort). - Several hardy herbaceous plants are included in Tradescantia (Natural Order Commelinaceae). The best-known kind is virginiana, a native of North America, and known under the names of Virginian Spider-wort and Flower of a Day, the last name denoting the fugitive character of the flowers. This and other kinds thrive in any good garden soil, that of a light loamy character being most satisfactory, and are easily increased by division of the clumps in February or March. They should be planted as groups in the herbaceous border, as large masses in the wild garden, or for any other purpose where vigorous plants of compact habit, with a long flowering period, are required. Tradescantia virginiana grows from $I_{2}^{\frac{1}{2}}$ to $2 \frac{1}{2}$ feet high, and bears purple flowers in succession throughout the greater part of the summer. Individual blooms last in full beauty for a very short time, usually about one day. There are several varieties; alba has white flowers, and grandiflora bears larger and showier flowers than the type. Other species are: congesta, 2 feet, summer, North America; Crassula, I8 inches, white, Brazil.

Tragopogon (Goat's Beard).--The various plants found in this group of the Daisy family (Compositae) may be of biennial or perennial origin. They are not very showy, and are more suitable for the wild garden than for the herbaceous border. They may be expected to thrive in any ordinary garden soil, and are increased by seeds sown out-of-doors as soon as ripe, or kept in a cool room and sown out-ofdoors or in a frame in March. The kinds usually seen are natives of Europe, two-porrifolius (Salsafy) and pratensis (Goat's Beard) being included in the British Flora. Tragopogon major, 5 feet high, with yellow blooms in May, is perennial, Europe; pratensis, I2 to 
24 inches, bearing yellow flowers in June, is biennial ; and porrifolius, 3 feet, with rose or purple flowers in May, is also biennial. Tragopogon porrifolius is the Salsafy of the vegetable garden; it is grown for the sake of its long, thick, carrot-like roots. Seeds are sown ir deep, rich soil in April or May, in rows 12 to 15 inches apart, and the young plants are allowed to stand about 8 inches apart in the rows. The roots are lifted in autumn and stored for winter use.

Traveller's Joy.-(See Clematis Vitalba.)

Tree Mallow.-(See Lavatera.)

Tree of Heaven.-(See Ailanthus.)

Tricyrtis (Toad Lily).-Perennial herbaceous plants with slender stems and curiously spotted flowers are included in this genus of the Lily family (Liliaceae). The various kinds are natives of the Himalaya, China, and Japan, and although fairly hardy are rarely seen at their best on account of the flowers opening late in autumn and being subject to injury by inclement weather. They should be given a sheltered position in light loam or peat, and may be increased by seeds sown under glass during spring or by division of the clumps in February. A position in a border at the foot of a warm greenhouse wall sometimes hastens the expansion of the flowers. Tricyrtis hirta, 2 to 3 feet, white on pinkish ground colour with purple spots, October, Japan; macropoda, 2 to 3 feet, greenish-yellow with purple spots, October, China and Japan; pilosa, I2 to 24 inches, white or pink with purple spots, October, Himalaya, are the best-known kinds.

Trillium (Three-leaved Nightshade, Wood Lily).-A number of very interesting and beautiful herbaceous perennials are included in Trillium, which belongs to the Lily family (Liliaceae). They give the most satisfactory results when planted in moist, leafy, or peaty soil in a semi-shaded position, where they can be associated with advantage with Ferns, Windflowers, and Christmas Roses. All are natives of North America, and they are quite hardy. Increase is usually by division of the clumps in February or early March, though seeds can also be sown in boxes of peaty soil in a cold frame in February. Trillium grandiflorum, the Wake Robin, is the most important species; it grows upwards of I2 inches high, produces ornamental, three-parted leaves, and large elegant white flowers in May. Other kinds are: cernuum, I2 to I8 inches, white, April; crectum, I foot, purple, April ; crythrocarpum (Painted Wood Lily), 6 inches, red and white, May; nivale, I2 inches, white, May and June; ovatum, 6 inches, red, April ; and sessile, 6 to 9 inches, red, March and April.

Triteleia.-Hardy or half-hardy bulbous plants are found in this group of the Lily family (Liliacea). They are usually included with 
Brodiaea, and botanists regard Triteleia as a synonym of the former. Those still sometimes known as Triteleia are : aurea, 4 inches, yellow, April, North America; laxa, I2 to 15 inches, blue, July, California ; and uniflora (Spring Star Flower), 3 to 6 inches, white, spring, Buenos Ayres. They must be planted in well-drained, light loamy soil, 3 or 4 inches beneath the surface during autumn. Increase is by offsets from the bulbs.

Tritoma.-(See KNIPHOFIA.)

Tritonia.-Showy bulbous plants belonging to the Iris family (Iridaceae). They are often called by the synonymous name of Montbretia, and cultural requirements and descriptions of species are given under that heading in this work.

Trochodendron aralioides.-This tree belongs to the Natural Order Trochodendraceae, which includes several small but interesting groups of hardy trees and shrubs, such as Cercidiphyllum, Eucommia, and Tetracentron. Trochodendron aralioides is a native of Japan, where it forms an ornamental evergreen tree, the bark being used in the preparation of birdlime. It has been in cultivation in the British Isles for many years, but has never become common, although it is of interest by its glossy evergreen leaves and large clusters of yellowish flowers. It is better adapted for the southern than the northern parts of the country, and thrives in the open garden in warm, welldrained loamy soil into which a little peat has been dug, but it must have a position sheltered from cold north and east winds. Propagation is difficult by any other method than by seeds, which must be imported from Japan. Layers may, however, be tried. No systematic pruning is required.

Trollius (Globe Flower). -Very attractive and desirable border flowers are found in Trollius, which belongs to the Buttercup family (Ranunculaceae). They exhibit some

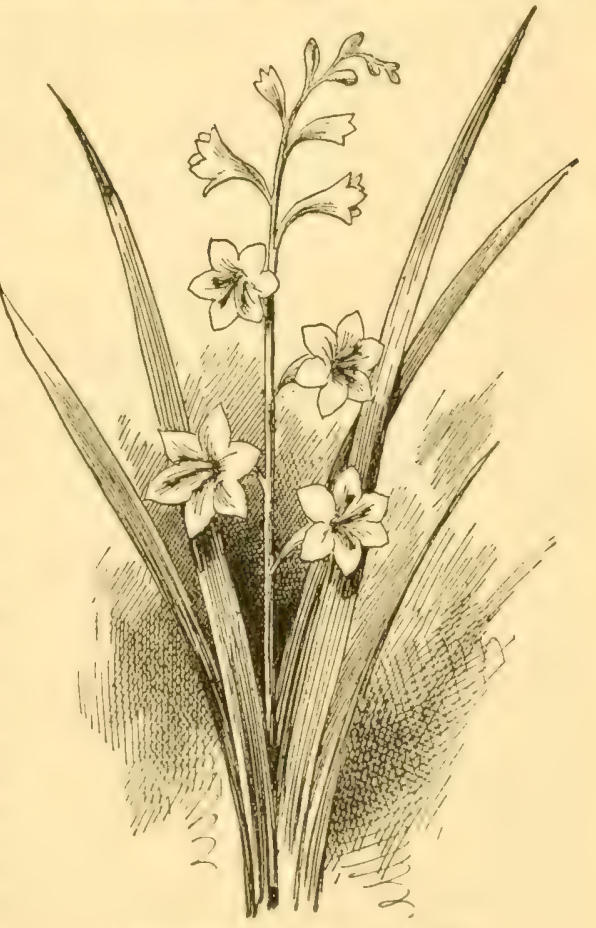

TRITONIA OR MONTBRETIA, 


\section{THE BOOK OF HARDY FLOWERS}

considerable difference in stature, but are generally of compact habit and flower profusely in their respective seasons, one or more kinds being in bloom from early April until June. The flowers are, as a rule, some shade of yellow or orange, but considerable variation is noticeable. They are common in alpine meadows in Europe, the Himalaya, Siberia, etc., and under cultivation give good results in ordinary, moist garden soil which has been enriched with manure. Propagation may be effected by division at various times of the year. Some people divide the plants as soon as they have flowered, planting the pieces in a border shaded from bright sun and watering them carefully until new roots are active. Others divide them at the end of the growing season, about September, and others, again, in February or March. The lastnamed time is, as a rule, less satisfactory than the others. Seeds may also be sown in pots or boxes in a cold frame in February. The Globe Flowers are excellent plants for the herbaceous border, for naturalising in the wild garden, or for planting in moist places in the rockery. The following are all very useful kinds: acaulis, 6 inches, rich yellow, June, Himalaya ; altaicus, I2 to I 8 inches, yellow, May, Siberia; asiaticus (Asiatic Globe Flower), I2 to I5 inches, golden, with less globular flowers than most of the others, May, Siberia, etc. (var. aurantiacus has richly coloured flowers); europaeus (Mountain Globe Flower), I2 to I8 inches, lemon-yellow, May and June, Europe, etc. (var. albidus has white blossoms, napellifolius golden blooms, and Golden Globe rich golden flowers); and Ledebourii, 2 fect, ycllow, May, Siberia.

Tropaeolum (Nasturtium, Indian Cress).-Very showy plants of annual or perennial duration are found in this group of the Geranium family (Geraniaceae). The flowers are usually brightly coloured, and each one produces a long spur containing nectar. They are mostly natives of Chili and Peru, occupying the higher regions, therefore the majority are suitable for the outdoor garden in this country. Some of the hardy perennial kinds have tuberous or rhizomatous roots, whilst one or two rather tender sorts are climbers, of which the branches persist for two or more years. The latter kinds are grown in greenhouses throughout winter and spring, and are planted out in summer. They are easily increased by cuttings inserted in pots of sandy soil under glass during spring or summer. The tuberous and rhizomatous kinds are increased by division of the roots during winter or early spring, and the annual sorts by seeds. Sceds of annuals can be sown under glass in March or April, or out-of-doors during the latter month. They are generally of very rapid growth, 
and the more vigorous climbing kinds form shoots several yards long in the course of two or three months. For this reason, combined with their free-flowering qualities, they are very popular for planting to cover walls and trellises. There are few places where they will not grow, but a little frost in autumn is sufficient to injure them. The dwarf annual kinds are very useful for summer bedding, and continue to bloom freely from June until the advent of frost. One or two dwarf bedding kinds can be increased by cuttings placed in pots in the greenhouse or frame in August and potted singly in January. From these, cuttings are again taken in spring. They are usually grown singly in pots until they can be planted out.

Tropaeolum aduncum (Canary Creeper) is an annual, native of Peru, with long, slender, climbing branches which bear elegant green leaves and large numbers of yellow flowers; it is of very rapid growth and a popular plant. Tropaeolum Leichtlini is of hybrid origin, and is suitable for planting on rockwork, where its scandent branches can trail over large stones; it is of perennial habit, and bears yellow flowers with red spots. Tropaeolum majus is the common trailing or climbing Nasturtium of gardens, an annual from Peru; its large flowers vary widely in colour, some being pale yellow, others deep yellow, orange, or brown, while the blooms of others, again, may be striped or double. There are also varieties of dwarf habit. Of the tall-growing sorts those described as Tall Crimson and Tall Yellow are specially worthy of note, whilst good dwarf kinds, suitable for bedding, are: Aurora, primrose to pink; Cloth of Gold, yellow; Crystal Palace Gem, spotted; Empress of India, crimson; Golden King, golden-yellow; Ladybird, scarlet and yellow; Pearl, creamy-white (all are about $\mathrm{I} 2$ inches high); King of Tom Thumbs, dark scarlet, and Queen of Tom Thumbs, scarlet and yellow, are somewhat dwarfer. Vesuvius is a scarlet-flowered climbing sort, which is grown on arbours and trellises during summer, but blossoms all the year round in a greenhouse. It is increased by cuttings during spring and summer. Tropacolum polyphyllum is a perennial kind from Chili ; it produces scandent branches clothed with glaucous leaves, and bears large quantities of golden flowers during summer. Increase is by division of the underground stems during winter or early spring. It is seen to the best advantage when planted on rockwork in such a position that its branches can hang over the face of a miniature cliff. Tropaeolum speciosum, another Chilian kind, is also a perennial with creeping underground stems by which it is increased by division during winter or spring. Slender branches of annual duration grow to a height of I2 or I5 feet, bearing dainty green leaves and scarlet flowers during 


\section{8

summer. The blossoms are so brilliant that the plant is sometimes called the Flame Flower. It gives the best results in a fairly moist and cool situation, often at the foot of a wall with a west or northwest exposure, and in loam and leaf-soil. Tropacolum tuberosum, from Peru, has tuberous roots, annual shoots and reddish-yellow flowers borne during late summer. Propagation is by division of the tubers during winter or early spring.

\section{Trumpet Flower.-(See Bignonia.)}

Tsuga (Hemlock Spruce).- - Though there are but few species of Tsuga (Natural Order Coniferae), they are widely distributed, for one is found in the Himalaya, others in China and Japan, and three more in different parts of North America. Several are hardy throughout the British Isles, but others are only available for the milder parts. They thrive most satisfactorily in moist, but well-drained soil, which is fairly free from lime. A clear atmosphere and moist atmospheric conditions are desirable. Increase is by seeds, and pruning is limited to clearing the leading shoots of rivals and shortening overgrown side shoots. Tsuga Brunoniana, the Indian Hemlock Spruce, is found in the Himalaya and forms a handsome specimen in Devonshire, Cornwall, and Ireland. Tsuga canadensis is the Hemlock Spruce of North-East America ; it forms a large tree with usually several trunks springing from one base. It is inferior in beauty and timber value to Tsuga Mertensiana (Albertiana), from North-West America, however, which is one of the most handsome of garden trees; Pattoniana, from the Mountains of California, is a very beautiful but rather tender bush with glaucous leaves; Sieboldi, the Japanese Hemlock Spruce, is a Yew-like bush, I5 feet or more high, native of Japan; it might well be planted instead of the Yew in many places, by reason of its lighter habit and more pleasing foliage; diversifolia and Yunnanensis are new, closely allied kinds.

Tulip.-(See Tulipa.)

Tulip Tree.-(See LIRIODENDRON.)

Tulipa (Tulip).- This group is composed of a very large number of species and several distinct races of varieties which have been raised in gardens, and are included amongst those plants popularly described as "Florists' Flowers." The Tulips belong to the Lily family (Liliaceac), and have long been grown in our gardens. The species or wild types are comparatively little grown and have been supplanted by the florists' kinds, of which the respective groups are known as Early-flowering; Late-flowering Cottage; English Tulips, which are again subdivided according to the markings of the flowers; Darwin Tulips; and Parrot Tulips. 


\section{TULIPA}

Tulips require well-drained loamy soil, but dislike fresh manure, and it is advisable to apply manure in spring to ground which is destined for Tulips, and take some other crop from it before planting the bulbs. It should be well dug, and the bulbs planted from 3 to 4 inches beneath the surface between the middle of October and the middle of November. They are usually lifted each year, sometimes soon after the flowers fade, but the proper time is after the leaves have turned yellow. Bulbs lifted while the leaves are green deteriorate in quality, and are more likely to fall a prey to fungus diseases than those which are lifted later. It is not wise to leave them more than two years in one position except in the cases of those that are naturalised; neither is it wise to plant them on the same ground year after year. Bulbs grown repeatedly in the same soil usually deteriorate and often contract a fungus disease which is fatal to the bulbs, and known commonly as "fire." When once this disease appears, affected bulbs should be burnt at once and the ground kept clear of Tulips for several years. The presence of the disease may be known by poor growth, generally unhealthy foliage, and decaying of the bulbs. Propagation is conducted by means of offsets; these are planted in early autumn in beds 3 or 4 feet wide, in rows 4 to 6 inches apart, the bulbs being about an inch apart in the rows; they quickly grow to flowering size. Seeds of species or of kinds which have been hybridised should be sown thinly in light soil in pans, boxes, or a prepared bed in a cold frame, as soon as ripe. When large enough to handle, the young plants are pricked out about an inch apart each way. It is wise to use a cold frame for the purpose, and to allow them to remain for two years without disturbance.

A good selection of species or wild Tulips is as follows: australis, I5 inches, yellow and red, April, South-West Europe; Batalinii, 8 inches, lemon-yellow, April, Asia Minor; Billietiana, 2 feet, yellow, May, Europe ; biflora, 6 inches, white with yellow eye, April, Caucasus ; Clusiana, 8 inches, white and red with black base, Southern Europe, Orient ; Didieri, 2 feet, red, May, Southern Europe ; elegans, I foot, red with yellow eye, May, garden origin. Tulipa Gesneriana, 2 to 3 feet high, with red blooms in May, native of Southern Russia and Asia Minor, has exerted a considerable influence upon the production of the vigorous kinds of garden Tulips. Tulipa Greigi, 9 to I2 inches, scarlet, April, Turkestan, is one of the most beautiful of all Tulips, the flowers being very large and brilliantly coloured. Others are Kaufmanniana, 6 to 12 inches, April, white, yellow, or red, often striped and very showy, Turkestan; macrospila, 2 feet, crimson with black blotch, May, garden origin; sylvestris, I to 2 feet, yellow, April and May, 
Europe, including the British Isles; can be naturalised in grass land with little trouble.

A selection of garden kinds is as follows: Single Early Flowcring (April)-alba regalis, white; Belle Alliance, scarlet ; Bride of Haarlem, crimson-scarlet, striped white; Canary Bird, yellow; Cottage Maid, rose, flushed white; Crimson King, crimson-scarlet; Duchess de Parma, red with orange margin; Golden Eagle, gold; Goldfinch, golden-yellow; Keizerskroon, scarlet with yellow colge; La Reine, white, shaded rose; Pink Beauty, pink ; Pottebakker, scarlet or yellow, according to variety; Rose Queen, rose; White Swan, white. Double Early-fluwcring-Agnes, red; Blanche Latine, white; Blanche Rosette, rosy-white; Duc van Thol, red, edged yellow; Duke of York, rosycarmine; Ia Candeur, white; Prince of Wales, cerise; Rosine, white and rose; Snowball, white.

May'-flowering or Cottage Tulips-Albion, soft lilac; Bridesmaid, rose, white striped; Dainty Maid, white lilac; Firefly, orange; fulgens, scarlet; Golden Beauty, yellow; Golden Crown, Jellow, edged scarlet; Goldflake, orange-scarlet and gold; Golden Eagle, yellow; Maid of Holland, yellowish-white, striped; Royal White, white with yellow centre; Scarlet Emperor, scarlet with yellow centre; Sweet Nancy, white, edged rose.

Darwin Tulips (May flowering)-Antony Roozen, blush; Carminea, rich carmine-rose; Clara Butt, soft, delicate rose, one of the most popular; Dream, heliotrope, shaded lilac; Europe, glowing salmon-scarlet; Fanny, pale rose; Glory, cherry-red ; Kate Greenaway, white, shaded rose; La Tulipe Noire, almost black; Maiden's Blush, satiny-rose; Mrs. Cleveland, blush, shaded rose; Nargaret, blush outside, pink inside; Pride of Haarlem, salmon-rose, large; The Sultan, maroon-black; White Queen, white.

Parrot Tulips (these are remarkable for their ragged flower segments)-Admiraal van Constantinopel, scarlet and orange; Café Pourpre, brownish-red, flushed yellow ; Cramoisie Brilliante, crimsonscarlet; lutea major, yellow with tips of scarlet and green; Perfecta, golden-yellow, feathered with scarlet; Preciosa, scarlet, striped yeilow. Nany more varieties of each kind are enumerated in bulb merchants' lists.

Tunica.-Several elegant little annuals and herbaccous perennials, suitable for the rockery or wall garden, are contained in this group of the Pink family (Caryophyllaceae). Tunica Saxifraga is the most important species. It is a native of the mountainous regions of Europe, grows from + to 2 inches high, and is recognised by its wiry branches, which bear during July and early August innumerable tiny 
white or pink blossoms, the whole plant being suggestive of a miniature Gypsophila. Any light, stony soil is suitable, and the best way to establish it, either upon a wall or in the rock garden, is to sow a few seecls in March where the plants are to grow. Tunica olympica, from Asia Minor, and illyrica, from South Europe, are dwarf plants requiring similar treatment.

Tussilago (Coltsfoot).- Tussilago Farfara, the Common Coltsfoot, a weed in sandy or stony ground in the British Isles, is the only authentic species that can be grown in this country, although other kinds, notably fragrans and Petasites, are sometimes included in the genus; they, however, are correctly species of Petasites. Tussilago belongs to the Daisy family (Compositae), and is a low-growing, herbaceous perennial, with rounded grey-green leaves and creeping underground stems : the heads of yellow flowers rise to a height of from 4 to 6 inches, and appear in early spring in advance of the leaves; it is showy, and often carpet poor ground where other plants would not grow. When once established it is difficult to eradicate; the only way to get rid of it is to cut off the growths as fast as they appear. There is a variety with prettily variegated leaves. Tussilago fragrans (correctly Petasites fragrans) is the Winter Heliotrope; it is a native of the Mediterranean region, grows about I2 or 18 inches high, and bears heads of fragrant purplish flowers in winter. Tussilago Petasites (Petasites officinalis), the Common Butter Burr, a British plant suitable for rough ground near water, grows I2 to I8 inches high, and bears purplish flowers in spring. All can be increased by division during winter.

Typha (Reed Mace).-Ornamental water plants belonging to the Natural Order Typhaceae are found in this class. Two species, angustifolia and latifolia, are wild in many parts of the British Isles, and are well known by reason of their long grass-like leaves and tall, polier-like inflorescences and seed heads. When ripe, the fruiting portions are dark brownish-black, 9 to I2 inches in length, of a velvety character, and produced on stout stems 4 to 6 feet high. Both plants should be planted in water gardens, for they are amongst the most beautiful of tall-growing aquatics. They thrive in mud covered by 6 inches to 2 feet of water, and develop quickly into goodsized masses. To form colonies, take clumps of rhizomes a foot across and bury them in mud, or, if no mud exists, plant them in baskets of loam and sink them beneath the water. This may be done during January or February. In some places they are called Bulrushes, other common names being Club Rush and Cat's Tail. If the fruitbearing rods are cut cluring early autumn before the seeds begin to 
disperse, they can be kept intact all winter and be used for decorative purposes.

Ulex (Gorse).- This group of shrubs (Natural Order Leguminosae) is well known by reason of the commonest kind, Ulex curopacus, the Furze, Whin, or Gorse, of our commons and hillsides, which is one of the most beautiful of early-flowering shrubs, its golden blossoms being conspicuous from January to May. Its intensely spiny shoots have led to its being used sometimes as a hedge plant, but its doubleflowered variety is better adapted for that purpose and for planting in large, informal groups about the garden. In addition to being of more compact growth than the type, the double kind is of better appearance throughout the summer, for it does not bear seed pods, which have a rather disfiguring effect. It is increased from cuttings of short shoots inserted in sandy soil in a cold frame in August. Young plants must be grown in pots until they can be placed in permanent positions, for they transplant badly from the open ground. Plant in quite poor soil on dry, sandy banks for preference, and shorten the branches a little after the flowers are over. Old plants may be cut hard back if necessary. The next most useful kind is Ulex Gallii, the French Gorse; it blooms in August and September, and is remarkable for its close compact growth. Ulex nanus and parviflorus are other kinds of less value.

Ulmus $(\mathrm{Elm})$ is an important group of trees belonging to the Natural Order Urticaceae. The various kinds are known as Elms, and are distributed through Europe, China, and North America. Several of them form trees up to 90 or Ioo feet high, while others are hardly more than bushes. They are popular for planting in parks and hedgerows, and fine examples are often found in gardens. The taller and more effective kinds are also used for avenues. It is not, however, advisable to allow large Elms to stand in the vicinity of houses or other buildings, for heavy branches of old trees are very brittle, and often fall from the trees without the slightest warning, such breakages being as likely to occur on a quite calm day as during rough weather. Elms have the faculty of rejuvenating themselves after the leading branches have died, for if they are cut back well below the dead parts a new branch system starts again from adventitious buds upon the trunk and stumps of the branches. In the same way trees with badly decayed trunks will produce perfectly healthy foliage for many years. They thrive in almost any kind of soil, and some sorts are increased by seeds and others by suckers. Many varieties are usually increased by grafting upon stocks of their respective types. The varieties with weeping branches are amongst the most 
popular of all weeping trees, the Weeping IVych Elm (Ulmus montana pendula) being perhaps the best of all; it is frequently planted upon lawns. Those kinds of narrow fastigiate growth are also to be encouraged, more especially as street trees; the Cornish Elm and Hertfordshire Elm are two of the best. Several Elms have prettily variegated leaves - a sclection of the best includes campestris antarctica aurea, a dwarf tree with golden leaves; campestris variegata, with silver variegated leaves; campestris Louis van Houtte, a vigorous kind with golden leaves; montana fastigiata aurea, a stiff, uprightgrowing tree with golden leaves; and viminalis variegata, a slender elegant tree with silvery foliage.

Of green-leaved Elms the following are all vigorous trees, suitable for parks or hedgerows: campestris, glabra, major, montana. For gardens americana, parviflora, and pedunculata may be used. Ulmus montana fastigiata is a stiff, columnar or, when young, pyramidal tree, of slow growth, suitable for small gardens. The pruning of Elms is directed towards securing unbranched trunks and symmetrical form. It may be carried out during summer.

Umbellularia californica.-This is an evergreen bush, or tree in its native habitat, belonging to the Natural Order Lauraceae. It is a native of California, and is allied to the Bay Laurel, its leaves emitting a rather similar spicy odour when bruised. Although not very hardy, it thrives throughout the South and West of England, cscaping injury except when a particularly severe winter is experienced. In those parts it grows into a shapely bush I5 feet high or more, with oblong leaves 3 to 4 inches long, of bright green shade. The yellowish flowers are small and are often borne in April or May. They are succeeded in warm, sunny summers by nut-like fruits $\frac{1}{2}$ to 4 inch long. Plant in ordinary garden soil; increase by seeds or cuttings, the latter being taken in summer and rooted in a close warm frame; pruning, which is directed towards keeping the bushes shapely, may be done in summer.

\section{Umbrella Pine.-(See Sciadopitys.)}

Uvularia (Bellivort).- In this group of the Lily family (Natural Order Liliaceae) there are several pretty herbaceous perennials suitable for planting in moist, peaty, or loamy soil in semi-shade. They are allied to the Solomon's Seal, and are easily increased in spring by division of the underground stems. Groups may be formed in shady parts of the garden, near the borders of a stream, just out of the water, or in thin woodland where the soil is fairly moist. Uvularia grandiflora, I foot to 2 feet high, native of North America, bears yellow flowers in May; perfoliata, from North America, grows 12 inches 
high and bears yellow flowers in May; and sessilifolia, from the same country, I2 to I5 inches high, has yellow flowers in June:

Vaccinium.-A group of shrubs (Natural Order Vacciniaceae) widely distributed throughout the Northern Hemisphere; two or three species are included in the British Flora. They usually uccupy moist and, in some instances, boggy land, and are very fond of peaty soil. The majority dislike lime, and are not a success if planted in very dry situations. The native kinds are widely distributed upon commons and hillsides right to the north of Scotland. When planted in gardens, Vacciniums should be provided with cool, moist soil, and if possible be sheltered a little from the fiercest midday sun. They are increased by division of the clumps, by seeds, or by cuttings, and require no systematic pruning. The fruits of some kinds are used for culinary purposes and for dye, a case in point being our Common Bilberry or Blaeberry (Vaccinium Myrtillus). This is well known as a bush 6 to 24 inches high, found throughout the country. Another British kind is the evergreen Vaccinium Vitis-Idaea, sometimes called the Cowberry. Though often but a few inches high, it sometimes grows to a height of $I_{\frac{1}{2}}$ feet; the leaves are deep green, and the berries red.

Of exotic kinds Vaccinium arboreum, the Farkle-berry of the South-East United States, is very showy with reddish flowers; it is, however, rather difficult to grow well here. Vaccinium corymbosum, the Blueberry or Swamp Blueberry of North America, is, on the other hand, one of the most accommodating kinds; growing 2 to 3 feet high, it forms a nice bush and bears its creamy-white rosetinged flowers freely in April or May. Vaccinium crassifolium, hirsutum, japonicum, pensylvanicum, and uliginosum are other available species.

\section{Valerian, Red.-(See Centranthus.)}

Valeriana (Valcrian).-A considerable number of species are included in this group of the Natural Order Valerianaceae. Several kinds can be grown in the herbaceous border or rock garden, but, as a rule, they lack that delicate beauty which is usually associated with rock plants, and very few are of sufficient interest to justify a place in the border. They have also a rather disagreeable perfume. Valeriana Phu, the Cretan Spikenard, is, however, worth growing; it reaches a height of 2 feet, has showy yellow leaves, and bears white flowers in August. It is a native of the Caucasus, and is increased by division in February; ordinary garden soil suits. Valeriana officinalis is grown in this country as a field crop for the sake of its roots, which possess anti-spasmodic properties; it is a native of Europe, including the British Isles, grows 3 feet high, and bears pinkish 
flowers in June. Clumps can be formed in the wilder parts of the garden with good effect. The pretty red-flowered border plant which is usually called the Red Valerian is correctly Centranthus ruber. It is seen in most gardens, a handsome border or wall plant, and is found wild in many parts of the country. Ordinary garden soil suits, and increase is by seeds or division during February or March.

Valerianella (Corn Salad).-Herbaceous plants, often of annual duration, form this group of the Valerian family (Valerianaceae). Many species are found in the British Flora, but few are of sufficient interest to cultivate as border plants. They thrive in ordinary garden soil, and can be raised from seeds sown in spring. Valerianella carinata (Corn Salad), 6 to I2 inches, white, summer ; olitoria (Lamb's Lettuce), 6 to I2 inches, white, summer; Auricula, 6 to I 2 inches, white, summer ; are a few of the kinds.

Vancouveria (Barrenwort).-Hexandra is the only species of Vancouveria (which belongs to the Berberis family, Berberidaceae) available for cultivation in this country. It is a dwarf, interesting plant, native of North-IVest America, suitable for a moist position in light peaty soil in the rock garden. It is allied to Epimedium, and is seen as a tufted plant 9 inches high, bearing white or pale lilac flowers in May. Propagation is by division of the clumps in March.

Veltheimia.-Bulbous plants from South Africa, belonging to the Lily family (Natural Order Liliaceae). They can only be grown out-of-doors in the mildest parts of the country, and even then must be given a position in light, well-drained loamy soil, at the foot of a wall for preference. Where, however, a frame with a southern aspect is available, they can be grown quite well, while they are also useful for the greenhouse. Propagation is by the removal of offsets from the bulbs. Veltheimia viridifolia is the best-known kind; it has vivid green leaves I 2 to I 8 inches long, and bears large heads of flesh-coloured flowers on stems I2 to I 8 inches long during summer. Veltheimia glauca is a somewhat similar plant, with glaucous leaves and flesh-coloured blooms.

\section{Venus' Looking-glass.-(See SPEcularia.)}

Veratrum (False Hellebore).-Hardy herbaceous perennials of vigorous habit, belonging to the Lily family (Natural Order Liliaceae). They are natives of Europe, Siberia, and North America, and thrive in any good garden soil which has been enriched with manure, for it is only when the large plaited leaves and vigorous inflorescences are developed to their greatest extent that their decorative qualities can be fully appreciated. Propagation may be conducted by means of seeds sown in boxes of light soil in a cold frame as soon as they 
are ripe, or by division of the clumps in February or March. They possess acrid, poisonons properties, and the rootstocks of one or two species are powdered and used to destroy insects. The rootstock of Veratrum album, a European species, provides the White Hellebore powder of commerce. Some of the chief kinds are: album, 3 to 4 feet, greenish-white, June; Maackii, 2 to $2 \frac{1}{2}$ feet, purplish, June and July, Siberia ; nigrum, 3 feet, almost black, summer, Europe, etc. ; viride, 3 to 4 feet, greenish, summer, North America. Hellebore powder from Veratrum viride has been used in some countries for killing slugs and worms, whilst that from Veratrum album is often used for similar purposes here. They should not be planted in places where they are likely to suffer from drought.

Verbascum (Mullein).-Hardy biennial or perennial herbaceous plants are found in this group of the Snapdragon family (Scrophulariaceae). There are many species widely distributed through Europe and Asia Minor, whilst representatives are found in the British Flora. They succeed in ordinary garden soil, while several grow well in pure sand. Propagation is by seeds sown as soon as ripe out-ofdoors, or kept in a cool room and sown the following spring. Some kinds produce very large leaves and are worth a position in the garden for that reason alone. Verbascum Chaixi is a case in point. Generally, however, they are grown for the sake of their tall inflorescences, which are densely clothed with yellow, purple, or violet flowers, according to the kind. Some kinds are suitable for clumps in the herbaceous border, but they are usually seen at their best when naturalised in large masses in a prominent position, or used as clumps in thin shrubberies. Useful sorts are Blattaria (Moth Mullein), I2 to 36 inches, biennial, yellow, summer, Europe, including British Isles; Chaixi (Nettle-leaved Nullein), 3 feet, perennial, yellow, summer, SouthWest Europe; longifolium, 4 feet, biennial, yellow, summer, Europe; nigrum, 2 to 3 feet, perennial, golden-yellow, summer, Europe; olympium, 3 to 6 feet, biennial, yellow, very fine leaves, Bithynia; phoeniceum, 3 feet, perennial, rose, purple, violet, or copper, summer, Europe and North Asia, a very pretty kind; Thapsus (Flannel Plant), 2 to 6 feet, biennial, yellow, summer, Europe.

Verbena.- Very beautiful flowering plants of annual or perennial duration (Natural Order Verbenaceae). There are many species, some of herbaccous and some of sub-shrubby growth, but comparatively few are in general cultivation owing to the fact that numerous varieties have been raised which are far more popular than their respective parents for garden decoration. They are more tender than some of the species, and are not suitable for outdoor 


\section{VERBENA}

cultivation throughout the year. They are, livwever, popular for summer bedding, and large numbers of plants are grown annually for that purpose. Some years ago the custom obtained of naming special varieties, and these were kept true to name by propagating them from cuttings; now, most of the distinct colours can be raised true from seeds, therefore the more difficult task of increase from cuttings can usually be dispensed with, and seedling plants are, as a rule, more vigorous and less liable to contract disease than those raised from cuttings. There is, however, still a very popular variety in Miss Willmott, which must be raised from cuttings; in this case the flat heads of flowers are a pretty pink shade. When propagation is effected by means of cuttings, it is usual to cultivate a few plants in pots in a frame throughout summer. Towards October the tops are cut back well and in December the plants are placed in a warm greenhouse to form new growth. When the young shoots are 2 inches or so long they are removed and inserted in light sandy soil, or in a sand bed, in a warm and moist greenhouse. When rooted they are potted singly in 2 - or $2 \frac{1}{2}$-inch pots and kept in a light greenhouse near the glass until early May, when they are removed to a cold frame, and are finally planted out at the end of May. The points of the shoots are removed several times, and repotting is practised if necessary. Another method of taking cuttings is to select short growths which are not showing flowers, in August, and insert them in 5- or 6-inch pots or boxes about ${ }_{4}^{3}$ inch apart. Place them in a greenhouse until rooted, then keep them in a dry and cool frost-proof frame, and pot the young plants singly in January, giving similar treatment to those raised from spring cuttings. Seeds may be sown under glass in January or early February, the seedlings being pricked out in 2 parts loam, I part leaf-mould, and I part sand, in boxes; the plants are eventually potted singly. It is usual to plant them in beds of single or mixed colours, and it is wise to peg the shoots to the soil until a complete ground covering has been obtained. Flowering is continuous throughout summer. Formerly such varieties as Scarlet Defiance, Royal Purple, Coelestial blue, Crimson King, Boule de Neige, Purple King, Pink Perfection, etc., were obtainable; now seedsmen offer varieties which are quite equal in merit as Purple, Crimson, Blue, White, Pink, etc.

Amongst species the following deserve attention: Aubletia (Rose Vervain), hardy biennial, 6 to 12 inches, red, purple, or lilac, summer, North America ; officinalis (Common Vervain), I2 to 24 inches, perennial, lilac, summer, Europe; teucroides, 2 feet, perennial, pink or white, summer, Brazil, etc. ; venosa, I2 to 24 inches, perennial, lilac, 


\section{THE BOOK OF HARDY FLOWERS}

blue or purple, summer, Argentine. Amateurs should avoid keeping their plants in a close, stuffy atmosphere after they are once rooted, for such conditions encourage the spread of mildew, to which Verbenas are rather subject. They are also better adapted for light, warm soils than for those that are heavy and cold.

Veronica (Speedwell).--This group of the Snapdragon family (Scrophulariaceae) is made up of showy shrubs and herbaceous plants, together with many weeds, which are widely distributed through many countries. With one or two exceptions, the shrubby kinds are natives of New Zealand, and all are evergreens of more than ordinary beauty. Unfortunately, the majority are but half-hardy, and are only suitable for out-of-doors in the milder counties, but they are acknowledged to be among the most useful of all garden shrubs in those places. A few kinds are hardier, and may be grown in the Midlands. All the more vigorous sorts are suitable for specimen beds, groups in shrubberies, or informal hedges, while those of dwarf growth are excellent for the rock garden. As the various species bloom from early summer until Christmas, anyone with a small collection may have flowers for a period of seven or eight months. They thrive in ordinary garden soil and are easily increased by cuttings of young shoots inserted in sandy soil in a closed frame during summer. Regular pruning is unnecessary, but the points of the shoots may be removed if the bushes appear to be growing straggly. There are a great many shrubby kinds, of which the following are fair representatives: buxifolia, a neat-growing plant, I2 to 24 inches high, with small dark green Box-like leaves; carnea, a bush 3 to 4 feet high, with long, narrow, Willow-like leaves and long inflorescences of pinkish-white flowers ; chathamica, a dwarf, compact shrub; cupressoides is a dwarf kind with small leaves, suitable for the rock garden ; diosmifolia is a compact plant I2 to I 8 inches high, its racemes of small white flowers are very elegant. Veronica Hulkeana is a tender kind with very large terminal panicles of lilac flowers; salicifolia, 5 feet high, bears long pendent racemes of white flowers. Veronica speciosa is a very variable kind; it forms a large bush 5 feet high and more across; the dense flower spikes may be composed of white, red, pink, blue, or purple flowers. Veronica Traversii is the hardiest of all; growing 3 to 4 feet high, it is recognised by its small oval leaves and dense spikes of white, lilac-tinged flowers.

The herbaceous sorts may be used for the herbaceous border or for the rockery. Many of them are very beautiful when in flower and are easily grown in ordinary garden soil, propagation being effected by division of the clumps. The following are all useful sorts : Teronica 
corymbosa is a pretty blue-flowered species growing up to 9 inches high; it blooms during late summer and is suitable for the rock garden. Gentianoides, a native of South-East Europe, is usually grown for spring bedding; its blue flowers are borne on stems I2 to Is inches high in May; there are forms with white flowers and variegated leaves. Veronica longifolia is a favourite kind for the herbaceous border ; its long spikes of blue, white, or rose-coloured flowers, according to variety, are borne during August on branches 2 to 3 feet high ; spicata is a somewhat similar plant. Teucrium is a handsome blueflowered sort which blooms in July; its vars. dubia (rupestris) and Pseudo-chamaedrys are suitable for the rock garden; virginica grows from 2 to 4 feet high and blooms in July.

Vesicaria (Bladder Pod).--Rather curious and interesting perennial or annual plants of the Wallflower family (Cruciferae). They are of dwarf stature, thrive in ordinary garden soil, and are suitable for the herbaceous border or rock garden. All can be increased by seeds sown in light soil in a cold frame in spring, while those of perennial duration may also be propagated by division in spring or by cuttings during summer. Of the many kinds the following will be sufficient for most gardens: graeca, a sub-shrubby perennial, 6 to I2 inches high, yellow flowers in early summer, native of Dalmatia, etc., suitable for a sunny position in the rock garden; grandiflora, annual, 9 to 12 inches, yellow, summer, Texas; utriculata, perennial, 6 to I2 inches, yellow, summer, Europe, suitable for a sunny position in stony soil in the rock garden.

\section{Vetch.-(See Vicia.)}

Viburnum (Guelder Rose).-- Showy shrubs from Europe, Asia, and North America, belonging to the Natural Order Caprifoliaceae. Many of them rank among the most ornamental of all shrubs, some being of value for their flowers, others for their foliage, and others for their fruits. Two kinds are natives of the British Isles, and they are very useful either for groups in parks and plantations or for garden planting. All may be grown in loamy soil, though one or two of the more delicate sorts appreciate a little peat in the soil. The deciduous kinds may be planted any time during autumn, winter, or early spring, but those with evergreen leaves are best put in during early autumn or late spring. Propagation is by cuttings of young shoots inserted in sandy soil in a close and warm frame during summer, while they may also be increased by seeds. Regular pruning is not required, but when plants are outgrowing their positions a little may be done during summer.

Viburnum Carlesii is a very pretty species from Corea ; its rounded, 


\section{0

deciduous leaves are of a greyish hue, and its flat heads of fragrant flowers are of wax-like character, white, tinged with pink; dilatatum, a deciduous Japanese kind, bears creamy-white flowers which are followed by bright red fruits. Viburnum Lantana, the Wayfaring Tree of the British Isles, grows 4 or 5 feet high, and is recognised by its broadly-oval, grey-green leaves and large flat heads of white flowers, which appear in May, to be followed later by showy red and black fruits. It thrives with conspicuous success on chalky soil.

Viburnum macrocephalum, from China, is known only by the form which produces white, sterile flowers; these are very similar to the sterile flowers of a Hydrangea, and are borne in large heads up to 6 or 7 inches across. It is of rather slender growth, and unfortunately rather tender, requiring the shelter of a wall except in the milder parts of the country, where it has been noted in excellent condition growing over the rocks of rock gardens. Viburnum ocloratissimum is a very vigorous, large-leaved evergreen from China; it is sometimes met with I2 feet high and as far through in Cornish gardens. Viburnum Opulus is the Common Guelder Rose of our gardens, and is a familiar object in hedgerows in many parts of the country, where its white flowers followed by bright red fruits make it conspicuous, during May and late summer. The form with sterile flowers is, however, more popular than the type; the inflorescences appear in round heads, and as the mature flowers are white the common name of Snowball Tree has resulted. It grows from I2 to 15 feet in height and as far through. Viburnum rhytidophyllum is a remarkable shrub, which was introduced from China about twelve or fifteen years ago : its evergreen leaves are strap-shaped and often 9 to Io inches long, with a curiously wrinkled surface and the underside densely covered with brown felt; the creamy-white flowers appear in large flat leads in May, and are succeeded by red and black fruits. It must be given a position sheltered from cold winds.

Viburnum Tinus is the Laurustinus of gardens; it is a native of the Mediterranean region and well known as a winter- and springflowering evergreen, the heads of white flowers being prominent from December until May; lucidum is a vigorous, large-flowered variety. Viburnum tomentosum, from China, is a handsome bush + to 6 feet high, with flat heads of white flowers; there are, however, varieties with sterile flowers known as plicatum and plicatum grandiflorum, which are more popular for garden planting. The round heads of white flowers are borne with great freedom in June, and they are amongst the first rank of flowering shrubs. Viburnum utile is a new kind from Central China, which promises to be of value by reason 


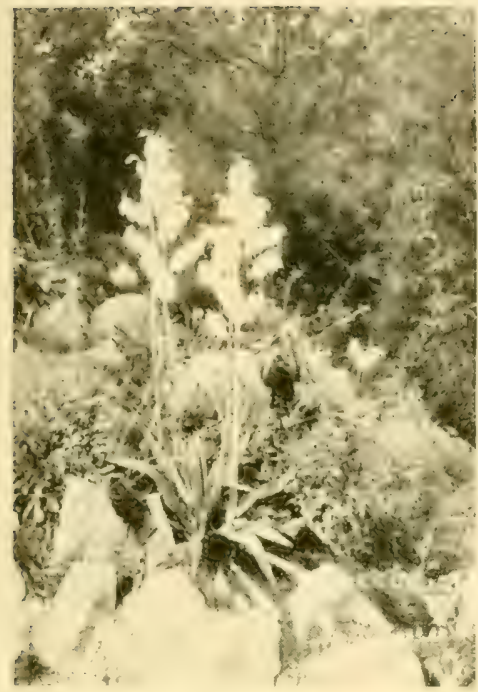

YUCCA FILAMENTOSA ON THE ROCKERY

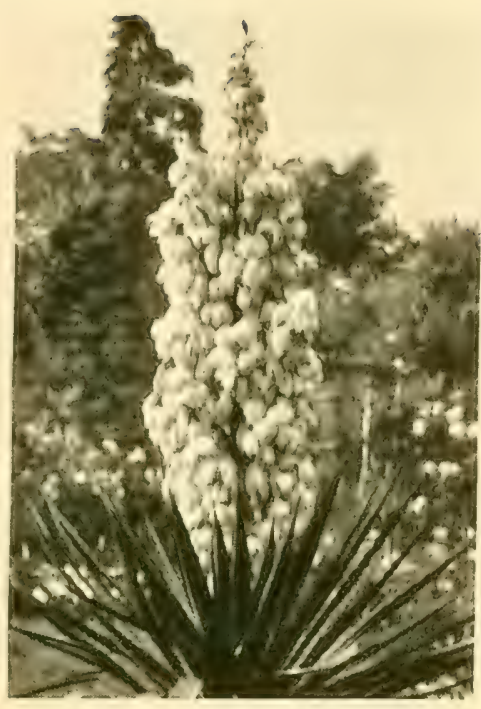

ADAM'S NEEDLE (YUCCA GLORIOSA)

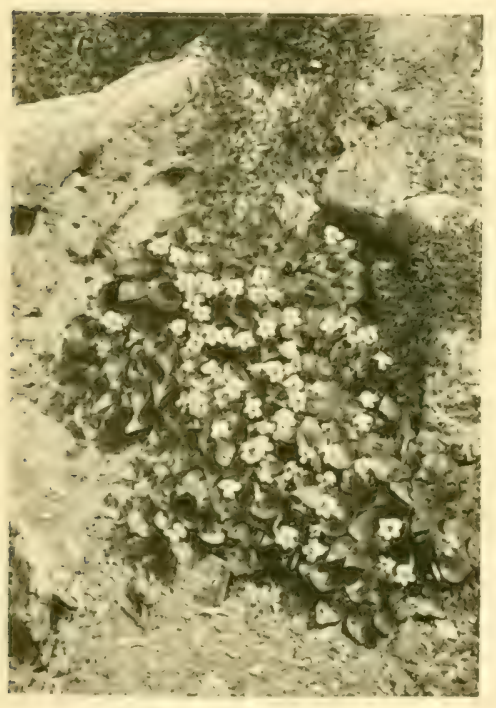

AN ALPINE VIOLA (VIOLA CUCULLATA)

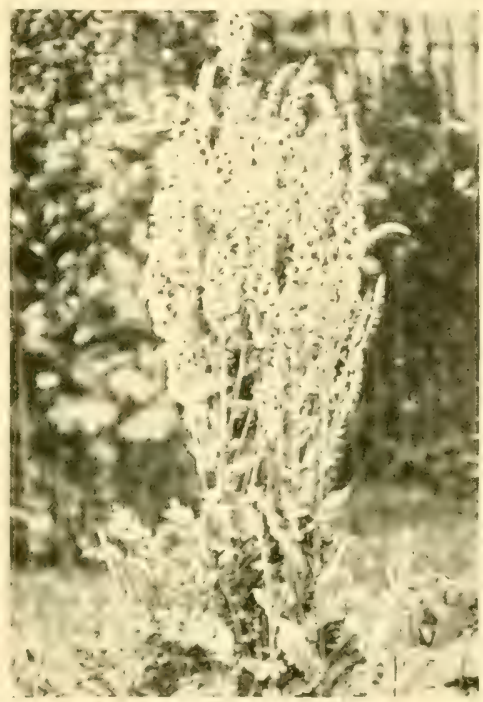

ONE OF THE MULLEINS

VERBASCUM DENSIFLORUM 

of its heads of white flowers. The sterile forms of Viburnum Opulus and tomentosum are excellent shrubs for forcing for greenhouse decoration in spring.

Vicia (Vetch, Tare).-Annual or perennial plants with slender, prostrate, or climbing branches, or of sturdy, upright growth, are found in this group of the Pea family (Leguminosae). They have no great decorative value, though they are easily grown and the flowers are pretty. Several are natives of the British Isles and have some considerable value as fodder plants, whilst the seeds of others are used for human food. All are easily increased by sowing seeds in spring where the plants are intended to grow. When grown in gardens the slender kinds should be sown in round patches and be given a few birch twigs for support. A few kinds suitable for the garden are: argentea, I2 to I8 inches, summer, pink and black, leaves silvery, Pyrenees; Cracca (Tufted Vetch), 2 to 4 feet, blue, June, widely distributed in the Northern Hemisphere; Faba, the Broad Bean of the vegetable garden, and its var. equina, the Horse Bean, though not suitable for the flower garden, are important food-stuffs and worthy of mention ; fulgens, 3 to 4 feet, scarlet, summer, Algeria ; orobioides, I2 to 24 inches, blue, summer, Southern Europe ; pyrenaica, I2 inches, purple, May, Pyrenees.

Vinca (Periwinkle) is a group of hardy and tender plants belong. ing to the Natural Order Apocynaceae. The most familiar kinds are the Greater and Lesser Periwinkles, Vinca major, and Vinca minor respectively. Both are trailing shrubs, natives of Europe, etc., and they are included in the British Flora. They are very useful plants, Vinca minor more particularly, for planting as an undergrowth to taller shrubs or for carpeting a thin wood. The larger plant grows about I8 or 24 inches high, and bears large blue flowers I inch to I $\frac{1}{2}$ inches cross. Its var. elegantissima has pretty silver variegated leaves. Vinca minor scarcely attains a height of 6 inches, but forms a dense carpet and bears its showy blue flowers very freely in spring; there are varieties with variegated leaves and with white, purple, or reddish single or double flowers. Both species are increased easily from cuttings or division of the clumps, and may be grown in any fairly good garden soil. Other outdoor kinds are: diffusa, from South-West Europe, and herbacea, also from Europe. All are dwarf plants. Pruning is unnecessary. Vinca rosea, from the Tropics, requires greenhouse shelter; it forms an upright bush 18 to 24 inches or more in height, with showy red flowers, which are borne during the greater part of summer. The variety alba is similar to the type in all respects except that the flowers are white. 


\section{Vine.-(See Vitis.)}

Viola (Pansy, Violct).--This group of the Violet family (Violaceac) is of considerable importance in the garden, for it provides the races of plants known under the common names of Pansy, Viola, and Violet, each of which is represented by many varieties. In addition, it gives us many very beautiful alpine speries which are attractive in the rock garden. Violas, too, are among our most charming wild plants, and many banks and woods are made fragrant in spring by carpets of their blue or white blossoms. As a rule, the Violas are of perennial duration, though they are often grown as annuals or biennials. Seeds may be sown during early summer out-of-doors or in boxes under glass in February. It is, however, usual to cultivate many of the garden kinds of Pansy and Viola, also certain species, from cuttings. These are taken during July, August, or carly September and inserted in a cold frame filled with light soil, leaf-mould and sand. The frames are kept fairly close until the cuttings are rooted, when as much air as possible is admitted, the lights being removed on all possible occasions; excessive moisture and severe frost alone are excluded. This treatment results in strong, sturdy plants, which can be removed for permanent planting in March. Twenty years ago there were numerous named varieties of Pansy, but many of them have now disappeared in favour of the more easily grown seedlings, which from a good strain are quite as beautiful. Seeds sown in May produce seedlings suitable for pricking out, 4 to 6 inches apart, in a cold frame or open border in June. These form excellent plants for permanent planting either in October or March. When the flowering time is over they are usually destroyed. Violas are still largely grown from cuttings. Violets require somewhat different treatment, which is described under the heading of Violet.

Some of the chief species are: alpina, 3 inches, purple, June, European Alps; biflora, 3 inches, yellow, June, Alps, gives good results in crevices between rocks, in stony soil in the rock garien, or on walls; calcarata (Spurred Violet), 6 inches, blue, May, Europe; var. alba has white flowers, suitable for the rock garden, increased from runners; canina (Dog Violet), is the pretty, blue, scentless Violet of our woods. Viola cornuta (Horned Violet), 6 inches high, with purple or blue flowers in spring and summer, is from the Pyrences, an cxcellent sort for masses in the rock garden or for beds and borders; it has a very long flowering season, and there is a white variety. Cucullata (Large American Violet), 4 inches high, with blue, purple, or violet flowers in spring and early summer, North America, is a very beautiful kind for a large mass in the rock garden; gracilis, 3 inches, June, purple, 
Greece, is a very attractive kind for the rockery; lutea (Mountain Tiolet), 3 to 4 inches, yellow, April to June, Europe, is suitable for rock gardens or a wall; Mumbyana, 4 inches, purple, spring, Spain, is a pretty kind for the rockery. Viola odorata is the Sweet Violet of our woods, from which the garden Violets have sprung; pedata (Bird's-foot Violet), 6 inches, bears blue, white, or purple flowers according to variety, in Nay, June, and is a showy and useful North American kind for massing in the rock garden ; rothomagensis (Rouen Violet), 6 inches, blue, summer, Europe, forms a pretty patch in the rockery; tricolor (Heart's-ease Pansy) is the common wild species from which the garden Pansies have been raised.

Florists' Pansies. - Pansies are well known as dwarf-tufted plants, which produce large flowers of rich velvety colouring during spring and early summer. The flowers are usually made up of two or more colours in which yellow, white, bronze, purple, or reddish-brown may be conspicuous; the arrangement of the colours forms a means whereby the florist distinguishes certain types, but such distinctions are unnecessary for the present work. The cultural details have already been dealt with. As a rule, the finest flowers are borne during early spring, both size and colour deteriorating as the plants advance in age and the shoots become long and bare at the base. Any specially good forms can be retained by rooting cuttings of young shoots in a frame in August, otherwise seeds are the best means of increase. They are said to have been raised from the British Viola tricolor and the Siberian Viola altaica.

Tufted Pansies.-These are an important race of garden plants, for many kinds blossom continuously from early spring until early autumn. They were raised by the intercrossing of the garden Pansy with the long-flowering Viola cornuta; the most floriferous kinds, and those with the best growth, are kinds in which the Viola cornuta predominates. Although they can be grown on from year to year, and may be increased by division, the best plants are raised each year from cuttings rooted as previously advised. Florists' Violas are invaluable for spring and summer bedding, and they can be used with advantage for bordering paths or for clumps in the front of the herbaceous border. The following varieties can be recommended: Christiana, Countess of Hopetoun, and White Empress. white; Ardwell Gem, Bullion, Primrose Dame, yellow ; Blue Cloud, Countess of Kintore, Laverock, White Duchess, white and blue; Duchess of Fife, Golden Fleece, yellow and blue; Bessie Clarke, Duchess of Sutherland, J. B. Riding, mauve; Lilacina, Maggie Mott, lilac-blue; Crimson Fing, Councillor Waters, crimson. There is also a strain 
with small flowers known as the Violetta; it needs similar treatment to the ordinary Tufted Pansy.

Violet.-The Violets of gardens have been raised from the Wild sweet Violet (Viola odorata). They are important plants, not alone on account of their decorative garden qualities, but by reason of their value as market flowers, and also on account of the cssential oil contained in their blossoms, which is expressed for perfumery purposes. The flowers are also candied and used in the preparation of sweetmeats. In the warmer parts of this country and in France, where large quantities are grown for our markets, Violets are planted in long beds in fields, and the flowers are gathered during winter and spring. The object aimed at by growers is to obtain large, well-developed, clean flowers on long vigorous stalks, and to secure this combination the plants must be grown in rich and deep, moist loamy soil. Propagation is conducted in May, or as soon as the flowering season is over. Plants may either be divided into small sections or runners may be used. Plant in rows $x 6$ inches apart, allowing 9 to 12 inches between each two plants in the rows, according to the variety. During summer give water when necessary and remove the runners and weeds now and then. In some gardens the beds are covered with lights raised 2 or 3 inches above the plants during the flowering time. In colder parts of the country the plants are lifted carefully in September and planted in frames in about 6 inches of soil on a slight hotbed. They are watered as soon as planted, kept close for a few days, and then well ventilated on all favourable occasions. Under these conditions large quantities of flowers are produced. Where long dry periods are usual in summer, the coolest position possible should be selected for summer quarters, otherwise the plants may be attacked and injured by red spider.

Good varieties are: California, Czar, La France, Princess of Wales, blue or purple; White Czar, white (all single-flowered); and Comte de Brazza, white; de Parma and Marie Louise, lavender; Mdlle. B. Barron, blue; and Neapolitan, mauve with white centre (all double). Princess of Wales, Czar, and Marie Louise are three of the best varieties.

Violet.-(See Vrola.)

Virginian Creoper.-(See VITIS.)

Virginian Stock.-(See MaLColmia.)

Viscum album (Mistletoe).--This belongs to the Natural Order Loranthaceae, and is a well-known parasite upon the Apple, Lime, Poplar, Oak, and other kinds of trees in some parts of the British Isles, more particularly Gloucestershire, Herefordshire, and adjacent counties. As the Mistletoe is a popular plant both by reason of its 
use for Christmas decorations and its legendary associations, people usually like to possess a specimen. Nale and female flowers are on different plants, therefore fruits are not borne by all. To establish it upon the Apple take fruits in February or March and rub the seeds lightly into natural crevices of the bark. Protect them from birds by means of a little netting, and leave them to look after themselves. Growth is very slow for two or three years.

Vitex Agnus-Castus is the most useful shrub in this group, which belongs to the Natural Order Verbenaceae. It is a native of the Mediterranean region, and is only of sufficient hardiness for outdoor planting in the milder parts of the country, and must then be grown against a wall with a south or west aspect. The white flowers are borne in large panicles at the points of the current year's shoots in September, their elegance and purity giving rise to the popular name of Chaste Tree which is applied to this shrub. The best show of flowers is seen after a sunny summer. Plant in warm, loamy soil, increase by cuttings in summer, and prune the previous year's wood back to within a bud or two of the base in February.

Vitis (Vine).-This is an important group of climbing plants (Natural Order Ampelidaceae), for besides Vitis vinifera, the Common Grape Vine, it contains numerous other ornamental kinds. They are chiefly natives of Asia and North America, although represented in other countries. There are both hardy and tender sorts, but for decorative gardening the hardy kinds quite surpass the others. There ar. many ways in which the hardy Vines may be grown with effect. Few plants are better adapted for planting on a pergola or for covering an arbour, while certain kinds are of considerable value for clothing bare walls and trellises. It is possible, however, that they are seen to the greatest advantage when planted at the base of a tree or bush over which they may ramble at will. When planted in positions where space is restricted, it is necessary to prune the branches back severely during winter and often a second time in early summer, but when placed against a tree or bush they may be left unpruned for many years. The Vines shoukl be planted in really good loamy soil, and a surface-dressing of cow manure given occasionally is attended by good results. Propagation is by seeds, cuttings of soft wood in the case of the softer-wooded kinds, and of ripened wood or eyes for those of more vigorous growth. When Vines are planted to grow over trees or bushes, they must be inserted some distance from the trunk and, if possible, just outside the radius of the branches. $\Lambda$ hole several feet wide, filled with good soil, must be provided in order to give the Vines a start. 
Vitis arborea, from the Southern United States, is a decorative kind with doubly pinnate leaves; it is suitable for the southern counties; armata is a new species from China, with conspicuously prickly branches; its leaves colour well in autumn. Vitis Coignetiae, a very free-growing Japanese plant, is one of the most satisfactory kinds for general planting; its large handsome foliage sometimes colours well in autumn; heterophylla, from China and Japan, is chicfly remarkable by reason of its small blue fruits in autumn. The var. humulifolia is often regarded as an improvement on the type. Vitis inconstans is better known under the name of Ampelopsis Veitchii; it is one of the best of all self-clinging climbers, and may be grown almost anywhere, the brilliant colouring of its foliage in autumn is well known. The specific name of inconstans refers to the various shapes of the leaves found on the same plant. Vitis Labrusca, the Fox Grape or Skunk Grape of North America, is the parent of many of the North American cultivated Grapes, it is a very hardy lkind, and has large handsome leaves; megalophylla, a new species from China, is of interest by reason of its very large bipinnate leaves. Vitis quinquefolia, the common Virginia Creeper, is useful for planting to grow over bushes or trees, but a better plant is the closely allied kind Vitis Engelmanni ; the leaves colour brilliantly in autumn. Thomsoni, is a new kind from China, bearing five-parted leaves of a purplish colour. Vitis Thunbergii of gardens is a glorified Coignetiae, and a very vigorous and ornamental kind; the true Thunbergii is less vigorous and produces smaller leaves. Vitis vinifera is better known by its fine fruiting varieties than by the type. The purple-leavel var. purpurea ought, however, to be grown.

Vittadenia (Australian Daisy).-Vittadenia australis is the only kind in this group of the Daisy family that deserves attention for the outdoor garden. It is a native of Australia and New Zealand and closely allied to Erigeron. Growing about 9 inches high, it bears large quantities of Daisy-like flowers in summer, which are first pink, then white. It can be grown in the rockery or in the front of the herbaceous border in ordinary garden soil, and is increased by division of the clumps in February. It grows very readily from seed sown in April out-of-doors, and is often treated as an annual.

Wahlenbergia.--This is a large and interesting group of the Bellflower family (Campanulaceae). It includes hardy and tender plants of annual or perennial duration, a few having partly wooly branches. The hardy sorts require similar cultural conditions to the Campanulas, and some may be grown in the rock garden, others in the herbaceous border. All may be raised from seeds sown in the 
greenhouse in spring, while the perennials can also be increased by division in spring. They like rather light, well-drained soil. Wahlenbergia hederacea is a dwarf plant with creeping stems and pale blue flowers; it is a native of Europe, suitable for the rock garden, and is sometimes called the Ivy-leaved Hairbell; gracilis, 6 to IS inches, a widely distributed plant in the Southern Hemisphere, is of annual duration, and bears blue, purple, or white flowers, according to variety. Kitaibelii, from Transylvania, is a perennial growing 6 inches high bearing blue flowers in summer; it should be grown in the rock garden; tenuifolia, 6 to 24 inches high, bears blue or white flowers in summer; it is from Dalmatia.

Waldsteinia.-Dwarf plants belonging to the Rose family (Rosaceae). They are natives of Europe, North America, and Siberia. A few may be planted on a dry bank or in the rock garden, but there are many more beautiful plants. Plant in ordinary garden soil and increase by division in spring or by seeds sown at the same time. Waldsteinia fragarioides, a creeping plant from North America, bearing yellow flowers in June, and trifolia, a low-growing European kind, producing yellow flowers during late spring, should be grown.

Wallflower.-(See CheIRANTHUS.)

Wall-Rue.-(See Asplenium RUta MURARIA.)

Water Hawthorn.-(See APONOGETON.)

water Violet.-(See HotTonIA.)

Water Lily.-(See NymphaEA.)

Watsonia.-A number of half-hardy bulbous plants, natives of South Africa and allied to Gladiolus, are found in this group of the Iris family (Iridaceae). They can only be grown out-of-doors under the most favourable conditions in this country, and the most successful method is to plant the bulbs or corms in March or early April in deep, but well-drained loamy soil in a border at the foot of a warm wall. Each corm should be placed amongst a handful of sand about 4 inches beneath the surface of the ground. In some gardens the plants are even started in pots and planted out in May. As soon as the leaves die lift the plants, clean the corms, and store them in a frost-proof room for winter. I'ropagation is by offsets, which form in the same way as is usual with Gladioli. Watsonia Meriana, a plant growing 3 feet high, is one of the hardiest kinds, its large flowers are purple or scarlet in colour, but in the var. O'Bricni, which is quite as hardy, the blossoms are white. In each case the flowers appear during summer. Coccinea, 2 to 3 feet, scarlet, summer; densiflora, 2 feet, red, summer; and rosea, 2 feet, rose, summer, are other useful kinds. 
Wattle.-(See ACACIA.)

Whitlavia.-Several useful annual or perennial herbaceous plants are sometimes included in Whitlavia, which belongs to the Natural Order Hydrophyllaceae. They are not, however, recognised by botanists as belonging to this group, but to Phacelia. Some of the chief sorts are: pinnatifida, from North America; campanulata, divaricata and loasaefolia, from California. For descriptions and cultural directions, sce "Phacelia." The annual plant usually grown as Whitlavia grandiflora is correctly Phacelia Whitlavia; it has handsome, bell-shaped, purple flowers, which open during summer; seeds may be sown out-of-doors in March.

wigandia. - The Wigandias, which are members of the Natural Order Hydrophyllaceae, are tropical plants used out-of-doors in summer on account of their large handsome leaves. The various kinds are increased by imported seeds or by cuttings, and are grown rapidly in rich loamy soil, to plant out in well-manured ground in June. As soon as they become established, growth is quick and enormous leaves are formed. In autumn the plants may be lifted and stored under glass in winter, cuttings being obtained from them in spring. The chief kinds are: caracassana, from Mexico, and Vigieri and macrophylla from the same country.

\section{Willow Herb.-(See E PILobium.) \\ Windflower.-(See ANEMONE.) \\ Winter Cherry.-(See Physalis.)}

Wistaria.-Two kinds of Wistaria, which belongs to the Pea family (Leguminosae), are included amongst the best of all ornamental climbers. The commonest kind, Wistaria chinensis, is a native of China, and is well known as a vigorous climber capable of attaining a height of 40 or 50 feet, with pinnate leaves and dense pendent racemes of fragrant mauve-coloured flowers. The principal flowering time is late Nay or early June, but later inflorescences appear towards the end of summer. Although such a vigorous plant naturally, it can be casily stunted or dwarfed to make it suit almost any position, and it is frequently grown as a bush 2 to 4 feet high, for forcing for greenhouse decoration in spring. Fortunately, this dwarfing process does not impair, but rather adds to, its flowering qualities, and the most floriferous plants are often those that have become stunted. In view of this, the Wistaria is often pruned on the "spur" system. A number of branches are allowed to grow (the points being removed occasionally to ensure the development of side growths) and cover the wall or trellis space at disposal, then all secondary shoots are pruned back to form spurs. It is usual to look over the plants about 
the end of June and then to shorten side shoots to within five or six buds of the base. During carly winter further secondary shoots that have formed are removed, and the original side shoots - those that were "stopped" -are shortened to within two or three buds of the base. These hard pruned shoots gradually form large stunted branches which bloom with considerable freedom.

There are few places where this Wistaria will not thrive, except, perhaps, in the extreme north. In the south it may be used for all kinds of purposes-namely, for covering walls, trellises, pergolas, arbours, or trees in the open ground. Plants grown in pots for the greenhouse may be forced for a number of years in succession by keeping them in the same pots and giving manure water now and then. The var. alba should also be grown.

A second beautiful kind is found in the Chinese Wistaria multijuga. In this case the fragrant mauve flowers are in less dense racemes than in Chinensis, but the racemes often exceed 3 feet in length. There is a white-flowered variety with racemes 18 inches long. Both are excellent for pergolas, and they are the plants so freely shown by Chinese and Japanese artists. The correct treatment of this kind is similar to that advised for the other. All grow well in loamy soil and may be increased by layers. Other species are: brachybotrys, frutescens, and japonica.

Witches' Brooms.-This term is applied to curious bunches of twiggy growths which are often seen in Birch and Hornbeam trees. They bear a resemblance to and are sometimes called Crows' Nests. As a rule, a few only occur on a single tree, although twenty or thirty or more may be found on some trees. They are due to an abnormal development of adventitious buds, brought about in the first instance by irritation caused by a fungus, often a species of Exoascus. Such growths are found more rarely upon other trees than Birch and Hornbeam, such, for example, as Cherry, Thorn, Lime, Sloe, Pine, Larch, Spruce, Chestnut, etc. On the Cherry they often assume a stiff, fastigiate growth, almost like an inverted birch broom, and are then called Mares' Tails. 'They do not, as a rule, cause the trees any serious harm, but there are other growths found on the Birch which are decidedly harmful. In time the trees become covered by small, stunted growths due to the abnormal development of buds through the presence of an insect closely allied to the Black Currant mite. Infested branches should be burnt, otherwise the whole tree may be killed. Small broom-like growths are also frequent upon Willow trees. They are due to the abnormal development of the catkins after being punctured and irritated by insects. 
Woodsia.-The Woodsias are pretty little ferns (Natural Order Filices) needing a moist, shaded position in the outdoor fernery or rock garden, and should be planted in light leafy or peaty soil near a brook or waterfall for preference. They rarely grow more than 6 inches high, and are delicate in outline. Woodsia ilvensis, from the arctic and north temperate zone, and oregana and scopulina, from North America, are useful sorts. Propagation is by division in spring.

Woodwardia.-Several vigorous and handsome ferns are included in Woodwardia, which belongs to the Natural Order Filices. The hardier ones can be grown out-of-doors in the warmer parts of the country, where they make valuable additions to the hardy fernery ; they thrive best in light loam and leaf-mould or in peaty soil, in semishade, in the vicinity of water. Propagation is by division of the clumps in spring. Woodwardia areolata, from the United States; japonica, from China and Japan; virginica, from North America; and radicans, native of the north temperate zone, are all vigorous plants with long, arching leaves.

Wulfenia.-Several hardy, perennial, herbaceous plants are found in this group of the Snapdragon family (Scrophulariacea). Wulfenia Amherstiana, from the Himalaya, grows from 6 to Io inches high and bears blue flowers in July; and carinthiaca, from Carinthia, an evergreen stemless plant, I2 to I 8 inches high, also bears blue flowers in July. Plant in light loamy soil in a well-drained place in the rockery, and increase by division in February.

Xanthoceras sorbifolia is a low tree or shrub in this country, a moderate-sized tree in its native country, China. It belongs to the Natural Order Sapindaceae, and is allied to the Horse Chestnut. In the South of England it may be grown in the open ground, but in colder parts it is probable that wall shelter will prove more satisfactory. In some gardens it is used for forcing for greenhouse decoration in spring. Its attractions lie in its pinnate leaves and dense inflorescences, 3 to 5 inches long, of white flowers marked with brown: Plant in well-drained loamy soil, and increase by imported seeds or layers. Systematic pruning of bushes is unnecessary. After flowering, wall plants may be pruned so far as is necessary to admit of their being trained to the wall.

Xeranthemum (Immortelle).-Handsome annual plants with so-called everlasting flowers, which, when cut, remain attractive for a long period; they belong to the Daisy family (Compositae). The flowers are known as Immortelles or Everlasting Flowers, and they are usually gathered when at their best, dried, and kept for winter decoration. The plants are of the easiest cultivation, and seeds 
should be sown out-of-doors in ordinary soil during late March or carly April in the positions the plants are to occupy; when the seedlings are large enough to handle, thin them out to 3 or 4 inches apart each way. The best-known kind is Xeranthemum annuum, from Southern Europe; it grows $I_{\frac{1}{2}}$ to 2 feet high and bears purple, yellow, violet, or white single, semi-double, or double flowers. Seeds of mixed colours can be procured or either of the colours can be obtained separately. Another kind is Xeranthemum cylindraceum, also from Southern Europe.

Xerophyllum (Turkey's Beard).-Xerophyllum asphodeloides, a North American plant, is the only representative of this group of the Lily family (Liliaceae). It is a tufted plant, and forms a mass of elegant, grass-like leaves from amongst which the inflorescences of white flowers rise to a height of 3 or 4 feet during early summer. It requires light, moist soil, containing peat or leaf-mould, and does well in semi-shade. Propagation is by division of the tuberous roots during early autumn.

Yucca (Adam's Needle).-This is a genus of attractive evergreens which produce large inflorescences of showy cream-coloured flowers between the end of July and early autumn. It belongs to the Lily family (Liliaceae), and contains a large number of species, a few only of which are sufficiently hardy for outdoor planting. The hardier species are from the South-East United States, and the stronggrowing ones form large bushes 6 or 8 feet high, each branch being clothed with an immense head of strap-shaped leaves, each one 2 to 3 feet long; from the centre of the head a large panicle of flowers, 3 to 5 feet high, appears at the proper season. They give the best results in a sunny position in well-drained loamy soil, and are excellent for planting on dry banks or on the higher points of the rockery. Large plants do not bear transplanting well, and it is wise to place plants in permanent places from pots. Fortunately, they succeed in both town and country gardens. Propagation is by offsets which appear freely from cut back stems in spring; they are inserted as cuttings in pots of sandy soil, and quickly form roots if kept under glass. If a stem without roots is laid on a greenhouse stage it will produce good cuttings from adventitious buds. The tops of branches injured by wind may also be used as cuttings. Remove some of the lower leaves, tie the others together, and place the branch in a pot as a cutting. Keep it in a greenhouse, and do not give much water until roots are formed.

The best kinds are Yucca filamentosa, from the South-East United States, a dwarf plant with scarcely any stem, spreading into 
a mass by means of side shoots; the panicles of flowers are 3 to 5 feet high, and appear in July and August. Yucca glauca, a graceful lowgrowing plant with long, narrow glaucous leaves and panicles of flowers up to 4 feet high, is a native of the Southern United States and excellent for massing in the rock garden, etc. Yucca gloriosa, from the South-East United States, is an excellent evergreen 6 or $\delta$ feet high, with handsome heads of stiff leaves which are over 2 feet long and 2 or 3 inches wide; the inflorescences are large and handsome. Yucca recurvifolia is as vigorous a shrub as the last-named with as fine an inflorescence; it is distinguished by its longer and narrower leaves, which have pendent ends and is native of the SouthEast United States. The two last-mentioned kinds are the best for general purposes.

Zanthoxylum.-Trees or shrubs, usually with spiny branches, natives of India, China, Japan, North America, etc., and belonging to the Natural Order Rutaceae. Although not in the front rank of decorative plants, a few kinds are of sufficient interest for planting in the shrubbery, for the leaves are decidedly pretty, and although the flowers are not attractive, they are sometimes followed by brightly coloured fruits. They are good-natured plants, and do not require special attention; they may be planted in ordinary garden soil, and require no other pruning save what is necessary to keep the plants in shape. Increase is by seeds. Zanthoxylum ailanthoides, from Japan and Formosa, is a decorative tree with long, Ailanthus-like leaves; it is suitable for the milder counties. Zanthoxylum americanum, from the United States, is commonly called the Prickly Ash, or Toothache Tree, on account of its supposed virtue as a cure for toothache. Other available kinds are: Bungei, piperitum, and schinifolium.

Zea Mays (Maize).- This plant belongs to the Natural Order Gramineae, and is of considerable commercial importance in addition to being of decorative value. In many warm temperate and subtropical countries, it forms one of the principal agricultural crops, and even in temperate regions where a hot summer is experienced the corn can be ripened. It is an important plant in South Africa, Rhodesia, and British Central Africa, and is cultivated extensively in the United States, many European countries, India, Egypt, and elsewhere. The popular name of Maize is in general use in the British Isles, but in Africa it is recognised as Mealies; elsewhere, Indian Corn and Pop Corn are popular names. Although little use is made of the ripe corn for food here, the unripe cobs are boiled and eaten as a vegetable, and in this state they have been compared with green peas. In this and other countries where the corn does not ripen 
well, it can be produced large enough for use as a vegetable. To secure a crop for this purpose, sow seeds in boxes, pots or a bed in a frame in March. Let the plants stand well apart, and transplant them to rich and deeply-dug kitchen garden soil in May. Place the plants in rows $2 \frac{1}{2}$ feet apart and 2 feet apart in the rows. Should the weather be dry, give plenty of water during the period of growth. The cobs of corn, which are usually about 9 inches long, are in the proper condition for use when the seeds are about the size of Gradus Peas. There are several kinds with variegated foliage, and they are in great demand for sub-tropical and other kinds of decorative gardening. Sow the seeds in pots in Marcn, and place each young plant separately in good loamy soil in a 5 -inch pot. Grow in a frame, and plant out in rich soil in May. Plenty of room is required, for plants may grow 5 or 6 feet high with fine leaves 2 to 3 feet long and 2 to 3 inches wide. Seeds of the variegated kinds can be obtained from any seedsman.

Zelkova.-This is a group of hardy trees closely allied to the Elms and belonging to the Natural Order Urticaceae. They are distinct by reason of their smooth greyish bark and often furrowed trunks; the wood is very hard and valuable in countries where the trees grow wild. Here they are cultivated as ornamental trees only. The leaves are Elm-like, but the leaf and the branch system are usually lighter than in the Elms. They may be planted in good loamy soil, and are increased by imported seeds. Pruning is directed towards keeping the leading shoots free from rivals and shortening sicle branches when they are outgrowing the leaders. Zelkova crenata, a native of the Caucasus, is the commonest species, and numbers of fully-grown trees, 50 to 60 feet high, may be found. Zelkova acuminata, from Japan, is an important timber tree in Japan, the wood being very prettily figured and useful for building and cabinet work; it is of elegant growth here. Another but very rare species is Zelkova Verschaffelti, of East Asia.

Zenobia speciosa is a very decorative shrub belonging to the Heather family (Ericaceae). It is found in the South-East United States, from Florida to North Carolina, and succeeds in this country when planted under similar conditions to Kalmia and Pieris. Mature plants are from 2 to 3 feet high, and are recognised by their broadly oval leaves which are I to 2 inches long and greyish-green in colour, and by the wax-like white flowers which are borne in profusion from axillary buds in May and June, or in some cold districts they may be as late as July. Showy as the typical kind is, however, it is eclipsed in beauty by the var. pulverulenta, of which the leaves and 
stems are clothed with a mealy glaucous covering. When propagating the plant it is a good plan to sow seeds of this variety, then a good percentage come true, and the remainder represent the typical sort. Plant in moist soil free from lime, and limit pruning to the removal of the points of the branches which have flowered as soon as the flowers are over. Within the last few years a demand has sprung up for plants of Zenobia for forcing for greenhouse decoration in spring; they are lifted in autumn, placed in pots, and brought into bloom in a cool greenhouse.

Zephyranthes (Zephyr Flower, or Swamp Lily).-Zephyranthes candida, a dainty, little bulbous plant from the Argentine, is the only species of this group of the Amaryllis family (Amaryllidaceae) available for the outdoor garden. Growing 3 to 6 inches high, it is suitable for bordering paths, for planting in beds, or for clumps in the rock garden. Its grass-like leaves are retained for the greater part of the year and its white dainty flowers appear during July and August. It thrives in ordinary garden soil, and is increased by division of the clumps, for the bulbs form large numbers of offsets. In cold districts it should be planted at the foot of a wall.

Zinnia.-The Zinnias are half-hardy annuals belonging to the Daisy family (Compositae). Zinnia elegans, a native of Mexico, is the best-known and most useful kind. Growing about 2 feet high, it branches freely and bears handsome heads of flowers 2 to 3 inches across during summer. The flowers vary in colour from white to yellow, orange, bronze, purple, scarlet, and red. Seeds are sown under glass in March, in a compost of 2 parts loam, I part leaf-mould, and I part sand. The young plants should be pricked off in boxes or in a bed of soil on a slight hotbed and planted out in well-manured soil towards the end of May. Good varieties are alba flore pleno, double white; atrococcinea flore pleno, double crimson; aurea flore pleno, double yellow; coccinea flore pleno, double scarlet; purpurea flore pleno, double purple. Other species are: Zinnia Haageana, I2 inches, orange, summer, native of tropical America; pauciflora, 2 feet, yellow, summer, from Mexico; and tenuiflora, 2 feet, scarlet, summer, from Mexico.

Zizania (Indian Rice).-Two ornamental grasses are found in Zizania (Natural Order Gramineae). One, Zizania latifolia, is a perennial from Siberia and Japan, growing 5 to 6 feet high, with long, strap-shaped leaves; it should be grown in rich mud near the margin of a lake, where the roots are covered by a few inches of water. It is easily increased by division of the clumps in spring. The other species, Zizania aquatica, is a native of North America, where the 


\section{ZYGADENUS}

Indians have used its seeds for food in times of scarcity; it is a very handsome plant of annual duration, and attains a height of from 8 to I2 feet with handsome foliage and tall, stately inflorescences. It must be planted in rich soil a few inches beneath the surface of water, and be protected from water-forvl. It is a good plan to sow seeds in pots of loamy soil placed in a tank of shallow water under glass, and keep the plants in a frame until mid-May, then plant them out. Increase is entirely by seeds, and the seeds can only be kept sound until the sowing time, February or March, by placing them in water. They may either be stored in a jar and the water be changed frequently, or they may be tied in canvas and sunk in a pond out-of-doors.

Zygadenus.-This group, which belongs to the Lily family (Liliaceae), comprises several bulbous plants which have no great claim on the gardener, their interest being of botanical rather than horticultural character. They require well-drained, light loamy soil, and are increased by separating the offsets from the parent bulbs after the death of the leaves. A few species are: Zygadenus elegans, $2 \frac{1}{3}$ feet, greenish-white, July, North America; glaberrimus, I $I_{2}^{\frac{1}{2}}$ feet, white, July, North America; Nuttallii, I $\frac{1}{2}$ feet, white, July, California. 



\section{INDEX TO POPULAR NAMES}

\section{POPULAR NAME}

Abele

Acacia, False

Acacia, Rose

Aconite, Winter

Adder's Tongue

Agrimony

Alder, Common

Alder, Mountain

Alder, Speckled

Alkanet

Allspice

Almond, Common

Aloe

Alyssum, Sweet

Andaman Marble.

Anemone, Apennine

Anemone, Poppy .

Anemone, Wood

Anemone, Yellow Wood

Angelica Tree

Apricot

Apricot, Japanese .

Arbor-vitae .

Arrow Head

Artichoke

Arum, Black

Arum, Italian

Ash

Aspen

Asphodel

Asphodel, Bog

Asphodel, False

Asphodel, Giant

Asphodel, Leafless.

Aster, Cape .

Aster, China

Avens.

Avens, Mountain .

Azalea, Indian

Balm

Balm Bee

Balm, Honey
BOTANICAL NAME

Populus alba

PAG $\pi$

349

Robinia • . . . 379

Robinia hispida . . 380

Eranthis hyemalis . . 167

Ophioglossum . . . 312

Agrimonia . . . 16

Alnus glutinosa . . . 2 I

Alnus viridis . . 22

Alnus incana . . . 22

Anchusa . . . . 29

Calycanthus . . 82

Prunus Amygdalus • • 357

Agave . . . 15

Alyssum maritimum . . 25

Diospyros Kurzii . . I57

Anemone apennina . . 32

Anemone coronaria . . 32

Anemone nemorosa . . 33

Anemone ranunculoides . 33

Aralia spinosa . • . 39

Prunus Armeniaca $\quad$. 359

Prunus Mume . . . 359

Thuya . . . 437

Sagittaria . . . 39 I

Cynara . . . 138

Arum sanctum . . . 45

Arum italicum . . . 45

Fraxinus . . . 187

Populus tremula. . . 350

Asphodelus . . . 48

Narthecium ossifragum $\cdot 303$

Tofieldia . . . 44I

Eremurus . . . 168

Asphodeline . . . 48

Kaulfussia amelloides . . $24 \mathrm{I}$

Callistephus hortensis . . 80

Geum • . . . 199

Dryas . . . 160

Rhododendron indicum $\quad 374$

Melissa . . . 283

Monarda . . . 292

Melittis . . . 284 
POPULAR NAME

Balm of Gilead

Balsam

Bamboo

Bamboo

Banana

Bane-berry

Barberry

Barley

Barren Wort

Basil

Basil, Wild

Bay, Sweet

Bead Plant

Beam, White

Bean, Wild

Bearberry

Bear Bind

Bear's Breech

Bear's Ears .

Beech

Beet

Belladonna

Bellflower

Bell Flower, Asiatic

Bellflower, Chimney

Bell Flower, Chinese

Bellflower, Gland .

Bergamot

Berry, Pheasant

Bigwood

Bindweed

Bindweed, Hedge .

Birch

Bird's-foot Trefoil

Bitter Sweet

Blackberry, Wild .

Blackthorn

Bladder-nut .

Bladder Senna

Blanket Flower

Bleeding Heart

Bloodroot

Bluebell

Bluebell

Bluebell, Californian

Bluebell Creeper, Australian

Bluebell, Italian

Blue Gum

Bluets .

Bog Bean

Borage.

Bottle Gourd

Bottle Tree.

Box
BOTANICAL NAME

FAGE

96

230

45

335

295

IO

$22 I$

I 66

309

Calystegia . . $\quad 83$

Auricula . . . . 53

Fagus . . . $\quad 182$

Beta vulgaris . . . 63

Atropa . . . . 59

Campanula . . . $\quad$. 84

Ostrowskia magnifica . . 3I5

Campanula pyramidalis . 85

Platycodon grandiflorum . 344

Adenophora . . . II

Monarda . . . . 292

Leycesteria formosa . . 254

Sequoia gigantea $\quad .4 \mathrm{I} 2$

Convolvulus . . . I I I

Calystegia sepium . $\quad . \quad 83$

Betula . . . . 64

Lotus . . . 268

Solanum Dulcamara • . 416

Rubus fruticosus . . 387

Prunus spinosa flore pleno . $35^{8}$

Staphylea pinnata . . 423

Colutea . . . . II9

Gaillardia . . . I9I

Dicentra . . . . 153

Sanguinaria. . . 394

Campanula rotundifolia $\quad . \quad \mathrm{S}_{5}$

Scilla nutans . . . 406

Nemophila . . . . 304

Sollya . $\quad \cdot \quad \cdot 4 \mathrm{IS}$

Scilla italica . . . 406

Eucalyptus . . . . 176

Houstonia . . . . 222

Menyanthes . . . 285

Borago . . . . 68

Lagenaria . . . . 244

Sterculia rupestris . . 425

Buxus . . . . 76 
POPULAR NAME

Box Edging

Box Elder

Box Thorn

Bracken

Bramble

Bramble, White-stemmed

Bridal Wreath

Broom

Broom

Broom, Butcher's .

Broom, Spanish

Browallia, Jameson's

Bryony

Buck Bean, Fringed

Buckeye

Buckthorn

Buckthorn, Sea

Bugbane

Bugle.

Bugloss

Bull Bay

Bur, New Zealand

Burning Bush

Butter Burr

Buttercup

Butterfly Flower

Butterfly Weed

Butternut

Butter Wort

Calico Bush

Calla, Marsh

Calvary Clover

Campion

Campion

Campion, Rose

Canary Creeper

Candy tuft

Candytuft, Burnt .

Candy tuft, Lebanon

Candytuft, Persian

Canterbury Bell

Cape Pond Weed.

Carnation

Carpenter's Leaf

Castor Oil Plant

Catchifly

Catmint

Cat's Ear

Cedar.

Cedar, Japanese

Cedar, West Indian

Celandine

Celandine, Greater
BOTANICAL NAME

Buxus suffruticosa

FAGE

Acer negundo

$.69,7^{6}$

Lycium Chinense

7

Pteris Aquilina

271

Rubus

$36 x$

Rubus

387

388

Francoa ramosa. . $\quad 187$

Cytisus . . . . 140

Genista . . . . 196

Ruscus aculeatus . $\quad 390$

Spartium junceum . . 419

Streptosolen . . . 427

Bryonia . . . $\quad 73$

Limnanthemum peltatum . 260

Aesculus . . . . 13

Rhamnus . . . 37I

Hippophaë rhamnoides . $22 \mathrm{I}$

Cimicifuga . . . . IIo

Ajuga . . . . 18

Echium . . . . I62

Magnolia grandiflora . $\quad 274$

Acaena . . . . 5

Dictamnus . . . . I 54

Petasites . . . . 328

Ranunculus. . . $\quad 369$

Schizanthus . . . 404

Asclepias tuberosa . . 47

Juglans cinerea . . . 239

Pinguicula . . . 339

Kalmia latifolia . . . 240

Calla palustris . . . 79

Medicago Echinus . 282

Lychnis . . . 270

Silene . . . $4 \mathrm{I} 3$

Agrostemma . . . I6

Tropaeolum aduncum . $\quad 447$

Iberis . . $\quad 227$

Aethionema coridifolium . I4

Aethionema grandiflorum . I4

Aethionema . . . I4

Campanula Medium . $\quad 85$

Aponogeton . . . 37

Dianthus Caryophyllus . I 52

Galax aphylla • . . 192

Ricinus communis . $\quad 379$

Silene . . . . 413

Nepeta . . . . 304

Antennaria . . . 34

Cedrus . . . . 97

Cryptomeria japonica . . I34

Cedrela odorata . . . 96

Chelidonium majus . . 103

Stylophorum . . $\quad 428$ 


\section{POPULAR NAME}

Centaury

Century Plant

Chalk Plant

Chamomile

Chamomile, Red

Chamomile, Wild

Cherry

Cherry Cornelian.

Cherry Pie

Cherry, Winter

Cherry, Winter

Chestnut, Eating

Chestnut, Golden-leaved

Chestnut, Horse

Chestnut, Spanish

Chickweed, Mouse Ear

Chicory

Chili Pine

Chittam Wood

Choke-berry

Christ's Thorn

Cinquefoil

Clary

Cobnut

Cockcomb

Codlins and Cream

Coffee Tree, Kentucky .

Columbine

Comfrey

Cone Flower

Cone Flower, Purple

Coral-berry .

Coral Tree

Cornel

Cornflower

Cornflower, Perennial

Cotton Grass

Cotton Thistle

Cowslip, American

Cowslip, Virginian.

Crab Apple, American.

Crab, Siberian

Cranberry, Common

Creeping Jenny

Cress, Indian

Cress, Rock .

Cress, Rock, Purple

Cress, Violet

Cress, Water

Crimson Leaf

Crocus, Chilian

Crosswort

Crowfoot, Common

Cuckoo Pint
BOTANICAL NAME

Erythraea

races

Agave

17.1

Gypsophila .

15

Anthemis

207

Adonis autumnalis

3.4

12

Matricaria Chamomilla. $\quad . \quad 279$

Prunus Avium . . . 358

Cornus mas . . $\mathrm{I}_{24}$

Heliotropium

$2 \mathrm{I}+4$

Physalis

$33^{\prime \prime}$

Solanum capsicastrum

$+10$

Castanea sativa

92

Castanopsis chrysophylla . 93

Aesculus Hippocastanum . 13

Castanea

92

Cerastium

Cichorium Intybus

IOI

I I ()

Araucaria . . . $\quad 39$

Rhus canadensis . . . 377

Pyrus adenorachis . . $\left.3^{f}\right)$

Paliurus australis . . 320

Potentilla . . . 350

Salvia Horminum . $\quad 393$

Corylus . . . . $12(3$

Celosia cristata. . . $\quad 0.3$

Epilobium hirsutum . . I $($, $)$

Gymnocladus canadensis $\quad 207$

Aquilegia . . . $\quad 37$

Symphytum . . . 430

Rudbeckia . . . . 38i

Echinacea . . . It, I

Symphoricarpus orbiculatus . $\quad+29$

Erythrina . . . I It

Cornus mas . . . 124

Centaurea Cyanus . . 99

Centaurea montana . . 99

Eriophorum . . 172

Onopordon . . . 312

Dodecatheon . . $15 \mathrm{~S}$

Mertensia pulmonarioides . 280

Pyrus coronaria . . . . 305

Pyrus baccata . . $\quad 365$

Oxycoccus palustris . $\quad 317$

Lysimachia . . 272

Tropacolum . . . $44^{\prime}$

Arabis . . . . 3s

Aubrictia . . . 52

Ionopsidium acaule . $\quad 2,3 \mathrm{I}$

Nasturtium . . . . $\quad 303$

Shortia . . . . . $\mathrm{I}_{3} 3$

Tecophilaea . . . 435

Crucianella . . . $\quad 133$

Geranium pratense . . IgS

Arum 


\section{POPULAR NAME}

Cucumber Root, Indian

Cucumber Tree

Cupidone

Currant, Flowering

Currant, Indian

Cypress

Cypress, Deciduous

Cypress, Summer .

\section{Daffodil}

Daffodil, Winter

Dahlia, Climbing

Daisy .

Daisy, Barberton .

Daisy, Blue

Daisy, Bush

Daisy, False

Daisy, Globe

Daisy, Horse

Daisy, Swan River

Daisy, Transvaal

Date Plum, Chinese

Deodar

Dewberry

Dock

Dock, Great Water

Dodder

Dogwood

Dragon Plant

Dragon's Head

Duck Foot

Duckweed

Dutchman's Pipe.

Dyer's Greenwood

\section{Ebony \\ Edelweiss \\ Egg Plant \\ Elderberry \\ Everlasting Flower \\ Everlasting, Pearly \\ Everlasting, Winged}

Fair Maids of France

False Indigo

Feather Grass

Fennel

Fern, Beech

Fern, Bladder

Fern, Buckler

Fern, Hard .

Fern, Hart's Tongue

Fern, Holly .

Fern, Lady.
BOTANICAL NAME

Medeola . . . 282

Magnolia acuminata . $\quad 274$

Catananche . . . 94

Ribes sanguineum . $\quad 378$

Symphoricarpus orbiculatus . 429

Cupressus . • . . I35

Taxodium distichum . . 433

Iochia tricophylla . . 242

Narcissus . . . . 299

Sternbergia lutea . . $\quad t^{25}$

Hidalgoa Wercklei . . 219

Bellis . . . 59

Gerbera Jamesoni . . 198

Agathaea caelestis . . 15

Olearia . . . 310

Bellium . . . . 60

Globularia . . . . 204

Leucanthemum . . . IIO

Brachycome iberidifolia . 70

Gerbera Jamesoni . . 198

Diospyros Kaki . . . I 57

Cedrus Deodara . . . 97

Rubus Caesius . . . 388

Rumex . . . . 389

Rumex hydrolapathum . 389

Cuscuta . . . . 136

Cornus . . . . 123

Arum Dracunculus . . 45

Dracocephalum . . . I60

Podophyllum . . . 346

Lemna • • . 252

Aristolochia Sipho . . 43

Genista tinctoria . . 196

Diospyros Ebenum . . I57

Leontopodium • • . 252

Solanum Melongena • . 416

Sambucus . . $\quad$. 394

Helichrysum . . . 214

Anaphalis . . . . 29

Ammobium . $\quad$. 28

Ranunculus aconitifolius . 369

Amorpha fruticosa . $\quad 28$

Stipa . . . . 426

Ferula . . . . 183

Polypodium Phegopteris - 349

Cystopteris . . . . I40

Aspidium . . . . 48

Blechnum Spicant . . 66

Scolopendrium . . . 406

Aspidium lonchitis . . 49

Asplenium . . . . 49 


\section{POPULAR NAME}

Fern, Male

Fern, Oak

Fern, Polypody

Fern, Royal .

Fern, Shield

Fescue Grass

Feverfew

Fig

Fig, Prickly.

Figwort, Cape

Filbert

Fir, Douglas

Fir, Silver

Flag, Corn

Flag, Sweet .

Flax

Flax, New Zealand

Flea Bane

Floss Flower

Flower of Adonis.

Foam Flower

Forget-me-not

Forget-me-not, Chatham Island

Foxglove

Fraxinella

Fringe Flower

Fritillary

Frog Bit

Fumitory

Fumitory

Fumitory, Climbing

Gardener's Garters

Garland Flower

Garlic, Golden

Gentian

Germander

Globe Flower

Globe Thistle

Glory of the Snow

Goat's Beard

Goat's Rue .

Gold Dust

Golden Bell .

Golden Drop

Golden Rod

Gooseberry, Fuchsia-flowered .

Gorse, Spanish

Gourd

Grass, Blue-eyed .

Grass, Broom

Grass, Cloud

Grass, Cock's-foot

Grass, Fox-tail
BOTANICAL NAME

Nephrodium

Polypodium Dryopteris

Polypodium

Osmunda

Aspidium

Festuca

Parthenium.

Ficus .

Opuntia

Phygelius capensis

Corylus

Pseudotsuga Douglasii

Abies .

Gladiolus

Acorus

Linum

Phormium.

Erigeron

Ageratum

Adonis

Tiarella

Myosotis

Digitalis . . . . I55

Dictamnus . . . . I5.t

Chionanthus . . . $10_{4}$

Fritillaria . . . . I 88

Hydrocharis . . . 220

Corydalis . . . . I25

Fumaria . . . . 190

Adlumia cirrhosa . . 12

Phalaris arundinacea variegata 330

Daphne Cneorum . . 145

Allium Moly . . . 20

Gentiana . . . I9u

Teucrium . . . $\quad 435$

Trollius . . . . +45

Echinops . . . . IUI

Chionodoxa . . . $\mathrm{IO}_{4}$

Astilbe . . . 50

Galega . . . . 193

Alyssum . . . . $\quad 25$

Forsythia . . . . $\mathrm{I}_{5}$

Onosma . . . . 312

Solidago . . . . +117

Ribes speciosum . $\quad . \quad 379$

Genista hispanica . . I yu

Cucurbita . . . I3.t

Sisyrinchium angustifolium . 115

Bromus . . . $7 \mathrm{I}$

Agrostis . . . . I I

Dactylis . . . . I.t2

Alopecurus . . . . 22 
POPULAR NAME

Grass, Goose

Grass, Hair .

Grass, Hare's Tail

Grass, Love.

Grass, Lyme

Grass, Oat

Grass of Parnassus

Grass, Pampas

Grass, Quaking

Grass, Ribbon

Grass, Soft

Grass, Spear

Grass, Vernal

Grass, Whitlow

Grey Feather, Kansas

Gromwell

Groundsel

Gum Iree, Sweet .

Harebell

Hare's Ear.

Haw, Scarlet

Hawkweed

Hawthorn

Hawthorn, Water.

Hazel

Heath .

Heath, Irish

Heath, St. Dabeoc

Heath, Sea

Heath, Tree.

Helleborine

Hemlock Spruce

Hemp .

Hemp Agrimony

Hepatica, Common

Herb Christopher.

Herb Paris

Hercules Club

Heron's Bill

Hickory

Holly

Holly, Sea

Holly, Weeping

Hollyhock

Honesty

Honey Flower

Honeysuckle

Honeysuckle, Bush

Honeysuckle, French

Hop

Hop Tree

Horehound, White

Hornbeam
BOTANICAL NAME

Galium Aparine . . . $\quad$ I9t

Aira . . . 18

Lagurus . . . . 244

Eragrostis . . . . 167

Elymus . . . . $\mathrm{I}_{3}$

Arrhenatherum . . . 44

Parnassia . . . . 322

Cortaderia . . . $\times 24$

Briza . . . . $7 \mathrm{I}$

Phalaris arundinacea variegata $33^{\circ}$

Holcus . . . $22 \mathrm{I}$

Agrostis . . . . I7

Anthoxanthum . . . 35

Draba . . . I 59

Liatris pycnostachya . . 255

Lithospermum . . 264

Senecio . . . tII

Liquidambar . . . 263

Campanula rotundifolia $\quad 85$

Bupleurum . . . . 75

Crataegus coccinea . . I30

Hieracium . . . 220

Crataegus Oxyacantha . I3I

Aponogeton . . $\quad 37$

Corylus Avellana . . 127

Erica . . . . 169

Daboëcia polifolia . . I4I

Daboëcia polifolia . . I $4 \mathrm{I}$

Frankenia laevis . . . $\quad$ I 87

Erica arborea . . . I70

Epipactis . . . . $\mathbf{I 6 6}$

Tsuga . . . . $44^{8}$

Cannabis sativa. . $\quad 87$

Eupatorium . . 180

Anemone Hepatica . . 32

Actaea . . . ro

Paris . . . $32 \mathrm{I}$

Aralia spinosa . . $\quad 39$

Erodium . . . . 173

Carya . $\quad . \quad$. 90

Ilex . . . . 228

Eryngium . . . . 173

Ilex pendula . . . 229

Althaea . . . $\quad 24$

Lunaria . . . . 268

Melianthus . . . $\quad 282$

Lonicera . . . . 267

Diervilla (Weigela) . . 154

Hedysarum coronarium . 212

Humulus . . . 223

Ptelea trifoliata . . 360

Marrubium . . . . 278

Carpinus . . . $\quad 89$ 


\section{POPULAR NAME}

Horsetail

Hound's Tongue

Hound's Tongue, Himalayan .

Houseleek

Huntsman's Horn

Hyacinth

Hyacinth, Cape

Hyacinth, Grape

Hyacinth, Missouri

Hyacinth, Starch .

Hyssop

Ice Plant

Immortelle

Immortelle, Australian .

Indian Shot

India-rubber Plant

Iris, Tiger

Ironwood

Ivy

Ivy, British Ground

Ivy, Kenilworth .

Jacob's Ladder

Jasmine

Jasmine, Rock

Jerusalem Cross

Jew's Mallow

Job's Tears.

Joseph's Coat

Judas Tree.

June-berry

Juniper

Kerria, White-flowered

King's Spear

Knapweed

Knot Grass .

Labrador Tea

Laburnum, Himalayan.

Lace Flower

Lady's Mantle

Lady's Slipper

Lady's Tresses

Larch.

Larch, European

Larch, Golden

Larkspur

Laurel.

Laurel, Alexandrian

Laurel, Portugal

Lavender
BOTANICAL NAME

Equisetum r66

Cynoglossum . . . 138

Lindelofia . . . . 261

Sempervivum . . . tro

Sarracenia . . . . 396

Hyacinthus . . . 223

Galtonia candicans . . 194

Muscari . . . . 296

Brodiaea . . . . 71

Muscari racemosum . . 296

Hyssopus officinalis . $\quad 227$

Mesembryanthemum crystallinum

286

Helipterum . . . 215

Acroclinium . . . 10

Canna $\quad . \quad 2 \quad . \quad 86$

Ficus elastica . . . 185

Tigridia . . . . 439

Ostrya virginica . . . 316

Hedera . . . 2 IO

Nepeta Glechoma . . 304

Linaria Cymbalaria . . 261

Polemonium . . . 346

Jasminum . . . . 237

Androsace . . . . $3 I$

Lychnis chalcedonica . . $27 \mathrm{I}$

Kerria japonica . . . $24 \mathrm{I}$

Coix lachryma . . . 1 I7

Amarantus tricolor . . $\quad 26$

Cercis Siliquastrum . . IOI

Amelanchier canadensis $\quad 27$

Juniperus • . . 239

Rhodotypos kerrioides . 376

Asphodelus ramosus . $\quad 48$

Centaurea . . . $\quad$. 99

Polygonum . . . $\quad 347$

Ledum latifolium . . 25 I

Piptanthus nepalensis . . 342

Schizopetalon . . . 404

Alchemilla . . . . I9

Cypripedium . . . 139

Spiranthes . . . . 422

Larix . . . . . 246

Larix europaea . . . 246

Pseudolarix Fortunei . . 359

Delphinium . . . 147

Prunus Laurocerasus . . 359

Danaea Laurus . . . 144

Prunus lusitanica . . 359

Lavandula . . . . 250 


\section{POPULAR NAME}

Lavender, Cotton .

Lavender, Sea

Lead Plant

Lead Wort

Leather Leaf

Leatherwood

Leopard's Bane

Leopard Flower

Lettuce, Flowering

Lilac

Lilac, Californian .

Lily

Lily, African

Lily, Arum .

Lily, Belladonna

Lily, Corfu .

Lily, Day

Lily, Jacobean

Lily, Kaffir .

Lily, Mariposa

Lily of the Field .

Lily of the Valley

Lily of the Valley

Lily of the Valley Tree

Lily, Peruvian

Lily Pink

Lily, Plantain

Lily, St. Bernard's

Lily, St. Bruno's .

Lily, Toad

Lily, Torch .

Lily Tree

Lily, Water .

Lily, Water, Yellow

Lily, Wood .

Lime

Locust Tree

Loosestrife

Loosestrife, Purple

Loquat

Love-in-a-Mist

Love-lies-Bleeding

Lungwort

Lungwort, Smooth

Lupin .

Lupin, Tree .

Lyre Flower

Madwort

Maidenhair Fern

Maidenhair Tree

Mallow

Mallow

Mallow
BOTANICAL NAME

PAGE

Santolina . . . 395

Statice . . . . 424

Amorpha canescens . $\quad 28$

Plumbago • • • . 344

Cassandra calyculata . 9 I

Cyrilla racemiflora . I 40

Doronicum . . . . 159

Pardanthus Chinensis . . $32 \mathrm{I}$

Lactuca . . . . 244

Syringa . . . 430

Ceanothus thyrsiflorus $\quad 96$

Lilium . . . 257

Agapanthus . . . It

Richardia . . . . 379

Amaryllis Belladonna . . 26

Funkia subcordata . . I9I

Hemerocallis . . . 217

Sprekelia . . . . 422

Schizostylis . . . 405

Calochortus . . . 8 I

Sternbergia . . . 425

Convallaria majalis . . I20

Maianthemum . . . 275

Clethra arborea . . . . II6

Alstroemeria . . . 23

Aphyllanthes . . . 36

Funkia . . . . I9I

Anthericum . . . 34

Paradisia Liliastrum . . 321

Tricyrtis . . . . 444

Kniphofia . . . . 24 I

Magnolia . . . . 273

Nymphaea . . . 308

Nuphar . . . . 307

Trillium . . . . 444

Tilia . . . . . $44^{\circ}$

Gleditschia . . . . 204

Lysimachia . . . 272

Lythrum . . . 273

Eriobotrya japonica . . I72

Nigella . . . 306

Amarantus . . . 26

Pulmonaria . . . 362

Mertensia . . . . 286

Lupinus . . . . 269

Lupinus arboreus . . 270

Dicentra . . . . 153

Alyssum . . . . 25

Adiantum . . . . II

Ginkgo biloba . . . 200

Hibiscus . . . . 2 r9

Lavatera . . . . $25^{\circ}$

Malva . . . . 276 
POPULAR NAME

Mallow, False

Mallow, Greek

Mallow, Indian

Mallow, Poppy

Mallow Tree.

Mandrake

Maple .

Marguerite

Marguerite, Blue

Marigold

Marigold

Marigold, Bur

Marigold, Cape

Marigold, Fig

Marigold, Marsh

Marjoram

Marvel of Peru

Mask Flower

Master-wort

May Flower

Mayweed

Meadow Grass

Meadow Saffron

Meadow Saffron, Spring

Meadow Sweet

Medlar.

Mezereon

Michaelmas Daisy.

Mignonette

Milfoil .

Milk Weed

Milkwort, Sea

Mimosa

Mint

Mocassin Flower

Money-wort

Money-wort .

Monkey Flower

Monkey Puzzle

Monkshood .

Moon Wort

Morning Glory

Moss, Club

Mountain Ash

Mountain Flower

Mountain Sweet

Mourning Widow

Mulberry

Mullein, Cretan

Musk

Muskwood

Myrtle

Myrtle Bog .

Myrtle, Sand

\section{BOTANICAL NAME}

Malvastrum

PAGR

Sidalcea

277

Abutilon

413

Callirhoë

Lavatera arborea . . 250

Mandragora . . $\quad 277$

Acer . . . . 7

Chrysanthemum frutescens. ro 8

Arctotis grandis . . . 4 I

Calendula . . . . 79

Tagetes . . . 4 $4 \mathrm{I}$

Bidens . . . 114

Dimorphotheca . . . T 5 (5)

Mesembryanthemum . . 286

Caltha . . . . 82

Origanum . . . . 313

Mirabilis . . . 200

Alonsoa . . . . 22

Astrantia . . . $5 \mathrm{I}$

Epigaea repens . . . 11,5

Matricaria . . . . 279

Poa . . . . . 345

Colchicum . . . il

Bulbocodium vernum . . 74

Spiraea Ulmaria . . + 2 I

Pyrus Mespilus . . . 367

Daphne Mezereum . . 145

Aster . . . . 49

Reseda . . . $37^{\circ}$

Achillea . . . 8

Asclepias . . . . 47

Glaux maritima . . . 203

Acacia . . . . 4

Mentha . . . . $\quad 28_{4}$

Cypripedium . . 1 . 40

Lysimachia nummularia . 272

Sibthorpia . . . . + 13

Mimulus . . . . 289

Araucaria . . . 39

Aconitum . . . 9

Botrychium . . . $\quad 18$

Ipomoea . . . . $\quad 232$

Lycopodium . . $\quad 27 \mathrm{I}$

Pyrus Aucuparia . . 36,5

Stenanthium . . . $\$ 25$

Ceanothus . . . . 95

Geranium phaeum . . [1) 8

Morus . . . 29.4

Celsia cretica $\quad . \quad$. 98

Mimulus . . . . 280

Olearia argophylla . . 310

Myrtus . . . . 299

Myrica Gale . . 298

Leiophyllum buxifolium . $\quad 252$ 


\section{INDEX TO POPULAR NAMES}

POPULAR NAME

Myrtle, Wax

Nasturtium .

Navelwort

Nettle, Chili

Nettle, Dead.

Nettle, Indian

Nightshade, Deadly

Nut

Oak

Old Man's Beard .

Olive

Orange Flower, Mexican

Orange, Mock

Orange, Osage

Orchis, Bee .

Orchis, British Frog

Orchis, Butterfly

Orchis, Green Man

Orchis, Humble Bee

Orchis, March

Orchis, Musk

Orphine, The

Orris Root

Oso Berry

Oswego Tea

Ox-eye

Ox-eye

Oyster Plant, Spanish

Paeony

Paeony Tree

Palm, Chusan

Parsley Fern

Parsnip, Cow

Partridge Berry

Partridge Berry

Pasque Flower

Passion Flower

Pea, Perennial

Pea, Sweet

Peach

Peach .

Pear

Pearlwort

Pennyroyal

Peppermint

Persimmon

Pheasant's Eye

Picotee

Pimpernel

Pine

Pine, Adventure Bay
BOTANICAL NAME

PAGE

Myrica cerifera . . $\quad 208$

Tropaeolum . . . $t t^{6}$

Omphalodes . . . 3II

Loasa lateritia . . . $\quad 265$

Lamium . . . . 245

Lantana . . . $2+5$

Atropa . . . . 52

Corylus . . . 126

Quercus . . . . 357

Clematis Vitalba. $\quad$. $\quad$ II 3

Olea . . . . . 309

Choisya ternata. . . 105

Philadelphus . . 330

Maclura aurantiaca . . $\quad 273$

Ophrys apifera . . . 312

Habenaria viridis . . 208

Habenaria bifolia . . 208

Aceras anthropophora . . 8

Ophyrs bombilifera . . 3I3

Orchis latifolia . . . 313

Herminium . . 218

Sedum Telephium . . 409

Iris Florentina . . . 314

Nuttallia cerasiformis . . 307

Monarda didyma . . 292

Buphthalmum . . . 75

Leucanthemum . . . IIO

Scolymus hispanicus . 407

Paeonia . . 318

Paeonia Moutan . . 319

Trachycarpus . . . 442

Allosorus crispus . 20

Heracleum . . 217

Gaultheria procumbens . 195

Mitchella . . . 291

Anemone Pulsatilla . . 33

Passiflora . . . 323

Lathyrus . . . . 247

Lathyrus . . . $\quad 247$

Prunus Amygdalus . . 357

Prunus Persica . . . 357

Pyrus . . . . 364

Sagina . . . 390

Mentha Pulegium . . 284

Mentha piperita . . . 284

Diospyros . . . . 156

Adonis . . . . I2

Dianthus . . . . 550

Anagallis . . . . 29

Pinus . . . $34^{\circ}$

Phyllocladus rhomboidalis . 335 
POPULAR NAME

Pine, Norfolk Island

Pine, Umbrella

Pink

Pink Barren Beauty

Pink, Cushion

Pink, Moss

Pink, North American Fire

Pink, Sea

Pitcher Plant, Californian

Plane

Plane, Corstorphine

Plantain, Rattlesnake

Plantain, Water

Plum

Plum, Cherry

Poke Weed.

Pomegranate

Poplar

Poppy .

Poppy

Poppy, Californian

Poppy, Horned

Poppy, Nepaul

Poppy, Plume

Poppy, Prickly

Poppy, Tree

Poppy, Welsh

Poppy Wort, Chinese

Primrose

Primrose, Evening

Prince's Feather

Privet .

Prophet Flower

Purslane

Purslane, Rock

Ragwort

Rampion

Raspberry, Wild

Red-hot Poker

Redwood

Reed, Giant .

Rest Harrow

Resurrection Plant

Rhubarb

Rock Rose

Rocket

Rockfoil

Rockspray

Rose

Rose, Christmas

Rose, Cliffe

Rose, Lenten

Rose of Heaven

\section{BOTANICAL NAME}

Araucaria excelsa

PAGE

Sciadopitys verticillata

Dianthus

Pyxidanthera barbulata

Armeria maritima

I 50

367

Phlox subulata

44

333

Silene virginica . . . $4 \mathrm{r}+$

Armeria

43

Darlingtonia

I. 45

Platanus

$3+3$

Acer flavo-marginatum - 8

Goodyera Menziesii . 205

Alisma

Prunus

357

Prunus cerasifera

358

Phytolacca decandra . $\quad 337$

Punica Granatum . . 362

Populus . . . . 3.49

Papaver . . . 320

Platystemon californicus $\quad 3+4$

Eschscholtzia . . . 176

Glaucium . . . 203

Meconopsis nepalensis . $\quad 282$

Bocconia . . . . 66

Argemone . . . . 42

Romneya Coulteri . . 38I

Meconopsis cambrica . . $2 \mathrm{SI}_{\mathrm{I}}$

Eomecon chionantha . . 165

Primula . . . 35I

Oenothera . . . 309

Amarantus hypochondriacus 20

Ligustrum . . . $25^{\circ}$

Arnebia . . . . 4t

Portulaca . . . $35^{\circ}$

Calandrinia $\quad . \quad$. $\quad 78$

Senecio . . . 4 II

Phyteuma . . . . 336

Rubus Idaeus . . . 387

Kniphofia . . . . $24 \mathrm{I}$

Sequoia sempervirens . . 412

Arundo . . . 47

Ononis . . . 3 II

Anastatica . . . 20

Rheum . . . 372

Cistus . . . . I I I

Hesperis matronalis . 218

Saxifrage . . . 399

Cotoneaster . . . 127

Rosa . . . . 38I

Helleborus niger . . 215

Armeria maritima . . 44

Helleborus orientalis . . 215

Agrostemma caeli-rosa . $\quad$ I7 
POPULAR NAME

Rose of Heaven

Rose of Jericho

Rose, Sun

Rosemary

Rowan

Rue

Rue, Meadow

Rush

Rush, Club .

Rush, Flowering

Sage
Sage, Wood
Salsafy
Salt Tree
Sandwort
Satin Flower

Satin Flower, New Zealand

Savin, Common

Scabious

Scabious, Sheep's Bit

Seakale

Sedge .

Sedge, Myrtle

Self Heal

Service-berry

Service Tree

Shallon

Shamrock

Shamrock, Blue-flowered

Sheep Laurel

Shooting Stars

Silver Bell

Siris, Pink

Skull Cap

Slipper Wort

Sloe

Snake Plant

Snapdragon .

Sneeze Wort

Sneezewort, Double

Snow in Summer

Snowberry

Snowdrop

Snowdrop Tree

Snowflake

Snowy Mespilus

Soapwort

Solomon's Seal

Sorrel Tree.

Sourwood

Southernwood

Sowbread

Spearmint

\section{BOTANICAL NAME}

Lychnis Coeli-rosa

PAGE

Anastatica . .

271

Helianthemum

Rosmarinus officinalis . . 386

Pyrus Aucuparia . . 366

Ruta • . . . 390

Thalictrum . . . 436

Juncus . . . 239

Scirpus . . . . 406

Butomus umbellatus . $\quad 76$

Salvia . . . . 393

Teucrium Scorodonia $\quad+36$

Tragopogon pratensis . . 443

Halimodendron argenteum . 209

Arenaria * . $\quad . \quad 42$

Sisyrinchium . . +14

Libertia . . . . 255

Juniperus Sabina . . 240

Scabiosa . . . . 403

Jasione . . . 237

Grambe maritima . $\quad$ I 29

Carex . . . . 88

Acorus . $\quad$. $\quad$. $\quad .9$

Prunella • • • . 356

Amelanchier canadensis . 27

Pyrus Sorbus . . . 366

Gaultheria Shallon • . 194

Oxalis Acetosella. . 3 I6

Parochetus communis $\quad 322$

Kalmia angustifolia . 240

Dodecatheon . . ${ }^{2} 8$

Halesia tetrapetra . . 208

Albizzia Julibrissin . . 19

Scutellaria . . . . 407

Calceolaria . . . 78

Prunus spinosa flore pleno . $35^{8}$

Arum Dracunculus . . 45

Antirrhinum . . $\quad 35$

Helenium . . . . 212

Achillea Ptarmica . . 8

Cerastium tomentosum . IOI

Symphoricarpus racemosus . 429

Galanthus . . . . I92

Halesia . . . 208

Jeucojum • . • . 253

Amelanchier . . . 27

Saponaria . . . $\quad$. 395

Polygonatum . • . 347

Oxydendron arboreum . 317

Oxydendron arboreum . 317

Artemisia Abrotanum . . 45

Cyclamen . . . . 137

Mentha viridis . . . 284 
Spider-wort .

Tradescantia

PAGE

Spinach, Mountain

Atriplex hortensis

443

Spleenwort .

Spring Beauty

Asplenium .

Claytonia .

Spruce

Picea

I 13

Spurge.

Squill .

Squill, Striped

St. John's Wort

Star Flower, Spring

Star of Bethlehem

Starwort

Starwort, False

Stock .

Stock, Virginian

Stokes' Aster

Stonecrop

Strawberry

Strawberry Tree

Succory

Sumach

Sunflower

Sunflower, Orange.

Supple Jack

Swallow Wort

Swamp Bay

Sweet Cicely

Sweet Gale.

Sweet William

Sycamore

Euphorbia .

Scilla.

Puschkinia scilloides . . 362

Hypericum

Triteleia uniflora.

Ornithogalum umbellatum . $3 x_{4}$

Aster .

Boltonia

Matthiola

Malcolmia

Stokesia

Sedum

Fragaria

Arbutus Unedo

Cichorium Intybus

Rhus

Helianthus

Heliopsis . . . 214

Berchemia volubilis . . 63

Asclepias

Magnolia glauca

Nyrrhis

Myrica Gale

Dianthus barbatus

Acer Pseudo-platanus

Tamarisk

Tamarix

Tarragon

Artemisia dracunculoiles

Emilia coccinea

Tea Tree

Lycium Chinense

271

Dipsacus

Thistle

Thistle, Blessed

Carduus

Carbenia benedicta . 88

Thistle, Fish-Bone

Thistle, Golden

Chamaepeuce

Scolymus

407

Cnicus

Sonchus

418

Thistle, Sow

Thorn

Thorn Apple

Thrift

Thrift, Prickly

Thyme

Thyme, Cat's

Tickseed

Toadflax

Tobacco

Toon Tree

Toothwort

Traveller's Joy

Crataegus

Datura

Armeria

Acantholimon

Thymus

Teucrium Narum . . 436

Coreopsis . . . . I22

Linaria . . . . 26I

Nicotiana . . . 306

Cedrela Toona . . . 96

Lathraea . • • . 247

Clematis Vitalba. . . 113 
POPULAR NAME

Treasure Flower

Tree of Heaven

Tree Poppy.

Trefoil, Moon

Trumpet Flower

Trumpet Flower

Tulip

Tulip, Butterfly

Tulip Tree

Twin Flower

Umbrella Tree

Valerian

Venus' Looking Glass

Verbena, Lemon-scented

Verbena, Sand

Verbena, Scented

Vetch, Horseshoe

Vetch, Kidney

Vetch, Spring

Vine, Cross

Vine, Madeira

Violet, Adder's

Violet, Dame's

Violet, Dog's Tooth

Violets, Water

Wake Robin

Wall Pepper

Wallflower

Wallflower, Fairy.

Walnut

Water Leaf.

Water Soldier

Wattle

Wedding Flower

Whitehorn

Willow

Willow Herb

Windflower

Wineberry

Winter Sweet

Wintergreen

Wintergreen, Creeping

Witch Hazel

Woad

Wolf's-bane

Wonder Berry

Wood Sorrel

Woodbine, Common

Woodruff

Wormwood.

Woundwort
BOTANICAL NAME

Gazania

Ailanthus glandulosa

Dendromecon

Medicago arborea

Incarvillea .

Tecoma

Tulipa

Calochortus

Liriodendron tulipifera

Linnaea

Magnolia tripetala

275

Centranthus

100

Specularia.

Aloysia citriodora

Abronia

$+20$

22

2

Lippia citriodora . . 263

Hippocrepis . . . 221

Anthyllis

35

$3 \mathrm{I} 4$

Bignonia capreolata

65

69

205

218

I75

222

Hottonia palustris

Trillium grandiflorum . $\quad 444$

Sedum acre . . . 408

Cheiranthus . . . 103

Erysimum . . . . 173

Juglans . . . . 238

Hydrophyllum . . . 226

Stratiotes . . . . 426

Acacia . . . . 4

Moraea Robinsonia . . 293

Crataegus Oxyacantha . I3I

Salix . . . . 391

Epilobium . . . . 165

Anemone . • . . 31

Rubus phoenicolasius . . 388

Chimonanthus fragrans $\quad$ IO4

Pyrola . . . 363

Gaultheria procumbens . I95

Hamamelis . . . 209

Isatis . . . . 236

Aconitum . . . . 9

Solanum nigrum . . . 416

Oxalis . . 316

Lonicera Periclymenum . 267

Asperula . . . . 47

Artemisia . . . . 45

Stachys . . . 422 


\section{$4: 2$ THE BOOK OF HARDY FLOWERS \\ POPULAR NAME \\ BOTANICAL NAME}

Yam

Yarrow

Yellow Wood

Yew, Common

Yew, Plum-fruited

Yew, Prince Albert's

Yulan

Zebra Wood
Dioscorea

Achillea

Cladrastis

Taxus baccata

Prumnopitys elegans

Saxegothea conspicua.

Magnolia conspicua

Diospyros IIurzii raw:

150

$\mathrm{S}$

II 2

434

355

307

274

I 57 









\section{LIBRARY OF CONGRESS

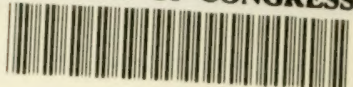 \\ 00009195166}

